\title{
3BITHICTb ПІАПРИЕМСТВ
}

Навчамьний посібник

А^я стУАентів зак^аАї вищої освіти 


\author{
Рекомендувала до друку вчена рада \\ Національного університету "Острозька академія" \\ (протокол № 7 віА 28 січня 2021 року)
}

\title{
Рецензенти:
}

$\boldsymbol{\epsilon .}$. Іонін, Аоктор економічних наук, професор, завідувач кафедри обліку, аналізу і аудиту Аонецького національного університету імені Василя Стуса;

О. Р. Антонюк, Аоктор економічних наук, доцент, професор кафедри обліку і аудиту Національного університету водного господарства та природокористування;

Н. А. Мамонтова, Аоктор економічних наук, професор, завідувач кафедри фінансів, обліку і аудиту Національного університету "Острозька академія".

\section{Іванчук Н. В.}

Звітність піАприємств : навчальний посібник. Острог : Видавництво Національного університету "Острозька академія", 2021. 208 с.

\section{DOI 10.25264/28.01.2021-2}

Висвітлено склаА, структуру, порядок складання і подання фінансової звітності за національним положеннями (стандартами) бухгалтерського обліку, зокрема балансу (звіту про фінансовий стан), звіту про фінансові результати (звіту про сукупний АохіА), звіту про рух грошових коштів за прямим і непрямим методом, звіту про власний капітал, приміток Ао річної фінансової звітності, консолідованої фінансової звітності. В посібнику також викладено склаА, структуру, методику складання, вимоги до подання податкової і статистичної звітності.

Навчальний посібник розрахований на студентів спеціальності "Облік і оподаткування" закладів вищої освіти та широке коло фахівців. 


\section{MICT}

ПEPEAMOBA

TEMA 1. ЗАГАЯЬНI ВИМОГИ АО ЗВІTНОСТІ

1.1. ВиАи, класифікація та склаА звітності піАприємств …….............................................. 5

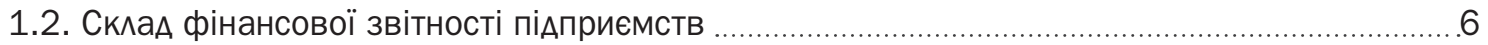

1.3. ПоряАоК ПоАання та оприлюАнення фінансової звітності піАприємств _............................. 8

TEMA 2. БАЛАНС (ЗВІТ ПРО ФІНАНСОВИЙ СТАН) ПІАПРИЕМСТВА

2.1. Структура балансу (звіту про фінансовий стан) та вимоги до нього ……….......................13

2.2. Зміст статей балансу та методика його складання …………………………………………......

TEMА 3. ЗВІТ ПРО ФІНАНСОВІ РЕЗУАЬТАТИ (ЗВІТ ПРО СУКУПНИЙ АОХІА) ………...................

3.1. Структура звіту про фінансові результати (звіту про сукупний АохіА) ……........................... 26

3.2. Зміст статей та методика заповнення звіту про фінансові результати …….......................30

TEMA 4. ЗВIT ПРО РУХ ГРОШОВИХ КОШТІВ

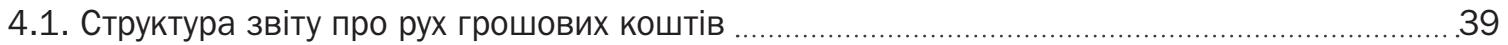

4.2. Зміст статей звіту про рух грошових коштів та методика його складання

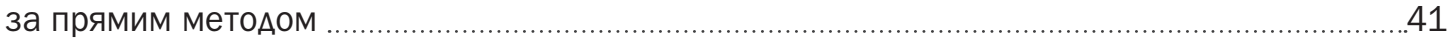

4.3. Зміст статей звіту про рух грошових коштів та методика його склаАання

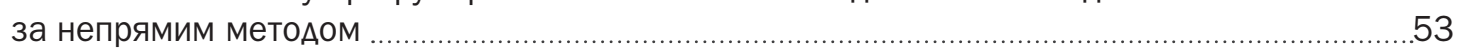

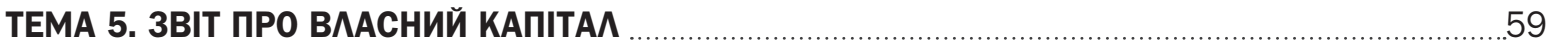

5.1. Власний капітал та його функції. Статті власного капіталу та їх зміни ............................59

5.2. Зміст статей звіту про власний капіталу та методика його складання .................................65

TЕМА 6. ПРИМІТКИ АО РІЧНОї ФІНАНСОВОї ЗВІТНОСТІ ........................................................ 71

6.1. СклаА та вимоги Ао приміток Ао річної фінансової звітності .................................... 71

6.2. Структура, інформаційне забезпечення та методика складання приміток до річної

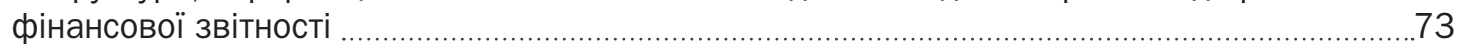

TЕМА 7. ВИПРАВАЕННЯ ПОМИАОК І ЗМІНИ У ФІНАНСОВИХ ЗВІТАХ

7.1. Правила виправлення помилок у фінансовій звітності піАприємств _..............................95

7.2. Порівнянність показників форм річної фінансової звітності _..................................... 99

TEMA 8. KOHCOЛIAОВАНА ФIHАНСОВА ЗВITHICTЬ

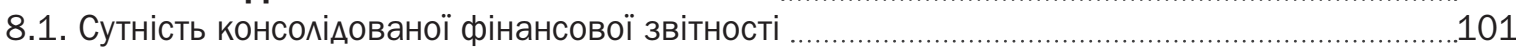

8.2. Вимоги і методика складання консолідованої фінансової звітності .................................... 104

TEMA 9. ФІНАНСОВИЙ ЗВІТ МАЛОГО ТА МІКРОПІАПРИЕМСТВА

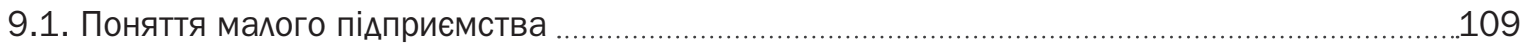

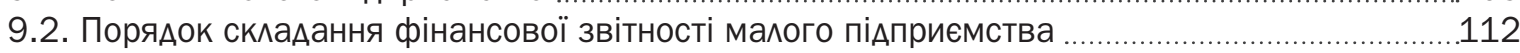

9.3. Порядок складання фінансової звітності мікропіАприємства ……....................................

TEMA 10. ПOAATKOBA 3BITHICTЬ

10.1. Загальні вимоги Ао складання і подання податкової звітності .....................................131

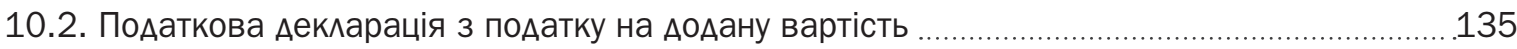

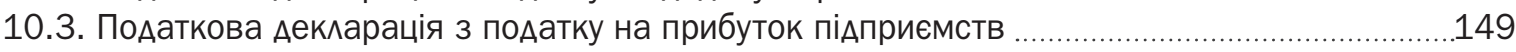

10.4. Звіт про суми нарахованої заробітної плати (Аоходу, грошового забезпечення, Аопомоги, надбавки, компенсації) застрахованих осіб та суми нарахованого єАиного внеску на загальнообов'язкове державне соціальне страхування …………….................... 159

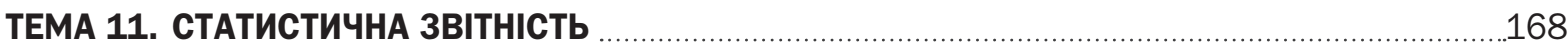

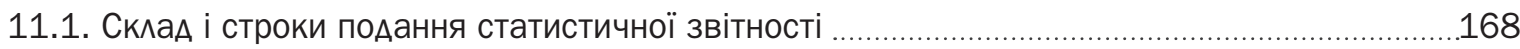

11.2. Методика складання статистичної звітності з оплати праці та соціально-трудових

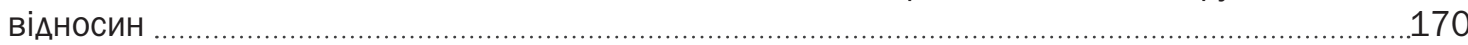

11.3. Методика складання статистичної звітності з основних засобів _................................... 180

ТЕСТИ АЛЯ САМОСТІЙНОї РОБОТИ СТУАЕНТІВ

СПИСОК ВИКОРИСТАНИХ АЖЕРЕА 


\section{ПЕРЕАMOBA}

Важливою передумовою якісної підготовки бакалаврів обліку і оподаткування є набуття практичних навичок склаАання та подання основних форм звітності піАприємств. Це переАбачає ознайомлення з основними нормативними документами, що визначають вимоги Ао склаАання, подання і оприлюАнення звітності, розгляА методики склаАання звітності піАприємств та Ажерел інформації, які при цьому використовуються.

Якісно складені форми звітності Аозволяють сформувати належне інформаційно-аналітичне забезпечення процесу управління піАприємством, ознайомити потенційних інвесторів із основним результатами Аіяльності господарюючого суб'єкта, задовільнити широке коло інформаційних потреб як внутрішніх, так і зовнішніх користувачів.

Мета навчальної Аисципміни "Звітність піАприємств" - наАання знань про зміст, структуру, поряАок склаАання і використання звітності піАприємств.

ЗавАанням навчальної дисципліни $є$ вивчення методики склаАання фінансової, податкової та статистичної звітності, передбаченої стандартами бухгалтерського обліку і законодавством України.

У процесі вивчення Аисципліни слухачі набувають і розвивають такі загальні та фахові компетентності, як:

- зАатність вчитися і оволодівати сучасними знаннями;

- зАатність до абстрактного мислення, аналізу та синтезу;

- зАатність до відображення інформації про господарські операції суб'єктів господарювання в фрінансовому та управлінському обліку, їх систематизації, узагальнення у звітності та інтерпретації Аля задоволення інформаційних потреб осіб, що приймають рішення;

- іАентифікувати та оцінювати ризики неАосягнення управлінських цілей суб'єкта госпоАарювання, недотримання ним законодавства та регулювання Аіяльності, недостовірності звітності, збереження й використання його ресурсів;

- зАатність застосовувати етичні принципи піА час виконання професійних обов'язків;

- Аемонструвати розуміння вимог щодо професійної Аіяльності, зумовлених необхіАністю забезпечення сталого розвитку України, ії зміцнення як демократичної, соціальної, правової Аержави.

За результатами навчання слухачі зможуть:

- знати вили, зміст та структуру звітності піАприємств;

- застосовувати методику складання форм фінансової звітності;

- узгоджувати показники форм фрінансової звітності;

- вносити зміни у форми фрінансової звітності;

- використовувати методику складання податкової звітності;

- знати сутність та порядок склаАання статистичної звітності.

Посібник розрахований на студентів спеціальності "Облік і оподаткування" заклаАів вищої освіти та фахівців-практиків у сфері бухгалтерського обліку. 


\section{TEMA 1.}

\section{ЗАГААЬНІ ВИМОГИ АО ЗВІТНОСТІ}

\section{1. ВиАи, класифікація та склаА звітності піАприємств}

Ефективність управління розвитком піАприємства значною мірою залежить віА Аостовірного, повного, своєчасного та Аоречного інформаційного забезпечення, важливим АжереАОМ якого є звітність.

Звітність піАприємства - це система взаємопов'язаних показників, сформована згінно 3 Аіючим законодавством, що відображає фінансовий стан, результати Аіяльності, формування та використання матеріальних, трудових та фрінансових ресурсів підприємства.

Нормативно-правове регулювання звітності піАприємств в Україні зАійснюється постановами Кабінету Міністрів України, указами Президента, Законами України, наказами Міністерства фінансів України та іншими нормативно-правовими актами.

Ао основних законодавчих Аокументів, які регулюють склаАання звітності в Україні, сліА віАнести:

1) Податковий кодекс України віА 2 грудня 2010 року № 2755-Vl;

2) Закон України "Про бухгалтерський облік та фінансову звітність в Україні" віА 16.07.1999 р. №996-XIV;

3) наказ Міністерства фінансів України «Про затвердження Методичних рекомендації 3 перевірки порівнянності показників фінансової звітності» віА 11 квітня 2013 р. №476;

4) наказ Міністерства фрінансів України "Про затвердження Методичних рекомендації щодо заповнення форм фінансової звітності» віА 28 березня 2013 р. №433;

5) наказ Аержавної служби статистики України «Про затвердження загального табеля (переліку) форм державних статистичних спостережень на 2020 рік" віА 02.11.2020 № 310 .

6) національні положення (стандарти) бухгалтерського обліку;

7) міжнародні стандарти бухгалтерського обліку;

8) міжнародні стандарти фінансової звітності.

ВіАповіАно АО п. 3 НП(С)БО 1 "ЗагаАьні вимоги Ао фінансової звітності" звітність піАприємств поділяється на бухгалтерську, фінансову та консолідовану.

Бухгалтерська звітність - це звітність, що складається на піАставі даних бухгалтерського обліку Аля задоволення потреб певних користувачів.

Фінансова звітність - звітність, що містить інформацію про фінансовий стан та результати Аіямьності піАприємства.

КонсоліАована фінансова звітність - фінансова звітність піАприємства, яке зАійснює контроль, та піАприємств, які ним контролюються, як єАиної економічної одиниці.

ЗгіАно п. 2 ст. 3 Закону України "Про бухгалтерський облік та фінансову звітність в Україні" виділяють такі види звітності, як фінансова, податкова, статистична та інші, що використовують грошовий вимірник та грунтуються на Ааних бухгалтерського обліку.

Податкова звітність - це податкові декларації та розрахунки, що наАають інформацію про нарахування та/або сплату податкових зобов'язань з податків і зборів, які складаються і подаються суб'єктами господарювання, що є платниками податків, у встановлені строки контролюючим органам і характеризують стан розрахунків піАприємства з бюАжетом за податками і зборами [13, с. 29].

Статистична звітність - це звітність, яка склаАається на піАставі даних бухгалтерського обліку Аля розрахунку статистичних показників щодо економічних, соціальних, Аемографіч- 
них, екологічних явищ та процесів, які вілбуваються в країні, її регіонах та галузях економіки Аля забезпечення цією інформацією держави та суспільства [13, с. 29].

За місцем використання розрізняють звітність зовнішню і внутрішню [13, с. 29].

Зовнішня звітність використовується як за межами піАприємства, так і на піАприємстві - це фінансова, податкова, статистична і спеціальна звітність (звітність до органів соціального страхування, відомча та інша), що використовується як за межами піАприємства, так і на піАприємстві й обов'язково піАписується керівником і головним бухгалтером.

Внутрішня (управАінська) звітність використовується тільки на піАприємстві менеАжерами різних рівнів.

За змістом звітних даних виАіляють типову і спеціалізовану звітність [13, с. 30].

У типовій звітності віАображаються оАнакового змісту показники, що характерні Аля усіх піАприємств незалежно віА виАу Аіяльності та форми власності.

Ао спеціалізованої звітності віАносять звітність, що характеризує Аіяльність піАприємств і організацій окремої галузі економіки або її піАгалузей.

За обсягом показників звітність поАіляється на коротку і повну [13, с. 30].

Коротка звітність подається із скороченим числом показників за звітний місяць або квартал.

Повна звітність подається за всіма показниками, затвердженими в установленому порялку, включаючи й ті, за якими спочатку були віАправлені короткі звіти.

За періодом скмадання звітність поділяється на річну і проміжну (періодичну) [13, с. 31].

Періодична звітність - це місячна і квартальна звітність. Вона віАображає фінансовий стан і результати Аіяльності піАприємства наростаючим піАсумком з початку року за віАповіАний місяць, квартал.

Річна звітність містить показники Аіяльності піАприємств за звітний (каленАарний) рік.

За терміном подання розрізняють звітність термінову і звичайну [13, с. 31]. Термінова звітність подається протягом чотирьох Анів після закінчення звітного періоду. Звичайна звітність поАається в термін встановлений органом управління, Ао сфери управління, якого належить піАприємство.

\section{2. СкмаА фінансової звітності піАприємств}

Фінансова звітність $є$ одним із найважливіших документів, які склаАає піАприємство. Вона Аає змогу зацікавленим сторонам (потенційним інвесторам, кредиторам, покупцям, постачальникам, державним органам, консалтинговим компаніям тощо) оцінити основні аспекти фінансово-майнового стану суб'єкта господарювання та фінансових результатів його Аіямьності.

Фінансова звітність може бути повною і скороченою [5].

Повну фінансову звітність подають усі підприємства, що застосовують національні станАарти, крім бюАжетних установ і пілприємств, які подають віАповідно до законодавства скорочену фінансову звітність. ІІї склаА визначений п. 1 розА. II НП(С)БО 1.

Скорочену за показниками фінансову звітність подають:

1) мікропіАприємства;

2) малі піАприємства;

3) непіАприємницькі товариства;

4) представництва іноземних суб'єктів господарської діяльності;

5) піАприємства, які ведуть спрощений бухгалтерський облік доходів і витрат віАповіАно Ао податкового законодавства, зокрема юридичні особи, які є платниками єАиного податку групи 3.

При цьому скорочена фінансова звітність буває Авох виАів:

1) фінансова звітність малого піАприємства (форми № 1-м і № 2-м);

2) фінансова звітність мікропіАприємства (форми № 1-мс і № 2-мс). ВіАповіАні форми і порядок їх складання наведено в НП(С)БО 25. 
СклаА фрінансової звітності для різних суб'єктів господарювання наведено в таблиці 1.1 .

СклаА річної фінансової звітності

\begin{tabular}{|c|c|}
\hline Суб'єкти господарювання & Ск^аА річної фінансової звітності \\
\hline $\begin{array}{l}\text { Малі підприємства (крім платників єАиного } \\
\text { податку групи 3) } \\
\text { ПреАставництва іноземних суб'єктів госпо- } \\
\text { дарської Аіяльності }\end{array}$ & $\begin{array}{l}\text { Фінансова звітність малого підприємства: } \\
\text { 1) форма № 1-м “Баланс"; } \\
\text { 2) форма № 2-м “Звіт про фінансові результати" }\end{array}$ \\
\hline $\begin{array}{l}\text { МікропіАприємства } \\
\text { Платники єАиного податку групи } 3 \text { (незалеж- } \\
\text { но віА того, Ао якої категорії піАприємств } \\
\text { вони потрапяяють) }\end{array}$ & \multirow[t]{2}{*}{$\begin{array}{l}\text { Фінансова звітність мікропідприємства: } \\
\text { 1) форма № 1-мс “Баланс"; } \\
\text { 2) форма № 2-мс “Звіт про фінансові результати" }\end{array}$} \\
\hline НепіАприємницькі товариства & \\
\hline Інші піАприємства, що застосовують П(С)БО & 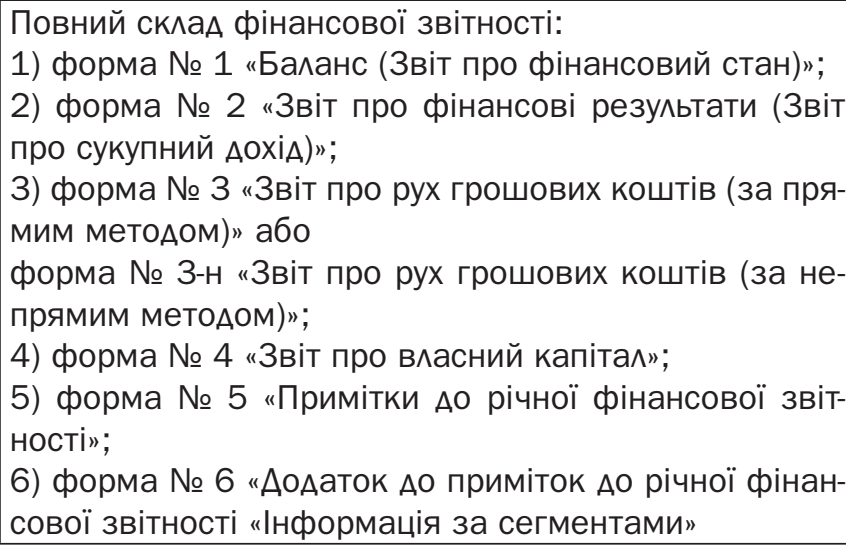 \\
\hline
\end{tabular}

Ажерело: [5].

Баланс (звіт про фінансовий стан) - це звіт про фінансовий стан піАприємства, який відображає на певну дату його активи, зобов'язання і власний капіта^.

Звіт про фінансові результати (звіт про сукупний АохіА) - це звіт про АохоАи, витрати, фінансові результати та сукупний дохіА.

Звіт про рух грошових коштів - це звіт, який віАображає наАходження і вибуття грошових коштів (грошей) протягом звітного періоду в результаті операційної, інвестиційної та фінансової діяльності.

Звіт про власний капітал - це звіт, який віАображає зміни у склаАі власного капіталу піАприємства протягом звітного періоду.

Примітки до фінансової звітності - це сукупність показників і пояснень, які забезпечують Аеталізацію і обґрунтованість статей фінансової звітності, а також інша інформація, розкриття якої переАбачено віАповіАними національними положеннями (стандартами) бухгалтерського обліку або міжнародними стандартами фінансової звітності.

Інформація за сегментами - це Аодаток до приміток Ао річної фрінансової звітності, Ае розкривають інформацію про доходи, витрати, фінансові результати, активи та зобов'язання звітних сегментів.

\section{Основні вимоги Ао піАготовки фінансової звітності:}

1) фінансову звітність склаАають у грошовій одиниці України - гривні. Проте на вимогу користувачів вона може бути Аодатково перерахована в іноземну валюту;

2) форми повної фінансової звітності заповнюють у тисячах гривень без десяткових знаків. Виняток - розАіл IV форми № 2. Його складають у гривнях з копійками. А ось форми скороченої фінансової звітності складають у тисячах гривень з одним Аесятковим знаком;

3) показники про податок на прибуток, витрати і збитки, вирахування з Аоходу, вибуття коштів, зменшення складових власного капіталу наводять у дужках; 
4) при складанні фінансової звітності неприпустимо згортати статті активів і зобов'язань, Аоходів і витрат, крім випадків, передбачених віАповіАними національними положеннями (стандартами) бухгалтерського обліку або міжнародними стандартами фінансової звітності;

5) піАприємства можуть не наводити статті, за якими віАсутня інформація до розкриття (виняток - випадки, коли така інформація була в попередньому звітному періоді). Також при складанні повної фінансової звітності можна додавати статті зі збереженням їх назви і коду рялка з переліку додаткових статей. Але Аля цього необхіАно, щоб інформація була суттєвою, а оцінка статті могла бути Аостовірно визначена;

6) показники річної фрінансової звітності піАтверджують результатами попереАньо провеАеної інвентаризації активів і зобов'язань;

7) Ао фінансової звітності включають показники Аіяльності філій, преАставництв, віААілень та інших віАокремлених підрозАілів піАприємства;

8) фінансова звітність піАписується керівником (власником) піАприємства або уповноваженою особою у визначеному законодавством порядку і бухгалтером або особою, яка забезпечує ведення бухгалтерського обліку піАприємства [5].

Якщо бухгалтерський облік на піАприємстві веде юридична особа, яка провадить Аіяльність у сфері бухгалтерського обліку та/або аудиту, фінансову звітність підписують керівник пілприємства (або уповноважена ним особа), а також керівник аудиторської/бухгалтерської фірми (чи уповноважена ним особа).

Фінансову звітність піАприємства, яке становить суспільний інтерес, піАписують керівник (або уповноважена ним особа) і головний бухгалтер.

Форми фінансової звітності та порядок їх заповнення А^я різних суб'єктів господарювання встановлюються такими державними органами:

1) Аля піАприємств (крім банків) - центральним органом виконавчої влади, що забезпечує формування державної фінансової політики, за погодженням з центральним органом виконавчої влади, що реалізує державну політику у сфері статистики;

2) Аля банків - Національним банком України;

3) Аля бюджетних установ - центральним органом виконавчої влаАи, що забезпечує формування Аержавної фінансової політики [13, с. 31].

\section{3. ПоряАоК поАання та оприлюАнення фінансової звітності піАПриємств}

ВіАповіАно Ао ст. 2 Закону України «Про бухгалтерський облік та фінансову звітність в Україні» і п. 1 Порялку подання фрінансової звітності фінансову звітність зобов'язані подавати:

1) всі юридичні особи, створені віАповіАно до законодавства України (незалежно віА організаційно-правової форми господарювання та форми власності);

2) преАставництва іноземних суб'єктів господарської Аіяльності.

Фінансову звітність і консоліАовану фінансову звітність піАприємства (крім суб'єктів державного сектора) складають віАповіАно Ао:

- національних положень (станАартів) бухгалтерського обліку $(П(С) Б О) ;$

- міжнародних стандартів фінансової звітності (МСФЗ).

СкмаАати фінансовУ звітність віАповіАно Ао МСФЗ зобов'язані:

1) піАприємства, які становлять суспільний інтерес, а саме:

- емітенти цінних паперів, цінні папери яких допущені до торгів на фондових біржах або щодо цінних паперів яких зАійснено публічну пропозицію;

- банки;

- страховики;

- недержавні пенсійні фонди (крім мікро- і малих піАприємств);

- інші фінансові установи (крім мікро- і малих піАприємств);

- великі піАприємства; 
2) публічні акціонерні товариства;

3) підприємства, що проваАять Аіяльність у видобувних галузях. Ао таких піАприємств належать суб'єкти господарювання, які зАійснюють види Аіяльності, зазначені в розАілах 05-08 секції В "Аобувна промисловість і розроблення кар'єрів" КBEA-2010;

4) піАприємства, що зАійснюють господарську Аіяльність за такими видами:

- надання фінансових послуг, крім страхування та пенсійного забезпечення (розділ 64 KBEA-2010);

- недержавне пенсійне забезпечення (група 65.3 KBEA-2010);

- Аопоміжна Аіяльність у сферах фінансових послуг і страхування (розАіл 66 KBEA-2010), крім Аопоміжної Аіяльності у сфері страхування та пенсійного забезпечення (група 66.2 KBEA-2010).

ПіАприємства, що не зобов'язані склаАати фінансову звітність за МСФ3, можуть самостійно визначити Аоцільність застосування МСФЗ Аля склаАання фінансової звітності.

Усі інші юридичні особи склаАають фінансову звітність віАповіАно Ао національних П(С)БО.

Аля цілей складання фрінансової звітності важливо, до якої категорії (великих, сереАніх, малих чи мікро-) належить підприємство. При цьому необхіАно керуватися вимогами Закону України «Про бухгалтерський облік та фінансову звітність в Україні» (табл. 1.2).

При цьому варто зазначити, що новостворені піАприємства Аля визначення своєї групи застосовують показники на дату складання першої річної фінансової звітності. Балансова вартість активів та чистий дохіА віА реалізації продукції (товарів, робіт, послуг) розраховуються за сереАньорічним курсом НБУ, а Аля розрахунку сереАньої кількості працівників сліА використовувати Інструкцію зі статистики кількості працівників, затверАжену Наказом Аержавного комітету статистики України 28.09.2005 р. № 286.

Таблиця 1.2

КАасифікація піАприємств віАповіАно Ао Закону України "Про бухгалтерський облік та фінансову звітність в Україні"

\begin{tabular}{|c|c|c|c|}
\hline \multirow[b]{2}{*}{ Категорія піАприємства } & \multicolumn{3}{|c|}{ Критерії оцінки за рік, що переАує звітному } \\
\hline & $\begin{array}{c}\text { Балансова вартість } \\
\text { активів, євро }\end{array}$ & $\begin{array}{c}\text { Чистий Аохї віА реалізації } \\
\text { проАукції (товарів, робіт, } \\
\text { послуг), євро }\end{array}$ & $\begin{array}{l}\text { Сереаня кімькість } \\
\text { працівників, осіб }\end{array}$ \\
\hline МікропіАприємства & Ао 350 тис. & Ао 700 тис. & Ao 10 \\
\hline Мa八i & AО $4 \mathrm{MAH}$ & Aо $8 \mathrm{M} \wedge \mathrm{H}$ & Ao 50 \\
\hline Середні & Aо $20 \mathrm{M} \wedge \mathrm{H}$ & АО $40 \mathrm{M} \wedge \mathrm{H}$ & Ao 250 \\
\hline Великі & ПонаА 20 млн & ПонаА 40 млн & Понад 250 \\
\hline
\end{tabular}

Ажерело: [30].

Аля віАнесення піАприємства до певної категорії Аостатньо, щоб показники фінансової звітності за попереАній рік віАповіАали оАночасно як мінімум Авом критеріям.

Якщо пілприємство за трьома критеріями відповідає одразу трьом різним категоріям (наприклаА, за оАнією ознакою піАприємство має потрапити до "малої" групи, за Аругою Ао "великої", за третьою - Ао "мікро-»), то, згіАно з рекоменАаціями Міністерства фінансів України, таке підприємство вважається малим.

Суб'єкти господарювання, які контролюють інші підприємства (материнські підприємства), крім фінансових звітів про власні господарські операції, повинні складати і подавати консолідовану фінансову звітність. Водночас такі піАприємства (крім тих, які становлять суспільний інтерес) можуть не подавати консолідовану фінансову звітність, якщо разом 3 контрольованими піАприємствами їх показники на Аату склаАання річної фінансової звітності не перевищують Авох із трьох таких критеріїв:

- балансова вартість активів - до 4 млн євро;

- чистий дохіА віА реалізації продукції (товарів, робіт, послуг) - Ао 8 мкн євро;

- сереаня кількість працівників - ао 50 осіб. 
Також, крім власної звітності, консоліАовану фінансову звітність повинні склаАати і поАавати об'єАнання підприємств. Ао такої звітності включають інформацію за всіма піАприємствами, які входять Ао складу об'єАнань, якщо це переАбачено установчими Аокументами таких об'єАнань віАповіАно Ао законоАавства.

Річну фінансову звітність підприємства зобов'язані подати:

- органам, до сфери управління яких вони належать;

- трудовим колективам на їх вимогу;

- власникам (засновникам) віАповідно до установчих документів;

- органам державної влади та іншим користувачам віАповіАно до законодавства.

Ао останніх належать, зокрема, органи Аержавної статистики й органи Аержавної податкової служби України (АПСУ).

Також законодавство зобов'язує Аеякі підприємства оприлюАнювати свою фінансову звітність (табл. 1.3).

Таблиця 1.3

\section{Строки і поряАоК оПриАюАНення фінансової звітності}

\begin{tabular}{|c|c|c|}
\hline ВиА ПіАприємства & Строки оПримюАНення & ПоряАок оПримюАнення \\
\hline $\begin{array}{l}\text { ПіАприємства, які становлять суспільний } \\
\text { інтерес (крім великих підприємств, що } \\
\text { не є емітентами цінних паперів) }\end{array}$ & \multirow{4}{*}{$\begin{array}{l}\text { Не пізніше ніж до } 30 \\
\text { квітня року, що настає за } \\
\text { звітним періодом }\end{array}$} & \multirow{4}{*}{$\begin{array}{l}\text { Разом з аудиторським } \\
\text { висновком на власній } \\
\text { веб-сторінці (у повному об- } \\
\text { сязі) або іншим способом у } \\
\text { випадках, визначених зако } \\
\text { нодавством }\end{array}$} \\
\hline Публічні акціонерні товариства & & \\
\hline $\begin{array}{l}\text { Суб'єкти природних монополій на за- } \\
\text { гальнодержавному ринку }\end{array}$ & & \\
\hline $\begin{array}{l}\text { ПіАприємства, які зАійснюють Аіяльність } \\
\text { у вилобувних галузях }\end{array}$ & & \\
\hline $\begin{array}{l}\text { Великі піАприємства, які не є емітента- } \\
\text { ми цінних паперів }\end{array}$ & \multirow{3}{*}{$\begin{array}{l}\text { Не пізніше ніж до } 1 \text { черв- } \\
\text { ня року, що настає за } \\
\text { звітним періодом }\end{array}$} & \multirow{3}{*}{$\begin{array}{l}\text { Разом з аудиторським } \\
\text { висновком на власній } \\
\text { веб-сторінці (у повному об- } \\
\text { сязі) }\end{array}$} \\
\hline СереАні піАприємства & & \\
\hline $\begin{array}{l}\text { Інші фінансові установи, які нале> } \\
\text { до мікро- і малих підприємств }\end{array}$ & & \\
\hline
\end{tabular}

Ажерело: [5].

Усі інші пілприємства, не наведені в табл. 1.3, оприлюднювати свою фрінансову звітність не зобов'язані.

Звітним періодом Аля складання фінансової звітності є календарний рік. При цьому усі піАприємства, за винятком мікропіАприємств, непіАприємницьких товариств (крім МСФЗ-зобов'язаних) і підприємств - платників єАиного податку групи 3, подають також проміжну фінансову звітність за перший квартал, перше півріччя і 9 місяців. Крім того, віАповіАно Ао облікової політики піАприємства фрінансова звітність може склаАатися за інші періоди.

У новостворених піАприємств перший звітний періоА може бути менше 12 місяців, але не може бути більше 15 місяців. Таким чином, пілприємства, які були зареєстровані в період з 1 жовтня по 31 грудня, річної фрінансової звітності за цей період можуть не подавати.

ОАнак платники податку на прибуток повинні подати фінансову звітність Ао органів АПСУ за період починаючи з дати, на яку припадає початок обліку новоствореного суб'єкта господарювання як платника податку, і закінчуючи останнім календарним днем податкового (звітного) періоду, в якому відбулася постановка на облік.

Річна фрінансова звітність подається не пізніше 28 яютого року, наступного за звітним.

Проміжну фінансову звітність (І квартал, перше півріччя, дев'ять місяців), крім консоліАованої, підприємства подають не пізніше 25 числа місяця, що настає за звітним кварталом.

Річну консоліАовану фінансову звітність юридичні особи, які мають Аочірні піАприємства, подають не пізніше строків, передбачених законодавством Аля ії̈ оприлюАнення (Ао 30 квітня або до 1 червня року, наступного за звітним) та не пізніше 45 днів після закінчення звітного кварталу. 
0б'єАнання піАприємств подають консоліАовану фінансову звітність (якщо це передбачено установчими Аокументами) щокварталу не пізніше 45 днів після закінчення звітного кварталу та щороку не пізніше 15 квітня наступного за звітним року.

Пматники поАатку на прибуток подають річну фінансову звітність Ао органів АПСУ у строки, передбачені для подання декларації із цього податку.

За порушення порядку подання та оприлюднення фінансової звітності або консолідованої фінансової звітності разом з аудиторським звітом передбачено аАміністративну віАповіАальність згіАно з Кодексом України про аАміністративні правопорушення (табл. 1.4).

Таблиця 1.4

\section{ААміністративна віАповіАальність за порушення поряАку поАання та оприлюАнення фінансової звітності}

\begin{tabular}{|c|c|c|c|}
\hline $\begin{array}{c}\text { № } \\
3 / n\end{array}$ & ВиА правопорушення & Штрафні санкції & Застосування \\
\hline 1. & $\begin{array}{l}\text { ВіАсутність бухгалтерського обліку або } \\
\text { ведення його з порушенням встановленого } \\
\text { порялку, внесення неправдивих Ааних до } \\
\text { фінансової звітності, неподання фінансової } \\
\text { звітності, несвоєчасне або неякісне прове- } \\
\text { дення інвентаризації грошових коштів та } \\
\text { матеріальних цінностей }\end{array}$ & $\begin{array}{c}\text { Штраф у розмірі } \\
\text { віА } 8 \text { до } 15 \text { неоподат- } \\
\text { ковуваних мінімумів } \\
\text { доходів громадян } \\
\text { (нмАг) } \\
\text { (віА } 136 \text { Ао } 255 \text { грн.) }\end{array}$ & \multirow{2}{*}{$\begin{array}{l}\text { Застосовують виключно Ао } \\
\text { підприємств, пов'язаних } \\
3 \text { бюджетними коштами, } \\
\text { оскільки каральними функ- } \\
\text { ціями в цьому випадку на- } \\
\text { ділені органи Аержавної ау- } \\
\text { диторської служби України }\end{array}$} \\
\hline 2. & $\begin{array}{l}\text { Вчинення Аій, перелічених у рял. } 1 \text { цієї } \\
\text { таблиці, особою, яку протягом року було піА- } \\
\text { Аано адміністративному стягненню за одне } \\
\text { з таких правопорушень }\end{array}$ & $\begin{array}{l}\text { Штраф у розмірі віА } \\
10 \text { Ао } 20 \text { нмАг } \\
\text { (віА } 170 \text { Ао } 340 \text { грн.) }\end{array}$ & \\
\hline 3. & $\begin{array}{l}\text { Порушення порядку оприлюднення фінансо- } \\
\text { вої звітності або консолідованої фінансової } \\
\text { звітності разом з аудиторським звітом }\end{array}$ & $\begin{array}{c}\text { Штраф у розмірі віА } \\
1000 \text { Ао } 2000 \text { нмАг } \\
\text { (віА } 17000 \\
\text { Ао } 34000 \text { грн.) }\end{array}$ & \multirow{2}{*}{$\begin{array}{l}\text { Штрафи на суб'єктів госпо- } \\
\text { Аарювання, зобов'язаних } \\
\text { оприлюАнити свою фінан- } \\
\text { сову звітність разом з ау- } \\
\text { Аиторським звітом (крім } \\
\text { банків, небанківських фі- } \\
\text { нансових установ та емі- } \\
\text { тентів цінних паперів), на- } \\
\text { кладає Орган суспільного } \\
\text { нагляду за аудиторською } \\
\text { Аіяльністю }\end{array}$} \\
\hline 4. & $\begin{array}{l}\text { Вчинення Аії, зазначеної в рял. } 3 \text { цієї табли- } \\
\text { ці, особою, яку протягом року було пілАано } \\
\text { адміністративному стягненню за таке пра- } \\
\text { вопорушення }\end{array}$ & $\begin{array}{c}\text { Штрафр у розмірі віА } \\
2000 \text { Ао } 3000 \text { нмАг } \\
\text { (віА } 34000 \\
\text { Ао } 51000 \text { грн.) }\end{array}$ & \\
\hline 5. & $\begin{array}{l}\text { Неподання органам державної статистики } \\
\text { даних Аля проведення державних ста- } \\
\text { тистичних спостережень або подання їх } \\
\text { недостовірними, не в повному обсязі, не } \\
\text { за формою, передбаченою звітно-статис- } \\
\text { тичною документацією, або із запізненням; } \\
\text { незабезпечення належного стану первин- } \\
\text { ного обліку }\end{array}$ & $\begin{array}{l}\text { Штраф у розмірі віА } \\
10 \text { Ао } 15 \text { нмаг } \\
\text { (віА } 170 \text { Ао } 255 \text { грн.) }\end{array}$ & \multirow[t]{2}{*}{$\begin{array}{l}\text { Накладають органи Аер- } \\
\text { жавної служби статистики } \\
\text { України за неподання їм } \\
\text { фінансової звітності }\end{array}$} \\
\hline 6. & $\begin{array}{l}\text { Aiї, перелічені в рял. } 5 \text { цієї таблиці, вчинені } \\
\text { повторно протягом року після накладення } \\
\text { адміністративного стягнення }\end{array}$ & $\begin{array}{l}\text { Штраф у розмірі віА } \\
15 \text { Ао } 25 \text { нмАг } \\
\text { (віА } 255 \text { Ао } 425 \text { грн.) }\end{array}$ & \\
\hline
\end{tabular}

Ажерело: [5].

Також існує віАповідальність у разі неподання фінансової звітності до органу АПсу платником податку на прибуток або неприбутковим піАприємствам, установою й організацією, оскільки фрінансова звітність є Аодатком Ао декларації з податку на прибуток (звіту про використання Аоходів (прибутків) неприбуткової організації) та її невіА'ємною частиною. У разі неподання Ао органу АПСУ фінансової звітності податкова звітність не визнається податковою Аекларацією. ЗгіАно з п. 120.1 Податкового кодексу України неподання фінансової звіт- 
ності до органу АПСУ призведе Ао накладення штрафу, що становить 170 грн. за кожне неподання або несвоєчасне подання. У разі вчинення тих же Аій платником податків, до якого протягом року був застосований штраф за таке порушення, санкція становитиме 1020 грн.

\section{КОНТРОАЬНІ ПИТАННЯ:}

1. Що таке звітність піАприємства та яке її призначення?

2. Назвіть нормативно-правові акти, що регламентують склаАання фінансової звітності піАприємств в Україні.

3. Що таке фінансова звітність та яке ії значення?

4. Аайте визначення терміну “бухгалтерська звітність".

5. Аайте визначення терміну "фінансова звітність".

6. Аайте визначення терміну "консоліАована фінансова звітність".

7. Що відображає податкова та статистична звітність?

8. Яким є склаА фінансової звітності підприємства?

9. Які суб'єкти складають і подають повну фінансову звітність?

10. Які суб'єкти складають і подають скорочену фінансову звітність?

11. Хто є користувачами фінансової звітності?

12. Охарактеризуйте сутність форм фінансової звітності.

13. Якими є основі вимоги Ао складання фінансової звітності?

14. Які суб'єкти зобов'язані оприлюАнювати фінансову звітність?

15. Кому подається фінансова звітність підприємств?

16. Якими є строки подання річної та проміжної фрінансової звітності?

17. Якими є строки подання річної та проміжної консолідованої фінансової звітності?

18. у чому полягає віАповіАальність за порушення поряду подання та оприлюАнення фінансової звітності? 


\section{БАМАНС (3ВIT ПРО ФІНАНСОВИЙ СТАН) ПІАПРИЕМСТВА}

\section{1. Структура балансу (звіту про фінансовий стан) та вимоги Ао нього}

Баланс піАприємства - це таблиця встановленої форми, в якій розміщуються активи піАприємства та пасиви, які включають власний капітал і зобов'язання. 3 метою отримання узагальненої інформації за видами активів і пасивів, вони в балансі об'єАнуються в розАіли за їх економічним змістом [13, с. 93].

ВіАповіАно АО П. 3 НП(С)БО 1 "Загальні вимоги Ао фінансової звітності", баланс (звіт про фінансовий стан) - це звіт про фінансовий стан піАприємства, який віАображає на певну дату його активи, зобов'язання і власний капітал.

Баланс складається з таких частин:

- титульна частина - в якій наводиться інформація про підприємство та дату, на яку склаАається баланс;

- предметна частина, яка склалається з активу і пасиву балансу, в яких наводиться цифрова інформація про майно і джерела його формування;

- заключна частина - ае наводяться пілписи, прізвище, ім'я та по-батькові осіб, які віАповідають за наведену інформацію [13, с. 93].

Актив балансу вк^ючає три розАіли, в яких об'єАнане майно за ступенем його ліквіАності.

У першому розАілі активу балансу "Необоротні активи" віАображається вартість необоротних активів, а саме: нематеріальних активів, незавершених капітальних інвестицій, основних засобів, об'єктів інвестиційної нерухомості, Аовгострокових біологічних активів, Аовгострокових фінансових інвестицій, Аовгострокової Аебіторської заборгованості, віАстрочених податкових активів та інших необоротних активів. Цей розАіл об'єАнує найменш АіквіАні активи.

У Аругому розАілі активу балансу "Оборотні активи" віАображається вартість оборотних активів, до яких вінносяться: запаси, поточні біологічні активи, поточна дебіторська заборгованість, поточні фінансові інвестиції, гроші та їх еквіваленти, витрати майбутніх періодів, інші оборотні активи. Цей розАіл об'єАнує сереАньо- та високоліквіАні активи.

У третьому розАілі активу балансу "Необоротні активи, утримувані А^я продажу, та групи вибуття" віАображається вартість необоротних активів та груп вибуття, утримуваних Аля продажу, що визначається віАповіАно Ао П(С)БО 27 «Необоротні активи, утримувані Аля продажу, та припинена Аіяльність".

Пасив балансу вк^ючає чотири розАіли, у яких згруповано зобов'язання з урахуванням терміновості їх погашення.

У першому розАілі пасиву балансу "Власний капіта^" наводиться інформація про власний капітал піАприємства - зареєстрований (статутний та пайовий капітал), капітал у Аооцінках, Аодатковий і резервний капітал, нерозподілений прибуток (непокритий збиток), неоплачений та вилучений капітал. Цей розАіл об'єАнує статті, які погашаються в останню чергу.

У Аругому розАілі пасиву балансу “Аовгострокові зобов'язання і забезпечення" ВіАображаються зобов'язання, які будуть погашені протягом періоду, що перевищує операційний цик^ пілприємства або 12 місяців з Аати балансу: віАстрочені податкові зобов'язання, пен- 
сійні зобов'язання, Аовгострокові кредити банків, інші Аовгострокові зобов'язання, Аовгострокові забезпечення (витрати на оплату майбутніх віАпусток, гарантійні зобов'язання тощо), величина яких на дату складання балансу може бути визначена тільки шляхом попередніх (прогнозних) оцінок та цільове фрінансування.

У третьому розАілі пасиву балансу “Поточні зобов'язання і забезпечення" віАображаються зобов'язання, які будуть погашені протягом операційного циклу піАприємства або протягом 12 місяців з Аати балансу: короткострокові кредити банків, поточна кредиторська заборгованість за Аовгостроковими зобов'язаннями, за товари, роботи, послуги, за розрахунками з бюджетом, зі страхування, з оплати праці, поточні забезпечення, Аоходи майбутніх періодів, інші поточні зобов'язання. Цей розді^ об'єАнує статті, які погашаються в першу чергу.

У четвертому розАілі пасиву балансу “Зобов'язання, пов'язані $з$ необоротними активами, утримуваними А^я проАажу, та групами вибуття" віАображаються зобов'язання, що пов'язані з необоротними активами, утримуваними Аля продажу, та групами активів, що належить Ао вибуття в результаті операції продажу.

Інформація, яка міститься в балансі, повинна бути суттєвою, повністю розкритою.

Суттєва інформація - це інформація, віАсутність якої може вплинути на рішення користувачів фінансової звітності.

Суттєвість інформації визначається П(С)БО, іншими нормативно-правовими актами та керівництвом піАприємства.

Аля кожного з фінансових звітів вибирають окрему базу визначення кількісних критеріїв і якісних ознак суттєвості статей.

У п.п. 2.20.3 Методичних рекомендацій щодо облікової політики підприємства (затверАжені наказом Міністерства фінансів Україні віА 27 червня 2013 року №635) запропоновані параметри кількісних критеріїв суттєвості Аля навеАення статей у фінансовій звітності.

А^я кожного зі звітів фінансової звітності обирають окрему базу визначення кіяькісних критеріїв та якісних ознак суттєвості статей фінансової звітності і Аіапазон кількісних критеріїв (табл. 2.1).

Таблиця 2.1

Кімькісні критерії суттєвості А^я статей фінансової звітності

\begin{tabular}{|l|c|l|}
\hline \multicolumn{1}{|c|}{ об'єкти суттевості } & $\begin{array}{c}\text { Аіапазон } \\
\text { (у \% віА бази) }\end{array}$ & База Аля визначення кількісного критерію суттєвості \\
\hline \multirow{2}{*}{ 1. Аля статей балансу } & Ао $5 \%$ & Сума піАсумку балансу \\
\cline { 2 - 3 } & Ао $15 \%$ & $\begin{array}{l}\text { ПіАсумок класу активів, власного капіталу або зобов'я- } \\
\text { зань }\end{array}$ \\
\hline \multirow{2}{*}{$\begin{array}{l}\text { 2. Аля статей звіту про } \\
\text { фінансові результати }\end{array}$} & Ао $5 \%$ & $\begin{array}{l}\text { Сума чистого Аоходу віА реалізації продукції (товарів, } \\
\text { робіт, послуг) }\end{array}$ \\
\cline { 2 - 3 } & Ао $25 \%$ & Сума фінансового результату віА операційної Аіяльності \\
\hline $\begin{array}{l}\text { 3. Аля статей звіту про рух } \\
\text { грошових коштів }\end{array}$ & Ао $5 \%$ & $\begin{array}{l}\text { Сума чистого руху грошових коштів віА операційної } \\
\text { Аіяльності }\end{array}$ \\
\hline $\begin{array}{l}\text { 4. Аля статей звіту про } \\
\text { власний капітал }\end{array}$ & Ао $5 \%$ & Розмір власного капіталу піАприємства \\
\hline
\end{tabular}

Ажерело: [61].

Основним елементом балансу (звіту про фінансовий стан) є балансова стаття, яка є непоАільним показником в балансі і характеризує окремий вил активів (активна стаття) або виА зобов'язань чи капіталу (пасивна стаття).

Стаття - це елемент фінансового звіту, який відповідає критеріям, встановленим НП(С)БО 1 , тобто визначенню активів, зобов'язань і власного капіталу [13, с. 95]. 
Стаття наводиться у балансі (звіті про фінансовий стан), якщо віАповіАає Авом критеріям:

- існує ймовірність наАходження або вибуття майбутніх економічних вигоА, пов'язаних 3 цією статтею;

- оцінка статті може бути Аостовірно визначена

\section{2. Зміст статей бамансу та метоАика його скмаАання}

Форма № 1 наведена в Аодатку 1 до НП(С)БО 1. у балансі піАприємства віАображають інформацію про активи, зобов'язання і власний капітал на звітну дату.

При складанні балансу потрібно враховувати такі правила (пп. 2.3 - 2.6 Методичних рекомендацій щодо заповнення форм фінансової звітності, затверджених наказом Міністерства фінансів України віА 28.03.2013 р. № 433):

1) активи вілображають у балансі за умови, що їх оцінка може бути Аостовірно визначена й очікується отримання в майбутньому економічних вигоА, пов'язаних з їх використанням;

2) витрати на придбання і створення активу, який не може бути віАображений у балансі, вк^ючають Ао складу витрат звітного періоду;

3) зобов'язання віАображають у балансі, якщо їх оцінка може бути достовірно визначена й існує ймовірність зменшення економічних вигод у майбутньому внаслідок їх погашення;

4) власний капітал показують у балансі одночасно з вілображенням активів або зобов'язань, які призводять Ао його зміни.

В піАрахунку піАсумків віАповіАних розділів балансу беруть участь рядки, коАи яких закінчуються на "0" і «5".

В активі балансу відображають відомості про активи піАприємства в розрізі їх видів, а в пасиві - інформацію про зобов'язання і власний капітал. При цьому піАсумок активів балансу має Аорівнювати сумі зобов'язань та власного капіталу.

Як сформувати показники балансу на підставі Ааних бухгалтерського обліку (рахунків класів 1-6), наведено в табл. 2.2

Таблиця 2.2

Методика заповнення форми № 1 "Баланс (Звіт про фінансовий стан)"

\begin{tabular}{|c|c|c|c|}
\hline Назва статті & $\begin{array}{c}\text { КоА } \\
\text { ряАКа }\end{array}$ & $\begin{array}{c}\text { Ажерело } \\
\text { інформації } \\
\text { Аля заповнення }\end{array}$ & Примітка \\
\hline \multicolumn{4}{|r|}{ AКТИВ } \\
\hline \multicolumn{4}{|r|}{ I. Необоротні активи } \\
\hline $\begin{array}{l}\text { Нематеріальні } \\
\text { активи }\end{array}$ & 1000 & $\begin{array}{l}\text { РяА. } 1001 \text { - РяА. } \\
1002\end{array}$ & $\begin{array}{l}\text { ВіАображають замишкову вартість об'єктів, включених } \\
\text { до складу нематеріальних активів відповідно до П(С)Бо } 8 . \\
\text { Також окремо показують: }\end{array}$ \\
\hline $\begin{array}{l}\text { первісна вар- } \\
\text { тість }\end{array}$ & 1001 & $\begin{array}{l}\text { Са^ьАо за Aт } \\
\text { pax. } 12\end{array}$ & $\begin{array}{l}\text { - первісну (переоцінену) вартість нематеріальних активів. } \\
\text { Не вк^ючають до підсумку бамансу }\end{array}$ \\
\hline $\begin{array}{l}\text { накопичена } \\
\text { амортизація }\end{array}$ & 1002 & $\begin{array}{l}\text { СамьАо за Кт } \\
\text { субрах. } 133\end{array}$ & $\begin{array}{l}\text { - суму накопиченої амортизації нематеріальних активів. } \\
\text { Показник наводять у Аужках. Не включають до підсумку } \\
\text { балансу }\end{array}$ \\
\hline $\begin{array}{l}\text { Незаверше- } \\
\text { ні капітальні } \\
\text { інвестиції }\end{array}$ & 1005 & $\begin{array}{l}\text { СамьАо } \\
\text { за Ат рах. } 15\end{array}$ & $\begin{array}{l}\text { Вілображають вартість незавершених на дату балансу ка- } \\
\text { пітальних інвестицій в необоротні активи на будівництво, } \\
\text { реконструкцію, модернізацію (інші поліпшення, що збіль- } \\
\text { шують первісну (переоцінену) вартість необоротних акти- } \\
\text { вів), виготовлення, створення, вирощування, придбання } \\
\text { об'єктів необоротних активів - основних засобів, немате- } \\
\text { ріальних активів, довгострокових біологічних активів (уклю- } \\
\text { чаючи необоротні матеріальні активи, призначені для замі- } \\
\text { ни діючих, та устаткування Аля монтажу) }\end{array}$ \\
\hline \multicolumn{4}{|c|}{$\begin{array}{l}\text { ЗгіАно з вимогами Мінфіну, Ао складу капітальних інвестицій не включають, а отже, не віАобра- } \\
\text { жають у цьому рялку форми № } 1 \text { вартість основних засобів і нематеріальних активів, внесених до } \\
\text { статутного капіталу підприємства або отриманих безоплатно, а також суму переоцінки необоротних } \\
\text { активів (див. мист Мінфіну віА 17.11.2003 р. № 31-04200-04-5/5570). }\end{array}$} \\
\hline
\end{tabular}


Продовження таблиці 2.2

\begin{tabular}{|c|c|c|c|}
\hline Назва статті & $\begin{array}{c}\text { КоА } \\
\text { ряАКа }\end{array}$ & $\begin{array}{c}\text { Ажерело } \\
\text { інформації } \\
\text { А^я заповнення }\end{array}$ & Примітка \\
\hline Основні засоби & 1010 & $\begin{array}{l}\text { РяА. } 1011 \text { - } \\
\text { ряА. } 1012\end{array}$ & $\begin{array}{l}\text { Наводять залишкову вартість власних і отриманих на умо- } \\
\text { вах фінансового лізингу об'єктів і орендованих цілісних } \\
\text { майнових комплексів, що вк^ючені до складу основних за- } \\
\text { собів відповідно Ао П(С)Бо 7; вартість основних засобів, } \\
\text { отриманих у довірче управління, на праві господарського } \\
\text { віАання або праві оперативного управління; вартість } \\
\text { інших необоротних матеріальних активів. Також окремо } \\
\text { показують: }\end{array}$ \\
\hline $\begin{array}{l}\text { первісна вар- } \\
\text { тість }\end{array}$ & 1011 & $\begin{array}{c}\text { СамьАо за Ат су- } \\
\text { брах. } 101-109 \text { i } \\
\text { pax. } 11\end{array}$ & $\begin{array}{l}\text { - первісну (переоцінену) вартість. Не вк^ючають Ао піА- } \\
\text { сумку балансу }\end{array}$ \\
\hline $3 \mathrm{HOC}$ & 1012 & $\begin{array}{c}\text { Самьдо за Кт суб- } \\
\text { рах. } 131 \text { і } 132\end{array}$ & $\begin{array}{l}\text { - нараховану в установленому порядку суму зносу. По- } \\
\text { казник наводять у Аужках. Не вк^ючають Ао підсумку } \\
\text { балансу }\end{array}$ \\
\hline \multirow{3}{*}{$\begin{array}{l}\text { Інвестиційна } \\
\text { нерухомість }\end{array}$} & \multirow{3}{*}{1015} & \multicolumn{2}{|c|}{ 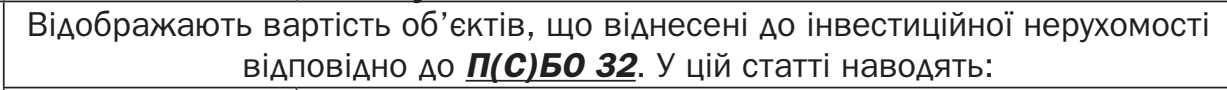 } \\
\hline & & \begin{tabular}{|c|} 
СальАо за Ат \\
субрах. 100 \\
(у частині \\
інвестиційної \\
нерухомості, що \\
обліковується за \\
справеАливою \\
вартістю) \\
\end{tabular} & $\begin{array}{l}\text { - справедливу вартість інвестиційної нерухомості (якщо } \\
\text { облік ведуть за справедливою вартістю) }\end{array}$ \\
\hline & & $\begin{array}{l}\text { РяА. } 1016 \text { - } \\
\text { ряА. } 1017\end{array}$ & $\begin{array}{l}\text { - залишкову вартість інвестиційної нерухомості (якщо } \\
\text { облік ведуть за первісною вартістю) }\end{array}$ \\
\hline $\begin{array}{l}\text { Аодатковий } \\
\text { рядок (Пер- } \\
\text { вісна вартість } \\
\text { інвестиційної } \\
\text { нерухомості) }\end{array}$ & 1016 & $\begin{array}{l}\text { Са^ьАо за Ат су- } \\
\text { брах. } 100 \text { (у ча- } \\
\text { стині інвестицій- } \\
\text { ної нерухомості, } \\
\text { що обліковуєть- } \\
\text { ся за первісною } \\
\text { вартістю) }\end{array}$ & $\begin{array}{l}\text { ВіАображають первісну вартість інвестиційної нерухомості, } \\
\text { яку обліковують за первісною вартістю. Не вк^ючають Ао } \\
\text { підсумку балансу }\end{array}$ \\
\hline $\begin{array}{l}\text { Аодатковий } \\
\text { рядок (Знос } \\
\text { інвестиційної } \\
\text { нерухомості) }\end{array}$ & 1017 & $\begin{array}{l}\text { СамьАо за Кт } \\
\text { субрах. } 135\end{array}$ & $\begin{array}{l}\text { Наводять суму зносу інвестиційної нерухомості, яку об- } \\
\text { ^іковують за первісною вартістю. Показник наводять у } \\
\text { Аужках. Не вк^ючають Ао піАсумку балансу }\end{array}$ \\
\hline \multirow{3}{*}{$\begin{array}{l}\text { Аовгостроко- } \\
\text { ві біологічні } \\
\text { активи }\end{array}$} & \multirow{3}{*}{1020} & \multicolumn{2}{|c|}{$\begin{array}{l}\text { ВіАображають вартість Аовгострокових біологічних активів, облік яких ве- } \\
\text { дуть віАповіАно до П(С)Бо } \mathbf{3 0} \text { У ц цій статті наводять: }\end{array}$} \\
\hline & & \begin{tabular}{|c|} 
СамьАо за Ат \\
субрах. 161, 163 \\
i 165 \\
\end{tabular} & $\begin{array}{l}\text { - справедливу вартість (якщо облік ведуть за справедли- } \\
\text { вою вартістю) }\end{array}$ \\
\hline & & $\begin{array}{c}\text { РяА. } 1021 \text { - ряА. } \\
1022\end{array}$ & $\begin{array}{l}\text { - залишкову вартість (якщо облік ведуть за первісною } \\
\text { вартістю) }\end{array}$ \\
\hline \begin{tabular}{|l|} 
АоАатковий \\
рядок \\
(Первісна \\
вартість Аов- \\
гострокових \\
біологічних \\
активів) \\
\end{tabular} & 1021 & $\begin{array}{c}\text { СальАо за Ат } \\
\text { субрах. } 162,164 \\
\text { і } 166\end{array}$ & $\begin{array}{l}\text { ВіАображають первісну вартість Аовгострокових біологіч- } \\
\text { них активів (якщо облік ведуть за первісною вартістю). Не } \\
\text { вк^ючають Ао піАсумку балансу }\end{array}$ \\
\hline
\end{tabular}


Продовження таблиці 2.2

\begin{tabular}{|c|c|c|c|}
\hline Назва статті & $\begin{array}{c}\text { КоА } \\
\text { ряАКа }\end{array}$ & $\begin{array}{c}\text { Ажерело } \\
\text { інформації } \\
\text { А^я заповнення }\end{array}$ & Примітка \\
\hline $\begin{array}{l}\text { Аодатковий } \\
\text { рядок } \\
\text { (Накопичена } \\
\text { амортизація } \\
\text { Аовгостроко- } \\
\text { вих біологічних } \\
\text { активів) }\end{array}$ & 1022 & $\begin{array}{l}\text { Самьдо за Кт } \\
\text { субрах. } 134\end{array}$ & $\begin{array}{l}\text { Показують суму накопиченої амортизації довгострокових } \\
\text { біологічних активів (якщо облік ведуть за первісною вар- } \\
\text { тістю). Показник наводять у дужках. Не вкмючають Ао } \\
\text { підсумку балансу }\end{array}$ \\
\hline
\end{tabular}

Слід мати на увазі: у ряд. 1020 - 1022 не відображають вартість тварин і багаторічних насаджень, не пов'язаних із сільськогосподарською діяльністю. Облік таких активів ведуть на субрах. 107 "Тварини" і 108 "Багаторічні насадження", а відомості про них наводять у рял. 1010 - 1012 форми № 1.

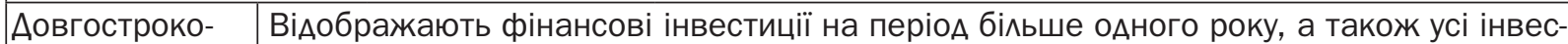
ві фінансові $\quad$ тиції, які не можуть бути вільно реалізовані в будь-який момент.

інвестиції: $\quad$ При цьому окремо виділяють:

\begin{tabular}{|c|c|c|c|}
\hline $\begin{array}{l}\text { такі, що обліко- } \\
\text { вуються за ме- } \\
\text { тодом участі в } \\
\text { капіталі інших } \\
\text { підприємств } \\
\end{array}$ & 1030 & $\begin{array}{l}\text { Сальдо за Ат } \\
\text { субрах. } 141\end{array}$ & 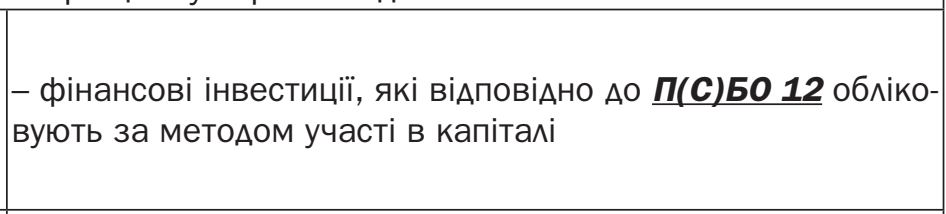 \\
\hline $\begin{array}{l}\text { інші фрінансові } \\
\text { інвестиції }\end{array}$ & 1035 & $\begin{array}{l}\text { СамьАо за Ат су- } \\
\text { брах. } 142 \text { і } 143 \\
\end{array}$ & $\begin{array}{l}\text { - інші фінансові інвестиції (інвестиції пов'язаним та не- } \\
\text { пов'язаним сторонам) }\end{array}$ \\
\hline $\begin{array}{l}\text { Аовгострокова } \\
\text { Аебіторська } \\
\text { заборгованість }\end{array}$ & 1040 & $\begin{array}{c}\text { Самьдо за Ат } \\
\text { субрах. } 181,182 \\
\text { i } 183\end{array}$ & $\begin{array}{l}\text { ВіАображають дебіторську заборгованість фізичних та юри- } \\
\text { Аичних осіб, що не виникає в ході нормального операцій- } \\
\text { ного циклу і буде погашена після } 12 \text { місяців з Аати балансу }\end{array}$ \\
\hline $\begin{array}{l}\text { ВіАстрочені по- } \\
\text { Ааткові активи }\end{array}$ & 1045 & $\begin{array}{l}\text { Самьдо за Ат } \\
\text { pax. } 17\end{array}$ & $\begin{array}{l}\text { ВіАображають суму податку на прибуток, що піАлягає віА- } \\
\text { шкодуванню в наступних періодах у результаті тимчасової } \\
\text { податкової різниці, що виникла між обліковою та податко- } \\
\text { вою базами оцінки }\end{array}$ \\
\hline \multicolumn{4}{|c|}{ У цьому рядку відображають віАстрочені податкові активи, визначені згідно з П(С)Бо 17.} \\
\hline $\begin{array}{l}\text { АоАатковий } \\
\text { ряАок (ГУАВі })\end{array}$ & 1050 & $\begin{array}{l}\text { СамьАо за Ат су- } \\
\text { брах. } 191 \text { і } 193 \\
\end{array}$ & $\begin{array}{l}\text { Наводять величину гудвіла, що виник у результаті придбан- } \\
\text { ня піАприємства та визначений віАповіАно Ао } \underline{\boldsymbol{\Pi ( C ) Б 0 ~ 1 9}}\end{array}$ \\
\hline $\begin{array}{l}\text { Інші необорот- } \\
\text { ні активи }\end{array}$ & 1090 & $\begin{array}{l}\text { Сальдо за Ат } \\
\text { субрах. } 184\end{array}$ & $\begin{array}{l}\text { Відображають вартість необоротних активів, які не мо- } \\
\text { жуть бути включені до наведених вище статей розділу I } \\
\text { активу форми № } 1\end{array}$ \\
\hline $\begin{array}{l}\text { Усього за роз- } \\
\text { Aілом I }\end{array}$ & 1095 & \multicolumn{2}{|c|}{$\begin{array}{c}\text { РяА. } 1000 \text { + ряА. } 1005 \text { + ряА. } 1010 \text { + ряА. } 1015 \text { + ряА. } 1020 \text { + ряА. } 1030 \text { + } \\
\text { ряА. } 1035 \text { + ряА. } 1040 \text { + ряА. } 1045 \text { + ряА. } 1050 \text { + ряА. } 1090\end{array}$} \\
\hline \multicolumn{4}{|r|}{ II. Оборотні активи } \\
\hline Запаси & 1100 & $\begin{array}{c}\text { СамьАо за Ат } \\
\text { рах. } 20,22,23, \\
25,26,27,28 \\
\text { (без урахування } \\
\text { самьАо за Ат } \\
\text { субрах. } 286 \text { і за } \\
\text { вирахуванням } \\
\text { самьАо за Кт } \\
\text { субрах. 285) }\end{array}$ & $\begin{array}{l}\text { Відображають загальну вартість запасів, що обліковують- } \\
\text { ся згіАно з П(С)Бо 9. У разі віАповіАності ознакам істот- } \\
\text { ності в Аодаткових статтях розшифровують інформацію } \\
\text { про складові ряА. } 1100\end{array}$ \\
\hline
\end{tabular}

Якщо піАприємство розшифровує Аані про всі запаси в Аодаткових ряд. 1101 - 1104, то рял. 1100 $==$ рял. $1101+$ рял. $1102+$ рял. $1103+$ рял. 1104. Якщо за наявності віАповіАних показників розшифровують не всі зазначені рядки, то значення ряд. 1100 перевищуватиме таку суму. 
Продовження таблиці 2.2

\begin{tabular}{|c|c|c|c|}
\hline Назва статті & $\begin{array}{c}\text { КоА } \\
\text { ряАКа }\end{array}$ & $\begin{array}{c}\text { Ажерело } \\
\text { інформації } \\
\text { А^я заповнення }\end{array}$ & Примітка \\
\hline $\begin{array}{l}\text { Аодатковий } \\
\text { рядок (Вироб- } \\
\text { ничі запаси) }\end{array}$ & 1101 & $\begin{array}{l}\text { СамьАо за Ат } \\
\text { рах. } 20 \text { і } 22\end{array}$ & $\begin{array}{l}\text { ВіАображають вартість запасів малоцінних і швилкозношу- } \\
\text { ваних предметів, сировини, основних і допоміжних мате- } \\
\text { ріалів, палива, покупних напівфабрикатів і комплектуючих } \\
\text { виробів, запасних частин, тари, будівельних матеріалів та } \\
\text { інших матеріалів, призначених для споживання в ході нор- } \\
\text { мального операційного циклу (у тому числі із рял. 1100). Не } \\
\text { вк^ючають до підсумку балансу }\end{array}$ \\
\hline $\begin{array}{l}\text { Аодатковий } \\
\text { рядок } \\
\text { (Незавершене } \\
\text { виробництво) }\end{array}$ & 1102 & $\begin{array}{l}\text { Самьдо за Ат } \\
\text { pax. } 23 \text { i } 25\end{array}$ & $\begin{array}{l}\text { Наводять витрати на незавершене виробництво і незавер- } \\
\text { шені роботи (послуги), а також вартість напівфабрикатів } \\
\text { власного виробництва (у тому числі із ряА. 1100). Крім } \\
\text { того, в цьому рядку наводять валову заборгованість за- } \\
\text { мовників за будівельними контрактами. Не вк^ючають Ао } \\
\text { підсумку бамансу }\end{array}$ \\
\hline $\begin{array}{l}\text { АоАатковий } \\
\text { рядок } \\
\text { (Готова продук- } \\
\text { ція) }\end{array}$ & 1103 & $\begin{array}{c}\text { Самьдо за Ат } \\
\text { рах. } 26 \text { і } 27\end{array}$ & $\begin{array}{l}\text { ВіАображають запаси виробів на склаАі, обробка яких за- } \\
\text { вершена і які пройшли випробування, приймання, укомп- } \\
\text { ^ектовані віАповіАно до умов Аоговорів із замовниками і } \\
\text { відповіАають технічним умовам і стандартам (у тому числі } \\
\text { із ряд. 1100). Не вк^ючають до піАсумку балансу }\end{array}$ \\
\hline
\end{tabular}

Продукцію, що не відповідає приведеним вимогам (крім браку), і роботи, не прийняті замовником, наводять у скиалі незавершеного виробництва (ряд. 1102 форми № 1).

\begin{tabular}{|c|c|c|c|}
\hline $\begin{array}{l}\text { Аодатковий } \\
\text { рядок (Товари) }\end{array}$ & 1104 & \begin{tabular}{|c|} 
Згорнуте саАьАо \\
за Ат рах. 28 без \\
врахування суб- \\
рах. 286 (са^ьАо \\
за Ат субрах. \\
$281,282,283$ і \\
284 за вираху- \\
ванням са^ьАо за \\
Кт субрах. 285 )
\end{tabular} & $\begin{array}{l}\text { ВіАображають вартість залишків товарів, придбаних } \\
\text { піАприємством Аля подальшого продажу, без суми торго- } \\
\text { вих націнок (у тому числі із ряА. 1100). Не вк^ючають Ао } \\
\text { підсумку балансу }\end{array}$ \\
\hline
\end{tabular}

у цьому рядку не відображають інформацію про вартість необоротних активів і груп вибуття, визнаних утримуваними Аля продажу віАповіАно Ао П(С)БО 27 (сальАо за Ат субрах. 286). Інформацію про такі активи наводять у ряА. 1200 форми № 1.

\begin{tabular}{|c|c|c|c|}
\hline $\begin{array}{l}\text { Поточні біоло- } \\
\text { гічні активи }\end{array}$ & 1110 & $\begin{array}{c}\text { СамьАо за Ат } \\
\text { рах. } 21\end{array}$ & 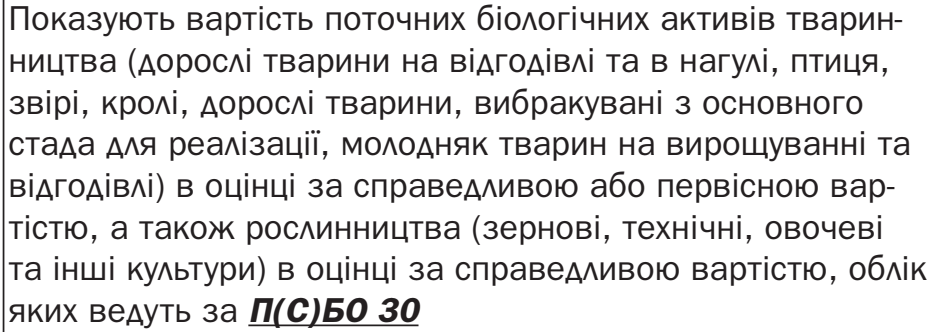 \\
\hline
\end{tabular}

У цій статті не вінображають вартість поточних біологічних активів, не пов'язаних із сільськогоспоАарською Аіяльністю. Їх облік ведуть на рах. 22 "Малоцінні та швидкозношувані преАмети" і віАображають у ряд. 1100 і 1101 форми № 1.

\begin{tabular}{|c|c|c|c|}
\hline $\begin{array}{l}\text { АоАатковий } \\
\text { ряАок } \\
\text { (Векселі одер- } \\
\text { жані) }\end{array}$ & 1120 & $\begin{array}{c}\text { Сальдо за Ат } \\
\text { рах. } 34\end{array}$ & $\begin{array}{l}\text { ВіАображають забезпечену векселями заборгованість } \\
\text { покупців, замовників та інших дебіторів за відвантажену } \\
\text { продукцію (товари), інші активи, виконані роботи та нада- } \\
\text { ні послуги. Показник дебіторської заборгованості в разі } \\
\text { створення щодо неї резерву сумнівних боргів наводять у } \\
\text { балансі за чистою реалізаційною вартістю }\end{array}$ \\
\hline
\end{tabular}


Продовження таблиці 2.2

\begin{tabular}{|c|c|c|c|}
\hline Назва статті & $\begin{array}{c}\text { КоА } \\
\text { ряАКа }\end{array}$ & $\begin{array}{c}\text { Ажерело } \\
\text { інформації } \\
\text { А^я заповнення }\end{array}$ & Примітка \\
\hline $\begin{array}{l}\text { Аебіторська } \\
\text { заборгованість } \\
\text { за продукцію, } \\
\text { товари, робо- } \\
\text { ти, послуги }\end{array}$ & 1125 & $\begin{array}{c}\text { СаАьАо за Ат } \\
\text { рах. } 36 \text { і } 34 \\
\text { (якщо векселі } \\
\text { оАержані не віАо- } \\
\text { бражені окремо } \\
\text { в ряА. 1120) } \\
\text { мінус самьАо за } \\
\text { Кт рах. } 38 \\
\end{array}$ & $\begin{array}{l}\text { Відображають дебіторську заборгованість покупців або } \\
\text { замовників за надані їм продукцію, товари, роботи або } \\
\text { послуги (крім заборгованості, забезпеченої векселями, } \\
\text { якщо таку інформацію наведено в окремій статті форми } \\
\text { № 1). У цьому рядку потрібно відображати чисту реалізаці- } \\
\text { йну вартість дебіторської заборгованості, тобто за міну- } \\
\text { сом нарахованого резерву сумнівних боргів }\end{array}$ \\
\hline \multicolumn{3}{|c|}{$\begin{array}{l}\text { Аебіторська заборгованість за розрахун- } \\
\text { ками: }\end{array}$} & $\begin{array}{l}\text { Показники дебіторської заборгованості в разі створення } \\
\text { щодо неї резерву сумнівних боргів наводять у формі № } 1 \\
\text { за чистою реалізаційною вартістю }\end{array}$ \\
\hline $\begin{array}{l}\text { за виданими } \\
\text { авансами }\end{array}$ & 1130 & $\begin{array}{l}\text { СальАо за Ат } \\
\text { субрах. } 371\end{array}$ & $\begin{array}{l}\text { Наводять залишок суми авансів, наАаних іншим пілприєм- } \\
\text { ствам у рахунок майбутніх постачань, якщо завершення } \\
\text { розрахунків за договорами планується протягом } 12 \text { міся- } \\
\text { ців з дати балансу. Інакше суми перерахованих авансів } \\
\text { відображають у рял. } 1040 \text { форми № } 1 \text { (Аив. мист Мінфіну } \\
\text { віА 29.04.2013 р. № 31-08410-07-29/13727) }\end{array}$ \\
\hline
\end{tabular}

На практиці часто не віАображають аванси, видані іншим підприємствам, на субрах. 371. При цьому вважають за краще робити проводку Ат 63 - Кт 30, 31, порушуючи вимоги Інструкції № 291. У такому разі сальдо за рах. 63 у формі № 1 сліл віАображати розгорнуто: у ряА. 1130 - Аебетові залишки рах. 63 за контрагентами та договорами, за якими перераховано аванси, а в ряд. 1615 - кредитові залишки рах. 63, тобто заборгованість перед контрагентами за окремими договорами (рахунками).

\begin{tabular}{|c|c|c|c|}
\hline \multirow[b]{2}{*}{ з бюАжетом } & \multirow[b]{2}{*}{1135} & $\begin{array}{l}\text { Са^ьАо за Ат су- } \\
\text { брах. } 641 \text { і } 642\end{array}$ & \multirow{2}{*}{$\begin{array}{l}\text { Відображають дебіторську заборгованість фінансових } \\
\text { і податкових органів, а також переплату за податками, } \\
\text { зборами та іншими платежами до бюджету }\end{array}$} \\
\hline & & $\begin{array}{c}\text { Ряа. } 1135 \geq \text { ряа. } \\
1136\end{array}$ & \\
\hline $\begin{array}{l}\text { у тому числі } \\
\text { з податку на } \\
\text { прибуток }\end{array}$ & 1136 & $\begin{array}{l}\text { СамьАо за Ат } \\
\text { субрах. } 641 \text { (у } \\
\text { частині поАатку } \\
\text { на прибуток) }\end{array}$ & $\begin{array}{l}\text { ВіАображають Аебіторську заборгованість } \\
\text { за розрахунками з бюджетом у частині податку на прибу- } \\
\text { ток (у тому числі з рял. 1135). Не вкАючають Ао підсумку } \\
\text { бамансу }\end{array}$ \\
\hline $\begin{array}{l}\text { Аодатковий } \\
\text { рядок (Аебітор- } \\
\text { ська забор- } \\
\text { гованість за } \\
\text { розрахунками } \\
\text { з нарахованих } \\
\text { доходів) }\end{array}$ & 1140 & $\begin{array}{l}\text { СальАо за Ат } \\
\text { субрах. } 373\end{array}$ & $\begin{array}{l}\text { ВіАображають суму дебіторської заборгованості за ди- } \\
\text { віАендами, процентами, роялті тощо, що нараховані та } \\
\text { піАлягають надходженню }\end{array}$ \\
\hline $\begin{array}{l}\text { Аодатковий } \\
\text { рядок (Аебітор- } \\
\text { ська забор- } \\
\text { гованість за } \\
\text { розрахунками } \\
\text { із внутрішніх } \\
\text { розрахунків) }\end{array}$ & 1145 & $\begin{array}{l}\text { СальАо за Ат су- } \\
\text { брах. } 682 \text { і } 683\end{array}$ & $\begin{array}{l}\text { Показують заборгованість пов'язаних сторін і дебіторську } \\
\text { заборгованість за внутрішніми розрахунками, зокрема } \\
\text { між учасниками групи }\end{array}$ \\
\hline $\begin{array}{l}\text { Інша поточна } \\
\text { Аебіторська } \\
\text { заборгованість }\end{array}$ & 1155 & $\begin{array}{c}\text { СамьАо за Ат су- } \\
\text { брах. } 372,374, \\
375,376,377, \\
378,379 \text { і } 685 \\
\text { pax. } 65 \text { і } 66\end{array}$ & $\begin{array}{l}\text { ВіАображають заборгованість дебіторів, що не може бути } \\
\text { вк^ючена до інших статей дебіторської заборгованості та } \\
\text { піАлягає відображенню у складі оборотних активів }\end{array}$ \\
\hline
\end{tabular}


Продовження таблиці 2.2

\begin{tabular}{|c|c|c|c|}
\hline Назва статті & $\begin{array}{c}\text { КоА } \\
\text { ряАКа }\end{array}$ & $\begin{array}{c}\text { Ажерело } \\
\text { інформації } \\
\text { А^я заповнення }\end{array}$ & Примітка \\
\hline $\begin{array}{l}\text { Поточні фінан- } \\
\text { сові інвестиції }\end{array}$ & 1160 & $\begin{array}{l}\text { СамьАо за Ат } \\
\text { субрах. } 352\end{array}$ & $\begin{array}{l}\text { ВіАображають фінансові інвестиції на строк, що не пере- } \\
\text { вищує одного року, які можуть бути вільно реалізовані в } \\
\text { будь-який момент (крім інвестицій, що є еквівалентами } \\
\text { грошових коштів), а також суму Аовгострокових фінансо- } \\
\text { вих інвестицій, що піляягають погашенню протягом } 12 \\
\text { місяців з дати балансу }\end{array}$ \\
\hline $\begin{array}{l}\text { Гроші та їх } \\
\text { еквіваленти }\end{array}$ & 1165 & \begin{tabular}{|c|} 
Са^ьАо за Ат \\
pax. $\mathbf{3 0 ,} \mathbf{3 1}, \mathbf{c y -}$ \\
брах. $\mathbf{3 3 3}, \mathbf{3 3 4}$, \\
$\mathbf{3 3 5}$ i $\mathbf{3 5 1}$ \\
РяА. $1165 \geq$ \\
ряА. $1166+$ ряА. \\
1167
\end{tabular} & $\begin{array}{l}\text { ВіАображають кошти в касі піАприємства, на поточних та } \\
\text { інших рахунках у банках, які можуть бути вільно вико- } \\
\text { ристані Аля поточних операцій, грошові кошти в Аорозі, } \\
\text { електронні гроші, а також еквіваленти грошових коштів } \\
\text { (як у національній, так і в іноземній валюті). У Аолаткових } \\
\text { рядках цієї статті окремо можуть бути наведені: }\end{array}$ \\
\hline \begin{tabular}{l|} 
АоАатковий \\
рядок (Готівка)
\end{tabular} & 1166 & $\begin{array}{c}\text { Са^ьАо за Aт } \\
\text { pax. } 30\end{array}$ & $\begin{array}{l}\text { - грошові кошти в готівковій формі (у тому числі із ряА. } \\
\text { 1165). Не вк^ючають Ао піАсумку балансу }\end{array}$ \\
\hline $\begin{array}{l}\text { Аодатковий } \\
\text { рядок (Рахунки } \\
\text { в банках) }\end{array}$ & 1167 & $\begin{array}{l}\text { Самьдо за Ат } \\
\text { pax. } 31\end{array}$ & $\begin{array}{l}\text { - грошові кошти на банківських рахунках піАприємства } \\
\text { (у тому числі з рял. 1165). Не вк^ючають до піАсумку } \\
\text { балансу }\end{array}$ \\
\hline $\begin{array}{l}\text { Зверніть увагу: } \\
\text { Ансу або протя } \\
\text { активів і відобр }\end{array}$ & кошти, & $\begin{array}{l}\text { які не можнна викс } \\
\text { ераційного циклу в } \\
\text { як необоротні акти }\end{array}$ & $\begin{array}{l}\text { ористовувати Аля операцій протягом одного року з Аати ба- } \\
\text { результаті обмежень, сліА виключати зі складу оборотних } \\
\text { иви. }\end{array}$ \\
\hline $\begin{array}{l}\text { Витрати май- } \\
\text { бутніх періодів }\end{array}$ & 1170 & $\begin{array}{l}\text { СамьАо за Ат } \\
\text { pax. } 39\end{array}$ & $\begin{array}{l}\text { Наводять витрати, що понесені протягом поточного або } \\
\text { попередніх звітних періодів, але належать до майбутніх } \\
\text { звітних періодів }\end{array}$ \\
\hline $\begin{array}{l}\text { Інші оборотні } \\
\text { активи }\end{array}$ & 1190 & $\begin{array}{l}\text { Самьдо за Ат су- } \\
\text { брах. } 331,332 \\
643 \text { і } 644\end{array}$ & $\begin{array}{l}\text { ВіАображають суми оборотних активів, які не можуть бути } \\
\text { включені до наведених вище статей розділу II активу фор- } \\
\text { ми № 1, зокрема вартість грошових документів у націо- } \\
\text { нальній та іноземній валютах }\end{array}$ \\
\hline $\begin{array}{l}\text { Усього за роз- } \\
\text { Аілом II }\end{array}$ & 1195 & \multicolumn{2}{|c|}{$\begin{array}{c}\text { РяА. } 1100 \text { + ряА. } 1110 \text { + ряА. } 1120 \text { + ряА. } 1125 \text { + ряА. } 1130+\text { + ряА. } 1135 \\
\text { + ряА. } 1140 \text { + ряА. } 1145 \text { + ряА. } 1155 \text { + ряА. } 1160+\text { + ряА. } 1165+\text { ряА. } \\
1170 \text { + ряА. } 1190\end{array}$} \\
\hline $\begin{array}{l}\text { III. Необоротні } \\
\text { активи, утри- } \\
\text { мувані А^я про- } \\
\text { Аажу, та групи } \\
\text { вибуття }\end{array}$ & 1200 & $\begin{array}{l}\text { СамьАо за Ат } \\
\text { субрах. } 286\end{array}$ & $\begin{array}{l}\text { ВіАображають вартість необоротних активів і груп вибут- } \\
\text { тя, утримуваних Аля продажу, що визначають віАповіАно } \\
\text { Ао П()БО } 27\end{array}$ \\
\hline Баманс & 1300 & & РяА. 1095 + ряА. 1195 + ряА. 1200 \\
\hline \multicolumn{4}{|c|}{$\begin{array}{l}\text { Показники ряд. } 1300 \text { гр. } 3 \text { і } 4 \text { форми № } 1 \text { повинні відповідати показникам ряд. } 1900 \text { гр. } 3 \text { і } 4 \text { фор- } \\
\text { ми № } 1 .\end{array}$} \\
\hline \multicolumn{4}{|r|}{ ПАСИВ } \\
\hline \multicolumn{4}{|r|}{ І. В^асний капіта^ } \\
\hline $\begin{array}{l}\text { Зареєстрова- } \\
\text { ний (пайовий) } \\
\text { капіта^ }\end{array}$ & 1400 & $\begin{array}{l}\text { Самьдо за Кт } \\
\text { рах. } 40\end{array}$ & $\begin{array}{l}\text { Наводять зафіксовану в установчих Аокументах суму ста- } \\
\text { тутного капіталу, іншого зареєстрованого капіталу, а також } \\
\text { пайового капіталу, що формується віАповіАно Ао законо- } \\
\text { Аавства. Крім того, на наш погляА, тут сліА віАображати } \\
\text { суму внесків Ао оголошеного, але ще не зареєстрованого } \\
\text { статутного капіталу }\end{array}$ \\
\hline $\begin{array}{l}\text { Аодатковий } \\
\text { рядок (Внески } \\
\text { Ао незареє- } \\
\text { строваного } \\
\text { статутного } \\
\text { капіталу) } \\
\end{array}$ & 1401 & $\begin{array}{l}\text { Сальдо за Кт } \\
\text { субрах. } 404\end{array}$ & $\begin{array}{l}\text { ВіАображають суму внесків Ао оголошеного, але ще не } \\
\text { зареєстрованого статутного капіталу (у тому числі з ряА. } \\
\text { 1400). Не вк^ючають Ао підсумку балансу }\end{array}$ \\
\hline
\end{tabular}


Продовження таблиці 2.2

\begin{tabular}{|c|c|c|c|}
\hline Назва статті & $\begin{array}{c}\text { КоА } \\
\text { ряАКа }\end{array}$ & $\begin{array}{c}\text { Ажере^о } \\
\text { інформації } \\
\text { А^я заповнення }\end{array}$ & Примітка \\
\hline $\begin{array}{l}\text { Капіта^ у Аоо- } \\
\text { цінках }\end{array}$ & 1405 & $\begin{array}{c}\text { Са^ьA0 3a Kт } \\
\text { pax. } 41\end{array}$ & $\begin{array}{l}\text { Наводять суму Аооцінки необоротних активів і фінансових } \\
\text { інструментів, відображкену у власному капіталі }\end{array}$ \\
\hline \multirow{3}{*}{$\begin{array}{l}\text { Аолатковий } \\
\text { капітал } \\
\text { (самьАо за Кт } \\
\text { 42) }\end{array}$} & \multirow[b]{3}{*}{1410} & $\begin{array}{l}\text { СамьАо за Кт } \\
\text { субрах. } 421\end{array}$ & Господарські товариства показують емісійний дохіА \\
\hline & & $\begin{array}{l}\text { СамьАо за Кт } \\
\text { субрах. } 422\end{array}$ & $\begin{array}{l}\text { Показують суму іншого вкладеного засновниками піАпри- } \\
\text { ємств (крім акціонерних товариств) капіталу, що переви- } \\
\text { щує статутний капітал }\end{array}$ \\
\hline & & \begin{tabular}{|c|} 
СамьАо за Кт су- \\
брах. $\mathbf{4 2 3 , 4 2 4}$ \\
$\mathbf{4 2 5}$ \\
РяА. $1410 \geq$ \\
ряА. $1411+$ ряА. \\
1412
\end{tabular} & $\begin{array}{l}\text { Наводять вартість безоплатно отриманих піАприємством } \\
\text { віА інших юридичних або фізичних осіб необоротних } \\
\text { активів, накопичені курсові різниці, які віАповідно до П(С) } \\
\text { БО відображають у складі власного капіталу, та інші види } \\
\text { додаткового капіталу }\end{array}$ \\
\hline $\begin{array}{l}\text { АоАатковий } \\
\text { ряАок (Емісій- } \\
\text { ний АохіА) }\end{array}$ & 1411 & $\begin{array}{l}\text { Самьдо за Кт } \\
\text { субрах. } 421\end{array}$ & $\begin{array}{l}\text { Господарські товариства АовіАково можуть показувати } \\
\text { суму емісійного Аоходу (у тому числі із ряА. 1410). Не } \\
\text { вк^ючають Ао підсумку балансу }\end{array}$ \\
\hline $\begin{array}{l}\text { АоАатковий } \\
\text { рядок (Нако- } \\
\text { пичені курсові } \\
\text { різниці) }\end{array}$ & 1412 & $\begin{array}{l}\text { СамьАо за Кт } \\
\text { субрах. } 423\end{array}$ & $\begin{array}{l}\text { Відображають суму накопичених курсових різниць, які } \\
\text { вк^ючають Ао складу Аодаткового капіталу і визнають в } \\
\text { іншому сукупному доході (у тому числі з рял. 1410). Не } \\
\text { вк^ючають Ао підсумку бамансу }\end{array}$ \\
\hline \multicolumn{4}{|c|}{ 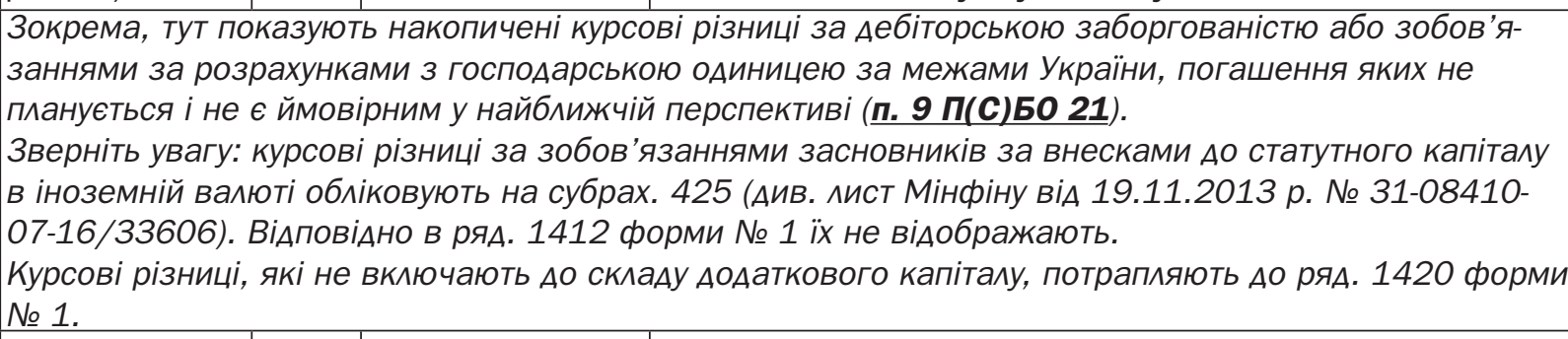 } \\
\hline $\begin{array}{l}\text { Резервний } \\
\text { капітал }\end{array}$ & 1415 & $\begin{array}{l}\text { Сальдо за Kт } \\
\text { рах. } 43\end{array}$ & $\begin{array}{l}\text { Наводять суму резервів, створених відповідно до чинно- } \\
\text { го законодавства або установчих документів за рахунок } \\
\text { нерозподіленого прибутку підприємства }\end{array}$ \\
\hline $\begin{array}{l}\text { Нерозподіле- } \\
\text { ний прибуток } \\
\text { (непокритий } \\
\text { збиток) }\end{array}$ & 1420 & $\begin{array}{l}\text { СальАо за Кт суб- } \\
\text { рах. } 441 \text { (або за } \\
\text { Ат субрах. 442) }\end{array}$ & $\begin{array}{l}\text { ВіАображають суму нерозподіленого прибутку (сальАо } \\
\text { за Кт субрах. 441) або непокритого збитку (сальдо за Ат } \\
\text { субрах. 442). Суму непокритого збитку наводять у Аужках } \\
\text { і віднімають при визначенні підсумку власного капіталу }\end{array}$ \\
\hline \multirow{2}{*}{$\begin{array}{l}\text { Неоплачений } \\
\text { капіта^ }\end{array}$} & \multirow{2}{*}{1425} & $\begin{array}{l}\text { Cа^ьAо за Aт } \\
\text { pax. } 46\end{array}$ & $\begin{array}{l}\text { Відображають суму заборгованості власників (учасників) } \\
\text { за внесками до статутного капіталу. Показник наводять }\end{array}$ \\
\hline & & \begin{tabular}{|c|} 
Рян. 1425 ड ряА. \\
1400
\end{tabular} & $\begin{array}{l}\text { у Аужках і віднімають при визначенні підсумку власного } \\
\text { капіталу }\end{array}$ \\
\hline \multirow{2}{*}{$\begin{array}{l}\text { Вилучений } \\
\text { капітал }\end{array}$} & \multirow{2}{*}{1430} & $\begin{array}{l}\text { СальАо за Aт } \\
\text { pax. } 45\end{array}$ & \multirow{2}{*}{$\begin{array}{l}\text { Господарські товариства віАображають фактичну собівар- } \\
\text { тість акцій власної емісії або часток, викуплених товари- } \\
\text { ством у його учасників. Показник наводять у дужках і } \\
\text { віднімають при визначенні підсумку власного капіталу }\end{array}$} \\
\hline & & $\begin{array}{c}\text { Ряа. } 1430 \leq \text { рян. } \\
1400\end{array}$ & \\
\hline $\begin{array}{l}\text { Усього за роз- } \\
\text { Aі^ом I }\end{array}$ & 1495 & РяA. $1400+$ ря & $\begin{array}{l}\text { А. } 1405 \text { + ряА. } 1410 \text { + ряА. } 1415 \text { + (-) ряА. } 1420 \text { - - ряА. } \\
1425 \text { - ряА. } 1430\end{array}$ \\
\hline \multicolumn{4}{|c|}{ II. Аовгострокові зобов'язання і забезпечення } \\
\hline $\begin{array}{l}\text { ВіАстрочені } \\
\text { податкові зо- } \\
\text { бов'язання }\end{array}$ & 1500 & $\begin{array}{l}\text { Сальдо за Кт } \\
\text { рах. } 54\end{array}$ & $\begin{array}{l}\text { ВіАображають суму податку на прибуток, що піАлягає } \\
\text { сплаті в майбутніх періодах у результаті утворення тим- } \\
\text { часової податкової різниці між обліковою та податковою } \\
\text { базами оцінки }\end{array}$ \\
\hline
\end{tabular}


Продовження таблиці 2.2

\begin{tabular}{|c|c|c|c|}
\hline Назва статті & $\begin{array}{c}\text { КоА } \\
\text { ряАКа }\end{array}$ & $\begin{array}{c}\text { Ажерело } \\
\text { інформації } \\
\text { А^я заповнення }\end{array}$ & Примітка \\
\hline \begin{tabular}{|l|} 
АоАатковий ря- \\
Аок (Пенсійні \\
зобов'язання) \\
\end{tabular} & 1505 & $\begin{array}{l}\text { Сальдо за Кт } \\
\text { субрах. } 472\end{array}$ & $\begin{array}{l}\text { Наводять суму Аовгострокових зобов'язань, пов'язаних } \\
\text { виплатами працівникам після закінчення трудової Аіяльнос }\end{array}$ \\
\hline \multicolumn{4}{|c|}{ Порядок обліку цих зобов'язань установлено пп. 13 - 29 П(С)БО 26.} \\
\hline $\begin{array}{l}\text { Аовгострокові } \\
\text { кредити банків }\end{array}$ & 1510 & $\begin{array}{c}\text { СамьАо за Кт су- } \\
6 \text { рах. 501, 502, } \\
503 \text { i } 504 \\
\end{array}$ & $\begin{array}{l}\text { ВіАображають суму заборгованості піАприємства банкам } \\
\text { за отриманими віА них позиками, які не є поточними } \\
\text { зобов'язаннями }\end{array}$ \\
\hline $\begin{array}{l}\text { Інші Аовгостро- } \\
\text { кові зобов'я- } \\
\text { зання }\end{array}$ & 1515 & $\begin{array}{c}\text { СамьАо за Кт } \\
\text { субрах. } 505 \text { i } \\
506, \text { pax. } 51,52 \\
53,55\end{array}$ & $\begin{array}{l}\text { Наводять суму Аовгострокової заборгованості піАприєм- } \\
\text { ства із залучення позикових коштів (крім кредитів банків } \\
\text { а також суму інших довгострокових зобов'язань, які не } \\
\text { можуть бути включені до інших статей розділу II пасиву } \\
\text { форми № } 1\end{array}$ \\
\hline $\begin{array}{l}\text { Аовгострокові } \\
\text { забезпечення }\end{array}$ & 1520 & \begin{tabular}{|c|} 
СамьАо за Кт \\
субрах. $\mathbf{4 7 1}$, \\
$\mathbf{4 7 3 , 4 7 4 ,} \mathbf{4 7 7}$, \\
$\mathbf{4 7 8}$ (у частині \\
Аовгострокових \\
забезпечень) \\
РяА. $1520 \geq$ ряА. \\
1521 \\
\end{tabular} & $\begin{array}{l}\text { Вілображають залишок коштів на Аовгострокові забез- } \\
\text { печення майбутніх витрат і платежів (на забезпечення } \\
\text { гарантійних зобов'язань, на виконання зобов'язань за } \\
\text { обтяжливими контрактами тощо), у тому числі на Аовго- } \\
\text { строкові забезпечення виплат персоналу }\end{array}$ \\
\hline
\end{tabular}

Зазначимо: згіАно з п. 2.52 МетодрекоменАацій № 433 у цьому ряАКу віАображають такожк Аовгострокові забезпечення на оплату майбутніх віАпусток працівникам.

\begin{tabular}{|c|c|c|c|}
\hline \begin{tabular}{|l} 
АоАатковий \\
рядок \\
(Аовгострокові \\
забезпечення \\
витрат персо- \\
налу) \\
\end{tabular} & 1521 & $\begin{array}{c}\text { СамьАо за Кт } \\
\text { субрах. 471, } \\
477 \text { (у частині } \\
\text { Аовгострокових } \\
\text { забезпечень ви- } \\
\text { пмат персонаму) }\end{array}$ & $\begin{array}{l}\text { ВіАображають залишок забезпечень майбутніх витрат і } \\
\text { платежів, що стосуються Аовгострокових виплат персона- } \\
\text { лу, нарахованих віАповіАно Ао П(С)Бо } 26 \text { (у тому числі з } \\
\text { ряА. 1520). Не вкмючають Ао піАсумку бамансу }\end{array}$ \\
\hline $\begin{array}{l}\text { Цільове фінан- } \\
\text { сування }\end{array}$ & 1525 & $\begin{array}{c}\text { СамьАо за Kт } \\
\text { pax. } 48 \\
\text { РяА. } 1525 \geq \text { ряА. } \\
1526\end{array}$ & $\begin{array}{l}\text { Наводять залишок коштів цільового фінансування і цільо- } \\
\text { вих наАходжень, отриманих з бюАжету та інших джерел }\end{array}$ \\
\hline
\end{tabular}

Зверніть увагу: у цій статті підприємства - платники податку на прибуток сереА іншого відображають суми грошових коштів, вивільнені віА оподаткування у зв'язку з наданням пільг з податку на прибуток. У бухгалтерському обліку суму податку на прибуток, не сплачену до бюджету унаслідок звільнення, показують записом: Ат рах. 98 - Кт субрах. 481.

\begin{tabular}{|c|c|c|c|}
\hline $\begin{array}{l}\text { АоАатковий ря- } \\
\text { Аок (БлагоАій- } \\
\text { на Аопомога) }\end{array}$ & 1526 & $\begin{array}{l}\text { СальАо за Кт } \\
\text { субрах. } 483\end{array}$ & $\begin{array}{l}\text { ВіАображають залишок коштів (вартість товарів, робіт, по- } \\
\text { слуг), отриманих як благоАійна Аопомога, які віАповіАно Ао } \\
\text { законодавства звільняються віА обкладення ПАВ (у тому } \\
\text { числі із ряА. 1525). Не вкмючають Ао підсумку балансу }\end{array}$ \\
\hline $\begin{array}{l}\text { Усього за роз- } \\
\text { Aілом II }\end{array}$ & 1595 & \multicolumn{2}{|c|}{ РяА. 1500 + ряА. 1505 + ряА. 1510 + ряА. 1515 + ряА. 1520 + ряА. 1525} \\
\hline \multicolumn{4}{|c|}{ III. Поточні зобов'язання і забезпечення } \\
\hline $\begin{array}{l}\text { Короткостро- } \\
\text { кові кредити } \\
\text { банків } \\
\end{array}$ & 1600 & $\begin{array}{l}\text { СамьАо за Кт } \\
\text { рах. } 31 \text { (овер- } \\
\text { Арафт) і } 60\end{array}$ & $\begin{array}{l}\text { Відображають суму поточних зобов'язань підприємства } \\
\text { перед банками за отриманими віА них кредитами }\end{array}$ \\
\hline \multicolumn{4}{|c|}{$\begin{array}{l}\text { У цьому рядку не наводять інформацію про інші отримані короткострокові позики (крім банків- } \\
\text { ських). Небанківські позики включають до рял. } 1690 .\end{array}$} \\
\hline \begin{tabular}{|l|} 
АоАатковий \\
рядок \\
(Векселі видані) \\
\end{tabular} & 1605 & $\begin{array}{l}\text { СамьАо за Kт } \\
\text { pax. } 62\end{array}$ & $\begin{array}{l}\text { Показують суму заборгованості, на яку підприємство } \\
\text { видало векселі в забезпечення поставок товарів (робіт, } \\
\text { послуг) постачальників, підрядників та інших кредиторів }\end{array}$ \\
\hline
\end{tabular}


Продовження таблиці 2.2

\begin{tabular}{|c|c|c|c|}
\hline Назва статті & $\begin{array}{c}\text { КоА } \\
\text { ряАКа }\end{array}$ & $\begin{array}{c}\text { Ажерело } \\
\text { інформації } \\
\text { А^я заповнення }\end{array}$ & Примітка \\
\hline \multicolumn{4}{|c|}{ Поточна кредиторська заборгованість за: } \\
\hline $\begin{array}{l}\text { Аовгострокови- } \\
\text { ми зобов'язан- } \\
\text { нями }\end{array}$ & 1610 & $\begin{array}{l}\text { Самьдо за Кт } \\
\text { pax. } 61\end{array}$ & $\begin{array}{l}\text { ВіАображають суму Аовгострокових зобов'язань, що піА- } \\
\text { ^ягає погашенню протягом } 12 \text { місяців з дати балансу }\end{array}$ \\
\hline $\begin{array}{l}\text { товари, робо- } \\
\text { ти, послуги }\end{array}$ & 1615 & \begin{tabular}{|} 
СамьАо за Кт \\
рах. 63, 62 \\
(якщо векселі \\
виАані не віАо- \\
бражено окремо \\
в ряА. 1605) \\
\end{tabular} & $\begin{array}{l}\text { Відображають суму заборгованості переА постачальника- } \\
\text { ми та підрядниками за матеріальні цінності, виконані робо- } \\
\text { ти та отримані послуги (крім заборгованості, забезпеченої } \\
\text { векселями, якщо їі наводять в окремій статті форми № 1) }\end{array}$ \\
\hline \multirow{2}{*}{$\begin{array}{l}\text { розрахунками } \\
\text { з бюджетом }\end{array}$} & \multirow{2}{*}{1620} & \begin{tabular}{|c|} 
СальАо за Кт суб- \\
рах. 641 і 642 \\
\end{tabular} & \multirow{2}{*}{$\begin{array}{l}\text { Наводять заборгованість піАприємства за всіма видами } \\
\text { платежів до бюджету, включаючи податки } 3 \text { працівників } \\
\text { підприємства }\end{array}$} \\
\hline & & \begin{tabular}{|c|} 
Рян. $1620 \geq$ ряА. \\
1621
\end{tabular} & \\
\hline $\begin{array}{l}\text { у тому числі } \\
3 \text { податку на } \\
\text { прибуток }\end{array}$ & 1621 & \begin{tabular}{|} 
Са^ьАо за Кт \\
субрах. 641 (у \\
частині заборго- \\
ваності з подат- \\
ку на прибуток) \\
\end{tabular} & $\begin{array}{l}\text { ВіАображають заборгованість піАприємства перед бюАже- } \\
\text { том з поточного податку на прибуток (у тому числі із ряА. } \\
\text { 1620). Не вк^ючають Ао підсумку балансу }\end{array}$ \\
\hline $\begin{array}{l}\text { розрахунками } \\
\text { зі страхування }\end{array}$ & 1625 & $\begin{array}{l}\text { Сальдо за Кт } \\
\text { pax. } 65\end{array}$ & $\begin{array}{l}\text { Відображають суму заборгованості за відрахуваннями на } \\
\text { загальнообов'язкове державне соціальне страхування, } \\
\text { страхування майна підприємства та індивідуальне страху- } \\
\text { вання його працівників }\end{array}$ \\
\hline $\begin{array}{l}\text { розрахунками } \\
3 \text { оплати праці }\end{array}$ & 1630 & $\begin{array}{c}\text { Самьдо за Kт } \\
\text { pax. } 66 \\
\end{array}$ & $\begin{array}{l}\text { Показують заборгованість піАприємства за оплатою пра- } \\
\text { ці, уключаючи депоновану заробітну плату }\end{array}$ \\
\hline $\begin{array}{l}\text { Аодатковий } \\
\text { рядок (Поточна } \\
\text { кредиторська } \\
\text { заборгованість } \\
\text { за одержаними } \\
\text { авансами) }\end{array}$ & 1635 & $\begin{array}{l}\text { Сальдо за Кт } \\
\text { субрах. } 681\end{array}$ & $\begin{array}{l}\text { Відображають залишок суми авансів, одержаних віА } \\
\text { інших осіб у рахунок подальших постачань продукції, вико- } \\
\text { нання робіт (надання послуг) }\end{array}$ \\
\hline \multicolumn{4}{|c|}{ 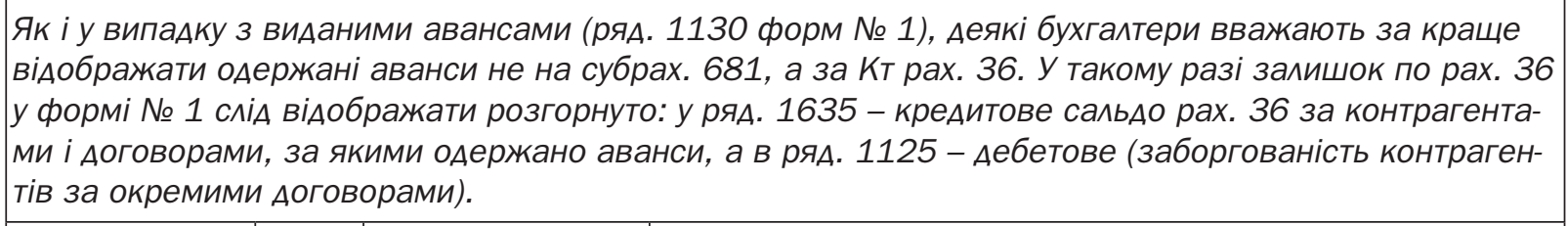 } \\
\hline $\begin{array}{l}\text { Аодатковий } \\
\text { рядок (Поточна } \\
\text { кредиторська } \\
\text { заборгованість } \\
\text { за розрахунками } \\
\text { з учасниками) }\end{array}$ & 1640 & $\begin{array}{l}\text { Сальдо за Кт } \\
\text { pax. } 67\end{array}$ & $\begin{array}{l}\text { Відображають заборгованість підприємства переА його } \\
\text { учасниками (засновниками), пов'язану з розподілом при- } \\
\text { бутку (Аивіленди тощо), за виплатами за користування } \\
\text { майном (земельним і майновим паєм) і виплатами у зв'язку } \\
\text { з отриманням належної учаснику (засновнику), який вибув, } \\
\text { частини активів підприємства }\end{array}$ \\
\hline $\begin{array}{l}\text { Аодатковий } \\
\text { рядок (Поточна } \\
\text { кредиторська } \\
\text { заборгованість } \\
\text { із внутрішніх } \\
\text { розрахунків) }\end{array}$ & 1645 & $\begin{array}{c}\text { СальАо за Кт суб- } \\
\text { рах. } 682 \text { і } 683\end{array}$ & $\begin{array}{l}\text { Наводять заборгованість підприємства пов'язаним сторо- } \\
\text { нам і кредиторську заборгованість із внутрішніх розрахун- } \\
\text { ків (наприклаА, заборгованість із розрахунків з виробнич- } \\
\text { ми одиницями та господарствами, виділеними на окремий } \\
\text { баланс, за взаємним віАпуском матеріальних цінностей, } \\
\text { реалізацією продукції, робіт, послуг, передачею витрат за- } \\
\text { гальноуправлінської Аіяльності, виплатою заробітної плати } \\
\text { працівникам цих господарств тощо) }\end{array}$ \\
\hline
\end{tabular}


Продовження таблиці 2.2

\begin{tabular}{|c|c|c|c|}
\hline Назва статті & $\begin{array}{c}\text { КоА } \\
\text { ряАКа }\end{array}$ & $\begin{array}{c}\text { Ажерело } \\
\text { інформації } \\
\text { А^я заповнення }\end{array}$ & Примітка \\
\hline $\begin{array}{l}\text { Поточні забез- } \\
\text { печення }\end{array}$ & 1660 & $\begin{array}{c}\text { СамьАо за Кт су- } \\
\text { брах. 471, 472, } \\
473,474,477, \\
478 \text { (у частині } \\
\text { поточних забез- } \\
\text { печень) } \\
\end{array}$ & $\begin{array}{l}\text { Відображають залишок коштів на забезпечення майбут- } \\
\text { ніх витрат і платежів, які планується використати про- } \\
\text { тягом } 12 \text { місяців з дати балансу (забезпечення оплати } \\
\text { віАпусток, забезпечення матеріального заохочення та } \\
\text { інші поточні забезпечення) }\end{array}$ \\
\hline $\begin{array}{l}\text { Аоходи майбут- } \\
\text { ніх періодів }\end{array}$ & 1665 & $\begin{array}{l}\text { Самьдо за Кт } \\
\text { pax. } 69\end{array}$ & $\begin{array}{l}\text { Відображають Аоходи, що отримані протягом поточного } \\
\text { або попередніх звітних періодів і належать до майбутніх } \\
\text { звітних періодів }\end{array}$ \\
\hline $\begin{array}{l}\text { Інші поточні } \\
\text { зобов’язання }\end{array}$ & 1690 & $\begin{array}{c}\text { СамьАо за Кт су- } \\
\text { брах. } 372,378 \\
643,644,684 \text { i } \\
685\end{array}$ & $\begin{array}{l}\text { Показують суми поточних зобов’язань, що не можуть бути } \\
\text { включені до інших статей розділу III пасиву форми № } 1\end{array}$ \\
\hline $\begin{array}{l}\text { Усього за роз- } \\
\text { Аілом III }\end{array}$ & 1695 & \multicolumn{2}{|c|}{$\begin{array}{l}\text { РяА. } 1600 \text { + ряА. } 1605 \text { + ряА. } 1610 \text { + ряА. } 1615 \text { + ряА. } 1620+\text { + ряА. } 1625 \\
\text { + ряА. } 1630 \text { + ряА. } 1635 \text { + ряА. } 1640 \text { + ряА. } 1645 \text { + ряА. } 1660 \text { + ряА. } 1665 \\
\text { + ряА. } 1690\end{array}$} \\
\hline $\begin{array}{l}\text { IV. Зобов'язан- } \\
\text { ня, пов'язані з } \\
\text { необоротними } \\
\text { активами, } \\
\text { утримуваними } \\
\text { А^я проАажу, } \\
\text { та групами } \\
\text { вибуття }\end{array}$ & 1700 & $\begin{array}{l}\text { Сальдо за Кт } \\
\text { субрах. } 680\end{array}$ & $\begin{array}{l}\text { Відображають зобов'язання, пов'язані з необоротними } \\
\text { активами і групами вибуття, утримуваними Аля продажу, } \\
\text { які визначають віАповіАно Ао } \underline{\boldsymbol{\Pi ( C ) Б 0 ~} \mathbf{2 7}}\end{array}$ \\
\hline \multicolumn{4}{|c|}{$\begin{array}{l}\text { Зокрема, Ао них віАносять зобов'язання, що вк^ючені Ао групи вибуття і будуть передані (погашені) } \\
\text { у результаті продажу групи вибуття. }\end{array}$} \\
\hline Баланс & 1900 & РяA. & 1495 + ряА. 1595 + ряА. 1695 + ряА. 1700 \\
\hline
\end{tabular}

Ажерело: [1, с. 9-16; 7].

\section{КОНТРОАЬНІ ПИТАННЯ:}

1. Аайте визначення балансу.

2. Скільки розділів включає форма № 1 "Баланс".

3. Охарактеризуйте вимоги до визнання активів і зобов'язань.

4. Назвіть статті I розділу активу балансу та охарактеризуйте їх.

5. Назвіть статті II розділу активу балансу та охарактеризуйте їх.

6. Яку назву має III розділ активу балансу? Поясніть, яка інформація в ньому відображається.

7. Яку назву має I розАіл пасиву балансу? Охарактеризуйте його статей.

8. Яку назву має II розАіл пасиву балансу? Розкрийте зміст його статей.

9. Яку назву має III розді^ пасиву балансу? Розкрийте зміст його статей.

10. Яку назву має IV розді^ пасиву балансу? охарактеризуйте його статті.

11. За якою оцінкою вк^ючаються в баланс нематеріальні активи, основні засоби? Як вона визначається?

12. За якою оцінкою вк^ючаються в баланс дебіторська заборгованість та як вона визначається? 
13. За якою оцінкою вк^ючаються в баланс зобов'язання?

14. Як розрахувати нерозподілений прибуток на кінець звітного періоду Аля вілображення в балансі?

15. Аайте визначення активів.

16. Аайте визначення зобов'язань.

17. Аайте визначення власного капіталу.

18. Яке значення балансу в управлінні підприємством? 


\section{TEMA 3.}

\section{3ВIT ПРО ФІНАНСОВІ РЕЗУАЬТАТИ (ЗВІТ ПРО СУКУПНИЙ АОХІА)}

\section{1. Структура звіту про фінансові результати (звіту про сукупний АохіА)}

Звіт про фрінансові резуяьтати (звіт про сукупний АохіА) - Звіт про Аоходи, витрати, фінансові результати та сукупний дохіА. Тобто, у звіті про фінансові результати (звіті про сукупний АохіА) розкривається інформація про Аоходи, витрати, прибутки і збитки, інший сукупний АохіА та сукупний АохіА піАприємства за звітний періоА.

Метою скАаАання звіту про фінансові результати (звіту про сукупний АохіА) $є$ наАання користувачам повної, правдивої і неупередженої інформації про Аоходи, витрати, прибутки і збитки та сукупний АохіА піАприємства за звітний періоА Аля прийняття управлінських рішень.

Форму звіту про фінансові результати (звіту про сукупний дохіА), зміст його статей та поряАок скмадання визначено Національним П(С)БО 1 “Загальні вимоги до фінансової звітності" віА 07.02.2013 р. № 73 та наказом Міністерства фінансів України «Про затверАження МетоАичних рекоменАацій щодо заповнення форм фінансової звітності" віА 28.03.2013 р. № 433.

Формування фінансових результатів у звіті про фінансові результати (звіті про сукупний АохіА) піАпорядковане видам Аіяльності піАприємства. Аіяльність піАприємства поділяється на звичайну, яка включає операційну (основну та іншу), фінансову та інвестиційну.

Аоходи - збільшення економічних вигод у вигляАі збільшення активів або зменшення зобов'язань, яке призводить Ао зростання власного капіталу (за винятком зростання капіталу за рахунок внесків власників).

Витрати - зменшення економічних вигод у вигляді зменшення активів або збільшення зобов'язань, що призводить Ао зменшення власного капіталу (за винятком зменшення капіталу за рахунок його вилучення або розподілення власниками).

Прибуток - сума, на яку Аоходи перевищують пов'язані з ними витрати.

Збиток - перевищення суми витрат наА сумою Аоходу, Аля отримання якого були зАійснені ці витрати.

Сукупний дохіА - зміни у власному капіталі протягом звітного періоду внасліАок господарських операцій та інших подій (за винятком змін капіталу за рахунок операцій з власниками).

Інший сукупний дохіА - Аоходи і витрати, які не включені до фінансових результатів піАприємства.

ВідповіАно Ао національних стандартів бухгалтерського обліку розрізняють такі види фінансових результатів:

- валовий прибуток (збиток):

різниця між чистим Аоходом віА реалізації продукції (товарів, робіт, послуг) і собівартістю реалізованої продукції (товарів, робіт, послуг);

- прибуток (збиток) віА операційної Аіямьності:

валовий прибуток (збиток) + інші операційні доходи - аАміністративні витрати - витрати на збут - інші операційні витрати;

- прибуток (збиток) Ао опоАаткування:

прибуток (збиток) віА операційної діяльності + дохіА віА участі в капіталі + інші фінансові Аоходи + інші доходи - фінансові витрати - втрати віА участі в капіталі - інші витрати; 


\section{- чистий прибуток (збиток):}

прибуток (збиток) до оподаткування -/+ витрати (дохіА) з податку на прибуток +/- прибуток (збиток) віА припиненої Аіяльності.

Аоходи, віАповіАно Ао П(С)БО 15 "АохіА" класифікують за такими групами:

1) дохіА (виручка) віА реалізації продукції (товарів, робіт, послуг);

2) чистий дохіА віА реалізації продукції (товарів, робіт, послуг);

3) інші операційні доходи;

4) фінансові доходи;

5) інші АОходи.

АохіА (виручка) віА реалізації продукції (товарів, робіт, послуг) - загальний дохіА (виручка) віА реалізації продукції, товарів, робіт або послуг без вирахування наданих знижок, повернення раніше проданих товарів та непрямих податків і зборів (податку на Аодану вартість, акцизного збору тощо).

Чистий АохіА віА реалізації проАукції (товарів, робіт, послуг) визначається шляхом вирахування з Аоходу віА реалізації продукції, товарів, робіт, послуг наАаних знижок, вартості повернутих раніше проданих товарів, доходів, що за договорами належать комітентам (принципалам тощо), та податків і зборів.

Ао склаАу інших операційних АохоАів вкмючаються суми інших АохоАів ВіА операційної Аіяльності піАприємства, крім чистого доходу віА реалізації продукції (товарів, робіт, послуг), зокрема: АохіА віА операційної оренди активів; дохіА віА операційних курсових різниць; віАшкодування раніше списаних активів; дохіА віА роялті, віАсотків, отриманих на залишки коштів на поточних рахунках в банках; дохіА віА реалізації оборотних активів (крім фінансових інвестицій), необоротних активів, утримуваних Аля продажу, та групи вибуття тощо.

Ао склаАу фінансових АохоАів вкАЮчаються АивіАенАИ, ВіАСотки та інші АОхоАИ, отримані віА фінансових інвестицій (крім доходів, які обліковуються за методом участі в капіталі).

АохіА віА участі в капіталі - це АохіА віА інвестицій в асоційовані, Аочірні та спільні піАприємства, які обліковуються методом участі в капіталі.

Ао складу інших доходів, зокрема, включаються АохіА віА реалізації фінансових інвестицій; дохіА віА неопераційних курсових різниць та інші Аоходи, які виникають у процесі госпоАарської Аіяльності, але не пов'язані з операційною Аіяльністю піАприємства.

НагаАаємо, що згінно з П(С)БО 16 "Витрати" Ао скмаАу витрат належать:

- собівартість реалізованої продукції (товарів, робіт, послуг), якою є виробнича собівартість реалізованої продукції (робіт, послуг) або собівартість реалізованих товарів;

- витрати, пов'язані з операційною Аіяльністю, які не включаються до собівартості реамізованої продукції (товарів, робіт, послуг): адміністративні витрати, витрати на збут та інші операційні витрати;

- фрінансові витрати (витрати на проценти за користування кредитами отриманими, за облігаціями випущеними, за фінансовою орендою та інші витрати піАприємства, пов'язані із залученням позикового капіталу);

- втрати від участі в капіталі - збитки віА інвестицій в асоційовані, дочірні або спільні підприємства, які обліковуються методом участі в капіталі;

- інші витрати - витрати, які виникають під час звичайної Аіяльності (крім фінансових витрат), але не пов'язані безпосередньо з виробництвом та/або реалізацією продукції (товарів, робіт, послуг);

- податки на прибуток (визнаються витратами згіАно з П(С)БО 17 "Податок на прибуток»).

Собівартість реалізованої продукції (робіт, послуг) склаАається з виробничої собівартості продукції (робіт, послуг), яка була реалізована протягом звітного періоду, нерозподілених постійних загальновиробничих витрат та наднормативних виробничих витрат.

Ао виробничої собівартості продукції (робіт, послуг) включаються:

1) прямі матеріальні витрати;

2) прямі витрати на оплату праці;

3) інші прямі витрати; 
4) змінні загальновиробничі та постійні розподілені загальновиробничі витрати.

Ао склаАу прямих матеріальних витрат включається вартість сировини та основних матеріалів, що утворюють основу вироблюваної продукції, купівельних напівфабрикатів та комплектуючих виробів, допоміжних та інших матеріалів, які можуть бути безпосередньо віАнесені Ао конкретного об'єкта витрат.

Ао складу прямих витрат на оплату праці включаються заробітна плата та інші виплати робітникам, зайнятим у виробництві продукції, виконанні робіт або наАанні послуг, які можуть бути безпосереАньо віннесені Ао конкретного об'єкта витрат.

Ао складу інших прямих витрат включаються всі інші виробничі витрати, які можуть бути безпосередньо віднесені до конкретного об'єкта витрат, зокрема віАрахування на соціальні заходи, плата за оренду земельних і майнових паїв, амортизація, втрати віА браку, які складаються з вартості остаточно забракованої з технологічних причин продукції (виробів, вузлів, напівфабрикатів), зменшеної на її справедливу вартість, та витрат на виправлення такого технічно неминучого браку.

Ао склаАу загальновиробничих витрат вкмючаються:

1. Витрати на управління виробництвом (оплата праці апарату управління цехами, Аільницями тощо; віАрахування на соціальні заходи й медичне страхування апарату управління цехами, Аільницями; витрати на оплату службових віАрялжень персоналу цехів, Аільниць тощо).

2. Амортизація основних засобів загальновиробничого (цехового, Аільничого, мінійного) призначення.

3. Амортизація нематеріальних активів загальновиробничого (цехового, Аільничого, лінійного) призначення.

4. Витрати на утримання, експлуатацію та ремонт, страхування, операційну оренду основних засобів, інших необоротних активів загальновиробничого призначення.

5. Витрати на вАосконалення технології й організації виробництва (оплата праці та віАрахування на соціальні заходи працівників, зайнятих удосконаленням технології й організації виробництва, поліпшенням якості продукції, піАвищенням її наАійності, Аовговічності, інших експлуатаційних характеристик у виробничому процесі; витрати матеріалів, купівельних комплектуючих виробів і напівфабрикатів, оплата послуг сторонніх організацій тощо).

6. Витрати на опалення, освітлення, водопостачання, водовіАведення та інше утримання виробничих приміщень.

7. Витрати на обслуговування виробничого процесу (оплата праці загальновиробничого персоналу; віАрахування на соціальні заходи, медичне страхування робітників та апарату управління виробництвом; витрати на зАійснення технологічного контролю за виробничими процесами та якістю продукції, робіт, послуг).

8. Витрати на охорону праці, техніку безпеки і охорону навколишнього природного сереАовища.

9. Інші витрати (внутрішньозаводське переміщення матеріалів, деталей, напівфабрикатів, інструментів зі складів до цехів і готової продукції на склади; нестачі незавершеного виробництва; нестачі і втрати віА псування матеріальних цінностей у цехах; оплата простоїв тощо).

Загальновиробничі витрати поділяються на постійні і змінні.

Ао змінних загальновиробничих витрат належать витрати на обслуговування і правління виробництвом (цехів, Аільниць), що змінюються прямо (або майже прямо) пропорційно Ао зміни обсягу Аіяльності. Змінні загальновиробничі витрати розподіляються на кожен об'єкт витрат з використанням бази розподілу (годин праці, заробітної плати, обсягу Аіяльності, прямих витрат тощо), виходячи з фактичної потужності звітного періоду.

Ао постійних загальновиробничих витрат віАносяться витрати на обслуговування і управміння виробництвом, що залишаються незмінними (або майже незмінними) при зміні обсягу Аіяльності. Постійні загальновиробничі витрати розподіляються на кожен об'єкт витрат з використанням бази розподілу (годин праці, заробітної плати, обсягу Аіяльності, прямих витрат тощо) при нормальній потужності. 
Нерозподілені постійні загальновиробничі витрати включаються Ао складу собівартості реалізованої продукції (робіт, послуг) у періоді їх виникнення. Загальна сума розпоАілених та нерозподілених постійних загальновиробничих витрат не може перевищувати їх фактичну величину.

Витрати, пов'язані з операційною діяльністю, які не включаються до собівартості реалізованої продукції (товарів, робіт, послуг), поділяються на адміністративні витрати, витрати на збут та інші операційні витрати.

Ао аАміністративних витрат віАносяться такі загальногосподарські витрати, спрямовані на обслуговування та управління піАприємством:

- загальні корпоративні витрати (організаційні витрати, витрати на провеАення річних зборів, преАставницькі витрати тощо);

- витрати на службові віАрядження і утримання апарату управління піАприємством та іншого загальногосподарського персоналу;

- витрати на утримання основних засобів, інших матеріальних необоротних активів загальногосподарського використання (операційна оренда, страхування майна, амортизація, ремонт, опалення, освітлення, водопостачання, водовіАведення, охорона);

- винагороди за професійні послуги (юридичні, аудиторські, з оцінки майна тощо);

- витрати на зв'язок (поштові, телеграфні, телефонні, телекс, факс тощо);

- амортизація нематеріальних активів загальногосподарського використання;

- витрати на врегулювання спорів у судових органах;

- податки, збори та інші передбачені законодавством обов'язкові платежі (крім податків, зборів та обов'язкових платежів, що вкмючаються Ао виробничої собівартості продукції, робіт, послуг);

- плата за розрахунково-касове обслуговування та інші послуги банків, а також витрати, пов'язані з купівлею-продажем валюти;

- інші витрати загальногосподарського призначення.

Витрати на збут вкмючають такі витрати, пов'язані з реалізацією (збутом) продукції (товарів, робіт, послуг):

- витрати пакувальних матеріалів Аля затарювання готової продукції на склаАах готової продукції;

- витрати на ремонт тари;

- оплата праці та комісійні винагороди продавцям, торговим агентам та працівникам піАрозділів, що забезпечують збут;

- витрати на рекламу та Аослідження ринку (маркетинг);

- витрати на передпродажну піАготовку товарів;

- витрати на віАрядження працівників, зайнятих збутом;

- витрати на утримання основних засобів, інших матеріальних необоротних активів, пов'язаних зі збутом продукції, товарів, робіт, послуг (операційна оренда, страхування, амортизація, ремонт, опалення, освітлення, охорона);

- витрати на транспортування, перевалку і страхування готової продукції (товарів), транспортно-експедиційні та інші послуги, пов'язані з транспортуванням продукції (товарів) віАповіАно Ао умов Аоговору (базису) поставки;

- витрати на гарантійний ремонт і гарантійне обслуговування;

- витрати на страхування призначеної Аля подальшої реалізації готової продукції (товарів), що зберігається на склаАі піАприємства;

- витрати на транспортування готової продукції (товарів) між складами підрозділів (фіілій, преАставництв) піАприємства;

- інші витрати, пов'язані зі збутом продукції, товарів, робіт, послуг.

Ао інших операційних витрат включаються:

- витрати на АосліАження та розробки віАповіАно до Положення (стандарту) бухгалтерського обліку 8 "Нематеріальні активи";

- собівартість реалізованих виробничих запасів, яка Аля цілей бухгалтерського обліку складається з їх облікової вартості та витрат, пов'язаних з їх реалізацією; 
- сума безнадійної дебіторської заборгованості та віАрахування до резерву сумнівних боргів;

- втрати віА операційної курсової різниці (тобто віА зміни курсу валюти за операціями, активами і зобов'язаннями, що пов'язані з операційною Аіяльністю піАприємства);

- втрати віА знецінення запасів;

- нестачі й втрати віА псування цінностей;

- визнані штрафи, пеня, неустойка;

- витрати на утримання об'єктів соціально-культурного призначення;

- інші витрати операційної Аіяльності.

Ао фінансових витрат відносяться витрати на проценти (за користування кредитами отриманими, за облігаціями випущеними, за фінансовою орендою тощо) та інші витрати піАприємства, пов'язані із запозиченнями (крім фінансових витрат, які включаються Ао собівартості кваліфікаційних активів віАповіАно до Положення (стандарту) бухгалтерського обліку 31 "Фінансові витрати".

Втрати віА участі в капіталі є збитками віА інвестицій в асоційовані, Аочірні або спільні підприємства, які обліковуються методом участі в капіталі.

Ао склаАу інших витрат включаються витрати, які виникають піА час Аіяльності (крім фінансових витрат), але не пов'язані безпосередньо з виробництвом та/або реалізацією продукції (товарів, робіт, послуг). Ао таких витрат належать:

- собівартість реалізованих фінансових інвестицій (балансова вартість та витрати, пов'язані з реалізацією фрінансових інвестицій);

- втрати віА зменшення корисності необоротних активів;

- втрати віА безоплатної передачі необоротних активів;

- втрати віА неопераційних курсових різниць;

- сума уцінки необоротних активів і фінансових інвестицій;

- витрати на ліквідацію необоротних активів (розбирання, демонтаж тощо);

- залишкова вартість ліквідованих (списаних) необоротних активів;

- інші витрати Аіяльності.

Звіт про фінансові результати (звіт про сукупний дохіА) складається з таких частин:

- титульна частина - наводиться інформація про підприємство та період за який складається звіт;

- предметна частина - складається з чотирьох взаємопов'язаних розділів;

- заключна частина - наводяться піАписи і ПІБ осіб, які віАповіАають за наведену інформацію $[13$, с. 156].

\section{2. Зміст статей та методика заповнення звіту про фінансові результати}

Звіт про фінансові результати (звіт про сукупний дохіА) склаАається з чотирьох розАілів:

Розаіл I. "Фінансові результати".

Розаім II. "Сукупний АохіА".

Розаіл III. "Елементи операційних витрат".

Розаіл IV. "Розрахунок показників прибутковості акцій".

Правильно заповнений перший розАіл звіту про фінансові результати містить вичерпну інформацію про доходи та витрати підприємства за звітний періоА, а також безпосередньо про результати його Аіяльності. Він охоплює Аоходи та витрати віА операційної, фрінансової та інвестиційних виАів Аіяльності.

Аля першого розділу характерні додаткові вписувані рядки. Необхідність у них виникає, якщо інформація, яку містять останні, $є$ суттєвою та оцінку статті можна Аостовірно визначити. Так, при бажанні укладачів перший розділ може поповнитися рядками з кодами 2010, 2011, 2012, 2013, 2014, 2070, 2105, 2110, 2111, 2112, 2121, 2122, 2181, 2241, 2275.

Рялки 2010 і 2112 призначені винятково Аля страхових піАприємств і розкривають інформацію про суму зароблених страхових премій, збитки за страховими преміями. 
Рялки 2121 та 2181 говорять про Аоходи та витрати віА зміни вартості активів, які оцінюються за справеАливою вартістю. У рялках 2122 і 2182 розкривають АохіА або витрати віА первісного визнання біологічних активів і сільськогосподарської продукції. Суму Аоходів віА благоАійної Аопомоги можна показати в рядку 2241. А прибуток/збиток віА Впливу інфмяції на монетарні статті - у рядку 2275.

РозАіл про сукупний АохіА розкриває Аані за іншим сукупним АохоАом, і в ньому розрахований сукупний дохіА за періоА. НагаАаємо, що НП(С)БО 1 трактує поняття сукупного Аоходу як зміни у власному капіталі протягом звітного періоду в результаті господарських операцій та інших подій (за винятком зміни капіталу за рахунок операцій їх власників). У свою чергу, інший сукупний дохіА - це Аоходи та витрати, які не вк^ючені у фінансові результати піАприємства.

третій розАіл - віАображає операційні витрати підприємства за елементами, які понесло піАприємство в процесі своєї Аіяльності протягом звітного періоду за вирахуванням внутрішнього обороту (тих витрат, які становлять собівартість продукції), тобто собівартість реалізованих товарів (робіт, послуг) тут не відображають.

Четвертий розАіл необхіАний тільки акціонерним товариствам. Тут вони показують інформацію про прибутковість своїх простих акцій і дивіАенАи на одну просту акцію. РозАі^ IV звіту про фінансові результати заповнюють акціонерні товариства, прості акції або потенційні прості акції яких віАкрито продаються та купуються на фондових біржах, включаючи товариства, які перебувають у процесі випуску таких акцій.

Також варто зазначити, що перший, Аругий і третій розАіли заповнюються в тисячах гривень, без Аесяткових знаків (без копійок), а ось Аані четвертого розАіку навоАять у гривнях із копійками (табл. 3.1).

Таблиця 3.1.

МетоАика заповнення форми № 2 “Звіт про фінансові результати (Звіт про сукупний АохіА)"

\begin{tabular}{|c|c|c|c|}
\hline $\begin{array}{c}\text { Найменування } \\
\text { статті }\end{array}$ & $\begin{array}{l}\text { КоА } \\
\text { ряАКа }\end{array}$ & $\begin{array}{c}\text { Ажерело інформації } \\
\text { А^я заповнення }\end{array}$ & Примітка \\
\hline \multicolumn{4}{|c|}{ РозАіл І. Фінансові результати } \\
\hline $\begin{array}{l}\text { Чистий АохіА віА } \\
\text { реалізації продук- } \\
\text { ції (товарів, робіт, } \\
\text { послуг) }\end{array}$ & 2000 & $\begin{array}{c}\text { Обороти за Ат субрах. } \\
701,702 \text { і } 703 \\
\text { з Кт субрах. } 791 \\
\text { мінус оборот за Кт } \\
\text { субрах. } 704 \text { з Ат суб- } \\
\text { рах. } 791\end{array}$ & $\begin{array}{l}\text { ВіАображають чистий АохіА віА реалізації про- } \\
\text { Аукції, товарів, робіт або послуг, тобто дохіА } \\
\text { (виручку) віА реалізації за вирахуванням: } \\
\text { - непрямих податків (ПАВ, акцизного податку); } \\
\text { - інших податків і зборів, що сплачуються } 3 \\
\text { обороту; } \\
\text { - наданих знижок; } \\
\text { - вартості повернених раніше проданих товарів; } \\
\text { - доходів, які за договорами належать комі- } \\
\text { тентам }\end{array}$ \\
\hline
\end{tabular}

Якщо в оренду наАається інвестиційна нерухомість або оренАа - основний виА Аіяльності піАприємства, то тут показують також дохід від операційної оренди.

Організації, основною Аіяльністю яких є торгівля цінними паперами, у цій статті відображають вартість, за якою реалізовано цінні папери, і суму винагороди за виконання інших операцій, пов'язаних з розміщенням, купівлею та продажем цінних паперів з урахуванням відповіАних вирахувань.

Крім того, у цьому рядку віАображають АохіА комісіонера (повіреного) віА наАання комісійних послуг.

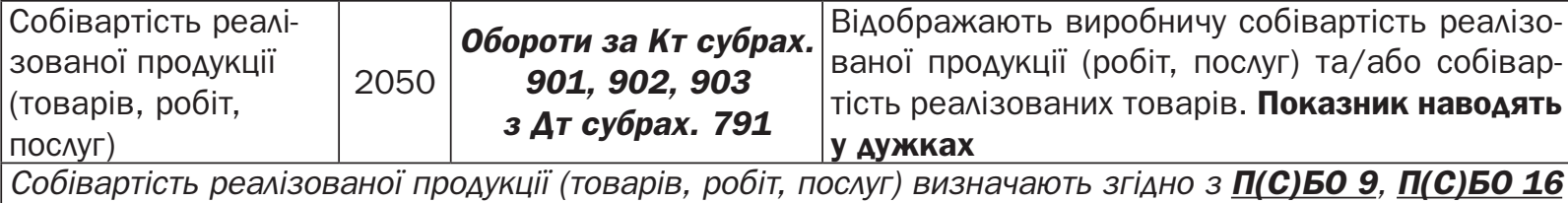
і П(С)БО 30. Зверніть увагу: Ао цієї статті, крім виробничої собівартості, уключають також постійні нерозподімені загамьновиробничі витрати, що входять Ао ск^аАу собівартості реалізованої продукції. Якщо в оренду наАають інвестиційну нерухомість або оренАа - основний виА Аіяльності піАприємства, тут показують фактичну собівартість наАаних послуг з оренди. Організації, основна Аіяльність яких - торгівля цінними паперами, віАображають у цьому рядку балансову вартість реалізованих цінних паперів. 
Продовження таблиці 3.1.

\begin{tabular}{|c|c|c|c|}
\hline $\begin{array}{c}\text { Найменування } \\
\text { статті }\end{array}$ & $\begin{array}{c}\text { KoA } \\
\text { ряAKa }\end{array}$ & $\begin{array}{c}\text { Ажерело інформації } \\
\text { А^я заповнення }\end{array}$ & Примітка \\
\hline \multicolumn{4}{|l|}{ Валовий: } \\
\hline \begin{tabular}{|l|} 
прибуток \\
3биток \\
\end{tabular} & 2090 & РяА. 2000 - ряА. 2050 & \begin{tabular}{|l|} 
АоАатний результат \\
ВіА'ємний результат. НавоАять у Аужках \\
\end{tabular} \\
\hline $\begin{array}{l}\text { Інші операційні } \\
\text { доходи }\end{array}$ & 2120 & $\begin{array}{c}\text { Рян. } 2120 \geq \text { ряА. } 2121 \\
\text { + ряА. } 2122 \text { + ряА. } \\
2123\end{array}$ & 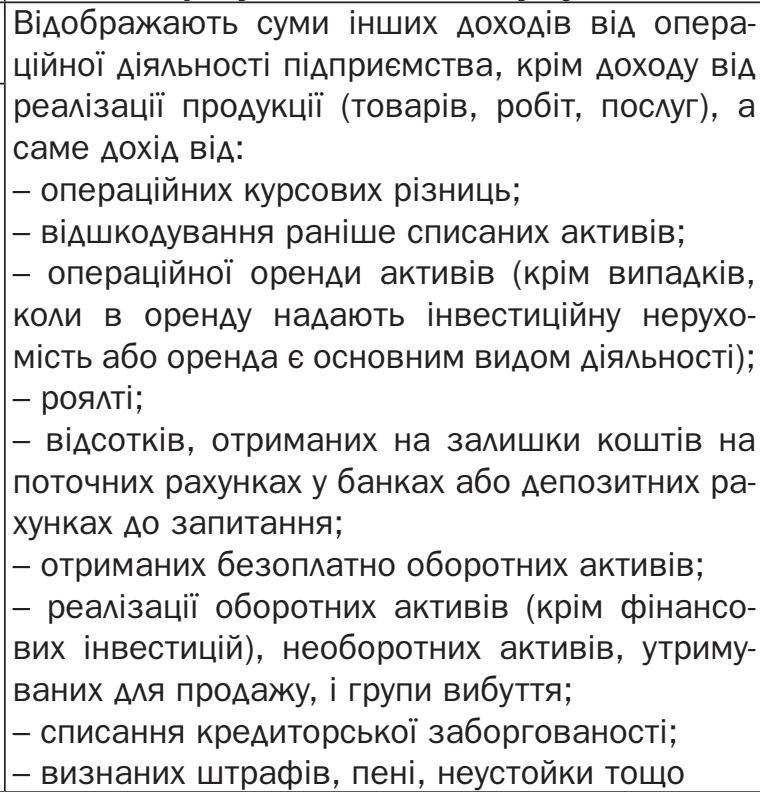 \\
\hline
\end{tabular}

Сюди включають також АохіА віА первісного визнання біологічних активів і сільськогосподарськоі продукції, а також дохіА віА зміни вартості активів, що оцінюються за справедливою вартістю. Крім того, у цьому рядку віАображають АохіА віА збільшення на Аату балансу чистої вартості реалізації необоротних активів (групи вибуття), утримуваних Аля продажу. Також сюАи потраплять Аоходи, пов'язані з купівлею-продажем іноземної валюти (Аив. Аист Мінфіну віА 01.03.2012 р. № 31-08410 07-27/5199).

Майте на увазі: у цьому рялку дохіА зазначають без урахування ПАВ, акцизного податку та інших непрямих податків і зборів.

\begin{tabular}{|c|c|c|c|}
\hline $\begin{array}{l}\text { Аодатковий рянок } \\
\text { (АохіА віА зміни } \\
\text { вартості активів, які } \\
\text { оцінюються за спра- } \\
\text { веАливою вартістю) }\end{array}$ & 2121 & $\begin{array}{c}\text { Обороти за Кт субрах. } \\
710 \text { (крім АохоАу віА } \\
\text { первісного визнання } \\
\text { біологічних активів і } \\
\text { сільськогосподарської } \\
\text { проАукції) }\end{array}$ & $\begin{array}{l}\text { Наводять АохіА віА зміни вартості активів } \\
\text { (інвестиційної нерухомості, біологічних активів } \\
\text { тощо), що оцінюються за справедливою вартіс- } \\
\text { тю (у тому числі з рял. 2120). Не бере участі в } \\
\text { розрахунку фінансового результату }\end{array}$ \\
\hline
\end{tabular}

ПіАприємства, основною Аіяльністю яких є торгівля цінними паперами, ук^ючають до цієї статті АохіА віА зміни вартості фінансових інструментів, що оцінюються за справеАливою вартістю.

\begin{tabular}{|c|c|c|c|}
\hline $\begin{array}{l}\text { Аодатковий рянок } \\
\text { (АохіА віА первісного } \\
\text { визнання біологіч- } \\
\text { них активів і сіль- } \\
\text { ськогосподарської } \\
\text { продукції) } \\
\end{array}$ & 2122 & \begin{tabular}{|c|} 
Обороти за Кт субрах. \\
710 з Ат рах. 23 (у \\
частині АохоАів віА \\
первісного визнання \\
біологічних активів і \\
сільгосппроАукції) \\
\end{tabular} & $\begin{array}{l}\text { ВіАображають АохіА віА первісного визнання } \\
\text { біологічних активів і сільгосппродукції, отрима- } \\
\text { них у результаті сільськогосподарської Аіяльно- } \\
\text { сті (у тому числі з ряА. 2120). Не бере участі в } \\
\text { розрахунку фінансового результату }\end{array}$ \\
\hline $\begin{array}{l}\text { АоАатковий ряАок } \\
\text { (АохіА віА вико- } \\
\text { ристання коштів, } \\
\text { вивіАьнених віА } \\
\text { оподаткування) } \\
\end{array}$ & 2123 & $\begin{array}{c}\text { Обороти за Кт рах. } 71 \\
\text { з Ат субрах. } 481\end{array}$ & $\begin{array}{l}\text { Показують окремо АохіА віА використання ко- } \\
\text { штів, вивільнених віА оподаткування віАповіА- } \\
\text { но Ао ПКУ (у тому числі з ряА. 2120). Не бере } \\
\text { участі в розрахунку фінансового результату }\end{array}$ \\
\hline $\begin{array}{l}\text { ААміністрати } \\
\text { витрати }\end{array}$ & 2130 & $\begin{array}{c}\text { Обороти за Кт рах. } 92 \\
\text { з Ат субрах. } 791\end{array}$ & $\begin{array}{l}\text { Відображають загальногосподарські витрати, } \\
\text { пов'язані з управлінням та обслуговуванням } \\
\text { підприємства. Показник наводять у Аужках }\end{array}$ \\
\hline
\end{tabular}


Продовження таблиці 3.1.

\begin{tabular}{|c|c|c|c|}
\hline $\begin{array}{c}\text { Найменування } \\
\text { статті }\end{array}$ & \begin{tabular}{|c|} 
КоА \\
ряАКа
\end{tabular} & $\begin{array}{c}\text { Ажерело інформації } \\
\text { А^я заповнення }\end{array}$ & Примітка \\
\hline Витрати на збут & 2150 & $\begin{array}{c}\text { Обороти за Кт рах. } 93 \\
\text { з Ат субрах. } 791\end{array}$ & $\begin{array}{l}\text { Наводять витрати підприємства, пов’язані з } \\
\text { реалізацією продукції (товарів, робіт, послуг), } \\
\text { а саме: витрати на утримання піАрозділів, що } \\
\text { займаються збутом продукції (товарів, робіт, } \\
\text { послуг), рекламу, доставку продукції спожива- } \\
\text { чам тощо. Показник наводять у Аужках }\end{array}$ \\
\hline & & \begin{tabular}{|c|} 
Обороти за Кт рах. 94 \\
з Ат субрах. 791 \\
\end{tabular} & $\begin{array}{l}\text { У цьому рялку відображають: } \\
\text { - собівартість реалізованих виробничих за- }\end{array}$ \\
\hline $\begin{array}{l}\text { Інші операційні } \\
\text { витрати }\end{array}$ & 2180 & $\begin{array}{l}\text { Ряа. } 2180 \geq \text { ряА. } 2181 \\
+ \text { рян. } 2182\end{array}$ & 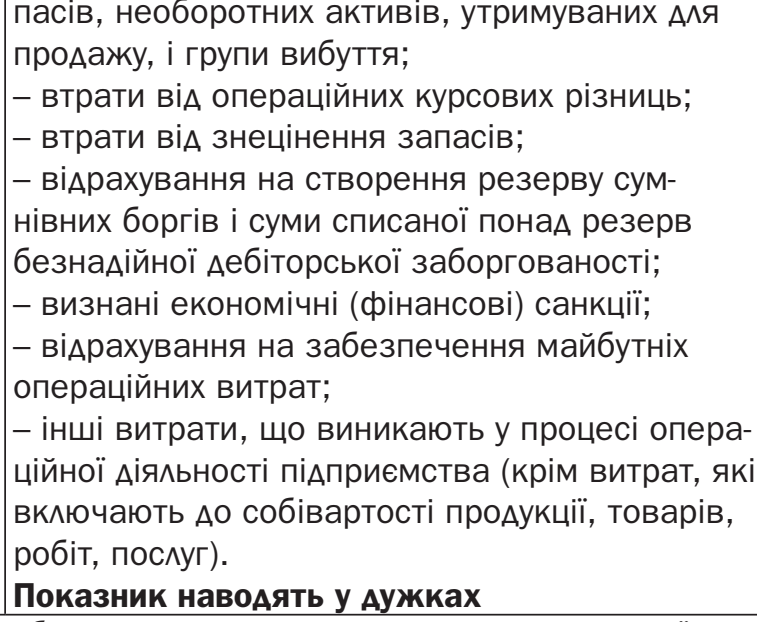 \\
\hline \multicolumn{4}{|c|}{$\begin{array}{l}\text { Тут показують також витрати віА первісного визнання біологічних активів і сільськогосподарської про- } \\
\text { дукції та витрати віА зміни вартості активів, що оцінюються за справеАливою вартістю. Крім того, у } \\
\text { цьому рядку віАображають витрати віА зменшення на Аату балансу чистої вартості реалізації необо- } \\
\text { ротних активів (групи вибуття), утримуваних Аля продажу. СюАи ж ук^ючають витрати, пов'язані } 3 \\
\text { купівлею-продажем іноземної валюти (Аив. мист Мінфіну віА 01.03.2012 р. № 31-08410-07-27/5199). }\end{array}$} \\
\hline $\begin{array}{l}\text { Аодатковий рядок } \\
\text { (Витрати віА зміни } \\
\text { вартості активів, які } \\
\text { оцінюються за спра- } \\
\text { ведливою вартістю) }\end{array}$ & 2181 & \begin{tabular}{|c|} 
Обороти за Ат субрах. \\
940 (крім витрат віА \\
первісного визнання \\
біологічних активів \\
і сільськогоспоАар- \\
ської проАукції)
\end{tabular} & $\begin{array}{l}\text { Відображають витрати віА зміни вартості акти- } \\
\text { вів (інвестиційної нерухомості, біологічних ак- } \\
\text { тивів тощо), що оцінюються за справеАливою } \\
\text { вартістю (у тому числі з ряА. 2180). Показник } \\
\text { наводять у дужках. Не бере участі в розраху- } \\
\text { ку фінансового результату }\end{array}$ \\
\hline \multicolumn{4}{|c|}{$\begin{array}{l}\text { ПіАприємства, основною Аіяльністю яких є торгівля цінними паперами, у цій статті відображають } \\
\text { витрати віА зміни вартості фінансових інструментів, що оцінюються за справедливою вартістю. }\end{array}$} \\
\hline $\begin{array}{l}\text { Аодатковий рядок } \\
\text { (Витрати віА пер- } \\
\text { вісного визнання } \\
\text { біологічних активів } \\
\text { і сільськогосподар- } \\
\text { ської продукції) } \\
\end{array}$ & 2182 & \begin{tabular}{|} 
Обороти за Ат субрах. \\
940 з Кт рах. 23 (у \\
частині витрат віА \\
первісного визнання \\
біологічних активів і \\
сільгосппродукції) \\
\end{tabular} & $\begin{array}{l}\text { Відображають витрати віА первісного визнан- } \\
\text { ня біологічних активів і сільгосппродукції, } \\
\text { отриманих у результаті сільськогосподарської } \\
\text { Аіяльності (у тому числі з ряА. 2180). Показник } \\
\text { наводять у дужках. Не бере участі в розра- } \\
\text { хунку фінансового результату }\end{array}$ \\
\hline \multicolumn{4}{|c|}{ Фінансовий результат віА операційної Аіяльності: } \\
\hline прибуток & 2190 & \multirow[b]{2}{*}{\begin{tabular}{|c|} 
РяА. 2090 + ряА. \\
2120 - ряА. 2130 - \\
ряА. 2150 - ряА. 2180 \\
або ряА. 2120 - ряА. \\
2095 - ряА. 2130 - \\
ряА. 2150 - ряА. 2180
\end{tabular}} & АоАатний результат \\
\hline збиток & 2195 & & ВіА'ємний результат. НавоАять у Аужках \\
\hline $\begin{array}{l}\text { АохіА віА участі в } \\
\text { капіталі }\end{array}$ & 2200 & $\begin{array}{c}\text { Обороти за Ат рах. } 72 \\
\text { з Кт субрах. } 792\end{array}$ & $\begin{array}{l}\text { Відображають АохіА, отриманий віА інвестицій } \\
\text { в асоційовані, Аочірні або спільні підприємства, } \\
\text { облік яких ведуть за методом участі в капіталі }\end{array}$ \\
\hline
\end{tabular}


Продовження таблиці 3.1.

\begin{tabular}{|c|c|c|c|}
\hline $\begin{array}{c}\text { Найменування } \\
\text { статті }\end{array}$ & $\begin{array}{c}\text { КоА } \\
\text { ряАКа }\end{array}$ & $\begin{array}{c}\text { Ажерело інформації } \\
\text { А^я заповнення }\end{array}$ & Примітка \\
\hline $\begin{array}{l}\text { Інші фінансові } \\
\text { Аоходи }\end{array}$ & 2220 & $\begin{array}{c}\text { Обороти за Ат рах. } 73 \\
\text { з Кт субрах. } 792\end{array}$ & $\begin{array}{l}\text { Наводять Аивіденди, віАсотки (у тому числі } \\
\text { отримані за строковими депозитними вклада- } \\
\text { ми) та інші доходи віА фінансових інвестицій } \\
\text { (крім доходів, які обліковуються за методом } \\
\text { участі в капіталі) }\end{array}$ \\
\hline & & \begin{tabular}{|c} 
Обороти за Ат рах. 74 \\
з Кт субрах. 793 \\
\end{tabular} & \multirow{2}{*}{$\begin{array}{l}\text { У цьому рялку віАображають АохіА віА: } \\
\text { - реалізації фінансових інвестицій; } \\
\text { - неопераційних курсових різниць; } \\
\text { - зміни балансової вартості фінансових інстру } \\
\text { ментів, що оцінюються за справеАливою вар } \\
\text { тістю (крім піАприємств, основною Аіяльністю } \\
\text { якихє торгівля цінними паперами); } \\
\text { - інші доходи, що виникають у процесі госпо- } \\
\text { дарської Аіяльності, але не пов'язані з опера- } \\
\text { ційною Аіяльністю підприємства }\end{array}$} \\
\hline Інші АОхОАИ & 2240 & РяА. $2240 \geq$ ряА. 2241 & \\
\hline
\end{tabular}

Крім того, Ао ряА. 2240 укАючають Аоходи віА безоплатного отримання необоротних активів (у сумі, пропорційній нарахованій амортизації), віА Аооцінки раніше уцінених об'єктів необоротних активів (у межах попередньої уцінки), віА віАновлення корисності активів (у межах раніше провеАених уцінок і зменшень корисності). Також тут відображають дохід у вигляді перевищення вартості частки покупця у справедиивій вартості придбаних іАентифікованих активів, зобов'язань і непередбачених зобов'язань об'єкта придбання наА сукупністю витрат на об'єАнання піАприємств та/або виАів їх господарської Аіяльності (П. 13 П(С)БО 19).

Важииво! АохіА зазначать без урахування ПАВ, акцизного податку та інших непрямих податків і зборів.

\begin{tabular}{|c|c|c|c|}
\hline $\begin{array}{l}\text { АоАатковий ряАок } \\
\text { (АохіА ВіА благоАій- } \\
\text { Ної АОпомоги) }\end{array}$ & 2241 & $\begin{array}{c}\text { Обороти за Кт рах. } \\
745 \text { з Ат субрах. } 483\end{array}$ & $\begin{array}{l}\text { ВіАображають окремо АохіА віА отриманої } \\
\text { у вигляді грошових коштів (товарів, робіт, } \\
\text { послуг) благоАійної Аопомоги, яка віАповіАно } \\
\text { Ао законоАавства звільняється віА обклаАення } \\
\text { ПАВ (у тому числі з ряА. 2240). Не бере участі } \\
\text { в розрахунку фінансового результату }\end{array}$ \\
\hline Фінансові витрати & 2250 & $\begin{array}{c}\text { Обороти за Кт рах. } 95 \\
\text { з Ат субрах. } 792\end{array}$ & $\begin{array}{l}\text { Показують витрати на віАсотки та інші витрати } \\
\text { піАприємства, пов'язані з позиками (крім фінан- } \\
\text { сових витрат, які вкмючають Ао собівартості ква- } \\
\text { Аіфікаційних активів згіАно з П(C)Б0 31). } \\
\text { Показник наводять у Аужках } \\
\end{array}$ \\
\hline $\begin{array}{l}\text { Втрати віА участі в } \\
\text { капіталі }\end{array}$ & 2255 & $\begin{array}{c}\text { Обороти за Кт рах. } 96 \\
\text { з Ат субрах. } 792\end{array}$ & $\begin{array}{l}\text { Відображають збиток віА інвестицій в асоці- } \\
\text { йовані, дочірні або спільні піАприємства, облік } \\
\text { яких веАуть методом участі в капіталі. Показ- } \\
\text { ник наводять у Аужках }\end{array}$ \\
\hline Інші витрати & 2270 & $\begin{array}{l}\text { Обороти за Кт рах. } 97 \\
\text { з Ат субрах. } 793\end{array}$ & $\begin{array}{l}\text { У цьому рялку віАображають: } \\
\text { - собівартість реалізації фінансових інвестицій; } \\
\text { - втрати віА уцінки фінансових інвестицій і не- } \\
\text { оборотних активів; } \\
\text { - втрати віА неопераційних курсових різниць; } \\
\text { - витрати піАприємств (крім тих, основною Аіяль- } \\
\text { ністю яких є торгівля цінними паперами) віА змі- } \\
\text { ни балансової вартості фінансових інструментів, } \\
\text { що оцінюються за справеАливою вартістю; } \\
\text { - інші витрати, що виникають у процесі госпо- } \\
\text { дарської Аіяльності (крім фінансових витрат), } \\
\text { але не пов'язані з операційною Аіяльністю піА- } \\
\text { приємства. Показник навоАять у Аужках }\end{array}$ \\
\hline
\end{tabular}


Продовження таблиці 3.1.

\begin{tabular}{|c|c|c|c|}
\hline $\begin{array}{l}\text { Найменування } \\
\text { статті }\end{array}$ & \begin{tabular}{c|} 
КоА \\
ряАКа
\end{tabular} & $\begin{array}{l}\text { Ажерело інформації } \\
\text { А^я заповнення }\end{array}$ & Примітка \\
\hline $\begin{array}{l}\text { АоАатковий рянок } \\
\text { (Прибуток (збиток) } \\
\text { віА впливу інфляції } \\
\text { на монетарні статті) }\end{array}$ & 2275 & \multicolumn{2}{|c|}{ 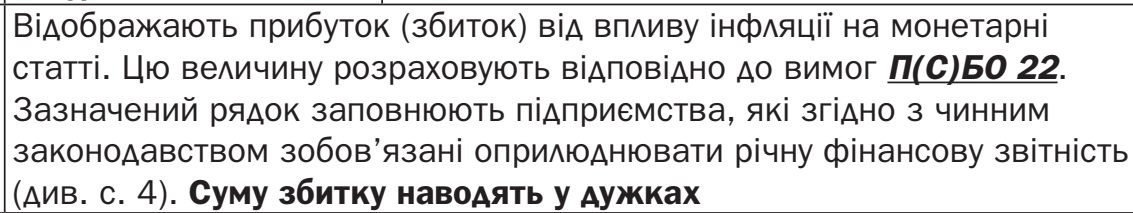 } \\
\hline \multicolumn{4}{|c|}{ 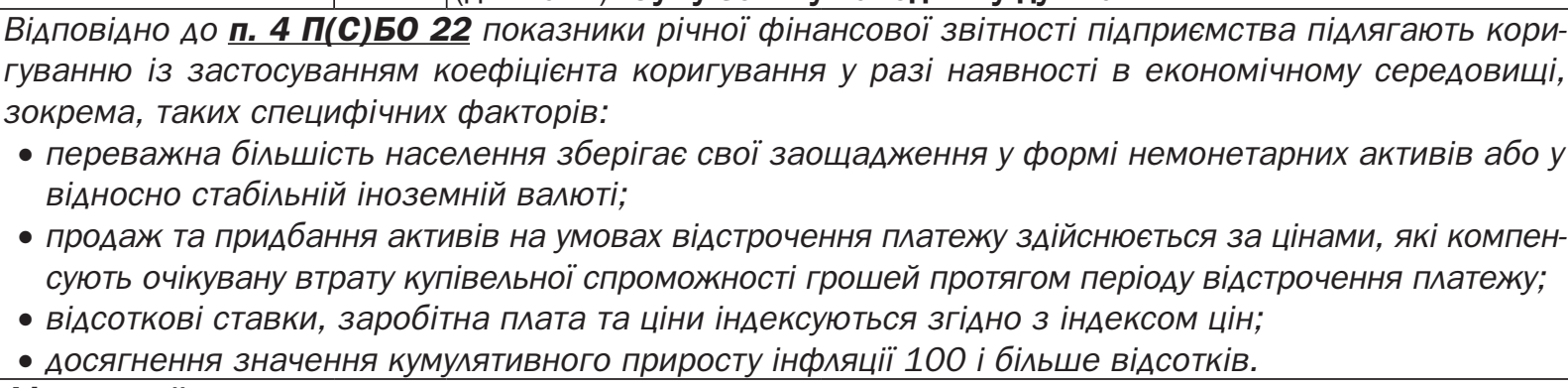 } \\
\hline \multicolumn{4}{|c|}{ Фінансовий результат Ао оподаткування: } \\
\hline прибуток & 2290 & \multirow[b]{2}{*}{$\begin{array}{c}\text { РяА. } 2190 \text { + ряА. } \\
2200 \text { + ряА. } 2220 \text { + } \\
\text { ряА. } 2240 \text { - ряА. } 2250 \\
\text { - ряА. } 2255 \text { - ряА. } \\
2270 \text { 土 ряА. } 2275 \text { або } \\
\text { ряА. } 2200 \text { + ряА. } 2220 \\
\text { + ряА. } 2240 \text { - ряА. } \\
2195 \text { - ряА. } 2250 \text { - } \\
\text { ряА. } 2255 \text { - ряА. } 2270 \\
\pm \text { ряА. } 2275\end{array}$} & АоАатний результат \\
\hline збиток & 2295 & & ВіА'ємний результат. НавоАять у Аужках \\
\hline \multirow{2}{*}{$\begin{array}{l}\text { Витрати (АохіА) } 3 \\
\text { податку на прибуток }\end{array}$} & \multirow[t]{2}{*}{2300} & $\begin{array}{c}\text { Обороти за Кт рах. } 98 \\
\text { з Ат рах. } 79\end{array}$ & $\begin{array}{l}\text { ВіАображають суму витрат з податку на прибу- } \\
\text { ток, визначений згіАно з П(C)БО 17. } \\
\text { Показник навоАять у Аужках }\end{array}$ \\
\hline & & \begin{tabular}{|c|} 
Обороти за Ат рах. 98 \\
з Кт рах. 79
\end{tabular} & $\begin{array}{l}\text { Зазначають суму АохоАу з податку на прибуток } \\
\text { підприємства віАповіАно Ао П(С)БО } \mathbf{1 7}\end{array}$ \\
\hline \multicolumn{4}{|c|}{$\begin{array}{l}\text { Платники єАиного податку зазначений рядок не заповнюють. } \\
\text { Коментар до заповнення ряд. } 2300 \text { форми № } 2 \text { див. на с. } 32 .\end{array}$} \\
\hline $\begin{array}{l}\text { Прибуток (збиток) } \\
\text { віА припиненої Аіяль- } \\
\text { ності після оподатку- } \\
\text { вання }\end{array}$ & 2305 & \multicolumn{2}{|c|}{ 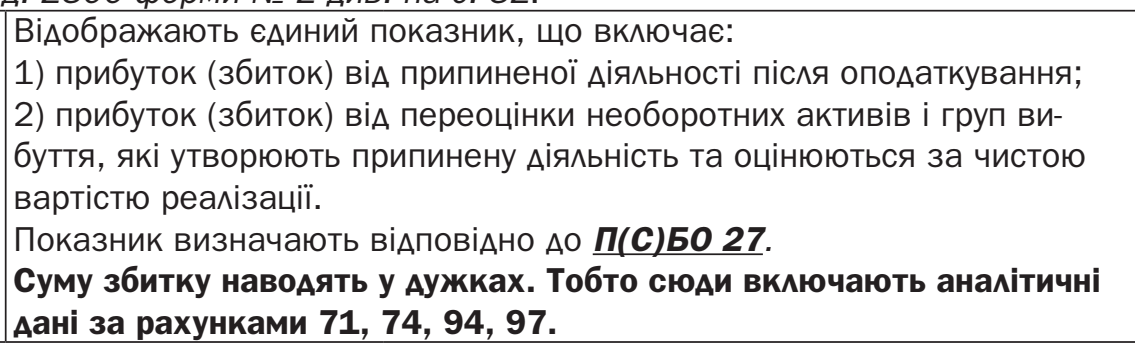 } \\
\hline \multicolumn{4}{|c|}{ Чистий фінансовий результат: } \\
\hline прибуток & 2350 & \multirow{2}{*}{$\begin{array}{l}\text { РяА. } 2290 \pm \text { ряА. } \\
2300 \pm \text { ряА. } 2305 \\
\text { або ряА. } 2295 \pm \text { ряА. } \\
2300 \pm \text { ряА. } 2305\end{array}$} & АоАатний результат \\
\hline збиток & 2355 & & ВіА'ємний результат. НавоАять у Аужках \\
\hline \multicolumn{4}{|c|}{ РозАіл II. Сукупний аохіА } \\
\hline \multicolumn{4}{|c|}{ 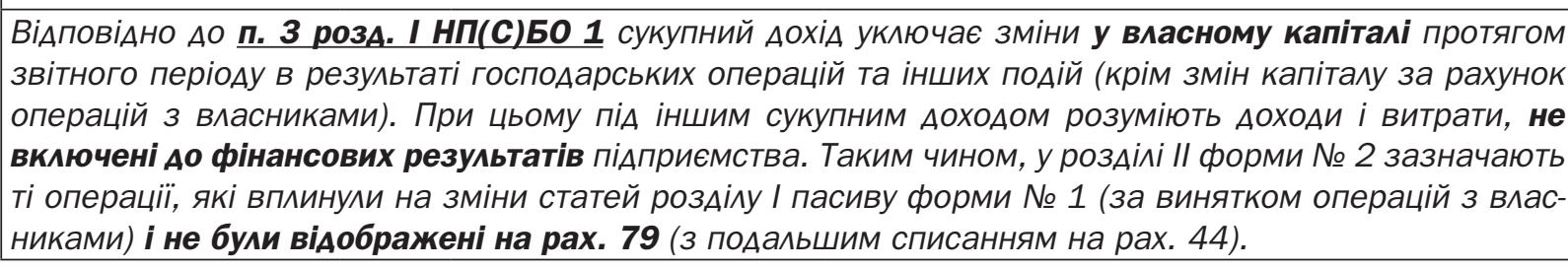 } \\
\hline
\end{tabular}


Продовження таблиці 3.1.

\begin{tabular}{|c|c|c|c|}
\hline $\begin{array}{c}\text { Найменування } \\
\text { статті }\end{array}$ & $\begin{array}{c}\text { КоA } \\
\text { ряAKa }\end{array}$ & $\begin{array}{c}\text { Ажерело інформації } \\
\text { А^я заповнення }\end{array}$ & Примітка \\
\hline $\begin{array}{l}\text { Аооцінка (уцінка) } \\
\text { необоротних активів }\end{array}$ & 2400 & $\begin{array}{c}\text { Обороти за Кт суб- } \\
\text { рах. } 411 \text { і } 412 \text { мінус } \\
\text { обороти за Ат субрах. } \\
411 \text { і } 412\end{array}$ & 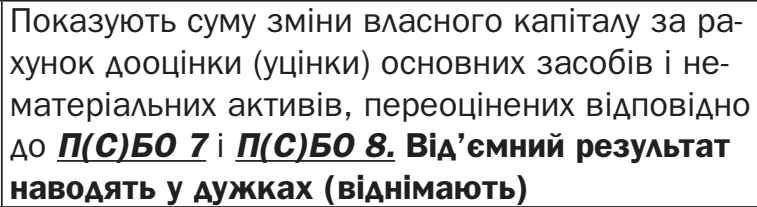 \\
\hline
\end{tabular}

Майте на увазі: Ао цього рядка повинна потрапляти тільки сума дооцінки (уцінки), що збільшуе (зменшує) додатковий капітал. Якщо ж дооцінку (уцінку) необоротних активів відображають у складі доходів (витрат), ії не вкАючають до цього рядка.

\begin{tabular}{|c|c|c|c|}
\hline $\begin{array}{l}\text { Аооцінка (уцінка) } \\
\text { фінансових інстру- } \\
\text { ментів }\end{array}$ & 2405 & $\begin{array}{c}\text { Обороти за Кт субрах. } \\
413 \text { мінус обороти за } \\
\text { Ат субрах. } 413\end{array}$ & $\begin{array}{l}\text { ВіАображають суму зміни власного капіталу за } \\
\text { рахунок Аооцінки (уцінки) фінансових інстру- } \\
\text { ментів, переоцінених віАповіАно Ао } \underline{\boldsymbol{n}(\boldsymbol{C}) Б 0} \\
\text { 13. ВіА'ємний результат навоАять у Аужках } \\
\text { (віАнімають) }\end{array}$ \\
\hline $\begin{array}{l}\text { Накопичені курсові } \\
\text { різниці }\end{array}$ & 2410 & $\begin{array}{c}\text { Обороти за Кт субрах. } \\
423 \text { мінус обороти за } \\
\text { Ат субрах. } 423\end{array}$ & $\begin{array}{l}\text { Наводять суму зміни Аодаткового капіталу за } \\
\text { рахунок накопичених курсових різниць, визна- } \\
\text { чених згіАно з П(С)Бо } 21 . \\
\text { ВіА'ємний результат навоАять у Аужках (віА- } \\
\text { німають) }\end{array}$ \\
\hline
\end{tabular}

Зокрема, тут показують накопичені курсові різниці щодо Аебіторської заборгованості або зобов'язань за розрахунками з господарською одиницею за межами України, погашення яких не планується і не є ймовірним у найближчій перспективі (п. 9 П(С)Б0 21).

Зауважте: операційні та неопераційні курсові різниці, відображені у складі доходів або витрат, у цьому рядку не відображають. Крім того, Ао сукупного доходу не включають і, віАповіАно, не показують у ряд. 2410 курсові різниці віА перерахунку зобов'язань учасників при формуванні статутного капіталу, відображені на субрах. 425 (Аив. мист Мінфіну віА 19.11.2013 р. № 31-08410-07-16/33606).

\begin{tabular}{|c|c|c|c|}
\hline $\begin{array}{l}\text { Частка іншого сукуп- } \\
\text { ного доходу асоці- } \\
\text { йованих та спільних } \\
\text { підприємств }\end{array}$ & 2415 & \begin{tabular}{|c|} 
Обороти за Кт рах. \\
41 і 42 мінус обороти \\
за Ат рах. 41 і 42 (у \\
частині частки іншого \\
сукупного АохоАу асо- \\
ційованих, Аочірніх і \\
спіАьних піАприємств)
\end{tabular} & $\begin{array}{l}\text { ВіАображають частку іншого сукупного Аоходу } \\
\text { асоційованих, Аочірніх і спільних піАприємств, } \\
\text { облік фінансових інвестицій у які веАуть за } \\
\text { методом участі в капіталі. ВіА'ємний результат } \\
\text { наводять у дужках (віАнімають) }\end{array}$ \\
\hline $\begin{array}{l}\text { Інший сукупний } \\
\text { АохіА }\end{array}$ & 2445 & $\begin{array}{c}\text { Обороти за Кт суб- } \\
\text { рах. 414, 424, 425 } \\
\text { мінус обороти за Ат } \\
\text { субрах. 414, 424, } 425 \\
\text { (крім змін капіталу за } \\
\text { рахунок операцій } 3 \\
\text { власниками) }\end{array}$ & $\begin{array}{l}\text { Наводять інші зміни у власному капіталі, що не } \\
\text { належать до операцій з власниками, не вклю- } \\
\text { чені до фінансових результатів піАприємства у } \\
\text { звітному періоді (не вілображені на рах. 79) і } \\
\text { не можуть бути наведені в інших статтях розді- } \\
\text { лу ІІ форми № 2. НаприклаА, тут віАображають } \\
\text { вартість безоплатно отриманих необоротних ак- } \\
\text { тивів. ВіА'ємний результат наводять у Аужках } \\
\text { (віднімають) }\end{array}$ \\
\hline $\begin{array}{l}\text { Інший сукупний } \\
\text { АохіА АО опоАатку- } \\
\text { вання }\end{array}$ & 2450 & \multicolumn{2}{|c|}{ А^гебраїчна сума ряА. 2400 - 2445} \\
\hline $\begin{array}{l}\text { Податок на при- } \\
\text { буток, пов'язаний } \\
\text { з іншим сукупним } \\
\text { доходом }\end{array}$ & 2455 & \multicolumn{2}{|c|}{$\begin{array}{l}\text { Відображають суму податку на прибуток, пов'язаного з іншим сукуп- } \\
\text { ним доходом }\end{array}$} \\
\hline \multicolumn{4}{|c|}{$\begin{array}{l}\text { Зверніть увагу: у рял. } 2455 \text { ук^ючають тільки той податок на прибуток, який пов'язаний з операці- } \\
\text { ями, відображеними на рахунках власного капіталу (п. } \mathbf{4} \text { П(C)Бо 17). Тобто податок на прибуток, } \\
\text { відображений на рах. 98, тут не показують. }\end{array}$} \\
\hline $\begin{array}{l}\text { Інший сукупний } \\
\text { АохіА після опоАат- } \\
\text { кування }\end{array}$ & 2460 & $\begin{array}{l}\text { РяА. } 2450 \pm \text { ряА. } \\
2455\end{array}$ & \\
\hline
\end{tabular}


Продовження таблиці 3.1.

\begin{tabular}{|c|c|c|c|}
\hline $\begin{array}{l}\text { Найменування } \\
\text { статті }\end{array}$ & \begin{tabular}{|c|} 
КоА \\
рянка
\end{tabular} & $\begin{array}{l}\text { Ажерело інформації } \\
\text { А^я заповнення }\end{array}$ & Примітка \\
\hline Сукупний АохіА & 2465 & $\begin{array}{l}\text { А^гебраїчна сума ряА. } \\
2350 \text { (або ряА. 2355) } \\
\text { і ряА. } 2460\end{array}$ & \\
\hline \multicolumn{4}{|c|}{ РозАіл III. Елементи операційних витрат } \\
\hline Матеріальні затрати & 2500 & \multicolumn{2}{|c|}{$\begin{array}{l}\text { Обороти за Ат рах. } 80 \text { або обороти за Ат рах. 23, 91, 92, 93, } 94 \text { (за } \\
\text { винятком собівартості реалізованих запасів і товарів) з Кт рах. 20, } \\
21,22,24,25,27\end{array}$} \\
\hline $\begin{array}{l}\text { Витрати на оплату } \\
\text { праці }\end{array}$ & 2505 & \multicolumn{2}{|c|}{$\begin{array}{l}\text { Обороти за Ат рах. } 81 \text { або обороти за Ат рах. 23, 91, 92, 93, } 94 \text { з Кт } \\
\text { рах. } 66 \text { і субрах. } 471 \text { (у частині сум забезпечень на виплату віАпус- } \\
\text { кних), } 477 \text { (у частині забезпечень на матеріальне заохочення) }\end{array}$} \\
\hline $\begin{array}{l}\text { ВіАрахування на } \\
\text { соціальні заходи }\end{array}$ & 2510 & \multicolumn{2}{|c|}{$\begin{array}{l}\text { Обороти за Ат рах. } 82 \text { або обороти за Ат рах. 23, 91, 92, 93, } 94 \text { з Кт } \\
\text { рах. } 65 \text { і субрах. } 471 \text { (у частині сум страхових внесків віА забезпечень } \\
\text { на оплату віАпусток), } 472,477 \text { (у частині сум страхових внесків віА за- } \\
\text { безпечень на матеріальне заохочення) }\end{array}$} \\
\hline Амортизація & 2515 & \multicolumn{2}{|c|}{$\begin{array}{l}\text { Обороти за Ат рах. } 83 \text { або обороти за Ат рах. 23, 91, 92, 93, } 94 \text { з Кт } \\
\text { рах. } 13\end{array}$} \\
\hline $\begin{array}{l}\text { Інші операційні } \\
\text { витрати }\end{array}$ & 2520 & \multicolumn{2}{|c|}{$\begin{array}{l}\text { Обороти за Ат рах. } 84 \text { або обороти за Ат рах. 23, 91, 92, 93, } 94 \text { (за } \\
\text { винятком собівартості реалізованих товарів і запасів) - не враховані } \\
\text { вище витрати за дебетовим оборотом вказаних рахунків. }\end{array}$} \\
\hline \multicolumn{4}{|c|}{ 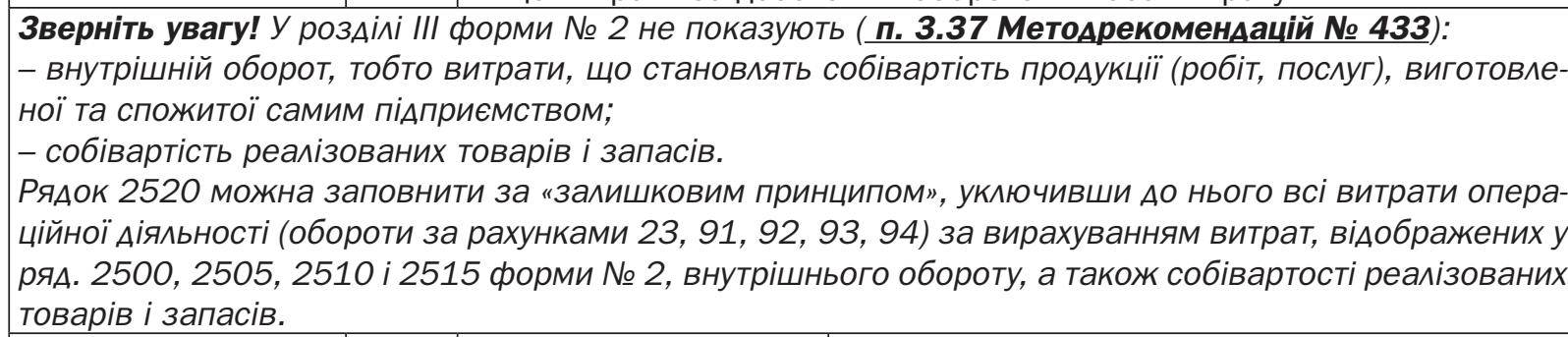 } \\
\hline Разом & 2550 & $\begin{array}{c}\text { РяА. } 2500+\text { ряА. } \\
2505+\text { ряА. } 2510+ \\
\text { ряА. } 2515 \text { + ряА. } 2520\end{array}$ & \\
\hline \multicolumn{4}{|c|}{ РозАіл IV. Розрахунок показників прибутковості акцій } \\
\hline \multicolumn{4}{|c|}{$\begin{array}{l}\text { РозАіл IV форми № } 2 \text { заповнюють акціонерні товариства, прості або потенційні прості акції яких } \\
\text { відкрито продаються та купуються на фондових біржах, уключаючи товариства, що перебувають у } \\
\text { процесі випуску таких акцій (п. 3.38 Методрекомендацій № 433). Урахуйте, що на віАміну віА інших } \\
\text { розділів форми № 2, у розділі IV вартісні показники наводять у гривнях з копійками. }\end{array}$} \\
\hline $\begin{array}{l}\text { Середньорічна кіль- } \\
\text { кість простих акцій }\end{array}$ & 2600 & \multicolumn{2}{|c|}{$\begin{array}{l}\sum(\text { Кількість простих акцій в обігу х Кількість Анів (місяців), протягом } \\
\text { яких акції перебували в обігу : Кількість Анів (місяців) у звітному році) }\end{array}$} \\
\hline \multicolumn{4}{|c|}{$\begin{array}{l}\text { Прикиал розрахунку сереАньорічної кількості простих акцій в обігу навеАено в Аодатку } 1 \text { Ао П(C) } \\
\text { Бо 24. }\end{array}$} \\
\hline $\begin{array}{l}\text { Скоригована сереА- } \\
\text { ньорічна кількість }\end{array}$ & 2605 & \multicolumn{2}{|c|}{$\begin{array}{l}\text { РяА. } 2600 \text { форми № } 2 \text { + Середньорічна кількість простих акцій, що } \\
\text { надійдуть в обіг у разі конвертації всіх розбавляючих потенційних } \\
\text { простих акцій }\end{array}$} \\
\hline $\begin{array}{l}\text { Чистий прибуток } \\
\text { (збиток) на оАну } \\
\text { просту акцію }\end{array}$ & 2610 & \multicolumn{2}{|c|}{$\begin{array}{l}\text { (Рян. } 2350 \text { (або рял. 2355) форми № } 2 \text { - АивіАенАи на привілейовані } \\
\text { акції) : : РяА. } 2600 \text { форми № } 2\end{array}$} \\
\hline Скоригований чи- & 2615 & \multicolumn{2}{|c|}{ Скоригований чистий прибуток (збиток) : РяА. 2605 форми № 2} \\
\hline \multicolumn{4}{|c|}{ 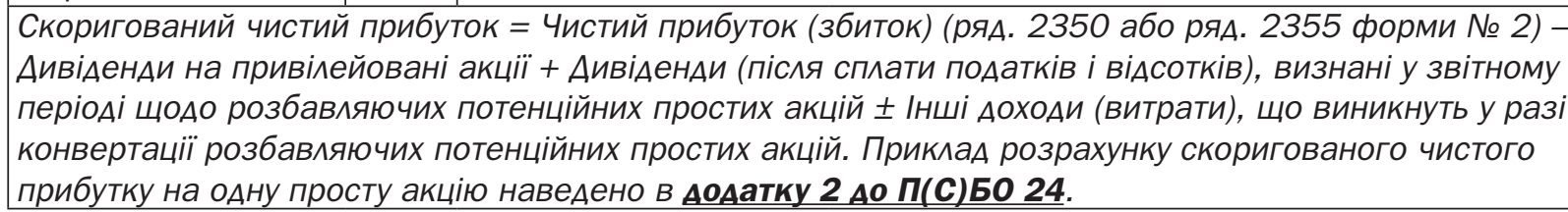 } \\
\hline
\end{tabular}


Продовження таблиці 3.1.

\begin{tabular}{|l|c|c|c|}
\hline $\begin{array}{c}\text { Найменування } \\
\text { статті }\end{array}$ & $\begin{array}{c}\text { КоА } \\
\text { рядка }\end{array}$ & $\begin{array}{c}\text { Ажерело інформації } \\
\text { Аля заповнення }\end{array}$ & Примітка \\
\hline $\begin{array}{l}\text { АивіАенди на оАну } \\
\text { просту акцію }\end{array}$ & 2650 & $\begin{array}{l}\text { Сума оголошених АивіАенАів : Кількість простих акцій, за якими випла- } \\
\text { чують АивіАенАи }\end{array}$ \\
\hline
\end{tabular}

Ажерело: [8; 62, с. 17-22].

\section{КОНТРОАЬНІ ПИТАННЯ:}

1. Як види Аіяльності підприємства впливають на структуру звіту про фінансові результати?

2. Яка мета складання звіту про фрінансові результати?

3. Які розАіли містить звіт про фінансові результати?

4. За Ааними яких класів рахунків бухгалтерського обліку заповнюються окремі розАіли звіту про фінансові результати?

5. Як відображаються Аоходи у звіті про фінансові результати?

6. Як віАображаються витрати у звіті про фінансові результати?

7. Чи Аопускаються згортання Аоходів і витрат?

8. Яка посліАовність розрахунку прибутку віА різних виАів Аіяльності до оподаткування?

9. Як визначається сума податку на прибуток?

10. Як розрахувати нерозподілений прибуток піАприємства?

11. На піАставі яких Ааних заповнюється II розАіл звіту?

12. На підставі яких Ааних заповнюється III розАіл звіту?

13. Як розрахувати середньозважену кількість простих акцій?

14. Як розрахувати прибуток на акцію?

15. Як розрахувати скоригований прибуток на акцію?

16. Яке значення звіту про фінансові результати в управлінні піАприємством?

17. Розкрийте взаємозв'язок звіту про фінансові результати з балансом.

18. В яких статтях звіту про фінансові результати віАображаються доходи і витрати віА інвестиційної Аіямьності? 


\section{3ВIT ПРО РУХ ГРОШОВИХ КОШТІВ}

\section{1. Структура звіту про рух грошових коштів}

ВіАповіАНо АО НП)С)БО 1, звіт про рух грошових коштів - це звіт, який віАображає наАходження і вибуття грошових коштів (грошей) протягом звітного періоду в результаті операційної, інвестиційної та фрінансової Аіямьності.

Операційна Аіяльність - це основна Аіяльність піАприємства, а також інші види Аіяльності, які не є інвестиційною чи фінансовою Аіяльністю.

Інвестиційна Аіяльність - це придбання та реалізація тих необоротних активів, а також тих фрінансових інвестицій, які не є складовою частиною еквівалентів грошових коштів.

Фінансова Аіяльність - це Аіяльність, яка призводить Ао змін розміру і склаАу власного та позикового капіталу піАприємства.

Грошові потоки - це наАходження та вибуття грошових коштів та їх еквівалентів.

Контроль грошових потоків Аає змогу оцінити раціональність використання грошових коштів за напрями Аіяльності піАприємства, платоспроможність, ск^асти прогноз на майбутній періол.

Метою склаАання звіту про рух грошових котів є наАання користувачам повної, правдивої та неупередженої інформації про зміни, що віАбулися у грошових коштах підприємства та їх еквівалентах за звітний період.

Рух коштів у результаті операційної Аіяльності піАприємства вкАючає:

- наАходження віА реалізації продукції (товарів, робіт, послуг);

- повернення податків і зборів;

- цільового фінансування;

- наАходження авансів віА покупців і замовників;

- наАходження віА повернення авансів;

- наАходження віАсотків за залишками коштів на поточних рахунках;

- наАходження віА боржників неустойки (штрафів, пені);

- наАходження віА операційної оренди;

- наАХоАження віА отримання роялті, авторських винагород;

- інші наАходження;

- витрачання на оплату товарів (робіт, послуг);

- витрачання на оплату праці;

- витрачання на оплату зобов'язань з податків і зборів;

- витрачання на оплату авансів;

- витрачання на оплату повернення авансів;

- витрачання на оплату цільових внесків;

- інші витрачання.

Рух коштів у резуяьтаті інвестиційної АіяАьності піАприємства вкАючає:

- наАходження віА реалізації фрінансових інвестицій;

- надходження віА реалізації необоротних активів;

- наАхоАження віА отриманих віАсотків;

- наАХоАження ВіА отриманих АивіАенАів;

- наАходження віА Аеривативів; 
- наАходження віА погашення позик;

- наАходження віА вибуття Аочірнього піАприємства та іншої господарської оАиниці;

- інші наАходження;

- витрачання на придбання фінансових інвестицій;

- витрачання на придбання необоротних активів;

- виплати за деривативами;

- витрачання на надання позик;

- витрачання на придбання Аочірнього підприємства та іншої господарської одиниці;

- інші платежі.

Рух коштів у результаті фінансової Аіяльності піАприємства вкАючає:

- налходження віА власного капіталу;

- отримання позик;

- наАходження віА продажу частки в Аочірньому піАприємстві;

- інші наАходження;

- витрачання на викуп власний акцій;

- погашення позик;

- сплату АивіАенАів;

- витрачання на сплату відсотків;

- витрачання на сплату заборгованості з фінансової оренди;

- витрачання на придбання частки в Аочірньому підприємстві;

- інші платежі.

Не вк^ючаються у звіт про рух грошових коштів внутрішні зміни грошових коштів (отримання грошей у банку і оприбуткування їх у касу тощо) та негрошові операції.

Ао негрошових операцій вінносяться операції, які не потребують використання грошових коштів та їх еквівалентів, а саме: бартерні операції, придбання активів шляхом емісії акцій, отримання активів на умовах фінансової оренди, перетворення зобов'язань на власний капітал.

Таким чином, звіт про рух грошових коштів налає інформацію внутрішнім і зовнішнім користувачам про наАходження і вибуття грошових коштів за видами Аіяльності: операційної, фінансової та інвестиційної, а також в цілому по піАприємству.

Звіт про рух грошових коштів складається з таких частин:

- титульна частина - наводиться інформація про найменування підприємства та період за який складається звіт;

- предметна частина - склалається з трьох взаємопов'язаних розділів;

- заключна частина - наводяться підписи, прізвище, ім'я та по-батькові осіб, які відповіАають за наведену інформацію [13, с.208].

Предметна частина звіту про рух грошових коштів (за прямим методом) (ф. № 3) та звіту про рух грошових коштів (за непрямим методом) (ф. № 3-н) складається із трьох розАілів, а саме:

1. Розділ І. Рух коштів у результаті операційної Аіяльності (ряАки 3000-3195 у формі № 3) та (рянки 3500-3195 у формі № 3-н).

2. РозАіл II. Рух коштів у результаті інвестиційної Аіяльності (ряАки 3200-3295).

3. Розділ III. Рух коштів у результаті фінансової діяльності (рялки 3300-3395).

У кожному з трьох розАілів у окремих рядках (р. 3195, 3295, 3395) вказується чистий рух коштів за виАами Аіяльності.

У р. 3400 вираховується загальна сума чистого руху грошових коштів за звітний періоА за трьома вилами Аіяльності.

У рялках 3405 і 3415 вілображається залишок коштів на початок і кінець звітного періоАу, а в р. 3410 - вплив зміни валютних курсів на залишок коштів. 


\section{2. Зміст статей звіту про рух грошових коштів та метоАика його скмаАання за прямим методом}

У комплекті річної фрінансової звітності подано два можливі варіанти заповнення звіту про рух грошових коштів:

- прямим методом (форма № 3);

- непрямим методом (форма № 3-н).

ПіАприємство може обрати на свій розсуд будь-яку із цих форм, що потрібно прописати в наказі про облікову політику. В цілому більшість практиків вважають, що складання звіту прямим методом дає змогу легше зрозуміти суть операцій і не Аопустити помилок.

Зазначені форми звіту про рух грошових коштів віАрізняються лише процеАурою склаАання I розАілу Звіту “Рух коштів у результаті операційної Аіяльності". РозАіли II "Рух коштів у результаті інвестиційної Аіяльності" та III "Рух коштів у результаті фінансової Аіяльності" в обох формах складаються однаково - прямим методом.

у будь-якому з варіантів заповнення Звіту логіка полягає в тому, що у звіті потрібно віАобразити рух грошових коштів та їх еквівалентів за звітний період у розрізі трьох видів Аіяльності: операційної, інвестиційної та фінансової (рис. 4.1).

У звіті про рух грошових коштів, складеному за прямим методом, чистий рух коштів у результаті операційної Аіяльності визначається за сумою надходжень віА операційної Аіяльності та сумою витрачань на операційну Аіяльність грошових коштів за Ааними записів їх руху на рахунках бухгалтерського обліку.

У звіті про рух грошових коштів, складеному за непрямим методом, чистий рух коштів у результаті операційної Аіяльності визначається шляхом коригування прибутку (збитку) віА звичайної Аіямьності до оподаткування.

Ао грошових коштів (Аалі - ГК) віАносять (Ф. №1 р. 1165):

1) готівку в касі (рахунок 30 "Готівка»);

2) грошові кошти на поточних рахунках у банках і депозити до запитання (рахунок 31 "Рахунки в банках");

3) грошові кошти, що знаходяться в Аорозі (субрахунки 333 «Грошові кошти в Аорозі в національній валюті" і 334 "Грошові кошти в дорозі в іноземній валюті»);

4) електронні гроші (субрахунок 335 «Електронні гроші, номіновані в національній валюті»).

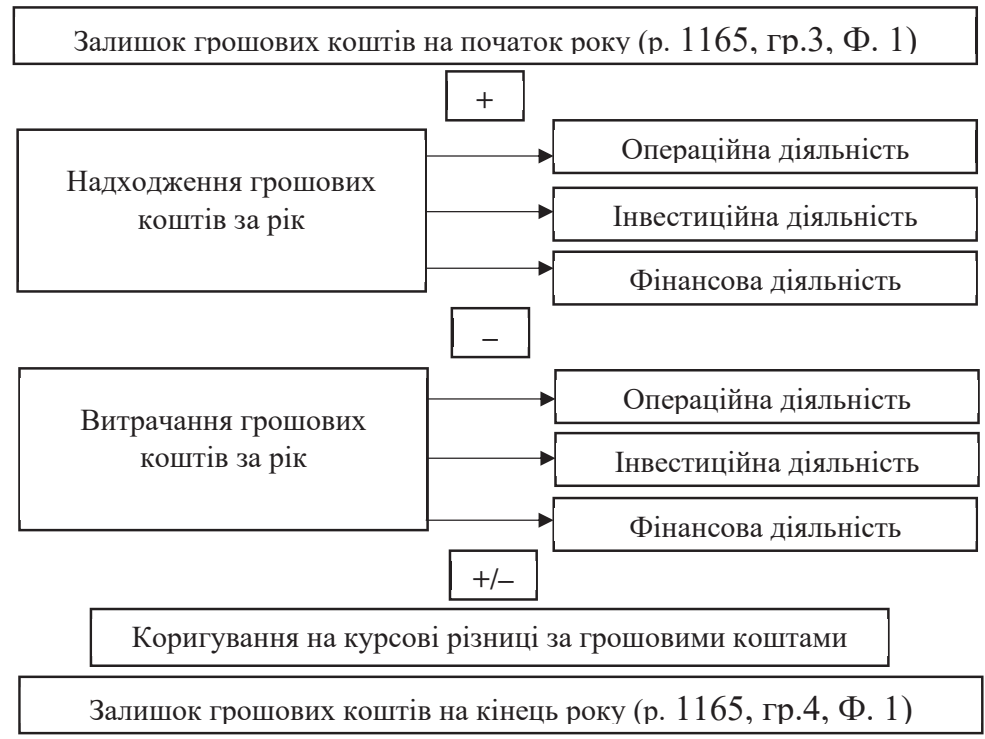

Рис. 4.1. Взаємозв'язок балансу та звіту про рух грошових коштів

Ажерело: $[18$, с. 23]. 
Крім того, у Звіті наводять операції з еквівалентами грошових коштів - короткостроковими високоліквіАними фінансовими інвестиціями, вільно конвертованими у визначені суми коштів, які характеризуються незначним ризиком зміни їх вартості (НП(С)БО 1 «Загальні вимоги Ао фінансової звітності»).

Фінансова інвестиція вважається еквівалентом грошових коштів тільки у випадку короткочасного строку ї̈ погашення, яким прийнято вважати тримісячний або коротший строк погашення з Аати придбання (МСБО 7 «Звіт про рух грошових коштів»). Там само говориться, що інвестиції в інструменти власного капіталу не вхолять до склаАу еквівалентів коштів, якщо вони не є, по суті, такими еквівалентами, наприклаА, у випадку привілейованих акцій, придбаних протягом короткого періоду їх погашення з визначеною Аатою викупу. На практиці активи, що відображають на субрахунку 351 "Еквіваленти грошових коштів" зустрічаються ріАко.

На практиці виникають труднощі з розмежуванням Аіяльності та операційну, інвестиційну та фінансову. Тому, оскільки до операційної діяльності відносять усі види Аіяльності, які не $\epsilon$ інвестиційною та фінансовою, то зручніше спочатку виАілити операції, що належать Ао останніх.

Таким чином, першим кроком необхіАно виАілити операції, що належать Ао інвестиційної Аіяльності.

Інвестиційна Аіяльність - це придбання та реалізація тих необоротних активів, а також тих фінансових інвестицій, які не $є$ складовою частиною еквівалентів грошових коштів (грошей).

Рух грошових коштів віА інвестиційної Аіямьності (наАходження і вибуття) віАображається на таких статтях балансу:

1) розАім I активу бамансу:

- нематеріальні активи;

- незавершені капітальні інвестиції;

- основні засоби;

- інвестиційна нерухомість;

- Аовгострокові біологічні активи;

- Аовгострокові фінансові інвестиції;

- інші фінансові інвестиції;

- Аовгострокова Аебіторська заборгованість;

- інші необоротні активи.

2) роздім II активу балансу:

- поточні фрінансові інвестиції;

- дебіторська заборгованість за нарахованими доходами;

- інша поточна дебіторська заборгованість;

3) роздім III активу бамансу:

- необоротні активи, що утримуються Аля продажу, і групи вибуття.

На піАставі цього заповнюємо розАіл II «Рух коштів у результаті інвестиційної Аіяльності" звіту про рух грошових коштів (табл. 4.1). 
РозАіл II “Рух коштів у результаті інвестиційної Аіяльності"

\begin{tabular}{|c|c|c|c|c|}
\hline \multirow{2}{*}{ Рянок Звіту } & \multirow{2}{*}{ Операції руху ГК } & \multicolumn{2}{|c|}{ Оборот за періоА } & \multirow{2}{*}{ Примітки } \\
\hline & & Аебет & КреАит & \\
\hline \multicolumn{5}{|c|}{ НаАхоАЖення віА реамізації: } \\
\hline \multirow{9}{*}{$\begin{array}{l}\text { Фінансових } \\
\text { інвестицій } \\
\text { (ряА. 3200) }\end{array}$} & \multirow{6}{*}{$\begin{array}{l}\text { НаАходження ГК віА погашен- } \\
\text { ня дебіторської заборговано- } \\
\text { сті за реалізовані фінансові } \\
\text { інвестиції }\end{array}$} & 30 & 36 & \multirow{9}{*}{$\begin{array}{l}\text { Аля того, щоб визначити, чи } \\
\text { була у звітному періоді реалі- } \\
\text { зація фрінансових інвестицій, } \\
\text { потрібно перевірити кореспон- } \\
\text { денції: Ат } \mathbf{3 6} \text { Кт 741; Ат } \mathbf{3 7 7} \text { Кт } \\
\mathbf{7 4 1 .}\end{array}$} \\
\hline & & 30 & 377 & \\
\hline & & 31 & 36 & \\
\hline & & 31 & 377 & \\
\hline & & 335 & 377 & \\
\hline & & 335 & 36 & \\
\hline & \multirow{3}{*}{$\begin{array}{l}\text { НаАходження ГК у частині } \\
\text { авансів, отриманих за реа- } \\
\text { лізовані у звітному періоді } \\
\text { фінансові інвестиції }\end{array}$} & 30 & 681 & \\
\hline & & 31 & 681 & \\
\hline & & 335 & 681 & \\
\hline \multirow{9}{*}{$\begin{array}{l}\text { Необоротних } \\
\text { активів } \\
\text { (ряА. 3205) }\end{array}$} & \multirow{6}{*}{$\begin{array}{l}\text { НаАходження ГК віА погашен- } \\
\text { ня Аебіторської заборговано- } \\
\text { сті за реалізовані необоротні } \\
\text { активи }\end{array}$} & 30 & 36 & \multirow{9}{*}{$\begin{array}{l}\text { У цьому рялку показують наАхо- } \\
\text { Аження ГК віА реалізації будь- } \\
\text { яких необоротних активів (крім } \\
\text { фінансових інвестицій). Аля } \\
\text { того, щоб визначити, чи була } \\
\text { у звітному періоді реалізація } \\
\text { необоротних активів, потрібно } \\
\text { перевірити кореспонденції: Ат } \\
\mathbf{3 6} \text { Кт 712 (746); АТ } \mathbf{3 7 7} \text { Кт } \\
\mathbf{7 1 2}(\mathbf{7 4 6 )}\end{array}$} \\
\hline & & 30 & 377 & \\
\hline & & 31 & 36 & \\
\hline & & 31 & 377 & \\
\hline & & 335 & 377 & \\
\hline & & 335 & 36 & \\
\hline & \multirow{3}{*}{$\begin{array}{l}\text { НаАходження ГК у частині } \\
\text { авансів, отриманих за реалі- } \\
\text { зовані у звітному періоді не- } \\
\text { оборотні активи (у тому числі } \\
\text { надходження ГК віА реаліза- } \\
\text { ції врахованих на субрахунку } \\
\mathbf{2 8 6} \text { необоротних активів, які } \\
\text { утримуються Аля продажу) }\end{array}$} & 30 & 681 & \\
\hline & & 31 & 681 & \\
\hline & & 335 & 681 & \\
\hline \multicolumn{5}{|c|}{ НаАхоАження віА отриманих: } \\
\hline \multirow[b]{4}{*}{$\begin{array}{l}\text { ВіАсотків } \\
\text { (ряА. 3215) }\end{array}$} & & 30 & 373 & \multirow[b]{4}{*}{ 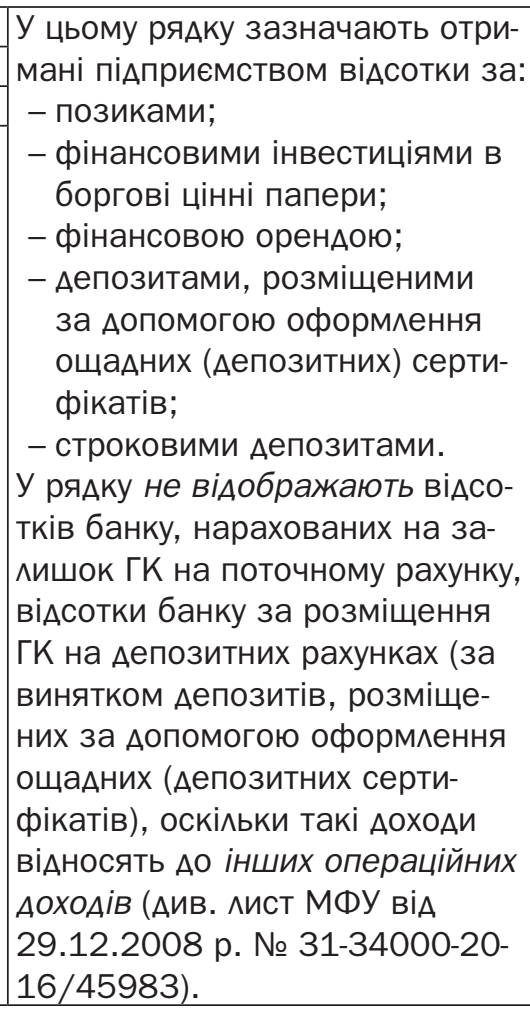 } \\
\hline & & 30 & 732 & \\
\hline & & 31 & 373 & \\
\hline & $\begin{array}{l}\text { НаАходження ГК у частині } \\
\text { отриманих віАсотків }\end{array}$ & 31 & 732 & \\
\hline
\end{tabular}


Продовження таблиці 4.1.

\begin{tabular}{|c|c|c|c|c|}
\hline \multirow{2}{*}{ РяАок Звіту } & \multirow{2}{*}{ Операції руху ГK } & \multicolumn{2}{|c|}{ Оборот за періоА } & \multirow{2}{*}{ Примітки } \\
\hline & & Аебет & КреАит & \\
\hline \multirow[b]{4}{*}{$\begin{array}{l}\text { АивіАенАів } \\
\text { (ряА. 3220) }\end{array}$} & \multirow[b]{4}{*}{$\begin{array}{l}\text { НаАходження ГК у частині } \\
\text { отриманих АивіАендів }\end{array}$} & 30 & 373 & \multirow{4}{*}{ 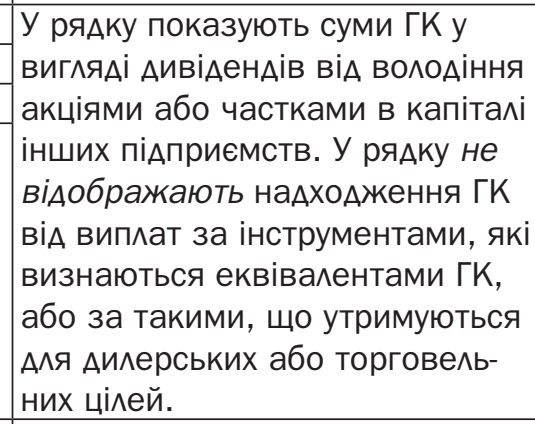 } \\
\hline & & 30 & 731 & \\
\hline & & 31 & 373 & \\
\hline & & 31 & 731 & \\
\hline \multirow[b]{2}{*}{$\begin{array}{l}\text { НаАхоАження } \\
\text { віА Аеривативів } \\
\text { (ряА. 3225) }\end{array}$} & \multirow[b]{2}{*}{$\begin{array}{l}\text { НаАходження ГК за дерива- } \\
\text { тивами }\end{array}$} & 30 & 379 & \multirow[b]{2}{*}{$\begin{array}{l}\text { У рялку показують наАходження } \\
\text { ГК віА: } \\
\text { - ф'ючерсних контрактів; } \\
\text { - форвардних контрактів; } \\
\text { - контрактів “своп»; } \\
\text { - опціонів. } \\
\text { Не показують наАходження ГК } \\
\text { віА тих контрактів, які уклаАа- } \\
\text { ються Аля основної Аіяльності } \\
\text { піАприємства або коли наАхо- } \\
\text { Аження класифікують як фінан- } \\
\text { сову Аіяльність. }\end{array}$} \\
\hline & & 31 & 379 & \\
\hline \multirow[b]{2}{*}{$\begin{array}{l}\text { НаАхоАження } \\
\text { віА вибуття } \\
\text { Аочірнього піА- } \\
\text { приємства та } \\
\text { іншої госпоАар- } \\
\text { ської оАиниці } \\
\text { (ряА. } 3235 \\
\text { - АОАаткова } \\
\text { стаття) }\end{array}$} & \multirow[b]{2}{*}{$\begin{array}{l}\text { НаАходження ГК віА вибуття } \\
\text { Аочірнього піАприємства та } \\
\text { іншої господарської одиниці }\end{array}$} & 30 & 377 & \multirow[b]{2}{*}{$\begin{array}{l}\text { У рялку показують наАходження } \\
\text { ГК віА продажу Аочірніх піАпри- } \\
\text { ємств та інших господарських } \\
\text { одиниць. } \\
\text { Не показують надходження ГК, } \\
\text { які були реалізовані в складі } \\
\text { майнового комплексу }\end{array}$} \\
\hline & & 31 & 377 & \\
\hline \multirow{10}{*}{$\begin{array}{l}\text { Інші наАхо- } \\
\text { Аження (ряА. } \\
\text { 3250) }\end{array}$} & \multirow{3}{*}{$\begin{array}{l}\text { НаАходження ГК віА повер- } \\
\text { нення авансів }\end{array}$} & 30 & 371 & \multirow{3}{*}{$\begin{array}{l}\text { У рялку не відображають наАхо- } \\
\text { Аження ГК віА повернення аван- } \\
\text { сів, пов'язаних з операційною } \\
\text { Аіяльністю }\end{array}$} \\
\hline & & 31 & 371 & \\
\hline & & 335 & 371 & \\
\hline & \multirow{4}{*}{$\begin{array}{l}\text { НаАходження ГК віА повер- } \\
\text { нення фінансових інвестицій }\end{array}$} & 31 & 143 & \multirow{4}{*}{$\begin{array}{l}\text { У рядку показують, зокрема, ви- } \\
\text { плати коштів за ощадними (Ае- } \\
\text { позитними) сертифікатами }\end{array}$} \\
\hline & & 31 & 183 & \\
\hline & & 31 & 184 & \\
\hline & & 31 & 352 & \\
\hline & \multirow[b]{2}{*}{$\begin{array}{l}\text { НаАходження ГК віА цільово- } \\
\text { го фінансування, пов'язано- } \\
\text { го із фінансуванням капіталь- } \\
\text { них інвестицій }\end{array}$} & 31 & 482 & \multirow{2}{*}{$\begin{array}{l}\text { На те, що такі суми показують } \\
\text { у цьому рялку, свого часу звер- } \\
\text { тав увагу Мінфін України в мист } \\
\text { віА } 12.04 .05 \text { р. № 31-04200-20 } \\
\text { 5/6318 }\end{array}$} \\
\hline & & 31 & 484 & \\
\hline & $\begin{array}{l}\text { НаАходження ГК віА інших } \\
\text { операцій, що належать Ао } \\
\text { інвестиційної Аіяльності }\end{array}$ & - & - & $\begin{array}{l}\text { У рялку показують суми наАхо- } \\
\text { Ажень ГК віА інвестиційної Аіяль- } \\
\text { ності, які не були відображені в } \\
\text { рял. 3200-3235 форми № } 3\end{array}$ \\
\hline
\end{tabular}


Продовження таблиці 4.1.

\begin{tabular}{|c|c|c|c|c|}
\hline \multirow{2}{*}{ РяАок Звіту } & \multirow{2}{*}{ Операції руху ГК } & \multicolumn{2}{|c|}{ Оборот за періоА } & \multirow{2}{*}{ Примітки } \\
\hline & & Аебет & КреАит & \\
\hline \multirow{6}{*}{$\begin{array}{l}\text { Фінансових ін- } \\
\text { вестицій (ряА. } \\
\text { 3255) }\end{array}$} & \multirow{6}{*}{$\begin{array}{l}\text { Витрачання ГК у частині } \\
\text { погашення зобов'язань піА- } \\
\text { приємства за фінансовими } \\
\text { інвестиціями }\end{array}$} & 63 & 30 & \multirow{6}{*}{$\begin{array}{l}\text { У рялку показують виплати ГК } \\
\text { Аля придбання акцій або борго- } \\
\text { вих зобов'язань інших піАпри- } \\
\text { ємств, часток участі в спільних } \\
\text { піАприємствах. } \\
\text { Не показують у рялку виплати ГК } \\
\text { за інструментами, які визнають- } \\
\text { ся еквівалентами коштів, або } \\
\text { утримуються Аля Аилерських або } \\
\text { торговельних цілей }\end{array}$} \\
\hline & & 685 & 30 & \\
\hline & & 371 & 30 & \\
\hline & & 63 & 31 & \\
\hline & & 685 & 31 & \\
\hline & & 371 & 31 & \\
\hline \multirow{10}{*}{$\begin{array}{l}\text { Необоротних } \\
\text { активів (ряА. } \\
\text { 3260) }\end{array}$} & \multirow{10}{*}{$\begin{array}{l}\text { Витрачання ГК у частині опла- } \\
\text { ти необоротних активів }\end{array}$} & 48 & 30 & \multirow{10}{*}{ 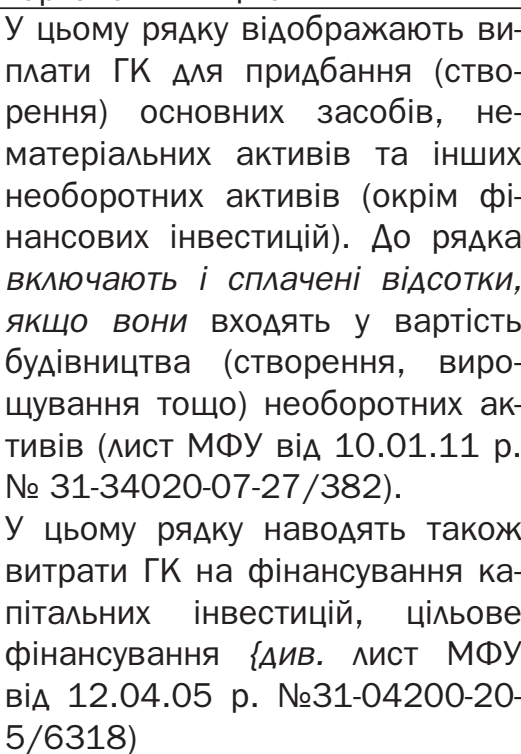 } \\
\hline & & 48 & 31 & \\
\hline & & 48 & 335 & \\
\hline & & 63 & 30 & \\
\hline & & 63 & 31 & \\
\hline & & 63 & 335 & \\
\hline & & 684 & 31 & \\
\hline & & 685 & 30 & \\
\hline & & 685 & 31 & \\
\hline & & 685 & 335 & \\
\hline \multirow[b]{2}{*}{$\begin{array}{l}\text { Виплати за } \\
\text { Аеривативами } \\
\text { (ряА. 3270) }\end{array}$} & \multirow[b]{2}{*}{$\begin{array}{l}\text { Витрачання ГК у частині ви- } \\
\text { плат за деривативами }\end{array}$} & 379 & 30 & \multirow[b]{2}{*}{$\begin{array}{l}\text { У рялку віАображають виплати } \\
\text { ГК за деривативами: } \\
\text { - ф'ючерсними контрактами; } \\
\text { - форвардними контрактами; } \\
\text { - контрактами "своп»; } \\
\text { - опціонами тощо. } \\
\text { Не показують виплати ГК за } \\
\text { контрактами, які укладають Аля } \\
\text { операційної Аіяльності підприєм- } \\
\text { ства, класифікують як фінансову } \\
\text { діяльність }\end{array}$} \\
\hline & & 379 & 31 & \\
\hline \multirow{6}{*}{$\begin{array}{l}\text { Витрачання на } \\
\text { наАання позик } \\
\text { (ряА. } 3275 \\
\text { - АоАаткова } \\
\text { стаття) }\end{array}$} & \multirow{6}{*}{$\begin{array}{l}\text { Витрачання ГК на надання } \\
\text { позик }\end{array}$} & 183 & 30 & \multirow{6}{*}{$\begin{array}{l}\text { ПіАприємства (крім фінансових } \\
\text { установ) відображають у рялку } \\
\text { виплати ГК Аля наАання авансів } \\
\text { і позик, пов'язаних з інвестицій- } \\
\text { ною Аіяльністю }\end{array}$} \\
\hline & & 183 & 31 & \\
\hline & & 371 & 30 & \\
\hline & & 371 & 31 & \\
\hline & & 377 & 30 & \\
\hline & & 377 & 31 & \\
\hline \multirow[b]{2}{*}{$\begin{array}{l}\text { Витрачання } \\
\text { на приАбання } \\
\text { Аочірнього } \\
\text { піАприємства } \\
\text { та іншої гос- } \\
\text { подарської } \\
\text { оАиниці (ряА. } \\
\text { З280 - АоАат- } \\
\text { кова стаття) }\end{array}$} & \multirow[b]{2}{*}{$\begin{array}{l}\text { Витрачання ГК на придбання } \\
\text { Аочірнього піАприємства та } \\
\text { іншої господарської одиниці }\end{array}$} & 685 & 30 & \multirow[b]{2}{*}{$\begin{array}{l}\text { У рялку відображають виплати } \\
\text { ГК на придбання Аочірніх піАпри- } \\
\text { ємств та інших господарських } \\
\text { одиниць. } \\
\text { Не показують витрачання ГК на } \\
\text { придбання ГК у склаАі майнового } \\
\text { комплексу }\end{array}$} \\
\hline & & 685 & 31 & \\
\hline
\end{tabular}


Продовження таблиці 4.1.

\begin{tabular}{|c|c|c|c|c|}
\hline \multirow{2}{*}{ РяАок Звіту } & \multirow{2}{*}{ Операції руху ГК } & \multicolumn{2}{|c|}{ Оборот за періоА } & \multirow{2}{*}{ Примітки } \\
\hline & & Аебет & КреАит & \\
\hline \multirow{4}{*}{$\begin{array}{l}\text { Інші платежі } \\
\text { (ряА. 3290) }\end{array}$} & \multirow{2}{*}{$\begin{array}{l}\text { Витрачання ГК на одержання } \\
\text { фінансових інвестицій }\end{array}$} & 143 & 31 & \multirow{2}{*}{$\begin{array}{l}\text { Ао рялка вк^ючають також ви- } \\
\text { трачання ГК на придбання ощаА- } \\
\text { них (Аепозитних) сертифікатів }\end{array}$} \\
\hline & & 352 & 31 & \\
\hline & $\begin{array}{l}\text { Витрачання ГК за депозит- } \\
\text { ним договором, укладеним } \\
\text { на строк, що перевищує } 12 \\
\text { місяців }\end{array}$ & 184 & 31 & $\begin{array}{l}\text { Ао рялка не вкАючають поточні } \\
\text { депозити (за Аоговорами, укла- } \\
\text { деними на строк менше } 12 \text { міся- } \\
\text { ців і депозити до запитання) }\end{array}$ \\
\hline & $\begin{array}{l}\text { Витрачання ГК за іншими } \\
\text { операціями, що належать Ао } \\
\text { інвестиційної Аіяльності }\end{array}$ & 377 & 31 & $\begin{array}{l}\text { У рялку показують вибуття ГК, } \\
\text { пов’язане } 3 \text { іншими операція- } \\
\text { ми інвестиційної Аіяльності, не } \\
\text { включеними Ао ряА. 3255-3280 } \\
\text { форми № } 3\end{array}$ \\
\hline $\begin{array}{l}\text { Чистий рух гро- } \\
\text { шових коштів } \\
\text { віА інвестицій- } \\
\text { ної Аіяльності } \\
\text { (ряА. 3295) }\end{array}$ & \multicolumn{3}{|c|}{$\begin{array}{l}\text { РяА. } 3200 \text { + ряА. } 3205 \text { + ряА. } 3215+\text { ряА. } 3220 \\
+ \text { ряА. } 3225+\text { + ряА. } 3230 \text { + ряА. } 3235+\text { ряА. } \\
3250 \text { - (ряА. } 3255+\text { ряА. } 3260 \text { + ряА. } 3270+ \\
\text { ряА. } 3275 \text { + ряА. } 3280 \text { + ряА. } 3290)\end{array}$} & $\begin{array}{l}\text { ВіА'ємне значення навоАять у } \\
\text { Аужках }\end{array}$ \\
\hline
\end{tabular}

Ажерело: [4; 18, с. 24-26].

Наступним кроком виАіляємо операції, що належать Ао фінансової Аіяльності.

Фінансова Аіяльність - це Аіяльність, яка призводить Ао змін розміру і складу власного та позикового капіталів піАприємства.

Рух грошових коштів віА фінансової Аіяльності (наАходження і вибуття) віАображається на таких статтях балансу:

1) розАіл I пасиву балансу:

- зареєстрований (пайовий) капітал;

- Аодатковий капітал;

- неоплачений капітал;

- вилучений капітал;

2) роздім II пасиву бамансу:

- Аовгострокові кредити банків;

- інші довгострокові зобов'язання;

- Аовгострокові забезпечення (у частині фінансової діяльності);

3) розАіл III пасиву бамансу:

- короткострокові кредити банків;

- поточна кредиторська заборгованість за Аовгостроковими зобов'язаннями;

- поточна кредиторська заборгованість за розрахунками з учасниками.

На піАставі цього заповнюємо розАіл II "Рух коштів у результаті фінансової Аіяльності" звіту про рух грошових коштів (табл. 4.2). 
Таблиця 4.2.

РозАік II "Рух коштів у результаті фінансової Аіяльності"

\begin{tabular}{|c|c|c|c|c|}
\hline \multirow{2}{*}{ РяАок Звіту } & \multirow{2}{*}{ Операції руху ГК } & \multicolumn{2}{|c|}{ Оборот за періоА } & \multirow{2}{*}{ Примітки } \\
\hline & & Аебет & КреАит & \\
\hline \multicolumn{5}{|l|}{ НаАхоАЖення віА: } \\
\hline \multirow{10}{*}{$\begin{array}{l}\text { Власного капіталу } \\
\text { (ряА. 3300) }\end{array}$} & \multirow{10}{*}{$\begin{array}{l}\text { НаАходження ГК } \\
\text { віА операцій з } \\
\text { власним капіта- } \\
\text { ^ом }\end{array}$} & 30 & 404 & \multirow{10}{*}{$\begin{array}{l}\text { У рялку відображають наАходження ГК } \\
\text { віА розміщення акцій та інших операцій, } \\
\text { які призводять Ао збільшення власного } \\
\text { капіталу }\end{array}$} \\
\hline & & 30 & 421 & \\
\hline & & 30 & 422 & \\
\hline & & 30 & 45 & \\
\hline & & 30 & 46 & \\
\hline & & 31 & 404 & \\
\hline & & 31 & 421 & \\
\hline & & 31 & 422 & \\
\hline & & 31 & 45 & \\
\hline & & 31 & 46 & \\
\hline \multirow{10}{*}{$\begin{array}{l}\text { ОАержання позик } \\
\text { (ряА. 3305) }\end{array}$} & \multirow{10}{*}{$\begin{array}{l}\text { НаАходження ГК } \\
\text { за операціями } \\
\text { позики }\end{array}$} & 30 & 50 & \multirow{10}{*}{ 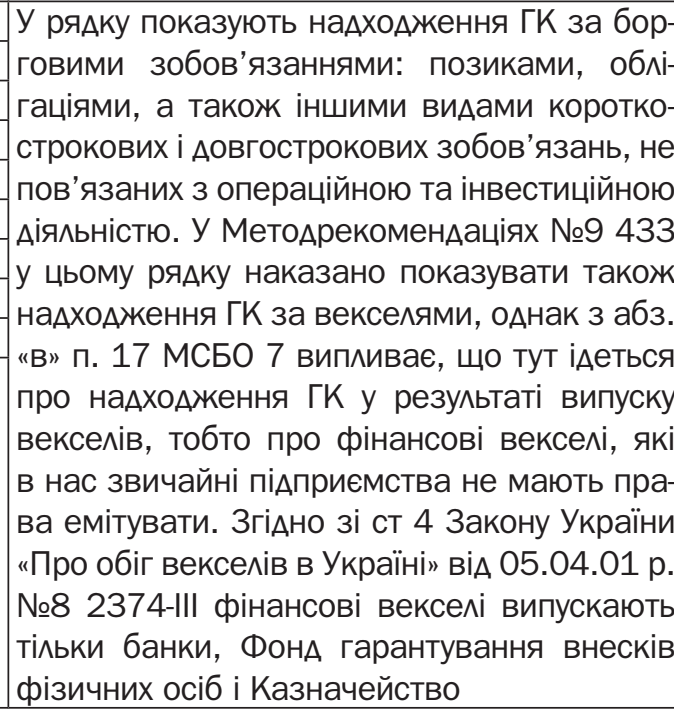 } \\
\hline & & 30 & 52 & \\
\hline & & 30 & 55 & \\
\hline & & 30 & 60 & \\
\hline & & 30 & 685 & \\
\hline & & 31 & 50 & \\
\hline & & 31 & 52 & \\
\hline & & 31 & 55 & \\
\hline & & 31 & 60 & \\
\hline & & 31 & 685 & \\
\hline \multirow{2}{*}{$\begin{array}{l}\text { НаАхоАження віА } \\
\text { продажу частини в } \\
\text { Аочірньому піАпри- } \\
\text { ємстві /ряА. } 3310 \\
\text {-АоАаткова стаття) }\end{array}$} & \multirow{2}{*}{$\begin{array}{l}\text { НаАходження } \\
\text { ГК віА прода- } \\
\text { жу частки в } \\
\text { Аочірньому } \\
\text { підприємстві }\end{array}$} & 30 & 685 & \multirow{2}{*}{$\begin{array}{l}\text { У рялку віАображають надходження ГК } \\
\text { віА продажу частки в Аочірньому піА- } \\
\text { приємстві, яка не призвела Ао втрати } \\
\text { контролю }\end{array}$} \\
\hline & & 31 & 685 & \\
\hline \multirow[b]{2}{*}{$\begin{array}{l}\text { Інші наАхоАження } \\
\text { (ряА. 3340) }\end{array}$} & \multirow[b]{2}{*}{$\begin{array}{l}\text { Надходження ГК } \\
\text { віА інших опера- } \\
\text { цій, що нале- } \\
\text { жать Ао фінан- } \\
\text { сової діяльності }\end{array}$} & 30 & 685 & \multirow[b]{2}{*}{$\begin{array}{l}\text { У рялку показують інші налходження } \\
\text { ГК, Аля відображення яких за ознаками } \\
\text { істотності не можна було виділити окре- } \\
\text { му статтю або які не включені до ряд. } \\
\text { 3зо0-3310 }\end{array}$} \\
\hline & & 31 & 685 & \\
\hline \multicolumn{5}{|l|}{ Витрачання на: } \\
\hline \multirow{2}{*}{$\begin{array}{l}\text { Викуп в^асних акцій } \\
\text { (ряА.3345) }\end{array}$} & \multirow{2}{*}{$\begin{array}{l}\text { Витрачання ГК } \\
\text { на викуп в^ас- } \\
\text { них акцій } \\
\end{array}$} & 45 & 30 & \multirow{2}{*}{$\begin{array}{l}\text { У рялку показують виплати ГК Аля при- } \\
\text { Абання власних акцій }\end{array}$} \\
\hline & & 45 & 31 & \\
\hline \multirow{12}{*}{$\begin{array}{l}\text { Погашення позик } \\
\text { (ряА. 3350) }\end{array}$} & \multirow{12}{*}{$\begin{array}{l}\text { Витрачання ГК } \\
\text { на погашення } \\
\text { позик }\end{array}$} & 50 & 30 & \multirow{12}{*}{$\begin{array}{l}\text { У рялку відображають виплати ГК Аля } \\
\text { погашення отриманих позик, у тому числі } \\
\text { и довгострокової, і заборгованості, пе- } \\
\text { реведеної до складу поточної (якщо вона } \\
\text { не пов'язана з операційною чи інвес- } \\
\text { тиційною Аіяльністю) }\end{array}$} \\
\hline & & 52 & 30 & \\
\hline & & 55 & 30 & \\
\hline & & 60 & 30 & \\
\hline & & 61 & 30 & \\
\hline & & 685 & 30 & \\
\hline & & 50 & 31 & \\
\hline & & 52 & 31 & \\
\hline & & 55 & 31 & \\
\hline & & 60 & 31 & \\
\hline & & 61 & 31 & \\
\hline & & 685 & 31 & \\
\hline
\end{tabular}


Продовження таблиці 4.2.

\begin{tabular}{|c|c|c|c|c|}
\hline \multirow{2}{*}{ РяАок Звіту } & \multirow{2}{*}{ Операції руху ГК } & \multicolumn{2}{|c|}{ Оборот за періоА } & \multirow{2}{*}{ Примітки } \\
\hline & & Аебет & КреАит & \\
\hline \multirow{2}{*}{$\begin{array}{l}\text { Спиату АивіАенАів } \\
\text { (ряА. 3355) }\end{array}$} & \multirow{2}{*}{$\begin{array}{l}\text { Витрачання ГК } \\
\text { на сплату Аиві- } \\
\text { Аендів } \\
\end{array}$} & 671 & 30 & \multirow{2}{*}{$\begin{array}{l}\text { У рядку показують суми ГК на сплату } \\
\text { Аивідендів }\end{array}$} \\
\hline & & 671 & 31 & \\
\hline \multirow[b]{2}{*}{$\begin{array}{l}\text { Витрачання на спма- } \\
\text { ту віАсотків (ряА. } \\
3360 \text { - АоАаткова } \\
\text { стаття) }\end{array}$} & \multirow[b]{2}{*}{$\begin{array}{l}\text { Витрачання ГК } \\
\text { на сплату віАсо- } \\
\text { тків }\end{array}$} & 684 & 30 & \multirow{2}{*}{$\begin{array}{l}\text { У рялку відображають суми ГК на сплату } \\
\text { віАсотків за користування позиковим } \\
\text { капіталом, використаним у фінансовій } \\
\text { Аіяльності, крім сум відсотків, які капіта- } \\
\text { лізуються }\end{array}$} \\
\hline & & 684 & 31 & \\
\hline \multirow{4}{*}{$\begin{array}{l}\text { Витрачання на спиа- } \\
\text { ту заборгованості із } \\
\text { фінансової оренАи } \\
\text { (ряА. } 3365 \text { - АоАат- } \\
\text { кова стаття) }\end{array}$} & \multirow{4}{*}{$\begin{array}{l}\text { Витрачання } \\
\text { ГК на сплату } \\
\text { заборгованості } \\
\text { з фрінансової } \\
\text { оренди } \\
\end{array}$} & 53 & 30 & \multirow{4}{*}{$\begin{array}{l}\text { У рялку віАображають суму ГК у частині } \\
\text { сплаченої заборгованості } 3 \text { фінансової } \\
\text { оренди }\end{array}$} \\
\hline & & 61 & 30 & \\
\hline & & 53 & 31 & \\
\hline & & 61 & 31 & \\
\hline \multirow[b]{2}{*}{$\begin{array}{l}\text { Витрачання на } \\
\text { приАбання части- } \\
\text { ни в Аочірньому } \\
\text { піАприємстві (ряА. } \\
\text { З370 - АоАаткова } \\
\text { стаття) }\end{array}$} & \multirow[b]{2}{*}{$\begin{array}{l}\text { Витрачання ГК } \\
\text { на придбан- } \\
\text { ня частини в } \\
\text { Аочірньому } \\
\text { підприємстві }\end{array}$} & 685 & 30 & \multirow[b]{2}{*}{$\begin{array}{l}\text { У рялку показують виплати ГК на при- } \\
\text { Абання Аодаткової частини в Аочірньому } \\
\text { піАприємстві }\end{array}$} \\
\hline & & 685 & 31 & \\
\hline $\begin{array}{l}\text { Витрачання на } \\
\text { виплати неконтро- } \\
\text { Аьованим частинам } \\
\text { у Аочірніх піАпри- } \\
\text { ємствах (ряА. 3375- } \\
\text { Аодаткова стаття) }\end{array}$ & $\begin{array}{l}\text { Витрачання } \\
\text { ГК на випла- } \\
\text { ти некон- } \\
\text { трольованим } \\
\text { частинам у } \\
\text { Аочірніх підпри- } \\
\text { ємствах } \\
\end{array}$ & 685 & 31 & $\begin{array}{l}\text { Рядок заповнюється в консоліАованому } \\
\text { Звіті }\end{array}$ \\
\hline \multirow{4}{*}{$\begin{array}{l}\text { Інші платежі (ряА. } \\
\text { 3390) }\end{array}$} & \multirow{4}{*}{\begin{tabular}{|l|} 
Витрачання \\
ГК на сплату \\
інших платежів, \\
що належать \\
до фінансової \\
Аіяльності
\end{tabular}} & 672 & 30 & \multirow{4}{*}{$\begin{array}{l}\text { У цьому рялку вілображають інші плате- } \\
\text { жі, пов'язані із фінансовою Аіяльністю, } \\
\text { які не вк^ючені до рял. 3345-3370 }\end{array}$} \\
\hline & & 685 & 30 & \\
\hline & & 672 & 31 & \\
\hline & & 685 & 31 & \\
\hline $\begin{array}{l}\text { Чистий рух гро- } \\
\text { шових коштів віА фі- } \\
\text { нансової АіяАьності }\end{array}$ & \multicolumn{3}{|c|}{$\begin{array}{l}\text { РяА. } 3300+\text { ряА. } 3305 \text { + ряА. } \\
3310 \text { + ряА. } 3340 \text { - (ряА. } 3345 \\
+ \text { ряА. } 3350 \text { + ряА. } 3355+\text { ряА. } \\
3360 \text { + ряА. } 3365+\text { ряА. } 3370+ \\
\text { ряА. } 3375 \text { + ряА. } 3390 \text { ) }\end{array}$} & ВіА'ємне значення навоАять у Аужках \\
\hline
\end{tabular}

Ажерело: [4; 18, с. 26-27].

Третій крок: показуємо операції, що намежать Ао операційної Аіямьності (прямий метод).

Операційна Аія^ьність - це основна Аія^ьність піАприємства, а також інші виАи Аія^ьності, які не є інвестиційною чи фінансовою Аія^ьністю.

Отже, всі операції, які не увійшли до розАілів II та III Звіту, включають у розАіл I Звіту (табл. 4.3). 
Таблиця 4.3

РозАіл I "Рух коштів у результаті операційної Аіямьності" (прямий метоА)

\begin{tabular}{|c|c|c|c|c|}
\hline \multirow{2}{*}{ РяАок Звіту } & \multirow{2}{*}{ Операції руху ГК } & \multicolumn{2}{|c|}{ Оборот за період } & \multirow{2}{*}{ Примітки } \\
\hline & & Аебет & КреАит & \\
\hline \multicolumn{5}{|l|}{ НаАхоАЖення віА: } \\
\hline \multirow[b]{6}{*}{$\begin{array}{l}\text { Реамізації продукції } \\
\text { (товарів, робіт, по- } \\
\text { слуг) (ряА. 3000) }\end{array}$} & \multirow[b]{6}{*}{$\begin{array}{l}\text { НаАходження ГК віА } \\
\text { реалізації продук- } \\
\text { ції (товарів, робіт, } \\
\text { послуг) }\end{array}$} & 30 & 36 & \multirow{6}{*}{ 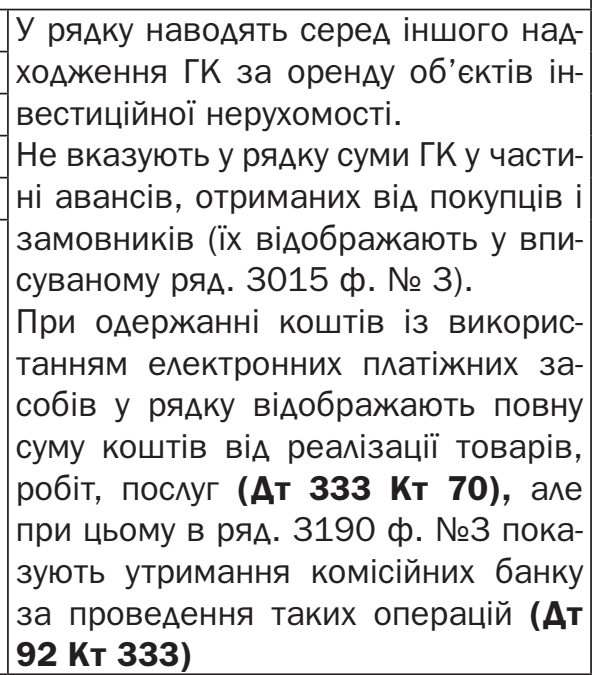 } \\
\hline & & 30 & 70 & \\
\hline & & 31 & 36 & \\
\hline & & 333 & 70 & \\
\hline & & 335 & 681 & \\
\hline & & 335 & 36 & \\
\hline \multirow[b]{2}{*}{$\begin{array}{l}\text { Повернення поАат- } \\
\text { ків і зборів (ряА. } \\
\text { з005) }\end{array}$} & \multirow[b]{2}{*}{$\begin{array}{l}\text { НаАходження ГК віА } \\
\text { повернення податків і } \\
\text { зборів) }\end{array}$} & 311 & 641 & \multirow[b]{2}{*}{$\begin{array}{l}\text { У рядку віАображають отримані } 3 \\
\text { бюджету на рахунки підприємства } \\
\text { в установах банків суми переплат } \\
\text { за іншими податками і зборами } \\
\text { (обов'язковими платежами), вк^ю- } \\
\text { чаючи ПАВ }\end{array}$} \\
\hline & & 311 & 642 & \\
\hline $\begin{array}{l}\text { у тому числі поАат- } \\
\text { ку на АоАану вар- } \\
\text { тість (ряА. З006) }\end{array}$ & \begin{tabular}{|l|} 
НаАходження ГК віА \\
бюАжетного віАшкоду- \\
вання ПАВ \\
\end{tabular} & 311 & $\begin{array}{l}641 / \\
П А В\end{array}$ & $\begin{array}{l}\text { Показник рянка не включають Ао } \\
\text { розрахунку руху ГК віА операційної } \\
\text { Аіяльності }\end{array}$ \\
\hline \multirow[b]{2}{*}{$\begin{array}{l}\text { Цімьового } \\
\text { фінансування (ряА. } \\
\text { 3010) }\end{array}$} & \multirow[b]{2}{*}{$\begin{array}{l}\text { НаАходження ГК віА } \\
\text { цільового фінансу- } \\
\text { вання }\end{array}$} & 311 & 378 & \multirow[b]{2}{*}{$\begin{array}{l}\text { У рялку показують отримані Аля } \\
\text { зАійснення витрат на операційну } \\
\text { Аіяльність наАходження } 3 \text { бюАжету } \\
\text { та державних цільових фондів, а та- } \\
\text { кожк кошти цільового фінансування } \\
\text { віА інших осіб }\end{array}$} \\
\hline & & 311 & 48 & \\
\hline \multirow{2}{*}{$\begin{array}{l}\text { НаАхоАження віА } \\
\text { оАержання субси- } \\
\text { Аій, Аотацій (ряА. } \\
\text { З011 -АоАаткова } \\
\text { стаття) } \\
\end{array}$} & \multirow[b]{2}{*}{$\begin{array}{l}\text { НаАходження ГК у ча- } \\
\text { стині субсидій, Аотацій }\end{array}$} & 311 & 378 & \multirow[b]{2}{*}{$\begin{array}{l}\text { Показник рядка не включають у } \\
\text { розрахунок руху ГК віА операційно) } \\
\text { Аіяльності }\end{array}$} \\
\hline & & 311 & 48 & \\
\hline \multirow{2}{*}{$\begin{array}{l}\text { НаАхоАження } \\
\text { авансів віА покупців } \\
\text { і замовників (ряА. } \\
\text { З015 - АоАаткова } \\
\text { стаття) }\end{array}$} & \multirow[b]{2}{*}{$\begin{array}{l}\text { Надходження ГК у } \\
\text { частині авансів віА } \\
\text { покупців і замовників }\end{array}$} & 30 & 681 & \multirow[b]{2}{*}{$\begin{array}{l}\text { Пілприємства, що відображають } \\
\text { одержання авансу на рахунку } \mathbf{3 6}, \\
\text { у цьому рядку показують “авансові" } \\
\text { обороти Ат } \mathbf{3 1} \text { Кт } \mathbf{3 6}\end{array}$} \\
\hline & & 31 & 681 & \\
\hline \multirow{2}{*}{$\begin{array}{l}\text { НаАХоАження віА } \\
\text { повернення авансів } \\
\text { (ряА. } 3020 \text { - АОАат- } \\
\text { кова стаття) }\end{array}$} & \multirow[b]{2}{*}{$\begin{array}{l}\text { Надходження ГК у } \\
\text { частині повернення } \\
\text { авансів }\end{array}$} & 30 & 371 & \multirow[b]{2}{*}{$\begin{array}{l}\text { У рялку показують повернені піА- } \\
\text { приємству постачальниками та піА- } \\
\text { рядниками суми авансів ГК }\end{array}$} \\
\hline & & 31 & 371 & \\
\hline \multirow[b]{2}{*}{$\begin{array}{l}\text { НаАХоАЖення віА } \\
\text { віАсотків за за- } \\
\text { Аишками коштів на } \\
\text { поточних рахунках } \\
\text { (ряА. } 3025 \text { - АОАат- } \\
\text { кова стаття) }\end{array}$} & \multirow[b]{2}{*}{$\begin{array}{l}\text { НаАходження ГК за } \\
\text { залишками коштів на } \\
\text { поточних рахунках }\end{array}$} & 31 & 377 & \multirow[b]{2}{*}{$\begin{array}{l}\text { У цьому рялку не показують отрима- } \\
\text { ні віА банків віАсотки за розміщені } \\
\text { кошти на Аепозитних рахунках. Ïх } \\
\text { відображкають у рял. } 3095 \text { ф. № } 3\end{array}$} \\
\hline & & 31 & 719 & \\
\hline
\end{tabular}


Продовження таблиці 4.3

\begin{tabular}{|c|c|c|c|c|}
\hline \multirow{2}{*}{ РяАок Звіту } & \multirow{2}{*}{ Операції руху ГК } & \multicolumn{2}{|c|}{ Оборот за періоА } & \multirow{2}{*}{ Примітки } \\
\hline & & Аебет & КреАит & \\
\hline \multirow{2}{*}{$\begin{array}{l}\text { НаАхоАження віА } \\
\text { боржників неустой- } \\
\text { ки (штрафів, пені) } \\
\text { (ряА. } 3035 \text { - АоАат- } \\
\text { кова стаття) }\end{array}$} & \multirow[b]{2}{*}{$\begin{array}{l}\text { НаАходження ГК віА } \\
\text { неустойки (штрафів, } \\
\text { пені) }\end{array}$} & 30 & 374 & \multirow[b]{2}{*}{$\begin{array}{l}\text { У рялку показують отримані ГК у } \\
\text { частині фінансових санкцій за пору- } \\
\text { шення законодавства та умов дого- } \\
\text { ворів }\end{array}$} \\
\hline & & 31 & 374 & \\
\hline \multirow{4}{*}{$\begin{array}{l}\text { НаАхоАЖення віА } \\
\text { операційної оренАи } \\
\text { (ряА. } 3040 \text { - АоАат- } \\
\text { кова стаття) }\end{array}$} & \multirow{4}{*}{$\begin{array}{l}\text { НаАходження ГК віА } \\
\text { орендної плати }\end{array}$} & 30 & 36 & \multirow{4}{*}{$\begin{array}{l}\text { У цьому рялку не зазначають наАхо- } \\
\text { Аження віА орендних платежів за орен- } \\
\text { ду об'єктів інвестиційної нерухомості, їх } \\
\text { відображкають у ряд. } 3000 \text { ф. № } 3 \\
\end{array}$} \\
\hline & & 30 & 377 & \\
\hline & & 31 & 36 & \\
\hline & & 31 & 377 & \\
\hline \multirow{3}{*}{$\begin{array}{l}\text { НаАХоАження віА } \\
\text { оАержання роялті, } \\
\text { авторських вина- } \\
\text { гороА (ряА. } 3045 \text { - } \\
\text { АОАаткова стаття) }\end{array}$} & \multirow{3}{*}{$\begin{array}{l}\text { НаАходження ГК віА } \\
\text { роялті та авторських } \\
\text { винагород }\end{array}$} & 30 & 373 & \multirow{3}{*}{$\begin{array}{l}\text { У рялку вілображають суми, отрима- } \\
\text { ні як винагорода за користування } \\
\text { або за надання права користування } \\
\text { будь-яким авторським і суміжним } \\
\text { правом }\end{array}$} \\
\hline & & 30 & 377 & \\
\hline & & 31 & 373 & \\
\hline \multirow{4}{*}{$\begin{array}{l}\text { НаАхоАження віА } \\
\text { страхових премій } \\
\text { (ряА. } 3050 \text { - АОАат- } \\
\text { кова стаття) }\end{array}$} & \multirow{4}{*}{$\begin{array}{l}\text { НаАходження ГК віА } \\
\text { страхових премій }\end{array}$} & 30 & 76 & \multirow{4}{*}{ РяАок заповнюють страховики } \\
\hline & & 31 & 76 & \\
\hline & & 30 & 36 & \\
\hline & & 31 & 36 & \\
\hline $\begin{array}{l}\text { НаАХоАЖення } \\
\text { фінансових уста- } \\
\text { нов віА повернення } \\
\text { позик (ряА. } 3055 \text { - } \\
\text { АОАаткова стаття) }\end{array}$ & $\begin{array}{l}\text { НаАходження ГК фі- } \\
\text { нансовим установам } \\
\text { віА повернення позик }\end{array}$ & - & - & $\begin{array}{l}\text { Рядок заповнюють фрінансові уста- } \\
\text { нови }\end{array}$ \\
\hline \multirow{18}{*}{$\begin{array}{l}\text { Інші наАхоАження } \\
\text { (ряА. 3095) }\end{array}$} & \multirow{4}{*}{$\begin{array}{l}\text { НаАходження ГК віА } \\
\text { реалізації оборотних } \\
\text { активів }\end{array}$} & 30 & 36 & \multirow{18}{*}{ 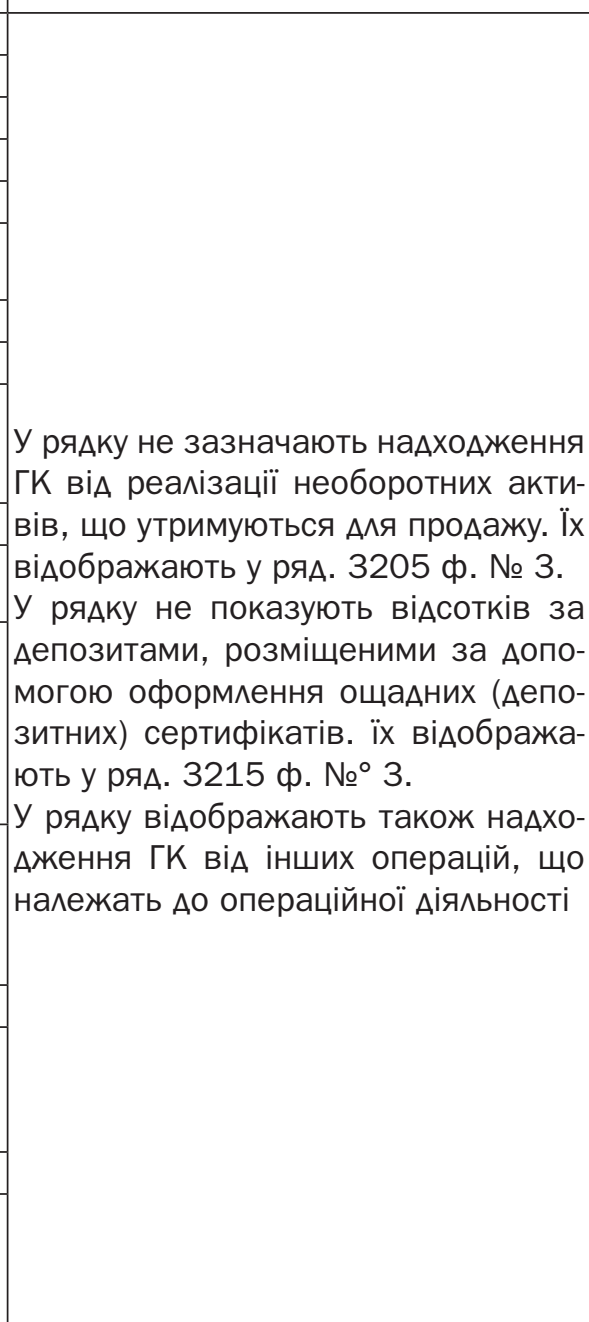 } \\
\hline & & 30 & 377 & \\
\hline & & 31 & 36 & \\
\hline & & 31 & 377 & \\
\hline & НаАходження ГК & 30 & 377 & \\
\hline & $\begin{array}{l}\text { ВіА Аіяльності о обслу- } \\
\text { говуючих господарств }\end{array}$ & 31 & 377 & \\
\hline & НаАходження ГК віА & 31 & 182 & \\
\hline & погашення векселів & 31 & 34 & \\
\hline & $\begin{array}{l}\text { НаАходження ГK віА } \\
\text { повернення в касу піА- } \\
\text { звітними особами ГК }\end{array}$ & 30 & 372 & \\
\hline & НаАхоАження ГК віА віА- & 30 & 375 & \\
\hline & $\begin{array}{l}\text { шкодування заподіяних } \\
\text { підприємству збитків }\end{array}$ & 31 & 375 & \\
\hline & $\begin{array}{l}\text { НаАходження ГК віА } \\
\text { внесення в касу піА- } \\
\text { приємства помилково } \\
\text { зайво виданих сум із } \\
\text { заробітної плати } \\
\end{array}$ & 301 & 661 & \\
\hline & НаАходженняГК віА по- & & & \\
\hline & $\begin{array}{l}\text { милково зарахованих } \\
\text { на поточний рахунок } \\
\text { підприємства коштів }\end{array}$ & 311 & 685 & \\
\hline & \multirow{2}{*}{$\begin{array}{l}\text { НаАходження ГК у ви- } \\
\text { ГАяАі віАсотків за Аепо- } \\
\text { зитними рахунками Ао } \\
\text { запитання }\end{array}$} & 31 & 373 & \\
\hline & & 31 & 719 & \\
\hline & \multirow{2}{*}{\begin{tabular}{|l} 
НаАходження ГК у вигля- \\
Аі Аодатного результату \\
віА операцій купівлі-про- \\
дажу іноземної валюти
\end{tabular}} & 333 & 711 & \\
\hline & & 334 & 711 & \\
\hline
\end{tabular}


Продовження таблиці 4.3

\begin{tabular}{|c|c|c|c|c|}
\hline \multirow{2}{*}{ РяАок Звіту } & \multirow{2}{*}{ Операції руху ГК } & \multicolumn{2}{|c|}{ Оборот за періоА } & \multirow{2}{*}{ Примітки } \\
\hline & & Аебет & КреАит & \\
\hline \multicolumn{5}{|l|}{ Витрачання на оплату: } \\
\hline \multirow{3}{*}{$\begin{array}{l}\text { Товарів (робіт, по- } \\
\text { слуг) (ряА. 3100) }\end{array}$} & \multirow{3}{*}{$\begin{array}{l}\text { Витрачання ГК на оп- } \\
\text { мату товарів (послуг) }\end{array}$} & 372 & 30 & \multirow{3}{*}{$\begin{array}{l}\text { У рядок не вкмючають авансів, ви- } \\
\text { даних постачальникам і підрядни- } \\
\text { кам. Такі суми зазначають у рял. } \\
3135 \text { ф. № } 3\end{array}$} \\
\hline & & 63 & 31 & \\
\hline & & 685 & 31 & \\
\hline \multirow[b]{2}{*}{ Праці (ряА. 3105) } & \multirow[b]{2}{*}{$\begin{array}{l}\text { Витрачання ГК на оп- } \\
\text { ^ату праці }\end{array}$} & 66 & 30 & \multirow[b]{2}{*}{$\begin{array}{l}\text { Ао цього рялка включають також } \\
\text { готівку або перераховані на рахун- } \\
\text { ки працівників у банку ГК у рахунок } \\
\text { погашення заборгованості за рані- } \\
\text { ше депонованими виплатами (Ат } \\
\mathbf{6 6 2} \mathbf{K \mathbf { T }} \mathbf{3 0}, \mathbf{3 1})\end{array}$} \\
\hline & & 66 & 31 & \\
\hline $\begin{array}{l}\text { ВіАрахувань на со- } \\
\text { ціальні заходи (ряА. } \\
\text { 3110) }\end{array}$ & $\begin{array}{l}\text { Витрачання ГК у ча- } \\
\text { стині відрахувань на } \\
\text { страхування } \\
\end{array}$ & 651 & 311 & $\begin{array}{l}\text { Ао рядка включають сплачені суми } \\
\text { єАиного внеску }\end{array}$ \\
\hline \multirow{3}{*}{$\begin{array}{l}\text { Зобов'язань за } \\
\text { податками і збора- } \\
\text { ми (ряА. 3115) }\end{array}$} & \multirow{3}{*}{$\begin{array}{l}\text { Витрачання ГК у ча- } \\
\text { стині спмати зобов'я- } \\
\text { зань за податками та } \\
\text { зборами }\end{array}$} & 641 & 311 & \multirow[b]{2}{*}{$\begin{array}{l}\text { У цьому рядку наводять суму всіх } \\
\text { сплачених податків і зборів, у тому } \\
\text { числі при виконанні функцій подат- } \\
\text { кового агента (податок на доходи } \\
\text { фіз.осіб), а також суми сплачених } \\
\text { фінансових санкцій за податками } \\
\text { та зборами, суми пені за простро- } \\
\text { чення таких платежів } \\
\end{array}$} \\
\hline & & 642 & 311 & \\
\hline & & 651 & 311 & $\begin{array}{l}\text { Зазначають суми віАрахувань Ао } \\
\text { Пенсійного фонду з окремих виАів } \\
\text { операцій }\end{array}$ \\
\hline $\begin{array}{l}\text { Витрачання на } \\
\text { опмату зобов'язань } \\
3 \text { податку на при- } \\
\text { буток (ряА. } 3116- \\
\text { АоАаткова стаття) }\end{array}$ & $\begin{array}{l}\text { Витрачання ГК у ча- } \\
\text { стині сплати поАатку } \\
\text { на прибуток }\end{array}$ & $\begin{array}{l}641 / \\
\text { прибу } \\
\text { ток }\end{array}$ & 311 & 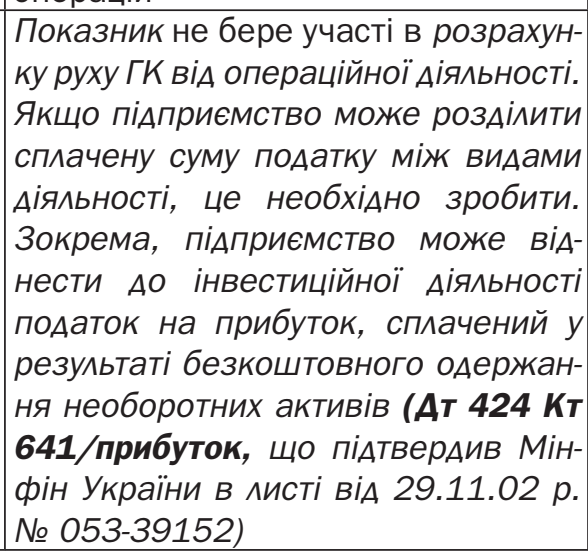 \\
\hline \begin{tabular}{|l|} 
Витрачання на \\
оплату зобов'язань \\
з поАатку на АоАану \\
вартість (ряА. 3117 \\
- АоАаткова стаття)
\end{tabular} & $\begin{array}{l}\text { Витрачання ГК на } \\
\text { сплату ПАВ }\end{array}$ & $\begin{array}{l}641 / \\
\text { ПАВ }\end{array}$ & 311 & $\begin{array}{l}\text { Показник не бере участі в розрахун- } \\
\text { ку руху ГК віА операційної Аіяльності }\end{array}$ \\
\hline \multirow{3}{*}{$\begin{array}{l}\text { Витрачання на оп- } \\
\text { Аату зобов'язань за } \\
\text { іншими поАатками i } \\
\text { зборам (ряА. } 3118 \text { - } \\
\text { АоАаткова стаття) } \\
\end{array}$} & \multirow{3}{*}{$\begin{array}{l}\text { Витрачання ГК на } \\
\text { оплату зобов'язань за } \\
\text { іншими податками та } \\
\text { зборами }\end{array} \mid$} & 641 & 311 & \multirow{3}{*}{$\begin{array}{l}\text { У рядку зазначають суму сплачених } \\
\text { податків і зборів (окрім ПАВ, подат- } \\
\text { ку на прибуток, єАиного внеску). По- } \\
\text { казник не бере участі в розрахунку } \\
\text { руху ГК віА операційної Аіяльності }\end{array}$} \\
\hline & & 642 & 311 & \\
\hline & & 651 & 311 & \\
\hline \multirow{2}{*}{$\begin{array}{l}\text { Витрачання на } \\
\text { оплату авансів (ряА. } \\
\text { З135- АоАаткова } \\
\text { стаття) }\end{array}$} & \multirow[b]{2}{*}{$\begin{array}{l}\text { Витрачання ГК на } \\
\text { оплату авансів }\end{array}$} & 371 & 30 & \multirow{2}{*}{$\begin{array}{l}\text { Якщо піАприємство віАображає пе- } \\
\text { рерахування авансу на рахунку } \mathbf{6 3}, \\
\text { а не субрахунку } \mathbf{3 7 1} \text {, то в рядку на- } \\
\text { водять віАповіАний оборот із рахун- } \\
\text { ку } 63\end{array}$} \\
\hline & & 371 & 31 & \\
\hline
\end{tabular}


Продовження таблиці 4.3

\begin{tabular}{|c|c|c|c|c|}
\hline \multirow{2}{*}{ Ряаок Звіту } & \multirow{2}{*}{ Операції руху ГК } & \multicolumn{2}{|c|}{ Оборот за періоА } & \multirow{2}{*}{ Примітки } \\
\hline & & Аебет & КреАит & \\
\hline $\begin{array}{l}\text { Витрачання на } \\
\text { оплату повернення } \\
\text { авансів (ряА. } 3140- \\
\text { АоАаткова стаття) }\end{array}$ & $\begin{array}{l}\text { Витрачання ГК на } \\
\text { повернення авансів }\end{array}$ & 681 & 30 & $\begin{array}{l}\text { Якщо піАприємство віАображає } \\
\text { одержання авансу віА покупця на } \\
\text { рахунку } \mathbf{3 6} \text {, а не субрахунку } \mathbf{6 8 1} \text {, то } \\
\text { в рялку наводять віАповіАний обо- } \\
\text { рот із рахунку } 36\end{array}$ \\
\hline \multirow{5}{*}{$\begin{array}{l}\text { Витрачання на оп^а- } \\
\text { ту цільових внесків } \\
\text { (ряА. } 3145 \text { - АоАат- } \\
\text { кова стаття) } \\
\text { Витрачання на } \\
\text { оплату зобов'язань } \\
\text { за страховими } \\
\text { контрактами (ряА. } \\
\text { З150 -АоАаткова } \\
\text { стаття) } \\
\end{array}$} & $\begin{array}{l}\text { Витрачання ГК на оп- } \\
\text { ^ату цільових внесків }\end{array}$ & 949 & 311 & $\begin{array}{l}\text { У рялку віАображають суму оплаче- } \\
\text { них цільових і благодійних внесків, } \\
\text { що належать Ао операційної Аіяль- } \\
\text { ності }\end{array}$ \\
\hline & \multirow{4}{*}{$\begin{array}{l}\text { Витрачання ГК на оп- } \\
\text { ^ату зобов'язань } \quad \text { за } \\
\text { страховими контрак- } \\
\text { тами }\end{array}$} & 76 & 30 & \multirow{4}{*}{ Рядок заповнюють страховики } \\
\hline & & 76 & 311 & \\
\hline & & 904 & 30 & \\
\hline & & 904 & 311 & \\
\hline $\begin{array}{l}\text { Витрачання } \\
\text { фінансових установ } \\
\text { на наАання позик } \\
\text { (ряА. } 3155 \text { - АоАат- } \\
\text { кова стаття) }\end{array}$ & $\begin{array}{l}\text { Витрачання ГК фінан- } \\
\text { совими установами на } \\
\text { надання позик }\end{array}$ & - & - & $\begin{array}{l}\text { РяАок заповнюють фінансові уста- } \\
\text { нови }\end{array}$ \\
\hline \multirow{13}{*}{$\begin{array}{l}\text { Інші витрачання } \\
\text { (ряА. 3190) }\end{array}$} & \multirow{2}{*}{\begin{tabular}{|l} 
Витрачання ГК на по- \\
гашення заборговано- \\
сті, забезпеченої ви- \\
Ааним векселем
\end{tabular}} & 51 & 31 & \multirow{13}{*}{ 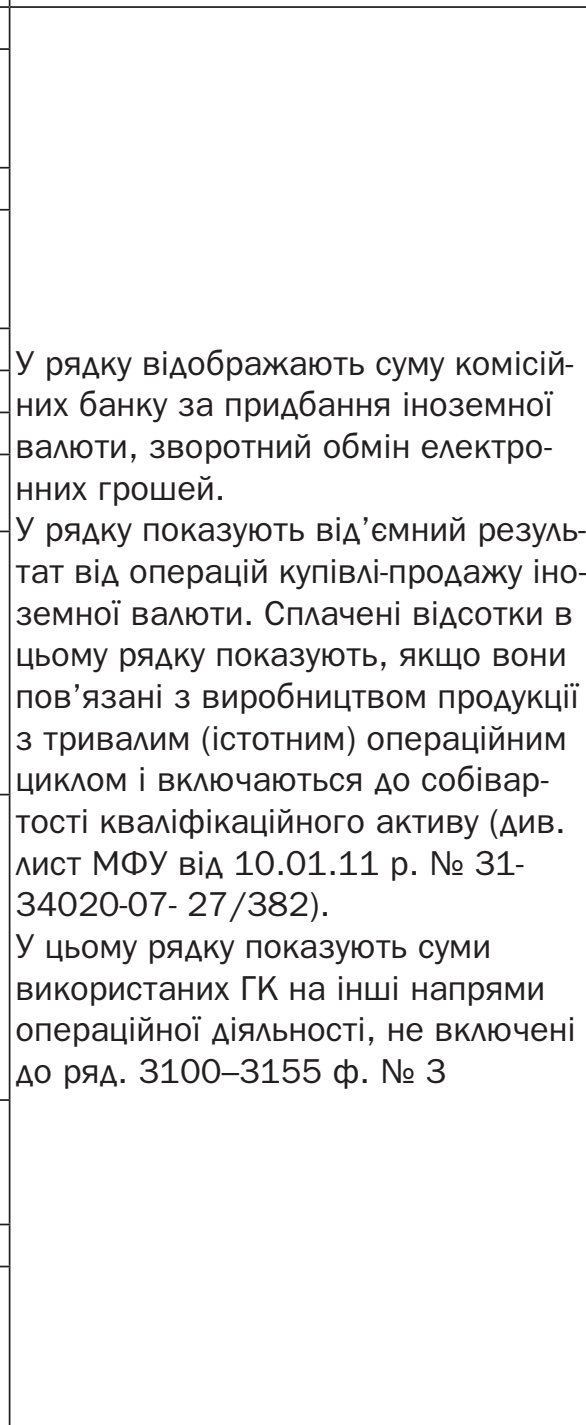 } \\
\hline & & 62 & 31 & \\
\hline & \multirow{2}{*}{\begin{tabular}{|l} 
Витрачання ГК на ви- \\
Аачу в піАзвіт на гос- \\
подарські потреби та \\
віАрядження
\end{tabular}} & 372 & 30 & \\
\hline & & 372 & 31 & \\
\hline & \multirow{4}{*}{\begin{tabular}{|l|} 
Витрачання ГК на спла- \\
ту комісійних банку \\
Витрачання ГК на опе- \\
рації купівлі-продажу \\
іноземної валюти \\
\end{tabular}} & 92 & 333 & \\
\hline & & 92 & 334 & \\
\hline & & 942 & 333 & \\
\hline & & 942 & 334 & \\
\hline & $\begin{array}{l}\text { Витрачання ГК на пе- } \\
\text { рерахування платежів } \\
\text { страховим організаці- } \\
\text { ям за індивідуальним } \\
\text { страхуванням персо- } \\
\text { налу підприємства }\end{array}$ & 654 & 311 & \\
\hline & $\begin{array}{l}\text { Витрачання ГK на пе- } \\
\text { рерахування платежів } \\
\text { страховим організа- } \\
\text { ціям зі страхування } \\
\text { майна підприємства та } \\
\text { майна працівників піА- } \\
\text { приємства }\end{array}$ & 655 & 311 & \\
\hline & $\begin{array}{l}\text { Витрачання ГК на спла- } \\
\text { ту платежів за об'єкти } \\
\text { операційної оренди } \\
\end{array}$ & 685 & 31 & \\
\hline & Витрачання ГК на & 685 & 31 & \\
\hline & $\begin{array}{l}\text { сплату неустойки, } \\
\text { штрафів, пені за пору- } \\
\text { шення умов господар- } \\
\text { ських договорів }\end{array}$ & 948 & 31 & \\
\hline
\end{tabular}


Продовження таблиці 4.3

\begin{tabular}{|c|c|c|c|c|}
\hline \multirow{2}{*}{ РяАок Звіту } & \multirow{2}{*}{ Операції руху ГК } & \multicolumn{2}{|c|}{ Оборот за періоА } & \multirow{2}{*}{ Примітки } \\
\hline & & Аебет & КреАит & \\
\hline & $\begin{array}{l}\text { Витрачання ГК на } \\
\text { повернення помил- } \\
\text { ково зарахованих } \\
\text { на поточний рахунок } \\
\text { підприємства коштів }\end{array}$ & 685 & 311 & \\
\hline & \multirow[b]{2}{*}{\begin{tabular}{|l} 
Витрачання ГК у \\
частині переведення \\
ГК, що значаться на \\
банківських рахунках, \\
якими піАприємство \\
не може скористати- \\
ся з вини банків, Ао \\
складу заборгованості
\end{tabular}} & 374 & 31 & \\
\hline & & 377 & 31 & \\
\hline & $\begin{array}{l}\text { Витрачання ГK на } \\
\text { сплату віАсотків }\end{array}$ & 684 & 311 & \\
\hline $\begin{array}{l}\text { Чистий рух грошо- } \\
\text { вих коштів віА опе- } \\
\text { раційної Аіямьності }\end{array}$ & \multicolumn{3}{|c|}{ 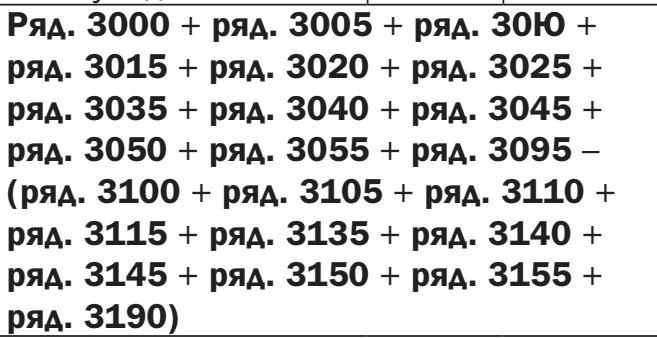 } & $\begin{array}{l}\text { ВіА'ємне значення навоАять у } \\
\text { Аужках }\end{array}$ \\
\hline
\end{tabular}

Ажерело: [4; 18, с. 28-30].

\section{3. Зміст статей звіту про рух грошових коштів та методика його скмаАання за непрямим метоАом}

РозАіл I звіту про рух грошових коштів (за непрямим методом) передбачає коригування прибутку (збитку) віА звичайної Аіяльності Ао оподаткування.

При заповненні цього розАілу звіту необхідно враховувати, що:

- оскільки при заповненні розділу коригується загальний прибуток піАприємства, то із нього необхіАно виключити прибутки віА неопераційної Аіяльності та АоАатки збитки віА такої Аіяльності;

- суми нарахованої амортизації основних засобів, інших необоротних матеріальних активів та нематеріальних активів зменшують прибуток піАприємства, оскільки є витратами, оАнак, не призводять Ао виАатку грошових коштів, а тому є наАХоАженням;

- створення забезпечень призводить до збільшення витрат піАприємства, однак, не передбачає видатку грошових коштів, а тому є надходженням;

- збиток віА нереалізованих курсових різниць $є$ надходженням коштів, а прибуток - виАатком. Нереалізовані курсові різниці - це курсові різниці, що виникають внаслілок перерахування статті "Гроші та їх еквіваленти" в іноземній валюті;

- при збільшенні залишків запасів відбувається вилаток грошових коштів, тому прибуток зменшується при коригуванні, при їх зменшенні, навпаки, наАхоАження, що призводить Ао зростання прибутку;

- збільшення розміру дебіторської заборгованості призводить до віАволікання коштів $з$ обороту, тому прибуток зменшується, зменшення заборгованості - Ао надходження коштів, тому прибуток збільшується;

- зменшення витрат майбутніх періодів призводить до їх часткового включення до витрат звітного періоду та не призводить Ао вибуття грошових коштів, тому прибуток збільшується, збільшення витрат майбутніх періодів, навпаки, призводить до зменшення прибутку; 
- збільшення поточних зобов'язань призводить до росту грошових коштів, що знахоАяться в розпоряАженні піАприємства та збільшує суму прибутку, їх зменшення, навпаки, призводить Ао зменшення прибутку;

- збільшення доходів майбутніх періодів у подальшому призведе до наАходження грошових коштів, а тому збільшує прибуток, їх зменшення, навпаки, зменшує прибуток [13, с. 210-211].

Методику заповнення розділу I "Рух коштів у результаті операційної Аіяльності" за непрямим методом наведено у таблиці 4.4 .

Таблиця 4.4

РозАіл I "Рух коштів у результаті операційної Аіямьності" (непрямий метоА)

\begin{tabular}{|c|c|c|}
\hline Назва статті & $\begin{array}{c}\text { Аані А^я заповнення графи } 3 \\
\text { "НаАхоАження" }\end{array}$ & $\begin{array}{c}\text { Аані А^я заповнення графи } 4 \\
\text { "ВиАаток" }\end{array}$ \\
\hline $\begin{array}{c}\text { Прибуток (збиток) віА звичайної } \\
\text { Аіяльності до оподаткування }\end{array}$ & $\begin{array}{c}\text { Прибуток віА звичайної Аіяльно- } \\
\text { сті (гр. } 3 \text { ряА. } 2290 \text { ф. №2) }\end{array}$ & $\begin{array}{c}\text { Збиток віА звичайної Аіяльності } \\
\text { (гр. } 3 \text { ряд. } 2295 \text { ф. № 2) }\end{array}$ \\
\hline \multicolumn{3}{|l|}{ Коригування на: } \\
\hline $\begin{array}{l}\text { амортизацію необоротних акти- } \\
\text { вів (ряА. 3505) }\end{array}$ & $\begin{array}{l}\text { Сума нарахованої а } \\
\text { (гр. } 3 \text { рян. } 2515 \text { q }\end{array}$ & $x$ \\
\hline \multirow[t]{2}{*}{$\begin{array}{l}\text { збільшення (зменшення) забез- } \\
\text { печень (ряА. 3510) }\end{array}$} & \multicolumn{2}{|c|}{ 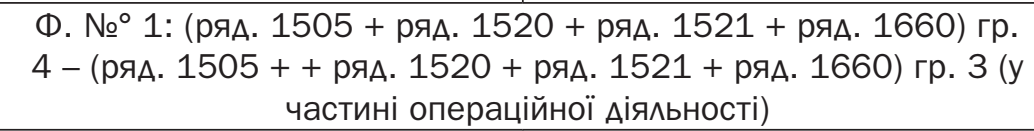 } \\
\hline & $>0$ & $<0$ \\
\hline \multirow[t]{2}{*}{$\begin{array}{l}\text { збиток (прибуток) віА нереалі- } \\
\text { зованих курсових різниць (ряд. } \\
\text { 3515) }\end{array}$} & \multicolumn{2}{|c|}{ 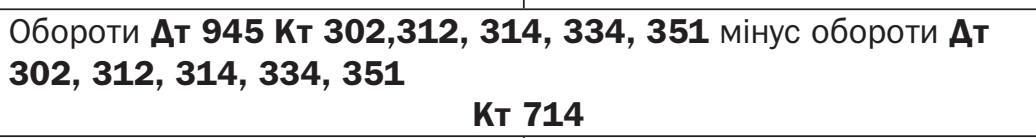 } \\
\hline & $>0$ & $<0$ \\
\hline
\end{tabular}

Примітка. У цьому рялку зазначають тільки нереалізовані курсові різниці за залишками ГК в іноземній валюті на кінець звітного періоду. Тут не враховують курсових різниць за монетарною заборгованістю, пов'язаною з операційною Аіяльністю

Ф. № 2, гр. 3: (ряА. 2255 + ряА. 2270) - (ряА. 2200 + ряА. 2220

+ ряА. 2240) плюс (ряА. 2180 - ряА. 2120) гр. 3 ф. № 2 (у ча-

збиток (прибуток) віА неопера- стині збитку віА реалізації необоротних активів, що утримуються

ційної Аіяльності та інших негро- Аля продажу, і груп вибуття, а також збитку віА зміни вартості

шових операцій (рял. 3520) активів, оцінюваних за справеАливою вартістю, і первісного

визнання біологічних активів

\begin{tabular}{l|l}
$>0$ & $<0$
\end{tabular}

Прибуток (збиток) віА участі в

капіталі (рял. 3521 - Аодаткова стаття)

Зміна вартості активів, які оцінюються за справедиивою вартістю, і АохіА (витрати) віА первісного визнання (ряА.

3522-Аодаткова стаття)

Збиток (прибуток) віА реалізації необоротних активів, що утримуються Аля продажу, та груп вибуття (ряА. 3523 - Аодаткова стаття)

РяА. 2255 - ряА. 2200 гр. 3 ф. № 2. Показник не бере участі в розрахунку руху ГК віА операційної Аіяльності

РяА. 2181 + ряА. 2182 - ряА. 2121 - ряА. 2122 гр. 3 ф. № 2. Показник не бере участі в розрахунку руху ГК віА операційної Аіяльності

$>0<0$

Обороти Ат 791 Кт 943 мінус обороти Ат 712 Кт 791 (у частині реалізації необоротних активів, що утримуються Аля продажу, і груп вибуття). Показник не бере участі в розрахунку руху ГК віА операційної Аіяльності

Примітка. Хоча у ф. № 2 операції з реалізації необоротних активів вілображають у склаАі операційних доходів і витрат (ряА. 2120 і 2180), у ф. № 3-н реалізацію необоротних активів, що утримуються Аля продажу, і груп вибуття вінносять Ао інвестиційної Аіяльності. У зв'язку із цим до субрахунків 712 і 943 можна віАкрити аналітичні субрахунки А^я окремого накопичення інформації про доходи та витрати віА продажу необоротних активів, що утримуються Аля продажу, і груп вибуття 
Продовження таблиці 4.4

\begin{tabular}{|c|c|c|}
\hline Назва статті & & \\
\hline \multirow{2}{*}{$\begin{array}{c}\text { Збиток (прибуток) віА реаліза- } \\
\text { ції фінансових інвестицій (ряА. } \\
3524 \text { - додаткова стаття) }\end{array}$} & \multicolumn{2}{|c|}{$\begin{array}{c}\text { Обороти Ат } 793 \text { Кт } 971 \text { мінус обороти Ат } 741 \text { Кт 793. Показник } \\
\text { не бере участі в розрахунку руху ГК віА операційної Аіяльності }\end{array}$} \\
\hline & $>0$ & $<0$ \\
\hline \multirow{2}{*}{$\begin{array}{c}\text { Зменшення (віАновлення) корис- } \\
\text { ності необоротних активів (ряА. } \\
3526 \text { - Аодаткова стаття) }\end{array}$} & \multicolumn{2}{|c|}{ Обороти Ат 972 мінус обороти Кт 742} \\
\hline & $>0$ & $<0$ \\
\hline \multirow{3}{*}{$\begin{array}{c}\text { Фінансові витрати (рял. 3540- } \\
\text { додаткова стаття) } \\
\text { Зменшення (збільшення) обо- } \\
\text { ротних активів (рял. 3550) }\end{array}$} & Ф. № 2: ряА. 2250 гр & $X$ \\
\hline & \multicolumn{2}{|c|}{$\begin{array}{c}\text { Ф. № 1: різниця між сумою рял. } 1100-1135,1140,1145,1155 \text {, } \\
\text { 1170, } 1190 \text { за гр. } 3 \text { і сумою цих самих рялків за гр. } 4\end{array}$} \\
\hline & $>0$ & $<0$ \\
\hline \multicolumn{3}{|c|}{ 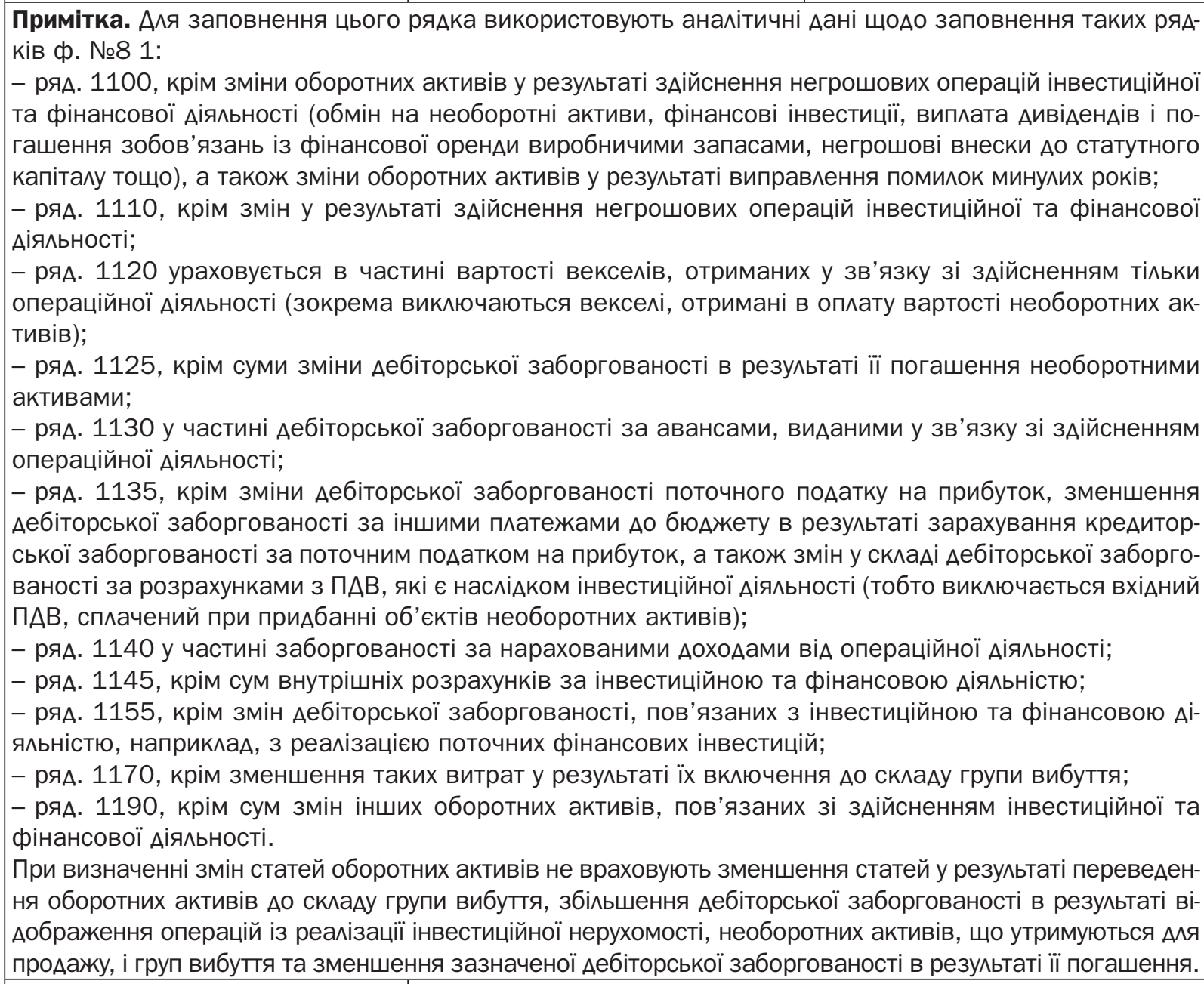 } \\
\hline \multirow{2}{*}{$\begin{array}{c}\text { Збільшення (зменшення) за- } \\
\text { пасів (рял. } 3551 \text { - Аодаткова } \\
\text { стаття) }\end{array}$} & \multicolumn{2}{|c|}{$\begin{array}{c}\text { Ф. № 1: різниця між гр. } 3 \text { і гр. } 4 \text { рял. 1100. Показник не бере } \\
\text { участі в розрахунку руху ГК від операційної діяльності }\end{array}$} \\
\hline & $>0$ & $<0$ \\
\hline \multirow{2}{*}{$\begin{array}{c}\text { Збільшення (зменшення) по- } \\
\text { точних біологічних активів (рял. } \\
3552 \text { - Аодаткова стаття) }\end{array}$} & \multicolumn{2}{|c|}{$\begin{array}{c}\text { Ф. № 1: різниця міжк гр. } 3 \text { і гр. } 4 \text { рял. 1110. Показник не бере } \\
\text { участі в розрахунку руху ГК віА операційної Аіяльності }\end{array}$} \\
\hline & $>0$ & $<0$ \\
\hline \multirow{2}{*}{$\begin{array}{l}\text { Збільшення (зменшення) Аебі- } \\
\text { торської заборгованості за про- } \\
\text { дукцію, товари, роботи, послуги } \\
\text { (ряд. } 3553 \text { - Аодаткова стаття) }\end{array}$} & \multicolumn{2}{|c|}{$\begin{array}{c}\text { Ф. № 1: різниця між гр. } 3 \text { і гр. } 4 \text { рял. 1125. Показник не бере } \\
\text { участі в розрахунку руху ГК віА операційної Аіяльності }\end{array}$} \\
\hline & & \\
\hline
\end{tabular}


Продовження таблиці 4.4

\begin{tabular}{|c|c|c|}
\hline Назва статті & & \\
\hline \multirow{2}{*}{$\begin{array}{c}\text { Зменшення (збільшення) витрат } \\
\text { майбутніх періодів (ряд. } 3556 \text { - } \\
\text { додаткова стаття) }\end{array}$} & \multicolumn{2}{|c|}{$\begin{array}{c}\text { Ф. № 1: різниця між гр. } 3 \text { і гр. } 4 \text { рял. 1170. Показник не бере } \\
\text { участі в розрахунку руху ГК віА операційної Аіяльності }\end{array}$} \\
\hline & $>0$ & $<0$ \\
\hline \multirow{2}{*}{$\begin{array}{c}\text { Зменшення (збільшення) інших } \\
\text { оборотних активів (ряА. } 3557 \text { - } \\
\text { Аодаткова стаття) }\end{array}$} & \multicolumn{2}{|c|}{$\begin{array}{c}\text { Ф. № 1: різниця міжк гр. } 3 \text { і гр. } 4 \text { рял. 1190. Показник не бере } \\
\text { участі в розрахунку руху ГК віА операційної Аіяльності }\end{array}$} \\
\hline & $>0$ & $<0$ \\
\hline \multirow[t]{2}{*}{$\begin{array}{c}\text { 3більшення (зменшення) поточ- } \\
\text { них зобов'язань (ряА. 3560) }\end{array}$} & \multicolumn{2}{|c|}{$\begin{array}{l}\text { Ф. № 1: різниця міжк сумою рял. } 1605,1615,1620,1625,1630 \text {, } \\
\text { 1635, 1645, 1665, } 1690 \text { за гр. } 4 \text { і сумою цих самих рядків за гр. } 3\end{array}$} \\
\hline & $>0$ & $<0$ \\
\hline \multicolumn{3}{|c|}{ 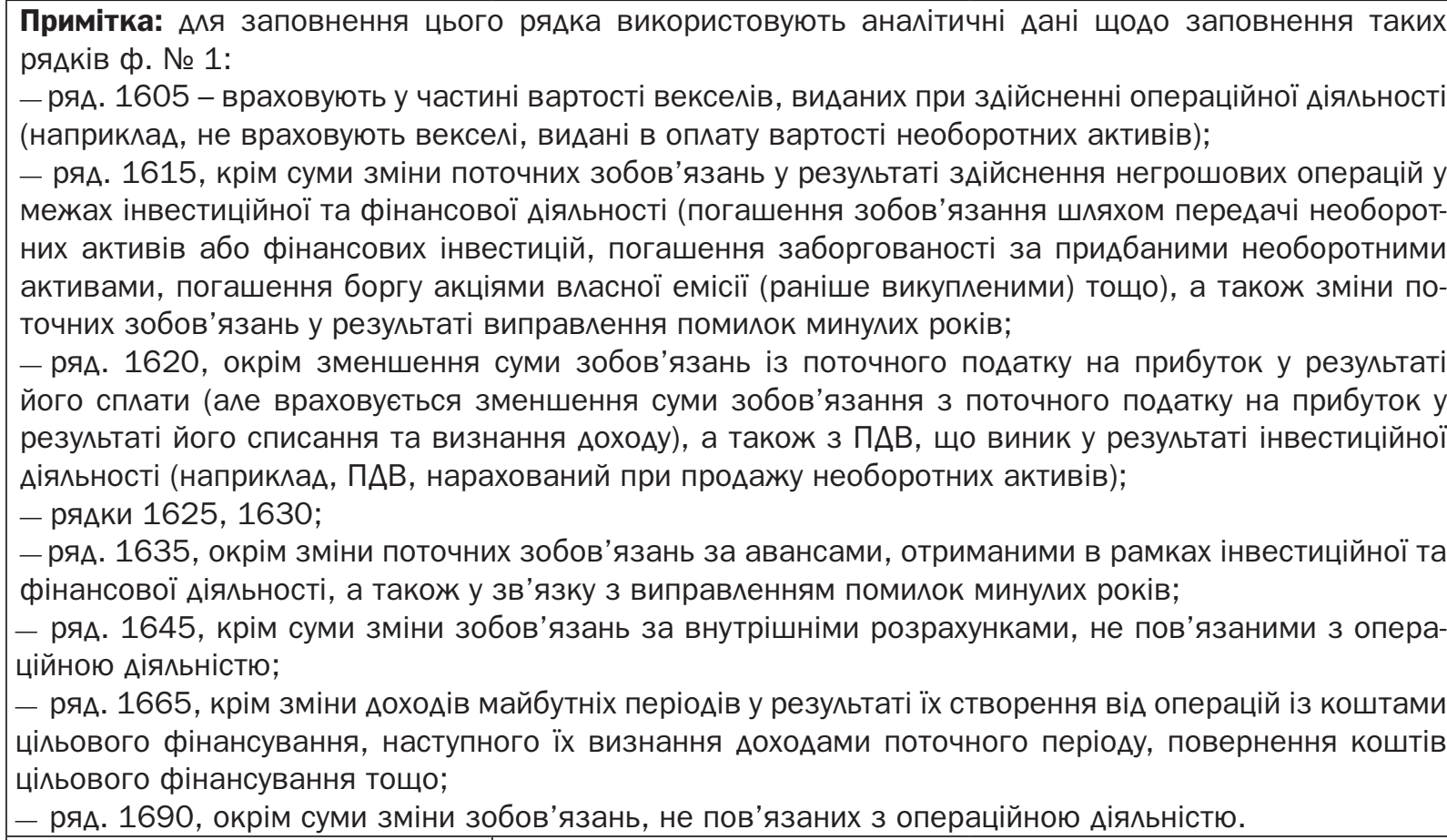 } \\
\hline \multirow{2}{*}{$\begin{array}{l}\text { Збільшення (зменшення) поточ- } \\
\text { ної кредиторської заборговано- } \\
\text { сті за товари, роботи, послуги } \\
\text { (рял, } 3561 \text {-Аодаткова стаття) }\end{array}$} & \multicolumn{2}{|c|}{$\begin{array}{c}\text { Ф. №1: різниця міжк гр. } 4 \text { і гр. } 3 \text { рял. 1615. Показник не бере } \\
\text { участі в розрахунку руху ГК віА операційної Аіяльності }\end{array}$} \\
\hline & & 0 \\
\hline \multirow{2}{*}{$\begin{array}{c}\text { Збільшення (зменшення) } \\
\text { поточної кредиторської забор- } \\
\text { гованості за розрахунками } 3 \\
\text { бюджетом (ряд. } 3562 \text { - Аолатко- } \\
\text { ва стаття) }\end{array}$} & \multicolumn{2}{|c|}{$\begin{array}{c}\text { Ф. № 1: різниця між гр. } 4 \text { і гр. } 3 \text { ряА. 1620. Показник не бере } \\
\text { участі в розрахунку руху ГК віА операційної Аіяльності }\end{array}$} \\
\hline & & $<0$ \\
\hline \multirow{2}{*}{$\begin{array}{c}\text { Збільшення (зменшення) поточ- } \\
\text { ної кредиторської заборговано- } \\
\text { сті за розрахунками зі страху- } \\
\text { вання (ряА. } 3563 \text { - Аодаткова } \\
\text { стаття) }\end{array}$} & \multicolumn{2}{|c|}{$\begin{array}{c}\text { Ф. № 1: різниця між гр. } 4 \text { і гр. } 3 \text { рял. 1625. Показник не бере } \\
\text { участі в розрахунку руху ГК віА операційної Аіяльності }\end{array}$} \\
\hline & & $<0$ \\
\hline \multirow{2}{*}{$\begin{array}{c}\text { Збільшення (зменшення) поточ- } \\
\text { ної кредиторської заборговано- } \\
\text { сті за розрахунками з оплати } \\
\text { праці (рял. } 3564 \text { - Аолаткова } \\
\text { стаття) }\end{array}$} & \multicolumn{2}{|c|}{$\begin{array}{c}\text { Ф. №9 1: різниця між гр. } 4 \text { і гр. } 3 \text { рял. 1630. Показник не бере } \\
\text { участі в розрахунку руху ГК від операційної Аіяльності }\end{array}$} \\
\hline & & $<0$ \\
\hline
\end{tabular}


Продовження таблиці 4.4

\begin{tabular}{|c|c|c|}
\hline Назва статті & $\begin{array}{c}\text { Аані А^я заповнення графи } 3 \\
\text { "НаАхоАження" }\end{array}$ & $\begin{array}{l}\text { Аані А^я заповнення графи } 4 \\
\text { "ВиАаток" }\end{array}$ \\
\hline $\begin{array}{l}\text { Збімьшення (зменшення) Ао- } \\
\text { ходів майбутніх періодів (ряА. }\end{array}$ & \multicolumn{2}{|c|}{$\begin{array}{c}\text { Ф. № 1: різниця міжк гр. } 4 \text { і гр. } 3 \text { рял. 1665. Показник не бере } \\
\text { участі в розрахунку руху ГК від операційної Аіяльності }\end{array}$} \\
\hline 3566 - додаткова стаття) & $>0$ & $<0$ \\
\hline $\begin{array}{l}\text { 3більшення (зменшення) інших } \\
\text { поточних зобов'язань (ряА. }\end{array}$ & \multicolumn{2}{|c|}{$\begin{array}{c}\text { Ф. №1: різниця міжк гр. } 4 \text { і гр. } 3 \text { рял. 1690. Показник не бере } \\
\text { участі в розрахунку руху ГК від операційної Аіяльності }\end{array}$} \\
\hline 3567 - додаткова стаття) & $>0$ & $<0$ \\
\hline \multirow[t]{2}{*}{$\begin{array}{l}\text { Кошти віА операційної Аіяльно- } \\
\text { сті (рян. 3570) }\end{array}$} & \multicolumn{2}{|c|}{$\begin{array}{l}\text { Ф. № 3-н: (ряА. } 3500 \text { + ряА. } 3505 \text { + ряА. } 3510 \text { + ряА. } 3515+ \\
\text { ряА. } 3520 \text { + ряА. } 3540 \text { + ряА. } 3550 \text { + ряА. } 3560 \text { ) гр. } 3 \text { - (ряА. } \\
3510 \text { + ряА. } 3515 \text { + ряА. } 3520 \text { + ряА. } 3550 \text { + ряА. } 3560) \text { гр. } 4\end{array}$} \\
\hline & $>0$ & $<0$ \\
\hline $\begin{array}{c}\text { Сплачений податок на прибуток } \\
\text { (ряА. 3580) }\end{array}$ & $X$ & $\begin{array}{c}\text { Оборот Ат 641/податок на при- } \\
\text { буток Кт } \mathbf{3 1}\end{array}$ \\
\hline $\begin{array}{c}\text { Сплачені віАсотки (ряА. 3585- } \\
\text { Аодаткова стаття) }\end{array}$ & $X$ & $\begin{array}{l}\text { Оборот Ат } 684 \text { Кт 30, } 31 \text { (крім } \\
\text { капіталізованих віАсотків і віАсо- } \\
\text { тків за позиками, що використо- } \\
\text { вуються у фінансовій та інвести- } \\
\text { ційній Аіяльності) }\end{array}$ \\
\hline $\begin{array}{l}\text { Чистий рух коштів віА опера- } \\
\text { ційної АіяАьності (ряА. 3195) }\end{array}$ & $>0$ & $<0$ \\
\hline
\end{tabular}

Ажерело: [4; 18, с. 30-32].

Методика заповнення піАсумкових рядків звіту про рух грошових коштів наведена в табмиці 4.5.

Таблиця 4.5

ПіАсумкові ряАки звіту про рух грошових коштів (за непрямим метоАом)

\begin{tabular}{|c|c|}
\hline Назва статті & Аані Аля заповнення \\
\hline Чистий рух коштів за звітний періоА (ряА. 3400) & $\begin{array}{l}\text { Рян. } 3195 \pm \text { ряа. } 3295 \pm \text { рян. } 3395 \text { форми № 3-Н. } \\
\text { ВіА'ємне значення наводять у графі } 4 \text { «Видаток” }\end{array}$ \\
\hline Залишок коштів на початок року (ряА. 3405) & Гр. 3 ряА. 1165 форми № 1 \\
\hline $\begin{array}{l}\text { Вплив зміни валютних курсів на залишок коштів } \\
\text { (ряА. 3410) }\end{array}$ & $\begin{array}{l}\text { Обороти Ат 302, 312, 314, 334, } 351 \text { Кт 714, } \\
744 ; \text { Ат } 333 \text { Кт 719 мінус обороти Ат 945, } 974 \\
\text { Кт 302, 312, 314, 334, 351 } \\
\text { ВіА'ємне значення наводять у графі } 4 \text { “ВиАаток» }\end{array}$ \\
\hline Залишок коштів на кінець року (ряА. 3415) & РяА. $3405 \pm$ ряА. $3400 \pm$ ряА. 3410 форми № 3-Н \\
\hline
\end{tabular}

Ажерело: [4; 18, с. 32].

Також варто зазначити: якщо виникають певні "нестандартні» операції, їх можна відобразити у Звіті так:

1) визначити, Ао якого вилу Аіяльності належить "грошова" операція: Ао операційної, інвестиційної чи фінансової;

2) включити оборот за цією операцією до загальних рялків Звіту з відповідного виду Аіяльності:

- операційної Аіяльності: наАходження - Ао ряА. 3095, витрачання - Ао ряА. 3190 Звіту;

- інвестиційної Аіяльності: наАходження - Ао ряА. 3250; витрачання - Ао ряА. 3290 Звіту;

- фінансової Аіяльності: надходження - Ао ряА. 3340, витрачання - Ао ряА. 3390 Звіту.

Аля полегшення заповнення Звіту в майбутньому доцільно відкрити Ао кожного субрахунку аналітичні субрахунки із зазначенням номера рядка Звіту. Тоді проблем із його складанням взагалі не виникатиме [18, с. 32]. 


\section{КОНТРОАЬНІ ПИТАННЯ:}

1. Яка мета скмадання звіту про рух грошових коштів?

2. Розкрийте поняття "грошові кошти"?

3. Розкрийте поняття "грошові потоки"?

4. Розкрийте поняття «негрошові операції»?

5. Чи відображаються негрошові операції в звіті про рух грошових коштів?

6. Розкрийте поняття "рух грошових коштів"?

7. За яким методом складається звіт про рух грошових коштів?

8. Скільки розділів має звіт про рух грошових коштів і назвіть які?

9. В чому полягає сутність прямого методу складання цього звіту?

10. На пілставі якої інформації складається звіт про рух грошових коштів?

11. Чи є взаємозв'язок окремих показників звіту про рух грошових коштів з балансом та іншими формами звітності?

12. Назвіть наАходження і витрачання віА операційної Аіяльності.

13. Назвіть наАходження і витрачання віА інвестиційної Аіяльності.

14. Назвіть надходження і витрачання віА фінансової діяльності.

15. Як розрахувати чистий рух грошових коштів віА операційної, інвестиційної та фінансової Аіямьності?

16. Як розрахувати залишок грошових коштів на кінець звітного періоду?

17. Яке значення звіту про рух грошових коштів в управлінні підприємством?

18. Яка інформація про грошові кошти наводиться у примітках до річної фінансової звітності? 


\section{ЗВІТ ПРО ВААСНИЙ КАПІТАА}

\section{1. ВАасний капіта^ та його функції. Статті в^асного капіталу та їх зміни}

Звіт про власний капітал - це звіт, який віАображає зміни у ск^аАі в^асного капіталу піАприємства протягом звітного періоду.

ВАасний капітал - це різниця між активами і зобов'язаннями підприємства.

Власний капітал утворюється за рахунок:

- внесення власниками (засновниками) грошей чи інших активів;

- накопичення суми прибутку, що залишається на піАприємстві;

- інших Ажерел.

Метою скмаАання звіту про власний капітал $є$ наАання користувачам повної, правдивої та неупередженої інформації про зміни у склаАі власного капіталу піАприємства протягом звітного періоду.

Іншими словами власний капітал - це власні Ажерела фінансування Аіяльності піАприємства, які без визначення строку повернення внесені його власниками (засновниками), або залишені ними на підприємстві із чистого прибутку [13, с. 247].

За рівнем віАповіАальності власний капітал поділяється на Аві частини:

- зареєстрований капітал, розмір якого визначається установчими Аокументами і обов'язково піАлягає реєстрації (статутний, пайовий, інший зареєстрований капітал);

- незареєстрований капітал, тобто Аодаткові внески засновників (учасників), капітал у Аооцінках, резервний капітал та нерозподілений прибуток [13, с. 248].

Значення власного капіталу підприємства розкривається через його функції:

1) Аовгострокового фінансування - власний капітал знаходиться у необмеженому розпоряАженні підприємства;

2) захист прав креАиторів віА втрати капіталу - власний капітал $є$ мірилом віАповіАальності на підприємстві і захистом кредиторів;

3) компенсації понесених збитків - тимчасові збитки погашаються за рахунок власного капіталу;

4) кредитоспроможності - кредити надаються, першою чергою, тим підприємствам, у яких більший власний капітал і менша кредиторська заборгованість;

5) фінансування ризиків - власний капіта^ використовується А^я фінансування ризикових операцій, на що можуть не погодитися кредитори;

6) незалежність і влада - величина власного капіталу визначає ступінь незалежності та вплив його власників на піАприємство;

7) розподілу доходів і активів - частки окремих власників є основою при розподілі фінансового результату та майна, якщо піАприємство ліквідується [13, с. 249].

Інформація про стан власного капіталу на початок і кінець звітного періоду віАображається у I розділі пасиву балансу (звіту про фінансовий стан) (табл. 5.1). 
ПобуАова I розАілу пасиву балансу

\begin{tabular}{|l|c|}
\hline \multicolumn{1}{|c|}{ Назва розАілу та статей (рахунки) } & КоА ряАка \\
\hline І. Власний капітал & \\
\hline Зареєстрований капітал (рах. 40) & 1400 \\
\hline Капітал у Аооцінках (рах. 41) & 1405 \\
\hline АоАатковий капітал (рах. 42) & 1410 \\
\hline Резервний капітал (рах. 43) & 1415 \\
\hline НерозпоАілений прибуток (рах. 441) або непокритий збиток (рах. 442) & 1420 \\
\hline Неоплачений капітал (рах. 46) & $(1425)$ \\
\hline Вилучений капітал (рах. 45) & $(1430)$ \\
\hline Усього за розАілом I & 1495 \\
\hline
\end{tabular}

Ажерело: [13, с. 250].

За Ааними I розділу пасиву балансу (звіту про фінансовий стан) можна з'ясувати мише стан власного капіталу за його видами на початок та кінець звітного періоду, його загальну зміну за звітний періоА, але неможливо з'ясувати за рахунок чого сталися зміни. А^я контро^ю за змінами власного капіталу введено окремо форму звітності “Звіт про власний капіта^" за формою № 4.

Рахунок 40 "Зареєстрований (пайовий) капітал" призначено Аля обліку та узагальнення інформації про стан і рух статутного й іншого зареєстрованого капіталу, пайового капіталу піАприємства віАповіАно Ао законодавства і установчих документів, а також внесків до ого^ошеного, але ще не зареєстрованого статутного капіталу.

За кредитом рахунку 40 "Зареєстрований (пайовий) капіта^" віАображається збільшення зареєстрованого і пайового капіталу, а також наАходження внесків Ао оголошеного, але ще не зареєстрованого статутного капіталу, за дебетом - його зменшення (вилучення).

Рахунок 40 має такі субрахунки:

401 "Статутний капіта^";

402 «Пайовий капіта^";

403 "ннший зареєстрований капіта^»;

404 «Внески до незареєстрованого статутного капіталу".

На субрахунку 401 "Статутний капітал" віАображається статутний капітал господарських товариств, державних і комунальних піАприємств. Статутний капітал - це сума грошових вклаАів чи іншого майна, що їх власник наАає в повне господарське володіння, користування, розпоряАження пілприємства, яке він створює (табл. 5.2).

На субрахунку 402 "Пайовий капітал" віАображається і узагальнюється інформація про суми пайових внесків членів споживчого товариства, колективного сільськогосподарського піАприємства, житлово-будівельного кооперативу, кредитної спілки та інших підприємств, що передбачені установчими документами. Пайовий капітал - це сукупність коштів фрізичних і юридичних осіб, Аобровільно розміщених у товаристві А^я проваАження його господарсько-фрінансової Аіяльності. Колективні сільськогосподарські пілприємства (КСП) на субрахунку 402 "Пайовий капіта^" обліковують частину вартості майна, яка була розпайована між його членами, частину вартості майна, яка не була розпайована між його членами, а також зростання (зменшення) вартості майна протягом Аіяльності піАприємства.

На субрахунку 403 "нший зареєстрований капітал" віАображається зареєстрований капітал інших підприємств, зокрема приватних підприємств, формування якого переАбачено в установчих Аокументах.

На субрахунку 404 "Внески Ао незареєстрованого статутного капіталу" відображаються внески, які наАходять Аля формування статутного капіталу, зокрема акціонерного товариства, після його оголошення і Ао реєстрації віАповіАних змін Ао установчих Аокументів. СальАо субрахунку 404 після реєстрації статутного капіталу в установленому поряАку списується у кореспонденції із кредитом субрахунку 401 "Статутний капіта^", а у разі якщо піАпри- 
ємству віАмовлено у реєстрації статутного капіталу, у кореспонденції із дебетом субрахунку 404 відображаються операції з повернення активів, які наАходили як внески.

Мінімальний розмір статутного капіталу піАприємств в Україні

Таблиця 5.2

\begin{tabular}{|c|c|}
\hline Товариство & Мінімальний розмір \\
\hline Акціонерне товариство & $\begin{array}{l}1250 \text { мінімальних заробітних плат, виходячи з розміру } \\
\text { мінімальної зарплати, що Аіє на момент створення то- } \\
\text { вариства }\end{array}$ \\
\hline Товариство з обмеженою віАповіАальністю & \multirow{4}{*}{$\begin{array}{l}\text { Мінімальний розмір статутного капіталу законодав- } \\
\text { ством не визначений, його розмір і розмір частки кож- } \\
\text { ного учасника повинні бути зазначені в засновницьких } \\
\text { документах }\end{array}$} \\
\hline Товариство з додатковою віАповіАальністю & \\
\hline Повне товариство & \\
\hline Командитне товариство & \\
\hline Приватне та Аочірнє піАприємство & $\begin{array}{l}\text { Мінімальний розмір статутного капіталу законодав- } \\
\text { ством не визначений, його розмір і розмір частки кож- } \\
\text { ного учасника повинні бути зазначені в засновницьких } \\
\text { документах }\end{array}$ \\
\hline Комунальне пілприємство & $\begin{array}{l}\text { Мінімальний розмір статутного капіталу встановлює } \\
\text { місцева рада, яка створює піАприємство }\end{array}$ \\
\hline
\end{tabular}

Ажерело: [13, с. 254].

Капітал у Аооцінках - це капітал, отриманий при проведенні дооцінки (уцінки) необоротних активів і фінансових інструментів.

Рахунок 41 "Капітал у дооцінках" призначено Аля обліку і узагальнення інформації про Аооцінки (уцінки) необоротних активів і фінансових інструментів, які віАповіАно Ао національних положень (стандартів) бухгалтерського обліку відображаються у склаАі власного капіталу і розкриваються у звіті про фінансові результати (звіті про сукупний АохіА). Залишок на цьому рахунку зменшується у разі уцінки та вибуття зазначених активів, зменшення їх корисності тощо.

Рахунок 41 "Капітал у дооцінках" має такі субрахунки:

411 "Аооцінка (уцінка) основних засобів"

412 "Аооцінка (уцінка) нематеріальних активів"

413 "Аооцінка (уцінка) фінансових інструментів"

414 "Інший капітал у дооцінках"

На субрахунку 411 "Аооцінка (уцінка) основних засобів" узагальнюється інформація про Аооцінки об'єктів основних засобів, уцінки таких об'єктів в межах сум раніше проведених Аооцінок, віАнесення сум Аооцінки Ао нерозподіленого прибутку.

На субрахунку 412 "Аооцінка (уцінка) нематеріальних активів" узагальнюється інформація про Аооцінки об'єктів нематеріальних активів, уцінки таких об'єктів в межах сум раніше проведених Аооцінок, віАнесення сум Аооцінки до нерозподіленого прибутку.

На субрахунку 413 "Аооцінка (уцінка) фінансових інструментів" узагальнюється інформація про зміну балансової вартості об'єкта хеджування при значенні коефіцієнта ефективності хеджування грошових потоків у межах, визначених національними положеннями (стандартами) бухгалтерського обліку, та віАнесення сум Ао первісної вартості фінансових активів чи фінансових зобов'язань або до складу інших доходів (витрат).

На субрахунку 414 "Інший капітал у дооцінках" узагальнюється інформація про інший капітал у дооцінках, не вілображений на інших субрахунках.

Аодатковий капітал - це сума, на яку вартість реалізації випущених акцій перевищує їх номінальну вартість; інший вкладений засновниками піАприємств (крім акціонерних товариств) капітал, що перевищує статутний капітал без рішень про зміну розміру статутного капіталу; накопичені курсові різниці; вартість безкоштовно отриманих необоротних активів тощо. За кредитом рахунку 42 "Аодатковий капітал" віАображається збільшення Аолаткового капіталу, за дебетом - його зменшення. 
Рахунок 42 "Аодатковий капітал" має такі субрахунки:

421 "Емісійний АохіА"

422 "Інший вкладений капітал"

423 «Накопичені курсові різниці"

424 «Безоплатно одержані необоротні активи"

425 "нший Аодатковий капіта^"

На субрахунку 421 "Емісійний АохіА” віАображається прибуток (збиток) віА продажу, випуску або анулювання інструментів власного капіталу. Сума перевищення збитку віА зазначених операцій нал залишком емісійного доходу відображається за дебетом рахунку 44 "Нерозподілені прибутки (непокриті збитки)"

На субрахунку 422 “нший вкладений капітал” обліковують інший вкладений засновниками піАприємств (крім акціонерних товариств) капітал, що перевищує статутний капітал, інші внески тощо без рішень про зміни розміру статутного капіталу.

На субрахунку 423 «Накопичені курсові різниці" узагальнюється інформація про курсові різниці, які віАповіАно Ао національних положень (стандартів) бухгалтерського обліку віАображаються у склаАі власного капіталу та визнаються в іншому сукупному дохоАі (курсові різниці, які виникають щодо Аебіторської заборгованості або зобов'язань за розрахунками із господарською одиницею за межами України, погашення яких не планується в найближкчій перспективі).

На субрахунку 424 "Безоплатно одержані необоротні активи" віАображається вартість необоротних активів, безоплатно одержаних піАприємством віА інших осіб. Залишок Аодаткового капіталу на цьому субрахунку зменшується на суму визнаного Аоходу протягом строку корисного використання безоплатно одержаних об'єктів необоротних активів (окрім землі) і при вибутті таких активів і землі.

На субрахунку 425 "нший Аодатковий капітал" обліковують інші види Аодаткового капіта^у, які не можуть бути включені до наведених вище субрахунків, зокрема капітал у сумі вартості необоротних активів, отриманих за договором оренди цілісних майнових комплексів.

Резервний капітал - це сума резервів, створених віАповіАно до чинного законодавства або установчих Аокументів. Резервний капітал акціонерного товариства формується у розмірі не менше, ніж 15\% статутного капіталу товариства шляхом щорічних віАрахувань віА чистого прибутку товариства або за рахунок нерозподіленого прибутку. Ао Аосягнення встановленого статутом розміру резервного капіталу розмір щорічних віАрахувань не може бути меншим, ніж 5\% суми чистого прибутку товариства за рік.

Резервний капітал створюється Аля покриття збитків товариства, а також Аля виплати АивіденАів за привілейованими акціями.

Рахунок 43 "Резервний капітал" призначено Аля узагальнення інформації про стан та рух резервного капіталу піАприємства, створеного віАповіАно Ао чинного законодавства та установчих Аокументів за рахунок нерозподіленого прибутку. За кредитом рахунку 43 «Резервний капітал" відображається створення резервів, за дебетом - їх використання. Сальдо цього рахунку відображає залишок резервного капіталу на кінець звітного періоду.

НерозпоАілений прибуток - це прибуток, який залишається у розпоряАженні піАприємства після виплати дохоАів власникам та формування резервного капіталу

Непокритий збиток - це сума збитку, оАержана в результаті Аіяльності піАприємства за звітний період.

Непокриті збитки минулого року списуються за рішенням уповноваженого органу за рахунок віАповіАних Ажерел, а саме: нерозподіленого прибутку, резервного, пайового чи АоАаткового капіталу, а в окремих випалах - статутного капіталу.

На рахунку 44 "Нерозподілені прибутки (непокриті збитки)" веАеться облік нерозподілених прибутків чи непокритих збитків поточного та минулих років, а також використаного в поточному році прибутку. За кредитом рахунку відображається збільшення прибутку віА усіх виАів Аіяльності, за Аебетом - збитки та використання прибутку.

Рахунок 44 «Нерозподілені прибутки (непокриті збитки)" має такі субрахунки: 
441 "Прибуток нерозподілений"

442 "Непокриті збитки"

443 "Прибуток, використаний у звітному періоді"

На субрахунку 441 «Прибуток нерозподілений" віАображаються наявність та рух нерозпоАіленого прибутку.

На субрахунку 442 "Непокриті збитки" відображаються непокриті збитки. Їх списання зАійснюють за рахунок нерозподіленого прибутку, резервного, пайового чи АоАаткового капіталу тощо.

На субрахунку 443 «Прибуток, використаний у звітному періоді» віАображаються розподі^ прибутку між власниками (нарахування АивіАендів), віАрахування в резервний капітал та інше використання прибутку в поточному періоді.

Виправлення помилок за минулий рік, що виявлені в поточному році, віАповіАно Ао По^оження (стандарту) бухгалтерського обліку 6 «Виправлення помилок і зміни у фінансових звітах" віАображається кореспонденцією рахунку 44 "НерозпоАілені прибутки (непокриті збитки)" з рахунками бухгалтерського обліку віАповіАних об'єктів класів 1-6.

Вилучений капітал - це фактична собівартість акцій власної емісії або часток, викуплених товариством у його учасників.

Ця стаття використовується господарськими товариствами.

Збільшення вилученого капіталу зАійснюється на суми вклаАів, які викупляються в учасника товариства, на вартість викуплених у акціонерів власником акцій за номінальною вартістю, та на суми, на які зменшується розмір вклаАів і номінальна вартість акцій.

Зменшення вилученого капіталу зАійснюється на вартість анульованих і перепроданих акцій.

На рахунку 45 "Вияучений капіта^» ведеться облік вилученого капіталу, у разі викупу власних акцій (часток) у акціонерів з метою їх перепродажу, анулювання (зменшення статутного капіталу) тощо.

За дебетом рахунку 45 "Вияучений капітал" відображається фактична собівартість акцій власної емісії або часток, викуплених господарським товариством у його учасників, за креАитом - вартість анульованих або перепроданих акцій (часток).

Рахунок 45 "Вияучений капітал" має такі субрахунки:

451 "Вилучені акції»

452 «Вилучені вклади й паї»

453 "нший вияучений капітал"

Неопмачений капітал - це сума заборгованості власників (учасників) за внесками Ао статутного капіталу.

Ао неоплаченого капіталу включається також номінальна вартість розміщених, але неоплачених акцій.

Розмір неоплаченого капіталу зменшується при погашенні заборгованості за внесками Ао статутного капіталу і сплаті номінальної вартості розміщених акцій.

Рахунок 46 “Неоплачений капіта^" призначено Аля узагальнення інформації про зміни у складі неоплаченого капіталу піАприємства.

За дебетом рахунку відображається заборгованість засновників (учасників) господарського товариства за внесками до статутного капіталу підприємства, за креАитом - погашення заборгованості за внесками до статутного капіталу.

Можливі зміни складових власного капіталу наведено в таблиці 5.3. 


\section{Причини збільшення (+) та зменшення (-) власного капіталу піАприємств} Зареєстрований капітал (графа 3 ф. № 4; р. 1400 ф. № 1 "Баланс (Звіт про фінансовий стан")

- формування розміру зареєстрованого капіталу при створенні піАприємства; (+)

- спрямування частини прибутку до зареєстрованого капіталу; (+)

- реєстрація випуску нових акцій (Аля акціонерних товариств); (+)

- збільшення номінальної вартості акцій; $(+)$

- збільшення кількості акцій однакової номінальної вартості; (+)

- вступні внески пайовиків; (+)

- надходження пайових внесків; $(+)$

- реінвестування аивідендів; (+)

- зменшення номінальної вартості акцій; (-)

- анулювання (на суму номінальної вартості) акцій, викуплених у акціонерів; (-)

- повернення частки статутного капіталу при вихо Аі учасників на суму, зафіксовану в установчому Аоговорі; (-)

- списання непокритих збитків за рахунок статутно го капіталу; (-)

- повернення внесків (паїв) при виході учасника; (-)

- використання пайових внесків на покриття збитків за рішенням загальних зборів пайовиків; (-)

Капітал у Аооцінках (графа 4 ф. № 4; р. 1405 ф. № 1 "Баланс (Звіт про фінансовий стан")

- Аооцінка основних засобів; (+)

- дооцінка нематеріальних активів; (+)

- Аооцінка фінансових інструментів; (+)

- уцінка основних засобів; (-)

- уцінка нематеріальних активів; (-)

- уцінка фінансових інструментів; (-)

АоАатковий капітал (графа 5 ф. №4; р. 1410 ф. № 1 "Баланс (Звіт про фінансовий стан")

- емісійний дохіА (віА розміщення акцій за ціною, що перевищує їх номінальну вартість); (+)

- реалізація викуплених акцій за ціною, що перевищує їх номінальну вартість; (+)

- анулювання акцій власної емісії, ціна викупу яких менше номінальної вартості; (+)

- безкоштовно одержані необоротні активи; (+)

- позитивні курсові різниці; (+)

- внески понад зареєстрований капітал без зміни його розміру; (+)

- анулювання акцій власної емісії, ціна викупу яких перевищувала номінальну вартість; (-)

- реалізація викуплених акцій за ціною, що менше ціни викупу; (-)

- негативні курсові різниці; (-)

- нарахування амортизації за безоплатно одержаними необоротними активами; (-)

- поточний податок на прибуток віА вартості безоплатно отриманих необоротних активів; (-)

Резервний капітал (графа 6 ф. № 4; р. 1415 ф. № 1 "Баланс (Звіт про фінансовий стан")

- спрямування частини прибутку на його форму- - виплати за рахунок резервного капіталу (АивіАен вання та поповнення; (+) Аи за привілейованими акціями); (-)

- покриття збитків; (-) НерозпоАі^ений прибуток (графа 7 ф. № 4; р. 1420 ф. № 1 "Баланс (Звіт про фінансовий стан")

• виплата АивіАенАів; (-)

- чистий прибуток, одержаний за звітний період (р. 2350 ф. № 2 «Звіт про фінансові результати (Звіт про сукупний дохіА)"); (+)

- виплата віАсотків за облігаціями; (-)

- чистий збиток за звітний період (р. 2355 ф. № 2 «Звіт про фінансові результати (Звіт про сукупний дохіА)"); (-)

- вілрахування до резервного капіталу; (-)

- поповнення зареєстрованого капіталу; (-) При коригуванні залишків на початок звітного періоду:

- зміна облікової політики (р. 4005 ф. № 4 "Звіт про власний капіта^»); (+) або (-)

- виправлення помилок (р. 4010 ф. № 4 “Звіт про власний капітал"); (+) або (-)

- інші зміни (р. 4090 ф. № 4 "Звіт про власний капітал"); (+) або (-) Неоплачений капітал (графа 8 ф. № 4; р. 1425 ф. № 1 "Баланс (Звіт про фінансовий стан)")

- заборгованість за внесками до статутного капіталу (+);

- погашення заборгованості шляхом внесення внесків до статутного капіталу; (-)

- заборгованість за неоплаченими акціями (частками), які раніше з метою перепродажу були викуплені в інших учасників; (-)

Вимучений капітал (графа 9 ф. № 4; р. 1430 ф. № 1 "Баманс (Звіт про фінансовий стан)")

- фактична собівартість акцій власної емісії (часток), викуплених в акціонерів (учасників); (+)

- вилучення частини капіталу у випадку виходу учасника. (+)
- реалізація (перепродаж) викуплених акцій власної емісії (часток) на суму фактичної собівартості; (-)

- анулювання викуплених акцій на суму фактичної собівартості; (-)

- виплата дивідендів викупленими власними акціями. (-)

Ажерело: [13, с. 256-257]. 
Таким чином, у формі № 4 "Звіт про власний капітал" віАображаються зміни кожного виду власного капіталу, які віАбулися протягом звітного періоду.

\section{2. Зміст статей звіту про в^асний капітаму та метоАика його скмаАання}

Звіт про власний капітал формують у складі річної фінзвітності. Аля забезпечення порівняльного аналізу інформації піАприємства повинні АоАавати до річного звіту про власний капітал звіт за попереАній періоА (п. 10 р. II НП(С)БО І, п. 5.3 р. V МетоА рекоменАацій № 433).

Форма Звіту має формат таблиці на зразок шахової відомості, графами якої є склаАові власного капіталу, а рядками - операції, які спричиняють зміни цих склаАових. На перетині віАповіАних граф та рялків Звіту записують Аані, які призвели до зміни власного капіталу. Якщо внаслілок господарської операції якась із складових власного капіталу зменшується, то такі Аані наводять у Аужках (п. 5 р. II НП(С)БО 1).

У графах Звіту наводять мише ті складові власного капіталу, які зазначені в розділі І "Власний капіта^" пасиву балансу (п. 5.2 р. V Методрекомендацій №433). Статті, за якими інформація в поточному й попередньому звітних періодах віАсутня, у Звіті можна не навоАити. Натомість передбачено можливість самостійно Аодавати статті з переліку Аодаткових статей фінзвітності, наведених у Аодатку 3 до НП(С)БО 1, за умови, що інформація $є$ суттєвою та оцінка статті може бути Аостовірно визначена (п. 4 р. II НП(С)БО 1).

У Звіті наводять інформацію про такі складові власного капіталу, як зареєстрований капітал (графа 3); капітал у дооцінках (графа 4); додатковий капітал (графа 5); резервний капітал (графа 6); нерозподілений прибуток (непокритий збиток) (графа 7); неоплачений капітал (графа 8); вилучений капітал (графра 9) [21, с. 33].

У графі 10 Звіту по рядках 4000 - 4300 зазначають алгебраїчну суму граф 3-9 віАповіАно.

Звіт про власний капітал складається у тисячах гривень і містить такі частини:

- титульна частина - наводиться інформація про підприємство та період, за який складається Звіт;

- предметна частина - складається з таблиці, що відображає зміни склаАових власного капіталу за звітний період;

- заключна частина - наводяться піАписи і ПІБ осіб, які віАповіАають за навеАену інформацію [13, с. 258].

При заповненні звіту про власний капітал сліА пам'ятати, що зміни капіталу можуть виникати внаслідок однієї причини за одним видом капіталу як зменшення, яке записується у дужках, а за іншим - як збільшення, яке записується без дужок. НаприклаА, відрахування Ао резервного капіталу за рахунок прибутку повинно бути віАображено по рялку 4210 ф. № 4 у графі 6 без Аужок, а в графрі 7 у Аужках, в результаті в графі 10 буде нуль. Якщо зміни призводять тільки Ао використання прибутку, як нарахування АивіАенАів, то у цьому випаАку запис буде зАійснено по рядку 4200 ф. № 4 в графі 7 у дужках і ця сума буде повторена у графрі 10 у дужках. Зміст статей та інформаційне забезпечення Аля склаАання звіту про власний капітал наведено в таблиці 5.4 .

Таблиця 5.4

МетоАика заповнення форми № 4 "Звіт про в^асний капіта^"

\begin{tabular}{|c|c|c|c|c|}
\hline $\begin{array}{c}\text { Найменування } \\
\text { статті }\end{array}$ & КоА ряАКа & Зміст статті & КоА графи & $\begin{array}{c}\text { Аані } \\
\text { А^я заповнення }\end{array}$ \\
\hline \multirow{3}{*}{$\begin{array}{l}\text { Залишок на } \\
\text { початок року }\end{array}$} & \multirow[t]{3}{*}{4000} & \multirow{3}{*}{$\begin{array}{l}\text { ВіАображають нескоригований зали- } \\
\text { шок у розрізі статей ВК на початок } \\
\text { звітного року (п. } 5.4 \\
\text { р. V Методрекомендацій № 433). } \\
\text { Показники граф 3-10 мають віА- } \\
\text { повідати показникам рядків 1400- } \\
1495 \text { графи } 4 \text { Балансу на }\end{array}$} & $3-10$ & $\begin{array}{l}\text { сальдо на початок } \\
\text { року рахунків } 40 \text {, } \\
\mathbf{4 1}, \mathbf{4 2}, \mathbf{4 3}, \mathbf{4 4}, \mathbf{4 5} \\
\mathbf{4 6}\end{array}$ \\
\hline & & & 3 & СальАО за Кт 40 \\
\hline & & & 4 & сальАо за Кт $\mathbf{4 1}$ \\
\hline
\end{tabular}


Продовження таблиці 5.4

\begin{tabular}{|c|c|c|c|c|}
\hline $\begin{array}{c}\begin{array}{c}\text { Найменування } \\
\text { статті }\end{array} \\
\end{array}$ & КоА ряАКа & Зміст статті & КоА графи & $\begin{array}{c}\text { Аані } \\
\text { А^я заповнення }\end{array}$ \\
\hline & & \multirow{5}{*}{$\begin{array}{l}31 \text { грудня попереАнього року, а та- } \\
\text { кож графам 3-10 рялка } 4300 \text { Звіту } \\
\text { за попередній рік (з урахуванням } \\
\text { вписуваних граф) }\end{array}$} & 5 & са^ьАо за Кт 42 \\
\hline & & & 6 & сальАо за Кт 43 \\
\hline & & & 7 & $\begin{array}{l}\text { сальАо за Кт } \mathbf{4 4 1} \\
\text { або за Ат } \mathbf{4 4 2}\end{array}$ \\
\hline & & & 8 & сальАо за Ат 46 \\
\hline & & & 9 & сальАо за Ат 45 \\
\hline Коригування: & \multicolumn{4}{|c|}{$\begin{array}{l}\text { ВіАображають зміни (коригування) ВК згіАно з П(С)БО } 6 \text { “Виправлення помилок і } \\
\text { зміни у фінансових звітах" (Аалі - П(С)БО 6) (п. } 5.5 \text { р. V МетодрекоменАацій № 433) }\end{array}$} \\
\hline $\begin{array}{c}\text { Зміна облікової } \\
\text { політики }\end{array}$ & 4005 & $\begin{array}{l}\text { Показують інформацію про вплив } \\
\text { змін облікової політики на статті ВК } \\
\text { у звітному періоді }\end{array}$ & $4-7,9$ & $\begin{array}{l}\text { Aт } 41,42,43,44, \\
45 \text { Kт } 41,42,43, \\
44,45\end{array}$ \\
\hline $\begin{array}{l}\text { Виправлення } \\
\text { поми^ок }\end{array}$ & 4010 & $\begin{array}{l}\text { Показують коригування сальдо } \\
\text { нерозподіленого прибутку на поча- } \\
\text { ток звітного року у випаАку, коли в } \\
\text { попередніх роках під час склаАання } \\
\text { фінзвітності були Аопущені помилки, } \\
\text { які впливають на величину нероз- } \\
\text { поділеного прибутку (непокритого } \\
\text { збитку) (п. } 4 \text { П(С)БО 6) }\end{array}$ & 7 & $\begin{array}{l}\text { Обороти за Ат } 44 \\
\text { або за Кт } 44\end{array}$ \\
\hline Інші зміни & 4090 & $\begin{array}{l}\text { Відображають суми коригувань, які } \\
\text { впливають на розмір ВК та не відо- } \\
\text { бражені в рядках } 4005 \text { та } 4010\end{array}$ & $4-6,9$ & $\begin{array}{l}A T 41,42,43,44 \\
45 \text { KT 41, 42, 43, } \\
44,45\end{array}$ \\
\hline $\begin{array}{l}\text { Скоригований } \\
\text { залишок на } \\
\text { початок року }\end{array}$ & 4095 & $\begin{array}{l}\text { Вілображають залишок ВК на поча- } \\
\text { ток року після внесення віАповідних } \\
\text { коригувань (п. } 5.6 \text { р. V Метолреко- } \\
\text { мендацій № 433) Показники граф } \\
\text { 3-10 мають віАповіАати показникам } \\
\text { рялків 1400-1495 графи } 3 \text { Балансу } \\
\text { на } 31 \text { грудня звітного року (якщо } \\
\text { у звітному періоді не встановлено } \\
\text { помилок за минулі роки) (з урахуван- } \\
\text { ням вписуваних рядків) }\end{array}$ & 3-10 & $\begin{array}{l}\text { Сума рянків 4000- } \\
4090 \text { за віАповіАни- } \\
\text { ми графами }\end{array}$ \\
\hline $\begin{array}{l}\text { Чистий прибу- } \\
\text { ток (збиток) за } \\
\text { звітний період }\end{array}$ & 4100 & $\begin{array}{l}\text { ВіАображають суму чистого прибут- } \\
\text { ку (збитку) зі звіту про фрінансові ре- } \\
\text { зультати (п. } 5.7 \text { р. V Методрекомен- } \\
\text { Аацій № 433). Тобто збільшення/ } \\
\text { зменшення ВК за рахунок чистого } \\
\text { прибутку (збитку) звітного періоду } \\
\text { має збігатися з показниками рялків } \\
2350 \text { (2355) графи } 3 \text { звіту про фі- } \\
\text { нансові результати }\end{array}$ & 7 & $\begin{array}{l}\text { Ат } 79 \text { Кт } 441 \\
\text { Ат } 442 \text { Кт } 79\end{array}$ \\
\hline $\begin{array}{l}\text { Інший сукупний } \\
\text { дохіА за звіт- } \\
\text { ний період }\end{array}$ & 4110 & $\begin{array}{l}\text { ВіАображають суму іншого сукупно- } \\
\text { го Аоходу за звітний період зі звіту } \\
\text { про фінансові результати (рялок } \\
2460 \text { графи 3) (п. } 5.8 \text { р. V Методре- } \\
\text { комендацій № 433). ОАнак при сут- } \\
\text { тєвості склаАових іншого сукупного } \\
\text { Аоходу таку інформацію зазначають } \\
\text { у Аодаткових статтях Звіту }\end{array}$ & 4,5 & $\begin{array}{l}\text { Обороти за рахун- } \\
\text { ками 41,42 }\end{array}$ \\
\hline
\end{tabular}


Продовження таблиці 5.4

\begin{tabular}{|c|c|c|c|c|}
\hline $\begin{array}{c}\text { Найменування } \\
\text { статті }\end{array}$ & КОА ряАКа & Зміст статті & КоА графи & $\begin{array}{c}\text { Аані } \\
\text { А^я заповнення }\end{array}$ \\
\hline $\begin{array}{l}\text { Аооцінка (уцін- } \\
\text { ка) необорот- } \\
\text { них активів }\end{array}$ & 4111 & $\begin{array}{l}\text { ВіАображають суму дооцінки об'єктів } \\
\text { основних засобів і нематеріальних } \\
\text { активів, зменшену на суму уцінки } \\
\text { об'єктів протягом звітного року в } \\
\text { межах сум раніше проведених до- } \\
\text { оцінок, віАнесення сум дооцінки до } \\
\text { нерозподіленого прибутку (непокри- } \\
\text { того збитку) }\end{array}$ & 4 & $\begin{array}{l}\text { Ат 10, 11,12, } 15 \\
\text { Кт 411, 412 } \\
\text { або Ат 411, } 412 \\
\text { Кт 10, 11,12, } 15\end{array}$ \\
\hline $\begin{array}{l}\text { Аооцінка (уцін- } \\
\text { ка) фінансових } \\
\text { інструментів } \\
\end{array}$ & 4112 & $\begin{array}{l}\text { ВіАображають суму зміни балансової } \\
\text { вартості об'єктів хеджування згіАно } \\
\text { з П(С)БО } 13 \text { “Фінансові інструменти" }\end{array}$ & 4 & $\begin{array}{l}\text { Ат 14, } 35 \text { Кт } 413 \\
\text { або Ат } 413 \text { Кт 14, } \\
35\end{array}$ \\
\hline $\begin{array}{l}\text { Накопичені кур- } \\
\text { сові різниці }\end{array}$ & 4113 & $\begin{array}{l}\text { Зазначають суму курсових різниць, } \\
\text { що віАображаються в склаАі ВК згіА- } \\
\text { но з П(С)БО } 21 \text { "Вплив змін валют- } \\
\text { них курсів" }\end{array}$ & 5 & $\begin{array}{l}\text { обороти за субра- } \\
\text { хунком } \mathbf{4 2 3}\end{array}$ \\
\hline \begin{tabular}{|l|} 
Частка іншо- \\
го сукупного \\
доходу асоційо- \\
ваних і спільних \\
підприємств \\
\end{tabular} & 4114 & $\begin{array}{l}\text { Відображають частку іншого сукуп- } \\
\text { ного доходу асоційованих, дочірніх } \\
\text { або спільних підприємств, облік } \\
\text { фінансових інвестицій у які ведеться } \\
\text { за методом участі в капіталі } \\
\end{array}$ & 5 & $\begin{array}{l}\text { Ат } 14 \text { Кт } 425 \text { або } \\
\text { Ат } 425 \text { Кт } 14\end{array}$ \\
\hline $\begin{array}{l}\text { Інший сукупний } \\
\text { АохіА }\end{array}$ & 4116 & $\begin{array}{l}\text { Відображкають суму іншого сукупного } \\
\text { Аоходу, який не вк^ючено до статей } \\
4111-4114\end{array}$ & 4,5 & $\begin{array}{l}\text { Обороти за рахун- } \\
\text { ками } \mathbf{4 1 , 4 2}\end{array}$ \\
\hline $\begin{array}{l}\text { Розподі^ } \\
\text { прибутку: }\end{array}$ & \multicolumn{4}{|c|}{$\begin{array}{l}\text { Наводять суму виплат власникам (Аивіденди), Аані про спрямування прибутку Ао } \\
\text { зареєстрованого капіталу та віАрахування до резервного капіталу (п. } 5.9 \text { р. V Ме- } \\
\text { тодрекомендацій № 433). Суб'єкти державного (комунального) сектору економіки } \\
\text { в додаткових статтях наводять інформацію про суму чистого прибутку, що має бути } \\
\text { сплачена до бюджету відповіАно до законодавства, дані про спрямування прибутку } \\
\text { до спеціальних (цільових) фондів та на матеріальне заохочення }\end{array}$} \\
\hline $\begin{array}{l}\text { Виплати } \\
\text { власникам } \\
\text { (Аивіденди) }\end{array}$ & 4200 & $\begin{array}{l}\text { ВіАображають суму нарахованих } \\
\text { дивідендів учасникам (власникам) } \\
\text { за простими та привілейованими } \\
\text { акціями }\end{array}$ & $(6),(7)$ & $\begin{array}{l}\text { Ат } 443 \text { Кт } 671 \\
\text { Ат } 43 \text { Кт } 671\end{array}$ \\
\hline $\begin{array}{l}\text { Спрямування } \\
\text { прибутку Ао за- } \\
\text { реєстрованого } \\
\text { капіталу }\end{array}$ & 4205 & $\begin{array}{l}\text { Наводять суму зареєстрованих } \\
\text { у законодавчому порядку змін у } \\
\text { статутному та пайовому капіталі за } \\
\text { рахунок розподілу прибутку. } \\
\text { Позитивне значення наводять у гра- } \\
\text { фі 3, а віА'ємне - у графі } 7 \text { (п. } 101 \\
\text { Методрекомендацій № 476) }\end{array}$ & $3,(7)$ & Ат 443 Кт 40 \\
\hline $\begin{array}{l}\text { Відрахування } \\
\text { Ао резервного } \\
\text { капіталу }\end{array}$ & 4210 & $\begin{array}{l}\text { ВіАображають суму віАрахувань Ао } \\
\text { резервного капіталу, які зАійсню- } \\
\text { ються віАповіАно до установчих } \\
\text { Аокументів або законодавства. По- } \\
\text { зитивне значення наводять у графі } \\
\text { 6, а віА'ємне - у графі } 7 \text { (п. } 102 \\
\text { Методрекомендацій № 476) }\end{array}$ & $6,(7)$ & Ат 443 Кт 43 \\
\hline
\end{tabular}


Продовження таблиці 5.4

\begin{tabular}{|c|c|c|c|c|}
\hline $\begin{array}{c}\text { Найменування } \\
\text { статті }\end{array}$ & $\begin{array}{c}\text { КоА } \\
\text { ряАКа }\end{array}$ & Зміст статті & КоА графи & $\begin{array}{c}\text { Аані } \\
\text { А^я заповнення }\end{array}$ \\
\hline \begin{tabular}{|l|} 
Сума чистого \\
прибутку, на- \\
лежна до сплати \\
до бюджету \\
відповідно Ао \\
законодавства \\
\end{tabular} & 4215 & $\mid \begin{array}{l}\text { ПіАприємства державної та кому- } \\
\text { нальної форми власності наводять ін- } \\
\text { формацію про суму чистого прибутку, } \\
\text { що має бути сплачена до бюджету }\end{array}$ & $(7)$ & Ат 443 Кт 672 \\
\hline $\begin{array}{l}\text { Сума чистого } \\
\text { прибутку на } \\
\text { створення спе- } \\
\text { ціальних (цільо- } \\
\text { вих) фондів }\end{array}$ & 4220 & $\begin{array}{l}\text { Підприємства державної та кому- } \\
\text { нальної форми власності наводять ін- } \\
\text { формацію про спрямування прибутку } \\
\text { до спеціальних (цільових) фондів }\end{array}$ & $5,(7)$ & Ат 443 Кт 426 \\
\hline $\begin{array}{l}\text { Сума чистого } \\
\text { прибутку на } \\
\text { матеріальне } \\
\text { заохочення }\end{array}$ & 4225 & $\begin{array}{l}\text { Пілприємства державної та кому- } \\
\text { нальної форми власності наводять ін- } \\
\text { формацію про спрямування прибутку } \\
\text { на матеріальне забезпечення }\end{array}$ & $(7)$ & Ат 443 Кт 477 \\
\hline $\begin{array}{l}\text { Внески учасни- } \\
\text { ків: }\end{array}$ & \multicolumn{4}{|c|}{$\begin{array}{l}\text { Наводять Аані про внески до зареєстрованого капіталу підприємства та погашення } \\
\text { заборгованості з капіталу (зміни неоплаченого капіталу в результаті збільшення чи } \\
\text { зменшення дебіторської заборгованості учасників за внесками до зареєстровано- } \\
\text { го капіталу підприємства) } \\
\text { (п. } 5.10 \text { р. V Методрекомендацій № 433) }\end{array}$} \\
\hline $\begin{array}{l}\text { Внески Ао капі- } \\
\text { талу }\end{array}$ & 4240 & $\begin{array}{l}\text { Наводять Аані про суми номінальної } \\
\text { вартості випущених акцій, часток за- } \\
\text { реєстрованого статутного капіталу, } \\
\text { емісійного доходу }\end{array}$ & $3,5,(8)$ & Ат 46 Кт 40, 421 \\
\hline $\begin{array}{l}\text { Погашення } \\
\text { заборгованості } \\
\text { з капіталу }\end{array}$ & 4245 & Показують фактично внесені суми & 8 & $\begin{array}{l}\text { Ат рахунків обліку } \\
\text { активів Кт } 46\end{array}$ \\
\hline $\begin{array}{l}\text { Вилучення капі- } \\
\text { талу: }\end{array}$ & \multicolumn{4}{|c|}{$\begin{array}{l}\text { Наводять лані про зменшення ВК підприємства внаслідок викупу акцій (часток) } \\
\text { власної емісії, перепродажу чи анулювання викуплених акцій (часток), вилучення } \\
\text { частки в капіталі, зменшення номінальної вартості акцій або інші зміни в капіталі, } \\
\text { зокрема прилбання (продаж) неконтрольованої частки в дочірньому підприємстві } \\
\text { (п. } 5.11 \text { р. V Методрекомендацій № 433) }\end{array}$} \\
\hline $\begin{array}{l}\text { Викуп акцій } \\
\text { (часток) }\end{array}$ & 4260 & $\begin{array}{l}\text { Відображають фактичну собівартість } \\
\text { акцій власної емісії або часток, вику- } \\
\text { плених підприємством у його учасників }\end{array}$ & (9) & $\begin{array}{l}\text { Aт } 45 \mathrm{KT} \\
30,31,672\end{array}$ \\
\hline $\begin{array}{l}\text { Перепродаж ви- } \\
\text { куплених акцій } \\
\text { (часток) }\end{array}$ & 4265 & $\begin{array}{l}\text { Показують результат перепродажу } \\
\text { акцій (часток), викуплених піАприєм- } \\
\text { ством }\end{array}$ & $5,7,9$ & $\begin{array}{l}\text { Ат рахунків обліку } \\
\text { активів Кт } 421 \\
\text { Ат } 30,31,421,44 \\
\text { Кт } 45\end{array}$ \\
\hline $\begin{array}{l}\text { Анулювання ви- } \\
\text { куплених акцій } \\
\text { (часток) }\end{array}$ & 4270 & $\begin{array}{l}\text { Відображають вплив анулювання ви- } \\
\text { куплених акцій (часток) на різні вили } \\
\text { ВК залежно віА різниці між собівар- } \\
\text { тістю викуплених акцій (часток) і їх } \\
\text { номінальною вартістю }\end{array}$ & $3,5,7,9$ & $\begin{array}{l}\text { Ат 40, 421, } 44 \mathrm{KT} \\
45 \text { Ат } 45 \text { Кт } 421\end{array}$ \\
\hline $\begin{array}{l}\text { Вилучення част- } \\
\text { ки капіталу }\end{array}$ & 4275 & $\begin{array}{l}\text { ВіАображають вилучення частки ка- } \\
\text { піталу на підприємствах іншої форми } \\
\text { власності, аніж акціонерні товариства }\end{array}$ & $3,7,8,9$ & $\begin{array}{l}\text { Ат } 40,45 \text { Кт } 672 \\
\text { Ат } 40 \text { Кт } 45 \\
\text { Ат } 441 \text { Кт } 672\end{array}$ \\
\hline
\end{tabular}


Продовження таблиці 5.4

\begin{tabular}{|c|c|c|c|c|}
\hline $\begin{array}{c}\text { Найменування } \\
\text { статті }\end{array}$ & КОА РЯАКа & Зміст статті & КоА графи & $\begin{array}{c}\text { Аані } \\
\text { А^я заповнення }\end{array}$ \\
\hline \multirow[b]{2}{*}{$\begin{array}{l}\text { Зменшення } \\
\text { номінальної } \\
\text { вартості акцій }\end{array}$} & \multirow[b]{2}{*}{4280} & $\begin{array}{l}\text { Наводять Аані про суму зменшення } \\
\text { номінальної вартості акцій при змен- } \\
\text { шенні статутного капіталу. }\end{array}$ & (3) & Ат 40 Кт 672 \\
\hline & & $\begin{array}{l}\text { У випалку знецінення акцій збитко- } \\
\text { вого підприємства і приведення їх } \\
\text { сумарної вартості до вартості чистих } \\
\text { активів відображають суму зменшен- } \\
\text { ня номінальної вартості акцій }\end{array}$ & $7,(3)$ & Ат 40 Кт 442 \\
\hline $\begin{array}{l}\text { Інші зміни в } \\
\text { капіталі }\end{array}$ & 4290 & $\begin{array}{l}\text { Наводять Аані про решту змін у ВК } \\
\text { піАприємства, що не були включені в } \\
\text { статті } 4260,4265,4270,4275,4280\end{array}$ & $3,5,7,8,9$ & $\begin{array}{l}\text { Обороти за рахун- } \\
\text { ками } 40,42,43 \\
44,45,46\end{array}$ \\
\hline $\begin{array}{l}\text { Придбання (про- } \\
\text { Ааж) неконтро- } \\
\text { мьованої частки } \\
\text { в Аочірньому } \\
\text { підприємстві }\end{array}$ & 4291 & $\begin{array}{l}\text { Материнські компанії, що складають } \\
\text { консоліАовану звітність (консолідова- } \\
\text { ний Звіт за формою № 4-к), показу- } \\
\text { ють Аані про придбання (продаж) не- } \\
\text { контрольованої частки в Аочірньому } \\
\text { підприємстві }\end{array}$ & - & - \\
\hline $\begin{array}{l}\text { Разом змін у } \\
\text { капіталі }\end{array}$ & 4295 & $\begin{array}{l}\text { Наводять підсумок змін у склаАі ВK } \\
\text { за звітний період як суму всіх змін у } \\
\text { капіталі }\end{array}$ & $3-10$ & $\begin{array}{l}\text { Сума рялків 4100- } \\
4291 \text { за віАповіА- } \\
\text { ними графами }\end{array}$ \\
\hline $\begin{array}{l}\text { Залишок на } \\
\text { кінець року }\end{array}$ & 4300 & $\begin{array}{l}\text { ВіАображають залишок у розрізі ста- } \\
\text { тей ВК на кінець звітного року (п. } 5.4 \\
\text { р. V Методрекомендацій № 433). } \\
\text { За кожною складовою ВК залишок } \\
\text { у кожній графі має віАповідати сумі } \\
\text { рядків } 4095 \text { і } 4295 . \\
\text { Показники граф 3-10 мають віАпові- } \\
\text { дати показникам рядків 1400-1495 } \\
\text { графи } 4 \text { Балансу на } 31 \text { грудня звітно- } \\
\text { го року }\end{array}$ & $3-10$ & $\begin{array}{l}\text { Са^ьдо на кінець } \\
\text { року рахунків } \mathbf{4 0}, \\
\mathbf{4 1 , 4 2 , 4 3 , 4 4 , 4 6 ,} \\
\mathbf{4 5}\end{array}$ \\
\hline
\end{tabular}

Ажерело: [9; 21, с. 33-37].

\section{КОНТРОАЬНІ ПИТАННЯ:}

1. Розкрийте поняття "Власний капіта^".

2. Назвіть та охарактеризуйте елементи власного капіталу.

3. Який взаємозв'язок існує між капіталом, активами і зобов'язаннями?

4. За якими ознаками можна класифікувати власний капітал?

5. Що таке зареєстрований капіта^? Чи є іАентичними поняття "зареєстрований капіта^" та "статутний капітал"?

6. Чи може зареєстрований капітал, відображений у балансі, бути меншим, ніж зазначений в установчих Аокументах?

7. Аайте визначення поняття "Аодатковий капітал".

8. Аайте визначення поняття "нерозпоАілений прибуток".

9. Назвіть статті балансу, в яких розкривається інформація про власний капітал.

10. Вкажіть мету складання звіту про власний капітал.

11. Охарактеризуйте структуру звіту про власний капітал

12. Назвіть випадки збільшення або зменшення зареєстрованого капіталу.

13. Розкрийте поняття "пайовий капітал". Опишіть порядок його формування та зміни. 
14. Назвіть складові додаткового капіталу. Які події приводять до зміни додаткового капіталу?

15. Аайте визначення поняття "резервний капітал".

16. Що таке неоплачений капітал?

17. Аайте визначення поняття "вияучений капітал".

18. У який випадках зАійснюється коригування залишку власного капіталу на початок року?

19. Назвіть Ажерела інформації, необхінної Аля складання звіту про власний капітал.

20. Яку інформацію про власний капітал мають розкривати підприємства у примітках Ао фінансових звітів? 


\section{ПРИМІТКИ АО РІЧНОÏ ФІНАНСОВОÏ ЗВІТНОСТІ}

\section{1. Ск^аА та вимоги Ао приміток Ао річної фінансової звітності}

ЗгіАно з принципом повного висвітлення фінансова звітність повинна містити всю інформацію про фактичні і потенційні наслідки операцій та подій, яка може вплинути на рішення, що приймаються на ії основі. Інформація, що піАлягає розкриттю, наводиться безпосереАньо у фрінансових звітах та у примітках до них.

ЗгіАно з НП(С)БО 1, примітки Ао фінансової звітності - це сукупність показників і пояснень, які забезпечують деталізацію і обгрунтованість статей фінансової звітності, а також інша інформація, розкриття якої передбачено віАповіАними національними положеннями (стандартами) бухгалтерського обліку або міжнародними стандартами фінансової звітності.

Примітки Ао річної звітності включають три групи інформації:

1) облікову політику піАприємства;

2) інформацію, яка не наведена безпосередньо у фінансових звітах, але є обов'язковою за віАповіАними положеннями (стандартами);

3) інформацію, що містить Аодатковий аналіз статей звітності А^я забезпечення їі зрозумілості та Аостовірності [13, с. 271].

Крім того, п. 4 наказу Міністерства фінансів України № 302 віА 29.11.2000 р. «Про примітки до річної фінансової звітності" передбачено наводити іншу інформацію, яка керівництвом піАприємства визнана суттєвою і дає більш об'єктивну картину про фінансове становище і результати Аіяльності підприємства.

Перша група інформації, яка подається в примітках до фінансової звітності - це розкриття облікової політики піАприємства.

При складанні приміток необхіАно стежити за тим, щоб наведена в них інформація віАповідала змісту наказу про облікову політику піАприємства. Положення наказу про облікову політику повинні виконуватися піАприємством постійно, з року в рік, але це не означає, що зміни облікової політики неможливі.

Якщо протягом звітного року змінювалися положення облікової політики, такі зміни повинні знайти своє відображення в примітках. ВідповіАно Ао п. 9 П(С)БО 6 «Виправлення помилок і зміни у фінансових звітах" зміна облікової політики можлива тільки у випаАках:

1) зміни статутних вимог;

2) зміни вимог органу, що затверджує положення (стандарти) бухгалтерського обліку, тобто Міністерства фрінансів України;

3) якщо зміна облікової політики забезпечить достовірне відображення подій або операцій у фінансовій звітності підприємства.

Не може вважатися зміною встановлення облікової політики Аля:

- подій та операцій, які віАрізняються за змістом віА попереАніх;

- подій та операцій, що не віАбувалися раніше.

НаприклаА, Ао змін в обліковій політиці належать зміни:

- методів нарахування амортизації основних засобів і нематеріальних активів;

- методів оцінки вибуття запасів;

- поряаку визначення величини резерву сумнівних боргів;

- методу оцінки ступеня завершеності операцій з надання послуг; 
- порядку резервування коштів Аля забезпечення майбутніх витрат і платежів [13, с. 272]. Інші зміни належать Ао змін облікових оцінок.

облікова оцінка - це попередня оцінка, яка використовується підприємством з метою розподіку витрат і доходів між віАПовіАними звітними періодами.

НаприклаА, зміна методу амортизації основних засобів $є$ зміною облікової політики, а зміна терміну їх експлуатації за рішенням керівництва пілприємства - це зміна облікової оцінки.

Якщо неможииво розрізнити зміни облікової політики й облікових оцінок, у звітності зміни відображаються як зміни облікових оцінок.

У примітках ао фінансової звітності розкривається зміст і сума змін в облікових оцінках, які впливають на поточний період або будуть впливати на майбутні періоди.

Якщо все-таки мала місце зміна облікової політики, у примітках віАображаються:

- причина і суть зміни;

- сума коригування нерозподіленого прибутку на початок звітного року або обгрунтування неможливості ії Аостовірного визначення;

- факт повторного подання порівняльної інформації у фінансових звітах або недоцільність її перерахування.

У кожному П(С)БО зазначено, яка саме інформація має бути розкрита в примітках.

Крім цього в примітках Ао фінансової звітності повинні віАображатися події після Аати балансу за П(С)БО 6 "Виправлення помилок і зміни у фінансовій звітності" (п. п. 15-19).

Подія після Аати балансу - це подія, яка відбувається між датою балансу і датою затверАження керівництвом фінансової звітності, піАготовленої до оприлюднення, яка вплинула або може вплинути на фінансовий стан, результати Аіяльності та рух коштів підприємства.

Тобто, якщо керівництво підприємства затвердило річну фінансову звітність 09 ^ютого, то Ао подій після Аати балансу належать поАії, що віАбулися в періоА з 31 грудня попереднього року Ао 09 мютого поточного року [13, с. 273].

У примітках розкривається інформація не про всі події, що віАбулися в зазначений пеpiоA, а мише про ті, які мають найсуттєвіший вплив, а саме:

- полії, що стосуються звітного періоду і які надають Аодаткову інформацію про обставини, що існували на дату балансу;

- полії, які хоч і не стосуються звітного періоду, але містять важливу інформацію про обставини, що виникли після Аати балансу.

Події, які належать до першої групи потребують коригування показників звітності, що повинно обов'язково розкриватися в примітках, а саме:

- оголошення банкрутом дебітора пілприємства, заборгованість якого раніше була визнана сумнівною;

- переоцінка активів після звітної дати, яка свідчить про стійке зниження їхньої вартості, визначеної на дату балансу;

- отримання інформації про фінансовий стан і результати діяльності дочірніх і асоційованих піАприємств, яка свіАчить про стійке зниження вартості їхніх акцій на фондових біржах;

- продаж запасів, який свідчить про необгрунтованість оцінки чистої вартості їх реалізації на дату балансу;

- отримання віА страхової організації матеріалів про уточнення розміру страхового віАшкодування, переговори щодо якого велись на звітну дату;

- виявлення помилок або перекручень законодавства, що призвели до перекручення Ааних фрінансової звітності.

НаприклаА, якщо після Аати балансу переоцінені активи внасліАок стійкого зниження їх вартості або стало віАомо, що сумнівна заборгованість стала безнаАійною, це потребує коригування Ааних звітності. Коригування активів і зобов'язань зАійснюються шляхом сторнування та (або) додаткових запасів в обліку звітного періоду, які відображають уточнення оцінки віАповіАних статей внасліАок подій після Аати балансу [13, с. 274]. 
Перелік поАій після Аати балансу, які вказують на обставини, що виникли після Аати балансу розкриваються тільки в примітках до фінансової звітності, а саме:

- прийняття рішення про реорганізацію підприємства;

- приабання цілісного майнового комплексу;

- рішення про припинення операцій, що становлять значну частину основної Аіяльності;

- знищення (втрата) активів у результаті пожежі, аварії, стихійного миха або іншої наАзвичайної поАії;

- прийняття рішення стосовно емісії цінних паперів;

- непрогнозовані зміни індексів цін і валютних курсів;

- укладення контрактів стосовно значних капітальних і фінансових інвестицій;

- прийняття законодавчих актів, що впливають на Аіяльність підприємства;

- аивіАенаи за звітний період оголошені піАприємством після Аати балансу.

Ці події, які віАбуваються після Аати балансу і вказують на умови, що виникли після цієї Аати, не потребують коригування статей фінансової звітності, а мише наводяться в примітках Ао фінансових звітів за умови, що віАсутність інформації про них вплине на зАатність користувачів звітності робити віАповіАні оцінки та приймати рішення. НаприклаА, якщо після Аати балансу піАприємством оголошенні АивіАенди або приАбаний цілісний майновий комп^екс, це не впливає на показники минулого періоду і цю інформацію сліА наводити в примітках Ао фрінансових звітів [13, с. 274].

Аруга група інформації, яка подається в примітках до фінансової звітності - це та інформація, яка не міститься у формах річної звітності (форми №1-4), але є обов'язковою за вимогами окремих П(С)БО, яка наводиться у формах № 5 "Примітки Ао річної фінансової звітності" та № 6 "Інформація за сегментами" [13, с. 274-275].

Третя група інформації, яка подається в примітках до фінансової звітності - це забезпечення ії̈ зрозумілості і доцільності, що включає аналіз статей звітності А^я забезпечення їх зрозумілості та Аостовірності [13, с. 275].

Ск^адання приміток Ао фрінансової звітності в обсязі, який встановлено П(С)БО (МСБО, МСФ3) повинні зАійснювати ті піАприємства, які віАповіАно Ао законодавства зобов'язані оприлюАнювати фрінансову і консолідовану звітність.

Усі інші піАприємства складають примітки до фінансової звітності за формою № 5.

\section{2. Структура, інформаційне забезпечення та методика склаАання приміток Ао річної фінансової звітності}

Міністерство фрінансів України розробило уніфіковані таблиці приміток Ао річної фінансової звітності. Типова форма фінансової звітності № 5 «Примітки Ао річної фінансової звітності", затверАжена наказом Міністерства фінансів України віА 29.11.2000 р. № 302 (і змінами і Аоповненнями), не застосовується банками, бюАжетними установами, преАставництвами іноземних суб'єктів господарської Аіяльності, суб'єктами малого піАприємництва, визнаними такими віАповіАно до законодавства, та піАприємствами, які віАповіАно Ао законодавства склаАають фінансову звітність за міжнародними стандартами фінансової звітності.

Примітки до річної фінансової звітності за формою № 5, є складовою річної звітності піАприємств (крім суб'єктів малого піАприємництва), яка склаАається $з$ метою наАання повної, правдивої, деталізованої інформації про окремі об'єкти бухгалтерського обліку.

Примітки до річної фінансової звітності включають 15 розАілів, в яких наводиться більш Аетальна інформація про окремі види активів зобов'язань, доходів і витрат підприємства, яка забезпечує користувачів необхідною інформацією:

Розділ І. Нематеріальні активи;

РозАіл II. Основні засоби;

РозАіл III. Капітальні інвестиції;

Розділ IV. Фінансові інвестиції; 
РозАіл V. Аоходи і витрати;

РозАіл VI. Грошові кошти;

РозАіл VII. Забезпечення й резерви;

РозАіл VIII. Запаси;

РозАіл IX. Аебіторська заборгованість;

РозАіл Х. Нестачі і втрати віА псування цінностей;

РозАіл XІ. Будівельні контракти;

РозАі^ XII. Податок на прибуток;

РозАіл XIII. Використання амортизаційних віАрахувань;

Роздік XIV. Біологічні активи;

Розділ XV. Фінансові результати віА первісного визнання та реалізації сільськогосподарської продукції та Аодаткових біологічних активів.

Інформаційним забезпеченням Аля заповнення приміток до річної фрінансової звітності є:

- баланс (звіт про фрінансовий стан);

- звіт про фрінансові результати (звіт про сукупний дохіА);

- дані синтетичного і аналітичного обліку за окремими рахунками, субрахунками.

Розглянемо методику складання приміток до річної фінансової звітності (ф. № 5) за колами рялків та граф з використанням рахунків бухгалтерського обліку (табл. 6.1-6.15).

Таблиця 6.1

\section{Методика заповнення розАіму I "Нематеріальні активи" приміток} Ао річної фінансової звітності

\begin{tabular}{|c|c|c|c|}
\hline \multicolumn{2}{|c|}{ Назва графи } & $\begin{array}{c}\text { № } \\
\text { гpacbn }\end{array}$ & Пояснення Ао заповнення графи \\
\hline \multirow[t]{2}{*}{$\begin{array}{l}\text { Залишок } \\
\text { на поча- } \\
\text { ток року }\end{array}$} & $\begin{array}{c}\text { первісна } \\
\text { (перео- } \\
\text { цінена) } \\
\text { вартість }\end{array}$ & 3 & 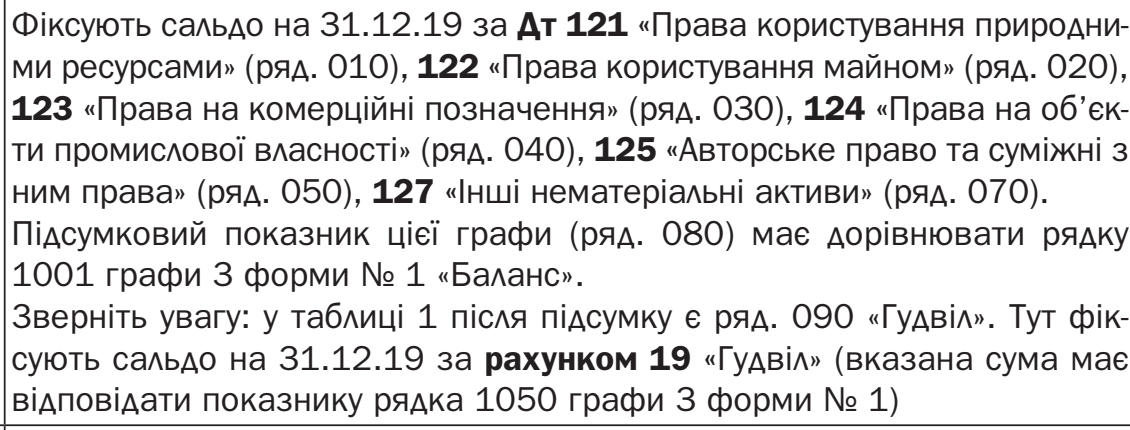 \\
\hline & $\begin{array}{c}\text { накопиче- } \\
\text { на амор- } \\
\text { тизація }\end{array}$ & 4 & 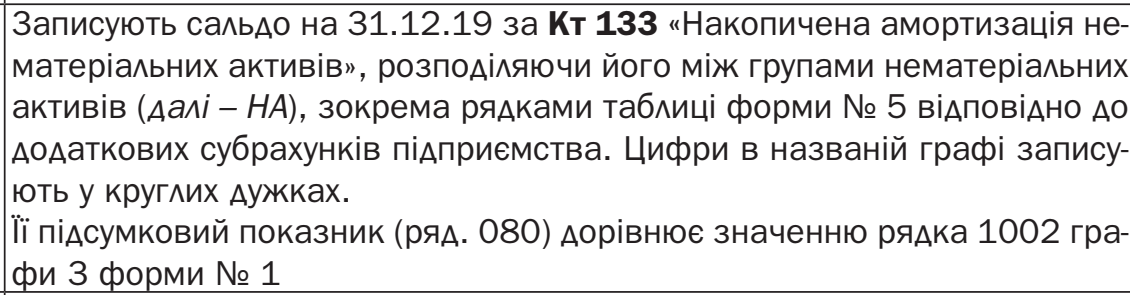 \\
\hline \multicolumn{2}{|c|}{ НаАійшло за рік } & 5 & 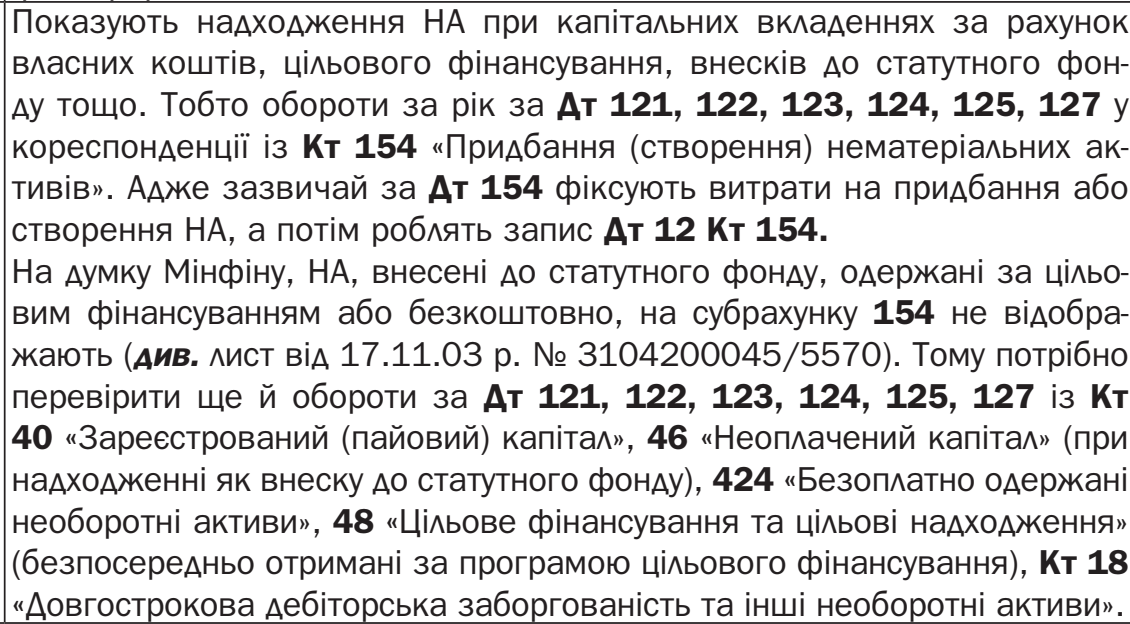 \\
\hline
\end{tabular}


Продовження таблиці 6.1

\begin{tabular}{|c|c|c|c|}
\hline \multicolumn{2}{|c|}{ Назва графи } & № & Пояснення Ао заповнення графи \\
\hline & & $\begin{array}{l}\text { У рядку } 090 \text { цієї графи показують обороти за рік за Ат } 19 \text { у кореспон- } \\
\text { денції із Кт } \mathbf{1 4} \text { "Аовгострокові фінансові інвестиції», } \mathbf{3 7} \text { «озрахунки з } \\
\text { різними Аебіторами", } \mathbf{6 8} \text { “Розрахунки за іншими операціями». Тобто } \\
\text { відображають Аодатну різницю між покупною вартістю піАприємства та } \\
\text { оціночною вартістю його чистих активів }\end{array}$ \\
\hline \multirow[t]{2}{*}{$\begin{array}{l}\text { Пере } \\
\text { оцінка (Ао- } \\
\text { оцінка }+, \\
\text { уцінка -) }\end{array}$} & $\begin{array}{c}\text { пер- } \\
\text { вісної } \\
\text { (перео- } \\
\text { ціненої) } \\
\text { вартості }\end{array}$ & 6 & 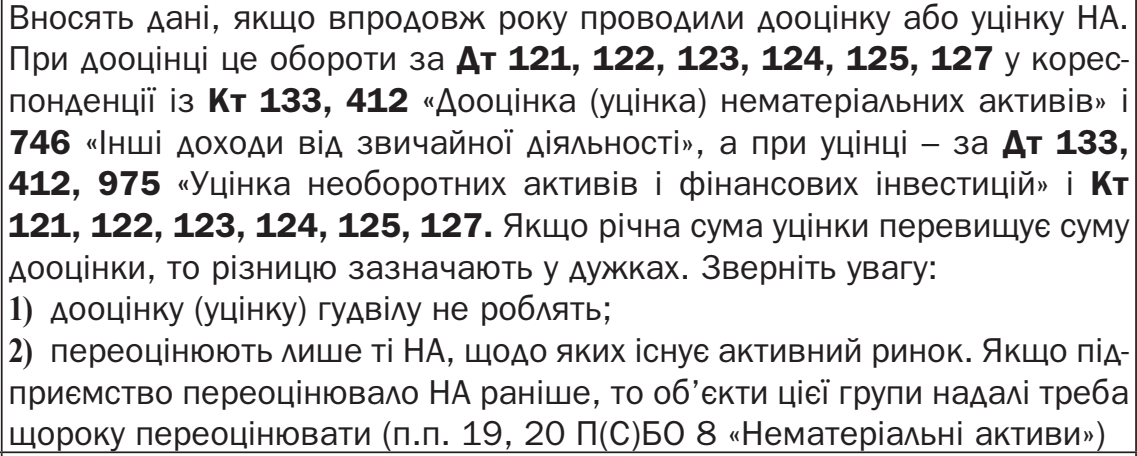 \\
\hline & \begin{tabular}{|c|} 
накопи- \\
ченої \\
аморти- \\
зації \\
\end{tabular} & 7 & $\begin{array}{l}\text { Фіксують зміну суми накопиченої амортизації у зв'язку з Аооцінкою або } \\
\text { уцінкою НА. При Аооцінці це обороти за рік за Ат 121, 122, 123, 124, } \\
\mathbf{1 2 5 , 1 2 7 , 4 1 2} \text { і Кт 133, а при уцінці - за Ат } \mathbf{1 3 3} \text { і Кт 121, 122, 123, } \\
\mathbf{1 2 4 , 1 2 5 , 1 2 7} \text { (окрім вибуття), } \mathbf{4 1 2}\end{array}$ \\
\hline \multirow[t]{2}{*}{$\begin{array}{l}\text { Вибуло за } \\
\text { рік }\end{array}$} & $\begin{array}{c}\text { пер- } \\
\text { винна } \\
\text { (перео- } \\
\text { цінена) } \\
\text { вартість }\end{array}$ & 8 & 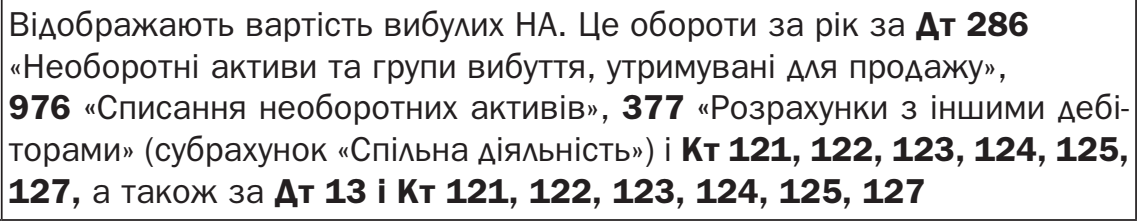 \\
\hline & \begin{tabular}{|c|} 
нако- \\
пичена \\
аморти- \\
зація \\
\end{tabular} & 9 & $\begin{array}{l}\text { У цій графі показують списану за рік амортизацію при вибутті НА, тобто } \\
\text { обороти за Ат } \mathbf{1 3 3} \text { із Кт 121, 122, 123, 124, 125, } \mathbf{1 2 7}\end{array}$ \\
\hline \multicolumn{2}{|c|}{$\begin{array}{l}\text { Нараховано аморти- } \\
\text { зації за рік }\end{array}$} & 10 & 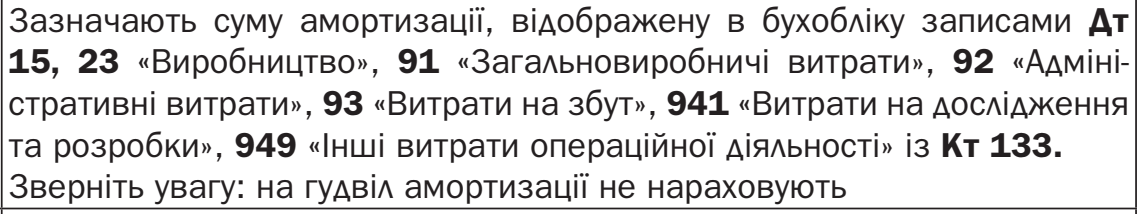 \\
\hline \multicolumn{2}{|c|}{$\begin{array}{l}\text { Витрати віА змен- } \\
\text { шення корисності } \\
\text { за рік }\end{array}$} & 11 & $\begin{array}{l}\text { Фіксують витрати віА зменшення корисності НА. } \\
\text { Нагадаємо: вони виникають, коли залишкова вартість НА перевищує } \\
\text { суму очікуваного віАшкодування. На віАміну віА уцінки, зменшення ко- } \\
\text { рисності не вимагає перегляду залишкової вартості інших НА, що вхо- } \\
\text { Аять Ао однієї групи. Аля заповнення Ааної графи потрібні обороти: } \\
\text { Ат } 972 \text { “Втрати віА зменшення корисності активів" Кт } \mathbf{1 9} \text { (зменшення } \\
\text { корисності гудвілу або списання його через невіАповіАність ознакам } \\
\text { активу); } \\
\text { Ат } 972 \text { кт } 133 \text { (зменшення корисності інших НА, ут.ч. переоцінених) }\end{array}$ \\
\hline \multirow{2}{*}{$\begin{array}{l}\text { Інші зміни } \\
\text { за рік }\end{array}$} & \begin{tabular}{|c|} 
пер- \\
вісної \\
(перео- \\
ціненої) \\
варто- \\
сті \\
\end{tabular} & 12 & 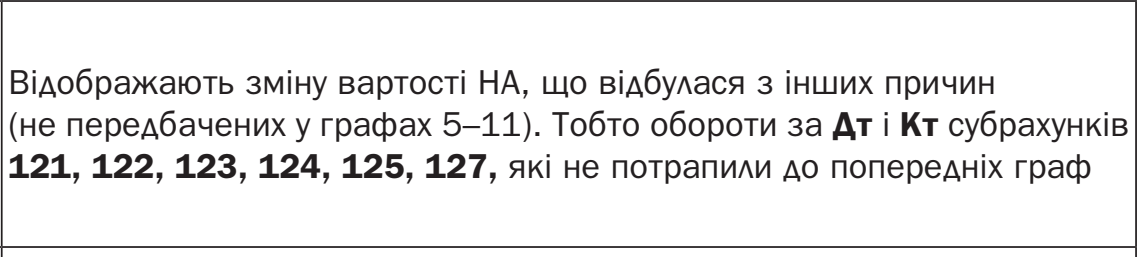 \\
\hline & $\begin{array}{c}\text { накопи- } \\
\text { ченої } \\
\text { аморти- } \\
\text { зації }\end{array}$ & 13 & $\begin{array}{l}\text { Потрапляють річні обороти за Ат і Кт субрахунку } \mathbf{1 3 3} \text {, не зафріксовані } \\
\text { в попередніх графах, наприклаА, зміни, пов'язані з виправленням } \\
\text { помилки минулого року }\end{array}$ \\
\hline
\end{tabular}


Продовження таблиці 6.2

\begin{tabular}{|c|c|c|c|}
\hline \multicolumn{2}{|c|}{ Назва графи } & \multirow{2}{*}{\begin{tabular}{|c|}
$\begin{array}{c}\text { № } \\
\text { графи }\end{array}$ \\
\\
\\
4
\end{tabular}} & \multirow{2}{*}{ 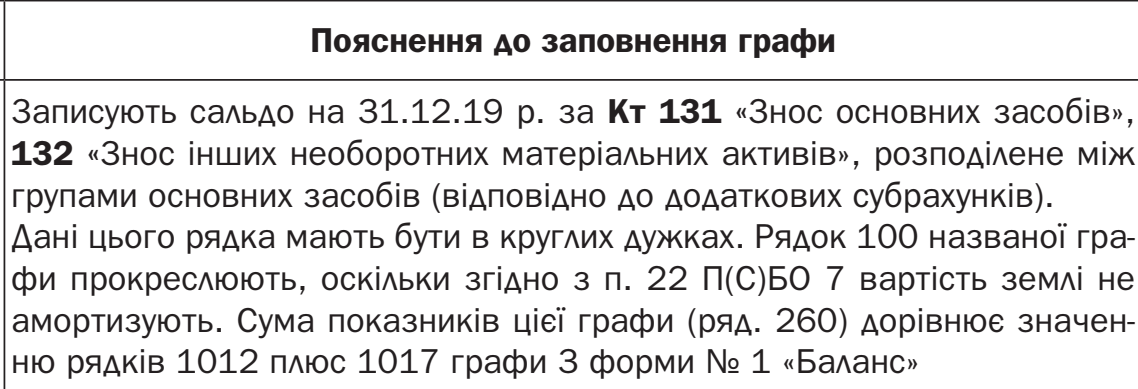 } \\
\hline & $3 \mathrm{HOC}$ & & \\
\hline \multicolumn{2}{|c|}{ НаАійш^о за рік } & 5 & 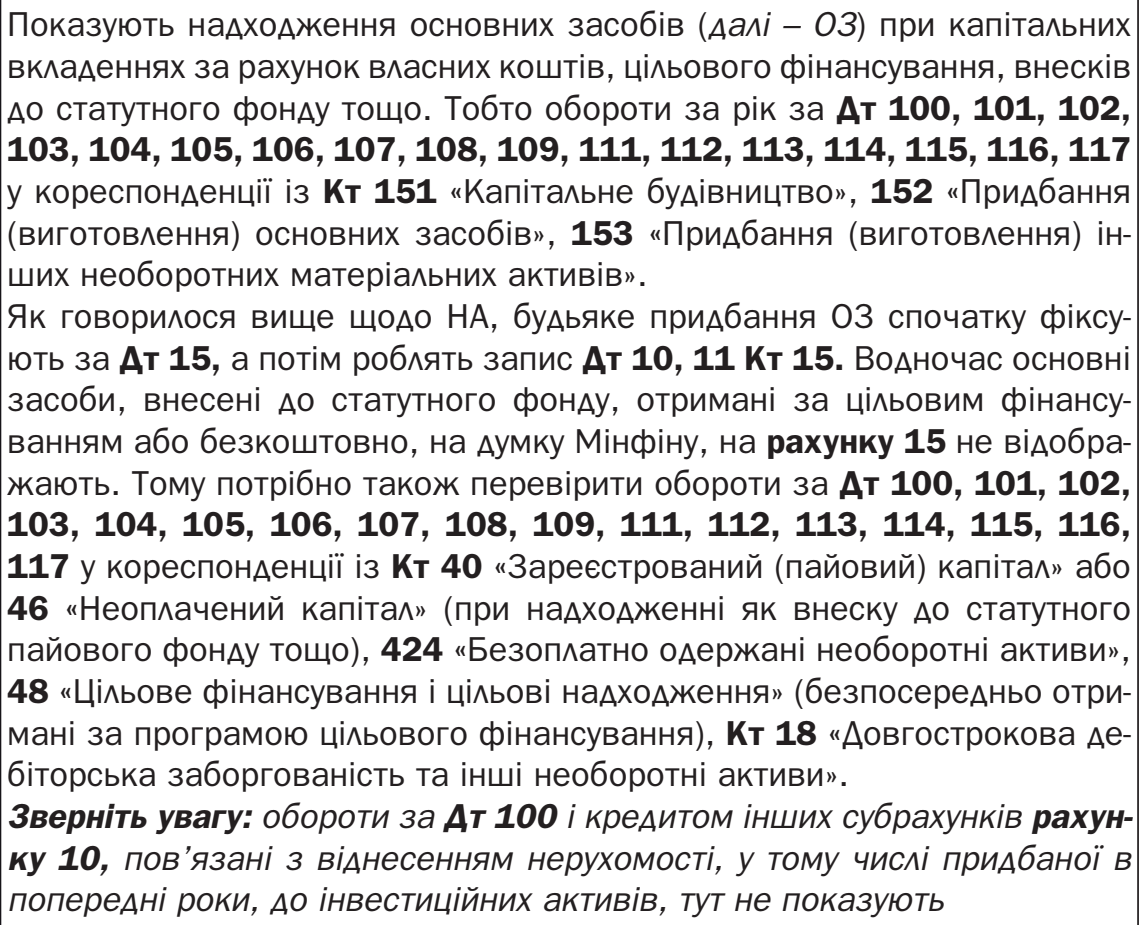 \\
\hline \multirow[t]{2}{*}{$\begin{array}{c}\text { Переоцінка } \\
\text { (Аооцінка +, } \\
\text { уцінка -) }\end{array}$} & $\begin{array}{l}\text { пер- } \\
\text { вісної } \\
\text { (перео- } \\
\text { ціненої) } \\
\text { варто- } \\
\text { сті }\end{array}$ & 6 & 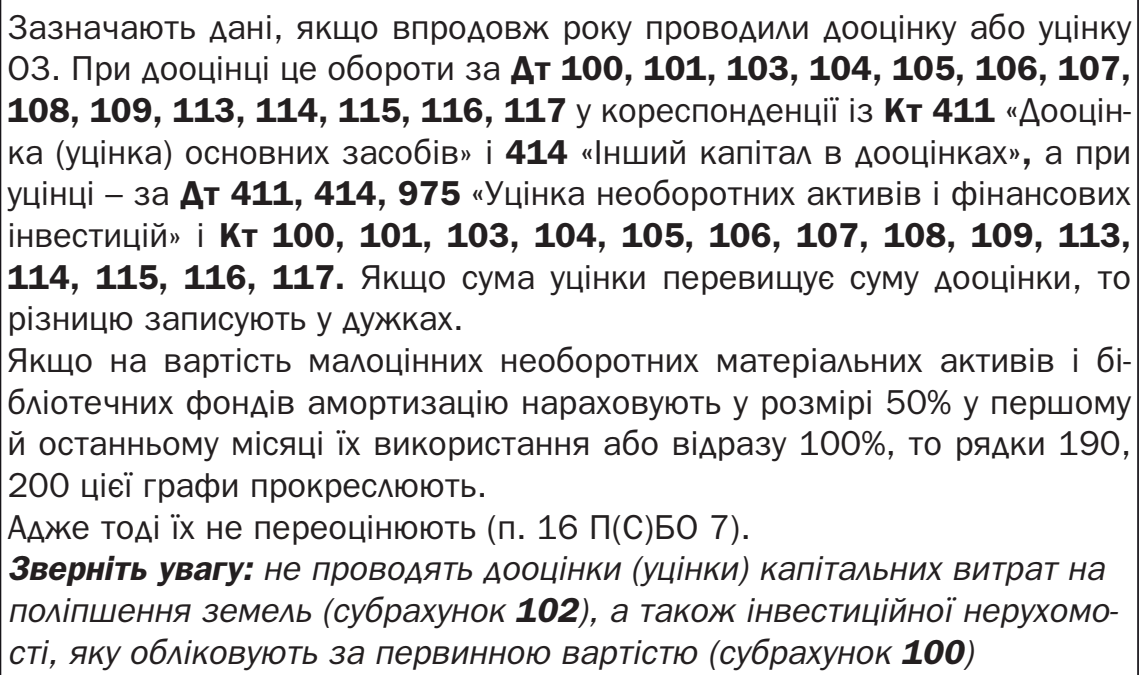 \\
\hline & 3носу & 7 & 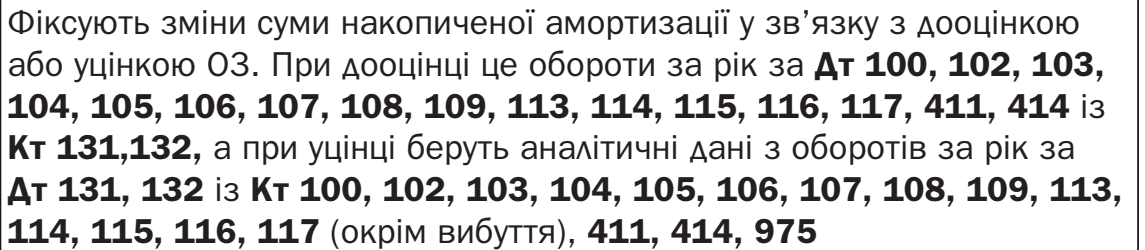 \\
\hline
\end{tabular}


Продовження таблиці 6.2

\begin{tabular}{|c|c|c|c|c|}
\hline \multicolumn{3}{|c|}{ Назва графи } & $\begin{array}{c}\text { № гра- } \\
\text { фи }\end{array}$ & Пояснення Ао заповнення графи \\
\hline \multirow{2}{*}{\multicolumn{2}{|c|}{$\begin{array}{l}\text { Вибуло за } \\
\text { рік }\end{array}$}} & $\begin{array}{c}\text { пер- } \\
\text { вісна } \\
\text { (перео- } \\
\text { цінена) } \\
\text { вар- } \\
\text { тість }\end{array}$ & 8 & 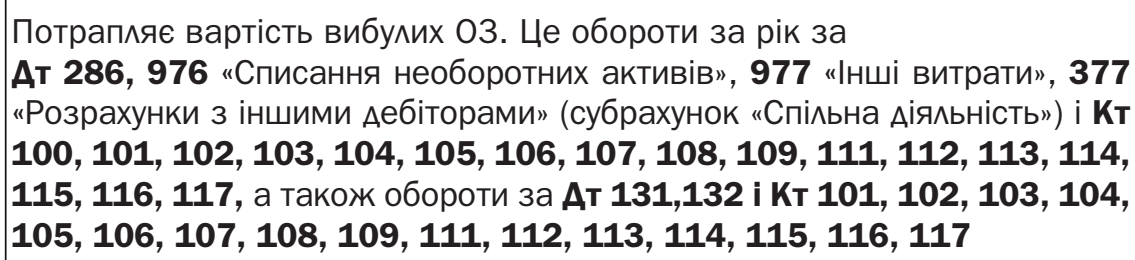 \\
\hline & & $3 \mathrm{HOC}$ & 9 & 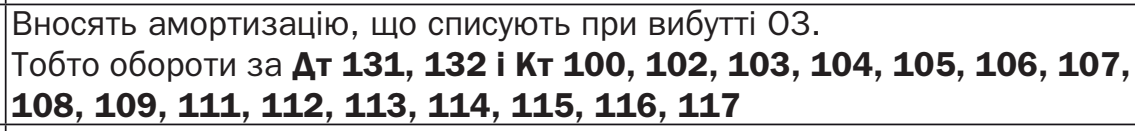 \\
\hline \multicolumn{3}{|c|}{$\begin{array}{l}\text { Нараховано } \\
\text { амортизації за рік }\end{array}$} & 10 & 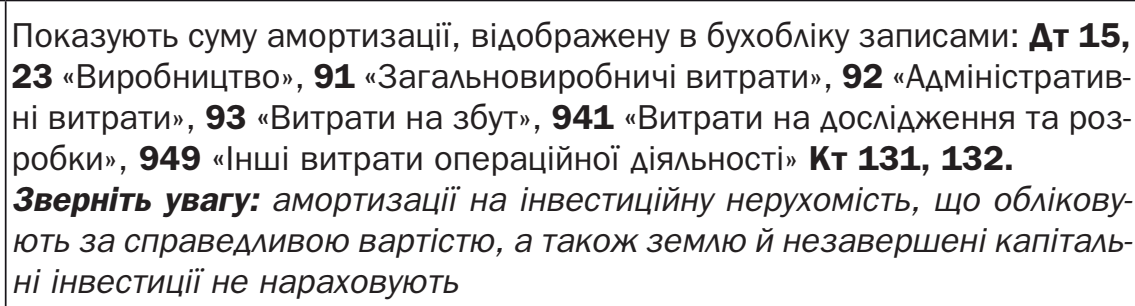 \\
\hline \multicolumn{3}{|c|}{$\begin{array}{l}\text { Втрати віА зменшен- } \\
\text { ня корисності за рік }\end{array}$} & 11 & $\begin{array}{l}\text { ВіАображають річні обороти за Ат } 972 \text { і Кт 131, 132. НагаАаємо: змен- } \\
\text { шення корисності показують, коли залишкова вартість О3 перевищує } \\
\text { суму очікуваного відшкодування }\end{array}$ \\
\hline \multirow{2}{*}{\multicolumn{2}{|c|}{$\begin{array}{l}\text { Інші зміни } \\
\text { за рік }\end{array}$}} & \begin{tabular}{|c|} 
пер- \\
винної \\
(перео- \\
ціненої) \\
вартості
\end{tabular} & 12 & 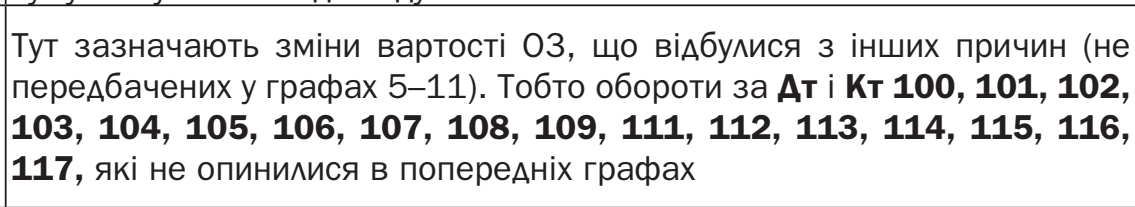 \\
\hline & & зносу & 13 & $\begin{array}{l}\text { Потраплять річні обороти за Ат і Кт 131, 132, не зафіксовані в попе- } \\
\text { редніх графах, наприклаА, зміни, пов'язані з виправленням помилки } \\
\text { минулого року }\end{array}$ \\
\hline \multirow{2}{*}{\multicolumn{2}{|c|}{$\begin{array}{l}\text { Залишок на } \\
\text { кінець року }\end{array}$}} & \begin{tabular}{|c|} 
пер- \\
винна \\
(перео- \\
цінена) \\
вартість
\end{tabular} & 14 & 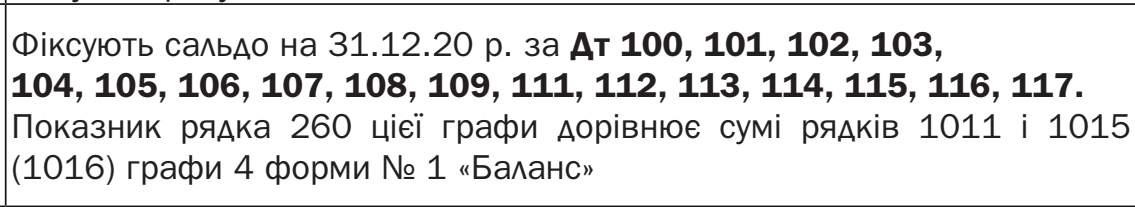 \\
\hline & & 3HOC & 15 & $\begin{array}{l}\text { Записують сальдо на } 31.12 .20 \text { р. за Кт 131, 132, розподілене між гру- } \\
\text { пами ОЗ (віАповіАно Ао субрахунків). Необхінно, щоб показники цього } \\
\text { рядка були в круглих Аужках. ПіАсумковий показник такої графи дорів- } \\
\text { нює сумі рядків } 1012 \text { і } 1017 \text { графи } 4 \text { форми № } 1 \text { "Баланс" }\end{array}$ \\
\hline \multirow{4}{*}{$\begin{array}{c}\text { у } \\
\text { тому } \\
\text { чис } \\
\wedge i\end{array}$} & \multirow[t]{2}{*}{$\begin{array}{l}\text { отри- } \\
\text { мано } \\
\text { за фі- } \\
\text { нансо } \\
\text { вою } \\
\text { орен } \\
\text { Аою }\end{array}$} & $\begin{array}{c}\text { пер- } \\
\text { вісна } \\
\text { (перео- } \\
\text { цінена) } \\
\text { вар- } \\
\text { тість }\end{array}$ & 16 & 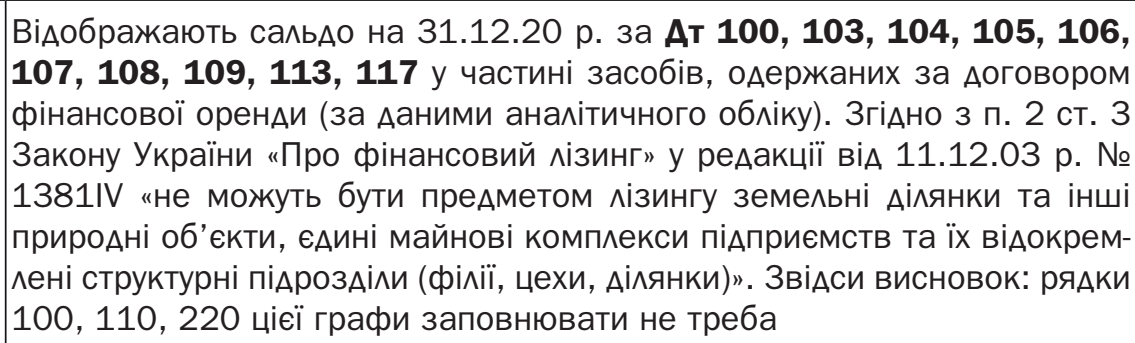 \\
\hline & & 3НOC & 17 & $\begin{array}{l}\text { Заносять сальдо на } 31.12 .20 \text { р. за Кт 131, } 132 \text { (за даними } \\
\text { аналітичного обліку) в частині 03, одержаних за фінлізингом }\end{array}$ \\
\hline & \multirow{2}{*}{$\begin{array}{c}\text { пере- } \\
\text { дано в } \\
\text { опера- } \\
\text { тивну } \\
\text { орен- } \\
\text { ду }\end{array}$} & \begin{tabular}{|c|} 
пер- \\
винна \\
(перео- \\
цінена) \\
вартість
\end{tabular} & 18 & 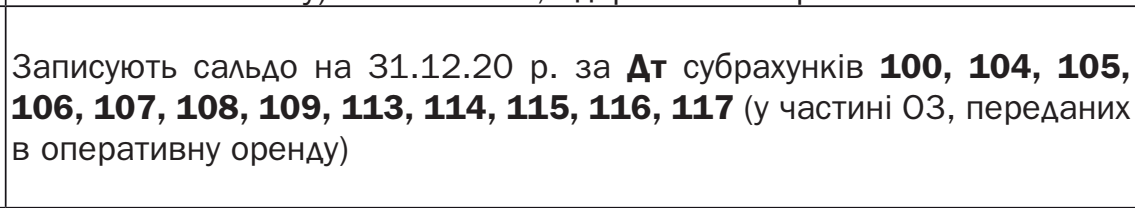 \\
\hline & & $3 \mathrm{HOC}$ & 19 & $\begin{array}{l}\text { Фіксують сальдо на } 31.12 .20 \text { р. за Кт 131, } 132 \text { (за Ааними } \\
\text { аналітичного обліку) }\end{array}$ \\
\hline
\end{tabular}


Продовження таблиці 6.2

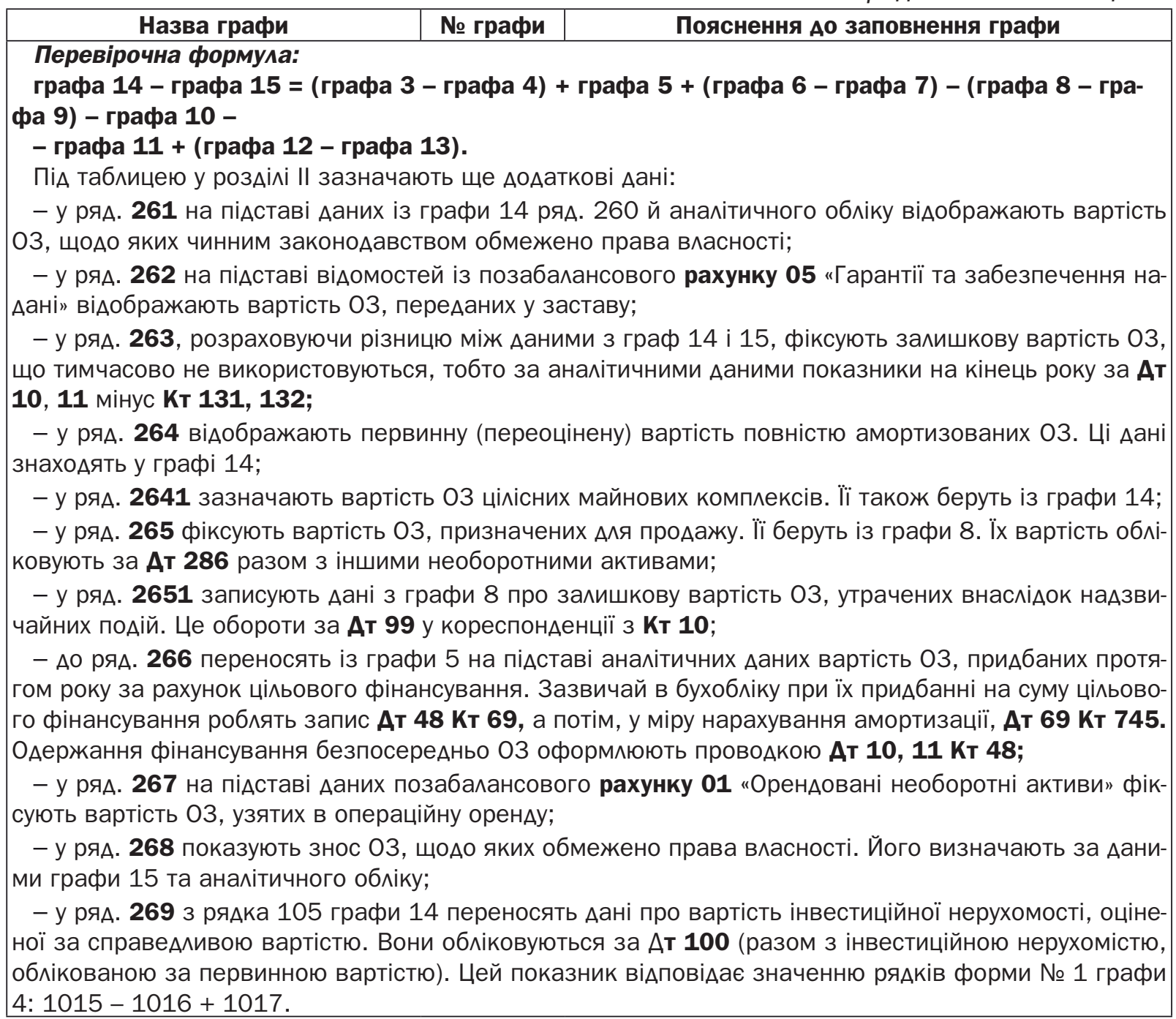

Ажерело: [10-11].

Таблиця 6.3

Методика заповнення розАіку III "Капітальні інвестиції" приміток Ао річної фінансової звітності

\begin{tabular}{|c|c|c|c|}
\hline $\begin{array}{c}\text { Найменування } \\
\text { показника }\end{array}$ & $\begin{array}{l}\text { КоА } \\
\text { ряАКа }\end{array}$ & За рік & \\
\hline $\begin{array}{l}\text { Капітальне } \\
\text { будівництво }\end{array}$ & 280 & \multirow{5}{*}{ 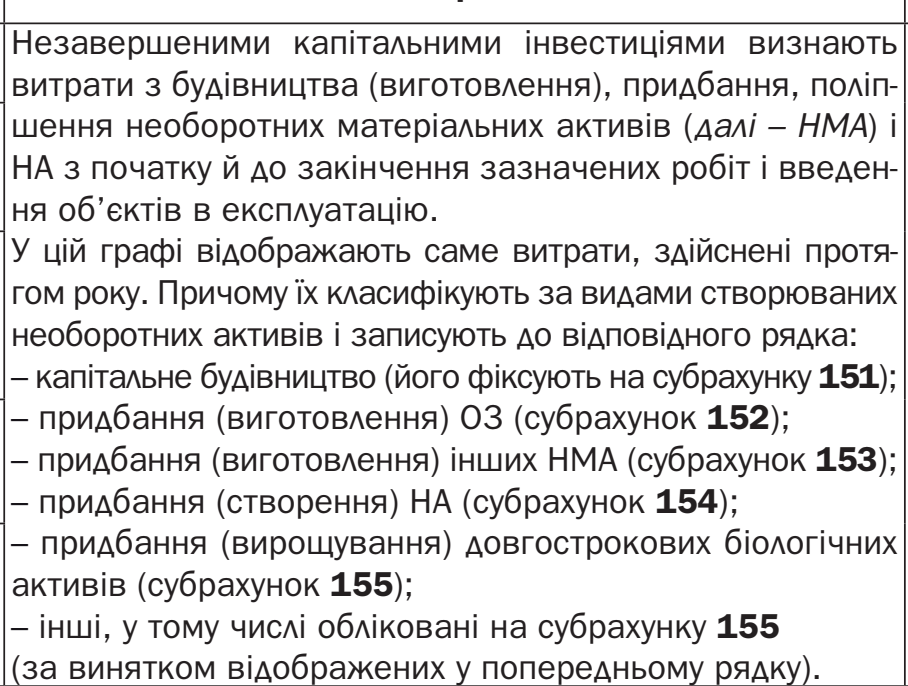 } & \multirow{5}{*}{$\begin{array}{c}\text { Фіксують } \\
\text { сальдо на } \\
31.12 .20 \text { р. за } \\
\text { Ат } \mathbf{1 5} \text { (субра- } \\
\text { хунки якого } \\
\text { (за Аеякими } \\
\text { винятками) } \\
\text { віАповідають } \\
\text { рядкам табли- } \\
\text { ці) }\end{array}$} \\
\hline $\begin{array}{c}\text { Придбання (виго- } \\
\text { товлення) основних } \\
\text { засобів }\end{array}$ & 290 & & \\
\hline $\begin{array}{c}\text { Придбання (виготов- } \\
\text { лення) інших необо- } \\
\text { ротних матеріальних } \\
\text { активів }\end{array}$ & 300 & & \\
\hline $\begin{array}{c}\text { Придбання (ство- } \\
\text { рення) нематеріаль- } \\
\text { них активів }\end{array}$ & 310 & & \\
\hline $\begin{array}{c}\text { Придбання (вирощу- } \\
\text { вання) Аовгостро- } \\
\text { кових біологічних } \\
\text { активів }\end{array}$ & 320 & & \\
\hline
\end{tabular}


Продовження таблиці 6.3

\begin{tabular}{|c|c|c|c|}
\hline $\begin{array}{c}\text { Найменування } \\
\text { показника }\end{array}$ & $\begin{array}{l}\text { КоА } \\
\text { ряАКа }\end{array}$ & За рік & $\begin{array}{l}\text { На кінець } \\
\text { року }\end{array}$ \\
\hline Інші & 330 & 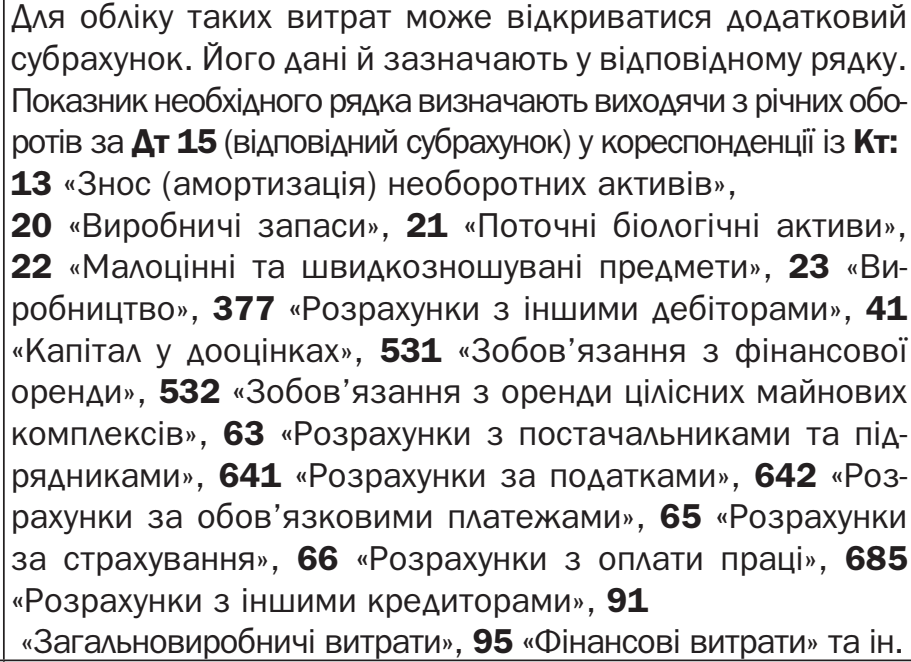 & $\begin{array}{c}\text { Фіксують } \\
\text { сальло на } \\
31.12 .20 \text { р. } \\
\text { за Ат } 15 \text { (суб- } \\
\text { рахунки якого } \\
\text { (за деякими } \\
\text { винятками) } \\
\text { віАповіАа- } \\
\text { ють рялкам } \\
\text { таблиці) }\end{array}$ \\
\hline Разом & 340 & Вносять суму ряаків 280-330 & $\begin{array}{c}\text { Показник } \\
\text { цього рялка } \\
\text { Аорівнює зна- } \\
\text { ченню рялка } \\
1005 \text { графи } 4 \\
\text { форми № } 1 \text { (з } \\
\text { урахуванням } \\
\text { розбіжностей, } \\
\text { викликаних су- } \\
\text { мами авансо- } \\
\text { вих платежів } \\
\text { підрядникам) }\end{array}$ \\
\hline
\end{tabular}

ПіА таблицею на піАставі Ааних із ряА. 340 графи 3 обирають ще Аодаткові Аані, які переносять Ао: - ряа. 341 - вартість капітальних інвестицій в інвестиційну нерухомість, тобто сюАи потрапляють витрати, спрямовані на купівлю (створення) нерухомості, яку не використовують або не планують використовувати при виробництві та поставці товарів, наАанні послуг, з аАміністративною метою або продажу в процесі звичайної Аіяльності. Таку нерухомість потім обліковують на Ат 100;

- ряА. 342 - величину фінансових витрат, віАнесених Ао капітальних інвестицій. Це обороти за Ат 15 у кореспонденції з Кт 95.

Ажерело: [10-11].

Таблиця 6.4

Методика заповнення розАіку IV “Фінансові інвестиції" приміток Ао річної фінансової звітності

\begin{tabular}{|c|c|c|c|c|}
\hline \multirow{2}{*}{$\begin{array}{c}\text { Найменування } \\
\text { показника }\end{array}$} & \multirow{2}{*}{$\begin{array}{c}\text { КоА } \\
\text { ряАКа }\end{array}$} & \multirow{2}{*}{ За рік } & \multicolumn{2}{|c|}{ На кінець року } \\
\hline & & & Аовгострокові & поточні \\
\hline $\begin{array}{l}\text { А. Фінансові } \\
\text { інвестиції за } \\
\text { методом участі в } \\
\text { капіталі в: } \\
\text { - асоційовані } \\
\text { підприємства } \\
\end{array}$ & 350 & $\begin{array}{l}\text { Відображають річні обороти за Ат } \\
\mathbf{1 4 1} \text { “нвестиції пов'язаним сторонам } \\
\text { за методом обліку участі в капіталі" } \\
\text { у кореспонденції із Кт } \mathbf{3 1} \text { “Рахунки в } \\
\text { банках", } \mathbf{1 4 3} \text { "Інвестиції непов'яза- } \\
\text { ним сторонам", } \mathbf{4 6} \text { "Неоплачений ка- }\end{array}$ & $\begin{array}{l}\text { Потрап^яє сальАо } \\
\text { на 31.12.20 р. за } \\
\text { субрахунком } \mathbf{1 4 1} \\
\text { (розподілене між } \\
\text { ряАками 350, 360, } \\
\text { З70 віАповіАно Ао }\end{array}$ & $\begin{array}{l}\text { Фінінвестиції } \\
\text { за методом } \\
\text { участі в капіта- } \\
\text { ^і можуть бути }\end{array}$ \\
\hline мі & 360 & $\begin{array}{l}\text { піта^", } 421 \text { "Емісійний АохіА”, } 422 \text { “н- } \\
\text { ший вкладений капіта^", } 425 \text { "Інший }\end{array}$ & $\begin{array}{l}\text { виду фінінвестиції). } \\
\text { Сума показників }\end{array}$ & о- \\
\hline $\begin{array}{l}\text { - спільну Аія^ь- } \\
\text { ність }\end{array}$ & 370 & $\begin{array}{l}\text { Аодатковий капітал", } 63 \text { "Розрахунки } \\
3 \text { постачальниками та підрядниками", } \\
685 \text { "Розрахунки з іншими кредитора- } \\
\text { ми", } 72 \text { "АохіА віА участі в капіталі". }\end{array}$ & $\begin{array}{l}\text { рялків 350-370 } \\
\text { Аорівнює значенню } \\
\text { рялка } 1030 \text { графи } 4 \\
\text { форми № } 1\end{array}$ & $\begin{array}{l}\text { ки цієї графи } \\
\text { прокреслюють }\end{array}$ \\
\hline
\end{tabular}


Продовження таблиці 6.4

\begin{tabular}{|c|c|c|c|c|}
\hline \multirow{2}{*}{$\begin{array}{c}\text { Найменування } \\
\text { показника }\end{array}$} & \multirow{2}{*}{\begin{tabular}{|c|} 
КоА \\
ряАКа
\end{tabular}} & \multirow{2}{*}{ За рік } & \multicolumn{2}{|c|}{ На кінець року } \\
\hline & & & Аовгострокові & поточні \\
\hline $\begin{array}{c}\text { Б. Інші } \\
\text { фінансові } \\
\text { інвестиції в: } \\
\text { - частки та паї } \\
\text { в статутному } \\
\text { капіта^і інших } \\
\text { підприємств }\end{array}$ & 380 & $\begin{array}{l}\text { Показують річні обороти за Ат } 142 \\
\text { “Інші інвестиції пов’язаним сторо- } \\
\text { нам», } \mathbf{1 4 3} \text { “Інвестиції непов’язаним } \\
\text { сторонам», } \mathbf{3 5 2} \text { “ншші поточні фінан- } \\
\text { сові інвестиції» } \\
\text { в кореспонденції з Кт 31, 377, } 40 \\
\text { «Зареєстрований (пайовий) капі- }\end{array}$ & $\begin{array}{l}\text { Фіксують сальАо } \\
\text { на 31.12.20 р. за } \\
\text { субрахунками 142, } \\
\text { 143. Сума } \\
\text { показників рядків } \\
\text { 380-410 цієї графи } \\
\text { дорівнює значенню }\end{array}$ & $\begin{array}{l}\text { Записують } \\
\text { сальдо на } \\
31.12 .20 \text { р. } \\
\text { за субрахун- } \\
\text { ком } 352 \text { (у } \\
\text { розрізі видів }\end{array}$ \\
\hline - акції & 390 & 195 732 & 4 & інвестицій за \\
\hline - облігації & 400 & 40, О00, 130 "НШШ АОХОАИ ВІА & 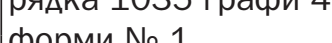 & рядками) \\
\hline & 410 & & & \\
\hline $\begin{array}{l}\text { Разом (розАіА А + } \\
\text { розАіл Б) }\end{array}$ & 420 & $\begin{array}{l}\text { Сума показників ряАків 350-410 } \\
\text { графи } 3\end{array}$ & $\begin{array}{l}\text { Сума показників } \\
\text { ряАків 350-410 } \\
\text { графи } 4\end{array}$ & $\begin{array}{c}\text { Показники } \\
\text { Ааного ряАка } \\
\text { й ряАка } 1160 \\
\text { графи } 4 \\
\text { форми № } 1 \\
\text { оАнакові } \\
\end{array}$ \\
\hline
\end{tabular}

ПіА таблицею в рялках 421-426 записують вартість фінінвестицій (Аовгострокових - 3 рялка 1035 графи 4 форми № 1 і поточних - з рялка 1160 графи 4 форми № 1) залежно віА того, як їх оцінюють: за собівартістю, справеАливою вартістю або амортизованою собівартістю.

При цьому фінінвестиції відображають у бухобліку:

1) за собівартістю - ті, що оцінюють і фіксують уперше. Вона складається із ціни придбання фінінвестиції, комісійної винагороди, мита та інших витрат, безпосередньо пов'язаних із придбанням (п. 4 П(С)БО 12);

2) за справеАливою вартістю - ті, що фіксують на дату балансу (крім інвестицій, утримуваних піАприємством до їх погашення або облікованих за методом участі в капіталі) (п. 8 П(С)БО 12);

3) за собівартістю з урахуванням зменшення корисності - ті, справедливу вартість яких достовірно визначити неможливо. Втрати віА зменшення корисності фінінвестицій показують у склаАі інших витрат, одночасно зменшуючи балансову вартість фінінвестицій (п. 9 П(С)БО 12);

4) за амортизованою собівартістю - ті, які підприємство утримує до їх погашення (на дату балансу). Різницю між собівартістю та вартістю погашення фінінвестицій (Аисконт або премія при придбанні) інвестор амортизує протягом періоду з дати придбання до Аати погашення за методом ефективної ставки віАсотка (п. 10 П(С)БО 12);

5) за собівартістю або справеАливою вартістю інвестицій, зАійснених в асоційовані та дочірні піАприємства, якщо:

а) їх придбали й утримують суто Аля продажу впродовж 12 місяців із Аати придбання;

б) асоційоване або дочірнє підприємство проводить Аіяльність в умовах, які обмежують його зАат-

ність передавати засоби інвесторові протягом періоду, що перевищує 12 місяців (п. 17 П(С)БО 12).

Ажерело: [10-11].

Таблиця 6.5

\section{МетоАика заповнення розАілу V "АохоАи і витрати" приміток Ао річної фінансової звітності}

\begin{tabular}{|c|c|c|c|}
\hline $\begin{array}{c}\text { Найменування } \\
\text { показника }\end{array}$ & $\begin{array}{c}\text { КоА } \\
\text { ряАКа }\end{array}$ & АОхоАи & Витрати \\
\hline $\begin{array}{c}\text { А. Інші операційні } \\
\text { АохоАи та витрати } \\
\text { Операційна оренда } \\
\text { активів }\end{array}$ & 440 & $\begin{array}{l}\text { Річний оборот за Ат } 713 \text { "АохіА віА } \\
\text { операційної оренАи активів" у } \\
\text { кореспонденції з Кт } 791 \text { "Резуль- } \\
\text { тат операційної Аіяльності" }\end{array}$ & $\begin{array}{l}\text { Річний оборот за Ат } 791 \text { у корес- } \\
\text { понденції з Кт } 949 \text { “нші витрати } \\
\text { операційної Аіяльності" (за Аани- } \\
\text { ми аналітичного обліку вибірково) }\end{array}$ \\
\hline $\begin{array}{l}\text { Операційна курсова } \\
\text { різниця }\end{array}$ & 450 & $\begin{array}{l}\text { Річний оборот за Ат } 714 \text { "АохіА } \\
\text { віА операційної курсової різниці" у } \\
\text { кореспонденції з Кт } 791\end{array}$ & $\begin{array}{l}\text { Річний оборот за Ат } 791 \text { у корес- } \\
\text { понденції } 3 \text { Кт } 945 \text { "Втрати віА } \\
\text { операційної курсової різниці" }\end{array}$ \\
\hline $\begin{array}{l}\text { Реалізація інших обо- } \\
\text { ротних активів }\end{array}$ & 460 & $\begin{array}{l}\text { Річний оборот за Ат } 712 \text { "АохіА віА } \\
\text { реалізації інших оборотних активів" } \\
\text { у кореспонденції з Кт } 791\end{array}$ & $\begin{array}{l}\text { Річний оборот за Ат } 791 \text { у корес- } \\
\text { понденції з Кт } 943 \text { "Собівартість } \\
\text { реалізованих виробничих запасів" }\end{array}$ \\
\hline
\end{tabular}


Продовження таблиці 6.5

\begin{tabular}{|c|c|c|c|}
\hline $\begin{array}{c}\text { Найменування } \\
\text { показника }\end{array}$ & $\begin{array}{c}\text { КоА } \\
\text { ряАКа }\end{array}$ & АОхОАи & Витрати \\
\hline $\begin{array}{l}\text { Штрафи, пені, не- } \\
\text { устойки }\end{array}$ & 470 & $\begin{array}{l}\text { Річний оборот за Ат } \mathbf{7 1 5} \text { “ОАержані } \\
\text { штрафи, пені, неустойки” у корес- } \\
\text { понденції з Кт } 791\end{array}$ & $\begin{array}{l}\text { Річний оборот за Ат } 791 \text { у ко- } \\
\text { респонденції з Кт } 948 \text { "Визнані } \\
\text { штрафи, пені, неустойки" }\end{array}$ \\
\hline $\begin{array}{c}\text { Утримання об'єктів } \\
\text { жит^ово комунального } \\
\text { та соціального } \\
\text { призначення }\end{array}$ & 480 & $\begin{array}{l}\text { Річний оборот за Ат } 719 \text { “нші Ао- } \\
\text { ходи віА операційної Аіяльності" у } \\
\text { кореспонденції з Кт } 791 \text { (вибірково } \\
\text { за Ааними аналітичного обліку) }\end{array}$ & $\begin{array}{l}\text { Річний оборот за Ат } 791 \text { у корес- } \\
\text { понденції з Кт } 949 \text { «Інші витрати } \\
\text { операційної Аіяльності» (за Аани- } \\
\text { ми аналітичного обліку вибірково) }\end{array}$ \\
\hline $\begin{array}{l}\text { Інші операційні доходи } \\
\text { та витрати }\end{array}$ & 490 & 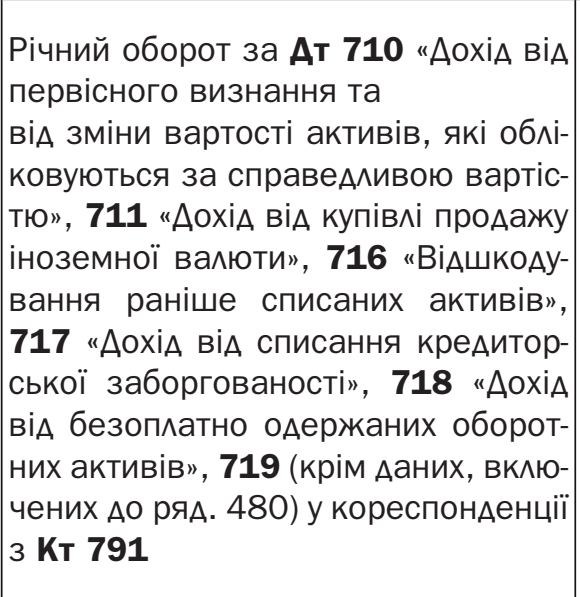 & 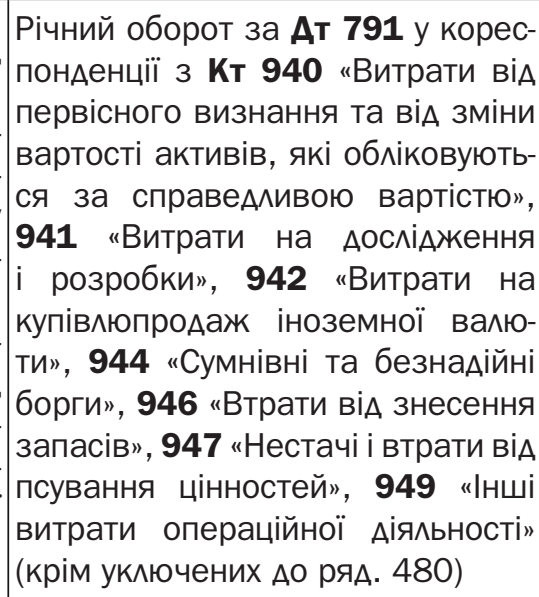 \\
\hline $\begin{array}{l}\text { У тому числі: } \\
\text { - відрахування в ре- } \\
\text { зерв сумнівних } \\
\text { боргів }\end{array}$ & 491 & $x$ & $\begin{array}{l}\text { Записують суму нарахованого } \\
\text { за рік резерву сумнівних боргів } \\
\text { - оборот за Ат } 944 \text { "Сумнівні та } \\
\text { безнадійні борги» в кореспон- } \\
\text { Аенції з Кт } 38 \text { "Резерв сумнівних } \\
\text { боргів". При цьому показник } \\
\text { рядка } 491 \text { дорівнює значенню } \\
\text { рядка } 775 \text { графи } 4 \text { розАілу VII } \\
\text { Приміток }\end{array}$ \\
\hline $\begin{array}{l}\text { - непродуктивні витра- } \\
\text { ти та втрати }\end{array}$ & 492 & $x$ & $\begin{array}{l}\text { Записують витрати, що прово- } \\
\text { Аять за Ат } 946 \text { “Втрати віА зне- } \\
\text { цінення запасів", } 947 \text { "Нестачі і } \\
\text { втрати віА псування цінностей" }\end{array}$ \\
\hline Примітка & & $\begin{array}{l}\text { Сума показників рядків 440-490 } \\
\text { цієї графи Аорівнює значенню ряА- } \\
\text { ка } 2120 \text { графри } 3 \text { форми № } 2 \\
\end{array}$ & $\begin{array}{l}\text { Сума показників рядків 440-490 } \\
\text { цієї графи дорівнює значенню } \\
\text { рядка } 2180 \text { графи } 3 \text { форми № } 2\end{array}$ \\
\hline $\begin{array}{l}\text { Б. АохоАи та втрати } \\
\text { віА участі в капіталі за } \\
\text { інвестиціями в: } \\
\text { - асоційовані піАпри- } \\
\text { ємства }\end{array}$ & 500 & $\begin{array}{l}\text { Річний оборот за Ат } 721 \text { "АохіА віА } \\
\text { інвестицій в асоційовані піАприєм- } \\
\text { ства" в кореспонденції } 3 \text { Кт } \mathbf{7 9 2} \\
\text { "Результат фінансових операцій" }\end{array}$ & $\begin{array}{l}\text { Річний оборот за Ат } 792 \text { в корес- } \\
\text { понденції з Кт } 961 \text { "Втрати віА } \\
\text { інвестицій в асоційовані піАпри- } \\
\text { ємства" }\end{array}$ \\
\hline $\begin{array}{l}\text { - Аочірні піАприєм- } \\
\text { ства }\end{array}$ & 510 & $\begin{array}{l}\text { Річний оборот за Ат } 723 \text { "АохіА віА } \\
\text { інвестицій у Аочірні піАприємства" } \\
\text { в кореспонденції з Кт } 792\end{array}$ & $\begin{array}{l}\text { Річний оборот за Ат } 792 \text { в корес- } \\
\text { понденції з Кт } 963 \text { "Втрати віА ін- } \\
\text { вестицій у Аочірні підприємства" }\end{array}$ \\
\hline - спільну Аіяльність & 520 & \multicolumn{2}{|c|}{$\begin{array}{l}\text { Повторимо: спільної Аіяльності зі створенням юридичної особи ЦКУ } \\
\text { не передбачено, а без створення жодного віАношення до фінансових } \\
\text { інвестицій немає. ОАнак Планом рахунків до рахунків } 72 \text { "АохіА віА } \\
\text { участі в капіталі" і } 96 \text { "Втрати віА участі в капіталі" встановлено субра- } \\
\text { хунки Аля обліку інвестицій у спільну Аіяльність: } 722 \text { "АохіА віА спільної } \\
\text { Аіяльності» і } 962 \text { “Втрати віА спільної Аіяльності" }\end{array}$} \\
\hline
\end{tabular}


Продовження таблиці 6.5

\begin{tabular}{|c|c|c|c|}
\hline $\begin{array}{c}\text { Найменування } \\
\text { показника }\end{array}$ & $\begin{array}{c}\text { КоА } \\
\text { ряАКа }\end{array}$ & АОхОАи & Витрати \\
\hline \multicolumn{2}{|l|}{ Примітка } & \begin{tabular}{|l|} 
Сума показників рядків 500-520 \\
цієї графи дорівнює значенню ряА- \\
ка 2200 графи 3 форми № 2 \\
\end{tabular} & $\begin{array}{l}\text { Сума показників рядків 500-520 } \\
\text { цієї графи дорівнює значенню } \\
\text { рядка } 2255 \text { графи } 3 \text { форми № } 2\end{array}$ \\
\hline $\begin{array}{c}\text { В. Інші фінансові } \\
\text { АохоАи та витрати } \\
\text { АивіАенАИ } \\
\end{array}$ & 530 & $\begin{array}{l}\text { Річний оборот за Ат } \mathbf{7 3 1} \\
\text { "Аивіденди одержані" } \\
\text { в кореспонденції з Кт } \mathbf{7 9 2} \\
\end{array}$ & $x$ \\
\hline ВіАсотки & 540 & $x$ & $\begin{array}{l}\text { Річний оборот за Ат 15, 23, } 792 \\
\text { в кореспонденції } 3 \text { Кт 951 "ВіА- } \\
\text { сотки за кредит", } 952 \text { "Інші фі- } \\
\text { нансові витрати" (вибірково за } \\
\text { Ааними аналітичного обліку в } \\
\text { частині віАсотків за Аоговора- } \\
\text { ми кредитування, відсотками за } \\
\text { власними векселями тощо) }\end{array}$ \\
\hline $\begin{array}{l}\text { Фінансова оренда } \\
\text { активів }\end{array}$ & 550 & \begin{tabular}{|l|} 
Річний оборот за Ат 732 “ВіАсотки \\
одержані» (вибірково за аналітич- \\
ними Ааними) \\
в кореспонденції з Кт 792 \\
\end{tabular} & $\begin{array}{l}\text { Річний оборот за Ат } 792 \\
\text { у кореспонденції із Кт } 952 \text { (ви- } \\
\text { бірково за Ааними аналітичного } \\
\text { обліку в частині фіноренди) } \\
\end{array}$ \\
\hline $\begin{array}{l}\text { Інші фінансові доходи } \\
\text { та витрати }\end{array}$ & 560 & \begin{tabular}{|l|} 
Річний оборот за Ат 732 (вибір- \\
ково за аналітичним даними: \\
віАсотки, одержані за облігаціями \\
або іншими цінними паперами, що \\
обліковують на субрахунку 732, за \\
винятком фіноренди), 733 в корес- \\
понденції з Кт 792 \\
\end{tabular} & $\begin{array}{l}\text { Річний оборот за Ат } 792 \\
\text { в кореспонденції з Кт 951, } 952 \\
\text { (вибірково за Ааними аналітично- } \\
\text { го обліку в частині операцій, не } \\
\text { включених Ао рядків 540-560) }\end{array}$ \\
\hline \multicolumn{2}{|l|}{ Примітка } & $\begin{array}{l}\text { Сума показників рядків 530-560 } \\
\text { цієї графи Аорівнює значенню рял- } \\
\text { ка } 2220 \text { графи } 3 \text { форми № } 2\end{array}$ & $\begin{array}{l}\text { Сума показників рялків 540-560 } \\
\text { цієї графи дорівнює значенню } \\
\text { рялка } 2250 \text { графи } 3 \text { форми № } 2 \\
+ \text { рядки } 342 \text { та } 633 \text { форми № } 5 \\
\end{array}$ \\
\hline $\begin{array}{c}\text { Г. Інші АохоАи } \\
\text { та витрати } \\
\text { Реалізація фрінансових } \\
\text { інвестицій }\end{array}$ & 570 & $\mid \begin{array}{l}\text { Річний оборот за Ат } 741 \text { "АохіА віА } \\
\text { реалізації фінансових інвестицій" у } \\
\text { кореспонденції з Кт } 793 \text { "Результат } \\
\text { віА іншої звичайної Аіяльності" }\end{array}$ & $\begin{array}{l}\text { Річний оборот за Ат } 793 \text { у корес- } \\
\text { понденції з Кт } 971 \text { "Собівартість } \\
\text { реалізованих фінансових інвес- } \\
\text { тицій" }\end{array}$ \\
\hline $\begin{array}{l}\text { Аоходи віА об'єАнання } \\
\text { піАприємств }\end{array}$ & 580 & $\begin{array}{l}\text { Річний оборот за Ат рахунків ак- } \\
\text { тивів у кореспонденції } 3 \text { Кт } \mathbf{7 4 6} \\
\text { "Інші доходи" (на суму перевищен- } \\
\text { ня справеАливої (ринкової) варто- } \\
\text { сті купленого піАприємства (чистих } \\
\text { активів) наА сукупністю витрат на } \\
\text { об'єАнання підприємств тощо) } \\
\end{array}$ & 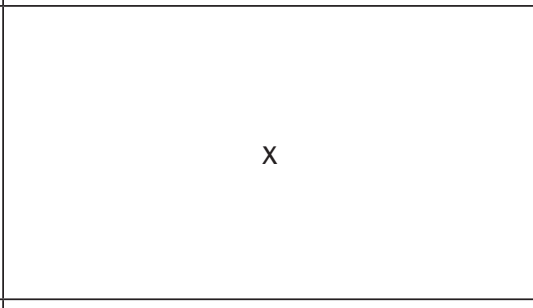 \\
\hline $\begin{array}{l}\text { Результати оцінки } \\
\text { корисності }\end{array}$ & 590 & $\mid \begin{array}{l}\text { Річний оборот за Ат } 742 \text { "АохіА віА } \\
\text { віАновлення корисності активів" } \\
\text { і } 746 \text { в кореспонденції з Кт } 791\end{array}$ & $\begin{array}{l}\text { Річний оборот за Ат } 791 \text { в корес- } \\
\text { понденції з Кт } 972 \text { "Втрати віА } \\
\text { зменшення корисності активів" }\end{array}$ \\
\hline $\begin{array}{l}\text { Неопераційна курсова } \\
\text { різниця }\end{array}$ & 600 & \begin{tabular}{|l|} 
Річний оборот за Ат 744 "АохіА віА \\
неопераційної курсової різниці" \\
в кореспонденції з Кт 793
\end{tabular} & $\begin{array}{l}\text { Річний оборот за Ат } 793 \text { в корес- } \\
\text { понденції } 3 \text { Кт } 974 \text { "Втрати віА } \\
\text { неопераційних курсових різниць" }\end{array}$ \\
\hline $\begin{array}{l}\text { Безоп^атно одержані } \\
\text { активи }\end{array}$ & 610 & \begin{tabular}{|l|} 
Річний оборот за Ат 745 "АохіА віА \\
безоплатно одержаних активів" \\
у кореспонденції з Кт 793
\end{tabular} & $x$ \\
\hline
\end{tabular}


Продовження таблиці 6.5

\begin{tabular}{|c|c|c|c|}
\hline $\begin{array}{c}\text { Найменування } \\
\text { показника }\end{array}$ & $\begin{array}{l}\text { KоА } \\
\text { ряАКа }\end{array}$ & АохоАи & Витрати \\
\hline $\begin{array}{l}\text { Списання необоротних } \\
\text { активів }\end{array}$ & 620 & $\mathrm{x}$ & $\begin{array}{l}\text { Річний оборот за Ат } 793 \text { у ко- } \\
\text { респонденції з Кт } 976 \text { "Списан- } \\
\text { ня необоротних активів" }\end{array}$ \\
\hline Інші Аоходи та витрати & 630 & $\begin{array}{l}\text { Річний оборот за Ат } \mathbf{7 4 6} \text { «нші } \\
\text { Аоходи віА звичайної Аіяльності» В } \\
\text { кореспонденції з Кт } \mathbf{7 9 3}\end{array}$ & $\begin{array}{l}\text { Річний оборот за Ат } 793 \text { в ко- } \\
\text { респонденції з Кт } 975 \text { “Уцінка } \\
\text { необоротних активів і фінансо- } \\
\text { вих інвестицій", } 977 \text { "Інші ви- } \\
\text { трати звичайної діяльності" } \\
\end{array}$ \\
\hline Примітка & & $\begin{array}{l}\text { Сума показників рядків 570-610 і } \\
630 \text { цієї графи дорівнює значенню } \\
\text { рядка } 2240 \text { графи } 3 \text { форми № } 2\end{array}$ & $\begin{array}{l}\text { Сума показників рядків 570- } \\
600,620 \text { і } 630 \text { цієї графри Аорів- } \\
\text { нює значенню рядка } 2270 \text { гра- } \\
\text { фи } 3 \text { форми № } 2\end{array}$ \\
\hline
\end{tabular}

У текстовій частині розАілу V у рядку 631 вілображають вартість проданої за бартером продукції (товарів, робіт, послуг), тобто це вибіркові дані з річних оборотів за ат 70 і кт 791.

Щоло рялка 632: його показник розраховують визначаючи вибірково за рядком 631 обсяг бартерних операцій із пов'язаними сторонами та Аілячи названий показник на значення рял- ка 631, а потім одержаний результат множать на $100 \%$.

НагаАаємо: п. 3 П(С)БО 23 встановлено, що пов'язаними сторонами вважаються:

- підприємства, що перебувають піА контролем або суттєвим впливом інших осіб;

- підприємства та фізичні особи, які прямо чи опосередковано зАійснюють контроль наА піАприємством або суттєво впливають на його Аіяльність, а також близькі члени сім'ї такої фізичної особи.

Перелік пов'язаних сторін визначається підприємством, ураховуючи сутність відносин, а не лише юридичну форму (превалювання суті наА формою). ВіАносини між пов'язаними сторонами - це, зокрема, віАносини: материнського (холАингового) піАприємства та його Аочірніх піАприємств; спільного підприємства та контрольних учасників спільної Аіяльності; піАприємства-інвестора та його асоційованих піАприємств; піАприємства та фізичних осіб, які зАійснюють контроль або суттєво впливають на це піАприємство, а також віАносини цього піАприємства з близькими членами сім'ї кожної такої фізичної особи; підприємства та його керівника й інших осіб, які належать до провіАного управлінського персоналу підприємства, а також близьких членів сім'ї таких осіб.

А ось близькими членами сім'ї вважаються "чоловік або дружина та родичі (визнані такими згідно із законодавством) фізичної особи, яка є пов'язаною стороною, що можуть впливати або знаходитися піА впливом такої фізичної особи щодо прийняття рішень стосовно фінансової, господарськоі та комерційної політики підприємства" (п. 4 П(С)БО 23).

У рялку 633 на піАставі Ааних із рядків 540-560 графи 4 показують фінансові витрати, включені до собівартості продукції основної Аіяльності. Їх проводять за Ат 23 у кореспонденції з Кт 95.

Ажерело: [10-11].

Таблиця 6.6

Методика заповнення розАілу VI "Грошові кошти" приміток Ао річної фінансової звітності

\begin{tabular}{|c|c|c|}
\hline Найменування показника & КоА ряАКа & На кінець року \\
\hline Kaca & 640 & \multirow{5}{*}{ 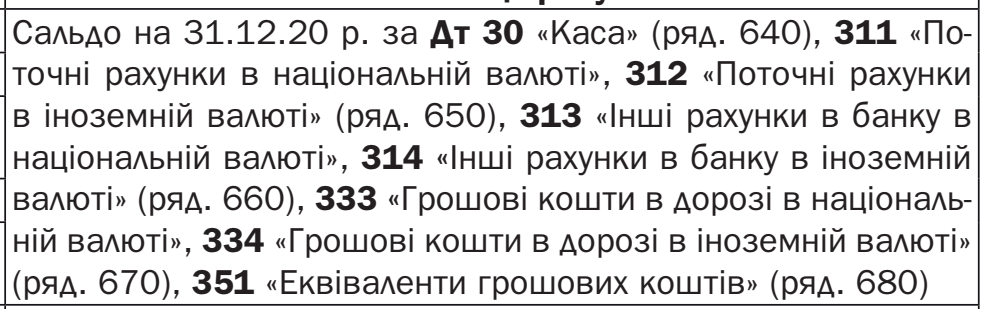 } \\
\hline Поточний рахунок у банку & 650 & \\
\hline $\begin{array}{l}\text { Інші рахунки в банку (акре- } \\
\text { дитиви, чекові книжки) }\end{array}$ & 660 & \\
\hline Кошти в Аорозі & 670 & \\
\hline Еквіваленти коштів & 680 & \\
\hline Разом & 690 & $\begin{array}{l}\text { Показник зазначеного рянка Аорівнює значенню рялка } 1165 \\
\text { графи } 4 \text { форми № 1, а такожк показнику рядка } 3415 \text { графи } \\
3 \text { форми № } 3\end{array}$ \\
\hline
\end{tabular}

Ажерело: [10-11]. 


\section{Методика заповнення розАілу VII "Забезпечення й резерви" приміток} Ао річної фінансової звітності

\begin{tabular}{|c|c|c|c|c|c|c|c|c|}
\hline \multirow{2}{*}{$\begin{array}{c}\text { Види забез } \\
\text { печень і ре } \\
\text { зервів }\end{array}$} & \multirow{2}{*}{$\begin{array}{c}\text { КоА } \\
\text { ряА- } \\
\text { ка }\end{array}$} & \multirow{2}{*}{$\begin{array}{c}\text { Захишок } \\
\text { на поча } \\
\text { ток року }\end{array}$} & \multicolumn{2}{|c|}{$\begin{array}{c}\text { 3більшення } \\
\text { за звітний рік }\end{array}$} & \multirow{2}{*}{$\begin{array}{c}\text { Викорис } \\
\text { тано у звіт } \\
\text { ному році }\end{array}$} & \multirow{2}{*}{$\begin{array}{c}\text { Сторновано } \\
\text { невико ри- } \\
\text { стану суму у } \\
\text { звітному році }\end{array}$} & \multirow{2}{*}{$\begin{array}{c}\text { Сума очікуваного } \\
\text { віА шкодування } \\
\text { витрат Аругою } \\
\text { стороною, врахо- } \\
\text { вана при оцінці } \\
\text { забезпечення }\end{array}$} & \multirow{2}{*}{$\begin{array}{c}\text { Замишок } \\
\text { на кінець } \\
\text { року }\end{array}$} \\
\hline & & & \begin{tabular}{|c|} 
нарахова \\
но (ство- \\
рено)
\end{tabular} & $\begin{array}{c}\text { АоАаткові } \\
\text { віАраху- } \\
\text { вання }\end{array}$ & & & & \\
\hline 1 & 2 & 3 & 4 & 5 & 6 & 7 & 8 & 9 \\
\hline $\begin{array}{c}\text { Забезпе- } \\
\text { чення на } \\
\text { виплати за } \\
\text { відпустками } \\
\text { працівникам }\end{array}$ & 710 & $\begin{array}{r}\text { У графі } \\
\text { У графі } \\
\text { майбутніх } \\
\text { трати на } 3 \\
\text { Аіяльності, } \\
\text { графу } 5 \text { - } \\
\text { У графу } \\
\text { "Забезпеч } \\
\text { ним соціал } \\
\text { сують річні } \\
\text { на дату ба/ } \\
\text { Графу } 8 \\
\text { (дебетовог }\end{array}$ & $\begin{array}{l}3 \text { зазначаң } \\
4 \text { - річні об } \\
\text { періодів", } \\
\text { ббут", } 941 \text { " } \\
\text { " при створ } \\
\text { обороти за } \\
6 \text { записую } \\
\text { ення випла } \\
\text { ьним страх } \\
\text { і обороти з } \\
\text { Аансу створ } \\
\text { не запов } \\
\text { го сальдо в }\end{array}$ & 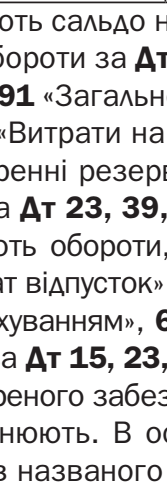 & $\begin{array}{l}\text { а 31.12.19 р } \\
15 \text { "Капіталь } \\
\text { овиробничі в } \\
\text { Аослідження } \\
\text { зу. Якщо зАій } \\
\text { 91, 92, 93, } \\
\text { пов'язані } 3 \\
\text { Кт } 651 \text { "За р } \\
61 \text { "Розрахуң } \\
\text { 39, 91, 92, 9 } \\
\text { печення в бік } \\
\text { станній граф } \\
\text { субрахунку н }\end{array}$ & $\begin{array}{l}\text { за Кт } 471 \text { "Заб } \\
\text { ні інвестиції», } 2 \\
\text { трати», } 92 \text { "ААл } \\
\text { та розробки», } 9 \\
\text { снюють Аодаткс } \\
\text { 41, } 949 . \\
\text { нарахуванням і } \\
\text { зрахунками за } \\
\text { ки за виплатамь } \\
\text { 3, 941, } 949 \text { Кт } \\
\text { зменшення (п. } \\
\text { фіксують саль } \\
\text { буває) }\end{array}$ & $\begin{array}{l}\text { зпечення виплат } \\
\text { “Виробництво», } 3 \\
\text { ністративні витрат } \\
9 \text { “Інші витрати о } \\
\text { і віАрахування, за } \\
\text { иплатою віАпускни } \\
\text { гальнообов'язков } \\
\text { працівникам». У гя } \\
71 \text { (сторно) - при к } \\
8 \text { П(С)БО } 11 \text { «Зобо } \\
\text { на } 31.12 .20 \text { р. }\end{array}$ & $\begin{array}{l}\text { Апусток". } \\
\text { "Витрати } \\
\text { ", } 93 \text { "Ви- } \\
\text { ераційної } \\
\text { овнюють } \\
\text { Ат } 471 \\
\text { мержав } \\
\text { дрі } 7 \text { фік- } \\
\text { ригуванні } \\
\text { язання"). } \\
\text { а Кт } 471\end{array}$ \\
\hline $\begin{array}{c}\text { Забезпечен- } \\
\text { ня майбутніх } \\
\text { витрат на } \\
\text { Аолаткове } \\
\text { пенсійне за- } \\
\text { безпечення }\end{array}$ & 720 & $\begin{array}{c}\text { Підприє } \\
\text { кам, коли } \\
\text { недержав } \\
\text { створити с } \\
\text { ником і вк } \\
\text { недержав } \\
\text { У графрі } \\
\text { Кт 472. П } \\
\text { реносять о } \\
\text { Кт } \mathbf{3 1} \text { "Рах } \\
\text { 31.12.20 } \\
\text { коли витра }\end{array}$ & $\begin{array}{l}\text { мство можк } \\
\text { колдоговор } \\
\text { не пенсійн } \\
\text { спільно з ін } \\
\text { ^аАником, } \\
\text { ного пенсій } \\
3 \text { показуют } \\
\text { ричому в о } \\
\text { суми, перер } \\
\text { хунки в бан } \\
\text { р. за Ат } \mathbf{4 7} \\
\text { өти нарахов }\end{array}$ & $\begin{array}{l}\text { е самостійн } \\
\text { оом передба } \\
\text { е забезпече } \\
\text { шими піАпр } \\
\text { або сплачув } \\
\text { йного фонду } \\
\text { ть сальАо за } \\
\text { станній фікс } \\
\text { раховані Ао } \\
\text { нках". У гра } \\
\text { 2. Але практ } \\
\text { вують раз на }\end{array}$ & $\begin{array}{l}\text { о резервуват } \\
\text { чено Аоплату } \\
\text { ння" віА } 09.0 \\
\text { иємствами нє } \\
\text { зати страхові } \\
\text { кт } 472 \text { на } 3 \\
\text { нують Аодатко } \\
\text { недержавног } \\
\text { фі } 7 \text { записую } \\
\text { ики зазначаю } \\
\text { рік або раз }\end{array}$ & $\begin{array}{l}\text { кошти А^я май } \\
\text { пенсіонерам. O } \\
.03 \text { р. № } 1057 \\
\text { ержавний пен } \\
\text { нески за праці } \\
12.19 \text { р. У гра } \\
\text { i нарахування } \\
\text { пенсійного фо } \\
\text { сторновану с } \\
\text { ь, що створюв } \\
\text { арік розрахову }\end{array}$ & $\begin{array}{l}\text { йний фона і стати } \\
\text { ника до будьякого } \\
\text { ах } 4 \text { і } 5 \text { - обороти } \\
\text { в виплатами. Ао г } \\
\text { Ау, тобто обороти } \\
\text { иу. У графі } 9 \text { буде } \\
\text { и таке забезпече } \\
\text { ться з пенсійним }\end{array}$ & $\begin{array}{l}\text { працівни- } \\
\text { раїни «Про } \\
\text { мству або } \\
\text { його учас- } \\
\text { існуючого } \\
\text { за Ат } 949 \\
\text { афи } 6 \text { пе- } \\
\text { за Ат } 472 \\
\text { сальАо на } \\
\text { нн є сенс, } \\
\text { ооном }\end{array}$ \\
\hline $\begin{array}{c}\text { Забезпечен- } \\
\text { ня майбутніх } \\
\text { витрат на } \\
\text { ви конання } \\
\text { гарантійних } \\
\text { зобов'язань }\end{array}$ & 730 & $\begin{array}{r}\text { ПіАприєІ } \\
\text { рюють заб } \\
\text { кою ресур } \\
\text { і відобр } \\
\text { Оборот за } \\
\text { При АоА } \\
\text { пляють АО } \\
\text { ремонтів, } \\
\text { хунками за } \\
\text { й за необх } \\
\text { записують } \\
\text { У графі } \\
\text { печення. } \\
\text { У графа }\end{array}$ & $\begin{array}{l}\text { мства, що } \\
\text { Језпечення } \\
\text { сів, необхі, } \\
\text { ажають у } \\
\text { цими субр } \\
\text { аткових ві } \\
\text { графи 5. Е } \\
\text { віАобража } \\
\text { аносять Ао } \\
\text { хіАності коя } \\
\text { Ат } 93 \text { Кт } \\
8 \text { показуют } \\
\text { Як і забезп } \\
\text { х } 3 \text { і } 9 \text { віАо }\end{array}$ & $\begin{array}{l}\text { випускають } \\
\text { я гарантійни } \\
\text { Аних Аля по } \\
\text { бухобліку - } \\
\text { ахунками фр } \\
\text { Арахуваннях } \\
\text { Зартість тов } \\
\text { Ють записал } \\
\text { графи 6. 3с } \\
\text { ригують. Якь } \\
\mathbf{4 7 3} \text { (сторно } \\
\text { ть суму очіку } \\
\text { ечення, її в } \\
\text { бражкють с }\end{array}$ & $\begin{array}{l}\text { і продають п } \\
\text { х зобов'язан } \\
\text {-ашення віАп } \\
\text { Ат } 93 \text { Кт 47 } \\
\text { іксують у гра } \\
\text { протягом ро } \\
\text { арів, робіт, П } \\
\text { ии Ат 473 Kт } \\
\text { алишок забез } \\
\text { цо резерв га } \\
\text { ) й обороти } 3 \\
\text { ваного віАшк } \\
\text { становлюють } \\
\text { альдо за Ат }\end{array}$ & $\begin{array}{l}\text { родукцію, на як } \\
\text { Його розмір в } \\
\text { овідного зобов" } \\
3 \text { “Забезпечен } \\
\text { рі } 4 . \\
\text { ку роблять анал } \\
\text { слуг, спрямова } \\
20,22,685 \text { то } \\
\text { печення перегл } \\
\text { рантійних зобов } \\
\text { а цими рахунка } \\
\text { одування, на як } \\
\text { виходячи з облі } \\
\mathbf{4 7 3} \text { на } 31.12 .1\end{array}$ & $\begin{array}{l}\text { встановлено гара } \\
\text { значають за облік } \\
\text { ання, } \\
\text { г гарантійних зоб } \\
\text {-ічні записи, і ці с } \\
\text { хх на виконання г } \\
\text {. Обороти за наз } \\
\text { ають на кожну да } \\
\text { зань зменшили, } \\
\text { 1 потраплять Ао г } \\
\text { зменшують створ } \\
\text { вої оцінки. } \\
\text { р. і } 31.12 .20 \text { р. ві }\end{array}$ & $\begin{array}{l}\text { нтію, ство- } \\
\text { овою оцін- } \\
\text { ов'язань". } \\
\text { уми потра- } \\
\text { арантійних } \\
\text { ваними ра- } \\
\text { тту балансу } \\
\text { у бухобліку } \\
\text { оафи } 7 . \\
\text { ене забез- } \\
\text { ідповідно }\end{array}$ \\
\hline $\begin{array}{c}\text { Забезпечен- } \\
\text { ня майбутніх } \\
\text { витрат на } \\
\text { реструктури } \\
\text { зацію }\end{array}$ & 740 & $\begin{array}{c}\text { Забезпе } \\
\text { реструктур } \\
\text { ганізаційн } \\
\text { власності, } \\
\text { есективнс } \\
\text { "Забезпе } \\
\text { затвердже } \\
\text { строками } \\
\text { цього плаң } \\
\text { сумою пря } \\
\text { БО 11). Ст } \\
\text { інших витр } \\
\text { АоАатков } \\
\text { записом. } 9 \\
\text { ють за Ат }\end{array}$ & 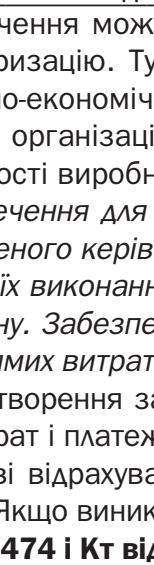 & $\begin{array}{l}\text { суть створюе } \\
\text { ут мається ' } \\
\text { Іних, правов } \\
\text { ійно-правов } \\
\text { ництва. } \\
\text { відшкодува } \\
\text { нництвом піА } \\
\text { ня та сумою } \\
\text { ечення Аля в } \\
\text {, не пов'яза } \\
\text { абезпеченн } \\
\text { ків (реструк } \\
\text { ання потрап } \\
\text { кають витра } \\
\text { Аповідних с }\end{array}$ & $\begin{array}{l}\text { зати Аля віАЦ } \\
\text { на увазі рест } \\
\text { зих, технічних } \\
\text { у форму Аля } \\
\text { ння витрат н } \\
\text { приємства п^ } \\
\text { зАійснених у } \\
\text { іАшкодування } \\
\text { них із триваю } \\
\text { А віАображаю } \\
\text { гуризація)" і ц } \\
\text { лять Ао граф } \\
\text { ти на проведе } \\
\text { убрахунків. П }\end{array}$ & $\begin{array}{l}\text { נкодування май } \\
\text { руктуризація пі, } \\
\text { заходів, щоб з } \\
\text { иого фінансово } \\
\text { а реструктуриза } \\
\text { ану реструктури } \\
\text { майбутньому ви } \\
\text { витрат на рест } \\
\text { чою діяльністю } \\
\text { ть записами Ат } \\
\text { і обороти зазна } \\
\text { и 5, а в бухобл } \\
\text { ння заходів із р } \\
\text { ри цьому річні о }\end{array}$ & 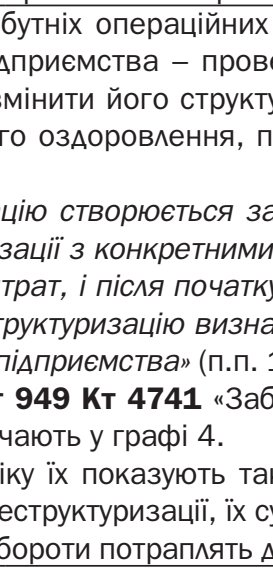 & $\begin{array}{l}\text { витрат на } \\
\text { Аення ор- } \\
\text { ру, форму } \\
\text { Авищення } \\
\text { наявності } \\
\text { заходами, } \\
\text { реалізації } \\
\text { нається за } \\
5,16 \text { П (C) } \\
\text { езпечення } \\
\text { им самим } \\
\text { му запису- } \\
\text { графи } 6 .\end{array}$ \\
\hline
\end{tabular}


Продовження таблиці 6.7

\begin{tabular}{|c|c|c|c|c|c|c|c|c|}
\hline \multirow{2}{*}{$\begin{array}{c}\text { Види забез } \\
\text { печень і ре } \\
\text { зервів }\end{array}$} & \multirow{2}{*}{$\begin{array}{c}\text { КоА } \\
\text { ряА- } \\
\text { ка }\end{array}$} & \multirow{2}{*}{$\begin{array}{c}\text { Залишок } \\
\text { на поча } \\
\text { ток року }\end{array}$} & \multicolumn{2}{|c|}{$\begin{array}{c}\text { Збімьшення } \\
\text { за звітний рік }\end{array}$} & \multirow{2}{*}{$\begin{array}{c}\text { Викорис } \\
\text { тано у звіт } \\
\text { ному році }\end{array}$} & \multirow{2}{*}{$\begin{array}{c}\text { Сторновано } \\
\text { невико ри- } \\
\text { стану суму у } \\
\text { звітному році }\end{array}$} & \multirow{2}{*}{\begin{tabular}{|c|} 
Сума очікуваного \\
віА шкодування \\
витрат Аругою \\
стороною, врахо- \\
вана при оцінці \\
забезпечення \\
\end{tabular}} & \multirow{2}{*}{$\begin{array}{c}\text { Зами- } \\
\text { шок на } \\
\text { кінець } \\
\text { року }\end{array}$} \\
\hline & & & $\begin{array}{c}\text { нарахова } \\
\text { но (ство- } \\
\text { рено) }\end{array}$ & $\begin{array}{l}\text { АоАаткові } \\
\text { віАраху- } \\
\text { вання }\end{array}$ & & & & \\
\hline 1 & 2 & 3 & 4 & 5 & 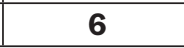 & 7 & 8 & 9 \\
\hline & & \multicolumn{7}{|c|}{$\begin{array}{l}\text { Не використану на кінець року суму резерву сторнують, роблячи запис Ат } \mathbf{9 4 9} \text { Кт 4741, і } \\
\text { віАображають у граффі } 7 . \\
\text { Графу } 8 \text { не заповнюють. } \\
\text { У графах } 3 \text { і } 9 \text { фіксують сальдо Кт } \mathbf{4 7 4 1} \text { на } 31.12 .19 \text { р. і } 31.12 .20 \text { р. віАповіАно }\end{array}$} \\
\hline \multirow[t]{2}{*}{$\begin{array}{c}\text { Забезпечен- } \\
\text { ня майбутніх } \\
\text { витрат на } \\
\text { виконання } \\
\text { зобов'язань } \\
\text { за обтяж- } \\
\text { ливими } \\
\text { контракта- } \\
\text { ми }\end{array}$} & 750 & \multicolumn{7}{|c|}{ 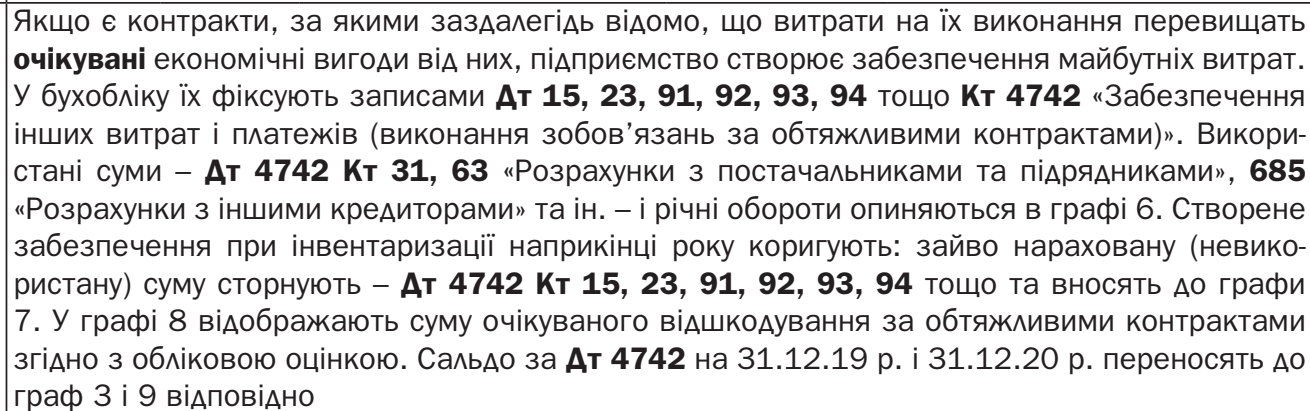 } \\
\hline & & \multicolumn{7}{|c|}{ Сюди записують інші види забезпечень, які створює підприємство } \\
\hline & 775 & \multicolumn{7}{|c|}{ 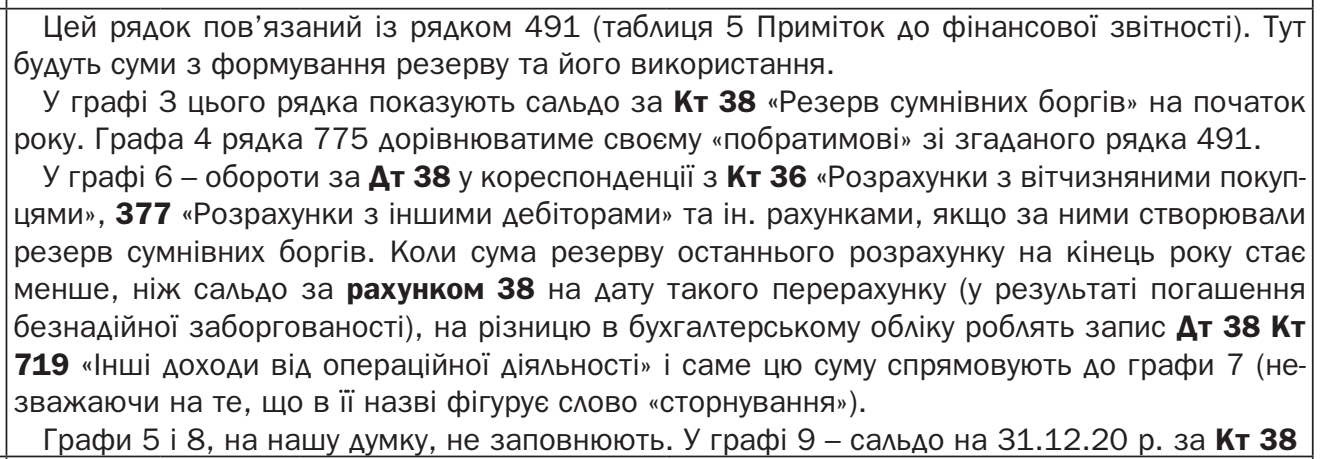 } \\
\hline I d & 80 & $x_{1}$ & & 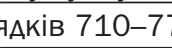 & & & & \\
\hline
\end{tabular}

Ажерело: [10-11].

Таблиця 6.8

Методика заповнення розАіму VIII "Запаси" приміток Ао річної фінансової звітності

\begin{tabular}{|c|c|c|c|c|}
\hline \multirow{2}{*}{$\begin{array}{c}\text { Найменування } \\
\text { показника }\end{array}$} & \multirow[b]{2}{*}{$\begin{array}{c}\text { КоА } \\
\text { ряАКа }\end{array}$} & \multirow[b]{2}{*}{ Балансова вартість на кінець року } & \multicolumn{2}{|c|}{ Переоцінка за рік } \\
\hline & & & $\begin{array}{l}\text { збільшення чистої } \\
\text { вартості реалізації }\end{array}$ & уцінка \\
\hline 1 & & 3 & 4 & 5 \\
\hline $\begin{array}{c}\text { Сировина } \\
\text { та матеріали }\end{array}$ & 800 & \multirow{8}{*}{$\begin{array}{l}\text { ВіАносять сальдо на } 31.12 .20 \text { р. за Ат } \\
201 \text { "Сировина й матеріали", } 202 \text { "Купі- } \\
\text { вельні напівфабрикати та комплектуючі } \\
\text { вироби", } 203 \text { "Паливо", } 204 \text { "Тара й тарні } \\
\text { матеріали", } 205 \text { "Будівельні матеріали", } \\
207 \text { "Запасні частини", } 208 \text { "Матеріали } \\
\text { сільськогосподарського призначення", } \\
\mathbf{2 1 1} \text { "Поточні біологічні активи рослинни- } \\
\text { цтва, які оцінені за справеАливою вартіс- } \\
\text { тю", } 212 \text { "Поточні біологічні активи тва- } \\
\text { ринництва, які оцінені за справедливою } \\
\text { вартістю", }\end{array}$} & \multirow{8}{*}{ 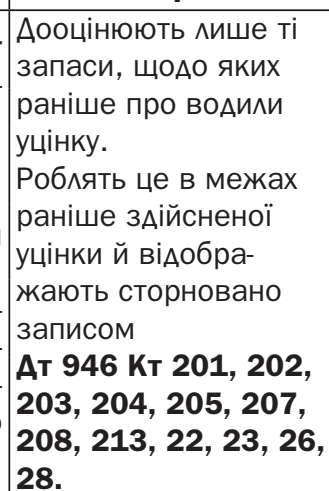 } & \multirow{8}{*}{$\begin{array}{l}\text { Запаси показують } \\
\text { у бухгалтерському } \\
\text { обліку та звітності } \\
\text { за найменшою з } \\
\text { Авох оцінок: пер- } \\
\text { винної вар тості } \\
\text { або чистої варто- } \\
\text { сті реалізації. }\end{array}$} \\
\hline Купів & & & & \\
\hline $\begin{array}{r}\text { півфрабри } \\
\text { компле }\end{array}$ & 810 & & & \\
\hline $\mathrm{BV}$ & & & & \\
\hline Пद & 20 & & & \\
\hline $\begin{array}{c}\text { Tара і тарні } \\
\text { матеріали }\end{array}$ & 830 & & & \\
\hline $\begin{array}{l}\text { Будівельні } \\
\text { матеріали }\end{array}$ & 840 & & & \\
\hline Запасні частини & 850 & & & \\
\hline
\end{tabular}


Продовження таблиці 6.8

\begin{tabular}{|c|c|c|c|c|}
\hline \multirow{2}{*}{$\begin{array}{l}\text { Найменування } \\
\text { показника }\end{array}$} & \multirow{2}{*}{$\begin{array}{l}\text { КоА } \\
\text { ряАКа }\end{array}$} & \multirow[b]{2}{*}{ Балансова вартість на кінець року } & \multicolumn{2}{|c|}{ Переоцінка за рік } \\
\hline & & & $\begin{array}{l}\text { збімьшення чистої } \\
\text { вартості реалізації }\end{array}$ & уцінка \\
\hline 1 & 2 & \multirow{9}{*}{ 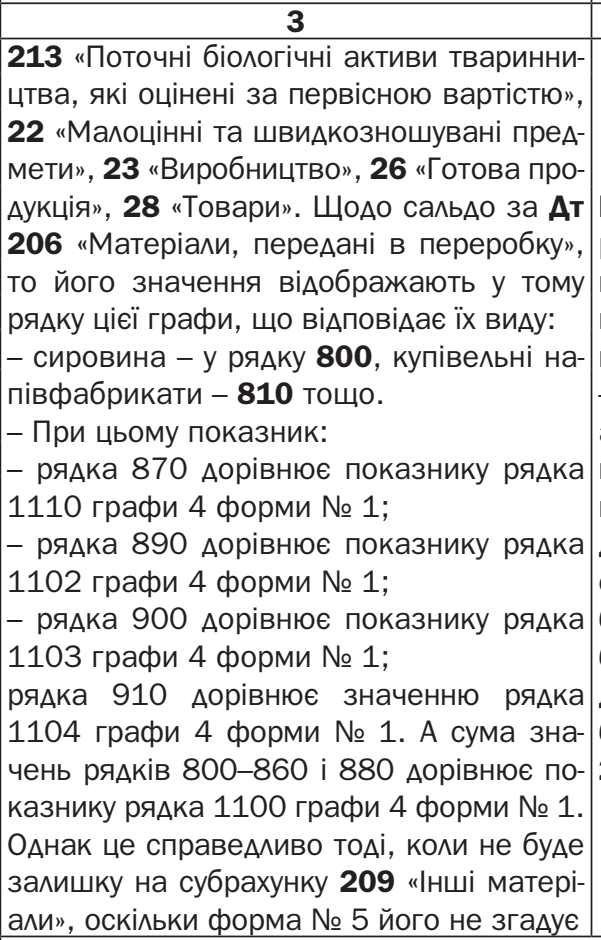 } & 4 & 5 \\
\hline $\begin{array}{c}\text { Матеріали } \\
\text { сі^ьськогоспо }\end{array}$ & 860 & & \multirow{8}{*}{$\begin{array}{l}\text { Річні обороти за цими } \\
\text { рахунками (субрахун- } \\
\text { ками) записують Ао } \\
\text { віА повіАних рялків } \\
\text { цієї графи. Виняток } \\
\text { - поточні біологічні } \\
\text { активи. Їх облікову- } \\
\text { ють за справеАливою } \\
\text { вартістю на кожну } \\
\text { Аату балансу. ПіАпри- } \\
\text { ємство має Аовести } \\
\text { балансову вартість } \\
\text { біологічних активів } \\
\text { до справеАливої. ТоАі } \\
\text { беруть обороти за Ат } \\
\mathbf{2 1 1 , ~ 2 1 2 , ~ К т ~} \mathbf{7 1 0}\end{array}$} & \multirow{8}{*}{$\begin{array}{l}\text { Суму, на яку пер- } \\
\text { винна вартість } \\
\text { запасів переви- } \\
\text { щує їх чисту вар- } \\
\text { тість реалізації, } \\
\text { віАображають у } \\
\text { бухобліку так: Ат } \\
\mathbf{9 4 6} \text { Кт 201, 202, } \\
\mathbf{2 0 3 , 2 0 4 , 2 0 5 ,} \\
\mathbf{2 0 7 , 2 0 8 , 2 2 , 2 3} \\
\mathbf{2 6 , 2 8 , ~ а ~ т а к о ж к ~} \\
\text { Ат } 940 \text { кт 212, } \\
\mathbf{2 1 3 .} \\
\text { Річні обороти за } \\
\text { переліченими } \\
\text { рахунками (субра } \\
\text { хунками) фіксу- } \\
\text { ють у віАповіАних } \\
\text { рядках цієї графи }\end{array}$} \\
\hline & & & & \\
\hline $\begin{array}{c}\text { Поточні біологічні } \\
\text { активи }\end{array}$ & 870 & & & \\
\hline & & & & \\
\hline $\begin{array}{c}\text { ШвиАкозношувані } \\
\text { предмети }\end{array}$ & 880 & & & \\
\hline $\begin{array}{c}\text { Незавершене } \\
\text { виробництво }\end{array}$ & 890 & & & \\
\hline Готова продукція & 900 & & & \\
\hline Товари & 910 & & & \\
\hline Разом & 920 & \multicolumn{3}{|c|}{ Сума значень рядків 800-910 віАповіАних граф } \\
\hline \multicolumn{5}{|c|}{ 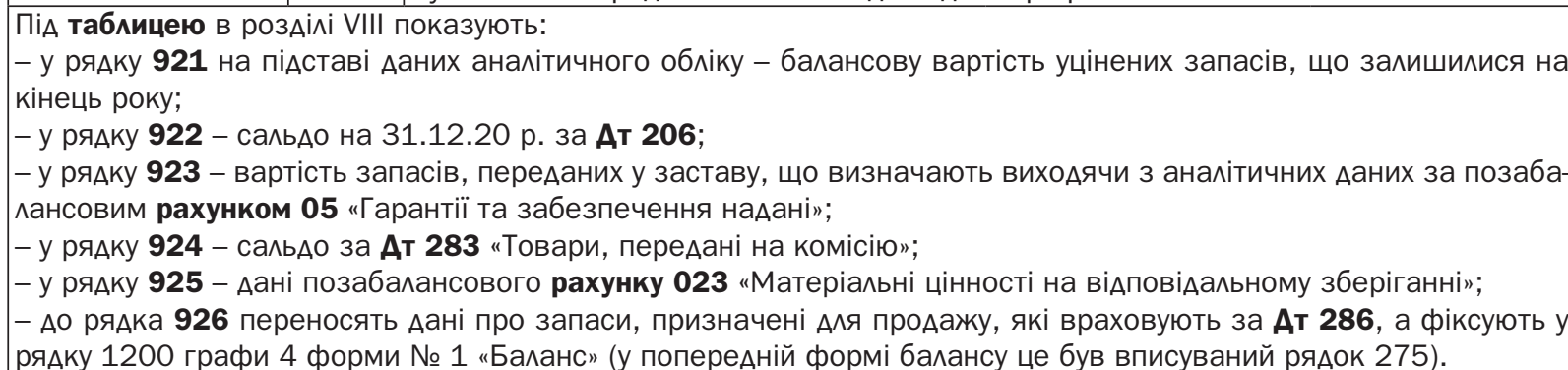 } \\
\hline
\end{tabular}

Ажерело: [10-11].

Таблиця 6.9

Методика заповнення розАілу IX "Аебіторська заборгованість" приміток Ао річної фінансової звітності

\begin{tabular}{|c|c|c|c|c|c|}
\hline \multirow{2}{*}{$\begin{array}{c}\text { Найменування } \\
\text { показника }\end{array}$} & \multirow[b]{2}{*}{ КоА ряАКа } & \multirow[b]{2}{*}{ Усього на кінець року } & \multicolumn{3}{|c|}{ У т.ч. за строками непогашення } \\
\hline & & & $\begin{array}{c}\text { Ао } 12 \\
\text { місяців }\end{array}$ & $\begin{array}{c}\text { віА } 12 \text { до } 18 \\
\text { місяців }\end{array}$ & $\begin{array}{l}\text { віА } 18 \text { Ао } \\
36 \text { місяців }\end{array}$ \\
\hline 1 & 2 & 3 & 4 & 5 & 6 \\
\hline $\begin{array}{c}\text { Аебіторська } \\
\text { заборгованість за } \\
\text { товари, роботи, } \\
\text { послуги }\end{array}$ & 940 & $\begin{array}{l}\text { Фіксують сальдо на } 31.12 .20 \text { р. за Ат } 36 \\
\text { "Розрахунки з покупцями та замовника- } \\
\text { ми». Показник цього рядка Аорівнює по- } \\
\text { казнику рядка } \mathbf{1 1 2 5} \text { графии } 4 \text { фрорми № } 1\end{array}$ & \multicolumn{3}{|c|}{ Аналітичні дані за рахунком 36} \\
\hline
\end{tabular}


Продовження таблиці 6.9

\begin{tabular}{|c|c|c|c|c|c|}
\hline \multirow[b]{2}{*}{$\begin{array}{c}\text { Найменування } \\
\text { показника }\end{array}$} & \multirow[b]{2}{*}{ КоА ряАКа } & \multirow[b]{2}{*}{ Усього на кінець року } & \multicolumn{3}{|c|}{ У т.ч. за строками непогашення } \\
\hline & & & \begin{tabular}{|c|} 
Ао 12 \\
місяців
\end{tabular} & $\begin{array}{c}\text { віА } 12 \\
\text { Ао } 18 \text { місяців }\end{array}$ & $\begin{array}{l}\text { вї } 18 \text { Ао } \\
36 \text { місяців }\end{array}$ \\
\hline 1 & 2 & 3 & 4 & 5 & 6 \\
\hline $\begin{array}{c}\text { Інша поточна Аебі- } \\
\text { торська заборгова- } \\
\text { ність }\end{array}$ & 950 & $\begin{array}{l}\text { ВіАображають сальдо на } 31.12 .20 \text { р. } \\
\text { за Ат } 37 \text { "Розрахунки } 3 \text { різними Аебі- } \\
\text { торами". ВіАповіАно Ао п. } 4 \text { П(С)БО } 10 \\
\text { "Аебіторська заборгованість": "Поточна } \\
\text { Аебіторська заборгованість - сума Ае- } \\
\text { біторської заборгованості, що виникає } \\
\text { в ході нормамьного операційного циклу } \\
\text { або буде погашена протягом АванаАцяти } \\
\text { місяців з Аати бамансу". Якщо Аебітор- } \\
\text { ська заборгованість значиться за інши- } \\
\text { ми рахунками, то їх показники також вно- } \\
\text { сять Ао ряАка } 950 \text { (наприклаА, Ат 685) }\end{array}$ & Аналітич & нні дані за раху & нком 37 \\
\hline \multicolumn{6}{|c|}{ 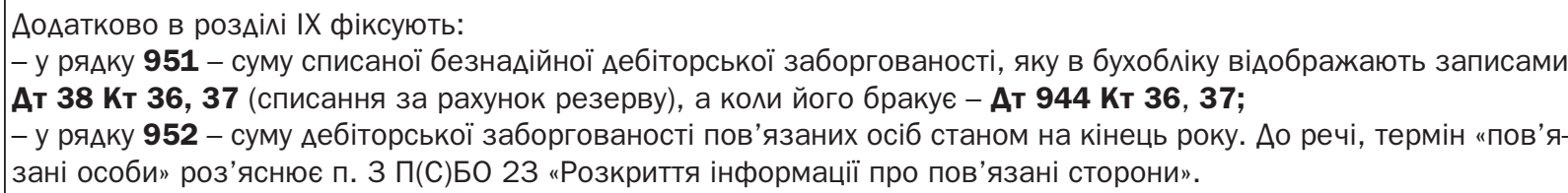 } \\
\hline
\end{tabular}

Ажерело: [10-11].

Таблиця 6.10

Методика заповнення розАіку X "Нестачі та втрати віА псування цінностей" приміток Ао річної фінансової звітності

\begin{tabular}{|c|c|c|}
\hline Найменування показника & $\begin{array}{c}\text { КоА } \\
\text { ряАКа }\end{array}$ & Сума \\
\hline $\begin{array}{l}\text { Виявлено (списано) за рік нестач } \\
\text { і втрат }\end{array}$ & 960 & 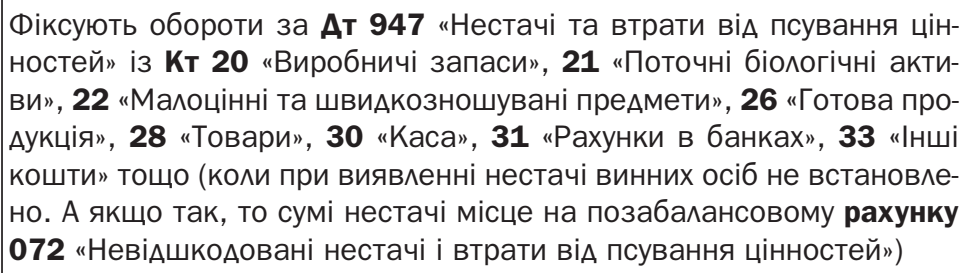 \\
\hline $\begin{array}{l}\text { Визнано заборгованістю винних } \\
\text { осіб у звітному році }\end{array}$ & 970 & $\begin{array}{l}\text { Сюди потрапляють обороти за Ат } \mathbf{3 7 5} \text { Кт } \mathbf{7 1 6} \text { "ВіАшкодування } \\
\text { раніше списаних активіВ" }\end{array}$ \\
\hline $\begin{array}{c}\text { Сума нестач і втрат, остаточне } \\
\text { рішення щодо винних за якими на } \\
\text { кінець не прийнято (позабалансо- } \\
\text { вий рахунок 072) }\end{array}$ & 980 & $\begin{array}{l}\text { Сюди переносять суму, що значиться на } 31.12 .20 \text { р. на позаба- } \\
\text { ^ансовому рахунку } \mathbf{0 7 2}\end{array}$ \\
\hline
\end{tabular}

Ажерело: [10-11].

Таблиця 6.11

Методика заповнення розАілу XI "БуАівельні контракти" приміток Ао річної фінансової звітності (цю таблицю заповнюють піАприємства, що виконують піАряАні буАівельні роботи)

\begin{tabular}{|c|c|c|c|}
\hline Найменування показника & $\begin{array}{c}\text { КоА } \\
\text { рялка }\end{array}$ & Сума \\
\hline $\mathbf{1}$ & $\mathbf{2}$ & $\mathbf{3}$ \\
\hline $\begin{array}{c}\text { АохіА за будівельними } \\
\text { контрактами за звітний рік }\end{array}$ & 1110 & $\begin{array}{l}\text { Аналітичні Аані щодо оборотів за Кт 703 “АохіА віА реалізації робіт, послуг” } \\
\text { (сума визнаного Аоходу за будівельними контрактами без урахування ПАВ). } \\
\text { Тобто це річні обороти за Ат 238 “Завершені етапи за незакінченими буді- } \\
\text { вельними контрактами" у кореспонденції з Кт 239 "Проміжні рахунки" }\end{array}$ \\
\hline
\end{tabular}


Продовження таблиці 6.11

\begin{tabular}{|c|c|c|}
\hline Найменування показника & $\begin{array}{l}\text { КоА } \\
\text { ряАКа }\end{array}$ & Сума \\
\hline 1 & 2 & 3 \\
\hline \multicolumn{3}{|l|}{$\begin{array}{l}\text { Заборгованість на кінець } \\
\text { звітного року: }\end{array}$} \\
\hline валова замовників & 1120 & $\begin{array}{l}\text { Якщо у вас сума проміжних рахунків збігається із сумою визнаного Аоходу } \\
\text { (без урахування ПАВ), то цей рядок Аля вас неактуальний - його прокреслю- } \\
\text { ють. Інакше сліА знати, що згіАно з п. } 2 \text { П(С)БО } 18 \text { "Будівельні контракти": } \\
\text { "Валова заборгованість замовників щодо робіт за будівельним контрактом } \\
\text { - сума перевищення витрат підрядника й визнаного ним прибутку (за вира- } \\
\text { хуванням визнаних збитків) наА сумою проміжних рахунків (без непрямих } \\
\text { податків) на дату балансу з початку виконання будівельного контракту". } \\
\text { Якщо у вас вона є, віАображають різницю між сумою витрат разом із при- } \\
\text { бутком і сумою проміжних рахунків. У бухобліку на різницю роблять запис } \\
\text { "сторно" Ат } 36 \text { "Розрахунки з покупцями та замовниками" Кт } 239\end{array}$ \\
\hline валова замовникам & 1130 & $\begin{array}{l}\text { Знову ж таки, якщо сума визнаного Аоходу віАповіАає сумі, виставленій у } \\
\text { проміжних рахунках, рялок прокреслюють. А якщо ні, зауважте - п. } 2 \text { П(С) } \\
\text { БО } 18 \text { установлює: “Валова заборгованість замовників щодо робіт за буді- } \\
\text { вельним контрактом - сума перевищення витрат піАрядника й визнаного } \\
\text { ним прибутку (за вирахуванням визнаних збитків) наА сумою проміжних } \\
\text { рахунків (без непрямих податків) на Аату балансу з початку виконання буді- } \\
\text { вельного контракту". Сума такого перевищення й потрапляє Ао цього ряА- } \\
\text { ка. А в бухобліку з'являється запис Ат } \mathbf{3 6} \text { Кт } 239\end{array}$ \\
\hline за авансами одержаними & 1140 & $\begin{array}{l}\text { Тут фіксують сальдо за Кт } \mathbf{6 8 1} \text { “Розрахунки за авансами одержаними” за } \\
\text { розрахунками із замовниками будівельних контрактів }\end{array}$ \\
\hline $\begin{array}{c}\text { Сума затриманих коштів на } \\
\text { кінець року }\end{array}$ & 1150 & 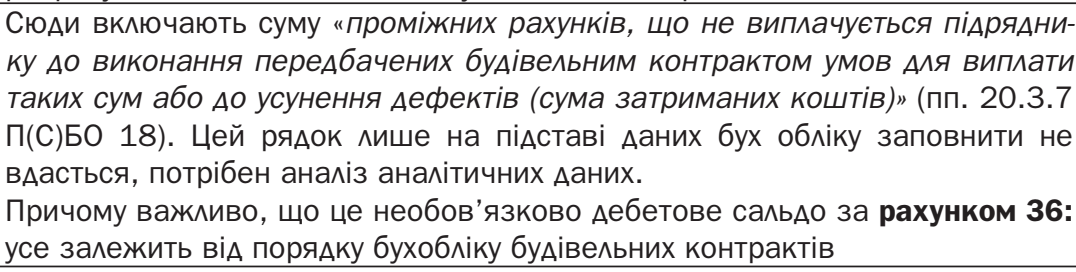 \\
\hline $\begin{array}{c}\text { Вартість виконаних субпі- } \\
\text { Арядниками робіт за неза- } \\
\text { вершеними будівельними } \\
\text { контрактами }\end{array}$ & 1160 & $\begin{array}{l}\text { Тут показують вартість робіт, виконаних субпіАряАником, яку впродовж } \\
\text { року було віАнесено Ао Ат } 23 \text { "Виробництво" за незавершеними на кінець } \\
\text { року будівельними контрактами. Отже, необхіАно проаналізувати Ат } 23 \text { й } \\
\text { обрати суми, що стосуються незавершених контрактів }\end{array}$ \\
\hline
\end{tabular}

Ажерело: [10-11].

Таблиця 6.12

\section{МетоАика заповнення розАіку XII "ПоАаток на прибуток" приміток} Ао річної фінансової звітності

\begin{tabular}{|c|c|c|}
\hline $\begin{array}{l}\text { Найменування } \\
\text { показника }\end{array}$ & \begin{tabular}{|c|} 
КоА \\
ряАКа
\end{tabular} & Сума \\
\hline 1 & 2 & 3 \\
\hline $\begin{array}{l}\text { Поточний податок на } \\
\text { прибуток }\end{array}$ & 1210 & 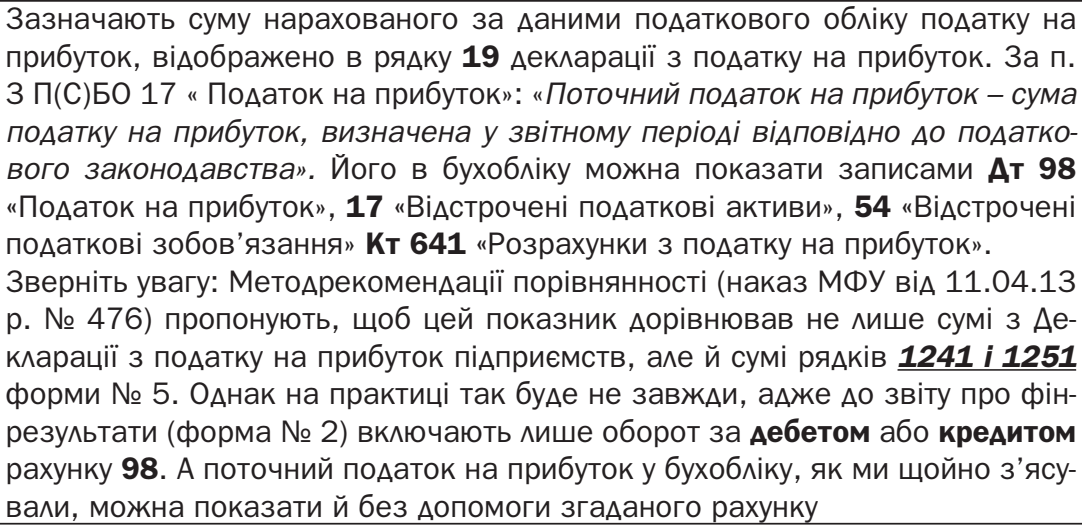 \\
\hline
\end{tabular}


Продовження таблиці 6.12

\begin{tabular}{|c|c|c|}
\hline $\begin{array}{c}\text { Найменування } \\
\text { показника }\end{array}$ & $\begin{array}{c}\text { КоА } \\
\text { ряАКа }\end{array}$ & Сума \\
\hline 1 & 2 & 3 \\
\hline $\begin{array}{c}\text { ВіАстрочені податкові } \\
\text { активи: } \\
\text { - на початок звітного року }\end{array}$ & 1220 & $\begin{array}{l}\text { Записують суму віАстрочених податкових активів }(В П А) \text { на початок звіт- } \\
\text { ного року, зафріксовану в рядку } 1045 \text { графи } 3 \text { форми № } 1 \text {. Це сальдо на } \\
\text { 31.12.19 р. за Ат } \mathbf{1 7}\end{array}$ \\
\hline - на кінець звітного року & 1225 & $\begin{array}{l}\text { Фіксують суму ВПА, обчислену на кінець року, що віАповіАає ряАку } 1045 \\
\text { графи } 4 \text { форми № 1. Це сальАо на } 31.12 .20 \text { р. за Ат 17. Показник наз- } \\
\text { ваного рядка Аорівнює: ряАоК } 1220 \pm \text { ряАок } 1242 \pm \text { ряАок } 1252\end{array}$ \\
\hline $\begin{array}{l}\text { ВіАстрочені податкові } \\
\text { зобов'язання: } \\
\text { - на початок звітного року }\end{array}$ & 1230 & $\begin{array}{l}\text { ВіАображають суму віАстрочених податкових зобов’язань (ВП3), що } \\
\text { віАповіАає значенню рялка } 1500 \text { графи } 3 \text { форми № } 1 \text {. Це сальдо на } \\
31.12 .19 \text { р. за Кт } \mathbf{5 4}\end{array}$ \\
\hline - на кінець звітного року & 1235 & 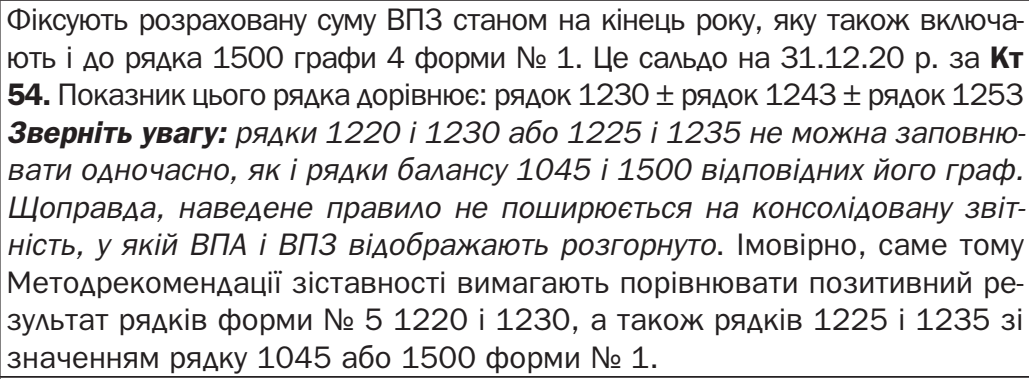 \\
\hline $\begin{array}{l}\text { Включено Ао Звіту про } \\
\text { фінансові результати - } \\
\text { усього }\end{array}$ & 1240 & 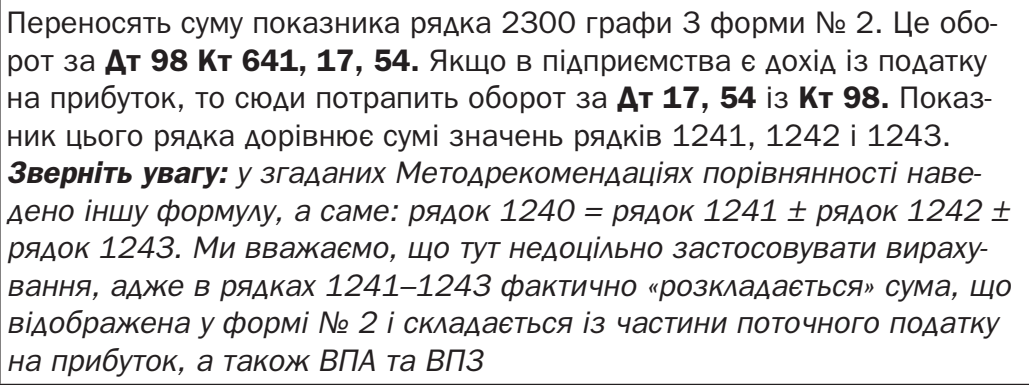 \\
\hline $\begin{array}{c}\text { у тому числі: } \\
\text { - поточний податок } \\
\text { на прибуток }\end{array}$ & 1241 & $\begin{array}{l}\text { іАображають ту частину суми поточного податку на прибуток, } \\
\text { оО значиться в склаАі витрат із податку на прибуток у формі № 2. Отже, } \\
\text { е сума, списана в Ат } 98 \text { із Кт } 641\end{array}$ \\
\hline $\begin{array}{c}\text { - зменшення (збільшення) } \\
\text { віАстрочених податкових } \\
\text { активів } \\
\end{array}$ & 1242 & $\begin{array}{l}\text { Фіксують суму, проведену в бухобліку записом Ат } \mathbf{9 8} \text { Кт 17. За наявно- } \\
\text { сті доходу з податку на прибуток у Ааному рядку опиниться сума, запи- } \\
\text { сана за Ат } \mathbf{1 7} \text { Кт } \mathbf{9 8}\end{array}$ \\
\hline $\begin{array}{c}\text { - збільшення (зменшення) } \\
\text { віАстрочених податкових } \\
\text { зобов'язань } \\
\end{array}$ & 1243 & $\begin{array}{l}\text { Зазначають оборот за Ат } \mathbf{9 8} \text { Кт 54. Якщо в піАприємства АохіА із подат- } \\
\text { ку на прибуток, тут відображають оборот за Ат } \mathbf{5 4} \text { Кт } \mathbf{9 8}\end{array}$ \\
\hline $\begin{array}{c}\text { ВіАображено в склаАі } \\
\text { власного капіталу - } \\
\text { усього } \\
\end{array}$ & 1250 & \multirow{3}{*}{$\begin{array}{l}\text { На рядках 1250-1253 зупинимося окремо. У п. } 4 \text { П(С)БО } 17 \text { «Податок } \\
\text { на прибуток" сказано: поточний і віАстрочений податок на прибуток не } \\
\text { визнають витратами й не віАображають у звіті про фрінансові результа- } \\
\text { ти, якщо його нараховують у зв'язку з: } \\
\text { - Аооцінкою активів, яку показують як збільшення власного капіталу; } \\
\text { - об'єАнанням піАприємств шляхом придбання. Ао того ж у другому аб- } \\
\text { заці п. } 4.2 \text { П(С)БО } 17 \text { говориться: “Поточний податок на прибуток і віА- } \\
\text { строчений податок на прибуток визнаються змінами власного капіталу, } \\
\text { якщо податки виникають за операціями, відображеними на рахунках } \\
\text { власного капіталу. }\end{array}$} \\
\hline $\begin{array}{c}\text { - у тому числі: } \\
\text { - поточний податок } \\
\text { на прибуток }\end{array}$ & 1251 & \\
\hline $\begin{array}{c}\text { - зменшення (збільшення) } \\
\text { віАстрочених } \\
\text { податкових активів }\end{array}$ & 1252 & \\
\hline $\begin{array}{c}\text { - збільшення (зменшення) } \\
\text { віАстрочених податкових } \\
\text { зобов'язань }\end{array}$ & 1253 & 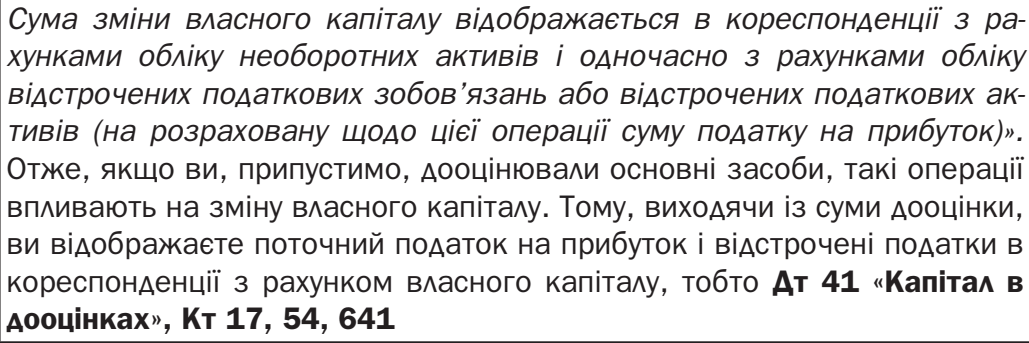 \\
\hline
\end{tabular}

Ажерело: [10-11]. 
Таблиця 6.13

МетоАика заповнення розАіму XIII "Використання амортизаційних віАрахувань" приміток Ао річної фінансової звітності

\begin{tabular}{|c|c|c|}
\hline $\begin{array}{c}\text { Найменування } \\
\text { показника }\end{array}$ & $\begin{array}{c}\text { KoА } \\
\text { ряАКа }\end{array}$ & Сума \\
\hline 1 & 2 & 3 \\
\hline $\begin{array}{l}\text { Нараховано за } \\
\text { звітний рік }\end{array}$ & 1300 & $\begin{array}{l}\text { Переносять суму значень рядків } 080 \text { (розділ I) і } 260 \text { (розАіл II) графи } 10 \text { і } 1430 \\
\text { (розді^ XIV графи 8) Приміток }\end{array}$ \\
\hline $\begin{array}{l}\text { Використано за } \\
\text { рік - усього }\end{array}$ & 1310 & 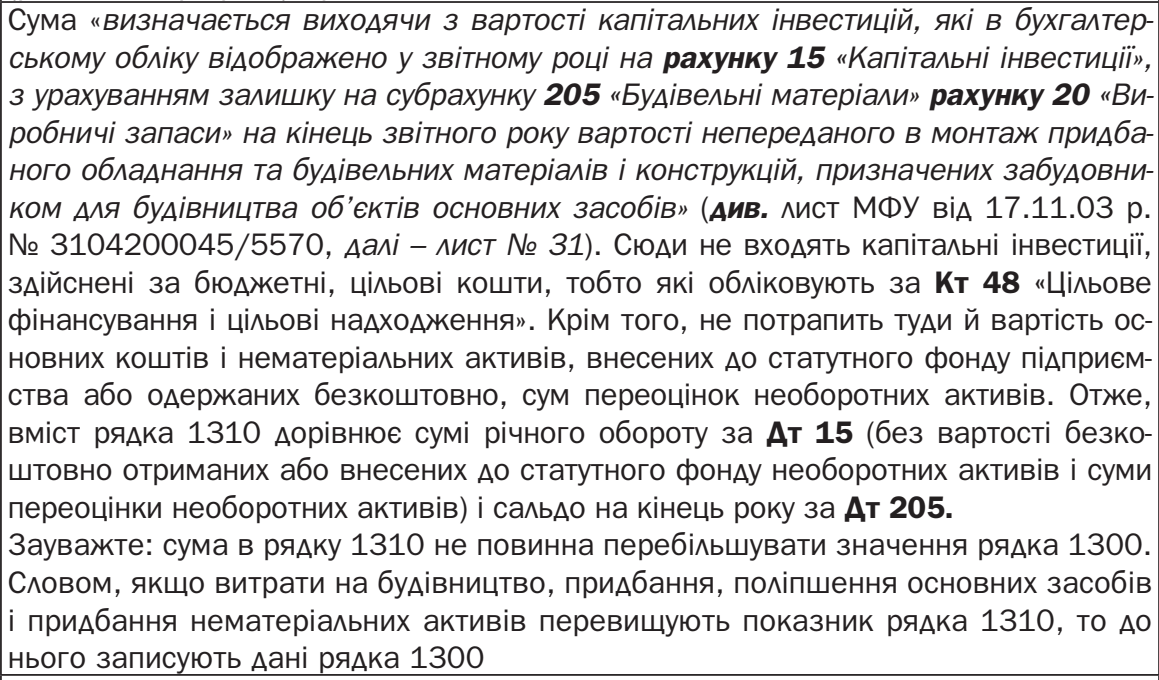 \\
\hline $\begin{array}{l}\text { у тому числі на: } \\
\text { - будівництво } \\
\text { об'єктів }\end{array}$ & 1311 & $\begin{array}{l}\text { Показник рядка Аорівнює: } \\
\text { - річному обороту за Ат } \mathbf{1 5 1} \text { “Капітальне будівництво”; } \\
\text { - сальдо за Ат } 205 \text { “Будівельні матеріали” у частині матеріалів Аля будівництва } \\
\text { об’єкта основних засобів }\end{array}$ \\
\hline \begin{tabular}{|l|}
- придбання (виго- \\
товлення) та поліп- \\
шення \\
засобів
\end{tabular} & 1312 & $\begin{array}{l}\text { Цей рялок віАповіАає: } \\
\text { - річному обороту за Ат } 152 \text { «Придбання (виготовлення) основних засобів»; } \\
\text { - сальдо за Ат } 205 \text { «Будівельні матеріали», а також за Ат } 207 \text { "Запасні части- } \\
\text { ни" стосовно матеріалів (запчастин), призначених Аля виготовлення або ремонту } \\
\text { об'єктів основних засобів }\end{array}$ \\
\hline $\begin{array}{l}\text { - із них машин та } \\
\text { облаАнання }\end{array}$ & 1313 & $\begin{array}{l}\text { Аналітична вибірка з оборотів за Ат } 152 \text { тих витрат, які сформували показник } \\
\text { субрахунку } 104 \text { «Машини та облаАнання" }\end{array}$ \\
\hline $\begin{array}{|lr|}- \text { придбання (ство- } \\
\text { рення) } \\
\text { альнитат активів } \\
\end{array}$ & 1314 & $\begin{array}{l}\text { Показник рядка Аорівнює річним оборотам за Ат } 154 \text { «Придбання (створення) } \\
\text { нематеріальних активів" }\end{array}$ \\
\hline \multirow[t]{3}{*}{$\begin{array}{l}\text { - погашення одер- } \\
\text { жаних на капіталь- } \\
\text { ні інвестиції позик }\end{array}$} & 1315 & 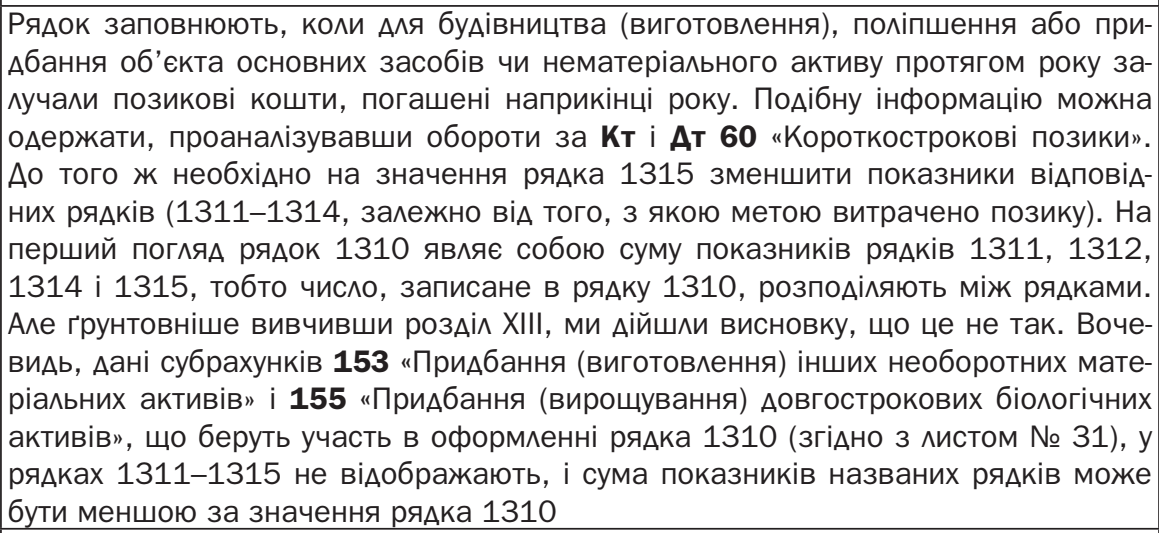 \\
\hline & 1316 & \multirow[b]{2}{*}{ 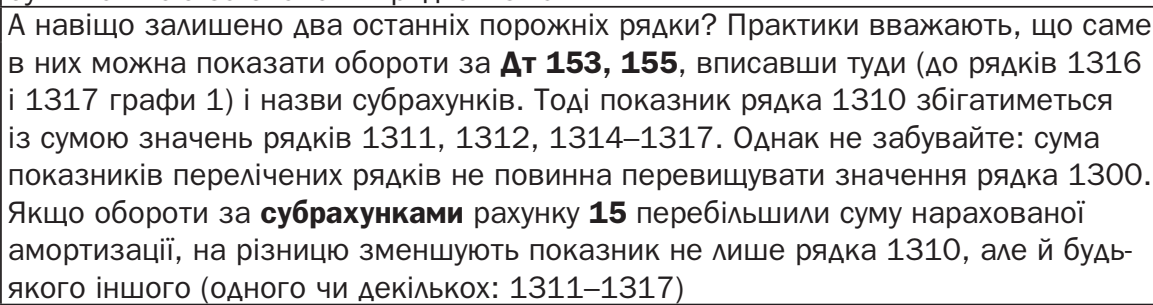 } \\
\hline & 1317 & \\
\hline
\end{tabular}

Ажерело: [10-11]. 
Методика заповнення розАіку XIV "Біологічні активи" приміток Ао річної фінансової звітності

\begin{tabular}{|c|c|c|c|c|}
\hline \multicolumn{3}{|c|}{ Назва графи } & \multirow[t]{2}{*}{\begin{tabular}{|c|} 
№ \\
графи
\end{tabular}} & Пояснення Ао заповнення графи \\
\hline \multirow[t]{2}{*}{$\begin{array}{l}\text { Облікову- } \\
\text { Ються за } \\
\text { первісною } \\
\text { вартістю }\end{array}$} & \multirow[t]{2}{*}{$\begin{array}{c}\text { зали- } \\
\text { шок на } \\
\text { поча } \\
\text { ток } \\
\text { року }\end{array}$} & $\begin{array}{l}\text { первісна } \\
\text { вартість }\end{array}$ & & $\begin{array}{l}\text { У рядках 1410-1415 відображають вартість активів, які обліковували за } \\
\text { первинною вартістю за Ат } \mathbf{1 6 2} \text { “Аовгострокові біологічні активи рослинни- } \\
\text { цтва, які оцінені за первісною вартістю", } \mathbf{1 6 4} \text { "Аовгострокові біологічні ак- } \\
\text { тиви тваринництва, які оцінені за первісною вартістю", } \mathbf{1 6 6} \text { "Незрілі Аовго- } \\
\text { строкові біологічні активи, які оцінюються за первісною вартістю". } \\
\text { Тобто тут показують їх первинну вартість станом на } 31.12 .19 \text { р. А в ряА- } \\
\text { ках } 1420-1424 \text { фіксують вартість поточних біологічних активів, що на } \\
\text { 31.12.19 р. значиться за Ат } \mathbf{2 1 3} \text { "Поточні біологічні активи тваринни- } \\
\text { цтва, які оцінені за первісною вартістю" }\end{array}$ \\
\hline & & $\begin{array}{c}\text { накопиче- } \\
\text { на амор- } \\
\text { тизація } \\
\end{array}$ & 4 & $\begin{array}{l}\text { Потрапляє сальдо на } 31.12 .19 \text { р. за Кт 134, тобто амортизація, нарахо- } \\
\text { вана на вартість Аовгострокових біологічних активів, які обліковували за } \\
\text { первинною вартістю }\end{array}$ \\
\hline $\begin{array}{l}\text { Облікову- } \\
\text { ються за } \\
\text { первісною } \\
\text { вартістю }\end{array}$ & \multicolumn{2}{|c|}{ наАійшло за рік } & 5 & 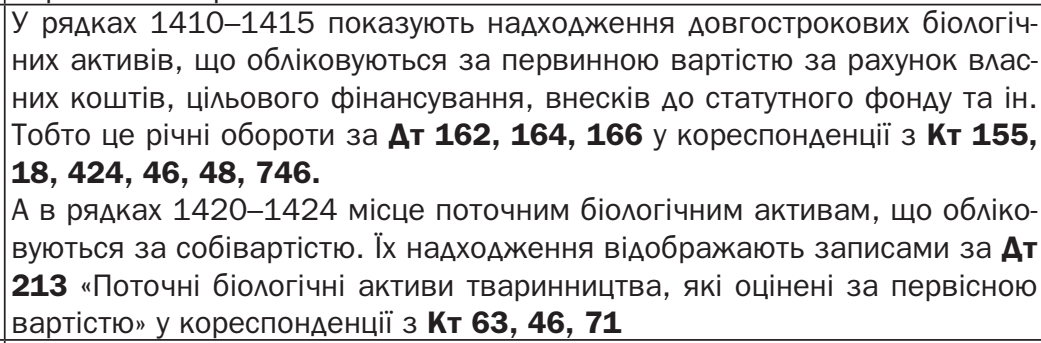 \\
\hline \multirow{7}{*}{$\begin{array}{l}\text { Облікову- } \\
\text { ються за } \\
\text { первісною } \\
\text { вартістю }\end{array}$} & \multirow[t]{2}{*}{$\begin{array}{l}\text { вибуло } \\
\text { за рік }\end{array}$} & $\begin{array}{l}\text { первісна } \\
\text { вартість }\end{array}$ & 6 & $\begin{array}{l}\text { Показують первинну вартість вибулих (з різних причин) біологічних активів. Аля } \\
\text { Аовгострокових активів це обороти за Ат 901, 947, 976, } 977 \text { у кореспонденції } \\
\text { з Кт 162, 164, } 166 \text { (збільшеним на суму нарахованої амортизації). } \\
\text { А вибуття поточних біологічних активів віАображають за Ат 15, } 901, \\
\mathbf{9 4 7 , 9 9 ~ і ~ К т ~} 213\end{array}$ \\
\hline & & $\begin{array}{l}\text { накопиче- } \\
\text { на амор- } \\
\text { тизація }\end{array}$ & 7 & $\begin{array}{l}\text { Фіксують амортизацію, нараховану на вибулі довгострокові біологічні ак- } \\
\text { тиви, що обліковували за первинною вартістю. } \\
\text { Це обороти за Ат } 134 \text { у кореспонденції } 3 \text { Кт 162, 164, } 166\end{array}$ \\
\hline & \multicolumn{2}{|c|}{$\begin{array}{l}\text { нараховано амор- } \\
\text { тизації за рік }\end{array}$} & 8 & $\begin{array}{l}\text { Записують суму амортизації довгострокових біологічних активів, нарахо- } \\
\text { вану за рік, яку в бухобліку відображають за Ат } 23 \text { і Кт } 134\end{array}$ \\
\hline & \multicolumn{2}{|c|}{\begin{tabular}{|c|} 
Втрати віА змен- \\
шення корисності
\end{tabular}} & 9 & $\begin{array}{l}\text { Фіксують обороти за Ат 972, } 977 \text { і Кт } 134 \text { (при зменшенні корисності Аов- } \\
\text { гострокових біологічних активів, що обліковуються за первинною вартістю) }\end{array}$ \\
\hline & \multicolumn{2}{|c|}{\begin{tabular}{|c|} 
ВигоАИ віА віАнов- \\
лення корисності \\
\end{tabular}} & 10 & $\begin{array}{l}\text { ВіАновлення корисності Аовгострокових біологічних активів віАобража- } \\
\text { ють за Ат } 134 \text { і Кт 746. Саме ці обороти потрапляють до цього ряАка }\end{array}$ \\
\hline & \multirow{2}{*}{$\begin{array}{l}\text { зали- } \\
\text { шок на } \\
\text { кінець } \\
\text { року }\end{array}$} & \begin{tabular}{|c|} 
первісна \\
вартість
\end{tabular} & 11 & Відображають сальдо на 31.12 .20 р. за Ат 162, 164, 166, 213 \\
\hline & & \begin{tabular}{|c|} 
накопиче- \\
на аморти- \\
зація
\end{tabular} & 12 & Записують сальдо на 31.12 .20 р. за Ат 134 \\
\hline \multirow{5}{*}{$\begin{array}{l}\text { Обліко- } \\
\text { вуються } \\
\text { за спра- } \\
\text { веАливою } \\
\text { вартістю }\end{array}$} & \multicolumn{2}{|c|}{$\begin{array}{c}\text { залишок } \\
\text { на початок року }\end{array}$} & 13 & $\begin{array}{l}\text { Фіксують вартість активів (сальдо на } 31.12 .19 \text { р.), які обліковували за } \\
\text { справеАливою вартістю за Ат } 161 \text { "Аовгострокові біологічні активи рос- } \\
\text { линництва, які оцінені за справеАливою вартістю", } 163 \text { "Аовгострокові } \\
\text { біологічні активи тваринництва, які оцінені за справеАливою вартістю,, } \\
\mathbf{1 6 5} \text { "Незрілі Аовгострокові біологічні активи, які оцінюються за спра- } \\
\text { веАливою вартістю", } 211 \text { "Поточні біологічні активи рослинництва, які } \\
\text { оцінені за справеАливою вартістю", } 212 \text { "Поточні біологічні активи тва- } \\
\text { ринництва, оцінені за справедливою вартістю" }\end{array}$ \\
\hline & \multicolumn{2}{|c|}{ налійшло за рік } & 14 & $\begin{array}{l}\text { Вносять річні обороти за Ат 161, 163, } 165 \text { і Кт 155, 162, 164, 18, } \\
424,46,48 \text {, а також Ат 211, } 212 \text { і Кт 23, 46, 63, 71 }\end{array}$ \\
\hline & \multicolumn{2}{|c|}{$\begin{array}{l}\text { зміни вартості } \\
\text { за рік }\end{array}$} & 15 & $\begin{array}{l}\text { Показують алгебраїчну суму оборотів за Ат 161, 163, 165, 211, } 212 \text { у } \\
\text { кореспонденції з Кт } 710 \text { і за Ат } 940 \text { у кореспонденції з Кт 161, 163, } \\
\text { 165, 211, } 212\end{array}$ \\
\hline & \multicolumn{2}{|c|}{ вибуло за рік } & 16 & Фіксують обороти за Ат 901, 947, 976, 99 і Кт 161, 163, 165, 211, 212 \\
\hline & \multicolumn{2}{|c|}{$\begin{array}{l}\text { залишок на } \\
\text { кінець року }\end{array}$} & 17 & Зазначають сальдо на 31.12 .20 р. за Ат 161, 163, 165, 211, 212 \\
\hline
\end{tabular}


Підприємства, Аля яких обов'язковість оприлюднення річної фінансової звітності не передбачена законодавством, крім інформації, зазначеної у формі № 5, наводять інформацію, розкриття якої передбачено положеннями (стандартами) бухгалтерського обліку:

- 1 "Загальні вимоги до фінансової звітності" - пункт 6 розділу IV;

- 6 "Виправлення помилок і зміни у фінансових звітах" - пункти 20, 21, 23;

- 7 "Основні засоби" - піАпункт 36.1 пункту 36;

- 8 «Нематеріальні активи" - піАпункт 36.1 пункту 36;

- 10 «Аебіторська заборгованість" - піАпункт 13.1 пункту 13;

ПіАприємства, Аля яких обов'язковість оприяюАнення річної фінансової звітності та консолідованої звітності встановлена законодавством, крім інформації, зазначеної у формі № 5, наводять всю іншу інформацію, розкриття якої переАбачено положеннями (стандартами) бухгалтерського обліку.

Інформацію, крім інформації, зазначеної у формі № 5, підприємства наводять у самостійно обраному вигляді (письмове пояснення, таблиця, графрік тощо).

У такому самому порядку може наводитися інша інформація, яка керівництвом підприємства визнана суттєвою і дає бімьш повну та об'єктивну картину про фінансове становище і результати Аіяльності піАприємства.

\section{КОНТРОАЬНІ ПИТАННЯ:}

1. Аайте визначення приміток Ао фінансової звітності.

2. Які вимоги висуваються П(С)БО Ао приміток Ао фінансової звітності?

3. Вкажіть складові приміток до фінансової звітності.

4. Яку інформацію акціонерні товариства зобов'язані розкривати у примітках до фінансової звітності?

5. За якими показниками існує зв'язок між примітками та балансом?

6. За якими показниками існує зв'язок між примітками та звітом про фінансові результати?

7. За якими показниками існує зв'язок між примітками та звітом про рух грошових коштів?

8. За якими показниками існує зв'язок між примітками та звітом про власний капітал?

9. Які групи інформації розкриваються у примітках?

10. Розкрийте сутність та структуру облікової політики піАприємства.

11. Назвіть елементи облікової політики підприємства.

12. Опишіть порядок зміни облікової політики піАприємства.

13. Розкрийте сутність поняття "облікова оцінка".

14. Опишіть порядок зміни облікових оцінок.

15. Розкрийте методику складання кожного з розАілів приміток.

16. Аайте визначення подій після Аати балансу.

17. Яка інформація про події після Аати балансу наводиться у звітності?

18. Яку інформацію, крім зазначеної у формі № 5, розкривають піАприємства, Аля яких обов'язковість оприлюднення річної фінансової звітності не передбачена законодавством? 


\section{ВИПРАВАЕННЯ ПОМИАОК I ЗМIHИ У ФІНАНСОВИХ ЗВІТАХ}

\section{1. Правияа виправ^ення поми^ок у фінансовій звітності піАприємств}

ПіА час складання річної фрінансової звітності високою є ймовірність того, що бухгалтер виявить помилки, Аопущені раніше при складанні звітності, яка вже була надана ії користувачам (органам статистики та АФСУ, власникам, акціонерам, кредиторам та ін.). Усі помилки можна розподілити на Аекілька груп, Аля кожної з яких є своя методика виправлення.

\section{Показник прибутку у фінансовій звітності.}

Отримання прибутку - це головна мета Аіяльності суб'єкта господарювання, на яку спрямована більша частина його господарських операцій. Показник прибутку (збитку) за звітний період формується за Ааними звіту про фінансові результати як різниця між сумою АохоАів та сумою витрат піАприємства за цей період (рядки звіту 2350, 2355).

Своєю чергою, прибуток як Ажерело активів піАприємства фіксується в пасиві балансу в сумі, накопиченій на початок та на кінець звітного періоду (рялок 1420, графи 3 і 4), а різниця між цими показниками балансу також віАображає результат роботи піАприємства за звітний періоА. Проте не тільки прибуток чи збиток звітного року впливають на цей показник балансу, а й інші показники. НаприклаА, якщо нерозпоАілений прибуток, що його має піАприємство, використовувався протягом звітного періоАу (наприклаА, на виплату АивіАенАів засновникам), різниця між графами 3 і 4 рялка 1420 балансу не збігатиметься зі значенням рядків 2350 або 2355 звіту про фінансові результати [2].

Усі помилки, Аопущені у бухгалтерському обліку і, як насліАок, - у фінансовій звітності, можна розпоАілити на Аві групи:

1) які не вплинули на суму доходів і витрат за попередні звітні періоди;

2) які вплинули на суму доходів і витрат за попередні періоди і внасліАок цього на суму прибутку за ці періоди, яка сформувала показник нерозподіленого прибутку в балансі на початок звітного року [2].

Виправлення помилок оформляють за Аопомогою бухгалтерської довіАки, в якій треба описати суть помилки, навести помилкові бухгалтерські провеАення, які були зроблені в минулих періолах, зазначити правильні проведення, які сліА було віАобразити в обліку. ВіАтак за даними цих проведень коригують віАповіАні статті фінансової звітності згіАно з п. 4, $\underline{\text { п. } 5}$ П(С)БО 6.

\section{Помияки, що не впливають на нерозподілений прибуток}

Переважно такі помилки полягають у тому, що в попередніх звітних періодах були неправильно класифіковані окремі статті балансу, при цьому на суму доходів та витрат це не вплинуло. Виправляють такі помилки шляхом коригування віАповіАних статей балансу без коригування сальдо нерозпоАіленого прибутку на початок звітного року [2].

ПриклаА 1. ПіА час склалання балансу за 2016 р. виявилося, що у фінансовій звітності за 2015 рік припустилися помилки: частина Аовгострокової заборгованості помилково не була переведена до складу поточних зобов'язань. Сума помилки - 24000 грн.

Суть помилки ось у чому. У 2015 р. піАприємство отримало Аовгостроковий креАит банку в сумі 120000 грн терміном на 5 років, зі щорічними виплатами в сумі по 24000 грн. У 2015 р. 
і 2016 р. було сплачено по 24000 грн, на кінець 2016 р. залишилося виплатити 72000 грн, із них 24000 грн - протягом 2017 р., а решту 48000 грн - після 31.12.2017р. У балансі за 2015 р. уся заборгованість за кредитом помилково була віАображена в рялку 1510 "Аовгострокові кредити банків" - на кінець 2015 р. в сумі $120000-24000=96000$ грн.

При складанні балансу за 2016 р. у рядку 1610 на початок і на кінець 2016 р. (у графах 3 і 4) сліА віАобразити одну і ту саму суму - 24000 грн, тому що протягом 365 Анів після 31.12.2015 р. і після 31.12.2016 р. саме ця сума щорічного платежу піАлягає сплаті. Станом на 31.12.2015 р. Аовгострокова частина заборгованості за кредитом становила: $120000-24000-24000=72000$ грн, а на 31.12.2016 р. Аовгострокова частина заборгованості зменшиться ще на 24000 грн (які сліА буде сплатити в короткостроковій перспективі - ло 31.12.2017р.) і становитиме 48000 грн. Таким чином, у рялку 1510 у графі 3 треба відобразити 72000 грн, а в графі 4 - віАповідно 48000 грн.

У приклаАі 1 піАприємство коригувало тільки статті пасиву балансу, тож загальний піАсумок (валюта) балансу не змінився. Аналогічні помилки можливі і при неправильній класифікації статей активу балансу: наприклаА Аовгострокової та короткострокової Аебіторської заборгованості, коштів (Аовгостроковий Аепозит був відображений у рядку 1165 «Гроші та їх еквіваленти" замість рядка 1090 «нші необоротні активи») тощо.

Можливе також одночасне коригування статей активу і пасиву, що спричинить зміну піАсумку балансу. НаприклаА, піАприємство помилково не віАобразило в балансі зарахування заборгованостей з одним із постачальників, який за іншим Аоговором $є$ покупцем. Аля виправлення помилки на однакову суму зарахування заборгованостей зменшуються стаття балансу 1125 "Аебіторська заборгованість за продукцію, товари, роботи, послуги" та стаття балансу 1615 «Поточна кредиторська заборгованість за товари, роботи, послуги».

\section{Помияки, що впливають на нерозподілений прибуток}

Аруга група помилок, що вплинули на нерозподілений прибуток, є більш численною та різноманітною. Помилкове віАображення господарської операції, що призводить Ао виникнення витрат або доходів, обов'язково потягне за собою і спотворення показника нерозпоАіленого прибутку, який сформується за підсумками того періоду, в якому припустилися помилки. Усі ці помилки можна розпоАілити ще на Аві піАгрупи:

А) уся сума помилки впливає тільки на показник нерозподіленого прибутку на кінець періоду, в якому припустилися такої помилки;

Б) сума помилки частково впливає на показник нерозподіленого прибутку, а частково на вартість активів піАприємства на кінець періоду, в якому припустилися помилки [2].

ПриклаА 2. ПіА час піАготовки Ао склаАання фрінансової звітності за 2016 р. (річної інвентаризації) виявили помилку за 2015 р.: не були списані використані канцтовари на суму 26000 грн. Списання канцтоварів мало збільшити суму аАміністративних витрат і зменшити вартість залишку канцтоварів на складі: потрібне проведення А-т 92 К-т 209. Аалі, ця сума вплинула на фінансовий результат 2015 р.: А-т 791 K-т 92, а при реформації балансу (вивеАенні сальдо нерозподіленого прибутку на кінець року) треба було зменшити суму нерозподіменого прибутку: А-т 442 K-т 791. Отже, після виправлення помилки сліА зменшити показник нерозподіленого прибутку в балансі (стаття 1420) на 26000 грн та значення статті балансу "Запаси" (у фінзвітності за 2016 р. це значення графи 3 рядків 1100 і 1420 балансу).

У прикладі 2 показано методику виправлення помилки у віАображенні суми витрат, яка в повній сумі вплинула на суму нерозпоАіленого прибутку. Так само виправляється помилка, що призвела Ао спотворення суми АохоАів.

ПрикмаА 3. У 2015 р. помилково не віАобразияи АохіА віА оприбуткування ТМЦ (піА час інвентаризації виявили наАлишки виробничої сировини) на суму 16000 грн. Аля виправлення помилки треба збільшити вартість запасів (стаття балансу 1100) й одночасно збільшити суму інших операційних доходів, що призведе до збільшення показника нерозподіленого прибутку на кінець 2015 р. ПіА час складання балансу за 2016 р. сліА збільшити значення графри 3 рядків 1100 і 1420 на суму 16000 грн на початок 2016 р. 
Аруга підгрупа помимок - ті, що вплинули і на показник нерозподіленого прибутку на кінець року, в якому зроблено помилку, і на вартість активів піАприємства. СюАи вхолять помилки при визначенні собівартості готової продукції, бо собівартість продукції включається Ао склаАу витрат звітного періоду не тоАі, коли були використані активи на виробництво продукції, а коли ця продукція була продана (п. 7, п. 11 П(С)БО 16), а також помилки в обліку капітальних інвестицій, виявлені вже після введення в експлуатацію необоротних активів, Аля створення яких зроблено такі інвестиції [2].

ПриклаА 4. У 2015 р. помилково завищили амортизацію ОЗ виробничого призначення на суму 100000 грн. Ця сума була включена до собівартості продукції, виготовленої в 2015 р. На кінець 2015 р. було продано 75\% такої продукції, віАповіАно, 25\% ще зберігається на склаАі станом на кінець 2015 р. Отже, на суму у розмірі 75\% віА суми наАміру нарахованої амортизації (75000 грн) сліА зменшити собівартість реалізованої продукції, що призведе Ао збільшення показника нерозподіленого прибутку (значення графи 3 рялка 1420 у фінзвітності за 2016 р.), а на суму у розмірі 25\% віА суми надміру нарахованої амортизації (25000 грн) зменшити вартість залишку готової продукції на скиаді (значення графи 3 рядка 1100 у фінзвітності за 2016 р. ). ОАночасно треба відкоригувати суму накопиченого зносу за рахунком 13 (значення грасри 3 рялка 1012 у фінзвітності за 2016 р. ) і суму залишкової (балансової) вартості основних засобів підприємства (значення графи 3 рялка 1010 у фінзвітності за 2016 р. ).

У таблиці 7.1 показано проведення, які потрібні Аля виправлення помилок, розгяянутих у приклаАах 1-4. ПровеАення роблять на 01.01.2016 р. Аеякі з них не переАбачені Інструкцією №291, наприклаА, у ній немає кореспонденції рахунка 44 з рахунком 20. Проте виправлення помилок - це особливий випадок, а піАприємство може застосовувати кореспонденцію рахунків, не передбачену Інструкцією №291, виходячи з норм П(С)БО, бо в цьому разі при застосуванні кореспонденції рахунків із передбачених Інструкцією №291 піАприємство не зможе виконати вимоги П(С)БО 6. Крім того, при виправленні помилок шляхом коригування сальдо нерозподіленого прибутку (різноманіття яких важко оцінити) рахунок 44 має кореспондувати практично зі всіма активними та пасивними рахунками, тим часом як Інструкція №291 містить мише "штатні" кореспонденції щодо операцій, пов'язаних із формуванням та використанням прибутку.

Таблиця 7.1

Коригуючі провеАення А^я виправлення помилоК

\begin{tabular}{|c|c|c|c|c|}
\hline \multirow{2}{*}{$\begin{array}{l}\text { При- } \\
\text { кмаA }\end{array}$} & \multirow[t]{2}{*}{ Господарська операція } & \multicolumn{2}{|c|}{$\begin{array}{c}\text { Бухгалтерське } \\
\text { провеАення }\end{array}$} & \multirow{2}{*}{$\begin{array}{c}\text { Сума, } \\
\text { грн }\end{array}$} \\
\hline & & A-T & K-T & \\
\hline 1 & $\begin{array}{l}\text { Переведення частини Аовгострокової заборгованості за кредитом } \\
\text { перед банком у короткострокову }\end{array}$ & 501 & 611 & 24000 \\
\hline 2 & $\begin{array}{l}\text { Списання канцтоварів за рахунок сальАо нерозподіленого прибутку } \\
\text { на початок } 2016 \text { р. }\end{array}$ & 442 & 209 & 26000 \\
\hline 3 & $\begin{array}{l}\text { ВіАображення Аоходу віА оприбуткування ТМЦ за } 2015 \text { р. за раху- } \\
\text { нок сальдо нерозподіленого прибутку }\end{array}$ & 201 & 441 & 16000 \\
\hline \multirow[t]{2}{*}{4} & $\begin{array}{l}\text { 3більшення показника нерозподіленого прибутку в сумі, що припа- } \\
\text { дає на реалізовану продукцію }\end{array}$ & 13 & 441 & 75000 \\
\hline & Зменшення собівартості залишку & 13 & 26 & 25000 \\
\hline
\end{tabular}

Ажерело: [2].

Коригування статей балансу наведене в таблиці 7.2.

Таблиця 7.2

Коригування статей балансу на 31.12.2016 р.

\begin{tabular}{|l|c|c|c|}
\hline \multicolumn{1}{|c|}{ Статті балансу } & КоА рядка & На початок звітного періоду & На кінець звітного періоду \\
\hline \multicolumn{1}{|c|}{$\mathbf{1}$} & $\mathbf{2}$ & $\mathbf{3}$ & $\mathbf{4}$ \\
\hline АКтив & & & - \\
\hline Основні засоби & 1010 & +100000 & - \\
\hline Основні засоби - знос & 1012 & $(-100000)$ & - \\
\hline
\end{tabular}


Продовження таблиці 7.2

\begin{tabular}{|c|c|c|c|}
\hline Статті балансу & КОА РЯАКа & На початок звітного періоАу & На кінець звітного періоду \\
\hline 1 & 2 & 3 & 4 \\
\hline Запаси & 1100 & $\begin{array}{l}+16000 \\
-26000 \\
-25000\end{array}$ & $\begin{array}{l}- \\
- \\
-\end{array}$ \\
\hline Баланс & 1300 & +65000 & - \\
\hline Пасив & & & \\
\hline $\begin{array}{l}\text { Нерозподілений прибуток } \\
\text { (непокритий збиток) }\end{array}$ & 1420 & $\begin{array}{l}-26000 \\
+16000 \\
+75000\end{array}$ & $\begin{array}{l}- \\
- \\
-\end{array}$ \\
\hline Аовгострокові креАити банків & 1510 & -24000 & - \\
\hline $\begin{array}{l}\text { Поточна кредиторська за- } \\
\text { боргованість за: Аовго- } \\
\text { строковими зобов'язаннями }\end{array}$ & 1610 & +24000 & - \\
\hline Баланс & 1900 & +65000 & - \\
\hline
\end{tabular}

Ажерело: [2].

Усі коригування робляться на початок 2016 р. При цьому значення рядків графи 3 бамансу на 31.12.2016 р. не збігатимуться зі значеннями тих самих рядків графи 4 балансу на 31.12.2015 р., якщо звітність за 2015 р. повторно не подається. Цей факт сліА буде розкрити в примітках до фінансової звітності, а також навести інформацію про помилки: їх зміст і суму, зазначити статті, які були перераховані внаслідок виправлення помилок та 3 метою повторного подання порівняльної інформації (за даними прикладів 1-4 у примітках треба буде навести всі статті, зазначені в таблиці 7.1, а порівняльна інформація - це графа 3 балансу на 31.12.2016 р. ) - п. 20 П(С)БО 6.

Пілприємство має прийняти рішення про повторну публікацію фінансової звітності за періоди, в яких були Аопущені помилки, наприклаА, чи буде воно повторно публікувати фінансову звітність за 2015 р. з виправленими показниками. Це також сліА зазначити в примітках Ао звітності за поточний рік (п. 20.3 П(С)БО 6). Якщо буде прийнято рішення про повторне подання фінансової звітності за 2015 р., то треба повторно скласти таку звітність уже з урахуванням виправлених показників. У цьому разі графа 3 балансу на 31.12.2016 р. збігатиметься з графою 4 балансу на 31.12.2015 р.

Якщо суми помилок $є$ неістотними і не вплинуть на рішення користувачів фінансової звітності, виправлення таких помилок можна не розкривати у фінансовій звітності.

\section{Помияки поточного року}

Помилки, Аопущені в бухгалтерському обліку за поточний рік, виправляють у первинних Аокументах та облікових регістрах згіАно з правилами, передбаченими розАілом 4 Положення №88 (Положення про Аокументальне забезпечення записів у бухгалтерському обліку, затверджене наказом Міністерства фінансів України віА 24.05.1995 р. №88). Зокрема, п. 4.2 Положення №88 описує коректурний спосіб виправлення помилок, а п. 4.3 - спосіб "сторно". Отже, в місяці виявлення помилки вона виправляється, і після цього Аані обліку буАуть правильними.

Усі помилки поточного року, виявлені та виправлені до склаАання фінансової звітності за цей рік, будуть включені Ао показників такої звітності, тож жодних коригувань статей звітності робити не треба. Проміжну звітність складають щокварталу наростаючим піАсумком з початку звітного року у склалі балансу та звіту про фінансові результати. Баланс піАприємства складають станом на кінець останнього Аня кварталу. Оскільки на цей момент помилки минулих кварталів поточного року вже будуть виправлені та проведені в обліку, вони будуть враховані в показниках статей балансу на цей момент, а також у складі доходів і витрат, віАображених наростаючим підсумком у звіті про фінансові результати. Звичайно, в цьому разі статті балансу на початок року не коригуються. 


\section{2. Порівнянність показників форм річної фінансової звітності}

У більшості випадків, коли у фрінансовій звітності підприємства немає помилок і не віАбувається змін у його капіталі, а також не зАійснювався розподі^ прибутку, піАсумок звіту про фрінансові результати (рядки 2350, 2355) є зміною показника прибутку за звітний періоА, тобто різницею між сумою нерозподіленого прибутку в балансі (рядок 1420) на кінець та на початок звітного періоду. Проте це окремий випадок, коли протягом року піАприємство мише заробляло прибуток (або накопичувало збиток).

У загальному випадку показники прибутку в балансі на початок та кінець звітного періоду (рядок 1420) повинні віАповіАати показникам рядків 4095 і 4300 графи 7 звіту про власний капітал (п. 97, п. 105 Методичних рекомендацій з перевірки порівнянності показників фінансової звітності, затверджених наказом Міністерства фінансів України віА 11.04.2013 р. №476), за винятком суми коригувань у зв'язку з виправленням помилок минулих років. Проте згіАно з П. 4 П(С)БО 6 при виправленні помилок минулих років, як ми вже бачили, сліА віАкоригувати суму нерозподіленого прибутку на початок звітного року в балансі [2].

ПриклаА 5. У 2016 р. піАприємство отримало чистий прибуток у сумі 350000 грн. При склаАанні звітності за 2016 р. виявили помилки минулих років (Аив. умови приклаАів 1 - 4), при виправленні яких показник нерозподіленого прибутку на початок 2016 р. має бути збільшено на 65000 грн. Сума накопиченого прибутку на початок 2016 р. становила 200000 грн. У 2016 р. були виплачені Аивіденди засновникам на суму 30000 грн.

Рядок 1420 балансу заповнюється таким чином: на початок 2016 р. - 200000 грн + 65000 грн $=265000$ грн, на кінець 2016 р. -265000 грн +350000 грн -30000 грн = 585000 грн. Графа 7 звіту про власний капітал буде заповнена таким чином (табл. 7.3). Як бачимо, сума зміни рядка 1420 балансу за 2016 р. $(585000-265000=320000)$ не Аорівнює сумі, віАображеній у рялку 2350 звіту про фінансові результати за 2016 р., - 350000 грн. Пояснити цю різницю і допоможе графа 7 звіту про власний капітал.

Таблиця 7.3

Фрагмент звіту про власний капітал за 2016 р.

\begin{tabular}{|c|c|c|c|}
\hline Стаття & КоА ряАКа & $\cdots$ & $\begin{array}{l}\text { НерозпоАілений прибуток } \\
\text { (непокритий збиток) }\end{array}$ \\
\hline 1 & 2 & & 7 \\
\hline Залишок на початок року & 4000 & & 200000 \\
\hline $\begin{array}{l}\text { Коригування: } \\
\text { Зміна облікової політики }\end{array}$ & 4005 & & - \\
\hline Виправлення помилок & 4010 & & 65000 \\
\hline Інші зміни & 4090 & & - \\
\hline Скоригований залишок на початок року & 4095 & & 265000 \\
\hline Чистий прибуток (збиток) за звітний періоА & 4100 & & 350000 \\
\hline \multicolumn{4}{|l|}{$\ldots$} \\
\hline $\begin{array}{l}\text { Розподі^ прибутку: } \\
\text { Виплати власникам (Аивіденди) }\end{array}$ & 4200 & & (30 000) \\
\hline \multicolumn{4}{|l|}{$\ldots$} \\
\hline Залишок на кінець року & 4300 & & 585000 \\
\hline
\end{tabular}

Ажерело: [2].

\section{КОНТРОАЬНІ ПИТАННЯ:}

1. Назвіть причини можливих помилок у фінансовій звітності.

2. На які групи поАіляються помилки, зроблені у фінансовій звітності?

3. Як класифікуються Аодатково помилки у межах кожної з груп? 
4. НавеАіть приклаАи помилок, які не вплинули на суму доходів і витрат за попередні звітні періоди.

5. НавеАіть приклаАи поми^ок, які вплинули на суму доходів і витрат за попереАні періоди і внасліАок цього на суму прибутку за ці періоди, яка сформувала показник нерозподіменого прибутку в балансі на початок звітного року.

6. Яка інформація щодо виявлених помилок відображається у примітках до фінансових звітів?

7. Яке значення А^я виправлення поми^ок має поріг суттєвості?

8. Назвіть порялок Аій бухгалтера по виправленню помилок.

9. Як виправляють поми^ки, Аопущені в бухгалтерському обліку за поточний рік?

10. Яким чином коригується звіт про власний капітал при виправленні помилок?

11. Чи потрібно робити коригування статей звітності за поточний рік при виявленні та виправленні помилок поточного року Ао склалання фінансової звітності за цей рік? 
TEMA 8.

\section{KOHCOАIAОВAHA ФIHAHCOBA ЗBITHICTЬ}

\section{1. Сутність консоліАованої фінансової звітності}

Закон України «Про бухгалтерський облік та фінансову звітність в Україні" (п. 1 ст. 12) визначає, що підприємства, які контролюють інші підприємства (материнські піАприємства), крім фінансових звітів про власні господарські операції, зобов'язані складати та подавати консоліАовану фінансову звітність віАповіАно Ао національних положень (стандартів) бухгалтерського обліку або міжнародних стандартів фінансової звітності.

Консолідована фінансова звітність - це фінансова звітність піАприємства, яке зАійснюе контроль, та піАприємств, які ним контролюються, як єАиної економічної оАиниці.

Міністерства, інші центральні органи виконавчої влади, Ао сфери управління яких належать суб'єкти державного сектору економіки, та органи, які зАійснюють управАіння майном суб'єктів комунального сектору економіки, крім власної звітності, складають та подають консолідовану фінансову звітність щодо піАприємств, які належать до сфери їх управління.

Об'єАнання піАприємств, крім власної звітності, склаАають та подають консолідовану фрінансову звітність щодо піАприємств, які входять до їх склаАу, якщо це переАбачено установчими Аокументами об'єАнань піАприємств віАповіАно Ао законоАавства.

Центральний орган виконавчої влади, що реалізує державну політику у сфері казначейського обслуговування бюджетних коштів, складає консоліАовану фінансову звітність про загальний майновий стан і результати Аіяльності суб'єктів Аержавного сектору та бюАжетів.

ЗгіАно з НП(С)БО 2 (п. 5-6), консоліАОвану фінансову звітність поАає материнське піАприємство.

Материнське (холАингове) піАприємство - це піАприємство, яке зАійснює контроль Аочірніх піАприємств (п. 4 П(С)БО 19).

Аочірнє піАприємство - це піАприємство, що перебуває піА контролем материнського (холАингового) піАприємства (П. 4 П(С)БО 19).

ПіА контролем розуміють вирішальний вплив на фінансову, господарську і комерційну політику піАприємства або піАприємництва з метою отримання вигоА віА його Аіяльності (п. 4 П(С)БО 19).

Як правило, про контроль наА господарським товариством можна говорити за наявності частки в його статутному капіталі, що перевищує $\mathbf{5 0 \%}$.

Материнське піАприємство не подає консоліАовану фінансову звітність за наявності всіх таких умов:

1) якщо воно є Аочірнім піАприємством іншого піАприємства (повністю або частково належить іншому піАприємству);

2) власники неконтрольованої частки поінформовані про це і не заперечують;

3) якщо воно не $є$ емітентом цінних паперів;

4) якщо його материнське піАприємство склаАає консоліАовану фінансову звітність, яка $€$ загальнодоступною.

НП(С)БО 2 (п. 4) використовує таку термінологію:

1) вмаАні повноваження - повноваження, обсяг яких наАає можливість піАприємству-інвестору, як правило, одноосібно управляти найбільш значущими видами Аіяльності, які суттєво вп^ивають на формування фрінансового результату піАприємства, яке є об'єктом 
інвестицій, зокрема через формування уповноваженого органу управління, визначення фінансової, інвестиційної і комерційної політики, та контроль за їх реалізацією;

2) внутрішньогрупові операції - операції між материнським та дочірніми піАприємствами або між Аочірніми піАприємствами однієї групи;

3) внутрішньогрупове самьАо - сальдо Аебіторської заборгованості та зобов'язань на Аату балансу, яке утворилося внасліАок внутрішньогрупових операцій;

4) група - це материнське (холАингове) піАприємство та його Аочірні піАприємства;

5) неконтрольована частка - частина чистого прибутку (збитку), сукупного Аоходу та чистих активів Аочірнього піАприємства, яка не належить материнському піАприємству (прямо або через інші дочірні підприємства);

6) нереалізовані прибутки та збитки віА внутрішньогрупових операцій - прибутки та збитки, які виникають внаслідок внутрішньогрупових операцій (продажу товарів, продукції, виконання робіт, послуг тощо) і включаються до балансової вартості активів підприємства;

7) права захисту інтересів інвесторів - повноваження, обмежений обсяг яких Аає піАприємству-інвестору мише можливість захистити свої права та інтереси стосовно піАприємства, яке є об'єктом інвестицій, без надання можливості управляти найбільш значущими виАами Аіяльності.

ПіАприємства, що контролюють інші піАприємства (крім піАприємств, що становлять суспільний інтерес), можуть не подавати консоліАованої фінансової звітності, якщо разом із контрольованими підприємствами їхні показники на дату складання річної фінансової звітності не перевищують Авох із таких критеріїв:

1) балансова вартість активів - до 4 мільйонів євро;

2) чистий дохіА віА реалізації продукції (товарів, робіт, послуг) - до 8 мільйонів євро;

3) сереАня кількість працівників - Ао 50 осіб.

Ао консоліАованої фінансової звітності вкАючають показники фінансової звітності материнського піАприемства та всіх Аочірніх піАприемств.

Аочірнє піАприємство вважається контрольованим з боку материнського піАприємства за наявності всіх таких умов:

1) материнське піАприємство має влаАні повноваження щодо Аочірнього піАприємства;

2) результати Аіяльності дочірнього піАприємства безпосередньо призводитимуть Ао змін у склаАі і вартості активів, зобов'язань, власного капіталу материнського піАприємства;

3) материнське піАприємство має фактичну можливість Аля зАійснення влаАних повноважень.

Наявність прав захисту інтересів інвестора не $є$ ознакою контролю.

Приклади владних повноважень, ознак наявності влаАних повноважень у пілприємстваінвестора, найбільш значущих виАів Аіяльності, прав захисту інтересів інвесторів наведені в АОАатКУ АО НП(С)БО 2.

ПрикмаАи влаАних повноважень:

1) право голосу (або потенційне право голосу) в Аочірньому пілприємстві;

2) право призначати, переводити на іншу посаду або звільняти провіАний управлінський персонал Аочірнього піАприємства, який може керувати найбільш значущими виАами Аіяльності;

3) право обирати або віАсторонювати інше піАприємство, що може керувати найбільш значущими виАами Аіяльності;

4) право вимагати зАійснення певних операцій або накладати вето на зАійснення операцій на користь материнського піАприємства;

5) інші права, які надають утримувачеві зАатність керувати найбільш значущими видами Аіямьності.

ПриклаАи ознак наявності влаАних повноважень у піАприємства-інвестора:

1) піАприємство-інвестор може призначати або затверджувати провіАний управлінський персонал піАприємства, яке є об'єктом інвестицій, який має можливість керувати найбільш значущими виАами Аіяльності; 
2) піАприємство-інвестор може вимагати віА піАприємства, яке є об'єктом інвестицій, зАійснення певних операцій або може накласти вето на зАійснення таких операцій;

3) підприємство-інвестор може віАігравати вирішальну роль у процесі висунення кандиАатур виборних членів керівного органу піАприємства, яке є об'єктом інвестицій, або в процесі отримання Аовіреності на голосування віА інших утримувачів права голосу;

4) провіАний управлінський персонал піАприємства, яке є об'єктом інвестицій, є пов'язаною стороною піАприємства-інвестора;

5) більшість членів керівного органу піАприємства, яке є об'єктом інвестицій, є пов'язаними сторонами піАприємства-інвестора;

6) провіАний управлінський персонал підприємства, яке є об'єктом інвестицій, який має можливість керувати найбільш значущими видами Аіяльності, преАставлений теперішніми або колишніми працівниками підприємства-інвестора;

7) Аіяльність піАприємства, яке є об'єктом інвестицій, залежить віА піАприємства-інвестора, наприклаА, у питаннях:

- фінансування значної частини Аіяльності;

- гарантування значної частини зобов'язань;

- налання важливих послуг, технологій, матеріалів чи сировини;

- контролю наА активами, такими як міцензії або торгові марки, які є необхіАними Аля провадження Аіямьності;

- калрового забезпечення персоналом, який володіє спеціалізованими знаннями, необхідними Аля провадження Аіямьності;

8) значна частина Аіяльності піАприємства, яке є об'єктом інвестицій, провадиться або за участю підприємства-інвестора, або віА його імені;

9) ризики або вигоди піАприємства-інвестора щодо результатів Аіяльності об'єкта інвестування непропорційно більші, ніж його право голосу або інші подібні права.

\section{ПриклаАи найбільш значущих виАів Аіямьності:}

1) придбання та продаж товарів, надання послуг, виконання робіт;

2) управління фінансовими активами;

3) відбір постачальника активів та їх асортименту, придбання або продаж активів;

4) Аослідження та розробка нових продуктів, матеріалів, приладів, продукції, процесів, систем або послуг;

5) визначення структури фрінансування господарської діяльності або окремих проектів та/ або залучення кредитів (позик), емісії інструментів власного капіталу, боргових цінних паперів.

\section{ПриклаАи прав захисту інтересів інвесторів:}

1) право кредитора забороняти позичальникові провадити діяльність, яка може суттєво змінити креАитний ризик позичальника на шкоду кредитора;

2) право сторони, якій належить неконтрольована частка в піАприємстві, яке є об'єктом інвестицій, узгоджувати рішення щодо інвестиційної Аіяльності у сумі більшій, ніж вимагається у нормальному процесі господарської Аіяльності, або ухвалювати рішення щодо емісії інструментів власного капіталу або боргових цінних паперів;

3) право кредитора вимагати обмеження права розпорядження активами позичальника, у разі якщо позичальник не виконує визначених умов погашення кредиту.

У разі якщо Аочірнє піАприємство перестає бути контрольованим, материнське підприємство:

1) не включає показників такого Аочірнього підприємства Ао консолідованої фінансової звітності;

2) визнає фінансові інвестиції в Аочірнє пілприємство за справеАливою вартістю та віАображає їх, а також будь-яку Аебіторську заборгованість та зобов'язання у розрахунках 3 Аочірнім піАприємством згіАно з віАповіАними національними положеннями (станАартами) бухгалтерського обліку;

3) припиняє визнавати інший сукупний дохіА, пов'язаний з таким дочірнім піАприємством, у порядку, передбаченому віАповіАними національними положеннями (стандартами) бухгалтерського обліку Аля вибуття активів та зобов'язань;

4) визнає доходи і витрати, пов'язані з втратою контролю. 


\section{2. Вимоги і метоАика склаАання консоліАованої фінансової звітності}

Фінансова звітність материнського піАприємства та його дочірніх піАприємств, що використовується при складанні консолідованої фінансової звітності, складається за той самий звітний період і на ту саму дату балансу.

КонсоліАовану фінансову звітність складають з фінансової звітності групи піАприємств з використанням єАиної облікової політики Аля подібних операцій та інших подій за схожих обставин. Якщо при складанні консоліАованої фрінансової звітності неможливо застосувати єАину облікову політику, то про це повіАомляється у примітках Ао консоліАованої фрінансової звітності.

КонсоліАована фінансова звітність складається шляхом впорядкованого Аодавання показників фінансової звітності дочірніх піАприємств Ао аналогічних показників фрінансової звітності материнського піАприємства.

Міністерства, інші центральні органи виконавчої влади, до сфери управління яких належать суб'єкти Аержавного сектору економіки, та органи, які зАійснюють управління майном суб'єктів комунального сектору економіки, складають окрему консоліАовану фінансову звітність шляхом впорядкованого Аодавання аналогічних показників фінансової звітності таких піАприємств.

ВіАповіАно Ао НП(С)БО 1 «Загальні вимоги до фінансової звітності» консолідована фінансова звітність скмадається з таких форм:

- КонсоліАований баланс (Звіт про фінансовий стан);

- КонсоліАований звіт про фінансові результати (Звіт про сукупний дохіА);

- Консоліаований звіт про рух грошових коштів (за непрямим методом);

- Консолідований звіт про рух грошових коштів (за прямим методом);

- Консолідований звіт про власний капітал;

- Примітки до консолідованої фінансової звітності;

- Аодаток до приміток до річної фінансової звітності «ннформація за сегментами».

При склаАанні консоліАованої фінансової звітності підлягають виключенню:

1) балансова вартість фінансових інвестицій материнського піАприємства в кожне Аочірнє піАприємство і частка материнського піАприємства в капіталі кожного Аочірнього піАприємства;

2) сума внутрішньогрупових операцій та внутрішньогрупового сальАо;

3) сума нереалізованих прибутків та збитків віА внутрішньогрупових операцій (крім збитків, які не можуть бути віАшкодовані).

Материнське підприємство Аля складання консолідованої фінансової звітності визначає неконтрольовану частку у власному капіталі, чистому прибутку (збитку) та сукупному доході Аочірніх піАприємств. Неконтрольована частка визначається як Аобуток віАсотка наявних голосів, які не належать материнському піАприємству, віАповіАно Ао власного капіталу, чистого прибутку (збитку) та сукупного Аоходу Аочірніх піАприємств з урахуванням суми нереалізованого прибутку (збитку) віА внутрішньогрупових операцій (крім випаАків, пов'язаних 3 об'єАнанням (приАбанням) піАприємств).

Якщо Аочірнім піАприємством випущені привілейовані акції, що класифікуються як інструменти власного капіталу, за якими накопичується сума дивіАендів та які перебувають у вомодінні за межами групи, то материнське піАприємство розраховує свою частку прибутку або збитку після коригування на суму АивіАендів за привілейованими акціями Аочірнього піАприємства незалежно віА оголошення Аивідендів.

Вартість гудвілу, що виникає при консоліАації фрінансової звітності материнського піАприємства і фінансової звітності дочірніх підприємств, та вартість неконтрольованої частки при об'єАнанні (придбанні) піАприємств визначаються згіАно з Положенням (стандартом) бухгалтерського обліку 19 “Об'єАнання піАприємств", затверАженим наказом Міністерства фінансів України віА 07 мипня 1999 року № 163, зареєстрованим у Міністерстві юстиції України 23 мипня 1999 року за № 499/3792 (із змінами). 
Курсові різниці, що виникають піА час переобрахунку показників фінансової звітності Аочірніх підприємств, які розташовані за межами України, у валюту України визначаються згінно з Положенням (станАартом) бухгалтерського обліку 21 "Вплив змін валютних курсів", затвердженим наказом Міністерства фінансів України віА 10 серпня 2000 року № 193, зареєстрованим у Міністерстві юстиції України 17 серпня 2000 року за № 515/4736 (із змінами).

У консолідованій фінансовій звітності неконтрольована частка у власному капіталі, чистому прибутку (збитку) та сукупному доході наводиться окремо.

У примітках до консолідованої фінансової звітності наводиться інформація про:

1) перелік дочірніх підприємств, які контролюються материнським піАприємством, із зазначенням назви дочірніх пілприємств, країни реєстрації та місцезнаходження, частки в капіталі, частки в розподілі голосів (у разі якщо вона не збігається з часткою в капіталі), іншої форми контролю;

2) причини, з яких показники фрінансової звітності дочірнього піАприємства не включено Ао консоліАованої фінансової звітності;

3) перелік Аочірніх підприємств, наА якими втрачено контроль протягом звітного періоду;

4) назви підприємств, у яких піАприємству, яке звітує, прямо або опосередковано (через Аочірні піАприємства) належить більше половини голосів, але яке з причин віАсутності контролю не є Аочірнім піАприємством;

5) вплив придбання або продажу дочірніх підприємств на фінансовий стан (на дату ба^ансу), фінансові результати звітного періоду та такі самі показники попереднього періоду;

6) статті консолідованої фінансової звітності, Ао яких застосовувалася різна облікова політика.

Міністерства, інші центральні органи виконавчої влади, до сфери управління яких належать суб'єкти державного сектору економіки, та органи, які зАійснюють управління майном суб'єктів комунального сектору економіки, у примітках до консолілованої фінансової звітності наводять інформацію про фінансові інвестиції (вкладення) у цінні папери та до статутних капіталів піАприємств за кожним піАприємством із зазначенням розміру частки в капіталі таких піАприємств.

\section{Етапи скмаАання консоліАованої фінансової звітності [56]:}

Етап 1. ПіАсумовування показників фінзвітності групи. Показники фінзвітності Аочірніх піАприємств упорядковано Аодаються Ао аналогічних показників фінзвітності материнського піАприємства. У консоліАованій звітності можна не наводити статті (рядки) форм звітності, за якими у групи піАприємств віАсутні показники. Виняток - випаАки, коли такі показники були в попередньому звітному році.

Етап 2. Виключення операцій. 3 отриманої зведеної звітності виключаються ті показники, які не впливають на фінансові результати холАингу:

- балансова вартість фінансових інвестицій материнського піАприємства в кожне Аочірнє піАприємство та частка материнського піАприємства в кожному Аочірньому піАприємстві;

- сума внутрішньогрупових операцій і внутрішньогрупового сальдо (Аебіторська та креАиторська заборгованість).

- сума нереалізованих прибутків і збитків віА внутрішньогрупових операцій (окрім збитків, які не можуть бути віАшколовані).

\section{Етап 3. Визначення неконтрольованої частки:}

- у консоліаованому балансі - у вписуваному рядку 1490 «Неконтрольована частка»;

- у консолілованому звіті про фінансові результати - у вписуваних рядках 2475 та 2485 (віА'ємні величини навоАяться в Аужках).

\section{Етап 4. ВіАображення гуАвілу та курсових різниць.}

ЗгіАно з АОАатком 3 Ао Н(П)СБО 1, гуАВіл вказується по рядку 1050 балансу піАприємства. ВідповіАно Ао форми балансу, наведеної в Аодатку 2 до цього ж стандарту, в рядку 1055 вказується гудвіл при консоліАації. Чим же віАрізняються показники Ааних рялків? В якому саме рядку балансу сліА зазначати показник гудвілу - 1055 або 1050? 
ЗгіАно з Аистом Мінфіну віА 23.09.2013 р. №31-08410-07-27/27851, гуАві^ - це перевищення вартості придбання наА часткою покупця у справеАливій вартості приАбаних іАентифікованих активів, зобов'язань і непередбачених зобов'язань на дату придбання.

Сума перевищення вартості придбання над часткою покупця у справеАливій вартості приАбаних іАентифікованих активів, зобов'язань і непередбачених зобов'язань на дату приАбання, яка визначається віАповіАно Ао П(С)БО 19, яке застосовують піАприємства, організації та інші юридичні особи всіх форм власності (крім бюджетних установ та підприємств, які віАповіАно до законодавства склаАають фінансову звітність за міжнародними стандартами фінансової звітності), віАображається в балансі (звіті про фінансовий стан) (форма № 1) піАприємства в Аодатковій статті "ГуАвіА" (рядок 1050).

ЗгіАно з НП(С)БО 2, вартість гуАвілу, що виникає при консоліАації фінансової звітності материнського піАприємства і фрінансової звітності дочірніх піАприємств, віАображається в консоліАованому балансі (звіті про фінансовий стан) (форма №1-к ) у рядку 1055 «ГуАві^ при консолідації".

Гудвіл при консоліАації є перевищенням величини інвестицій материнської компанії в Аочірню компанію наА справеАливою вартістю чистих активів, що припаАають на частку материнської компанії. Вартість гудвілу при консоліАації визначається згіАно з нормами П(С)БО 19. Зарахований на баланс гудвіл наАалі оцінюється на наявністю ознак зменшення корисності в порядку, передбаченому П(С)БО 28. Амортизація за гудвілом не нараховується.

Курсові різниці, що виникають піА час перерахунку показників фінансової звітності дочірніх піАприємств, які розташовані за межами України, у валюту України визначаються згіАно з П(С)БО 21 “Вплив змін валютних курсів". Курсові різниці у консоліАованому балансі (звіті про фінансовий стан) віАображаються у вписуваному рялку 1412 "Накопичені курсові різниці». Негативна курсова різниця наводиться у дужках і вираховується при визначенні піАсумку I розділу “Власний капіта^” пасиву балансу (звіту про фінансовий стан). Курсові різниці у консоліАованому звіті про фінансові результати (звіті про сукупний дохіА) віАображаються у рялку 2410 «Накопичені курсові різниці». Курсові різниці у консоліАованому звіті про власний капітал відображаються у вписуваному рядку 4113 «Накопичені курсові різниці".

Етап 5. Коригування нерозпоАіленого прибутку (збитку). НерозпоАілений прибуток (збиток) Аочірнього підприємства треба поАілити на Аві частини: прибуток, отриманий Ао його придбання материнським піАприємством, і прибуток, отриманий після приАбання. Перша частина враховується у склаАі чистих активів дочірньої компанії та увійде до склаАу консоліАованої звітності через віАображення гудвілу. А Аруга частина віАобразиться в консоліАованому балансі з урахуванням частки материнського піАприємства.

\section{ПриклаА.}

ТОВ «нвестор" придбало 70\% корпоративних прав ТОВ «Емітент" за 7000 тис. грн. Балансова вартість чистих активів ТОВ “Емітент» на дату придбання становить 5000 тис. грн. і віАповіАає їх справеАливій вартості. У подальшому ТОВ “нвестор" продало ТОВ "Емітент" 10 одиниць товару на суму 1200 тис. грн. (у т. ч. ПАВ - 200 тис. грн.). Прибуток віА продажу становив 5\% продажної вартості товарів. На 31.12.19 р. на склаАі ТОВ "Емітент" залишилися 2 одиниці товару (8 одиниць реалізовано на сторону). У загальній сумі дебіторської заборгованості ТОВ «нвестор" (9 000 тис. грн.) сума заборгованості ТОВ "Емітент" становить 1000 тис. грн. Фінансові показники ТОВ “нвестор" і ТОВ “Емітент" наведено в таблицях 1 і 2.

Ми бачимо по частці корпоративних прав ТОВ “Емітент", якими володіє ТОВ "ннестор", що останнє є материнським піАприємством Аля ТОВ “Емітент" (Аочірнього піАприємства). Складемо консолідований баланс і звіт про фінансові результати групи підприємств ТОВ "Інвестор" і ТОВ “Емітент" (табл. 1 і 2 нижче). Розіб'ємо цей процес на етапи:

Етап 1. ПіАсумовуємо показники фінансової звітності піАприємств групи.

Етап 2. Виключаємо інвестиції в Аочірнє піАприємство, внутрішньогрупові розрахунки (Аебіторську та кредиторську заборгованість, виручку та собівартість реалізованих товарів усередині групи). Виключаємо внутрішньогруповий прибуток віА продажу товарів: (1 $000: 10 \times 2) \times 5 \%=10$ (тис. грн.). 
Етап 3. Визначаємо неконтрольовану частку: $(4500+500)$ х 30\% $=1500$ (тис. грн.). Аля консолідованого звіту про фінрезультати неконтрольовані частки не розраховуємо, оскільки чистий прибуток Аочірнього піАприємства Аорівнює нулю (табл. 2).

Етап 4. Розраховуємо гудвіл: 7000 - (4 $500+500)$ х 70\% = 3500 (тис. грн.). Етапи склаАання консолідованого балансу та консолідованого звіту про фінансові результати наведено в таблицях 8.1-8.2.

Таблиця 8.1

Етапи ск^аАання консоліАованого балансу (тис. грн.)

\begin{tabular}{|c|c|c|c|c|c|c|c|c|}
\hline Стаття балансу & \begin{tabular}{|c|} 
КоА \\
ряАКа
\end{tabular} & $\begin{array}{c}\text { TOB } \\
\text { "Інвестор" }\end{array}$ & \begin{tabular}{|c|} 
TOB \\
"Емітент"
\end{tabular} & Етап 1 & $\begin{array}{c}\text { Етап } \\
2\end{array}$ & $\begin{array}{c}\text { Етап } \\
\mathbf{3}\end{array}$ & $\begin{array}{c}\text { Eтап } \\
4\end{array}$ & $\begin{array}{l}\text { КонсоАіАова- } \\
\text { ні показники }\end{array}$ \\
\hline 1 & 2 & 3 & 4 & 5 & 6 & 7 & 8 & 9 \\
\hline \multicolumn{9}{|c|}{ Актив } \\
\hline $\begin{array}{l}\text { I. Необоротні активи } \\
\text { Основні засоби (залиш- } \\
\text { кова вартість) }\end{array}$ & 1010 & $6500 * * *$ & $9000 * * *$ & 15500 & - & - & - & 15500 \\
\hline $\begin{array}{l}\text { Аовгострокові фінан- } \\
\text { сові інвестиції, що облі- } \\
\text { ковуються за методом } \\
\text { участі в капіталі }\end{array}$ & 1030 & 7000 & - & 7000 & -7000 & - & - & - \\
\hline ГуАві^ при консоліАації & 1055 & - & - & - & - & - & 3500 & 3500 \\
\hline $\begin{array}{l}\text { II. Оборотні активи } \\
\text { Товари }\end{array}$ & 1104 & $2000 * * *$ & 200 & 2200 & -10 & - & - & 2190 \\
\hline $\begin{array}{l}\text { Аебіторська заборгова- } \\
\text { ність (чиста реалізацій- } \\
\text { на вартість) }\end{array}$ & 1125 & 8000 & $500 * * *$ & 8500 & - & - & - & 8500 \\
\hline \begin{tabular}{|l|} 
Аебіторська заборго- \\
ваність за внутрішніми \\
розрахунками \\
\end{tabular} & 1145 & 1000 & - & 1000 & -1000 & - & - & - \\
\hline Гроші та їх еквіваленти & 1165 & $70 * * *$ & $10 * * *$ & 80 & - & - & - & 80 \\
\hline Баланс & 1300 & 24570 & 9710 & 34280 & -8010 & - & 3500 & 29770 \\
\hline \multicolumn{9}{|c|}{ Пасив } \\
\hline \begin{tabular}{|l|} 
I. ВАасний капітал \\
Зареєстрований (пайо- \\
Вий) капіта^
\end{tabular} & 1400 & 9000 & 4500 & 13500 & $-4500 *$ & & & 9000 \\
\hline $\begin{array}{l}\text { Нерозподілений прибу- } \\
\text { ток (непокритий збиток) }\end{array}$ & 1420 & 8000 & 500 & 8500 & $-510 * *$ & - & - & 7990 \\
\hline $\begin{array}{l}\text { Неконтрольована } \\
\text { частка }\end{array}$ & 1490 & - & - & - & - & 1500 & - & 1500 \\
\hline Усього за розАілом I & 1495 & 17000 & 5000 & 22000 & -5010 & 1500 & & 18490 \\
\hline \multicolumn{9}{|c|}{ II. Поточні зобов'язання і забезпечення } \\
\hline $\begin{array}{l}\text { Поточна кредиторська } \\
\text { заборгованість: за то- } \\
\text { вари, роботи, послуги }\end{array}$ & 1615 & - & $1000 * * *$ & 1000 & - & - & - & 1000 \\
\hline $\begin{array}{l}\text { за розрахунками зі } \\
\text { страхування }\end{array}$ & 1625 & $1570 * * *$ & $710 * * *$ & 2280 & - & - & - & 2280 \\
\hline $\begin{array}{l}\text { за розрахунками } 3 \\
\text { оплати праці }\end{array}$ & $\mid 1630$ & $6000 * * *$ & $2000 * * *$ & 8000 & - & - & - & 8000 \\
\hline $\begin{array}{l}\text { із внутрішніх розра- } \\
\text { хунків }\end{array}$ & 1645 & - & 1000 & 1000 & -1000 & - & - & - \\
\hline Баланс & 1900 & 24570 & 9710 & 34280 & -6010 & 1500 & - & 29770 \\
\hline \multicolumn{9}{|c|}{$\begin{array}{l}\text { * Оскільки збільшується пасив консолідованого балансу на суму неконтрольованої частки (етап 3), } \\
\text { виключаємо всю суму зареєстрованого капіталу, а не тільки частку материнського підприємства. } \\
\text { ** } 510 \text { тис. грн. = } 500 \text { тис. грн. (нерозподілений прибуток) + } 10 \text { тис. грн. (внутрішньосистемний } \\
\text { прибуток). Нерозподілений прибуток виключаємо в повній сумі з вищезгаАаної причини. } \\
\text { *** Сума умовна. }\end{array}$} \\
\hline
\end{tabular}

Ажерело: [56]. 
Таблиця 8.2

Етапи скмаАання консоліАованого звіту про фінансові результати (тис. грн.)

\begin{tabular}{|c|c|c|c|c|c|c|}
\hline Стаття & $\begin{array}{c}\text { КоА } \\
\text { ряАКа }\end{array}$ & $\begin{array}{c}\text { TOB } \\
\text { "Інвестор" }\end{array}$ & $\begin{array}{c}\text { TОВ } \\
\text { "Емітент" }\end{array}$ & Етап 1 & Eтап 2 & $\begin{array}{c}\text { КонсоліАовані } \\
\text { показники }\end{array}$ \\
\hline 1 & 2 & 3 & 4 & 5 & 6 & 7 \\
\hline $\begin{array}{l}\text { Чистий АохіА віА реалізації продукції } \\
\text { (товарів, робіт, послуг) }\end{array}$ & 2000 & 2000 & 860 & 2860 & -1000 & 1860 \\
\hline $\begin{array}{l}\text { Собівартість реалізованої продукції } \\
\text { (товарів, робіт, послуг) }\end{array}$ & 2050 & $(1400)$ & $(800)$ & (2 200) & $-950 *$ & $(1250)$ \\
\hline Ва^овий прибуток & 2090 & 600 & 60 & 660 & $-50 * *$ & 610 \\
\hline ААміністративні витрати & 2130 & $(100)$ & $(60)$ & $(160)$ & - & $(160)$ \\
\hline Прибуток віА операційної Аія^ьності & 2190 & 500 & - & 500 & -50 & 450 \\
\hline Прибуток Ао опоАаткування & 2290 & 500 & - & 500 & -50 & 450 \\
\hline Витрати (АохіА) з податку на прибуток & 2300 & (125) & - & $(125)$ & - & (125) \\
\hline Чистий прибуток & 2350 & 375 & - & 375 & -50 & 325 \\
\hline \multicolumn{7}{|c|}{$\begin{array}{l}\text { * У ТОВ “Інвестор" собівартість реалізованих ТОВ “Емітент" товарів становила: } \\
1 \text { оОо - 5\% = } 950 \text { (тис. грн.). } \\
\text { ** Внутрішньогруповий прибуток ТОВ “Інвестор" віА реалізації товарів ТОВ “Емітент»: } \\
1000 \text { - } 950=50 \text { (тис. грн.). }\end{array}$} \\
\hline
\end{tabular}

Ажерело: [56].

\section{КОНТРОАЬНІ ПИТАННЯ:}

1. Аайте визначення понять "материнське піАприємство", "Аочірнє піАприємство", "Група".

2. Що таке консолідована фінансова звітність? 3 якою метою її складають?

3. Назвіть та охарактеризуйте форми консолідованої фінансової звітності.

4. За яких умов Аочірнє піАприємство вважається контрольованим?

5. Аайте визначення поняття "владні повноваження" та навеАіть приклади.

6. Як відображається в бухгалтерському обліку покупця придбання іншого підприємства?

7. Як відображають гудвіл у консоліАованій фрінансовій звітності?

8. У яких випадках складання консолідованої фінансової звітності не є обов'язковим?

9. Що таке внутрішньогрупові операції та сальдо за ними? Як їх віАображають у консоліАованих фінансових звітах?

10. Що таке нереалізовані прибутки та збитки? Як їх відображають у консоліАованих звітах?

11. Що таке неконтрольована частка? Як її визначають та відображають у консолідованих фрінансових звітах?

12. Які коригування та з якою метою робляться в процесі консоліАації фінансових звітів?

13. Як зАійснюється процес консолідації фінансових звітів з використанням робочої таблиці?

14. Яка інформація про об'єАнання підприємств і консолідацію має наводитися у примітках Ао консолідованої фінансової звітності? 


\section{ФІНАНСОВИЙ ЗВІТ МАЯОГО ТА МІКРОПІАПРИЕМСТВА}

\section{1. Поняття мамого підприємства}

ВіАповіАно Ао ч. 2 ст. 2 Закону України «Про бухгалтерський облік та фрінансову звітність в Україні" малими $є$ підприємства, які не віАповіАають критеріям Аля мікропіАприємств та показники яких на дату складання річної фінансової звітності за рік, що передує звітному, віАповіАають щонайменше Авом із таких критеріїв:

- балансова вартість активів - до 4 млн євро;

- чистий дохіа віа реалізації продукції (товарів, робіт, послуг) - ао 8 млн євро;

- середня кількість працівників - ао 50 осіб.

Аля прикладу, якщо за показниками 2017 року (тобто за фінансовою звітністю станом на 31.12.2017) піАприємство було малим Аля цілей 2018 року, то, звітуючи за 2019 рік, воно також вважається ще малим, навіть якщо показники вже змінилися. ААже Аля перекласифікації воно змінить групу, якщо Ава роки поспіль не віАповіАає критеріям, за якими іАентифікувало себе в певній групі. Тобто, навіть якщо за фінансовою звітністю 2018 та 2019 рр. підприємство не віАповіАає вже малому, то змінить групу аж із 2020 року. А Аля цілей склаАання фінансової звітності за 2019 рік буде ще тим, Ао якого належало у 2018 році (за показниками фрінансової звітності 2017 року) [49].

У 2019 році були внесені зміни Ао П(С)БО 25, який змінив свою назву з “Фінансовий звіт суб'єкта малого піАприємництва" на "Спрощена фінансова звітність" (згіАно з наказом Мінфріну віА 31.05.2019 р. № 226).

ЗгіАно змін, малі піАприємства можуть обирати між скороченою та повною фінансовою звітністю.

Оновлений стандарт регламентує зміст, форму та порядок заповнення:

фінансової звітності малого піАприємства у склаАі добре віАомих балансу (форма № 1-м) та звіту про фінансові результати (форма № 2-м), наведених у АоАатку 1 Ао НП(С)БО 25.

фінансової звітності мікропіАприємства, яка вк^ючає баланс (форма № 1-мс) та звіт про фрінансові результати (форма № 2-мс), наведені в Аолатку 2 Ао $\underline{\mathrm{HП}(\mathrm{C}) Б О ~} 25$ (Аалі - Фінзвіт мікропіАприємства).

ЗгіАно з поправками Фінзвіт малого піАприємства призначено А^я:

- малих піАприємств, що визнані такими відповіАно до Закону України «Про бухгалтерський облік та фрінансову звітність в Україні" (Аалі - малі піАприємства) (крім тих, яким поАатковим законодавством наАано дозвіл на ведення спрощеного обліку Аоходів та витрат, - мають на увазі юросіб - єАинників групи 3, Аив. абз. 3 п. 44.2, пп. 3 п. 291.4, пп. 296.1.3. Податкового кодексу України, Аалі - ПКУ);

- представництв іноземних суб'єктів господарської діяльності.

Фінзвіт мікропіАприємств скмаАають:

- мікропіаприємства, які визнані такими віАповідно до "Про бухгалтерський облік та фрінансову звітність в Україні" (Аалі - мікропіАприємства);

- піАприємства, які веАуть спрощений бухоблік доходів і витрат згіАно з податковим законодавством, тобто юрособи - єАинники групи 3;

- непідприємницькі товариства. 
Утім, як і раніше, норми НП(С)БО 25 та віАповіАну спрощену фінзвітність не можуть застосовувати піАприємства, які згідно із законодавством склаАають фінзвітність за МСФЗ. Вони використовують повноформатну фінзвітність, передбачену ги до фінансової звітності”.

Своєю чергою, Аля всіх перелічених вище суб'єктів звітування - мікропідприємства, малі піАприємства, непіАприємницькі товариства, представництва іноземних суб'єктів господарської Аіяльності й піАприємства, які веАуть спрощений бухоблік Аоходів та витрат віАповіАно Ао податкового законодавства, - закріпили право вибору.

За загальним правилом вони складають скорочену за показниками фінзвітність у складі балансу і звіту про фінансові результати, передбачену НП(С)БО 25. ВоАночас імм наАали право самостійно визначати Аоцімьність скмаАання фінансової звітності за формами, переАбаченими НП(С)БО 1.

Практики рекоменаують, що свій вибір щодо застосовуваних форм фінзвітності таким піАприємствам потрібно буде закріпити в наказі про облікову політику, оскільки фінансова звітність $€$ невіА'ємним АоАатком Ао податкової Аекларації з поАатку на прибуток піАприємств (п. 46.2 ПКУ).

Також Міністерство фінансів уточнило, що типову форму фінансової звітності № 5 «Примітки до річної фрінансової звітності" не застосовують:

- банки;

- бюАжетні установи;

- представництва іноземних суб'єктів господарської діяльності;

- мікропіАприємства, махі піАприємства, непіАприємницькі товариства, піАприємства, які веАуть спрощений бухоблік АохоАів та витрат віАповіАно Ао поАаткового законоАавства;

- піАприємства, які згідно із законодавством складають фінансову звітність за МСФЗ.

План рахунків бухгалтерського обліку активів, капіталу, зобов'язань і господарських операцій суб'єктів малого підприємництва, затверджений наказом Мінфіну України віА 19.04.2001 р. № 186, перейменували у спрощений План рахунків бухгалтерського обліку активів, капіталу, зобов'язань і господарських операцій підприємств. Його можуть застосовувати:

- мікропіАприємства, малі піАприємства;

- непіАприємницькі товариства;

- пілприємства, які веАуть спрощений бухоблік доходів та витрат віАповіАно до податкового законодавства;

- представництва іноземних суб'єктів господарської діямьності.

Перелічені суб'єкти застосовують спрощений П^ан рахунків за умови, якщо вони ск^аАають фінзвітність у "спрощеному" форматі згіАно з НП(С)БО 25.

ВіАповіАно, якщо такі піАприємства вирішать складати фінзвітність за повними формами, передбаченими $\underline{\mathrm{H}(\mathrm{C}) Б О ~ 1}$, вони застосовуватимуть загальний План рахунків бухгалтерського обліку активів, капіталу, зобов'язань і господарських операцій підприємств і організацій, затверджений наказом Мінфіну України віА 30.11.1999 р. № 291. Тобто використовуватимуть у т.ч. рахунки кмасу 9 "Витрати Аіяльності" (з віАкриттям за власним рішенням рахунків класу 8 "Витрати за елементами"). При цьому можливість застосування такими піАприємствами спрощеного Плану рахунків та віАповіАні узгоджувальні поправки внесли Ао Інструкції про застосування Плану рахунків бухгалтерського обліку активів, капіталу, зобов'язань і господарських операцій підприємств і організацій, затвердженої наказом Мінфіну України віА 30.11.1999 р. № 291.

У балансі малого піАприємства (форма № 1-м) додали три рядки, призначені Аля окремого розкриття інформації про нематеріальні активи:

- 1000 «Нематеріальні активи»;

- 1001 «Первісна вартість»;

- 1002 «Накопичена амортизація». 
За статтею "Нематеріальні активи" віАображатимуть вартість об'єктів, віАнесених піАприємством до складу нематеріальних активів. При цьому окремо наводитимуть первісну вартість (ряАок 1001), суму накопиченої амортизації (рялок 1002) та залишкову вартість нематеріальних активів (рядок 1000). Залишкову вартість (показник рядка 1000) визначають як різницю між первісною вартістю (показник рядка 1001) і сумою накопиченої амортизації (показник рядка 1002), яку наводять у Аужках. Ао піАсумку балансу включатимуть саме замишкову вартість нематеріальних активів.

НагаАаємо, що згіАно із попередніми правилами вартість нематеріальних активів наводими у “малих" балансах за статтею "Основні засоби".

Також цікаво, що в балансі мікропіАприємств за формою № 1-мс статтю нематеріальних активів окремо не виАілили, тому вони так і продовжуватимуть віАображатися за статтею "Основні засоби" (п. 1.1 р. III $\underline{\mathrm{H}(\mathrm{C}) Б О ~ 25})$.

В оновленому НП(С)БО 25 прописано форми фінзвітності, наведені в таблиці 9.1.

Форми фінансової звітності віАПовіАНО АО НП(С)БО 25

Таблиця 9.1

\begin{tabular}{|c|c|}
\hline $\begin{array}{c}\text { Фінансова звітність малого піАприємства } \\
\text { Ба^анс (форма № 1-м) } \\
\text { Звіт про фінансові результати (форма № 2-м) }\end{array}$ & $\begin{array}{c}\text { Фінансова звітність мікропіАприємства } \\
\text { Баманс (форма № 1-мс) } \\
\text { Звіт про фінансові результати (форма № 2-мс) }\end{array}$ \\
\hline $\begin{array}{l}\text { Використовують: } \\
\text { - малі піАприємства (крім платників єАиного по- } \\
\text { Аатку } 3 \text { групи); } \\
\text { - преАставництва іноземних суб'єктів господар- } \\
\text { ської Аіяльності }\end{array}$ & $\begin{array}{l}\text { Використовують } \\
\text { - мікропіАприємства; } \\
\text { - піАприємства - платники єАиного податку } 3 \text { групи; } \\
\text { - непіАприємницькі товариства (тобто неприбутко- } \\
\text { ві організації) }\end{array}$ \\
\hline
\end{tabular}

Ажерело: [49].

Отже, малі піАприємства та представництва іноземних суб'єктів господарювання можуть використовувати форми № 1-м та № 2-м. Або ж, якщо вважають за Аоцільне, заповнювати загальні форми з НП(С)БО 1 (примітки Ао фінзвітності ф. № 5 можуть не склаАати). Тим часом піАприємства, що зобов'язані склаАати фінансову звітність за МСФЗ, повинні користуватися загальними формами звітності з НП(С)БО 1.

У балансі (ф. № 1-м) та звіті про фінрезультати (ф. № 2-м) малі піАприємства наводять показники в тисячах гривень з оАним Аесятковим знаком після коми (зазначено у шапці форми Фінансової звітності малого піАприємства).

Аля малих підприємств не переАбачено спеціальних строків подання фінзвітності. Зокрема, звітним періодом Аля склаАання фінзвітності $є$ каленАарний рік. Також малі піАприємства Ао органів статистики мають поАавати й проміжну фінансову звітність, яка сКлаАається за результатами I кварталу, 1 півріччя, 9 місяців. Крім того, віАповіАно Ао облікової політики підприємства фрінансову звітність можна складати за інші періоди (ст. 13 Закону Укаїни «Про бухгалтерський облік та фінансову звітність в Україні»).

Проміжну фрінзвітність (І квартал, 1 півріччя, 9 місяців), крім консолідованої, подають пілприємства в органи, зазначені в п. 2 Порядку № 419 (крім органів Казначейства), не пізніше 25 числа місяця, що настає за звітним кварталом, а річну - не пізніше 28 мютого наступного за звітним року (п. 5 Порядку № 419).

ЗгіАно з п. 10 Порядку № 419, якщо Аата подання звітності припаАає на неробочий день, строк подання переносять на перший робочий Аень після вихіАного.

Платники податку на прибуток разом із віАповіАною поАатковою Аекларацією подають фрінансову звітність у порядку, передбаченому Аля подання податкової декларації (п. 46.2 ПКУ). Така фінзвітність є АоАатком Ао ПоАаткової Аекларації з податку на прибуток та ії невіА'ємною частиною. А це означає, що за відсутності фінансової звітності податкова декларація може бути не прийнята.

Також з 2019 року фінансові установи, що належать до мікро- і малих підприємств, повинні оприлюАнити фінзвітність разом з аудиторським висновком. Малі та мікропіАприєм- 
ства, які не є фінансовими установами, та не є піАприємствами, що склаАають суспільний інтерес, не зобов'язані оприлюднювати свою фінзвітність з аудиторським висновком.

\section{2. ПоряАок склаАання фінансової звітності малого піАприємства}

у балансі відображають активи, зобов'язання та власний капітал. ПіАсумок активів бамансу повинен Аорівнювати сумі зобов'язань і власного капіталу.

Баланс стандартно склалається з 2 частин: активу та пасиву. У графі 1 визначено найменування статей, у графі 2 - їх коА, у графі 3 віАображають показники віАповіАної статті на початок звітного року. Їх беруть із річного минулорічного балансу. Тож, піА час складання проміжного квартального балансу показники цього рядка протягом року не змінюються. Ао графи 4 записують дані станом на кінець звітного періоду (залежно віА періоду склаАання). У разі склаАання квартальної звітності показники наводять наростаючим піАсумком із початку звітного року (табл. 9.2).

Таблиця 9.2

Заповнення балансу малого піАприємства (ф. № 1-м)

\begin{tabular}{|c|c|c|c|c|}
\hline \multirow[b]{2}{*}{ Назва статті } & \multirow{2}{*}{$\begin{array}{c}\text { КоА } \\
\text { ряАКа }\end{array}$} & \multirow{2}{*}{$\begin{array}{c}\text { Ао скмаАу суми віАповіАної } \\
\text { статті потрап^яє: }\end{array}$} & \multicolumn{2}{|c|}{ СамьАо віАПовіАного рахунка (субрахунку) } \\
\hline & & & $\begin{array}{c}\text { За загамьним } \\
\text { пманом рахунків }\end{array}$ & $\begin{array}{c}\text { За спрощеним } \\
\text { планом рахунків }\end{array}$ \\
\hline \multicolumn{5}{|c|}{ AКТИВ } \\
\hline \multicolumn{5}{|c|}{ I. Необоротні активи } \\
\hline $\begin{array}{l}\text { Нематеріальні } \\
\text { активи }\end{array}$ & 1000 & \multicolumn{3}{|c|}{$\begin{array}{l}\text { Відображають вартість об'єктів, віднесених до складу нематеріальних активів. } \\
\text { Ао підсумку балансу включають залишкову вартість, яку визначають як різницю } \\
\text { міжк первісною вартістю та сумою накопиченої амортизації, що наводять у дужках. } \\
\text { Тобто відображають різницю рядків } 1001 \text { та } 1002\end{array}$} \\
\hline $\begin{array}{l}\text { Первісна вар- } \\
\text { тість }\end{array}$ & 1001 & $\begin{array}{l}\text { первісна (переоцінена) } \\
\text { вартість об'єктів немате- } \\
\text { ріальних активів, які такими } \\
€ \text { за П(С)БО } 8\end{array}$ & $\begin{array}{l}\text { Ат субрахунків рахунка: } \\
12 \text { «Нематеріальні активи» }\end{array}$ & $\begin{array}{l}\text { Ат рахунка: } \\
10 \text { "Основні засоби" } \\
\text { (вибірка по немате- } \\
\text { ріальних активах) }\end{array}$ \\
\hline $\begin{array}{l}\text { Накопичена } \\
\text { амортизація }\end{array}$ & 1002 & $\begin{array}{l}\text { сума накопиченої амортиза- } \\
\text { ції нематеріальних активів } \\
\text { (іï̈ наводять у дужках) }\end{array}$ & $\begin{array}{l}\text { Кт субрахунку: } \\
133 \text { «Накопичена амор- } \\
\text { тизація нематеріальних } \\
\text { активів" }\end{array}$ & $\begin{array}{l}\text { Кт рахунка: } \\
13 \text { "Знос необоротних } \\
\text { активів" (вибірка за } \\
\text { нематеріальними ак- } \\
\text { тивами) }\end{array}$ \\
\hline $\begin{array}{l}\text { Незавершені } \\
\text { капітальні } \\
\text { інвестиції }\end{array}$ & 1005 & $\begin{array}{l}\text { вартість незавершених на } \\
\text { Аату балансу капітальних ін- } \\
\text { вестицій у необоротні активи } \\
\text { на будівництво, реконструк- } \\
\text { цію, модернізацію (інші поліп- } \\
\text { шення, що збільшують пер- } \\
\text { вісну (переоцінену) вартість), } \\
\text { виготовлення, придбання } \\
\text { об'єктів матеріальних необо- } \\
\text { ротних активів (у т.ч. необо- } \\
\text { ротних матеріальних активів, } \\
\text { призначених Аля заміни Аію- } \\
\text { чих, й устаткування Аля мон- } \\
\text { тажу) (див. примітку 2) }\end{array}$ & $\begin{array}{l}\text { Ат субрахунку: } \\
151 \text { «Капітальне будівниц- } \\
\text { тво»; } \\
152 \text { «Придбання (виготов- } \\
\text { лення) основних засобів»; } \\
153 \text { «Придбання (виготов- } \\
\text { лення) інших необоротних } \\
\text { матеріальних активів"; } \\
154 \text { "Придбання (створен- } \\
\text { ня) нематеріальних акти- } \\
\text { вів"; } \\
155 \text { "Придбання (вирощу- } \\
\text { вання) Аовгострокових бі- } \\
\text { ологічних активів» }\end{array}$ & $\begin{array}{l}\text { Ат рахунка: } \\
15 \text { "Капітальні інвес- } \\
\text { тиції» }\end{array}$ \\
\hline
\end{tabular}

Примітка 2. У складі рядка 1005, окрім незавершених капінвестицій у необоротні матактиви, потрапляють у т.ч. незавершені капінвестиції в необоротні нематактиви. ААже, незважаючи на те що про них не йдеться в п. 2.2 НП(С)БО 25, ряАОк 1005 найкраще піАхоАить Аля таких незавершених капінвестицій. Це випливає як із п. 1 П(С)БО 8 "Нематеріальні активи", так і з Інструкції про застосування Плану рахунків бухгалтерського обліку активів, капіталу, зобов'язань і господарських операцій піАприємств і організацій, затверАженої наказом Мінфіну України віА 30.11 .1999 р. № 291 (Аалі - Інструкція № 291), згіАно $з$ якою на субрахунку 154 обліковують витрати піАприємства на придбання (створення) нематеріальних активів. Ао речі, витрати на придбання (вирощування) Аовгострокових біологічних активів також необхіАно показувати у цьому рядку 
Продовження таблиці 9.2

\begin{tabular}{|c|c|c|c|c|}
\hline \multirow[b]{2}{*}{ Назва статті } & \multirow{2}{*}{$\begin{array}{l}\text { КоА } \\
\text { ряАКа }\end{array}$} & \multirow{2}{*}{$\begin{array}{c}\text { Ао склаАу суми віАповіАної } \\
\text { статті потрап^яє: }\end{array}$} & \multicolumn{2}{|c|}{ СамьАо віАповіАного рахунка (субрахунку) } \\
\hline & & & $\begin{array}{c}\text { За загальним } \\
\text { планом рахунків }\end{array}$ & $\begin{array}{c}\text { За спрощеним } \\
\text { планом рахунків }\end{array}$ \\
\hline $\begin{array}{l}\text { Основні за- } \\
\text { соби }\end{array}$ & 1010 & \multicolumn{3}{|c|}{$\begin{array}{l}\text { Відображають різницю рядків } 1011 \text { та 1012, плюс сума вартості інвестиційної } \\
\text { нерухомості, яку обліковують за справедливою вартістю (Аив. примітки } 3 \text { та 4) }\end{array}$} \\
\hline $\begin{array}{l}\text { первісна вар- } \\
\text { тість }\end{array}$ & 1011 & $\begin{array}{l}\text { первісна (переоцінена) вар- } \\
\text { тість об'єктів основних засо- } \\
\text { бів, інших необоротних ма- } \\
\text { тактивів, а також вартість } \\
\text { інвестнерухомості, якщо } \\
\text { її справедливу вартість не } \\
\text { можна Аостовірно визначи- } \\
\text { ти (п. } 16 \text { П(С)БО 32 "Інвести- } \\
\text { ційна нерухомість») } \\
\text { (Аив. примітку 3) }\end{array}$ & $\begin{array}{l}\text { Ат субрахунків рахунка: } \\
10 \text { «Основні засоби»; } \\
11 \text { «нші необоротні мате- } \\
\text { ріальні активи"; }\end{array}$ & $\begin{array}{l}\text { Ат рахунка: } \\
10 \text { «Основні засоби" } \\
\text { (крім нематеріальних } \\
\text { активів) }\end{array}$ \\
\hline
\end{tabular}

Примітка 3. У рядку 1011 не зазначають первісну вартість інвестиційної нерухомості (субрахунок 100), яку обліковують за справеАливою вартістю. У такому випалку справедлива вартість потрапляє віАразу

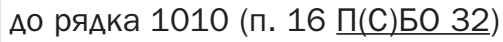

\begin{tabular}{|c|c|c|c|c|}
\hline $3 \mathrm{HOC}$ & 1012 & $\begin{array}{l}\text { сума зносу (ії наводять у } \\
\text { Аужках) }\end{array}$ & $\begin{array}{l}\text { Кт субрахунку: } \\
131 \text { "Знос основних } \\
\text { засобів"; } \\
132 \text { "Знос інших необо- } \\
\text { ротних матеріальних акти- } \\
\text { вів"; } \\
135 \text { "Знос інвестиційної } \\
\text { нерухомості" (якщо ї̈ об- } \\
\text { міковують за первісною, } \\
\text { а не справедмивою вар- } \\
\text { тістю) }\end{array}$ & $\begin{array}{l}\text { Кт рахунка: } \\
13 \text { "Знос необоротних } \\
\text { активів» (окрім зносу } \\
\text { Аовгострокових біоло- } \\
\text { гічних активів, нема- } \\
\text { теріальних активів) }\end{array}$ \\
\hline
\end{tabular}

Примітка 4. Наводять вартість власних й отриманих на умовах фінансового лізингу, Аовірчого управління об'єктів й орендованих цілісних Аержавних майнових комплексів, які віднесені до складу основних засобів. Аержавні (казенні) та комунальні підприємства у статті "Основні засоби" відображають вартість майна,

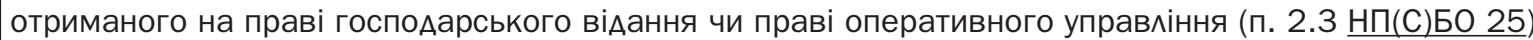

\begin{tabular}{|c|c|c|c|c|}
\hline $\begin{array}{l}\text { Аовгостроко- } \\
\text { ві біологічні } \\
\text { активи }\end{array}$ & 1020 & 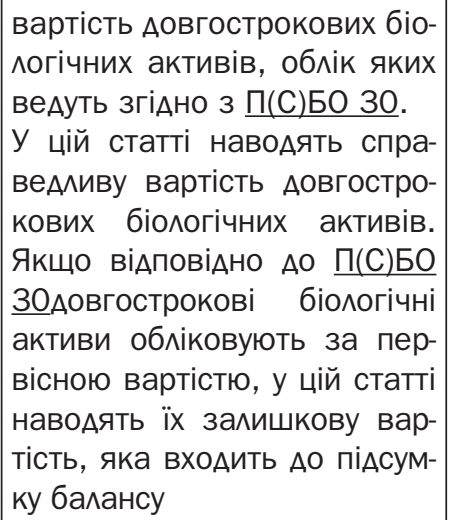 & $\begin{array}{l}\text { Ат субрахунку: } \\
\text { 161, 163, 165 - Аля біоак- } \\
\text { тивів, які обліковують за } \\
\text { справедливою вартістю; } \\
\text { 162, 164, } 166 \text { - Аля біоак- } \\
\text { тивів, які обліковують за } \\
\text { первісною вартістю, мінус } \\
\text { Кт субрахунку: } \\
\text { 134 (Аля біоактивів, які } \\
\text { обліковують за первісною } \\
\text { вартістю) }\end{array}$ & $\begin{array}{l}\text { Ат рахунка: } \\
16 \text { "Аовгострокові бі- } \\
\text { ологічні активи" - у } \\
\text { розрізі субрахунків } \\
\text { Аля обліку біологічних } \\
\text { активів за справеАли- } \\
\text { вою та первісною вар- } \\
\text { тістю мінус Кт рахунка: } \\
13 \text { (Аля біоактивів, які } \\
\text { обліковують за первіс- } \\
\text { ною вартістю) }\end{array}$ \\
\hline $\begin{array}{l}\text { Аовгостроко- } \\
\text { ві фінансові } \\
\text { інвестиції }\end{array}$ & 1030 & $\begin{array}{l}\text { вартість фінінвестицій на } \\
\text { період понал рік, а також } \\
\text { решти фінінвестицій, які не } \\
\text { можуть бути вільно реалізо- } \\
\text { вані в будь-який час }\end{array}$ & $\begin{array}{l}\text { Ат субрахунку: } \\
141 \text { «Інвестиції пов'яза- } \\
\text { ним сторонам за методом } \\
\text { обліку участі в капіталі"; } \\
142 \text { "Інші інвестиції пов’я- } \\
\text { заним сторонам»; } \\
143 \text { "Інвестиції непов'яза- } \\
\text { ним сторонам" }\end{array}$ & $\begin{array}{l}\text { Ат рахунка: } \\
14 \text { "Аовгострокові } \\
\text { фінансові інвестиції" }\end{array}$ \\
\hline
\end{tabular}


Продовження таблиці 9.2

\begin{tabular}{|c|c|c|c|c|}
\hline \multirow[b]{2}{*}{ Назва статті } & \multirow[b]{2}{*}{$\begin{array}{c}\text { КоА } \\
\text { ряАка }\end{array}$} & \multirow{2}{*}{$\begin{array}{c}\text { Ао ск^аАУ суми віАповіАної } \\
\text { статті потрап^яє: }\end{array}$} & \multicolumn{2}{|c|}{ СамьАо віАПовіАного рахунка (субрахунку) } \\
\hline & & & $\begin{array}{c}\text { За загальним } \\
\text { планом рахунків }\end{array}$ & $\begin{array}{c}\text { За спрощеним } \\
\text { пманом рахунків }\end{array}$ \\
\hline $\begin{array}{l}\text { Інші необорот- } \\
\text { ні активи }\end{array}$ & 1090 & $\begin{array}{l}\text { вартість інших необоротних } \\
\text { активів, які не можуть бути } \\
\text { вк^ючені до згаАаних вище } \\
\text { статей розділу «Необоротні } \\
\text { активи" } \\
\text { (Аив. примітку 5) }\end{array}$ & $\begin{array}{l}\text { Ат субрахунку: } \\
181 \text { "Заборгованість за } \\
\text { майно, що передано у } \\
\text { фінансову оренду"; } \\
182 \text { "Аовгострокові век- } \\
\text { селі одержані»; } \\
183 \text { «Інша дебіторська } \\
\text { заборгованість»; } \\
184 \text { "Інші необоротні } \\
\text { активи»; } \\
191 \text { "Гудвіл при придбанні»; } \\
193 \text { "Гудві^ при привати- } \\
\text { зації (корпоратизації)" }\end{array}$ & $\begin{array}{l}\text { Ат рахунка: } \\
18 \text { "Інші необоротні } \\
\text { активи" }\end{array}$ \\
\hline
\end{tabular}

Примітка 5. ПіА час переходу піАприємств на застосування $\mathrm{HП(C)БО} 25$ Ао такої статті на початок звітного року також вкмючають Аані, наведені у статті "ВіАстрочені податкові активи" (рядок 1045) балансу (звіту про фінансовий стан) (форма № 1) на кінець попереднього року

\begin{tabular}{|c|c|c|c|c|}
\hline $\begin{array}{l}\text { Усього } \\
\text { за розАілом I }\end{array}$ & 1095 & \multicolumn{3}{|c|}{ Сума рядків 1005, 1010, 1020, 1030, 1090} \\
\hline \multicolumn{5}{|c|}{ II. Оборотні активи } \\
\hline Запаси: & 1100 & $\begin{array}{l}\text { вартість запасів сировини, } \\
\text { основних і допоміжних ма- } \\
\text { теріалів, палива, покупних } \\
\text { напівфабрикатів і комплек- } \\
\text { тувальних виробів, запасних } \\
\text { частин, тари (крім інвентар- } \\
\text { ної), будівельних матеріалів } \\
\text { й інших матеріалів, призна- } \\
\text { чених Аля використання піА } \\
\text { час нормального операцій- } \\
\text { ного циклу. } \\
\text { у цій статті також наводять } \\
\text { витрати на незавершене } \\
\text { виробництво й незавершені } \\
\text { роботи (послуги), валову за- } \\
\text { боргованість замовників за } \\
\text { будівельними контрактами }\end{array}$ & $\begin{array}{l}\text { Ат субрахунків рахунка: } \\
20 \text { «Виробничі запаси»; } \\
22 \text { „Малоцінні та швиА- } \\
\text { козношувані предмети»; } \\
23 \text { "Виробництво»; } \\
25 \text { «Напівфабрикати» }\end{array}$ & $\begin{array}{l}\text { Ат рахунка: } \\
20 \text { «Виробничі запа- } \\
\text { си»; } \\
23 \text { «Виробництво» } \\
\text { (крім субрахунку, } \\
\text { призначеного Аля } \\
\text { відображення необо- } \\
\text { ротних активів та груп } \\
\text { вибуття, утримуваних } \\
\text { Аля продажу) }\end{array}$ \\
\hline $\begin{array}{l}\text { у тому числі } \\
\text { готова про- } \\
\text { Аукція }\end{array}$ & 1103 & $\begin{array}{l}\text { готова продукція, у якій на- } \\
\text { водять собівартість виро- } \\
\text { бів на склаАі, обробка яких } \\
\text { закінчена та які пройшли } \\
\text { випробування, прийман- } \\
\text { ня, укомплектовані згіАно } \\
\text { з умовами Аоговорів із за- } \\
\text { мовниками та віАповіАають } \\
\text { технічним умовам і стандар- } \\
\text { там, сільськогосподарська } \\
\text { продукція в оцінці, визна- } \\
\text { ченій віАповіАно Ао П(С) } \\
\text { БО зо, а такожк наводять } \\
\text { купівельну вартість товарів, } \\
\text { придбаних підприємствами } \\
\text { Аля подальшого продажу }\end{array}$ & $\begin{array}{l}\text { Ат субрахунків рахунка: } \\
26 \text { "Готова продукція»; } \\
27 \text { "Продукція сільсько- } \\
\text { господарського виробни- } \\
\text { цтва»; } \\
28 \text { "Товари" }\end{array}$ & $\begin{array}{l}\text { Ат рахунка: } \\
26 \text { «Готова продук- } \\
\text { ція" (крім субрахунку, } \\
\text { призначеного Аля } \\
\text { відображення необо- } \\
\text { ротних активів і груп } \\
\text { вибуття, утримуваних } \\
\text { Аля продажу) }\end{array}$ \\
\hline
\end{tabular}


Продовження таблиці 9.2

\begin{tabular}{|c|c|c|c|c|}
\hline \multirow[b]{2}{*}{ Назва статті } & \multirow[b]{2}{*}{$\begin{array}{c}\text { КоА } \\
\text { ряАка }\end{array}$} & \multirow{2}{*}{$\begin{array}{c}\text { Ао скмаАу суми віАповіАної } \\
\text { статті потрап^яє: }\end{array}$} & \multicolumn{2}{|c|}{ СамьАо віАповіАного рахунка (субрахунку) } \\
\hline & & & $\begin{array}{c}\text { За загальним } \\
\text { планом рахунків }\end{array}$ & $\begin{array}{c}\text { За спрощеним } \\
\text { планом рахунків }\end{array}$ \\
\hline $\begin{array}{l}\text { Поточні біоло- } \\
\text { гічні активи }\end{array}$ & 1110 & $\begin{array}{l}\text { вартість поточних біологіч- } \\
\text { них активів тваринництва } \\
\text { (Аорослі тварини на віАго- } \\
\text { Аівлі та в нагулі, птиця, зві- } \\
\text { рі, кролі, Аорослі тварини, } \\
\text { вибракувані з основного } \\
\text { стада Аля реалізації, молол- } \\
\text { няк тварин на вирощуванні } \\
\text { та віАгоАівлі), а також рос- } \\
\text { линництва (зернові, техніч- } \\
\text { ні, овочеві й інші культури), } \\
\text { облік яких веАуть віАповіА- } \\
\text { но до П(С)БО ЗО }\end{array}$ & $\begin{array}{l}\text { Ат субрахунку: } \\
211 \text { «Поточні біологічні } \\
\text { активи рослинництва, які } \\
\text { оцінені за справедливою } \\
\text { вартістю»; } \\
212 \text { «Поточні біологічні } \\
\text { активи тваринництва, які } \\
\text { оцінені за справедливою } \\
\text { вартістю"; } \\
213 \text { «Поточні біологічні } \\
\text { активи тваринництва, } \\
\text { які оцінені за первісною } \\
\text { вартістю" }\end{array}$ & $\begin{array}{l}\text { Ат рахунка: } \\
21 \text { "Поточні біологічні } \\
\text { активи" }\end{array}$ \\
\hline $\begin{array}{l}\text { Аебіторська } \\
\text { заборгова- } \\
\text { ність за това- } \\
\text { ри, роботи, } \\
\text { послуги }\end{array}$ & 1125 & $\begin{array}{l}\text { заборгованість покупців або } \\
\text { замовників за реалізовану } \\
\text { їм продукцію, товари, робо- } \\
\text { ти чи послуги, включаючи } \\
\text { забезпечену векселями за- } \\
\text { боргованість, скориговану } \\
\text { на резерв сумнівних боргів } \\
\text { (див. примітки } 6 \text { та 7) }\end{array}$ & $\begin{array}{l}\text { Ат субрахунків рахунка: } \\
34 \text { "Короткострокові век- } \\
\text { селі одержані»; } \\
36 \text { "Розрахунки з покуп- } \\
\text { цями та замовниками"; } \\
37 \text { "Розрахунки з різними } \\
\text { дебіторами" мінус Кт } 38 \\
\text { "Резерв сумнівних боргів" }\end{array}$ & $\begin{array}{l}\text { Ат рахунка: } \\
37 \text { "Розрахунки } 3 \text { різ- } \\
\text { ними Аебіторами" } \\
\text { (крім субрахунку ре- } \\
\text { зерву сумнівних бор- } \\
\text { гів) мінус Кт } 37 \text { (на } \\
\text { якому обліковують ре- } \\
\text { зерв сумнівних боргів) }\end{array}$ \\
\hline
\end{tabular}

Примітка 6. Величину резерву сумнівних боргів визначають за одним із методів:

1) застосування абсолютної суми сумнівної заборгованості;

2) застосування коефіцієнта сумнівності (п. 8 П(С)БО 10 "Аебіторська заборгованість").

Примітка 7. Виключення безнадійної дебіторської заборгованості з активів зАійснюють з одночасним зменшенням величини резерву сумнівних боргів. У разі недостатності суми нарахованого резерву сумнівних боргів безнадійну дебіторську заборгованість списують з активів на інші операційні витрати. Сума відшкодування раніше списаної безнадійної дебіторської заборгованості входить до складу інших опера-

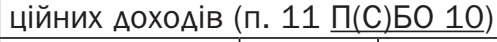

\begin{tabular}{|c|c|c|c|c|}
\hline $\begin{array}{l}\text { Аебіторська } \\
\text { заборго- } \\
\text { ваність за } \\
\text { розрахунками } \\
\text { з бюджетом }\end{array}$ & 1135 & $\begin{array}{l}\text { визнана дебіторська забор- } \\
\text { гованість казначейських, } \\
\text { фінансових і податкових } \\
\text { органів, державних цільо- } \\
\text { вих фондів, зокрема за } \\
\text { розрахунками з тимчасової } \\
\text { непрацездатності }\end{array}$ & 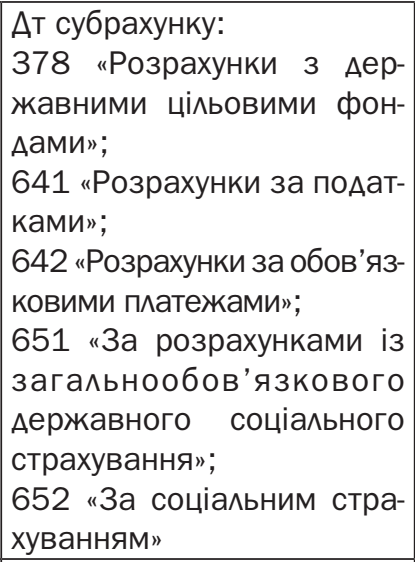 & $\begin{array}{l}\text { Ат рахунка: } \\
64 \text { «Розрахунки за } \\
\text { податками й плате- } \\
\text { жами» }\end{array}$ \\
\hline $\begin{array}{l}\text { у тому числі } \\
3 \text { податку на } \\
\text { прибуток }\end{array}$ & 1136 & $\begin{array}{l}\text { Аебіторську заборгованість } \\
\text { із податку на прибуток у } \\
\text { звіті наводять окремо }\end{array}$ & $\begin{array}{l}\text { Ат субрахунку: } \\
641 \text { (віАповіАний субра- } \\
\text { хунок) }\end{array}$ & $\begin{array}{l}\text { Ат рахунка: } \\
64 \text { (віАповіАний субра- } \\
\text { хунок) }\end{array}$ \\
\hline $\begin{array}{l}\text { Інша поточна } \\
\text { дебіторська } \\
\text { заборгова- } \\
\text { ність }\end{array}$ & 1155 & $\begin{array}{l}\text { заборгованість дебіторів, } \\
\text { яка не включена до інших } \\
\text { статей дебіторської забор- } \\
\text { гованості, скоригована на } \\
\text { резерв сумнівних боргів } \\
\text { (нетто), і яку відображають } \\
\text { у складі оборотних активів }\end{array}$ & $\begin{array}{l}\text { Ат субрахунків рахунка: } \\
37 \text { «Розрахунки з різними } \\
\text { Аебіторами» (крім субра- } \\
\text { хунку 378); } \\
66 \text { «Розрахунки за випла- } \\
\text { тами працівникам»; } \\
68 \text { «Розрахунки за інши- } \\
\text { ми операціями»; }\end{array}$ & $\begin{array}{l}\text { Ат рахунка: } \\
37 \text { «Розрахунки з } \\
\text { різними дебіторами» } \\
\text { (окрім короткостроко- } \\
\text { вих векселів і резерву } \\
\text { сумнівних боргів); }\end{array}$ \\
\hline
\end{tabular}


Продовження таблиці 9.2

\begin{tabular}{|c|c|c|c|c|}
\hline \multirow{3}{*}{ Назва статті } & \multirow{3}{*}{$\begin{array}{c}\text { КоА } \\
\text { ряАКа }\end{array}$} & \multirow{3}{*}{$\begin{array}{c}\text { Ао ск^аАу суми віАповіАної } \\
\text { статті потрап^яє: }\end{array}$} & \multicolumn{2}{|c|}{ СамьАо віАПовіАного рахунка (субрахунку) } \\
\hline & & & $\begin{array}{c}\text { За загамьним } \\
\text { пманом рахунків }\end{array}$ & $\begin{array}{c}\text { За спрощеним } \\
\text { планом рахунків }\end{array}$ \\
\hline & & & $\begin{array}{l}654 \text { "За індивідуальним } \\
\text { страхуванням"; } \\
655 \text { "За страхуванням } \\
\text { майна" }\end{array}$ & $\begin{array}{l}64 \text { «Розрахунки за по- } \\
\text { Аатками й платежами»; } \\
66 \text { «Розрахунки } 3 \text { оп- } \\
\text { лати праці»; } \\
68 \text { «Розрахунки за ін- } \\
\text { шими операціями» }\end{array}$ \\
\hline $\begin{array}{l}\text { Поточні фінан- } \\
\text { сові інвестиції }\end{array}$ & 1160 & $\begin{array}{l}\text { фінансові інвестиції на строк, } \\
\text { що не перевищує року, які } \\
\text { можуть бути вільно реалізова- } \\
\text { ні в будь-який момент (окрім } \\
\text { інвестицій, що є еквівалента- } \\
\text { ми грошових коштів) }\end{array}$ & $\begin{array}{l}\text { Ат субрахунку: } \\
352 \text { «нші поточні фрінан- } \\
\text { сові інвестиції» }\end{array}$ & $\begin{array}{l}\text { Ат рахунка: } \\
35 \text { «Поточні фінансові } \\
\text { інвестиції» }\end{array}$ \\
\hline $\begin{array}{l}\text { Гроші та їх } \\
\text { еквіваленти: }\end{array}$ & 1165 & $\begin{array}{l}\text { готівка в касі піАприємства, } \\
\text { гроші на поточних й інших } \\
\text { рахунках у банках, які мо- } \\
\text { жуть бути вільно використані } \\
\text { Аля поточних операцій, а та- } \\
\text { кож грошові кошти в Аорозі, } \\
\text { електронні гроші (Аив. при- } \\
\text { мітку 8), еквіваленти грошей. } \\
\text { У цій статті наводять кошти в } \\
\text { національній або іноземних } \\
\text { валютах. Кошти, які не мож- } \\
\text { на використати Аля операцій } \\
\text { протягом року, починаючи з } \\
\text { Аати балансу, або протягом } \\
\text { операційного циклу внаслі- } \\
\text { Аок обмежень, викюючають } \\
\text { зі складу оборотних активів і } \\
\text { відображають як необоротні } \\
\text { активи }\end{array}$ & $\begin{array}{l}\text { Ат рахунків: } \\
30 \text { «Готівка»; } \\
31 \text { «Рахунки в банках»; } \\
\text { 33З «Грошові кошти в } \\
\text { Аорозі в національній } \\
\text { валюті»; } \\
334 \text { «Грошові кошти в Ао- } \\
\text { розі в іноземній валюті»; } \\
\text { 335«Електронні гроші, } \\
\text { номіновані в національній } \\
\text { ва^юті»; } \\
\text { 351 Еквіваленти грошо- } \\
\text { вих коштів» (у нацвалюті } \\
\text { та іноземній валюті) }\end{array}$ & $\begin{array}{l}\text { Ат рахунка: } \\
30 \text { "Готівка"; } \\
31 \text { «Рахунки в банках" }\end{array}$ \\
\hline \multicolumn{5}{|c|}{$\begin{array}{l}\text { Примітка 8. Електронні гроші - одиниці вартості, які зберігають на електронному пристрої, приймають } \\
\text { як засіб платежу іншими особами, ніж особа, яка їх випускає, і є грошовим зобов'язанням такої особи, } \\
\text { що виконується в готівковій або безготівковій формі. Водночас із метою бухгалтерського обліку не ви- } \\
\text { знають електронними грошима наперед оплачені картки одноцільового використання: Аисконтні картки } \\
\text { торговців, картки автозаправних станцій, квитки Аля проїзду в міському транспорті тощо, які прийма- } \\
\text { ють як засіб платежу мише їх емітентами }\end{array}$} \\
\hline $\begin{array}{l}\text { Витрати май- } \\
\text { бутніх періодів }\end{array}$ & 1170 & \begin{tabular}{|l|} 
витрати, що мали місце \\
протягом поточного або \\
попередніх звітних періодів, \\
але належать Ао наступних \\
звітних періодів
\end{tabular} & Ат 39 «Витрати майбутніх г & теріодів" \\
\hline $\begin{array}{l}\text { Інші оборотні } \\
\text { активи }\end{array}$ & 1190 & $\begin{array}{l}\text { суми оборотних активів, які } \\
\text { не вкюючені до згаданих } \\
\text { вище статей розділу “Обо- } \\
\text { ротні активи». } \\
\text { У цій статті наводять, } \\
\text { зокрема, вартість грошо- } \\
\text { вих документів і сальдо } \\
\text { субрахунку } 643 \text { "Податкові } \\
\text { зобов'язання" }\end{array}$ & $\begin{array}{l}\text { Ат субрахунку: } \\
\text { 331 «Грошові Аокументи } \\
\text { в національній валюті»; } \\
\text { 332 «Грошові Аокументи } \\
\text { в іноземній валюті»; } \\
643 \text { «Податкові зобов”я- } \\
\text { зання» }\end{array}$ & $\begin{array}{l}\text { Ат рахунка: } \\
\text { 30 "Каса» (у частині } \\
\text { субрахунку, на якому } \\
\text { ведуть облік грошо- } \\
\text { вих документів); } \\
64 \text { «Розрахунки за } \\
\text { податками й плате- } \\
\text { жами» }\end{array}$ \\
\hline
\end{tabular}


Продовження таблиці 9.2

\begin{tabular}{|c|c|c|c|c|}
\hline \multirow[b]{2}{*}{ Назва статті } & \multirow[b]{2}{*}{$\begin{array}{c}\text { КоА } \\
\text { ряАКа }\end{array}$} & \multirow{2}{*}{$\begin{array}{c}\text { Ао ск^аАу суми віАповіАної } \\
\text { статті потрап^яє: }\end{array}$} & \multicolumn{2}{|c|}{ СамьАо віАповіАного рахунка (субрахунку) } \\
\hline & & & $\begin{array}{c}\text { За загамьним } \\
\text { пманом рахунків }\end{array}$ & $\begin{array}{c}\text { За спрощеним } \\
\text { планом рахунків }\end{array}$ \\
\hline & & & & $\begin{array}{l}\text { (у частині субрахунку, на } \\
\text { якому ведуть облік по- } \\
\text { Ааткових зобов'язань) }\end{array}$ \\
\hline $\begin{array}{l}\text { Усього за } \\
\text { розАілом II }\end{array}$ & 1195 & \multicolumn{3}{|c|}{ Сума рядків 1100, 1110, 1125, 1135, 1160, 1165, 1170, 1190} \\
\hline \multicolumn{5}{|c|}{ III. Необоротні активи, утримувані А^я продажу, та групи вибуття } \\
\hline $\begin{array}{l}\text { Необоротні } \\
\text { активи, утри- } \\
\text { мувані А^я } \\
\text { продажу, та } \\
\text { групи вибуття }\end{array}$ & 1200 & \begin{tabular}{|l|} 
вартість необоротних \\
активів і груп вибуття, які \\
утримують Аля продажу, що \\
визначається віАповіАно Ао \\
П(С)БО 27 "Необоротні акти- \\
ви, утримувані Аля продажу, \\
та припинена Аіяльність" \\
\end{tabular} & $\begin{array}{l}\text { Ат рахунка: } \\
286 \text { "Необоротні активи } \\
\text { та групи вибуття, утриму- } \\
\text { вані А^я продажу" }\end{array}$ & $\begin{array}{l}\text { Ат рахунка: } \\
26 \text { «Готова продукція» } \\
\text { (у частині субрахунку, } \\
\text { на якому ведуть облік } \\
\text { необоротних активів і } \\
\text { груп вибуття) }\end{array}$ \\
\hline Баланс & 1300 & \multicolumn{3}{|l|}{ Сума рялків 1095, 1195, 1200} \\
\hline \multicolumn{5}{|c|}{ ПАСИВ } \\
\hline \multicolumn{5}{|c|}{ I. В^асний капіта^ } \\
\hline $\begin{array}{l}\text { Зареєстрова- } \\
\text { ний (пайовий) } \\
\text { капіта^ }\end{array}$ & 1400 & \begin{tabular}{|l|} 
зафіксована в установчих \\
документах сума статутного \\
капіталу підприємства 3 \\
урахуванням суми внесків \\
Ао оголошеного, але ще не \\
зареєстрованого статутного \\
капіталу (див. примітку 9)
\end{tabular} & $\begin{array}{l}\text { Кт рахунка: } \\
40 \text { “Зареєстрований } \\
\text { пайовий капіта^» }\end{array}$ & $\begin{array}{l}\text { Кт рахунка: } \\
40 \text { «Власний капітал" } \\
\text { (у частині віАповіАно- } \\
\text { го субрахунку) }\end{array}$ \\
\hline
\end{tabular}

Примітка 9. ПіАприємства, А^я яких не передбачена фіксована сума статутного капіталу, відображають у цій статті суму фактичного внеску власників до статутного капіталу підприємства. У цій статті також наводять суму пайового капіталу (пайових внесків) членів споживчого товариства, спілок й інших організацій, внески засновників піАприємства понаА статутний капітал

\begin{tabular}{|c|c|c|c|c|}
\hline $\begin{array}{l}\text { Аодатковий } \\
\text { капітал }\end{array}$ & 1410 & $\begin{array}{l}\text { 1) сума Аооцінки необорот- } \\
\text { них активів; } \\
\text { 2) вартість безоплатно отри- } \\
\text { маних піАприємством віА ін- } \\
\text { ших юр- або фізосіб необо- } \\
\text { ротних активів; } \\
\text { 3) інші види Аодаткового ка- } \\
\text { піталу; } \\
\text { 4) сума пайового капіталу } \\
\text { (пайових внесків) членів спо- } \\
\text { живчого товариства, спілок } \\
\text { й інших організацій; } \\
\text { 5) внески засновників піА- } \\
\text { приємства понаА статутний } \\
\text { капітал }\end{array}$ & $\begin{array}{l}\text { Кт рахунка: } \\
41 \text { “Капіта^ в Аооцінках»; } \\
42 \text { "Аодатковий капіта^" }\end{array}$ & $\begin{array}{l} \\
\text { Кт рахунка: } \\
40 \text { “Власний капіта^» } \\
\text { (у частині субрахунку, } \\
\text { на якому обліковують } \\
\text { Аодатковий капітал) }\end{array}$ \\
\hline $\begin{array}{l}\text { Резервний } \\
\text { капітал }\end{array}$ & 1415 & $\begin{array}{l}\text { сума резервів, створених } \\
\text { віАповіАно до законо- } \\
\text { Аавства або установчих } \\
\text { документів за рахунок } \\
\text { нерозподіленого прибутку } \\
\text { підприємства }\end{array}$ & $\begin{array}{l}\text { Кт рахунка: } \\
43 \text { "Резервний капітал" }\end{array}$ & $\begin{array}{l}\text { Кт рахунка: } \\
40 \text { «Власний капіта^" } \\
\text { (у частині субрахунку, } \\
\text { на якому обліковують } \\
\text { резервний капітал) }\end{array}$ \\
\hline
\end{tabular}


Продовження таблиці 9.2

\begin{tabular}{|c|c|c|c|c|}
\hline \multirow[b]{2}{*}{ Назва статті } & \multirow[b]{2}{*}{$\begin{array}{c}\text { КоА } \\
\text { ряАКа }\end{array}$} & \multirow{2}{*}{$\begin{array}{c}\text { Ао ск^аАу суми віАповіАної } \\
\text { статті потрап^яє: }\end{array}$} & \multicolumn{2}{|c|}{ Са^ьАо віАПовіАного рахунка (субрахунку) } \\
\hline & & & $\begin{array}{c}\text { За загамьним } \\
\text { пманом рахунків }\end{array}$ & $\begin{array}{c}\text { За спрощеним } \\
\text { планом рахунків }\end{array}$ \\
\hline $\begin{array}{l}\text { НерозпоАіме- } \\
\text { ний прибуток } \\
\text { (непокритий } \\
\text { збиток) }\end{array}$ & 1420 & $\begin{array}{l}\text { сума нерозподіленого } \\
\text { прибутку чи непокритого } \\
\text { збитку. } \\
\text { Суму непокритого збитку } \\
\text { наводять у дужках і вирахо- } \\
\text { вують піА час визначення } \\
\text { підсумку власного капіталу }\end{array}$ & $\begin{array}{l}\text { Кт субрахунку: } \\
441 \text { «Прибуток нерозподі- } \\
\text { лений» } \\
\text { або } \\
\text { Ат субрахунку: } \\
442 \text { “Непокриті збитки" }\end{array}$ & $\begin{array}{l}\text { Кт або Ат рахунка: } \\
44 \text { "Нерозподілені } \\
\text { прибутки (непокриті } \\
\text { збитки)" }\end{array}$ \\
\hline
\end{tabular}

Примітка 10. У першому місяці року переходу на застосування НП(С)БО 25 сальАо рахунків 17 «ВіАстрочені податкові активи" і 54 “ВіАстрочені податкові зобов'язання" піАлягає згортанню взаємною кореспонАенцією цих рахунків із відображенням різниці на рахунку 44“Нерозподілені прибутки (непокриті збитки)"

\begin{tabular}{|c|c|c|c|c|}
\hline $\begin{array}{l}\text { Неоп^ачений } \\
\text { капітал }\end{array}$ & 1425 & $\begin{array}{l}\text { сума заборгованості власни- } \\
\text { ків (учасників) за внесками } \\
\text { Ао статутного капіталу. } \\
\text { Суми за цією статтею вира- } \\
\text { ховують піА час визначення } \\
\text { підсумку власного капіталу } \\
\text { (наводять у дужках) (Аив. } \\
\text { примітку 11) }\end{array}$ & $\begin{array}{l}\text { Кт рахунка: } \\
46 \text { «Неоплачений капіта^» } \\
\text { Кт субрахунку: } \\
451 \text { «Вилучені акції»; } \\
452 \text { «Вилучені вклади й } \\
\text { паї»; } \\
453 \text { “нший вилучений } \\
\text { капітал" }\end{array}$ & $\begin{array}{l}\text { Кт рахунка: } \\
40 \text { "Власний капіта^" } \\
\text { (у частині субрахунку, } \\
\text { на якому обліковують } \\
\text { неоплачений та вилу- } \\
\text { чений капітал) }\end{array}$ \\
\hline
\end{tabular}

Примітка 11. Господарські товариства у цій статті також відображають вилучений капітал, тобто фактичну собівартість часток, викуплених у своїх учасників. Аержавні (казенні) та комунальні піАприємства - передання майна віАповіАно до Положення про порядок бухгалтерського обліку окремих активів та операцій підприємств Аержавного, комунального секторів економіки та господарських організацій, які володіють та/або користуються об'єктами державної, комунальної власності, затвердженого наказом Мінфіну України віА 19.12.2006 р. № 1213

\begin{tabular}{|c|c|c|c|c|}
\hline $\begin{array}{l}\text { Усього } \\
\text { за розАілом I }\end{array}$ & 1495 & \multicolumn{3}{|c|}{ Сума рядків 1400, 1410, 1415 (+/-) 1420 (-) 1425} \\
\hline \multicolumn{5}{|c|}{ II. Аовгострокові зобов'язання, цільове фінансування та забезпечення } \\
\hline $\begin{array}{l}\text { Аовгострокові } \\
\text { зобов'язання, } \\
\text { цільове фі- } \\
\text { нансування та } \\
\text { забезпечення }\end{array}$ & 1595 & $\begin{array}{l}\text { 1) сума заборгованості } \\
\text { підприємства банкам за } \\
\text { отримані віА них кредити, } \\
\text { яка не є поточним зобов'я- } \\
\text { занням; } \\
\text { 2) сума довгострокової за- } \\
\text { боргованості піАприємства } \\
\text { за зобов'язаннями щодо } \\
\text { залучення позикових коштів } \\
\text { (окрім кредитів банків), на } \\
\text { які нараховують відсотки, } \\
\text { та за іншими довгостроко- } \\
\text { вими зобов'язаннями (Аив. } \\
\text { примітку 12) }\end{array}$ & 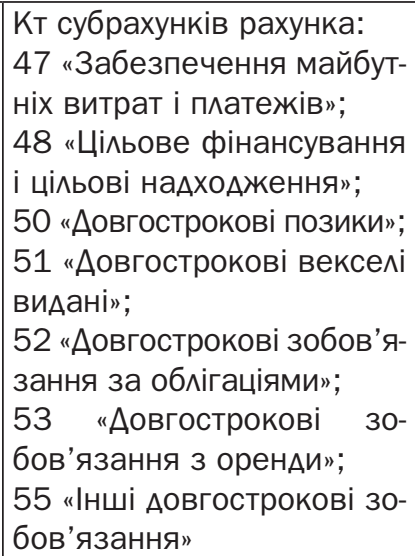 & $\begin{array}{l}\text { Кт рахунка: } \\
47 \text { «Забезпечення } \\
\text { майбутніх витрат і } \\
\text { платежів»; } \\
48 \text { «Цільове фінансу- } \\
\text { вання і цільові надхо- } \\
\text { Аження»; } \\
55 \text { «Інші Аовгостроко- } \\
\text { ві зобов"язання" }\end{array}$ \\
\hline
\end{tabular}

Примітка 12. У цьому розАілі відображають суму залишку коштів цільового фінансування та цільових надходжень, які отримані з бюАжету й інших джерел, у т.ч. коштів, вивільнених віА оподаткування у зв'язку з наданням пільг із податку на прибуток піАприємств, а також суми забезпечення А^я віАшкодування наступних витрат і платежів (на виплату віАпусток працівникам, виконання гарантійних зобов'язань тощо)

\begin{tabular}{|c|c|c|c|c|}
\hline \multicolumn{5}{|c|}{ III. Поточні зобов'язання } \\
\hline $\begin{array}{l}\text { Короткостро- } \\
\text { кові кредити } \\
\text { банків }\end{array}$ & 1600 & $\begin{array}{l}\text { сума поточних зобов'язань } \\
\text { підприємства перед банка- } \\
\text { ми щодо отриманих віА них } \\
\text { короткострокових позик. }\end{array}$ & $\begin{array}{l}\text { Кт субрахунків рахунка: } \\
60 \text { «Короткострокові } \\
\text { позики»; } \\
684 \text { «Розрахунки за нара- } \\
\text { хованими віАсотками» (у }\end{array}$ & $\begin{array}{l}\text { Кт рахунка: } \\
68 \text { «Розрахунки за } \\
\text { іншими операціями» } \\
\text { (у частині }\end{array}$ \\
\hline
\end{tabular}


Продовження таблиці 9.2

\begin{tabular}{|c|c|c|c|c|}
\hline \multirow{3}{*}{ Назва статті } & \multirow{3}{*}{$\begin{array}{c}\text { КоА } \\
\text { ряАКа }\end{array}$} & \multirow{3}{*}{$\begin{array}{l}\begin{array}{c}\text { Ао склалу суми віАповіАної } \\
\text { статті потрапмяє: }\end{array} \\
\text { Зобов'язання за кредитами } \\
\text { банків наводять у балансі } \\
\text { з урахуванням належної на } \\
\text { кінець звітного періоду Ао } \\
\text { сплати суми процентів за їх } \\
\text { користування }\end{array}$} & \multicolumn{2}{|c|}{ СамьАо віАповіАного рахунка (субрахунку) } \\
\hline & & & $\begin{array}{c}\text { За загамьним } \\
\text { пманом рахунків }\end{array}$ & $\begin{array}{c}\text { За спрощеним } \\
\text { пханом рахунків }\end{array}$ \\
\hline & & & $\begin{array}{l}\text { частині нарахованих бан- } \\
\text { ківських віАсотків) }\end{array}$ & $\begin{array}{l}\text { субрахунку, на якому } \\
\text { обліковують корот- } \\
\text { кострокові кредити } \\
\text { (позики) і відсотки за } \\
\text { ними) }\end{array}$ \\
\hline $\begin{array}{l}\text { Поточна } \\
\text { кредиторська } \\
\text { заборгованість } \\
\text { за: Аовгостро- } \\
\text { ковими зо- } \\
\text { бов'язаннями }\end{array}$ & 1610 & $\begin{array}{l}\text { суми зобов'язань, що утво- } \\
\text { рилися як Аовгострокові, } \\
\text { але з дати балансу піАляга- } \\
\text { ють погашенню протягом } \\
12 \text { місяців }\end{array}$ & \begin{tabular}{|l|} 
Кт субрахунку: \\
611 «Поточна заборгова- \\
ність за Аовгостроковими \\
зобов'язаннями в націо- \\
нальній валюті»; \\
612 «Поточна заборгова- \\
ність за Аовгостроковими \\
зобов'язаннями в інозем- \\
ній валюті" \\
\end{tabular} & $\begin{array}{l}\text { Кт рахунка: } \\
68 \text { «Розрахунки за ін- } \\
\text { шими операціями" (у } \\
\text { частині субрахунку, на } \\
\text { якому обліковують по- } \\
\text { точну заборгованість } \\
\text { за Аовгостроковими } \\
\text { зобов'язаннями) }\end{array}$ \\
\hline $\begin{array}{l}\text { товари, робо- } \\
\text { ти, послуги }\end{array}$ & 1615 & $\begin{array}{l}\text { 1) сума заборгованості } \\
\text { постачальникам і пілрянни- } \\
\text { кам за матеріальні цінності, } \\
\text { виконані роботи й отримані } \\
\text { послуги, включаючи за- } \\
\text { боргованість, забезпечену } \\
\text { векселями, } \\
\text { 2) сума заборгованості } \\
\text { постачальникам за невіА- } \\
\text { фактуровані постачання } \\
\text { й розрахунки з наАлишку } \\
\text { товарно-матеріальних цін- } \\
\text { ностей, який установлено } \\
\text { піА час їх приймання }\end{array}$ & $\begin{array}{l}\text { Кт субрахунку: } \\
621 \text { «Короткострокові } \\
\text { векселі, вилані в націо- } \\
\text { нальній валюті»; } \\
622 \text { "Короткострокові } \\
\text { векселі, видані в інозем- } \\
\text { ній валюті»; } \\
631 \text { «Розрахунки з вітчиз- } \\
\text { няними постачальниками»; } \\
632 \text { “Розрахунки з інозем- } \\
\text { ними постачальниками»; } \\
633 \text { "Розрахунки з учас- } \\
\text { никами ПФГ" }\end{array}$ & $\begin{array}{l}\text { Кт рахунка: } \\
68 \text { «Розрахунки за } \\
\text { іншими операціями» } \\
\text { (у частині субрахунку, } \\
\text { на якому обліковують } \\
\text { кредиторську забор- } \\
\text { гованість за товари, } \\
\text { роботи, послуги) }\end{array}$ \\
\hline $\begin{array}{l}\text { розрахунками } \\
\text { з бюджетом }\end{array}$ & 1620 & $\begin{array}{l}\text { заборгованість підпри- } \\
\text { ємства за всіма видами } \\
\text { платежів до бюджету, } \\
\text { вк^ючаючи суму податку з } \\
\text { працівників підприємства }\end{array}$ & $\begin{array}{l}\text { Кт субрахунку: } \\
641 \text { "Розрахунки за по- } \\
\text { Аатками»; } \\
642 \text { "Розрахунки за обо- } \\
\text { в’язковими платежами» }\end{array}$ & $\begin{array}{l}\text { Кт рахунка: } \\
64 \text { "Розрахунки за } \\
\text { податками й платежа- } \\
\text { ми" (у частині субра- } \\
\text { хунку, на якому облі- } \\
\text { ковують кредиторську } \\
\text { заборгованість за } \\
\text { розрахунками з бю- } \\
\text { джетом) }\end{array}$ \\
\hline $\begin{array}{l}\text { у тому числі } \\
3 \text { податку на } \\
\text { прибуток }\end{array}$ & 1621 & $\begin{array}{l}\text { У цій статті окремо наво- } \\
\text { Аять поточну кредиторська } \\
\text { заборгованість із податку } \\
\text { на прибуток }\end{array}$ & $\begin{array}{l}\text { Кт субрахунку: } \\
641 \text { «Розрахунки за } \\
\text { податками” (у частині } \\
\text { податку на прибуток) }\end{array}$ & $\begin{array}{l}\text { Кт рахунка: } \\
64 \text { «Розрахунки за } \\
\text { податками й платежа- } \\
\text { ми» (у частині податку } \\
\text { на прибуток) } \\
\end{array}$ \\
\hline \multicolumn{5}{|c|}{ Примітка 13. Рялок 1621 не бере участі в розрахунку піАсумкової суми по р. III } \\
\hline $\begin{array}{l}\text { розрахунками } \\
\text { зі страхування }\end{array}$ & 1625 & $\begin{array}{l}\text { заборгованість переА фон- } \\
\text { Аами загальнообов'язково- } \\
\text { го Аержавного соціального, } \\
\text { індивідуального страхування } \\
\text { та страхування майна }\end{array}$ & $\begin{array}{l}\text { Кт субрахунків рахунка: } \\
65 \text { "Розрахунки за страху- } \\
\text { ванням" }\end{array}$ & $\begin{array}{l}\text { Кт рахунка: } \\
64 \text { «Розрахунки за } \\
\text { податками й пла- } \\
\text { тежами» (у частині } \\
\text { субрахунків, на яких } \\
\text { обліковують }\end{array}$ \\
\hline
\end{tabular}


Продовження таблиці 9.2

\begin{tabular}{|c|c|c|c|c|}
\hline \multirow[b]{2}{*}{ Назва статті } & \multirow[b]{2}{*}{$\begin{array}{c}\text { КоА } \\
\text { ряАКа }\end{array}$} & \multirow[b]{2}{*}{$\begin{array}{c}\text { Ао ск^аАу суми віАповіАної } \\
\text { статті потрап^яє: }\end{array}$} & \multicolumn{2}{|c|}{ СамьАо віАповіАного рахунка (субрахунку) } \\
\hline & & & $\begin{array}{c}\text { За загамьним } \\
\text { планом рахунків }\end{array}$ & $\begin{array}{c}\text { За спрощеним } \\
\text { пманом рахунків }\end{array}$ \\
\hline & & & & $\begin{array}{l}\text { кредиторську заборго- } \\
\text { ваність із соціального } \\
\text { страхування, страху- } \\
\text { вання на випадок без- } \\
\text { робіття, індивідуаль- } \\
\text { ного страхування та } \\
\text { страхування майна) }\end{array}$ \\
\hline $\begin{array}{l}\text { розрахунками } \\
\text { з оплати праці }\end{array}$ & 1630 & $\begin{array}{l}\text { заборгованість за нарахова- } \\
\text { ною, але не виплаченою, а } \\
\text { також депонованою зарп- } \\
\text { латою }\end{array}$ & $\begin{array}{l}\text { Кт субрахунків рахунка: } \\
66 \text { «Розрахунки за випла- } \\
\text { тами працівникам» }\end{array}$ & $\begin{array}{l}\text { Кт рахунка: } \\
66 \text { «Розрахунки } 3 \\
\text { оплати праці" }\end{array}$ \\
\hline
\end{tabular}

Примітка 14. Заборгованість працівників переА підприємством за операціями з оплати праці наводять у статті «нша поточна дебіторська заборгованість" (рядок 1155)

\begin{tabular}{|c|c|c|c|c|}
\hline $\begin{array}{l}\text { Аоходи май- } \\
\text { бутніх періодів }\end{array}$ & 1665 & $\begin{array}{l}\text { зобов'язання, пов'язані з } \\
\text { необоротними активами } \\
\text { та групами вибуття, які } \\
\text { утримують Аля продажу, що } \\
\text { визначають віАповіАно до } \\
\text { НП(С)БО } 27 \\
\end{array}$ & $\begin{array}{l}\text { Кт рахунка: } \\
69 \text { “Аоходи майбутніх } \\
\text { періодів» }\end{array}$ & $\begin{array}{l}\text { Кт рахунка: } \\
69 \text { "Аоходи майбутніх } \\
\text { періодів" }\end{array}$ \\
\hline $\begin{array}{l}\text { Інші поточні } \\
\text { зобов'язання }\end{array}$ & 1690 & $\begin{array}{l}\text { суми зобов'язань, які не вхо- } \\
\text { Аять до інших статей, наве- } \\
\text { Аених у розділі "Поточна кре- } \\
\text { Аиторська заборгованість", } \\
\text { зокрема: заборгованість за } \\
\text { одержаними авансами, за- } \\
\text { боргованість засновникам } \\
\text { у зв'язку з розподілом при- } \\
\text { бутку, заборгованість пов'я- } \\
\text { заним сторонам, сальдо су- } \\
\text { брахунку 644 "Податковий } \\
\text { кредит", сума валової забор- } \\
\text { гованості замовникам за бу- } \\
\text { Аівельними контрактами }\end{array}$ & $\begin{array}{l}\text { Кт субрахунку: } \\
671 \text { "Розрахунки за нара- } \\
\text { хованими дивідендами»; } \\
672 \text { «Розрахунки за інши- } \\
\text { ми виплатами»; } \\
372 \text { «Розрахунки з піА- } \\
\text { звітними особами»; } \\
681 \text { "Розрахунки за аван- } \\
\text { сами одержаними»; } \\
682 \text { «Внутрішні розрахунки»; } \\
683 \text { "Внутрішньогоспо- } \\
\text { Аарські розрахунки»; } \\
685 \text { «Розрахунки з інши- } \\
\text { ми кредиторами»; } \\
644 \text { «Податковий кредит» }\end{array}$ & $\begin{array}{l}\text { Кт рахунків: } \\
\text { 37 "Розрахунки з різ- } \\
\text { ними Аебіторами" (у } \\
\text { частині розрахунків із } \\
\text { піАзвітними особами); } \\
64 \text { "Розрахунки за } \\
\text { податками й платежа- } \\
\text { ми» (у частині подат- } \\
\text { кового кредиту); } \\
68 \text { "Розрахунки за } \\
\text { іншими операціями" } \\
\text { (у частині віАповіАних } \\
\text { субрахунків) }\end{array}$ \\
\hline $\begin{array}{l}\text { Усього } \\
\text { за розАілом III }\end{array}$ & 1695 & \multicolumn{3}{|c|}{ Сума рялків 1600, 1610, 1615, 1620, 1625, 1630, 1665, 1690} \\
\hline \multicolumn{5}{|c|}{$\begin{array}{c}\text { PозАі^ IV. Зобов'язання, пов'язані з необоротними активами, } \\
\text { утримуваними А^я проАажу, та групами вибуття }\end{array}$} \\
\hline $\begin{array}{l}\text { Зобов'язання, } \\
\text { пов'язані з } \\
\text { необоротними } \\
\text { активами, } \\
\text { утримуваними } \\
\text { Аля продажу, } \\
\text { та групами } \\
\text { вибуття } \\
\end{array}$ & 1700 & $\begin{array}{l}\text { зобов'язання, пов'язані з } \\
\text { необоротними активами } \\
\text { та групами вибуття, які } \\
\text { утримують Аля продажу, що } \\
\text { визначають віАповіАно Ао } \\
\text { П(С)БО } 27\end{array}$ & $\begin{array}{l}\text { Кт субрахунку: } \\
680 \text { «Розрахунки, пов’я- } \\
\text { зані з необоротними } \\
\text { активами та групами } \\
\text { вибуття, утримуваними } \\
\text { Аля продажу" }\end{array}$ & $\begin{array}{l}\text { Кт рахунків: } \\
68 \text { «Розрахунки за } \\
\text { іншими операціями" } \\
\text { (у частині віАповіАних } \\
\text { субрахунків) }\end{array}$ \\
\hline Баланс & 1900 & \multicolumn{3}{|c|}{ Сума рядків 1495, 1595, 1695, 1700} \\
\hline
\end{tabular}

Ажерело: [6; 49].

Метою склаАання звіту про фінансові результати $є$ наАання користувачам повної, правАивої та неупереАженої інформації про Аоходи, витрати, прибутки та збитки віА Аіямьності піАприємства за звітний період.

Показники звіту наводять у тисячах гривень з оАним десятковим знаком (табл. 9.3). 
Таблиця 9.3

Заповнення звіту про фінансові результати малого піАприємства (ф. № 2-м)

\begin{tabular}{|c|c|c|c|c|c|}
\hline \multirow{2}{*}{ Назва статті } & \multirow{2}{*}{$\begin{array}{l}\text { КоА } \\
\text { ряАКа }\end{array}$} & \multirow{2}{*}{ Зміст статті } & \multicolumn{2}{|c|}{$\begin{array}{c}\text { Ажерело інформації } \\
\text { (оборот за рахунками з початку року) }\end{array}$} & \multirow{2}{*}{$\begin{array}{l}\text { Норма } \\
\text { П(С)Б0 }\end{array}$} \\
\hline & & & $\begin{array}{c}\text { П^ан рахунків } \\
\text { загальний }\end{array}$ & $\begin{array}{l}\text { П^ан рахунків } \\
\text { спрощений }\end{array}$ & \\
\hline $\begin{array}{l}\text { Чистий АохіА } \\
\text { віА реалізації } \\
\text { продукції (то- } \\
\text { варів, робіт, } \\
\text { послуг) }\end{array}$ & 2000 & $\begin{array}{l}\text { АохіА віА реалізації продук- } \\
\text { ції, товарів, робіт і послуг } \\
\text { без непрямих податків і } \\
\text { зборів та інших вираху- } \\
\text { вань із доходу }\end{array}$ & $\begin{array}{l}\text { Оборот за: } \\
\text { Ат } 701 \text { "Інший опе- } \\
\text { раційний АохіА", } 702 \\
\text { "АохіА віА участі в ка- } \\
\text { піталі", 703 "Інші фі- } \\
\text { нансові Аоходи" мінус } \\
\text { оборот за Кт 704«Ви- } \\
\text { рахування з Аоходу" }\end{array}$ & $\begin{array}{l}\text { Оборот за: } \\
\text { Ат 70"Аоходи віА } \\
\text { реалізації» мінус } \\
\text { оборот за Кт } \\
\text { 704 Вирахування } \\
\text { з доходу» }\end{array}$ & 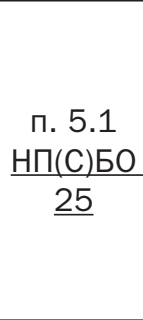 \\
\hline $\begin{array}{l}\text { Інші операцій- } \\
\text { ні Аоходи }\end{array}$ & 2120 & $\begin{array}{l}\text { суми інших Аоходів віА } \\
\text { операційної Аіяльності } \\
\text { підприємства, крім доходу } \\
\text { (виручки) віА реалізації } \\
\text { продукції (товарів, робіт, } \\
\text { послуг) (Аив. примітку 1) }\end{array}$ & $\begin{array}{l}\text { Оборот за: } \\
\text { Ат } 71 \text { "Інший опера- } \\
\text { ційний дохіА" }\end{array}$ & $\begin{array}{l}\text { Оборот за: } \\
\text { Ат } 74 \text { "Інші Ао- } \\
\text { ходи" (у частині } \\
\text { інших операцій- } \\
\text { них доходів) }\end{array}$ & 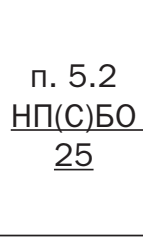 \\
\hline \multicolumn{6}{|c|}{$\begin{array}{l}\text { Примітка 1. Йлеться про: 1) АохіА віА операційної оренди активів; 2) АохіА віА операційних курсових } \\
\text { різниць; 3) віАшкодування раніше списаних активів; 4) дохіА віА реалізації оборотних активів (окрім } \\
\text { фінансових інвестицій), необоротних активів, утримуваних Аля продажу, та груп вибуття тощо. } \\
\text { АохіА віА первісного визнання біологічних активів і сільськогосподарської продукції та АохіА віА зміни } \\
\text { вартості поточних біологічних активів також наводять у цій статті }\end{array}$} \\
\hline Інші АОхоАИ & 2240 & 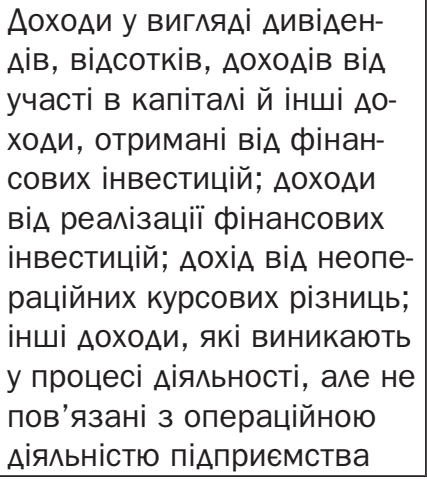 & $\begin{array}{l}\text { Оборот за: } \\
\text { Ат } 72 \text { "Аохід від участі } \\
\text { в капіталі", } 73 \text { "Інші } \\
\text { фінансові Аоходи", } 74 \\
\text { "Інші Аоходи" }\end{array}$ & $\begin{array}{l}\text { Оборот за: } \\
\text { Ат } 74 \text { «Інші Ао- } \\
\text { ходи» (у частині } \\
\text { інших Аоходів) }\end{array}$ & $\begin{array}{c}\pi .5 .3 \\
\mathrm{H}(\mathrm{C}) \mathrm{БO} \\
\underline{25}\end{array}$ \\
\hline Разом Аоходи & 2280 & \multicolumn{4}{|c|}{ Сума рялків $2000+2120+2240$} \\
\hline $\begin{array}{l}\text { Собівартість } \\
\text { реалізованої } \\
\text { продукції (то- } \\
\text { варів, робіт, } \\
\text { послуг) }\end{array}$ & 2050 & $\begin{array}{l}\text { показують виробничу } \\
\text { собівартість реалізованої } \\
\text { продукції (робіт, послуг) } \\
\text { та/або собівартість реа- } \\
\text { ^ізованих товарів, визна- } \\
\text { чену відповідно Ао П(С)БО } \\
\text { 16“Витрати” }\end{array}$ & \begin{tabular}{|l|} 
Оборот за: \\
Кт 901 “Собівартість \\
реалізованої готової \\
продукції», 902 "Собі- \\
вартість реалізованих \\
товарів», 903 “Собі- \\
вартість реалізованих \\
робіт і послуг»
\end{tabular} & $\begin{array}{l}\text { Оборот за: } \\
\text { Кт 90«Собівар- } \\
\text { тість реалізації» }\end{array}$ & $\begin{array}{r}\text { п. } 5.4 \\
\text { НП(С)БО } \\
\underline{25}\end{array}$ \\
\hline
\end{tabular}


Продовження таблиці 9.3

\begin{tabular}{|c|c|c|c|c|c|}
\hline \multirow{2}{*}{ Назва статті } & \multirow{2}{*}{$\begin{array}{l}\text { КоА } \\
\text { ряАКа }\end{array}$} & \multirow{2}{*}{ Зміст статті } & \multicolumn{2}{|c|}{$\begin{array}{c}\text { Ажерело інформації } \\
\text { (оборот за рахунками з початку року) }\end{array}$} & \multirow{2}{*}{$\begin{array}{l}\text { Норма } \\
\text { П(C)Б0 }\end{array}$} \\
\hline & & & $\begin{array}{c}\text { П^ан рахунків } \\
\text { загальний }\end{array}$ & $\begin{array}{l}\text { План рахунків } \\
\text { спрощений }\end{array}$ & \\
\hline $\begin{array}{l}\text { Інші операцій- } \\
\text { ні витрати }\end{array}$ & 2180 & 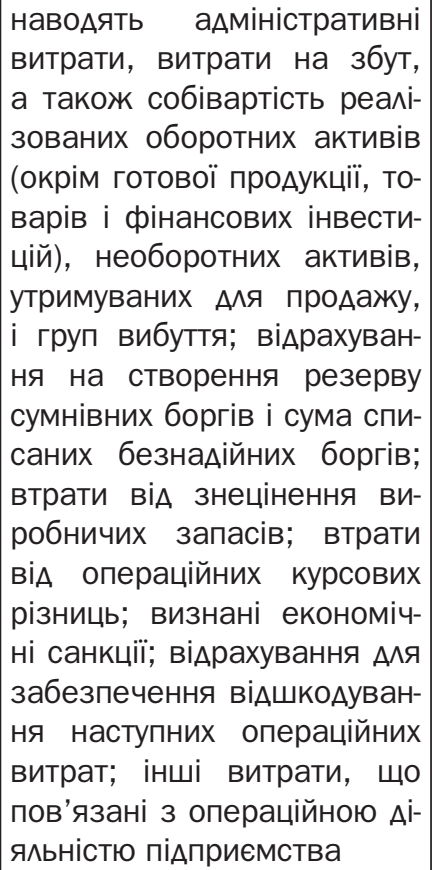 & $\begin{array}{l}\text { Ат рахунка: } \\
\text { 92“ААміністративні } \\
\text { витрати», 93«Витрати } \\
\text { на збут», } 94 \text { «нші } \\
\text { витрати операційної } \\
\text { Аіямьності" }\end{array}$ & $\begin{array}{l}\text { Ат рахунка: } \\
96 \text { "Інші витра- } \\
\text { ти" (віАповіАні } \\
\text { субрахунки) }\end{array}$ & 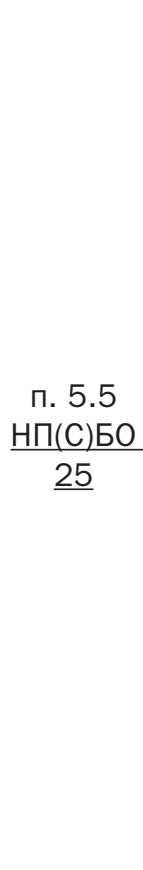 \\
\hline
\end{tabular}

Примітка 3. Аані в рялку 2180 указують у дужках.

Примітка 4. У цій статті також віАображають належну до сплати за звітний період віАповіАно Ао законоАавства суму податків і зборів

\begin{tabular}{|c|c|c|c|c|c|}
\hline Інші витрати & 2270 & $\begin{array}{l}\text { віАображають: } \\
\text { витрати на сплату процентів } \\
\text { й інші витрати підприємства, } \\
\text { пов'язані із запозиченнями; } \\
\text { втрати віА участі в капіталі; } \\
\text { собівартість реалізації фі- } \\
\text { нансових інвестицій; } \\
\text { втрати віА неопераційних } \\
\text { курсових різниць; } \\
\text { втрати віА уцінки фінансо- } \\
\text { вих інвестицій та необорот- } \\
\text { них активів; } \\
\text { інші витрати, які виникають } \\
\text { у процесі Аіяльності, але не } \\
\text { пов'язані з операційною ді- } \\
\text { яльністю підприємства } \\
\end{array}$ & $\begin{array}{l}\text { Ат рахунка: } \\
95 \text { "Фінансові витра- } \\
\text { ти», 96«Втрати віА } \\
\text { участі в капіталі", } \\
\text { 97 «Інші витрати» }\end{array}$ & $\begin{array}{l}\text { Ат рахунка: } \\
96 \text { "Інші витра- } \\
\text { ти» (інші звичай- } \\
\text { ні витрати, крім } \\
\text { операційних) }\end{array}$ & $\begin{array}{l}\text { ח. } 5.6 \\
\mathrm{H} \Pi(\mathrm{C}) \mathrm{BO} \\
\underline{25}\end{array}$ \\
\hline $\begin{array}{l}\text { Разом витра- } \\
\text { ти }\end{array}$ & 2285 & \multicolumn{4}{|c|}{ Сума рялків $2050+2180+2270$} \\
\hline \multicolumn{6}{|c|}{ Примітка 5. Аані в рядках 2270, 2285 указують у дужках } \\
\hline $\begin{array}{l}\text { Ф інансовий } \\
\text { результат до } \\
\text { оподаткування }\end{array}$ & 2290 & $\begin{array}{l}\text { Різниця між Аоходами та } \\
\text { витратами піАприємства }\end{array}$ & \multicolumn{2}{|c|}{ Різниця рялків 2280 - 2285} & $\begin{array}{c}\Pi .5 .7 \\
H \Pi(C) Б O \\
\underline{25} \\
\end{array}$ \\
\hline \multicolumn{6}{|c|}{ Примітки 6. Аані в рядку 2290 указують у дужках, якщо фінансовий результат до оподаткування - збиток } \\
\hline $\begin{array}{l}\text { Податок на } \\
\text { прибуток }\end{array}$ & 2300 & $\begin{array}{l}\text { Суму податку на прибуток, } \\
\text { яка визначають у розмірі } \\
\text { податку на прибуток за } \\
\text { звітний період }\end{array}$ & $\begin{array}{l}\text { Оборот за операціями: } \\
\text { Ат } 98 \text { «Податок на } \\
\text { прибуток" Кт 64/пода- } \\
\text { ток на прибуток }\end{array}$ & $\begin{array}{l}\text { Оборот за опе- } \\
\text { раціями: } \\
\text { Ат } 96 \text { «нші ви- } \\
\text { трати» (у частині } \\
\text { обліку податку } \\
\text { на прибуток) } \\
\end{array}$ & $\begin{aligned} & \text { ח. } 5.8 \\
& H П(C) Б 0 \\
& \underline{25}\end{aligned}$ \\
\hline
\end{tabular}


Продовження таблиці 9.3

\begin{tabular}{|c|c|c|c|c|c|}
\hline \multirow{2}{*}{ Назва статті } & \multirow{2}{*}{$\begin{array}{l}\text { КоА } \\
\text { ряАКа }\end{array}$} & \multirow{2}{*}{ Зміст статті } & \multicolumn{2}{|c|}{$\begin{array}{c}\text { Ажерело інформації } \\
\text { (оборот за рахунками з початку року) }\end{array}$} & \multirow{2}{*}{$\begin{array}{l}\text { Норма } \\
\text { П(С)Б0 }\end{array}$} \\
\hline & & & $\begin{array}{c}\text { План рахунків } \\
\text { загальний } \\
\end{array}$ & $\begin{array}{c}\text { План рахунків } \\
\text { спрощений }\end{array}$ & \\
\hline & & & & $\begin{array}{l}\text { Кт 64/податок } \\
\text { на прибуток }\end{array}$ & \\
\hline \multicolumn{6}{|c|}{ Примітка 7. Аані в рядку 2300 указують у Аужках } \\
\hline $\begin{array}{l}\text { Чистий прибу- } \\
\text { ток (збиток) }\end{array}$ & 2350 & $\begin{array}{l}\text { Чистий прибуток або чистий } \\
\text { збиток - різниця між сумою } \\
\text { фінансового результату до } \\
\text { оподаткування та сумою ви- } \\
\text { трат із податку на прибуток }\end{array}$ & \multicolumn{2}{|c|}{ Різниця ряАків 2290 - 2300} & $\begin{array}{c}\text { п. } 5.9 \\
\text { HП(C)Б0 } \\
\underline{25}\end{array}$ \\
\hline
\end{tabular}

Ажерело: [6; 49].

\section{3. ПоряАок скмаАання фінансової звітності мікропіАприємства}

Фінансова звітність мікропіАприємства складається з балансу (форма № 1-мс) і звіту про фінансові результати (форма № 2-мс).

Порялок складання та подання Фінансової звітності мікропіАприємства регламентується НП(С)БО 25 "Спрощена фінансова звітність".

ЗгіАно з п. 2 р. І Фінзвітність мікропіАприємства ск^аАають:

- мікропіаприємства, які визнані такими віАповіАно до Закону України "Про бухгалтерський облік та фрінансову звітність в Україні" віА 16.07.1999 р. № 996-XIV (Аалі - мікропіАприємства);

- пілприємства, які веАуть спрощений бухоблік доходів і витрат згіАно з поАатковим законодавством, тобто юрособи - єАинники групи 3 (Аив. абз. 3 п. 44.2 ПоАаткового кодексу України);

- непіаприємницькі товариства.

МікропіАприємствами $є$ підприємства, показники яких на дату склаАання річної фінансової звітності за рік, що передує звітному, віАповіАають щонайменше Авом із таких критеріїв:

- балансова вартість активів - до 350 тис. євро;

- чистий дохіа віА реалізації продукції (товарів, робіт, послуг) - до 700 тис. євро;

- сереаня кількість працівників - ао 10 осіб.

Як і раніше, норми НП(С)БО 25 та віАповіАну спрощену фінзвітність не можуть застосовувати піАприємства, які згіАно із законодавством складають фінзвітність за МСФЗ. Вони використовують повноформатну фінзвітність, переАбачену НП(С)БО 1 «Загальні вимоги Ао фінансової звітності".

НП(С)БО 25 не надає піАприємствам права вибирати між Фінансовою звітністю малого піАприємства (форми № 1-м, № 2-м) та Фінансовою звітністю мікропіАприємства (форми № 1-мс, 2-мс). Тому те ж мікропіАприємство не може звітувати за формами № 1-м і № 2-м.

А ось складати повноформатну фінзвітність, передбачену НП(С)БО 1, Аозволено. Право вибору між спрощеним та повноформатним комплектом фрінзвітності нині закріплено за “малюками" п. 2 р. ІІ НП(С)БО 1.

Аалі розглянемо порядок склаАання форм № 1-мс і № 2-мс. Що саме необхіАно зазначати у віАповіАних рядках балансу, наведено в таблицях 9.4 і 9.5. 
Порядок заповнення активу балансу (форма № 1-мс)

\begin{tabular}{|c|c|c|c|c|}
\hline \multirow{2}{*}{$\begin{array}{l}\text { Назва } \\
\text { статті }\end{array}$} & \multirow{2}{*}{$\begin{array}{l}\text { KoA } \\
\text { ряAKa }\end{array}$} & \multicolumn{2}{|c|}{ Ажерело інформації А^я заповнення } & \multirow[b]{2}{*}{ Пояснення піА час заповнення } \\
\hline & & $\begin{array}{l}\text { Спрощений пхан } \\
\text { рахунків }\end{array}$ & $\begin{array}{l}\text { Загамьний п^ан } \\
\text { рахунків }\end{array}$ & \\
\hline \multicolumn{5}{|c|}{ I. Необоротні активи } \\
\hline $\begin{array}{l}\text { Основні } \\
\text { засоби: }\end{array}$ & 1010 & \multicolumn{2}{|l|}{ ряа. 1011 - ряа. 1012} & 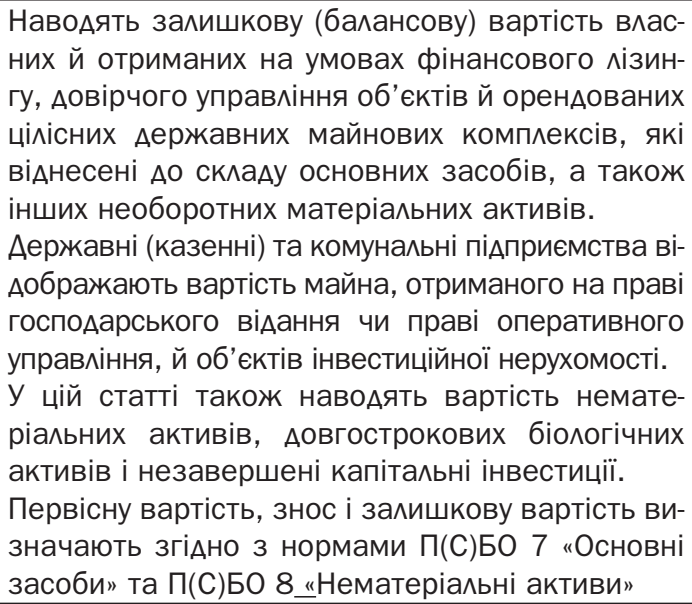 \\
\hline $\begin{array}{l}\text { первісна } \\
\text { вартість }\end{array}$ & 1011 & сальдо Ат 10, 15, 16 & $\begin{array}{l}\text { сальАо Ат 10, } \\
11,12,15,16\end{array}$ & $\begin{array}{l}\text { Показник рялка } 1011 \text { не включають Ао пілсум- } \\
\text { ку балансу }\end{array}$ \\
\hline 3ноC & 1012 & \multicolumn{2}{|l|}{ сальАо Кт 13} & $\begin{array}{l}\text { Аані цього рялка включають суми накопиченої } \\
\text { амортизації основних засобів, нематеріальних ак- } \\
\text { тивів із початку строку корисного використання. } \\
\text { Показник рядка } 1012 \text { не включають до піАсумку } \\
\text { балансу та відображають у дужках }\end{array}$ \\
\hline $\begin{array}{l}\text { Інші не- } \\
\text { оборотні } \\
\text { активи }\end{array}$ & 1090 & сальАо Ат 14, 18 & $\begin{array}{l}\text { СальАо Ат 14, } \\
18,19\end{array}$ & $\begin{array}{l}\text { Наводять суми інших необоротних активів, у } \\
\text { т.ч. довгострокові фінансові інвестиції. } \\
\text { Інші необоротні активи віАображають за пер- } \\
\text { вісною вартістю (історичною собівартістю). } \\
\text { Зверніть увагу: у цьому рядку також віАобража- } \\
\text { ють кошти, які не можна використати для опе- } \\
\text { рацій протягом року, починаючи: } \\
\text { - з дати балансу } \\
\text { або } \\
\text { - протягом операційного циклу }\end{array}$ \\
\hline $\begin{array}{c}\text { Усього } \\
\text { за розАілом I }\end{array}$ & 1095 & \multicolumn{2}{|c|}{ сума: рял. 1010 + рял. 1090} & - \\
\hline \multicolumn{5}{|c|}{ II. Оборотні активи } \\
\hline Запаси & 1100 & $\begin{array}{l}\text { сальдо Ат 20, 21, } \\
23,26\end{array}$ & $\begin{array}{l}\text { сальдо Ат 20, } \\
21,22,23,24, \\
25,26,27,28\end{array}$ & 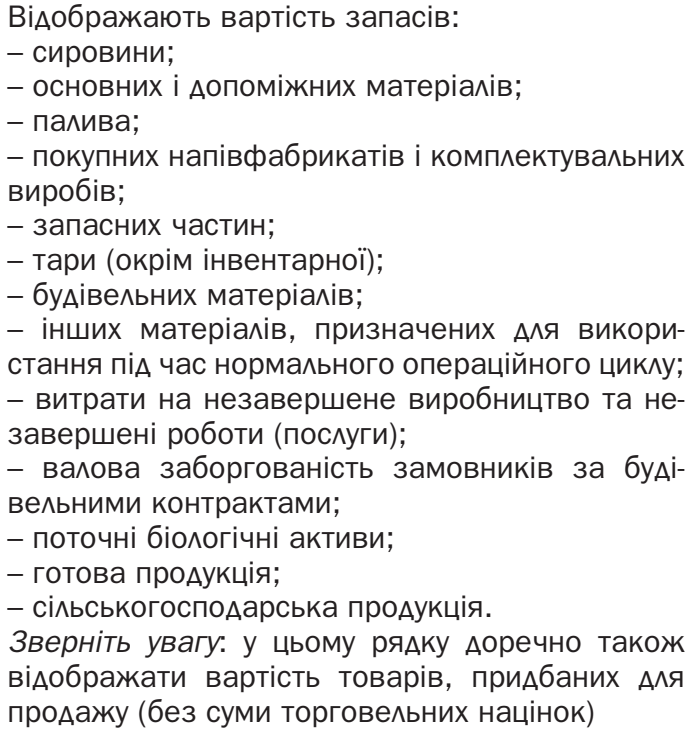 \\
\hline
\end{tabular}




\begin{tabular}{|c|c|c|c|c|}
\hline \multirow{3}{*}{$\begin{array}{l}\text { Назва } \\
\text { статті }\end{array}$} & & & & \\
\hline & \multirow{2}{*}{$\begin{array}{l}\text { КоА } \\
\text { ряAKa }\end{array}$} & \multicolumn{2}{|c|}{ Ажерело інформації А^я заповнення } & \multirow[b]{2}{*}{ Пояснення піА час заповнення } \\
\hline & & $\begin{array}{c}\text { Спрощений п^ан } \\
\text { рахунків }\end{array}$ & $\begin{array}{c}\text { Загамьний п^ан } \\
\text { рахунків }\end{array}$ & \\
\hline $\begin{array}{c}\text { Поточна } \\
\text { Аебіторська } \\
\text { заборгова- } \\
\text { ність }\end{array}$ & 1155 & $\begin{array}{l}\text { сальдо Ат } 37,64 \\
\text { (окрім 643, 644), } \\
66,68\end{array}$ & $\begin{array}{l}\text { сальдо Ат 34, 36, } \\
37,63,64 \text { (окрім } \\
643,644), 65 \\
66,685\end{array}$ & 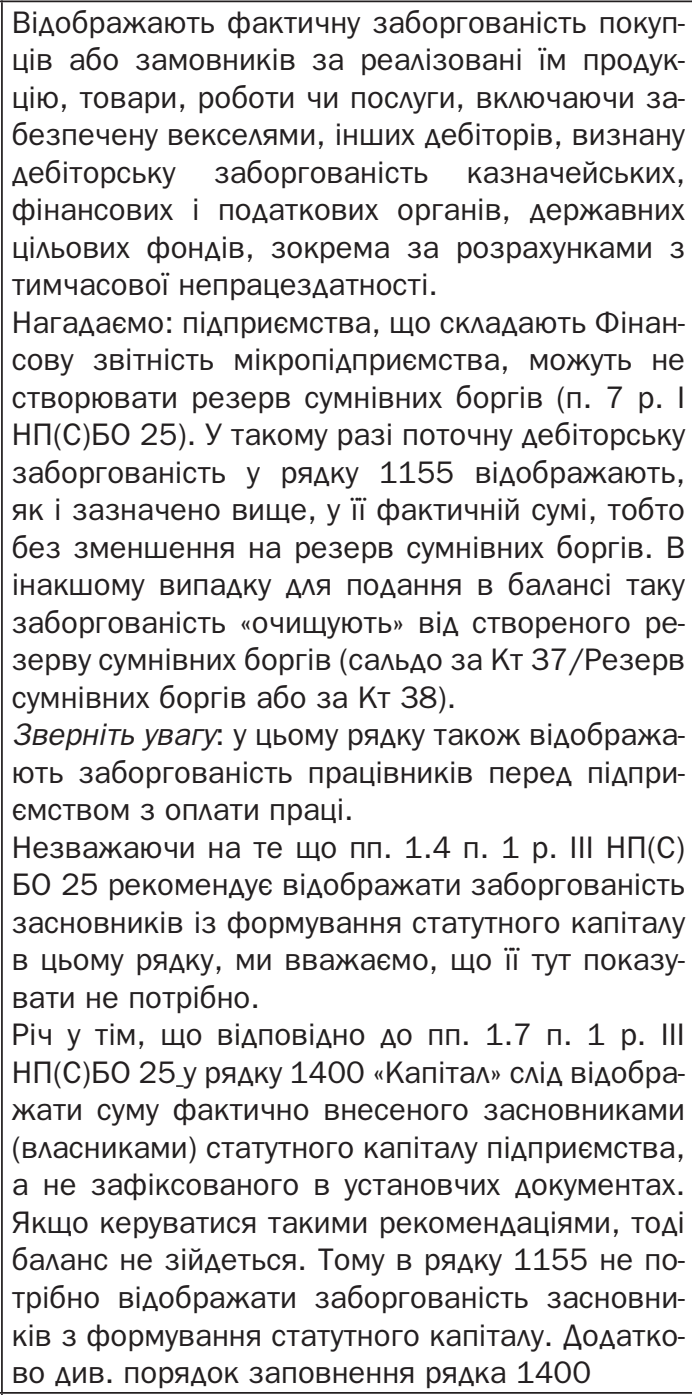 \\
\hline \begin{tabular}{|} 
Гроші та їх \\
еквіваленти
\end{tabular} & 1165 & $\begin{array}{c}\text { сальдо Ат } 30,31,35 \\
\text { (у частині грошових } \\
\text { коштів та їх еквіва- } \\
\text { ментів) }\end{array}$ & $\begin{array}{l}\text { сальдо Ат } 30,31 \\
\text { З33, } 334,335 \\
351\end{array}$ & $\begin{array}{l}\text { Відображають готівку в касі пілприємства, } \\
\text { гроші на поточних й інших рахунках у банках, } \\
\text { які можуть бути вільно використані Аля поточ- } \\
\text { них операцій, а такожк грошові кошти в Аорозі, } \\
\text { електронні гроші, еквіваленти грошей. у цій } \\
\text { статті наводять кошти в національній або іно- } \\
\text { земних валютах. } \\
\text { Зверніть увагу: кошти, які не можна викори- } \\
\text { стати А^я операцій протягом року, починаючи } \\
\text { з дати балансу чи протягом операційного циклу, } \\
\text { відображають у рялку } 1090 \text { "Інші необоротні } \\
\text { активи" }\end{array}$ \\
\hline $\begin{array}{l}\text { Інші } \\
\text { оборотні } \\
\text { активи }\end{array}$ & 1190 & $\begin{array}{c}\text { сальдо Ат } 35 \text { (крім } \\
\text { еквівалентів грошо- } \\
\text { вих коштів), 643, } \\
644\end{array}$ & $\begin{array}{l}\text { сальдо Ат } 331, \\
332,352,643 \\
\quad 644,39\end{array}$ & $\begin{array}{l}\text { Наводять суми оборотних активів, які не вкяю- } \\
\text { чені до згаданих вище статей розділу "Оборотні } \\
\text { активи", зокрема, поточні фінансові інвестиції }\end{array}$ \\
\hline $\begin{array}{l}\text { Усього за } \\
\text { розАілом II }\end{array}$ & 1195 & $\begin{array}{l}\text { сума: рял. } 1100+\text { ряА } \\
1165 \text { + рял. } 1190\end{array}$ & $1155+$ ряа & - \\
\hline Баланс & 1300 & сума: рял. $1095+$ ряд & 4.1195 & - \\
\hline
\end{tabular}

Ажерело: [6; 48]. 
ПоряАок заповнення пасиву балансу (форми № 1-мс)

\begin{tabular}{|c|c|c|c|c|}
\hline \multirow[b]{2}{*}{ Назва статті } & \multirow{2}{*}{$\begin{array}{c}\text { КоА } \\
\text { ряАКа }\end{array}$} & \multicolumn{2}{|c|}{ Ажерело інформації А^я заповнення } & \multirow[b]{2}{*}{ Пояснення піА час заповнення } \\
\hline & & $\begin{array}{c}\text { Спрощений п^ан } \\
\text { рахунків }\end{array}$ & $\begin{array}{c}\text { Загамьний пман } \\
\text { рахунків }\end{array}$ & \\
\hline \multicolumn{5}{|c|}{ І. В^асний капітал } \\
\hline Капітал & 1400 & сальАо Кт 40 & $\begin{array}{c}\text { сальдо Кт 40, 41, } \\
42,43 \text { за мінусом } \\
\text { сальАо за Ат 45, } 46\end{array}$ & 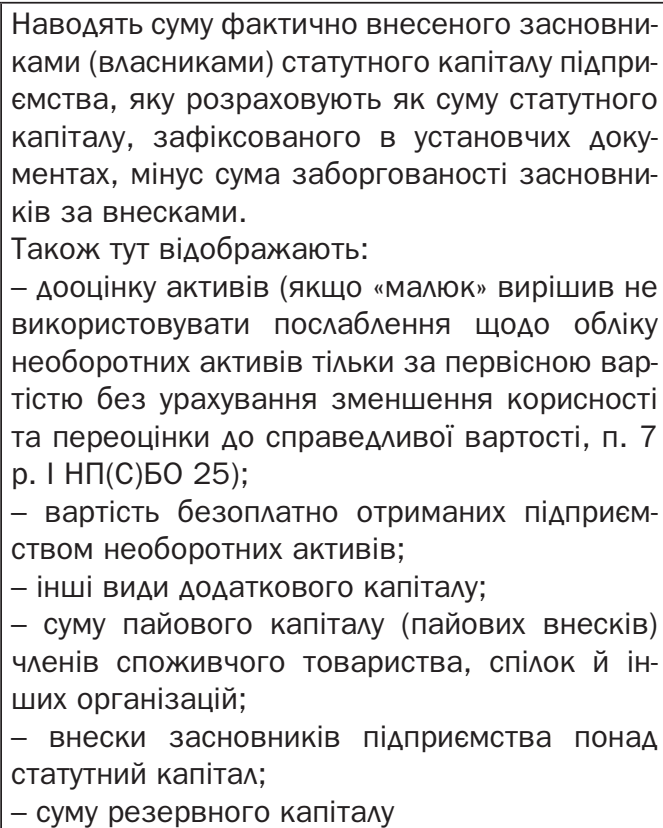 \\
\hline $\begin{array}{c}\text { Нерозподіле- } \\
\text { ний прибуток } \\
\text { (непокритий } \\
\text { збиток) }\end{array}$ & 1420 & $\begin{array}{c}\text { сальдо за Кт } \\
\text { (прибуток) чи за Ат } \\
\text { (збиток) } 44\end{array}$ & $\begin{array}{c}\text { сальАо Кт } 441 \text { чи } \\
\text { Ат } 442\end{array}$ & $\begin{array}{l}\text { ВіАображають суму нерозподіленого прибут- } \\
\text { ку чи непокритого збитку. } \\
\text { Суму непокритого збитку наводять у дужках } \\
\text { і вираховують піА час визначення піАсумку } \\
\text { власного капіталу }\end{array}$ \\
\hline $\begin{array}{l}\text { Усього за } \\
\text { розАілом I }\end{array}$ & 1495 & \multicolumn{2}{|c|}{ сума: рял. 1400 + ряа. 1420 (-ряд. 1420) } & - \\
\hline $\begin{array}{c}\text { ІІ. Аовго- } \\
\text { строкові } \\
\text { зобов'язан- } \\
\text { ня, цільове } \\
\text { фінансування } \\
\text { та забезпе- } \\
\text { чення }\end{array}$ & 1595 & $\begin{array}{c}\text { сальАо Кт } 48,47, \\
55\end{array}$ & $\begin{array}{l}\text { сальдо Кт 47, 48, } \\
50,51,52,53,55\end{array}$ & 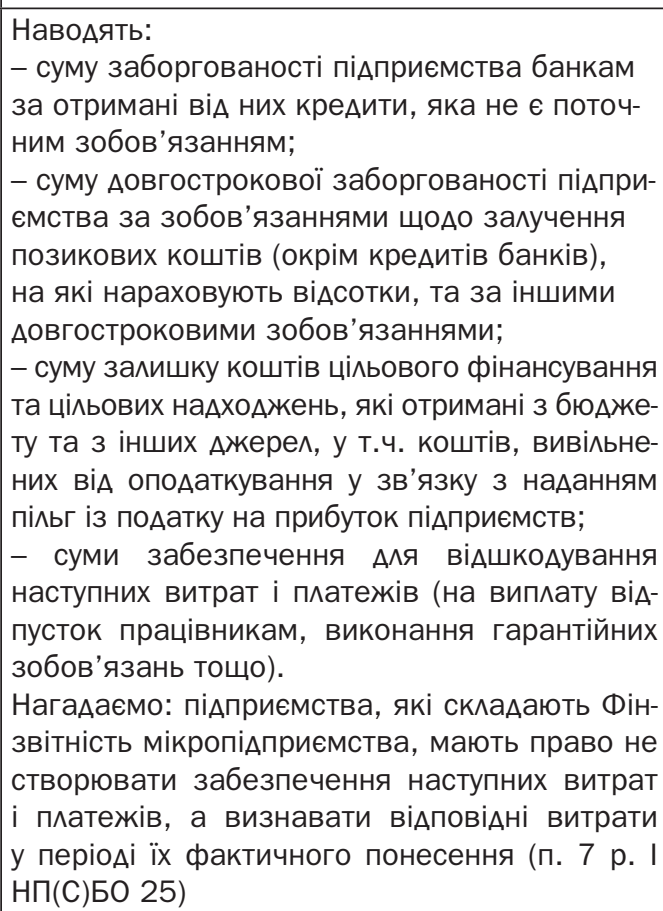 \\
\hline
\end{tabular}


Продовження таблиці 9.5

\begin{tabular}{|c|c|c|c|c|}
\hline \multirow[b]{2}{*}{ Назва статті } & \multirow[b]{2}{*}{$\begin{array}{c}\text { КоА } \\
\text { ряАКа }\end{array}$} & \multicolumn{2}{|c|}{ Ажерело інформації А^я заповнення } & \multirow[b]{2}{*}{ Пояснення піА час заповнення } \\
\hline & & $\begin{array}{c}\text { Cпрощений пхан } \\
\text { рахунків }\end{array}$ & $\begin{array}{c}\text { Загальний п^ан } \\
\text { рахунків }\end{array}$ & \\
\hline $\begin{array}{l}\text { Короткостро- } \\
\text { кові кредити } \\
\text { банків }\end{array}$ & 1600 & $\begin{array}{c}\text { сальдо Кт 60, } 68 \text { (у } \\
\text { частині кредитів і } \\
\text { відсотків за ними) }\end{array}$ & $\begin{array}{c}\text { сальдо Кт 60, } 61 \text { (у } \\
\text { частині заборгова- } \\
\text { ності за кредитами } \\
\text { банків, переведеної } \\
\text { до поточної), } 684 \text { (у } \\
\text { частині відсотків за } \\
\text { кредитами) }\end{array}$ & $\begin{array}{l}\text { Тут відображають: } \\
\text { - суму поточних зобов'язань піАприємства } \\
\text { перед банками щодо отриманих віА них } \\
\text { короткострокових позик; } \\
\text { - суми зобов'язань, які утворилися як дов- } \\
\text { гострокові, але з Аати балансу піАлягають } \\
\text { погашенню протягом } 12 \text { місяців. } \\
\text { Зобов'язання за кредитами банків наводять } \\
\text { у балансі з урахуванням належної на кінець } \\
\text { звітного періоду Ао сплати суми процентів за } \\
\text { їх використання }\end{array}$ \\
\hline $\begin{array}{l}\text { Поточна кре- } \\
\text { Аиторська } \\
\text { заборгова- } \\
\text { ність за: } \\
\text { товари, робо- } \\
\text { ти, послуги }\end{array}$ & 1615 & $\begin{array}{c}\text { сальдо Кт } 68 \text { (у } \\
\text { частині заборго- } \\
\text { ваності за товари, } \\
\text { роботи, послуги) }\end{array}$ & $\begin{array}{c}\text { сальдо Кт 62, 63, } \\
685\end{array}$ & $\begin{array}{l}\text { Тут мають місце такі види кредиторської } \\
\text { заборгованості, як: } \\
\text { - сума заборгованості постачальникам і } \\
\text { підрядникам за матеріальні цінності, вико- } \\
\text { нані роботи й отримані послуги, вк^ючаючи } \\
\text { заборгованість, забезпечену векселями; } \\
\text { - сума заборгованості постачальникам за } \\
\text { невідфактуровані постачання та розрахунки } \\
\text { з надлишку ТМЦ, який установлено піА час їх } \\
\text { приймання }\end{array}$ \\
\hline $\begin{array}{c}\text { розрахунка- } \\
\text { ми } 3 \text { бюАже- } \\
\text { том }\end{array}$ & 1620 & $\begin{array}{c}\text { сальдо за Кт } 64 \text { (у } \\
\text { частині заборгова- } \\
\text { ності за платежа- } \\
\text { ми до бюджету) }\end{array}$ & $\begin{array}{c}\text { сальдо за Кт } 641 \text { і } \\
642 \\
\text { (у частині заборгова- } \\
\text { ності за платежами } \\
\text { до бюджету) } \\
\end{array}$ & $\begin{array}{l}\text { Відображають заборгованість підприємства за } \\
\text { всіма видами платежків Ао бюджету, включаю- } \\
\text { чи суму податку з працівників підприємства }\end{array}$ \\
\hline $\begin{array}{l}\text { розрахунка- } \\
\text { ми зі страху- } \\
\text { вання }\end{array}$ & 1625 & $\begin{array}{c}\text { сальдо Кт } 64 \text { (у ча- } \\
\text { стині заборговано- } \\
\text { сті за платежами } \\
\text { зі страхування) }\end{array}$ & сальАо Кт 65 & $\begin{array}{l}\text { ВіАображають суму заборгованості з віАра- } \\
\text { хувань на загальнообов'язкове Аержавне } \\
\text { соціальне страхування, страхування майна } \\
\text { піАприємства й індивідуальне страхування } \\
\text { його працівників }\end{array}$ \\
\hline $\begin{array}{l}\text { розрахунка- } \\
\text { ми з оплати } \\
\text { праці }\end{array}$ & 1630 & сальАо Кт 66 & сальАо Кт 66 & $\begin{array}{l}\text { Відображають заборгованість за нарахо- } \\
\text { ваною, але ще не сплаченою сумою оплати } \\
\text { праці, а також за депонованою заробітною } \\
\text { п^атою }\end{array}$ \\
\hline $\begin{array}{c}\text { Інші поточні } \\
\text { зобов'язання }\end{array}$ & 1690 & $\begin{array}{c}\text { сальдо Кт 37, 68, } \\
643,644,69\end{array}$ & $\begin{array}{l}\text { сальдо Кт 37, 643, } \\
644,61,67,68,69\end{array}$ & $\begin{array}{l}\text { ВіАображають суми зобов’язань, які не } \\
\text { включені до наведених вище статей розділу } \\
\text { III «Поточні зобов'язання» форми № 1-мс, } \\
\text { зокрема: } \\
\text { - заборгованість за одержаними авансами; } \\
\text { - заборгованість засновникам у зв’язку з } \\
\text { розподілом прибутку; } \\
\text { - заборгованість пов'язаним сторонам; } \\
\text { - сума валової заборгованості замовникам } \\
\text { за будівельними контрактами }\end{array}$ \\
\hline $\begin{array}{c}\text { Усього за } \\
\text { розАілом IV }\end{array}$ & 1695 & $\begin{array}{l}\text { сума: рян. } 1600+\text { р } \\
\text { + ряА. } 1625+\text { ряА. }\end{array}$ & $\begin{array}{l}\text { яА. } 1615+\text { ряА. } 1620 \\
1630+\text { ряА. } 1690\end{array}$ & - \\
\hline Баланс & 1900 & сума: рял. $1495+$ p & яА. 1595 + ряА. 1695 & - \\
\hline
\end{tabular}

Ажерело: [6; 48].

ПоряАок заповнення звіту про фрінансові результати мікропідприємства (форма № 2-см) наведено в таблиці 9.6. 
Таблиця 9.6

Порядок заповнення звіту про фінансові результати (форма № 2-мс)

\begin{tabular}{|c|c|c|c|c|}
\hline \multirow[b]{2}{*}{ Назва статті } & \multirow[b]{2}{*}{$\begin{array}{c}\text { КоА } \\
\text { ряАКа }\end{array}$} & \multicolumn{2}{|c|}{ Ажерело інформації А^я заповнення } & \multirow[b]{2}{*}{ Пояснення піА час заповнення } \\
\hline & & $\begin{array}{c}\text { Спрощений п^ан } \\
\text { рахунків }\end{array}$ & $\begin{array}{c}\text { Загальний пман } \\
\text { рахунків }\end{array}$ & \\
\hline $\begin{array}{c}\text { Чистий дохіА } \\
\text { віА реалізації } \\
\text { продукції (то- } \\
\text { варів, робіт, } \\
\text { послуг) }\end{array}$ & 2000 & $\begin{array}{c}\text { обороти за Кт } 70 \\
\text { мінус обороти за } \\
\text { Кт } 704\end{array}$ & $\begin{array}{c}\text { оборот за Кт 701, } \\
702,703 \text { мінус обо- } \\
\text { роти за Кт } 704\end{array}$ & $\begin{array}{l}\text { ВіАображають АохіА віА реалізації продукції } \\
\text { товарів, робіт і послуг без непрямих податків } \\
\text { і зборів й інших вирахувань із доходу, а саме } \\
\text { - сум ПАВ; } \\
\text { - сум акцизного податку; } \\
\text { - сум інших обов'язкових зборів; } \\
\text { - наданої знижки покупцям; } \\
\text { - вартості повернених товарів; } \\
\text { - інших вирахувань із Аоходу. } \\
\text { у цьому ж рядку віАображають дохіА віА } \\
\text { оренди об'єктів інвестиційної нерухомості } \\
\text { а також дохіА віА операційної оренди інших } \\
\text { активів, якщо вона є основним виАом Аіяль } \\
\text { ності підпрємства }\end{array}$ \\
\hline Інші АОходи & 2160 & оборот за Кт 74 & $\begin{array}{l}\text { оборот за Кт 71, 72, } \\
73,74\end{array}$ & $\begin{array}{l}\text { ВіАображають суми інших Аоходів віА опера } \\
\text { ційної Аіяльності піАприємства, окрім доходу } \\
\text { (виручки) віА реалізації продукції (товарів, ро } \\
\text { біт, послуг): } \\
\text { - дохіА віА операційної оренди активів; } \\
\text { - дохіА віА операційних курсових різниць; } \\
\text { - віАшкодування раніше списаних активів; } \\
\text { - дохіА віА реалізації оборотних активів, віА } \\
\text { сотки, доходи віА участі в капіталі й інші дохо } \\
\text { ди, отримані віА фінансових інвестицій; } \\
\text { - дохіА віА реалізації фінансових інвестицій } \\
\text { необоротних активів; } \\
\text { - дохіА віА неопераційних курсових різниць; } \\
\text { - інші доходи }\end{array}$ \\
\hline $\begin{array}{c}\text { Разом Аохо- } \\
\text { Аи }(2000+ \\
2160)\end{array}$ & 2280 & \multicolumn{3}{|c|}{ Сума: рял. 2000 + ряА. 2160} \\
\hline $\begin{array}{c}\text { Собівартість } \\
\text { реалізованої } \\
\text { продукції (то- } \\
\text { варів, робіт, } \\
\text { послуг) }\end{array}$ & 2050 & обороти за Ат 90 & $\begin{array}{c}\text { оборот за Ат 901, } \\
902,903\end{array}$ & $\begin{array}{l}\text { Наводять виробничу собівартість реалізова } \\
\text { ної продукції (робіт, послуг) і/або собівар } \\
\text { тість реалізованих товарів (пп. } 2.3 \text { п.2 р. ІІ } \\
\text { НП(С)БО 25). } \\
\text { Якщо оренАа - основний виА Аіяльності піА } \\
\text { приємства або в оренду наАають інвестицій } \\
\text { ну нерухомість, Ао цього рядка входять та } \\
\text { кож витрати, пов'язані з наАанням майна в } \\
\text { оренду. Показник наводять у Аужках }\end{array}$ \\
\hline Інші витрати & 2165 & оборот за Ат 96 & оборот за Ат 92-97 & 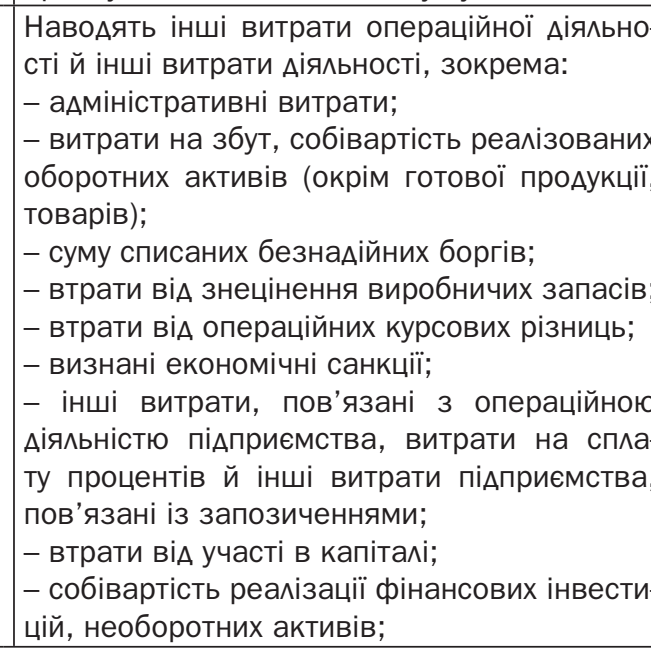 \\
\hline
\end{tabular}


Продовження таблиці 9.6

\begin{tabular}{|c|c|c|c|c|}
\hline \multirow[b]{2}{*}{ Назва статті } & \multirow[b]{2}{*}{$\begin{array}{l}\text { КоА } \\
\text { ряАКа }\end{array}$} & \multicolumn{2}{|c|}{ Ажерело інформації А^я заповнення } & \multirow[b]{2}{*}{ Пояснення піА час заповнення } \\
\hline & & $\begin{array}{c}\text { Cпрощений пман } \\
\text { рахунків }\end{array}$ & $\begin{array}{c}\text { Загамьний п^ан } \\
\text { рахунків }\end{array}$ & \\
\hline & & & & $\begin{array}{l}\text { - втрати віА неопераційних курсових різниць; } \\
\text { - інші витрати піАприємства. } \\
\text { У цьому рядку такожк віАображають належну } \\
\text { до сплати за звітний період віАповіАно Ао за- } \\
\text { конодавства суму податків і зборів (зокрема } \\
\text { суму єАиного податку). } \\
\text { Показник навоАять у дужках }\end{array}$ \\
\hline $\begin{array}{l}\text { Разом ви- } \\
\text { трати } \\
(2050+ \\
2165)\end{array}$ & 2285 & \multicolumn{3}{|c|}{ Сума: рян. 2050 + ряА. 2165} \\
\hline $\begin{array}{l}\text { Фінансовий } \\
\text { результат } \\
\text { АО оподатку- } \\
\text { вання } \\
(2280- \\
2285) \\
\end{array}$ & 2290 & \multicolumn{2}{|c|}{ Ряа. 2280 - ряА. 2285} & $\begin{array}{l}\text { ВіАображають різницю між Аоходами та } \\
\text { всіма витратами підприємства. } \\
\text { Якщо фінансовий результат Ао оподатку- } \\
\text { вання - збиток, тоді отриману суму в такому } \\
\text { рядку вказують у дужках }\end{array}$ \\
\hline $\begin{array}{c}\text { Податок на } \\
\text { прибуток }\end{array}$ & 2300 & $\begin{array}{c}\text { оборот за Ат } 96 \text { із } \\
\text { Кт } 64 \text { «Податок на } \\
\text { прибуток" }\end{array}$ & $\begin{array}{c}\text { оборот за Ат } 98 \text { із } \\
\text { Кт 641/“Податок на } \\
\text { прибуток» }\end{array}$ & $\begin{array}{l}\text { Тут віАображають суму податку на прибуток, } \\
\text { яку визначають у розмірі податку на прибу- } \\
\text { ток за звітний період. Показник наводять у } \\
\text { дужках. Платники єАиного поАатку цей рядок } \\
\text { не заповнюють. }\end{array}$ \\
\hline $\begin{array}{c}\text { Витрати } \\
\text { (Аоходи), які } \\
\text { зменшують } \\
\text { (збільшують) } \\
\text { фінансовий } \\
\text { результат } \\
\text { після оподат- } \\
\text { кування } \\
\end{array}$ & 2310 & - & - & Нині цей ряАок не заповнюють \\
\hline $\begin{array}{l}\text { Чистий } \\
\text { прибуток } \\
\text { (збиток) } \\
(2290- \\
2300-(+) \\
2310) \\
\end{array}$ & 2350 & РяА. 2290 - ряА. 23 & & $\begin{array}{l}\text { ВіАображають чистий прибуток або чистий } \\
\text { збиток - різниця між сумою фінансового } \\
\text { результату до оподаткування та сумою } \\
\text { витрат із податку на прибуток. } \\
\text { Якщо отримано чистий збиток, показник } \\
\text { зазначають у дужках }\end{array}$ \\
\hline
\end{tabular}

Ажерело: [6; 48].

\section{КОНТРОАЬНІ ПИТАННЯ:}

1. Вкажіть критерії віАнесення піАприємств до малих та мікропіАприємств.

2. Чи є різниця між поняттями "мале піАприємство" та "платник єАиного податку»?

3. Якими нормативно-правовими актами регулюється порядок ведення обліку та складання фінансової звітності малими та мікропіАприємствами?

4. Які основі зміни віАбулися у 2019 році, що стосуються склаАання фінансової звітності малими та мікропіАприємствами?

5. Які розділи має баланс малого піАприємства (ф. № 1-м)?

6. Які показники наводяться в активі балансу (ф. № 1-м)?

7. Які види активів відображуються в балансі за статтею 1011 «Первісна вартість основних засобів"?

8. Які вили дебіторської заборгованості відображуються в балансі за статтею 1135 «Аебіторська заборгованість за розрахунками з бюджетом"?

9. Які показники наводяться в пасиві балансу (ф. № 1-м)? 
10. Опишіть структуру звіту про фінансовий результат малого пілприємства (ф. № 2-м).

11. У чому полягає різниця в методиці складання звіту про фрінансові результати (ф. № 2-м) віА методики заповнення повної форми?

12. Як розраховується собівартість реалізованих товарів, робіт, послуг, що віАображується у звіті про фінансові результати малого піАприємства?

13. У чому полягає особливість відображення в звіті про фінансовий результат (ф. № 2-м) витрат піАприємства?

14. Які показники балансу (ф. № 1-м) узгоджуються зі звітом про фінансові результати (ф. № 2-м)?

15. Які піАприємства мають право складати спрощений фінансовий звіт за формами № 1-мс та № 2-мc?

16. У чому полягає різниця в методиці складання балансу (ф. № 1-мс) віА методики заповнення повної форми?

17. У чому полягає різниця в методиці складання звіту про фінансові результати (ф. № 2-мс) віА методики заповнення повної форми? 
TEMA 10.

\section{ПОААТКОВА 3BITHICTЬ}

\section{1. Загальні вимоги Ао скмаАання і поАання поАаткової звітності}

А^я будь-якого піАприємства - платника податків подання податкової звітності є невіА'ємною ^анкою в ^анцюжку заходів щодо нарахування та сплати більшості податків і зборів і при цьому оАним з основних обов'язків платника податку, що визначено Податковим кодексом (п.П. 16.1.3 ПКУ).

Податкова Аекларація, розрахунок, звіт - це Аокумент, що поАається платником податків (у тому числі відокремленим піАрозділом у випаАках, визначених цим Кодексом) контролюючим органам у строки, встановлені законом, на піАставі якого зАійснюється нарахування та/або сплата грошового зобов'язання, у тому числі податкового зобов'язання або віАображаються обсяги операції (операцій), доходів (прибутків), щодо яких податковим та митним законодавством передбачено звільнення платника податку віА обов'язку нарахування і сплати податку і збору, чи документ, що свіАчить про суми Аоходу, нарахованого (виплаченого) на користь платників податків - фізичних осіб, суми утриманого та/або сплаченого податку (п. 46.1 ст. 46 ПКУ).

Аодатки Ао податкової Аекларації є її невіА'ємною частиною.

Залежно віА того, за який податок або збір необхіАно віАзвітувати, податкове законодавство передбачає подання або податкової декларації, або ж податкового розрахунку. При цьому в розумінні ПКУ ці Ава поняття $€$ тотожними, тобто поАатковий розрахунок прирівнюється Ао податкової декларації без жодних обмежень і є обов'язковим Ао подання платниками віАповіАного податку або збору.

Тепер зупинимося на загальних вимогах до склаАання податкової звітності. Перш за все, Аоцільно розглянути, хто несе віАповіАальність за склаАення поАаткової звітності.

ВіАповіАно АО СТ. 47 ПКУ віАповіАамьність за непоАання, порушення поряАКу заповнення Аокументів податкової звітності, порушення строків їх подання контролюючим органам, неАостовірність інформації, наведеної у зазначених документах, несуть:

1) юридичні особи, резиденти або нерезиденти України, які віАповіАно до цього Кодексу визначені платниками податків, а також їх посадові особи. ВіАповіАальність за порушення податкового законодавства віАокремленим піАрозділом юридичної особи несе юридична особа, до скмаду якої він входить;

2) фізичні особи - платники податків та їх законні чи уповноважені представники у випадках, передбачених законом;

\section{3) податкові агенти.}

ВіАповіАно Ао ст. 48 ПКУ форма податкової декларації повинна містити необхідні обов'язкові реквізити і віАповіАати нормам та змісту віАповіАних податку та збору.

Обов'язкові реквізити - це інформація, яку повинна містити форма податкової декларації та за віАсутності якої документ втрачає визначений Податковим кодексом статус із настанням передбачених законом юридичних наслідків.

Податкова декларація повинна містити такі обов'язкові реквізити:

- тип Аокумента (звітний, уточнюючий, звітний новий);

- звітний (податковий) періоА, за який подається податкова декларація;

- звітний (поАатковий) періоА, що уточнюється (А^я уточнюючого розрахунку); 
- повне найменування (прізвище, ім'я, по батькові) платника податків згідно з реєстраційними Аокументами;

- коА платника податків згідно з ЄАиним Аержавним реєстром піАприємств та організацій України або податковий номер;

- реєстраційний номер облікової картки платника податків або серію та номер паспорта (Аля фізичних осіб, які через свої релігійні переконання віАмовляються віА прийняття реєстраційного номера облікової картки платника податків та повіАомили про це віАповіАний контролюючий орган і мають віАмітку у паспорті);

- місцезнаходження (місце проживання) платника податків;

- найменування контролюючого органу, до якого подається звітність;

- дата подання звіту (або дата заповнення - залежно віА форми);

- інформація про Аодатки, що Аодаються до податкової Аекларації та є її невіА'ємною частиною;

- ініціали, прізвища та реєстраційні номери облікових карток або інші віАомості, визначені в абзаці сьомому цього пункту, посаАових осіб платника податків;

- пілписи платника податку - фізичної особи та/або посадових осіб платника податку, визначених Податковим кодексом, засвідчені печаткою платника податку (за наявності).

У окремих випадках, коли це віАповіАає сутності податку або збору та є необхіАним Аля його аАміністрування, форма податкової декларації Аодатково може містити такі обов'язкові реквізити:

- відмітка про звітування за спеціальним режимом;

- коА виАу економічної Аіяльності (KBEA);

- КоА органу місцевого самовряАування за КОАТУУ;

- індивіАуальний поАатковий номер згіАно з Ааними реєстру платників податку на АоАану вартість за звітний (податковий) період;

- дата та номер рішення про включення неприбуткової організації до Реєстру неприбуткових установ та організацій;

- ознака неприбутковості організації;

- повне найменування нерезилента;

- місцезнаходження нерезидента;

- назва та код Аержави резиденції нерезидента;

- код нерезидента, що присвоєно державою, резидентом якої він є.

Податкова Аекларація повинна бути піАписана:

1) керівником платника податків або уповноваженою особою, а також особою, яка віАповідає за ведення бухгалтерського обліку та подання податкової декларації до контролюючого органу. У разі ведення бухгалтерського обліку та подання податкової декларації безпосередньо керівником платника податку така податкова декларація піАписується таким керівником.

Аостатнім піАтверАженням справжності документа податкової звітності є наявність оригіналу піАпису уповноваженої особи на документі у паперовій формі або наявність накладеного на електронний документ кваліфікованого електронного піАпису чи печатки платника полатку;

2) фізичною особою - платником податків або його представником;

3) особою, віАповіАальною за ведення бухгалтерського обліку та подання податкової декларації згіАно із Аоговором про спільну Аіяльність або угодою про розподіл продукції.

Якщо податкова Аекларація подається податковими агентами - юридичними особами, вона повинна бути пілписана керівником такого агента та особою, яка відповіАає за ведення бухгалтерського обліку та подання податкової декларації такого агента, а якщо податковим агентом $є$ платник податків - фізична особа - таким платником податків.

Загальні вимоги Ао поАання поАаткової звітності переАбачають такі способи подання податкової звітності (п. 49.3 ПКУ):

а) особисто пматником поАатків або уповноваженою на це особою; 
б) наАсимається поштою з повідомленням про вручення та з описом вкладення;

в) засобами електронного зв'язку в електронній формі з Аотриманням вимог законів України "Про електронні Аокументи та електронний Аокументообіг" та "Про електронні Аовірчі послуги".

ЄАиною піАставою Аля неприйняття податкової декларації засобами електронного зв'язку в електронній формі $є$ недійсність кваліфікованого електронного піАпису чи печатки такого платника полатків, у тому числі у зв'язку із закінченням строку Аії віАповіАного сертифіката віАкритого к^юча, за умови що така податкова декларація відповідає всім вимогам електронного Аокумента, містить Аостовірні обов'язкові реквізити та наАана у форматі, Аоступному А^я її технічної обробки.

Платники податків, що належать до великих та сереАніх підприємств, подають податкові Аекларації контролюючому органу в електронній формі з Аотриманням вимог законів України "Про електронні документи та електронний документообіг" та "Про електронні довірчі послуги".

Податкові декларації, крім випадків, передбачених Податковим кодексом, подаються за базовий звітний (поАатковий) періоА, що Аорівнює (п. 49.18 ПКУ):

1) каленАарному місяцю (у тому числі в разі сплати місячних авансових внесків) - протягом 20 каленАарних Анів, що настають за останнім календарним Анем звітного (податкового) місяця;

2) каленАарному кварталу або календарному півріччю (у тому числі в разі сплати квартальних або піврічних авансових внесків) - протягом 40 календарних Анів, що настають за останнім календарним Анем звітного (податкового) кварталу (півріччя);

3) календарному року, крім випадків, передбачених піАпунктами 49.18.4 та 49.18.5 протягом 60 каленАарних Анів, що настають за останнім каленАарним Анем звітного (поАаткового) року;

4) каленАарному року Аля платників податку на Аоходи фізичних осіб - Ао 1 травня року, що настає за звітним, крім випаАків, передбачених розАілом IV ПКУ;

5) каленАарному року Аля платників поАатку на Аоходи фізичних осіб - піАприємців - протягом 40 календарних Анів, що настають за останнім календарним Анем звітного (податкового) року;

6) каленАарному року Аля платників поАатку на прибуток (у тому числі платників частини чистого прибутку (Аоходу)), Аля податкової Аекларації (у тому числі розрахунку частини чистого прибутку (Аоходу), Аивідендів на Аержавну частку), яка розраховується наростаючим піАсумком за рік, - протягом 60 каленАарних Анів, що настають за останнім каленАарним Анем звітного (податкового) року;

7) календарному року Аля платників Аивілендів на державну частку (у тому числі госпоАарських товариств, корпоративні права яких частково належать державі, та господарських товариств, 50 і більше відсотків акцій (часток, паїв) яких належать господарським товариствам, частка Аержави в яких становить 100 віАсотків, які не прийняли рішення про нарахування АивіденАів Ао 1 травня року, що настає за звітним) Аля розрахунку частини чистого прибутку (Аоходу), АивіАенАів на Аержавну частку - Ао 1 мипня року, що настає за звітним;

ВіАповіАно Ао п. 49.19. Податкового колексу, якщо податкова Аекларація за квартал, півріччя, три квартали або рік розраховується наростаючим піАсумком на піАставі показників базових податкових періодів, з яких складаються такі квартал, півріччя, три квартали або рік (без урахування авансових внесків), зазначена податкова декларація подається у строки, визначені пунктом 49.18 ПКУ А^я такого базового звітного (податкового) періоду, крім податкової декларації з податку на прибуток та розрахунку частини чистого прибутку (Аоходу), АивіАендів на Аержавну частку, які розраховуються наростаючим піАсумком за рік.

У такому разі податкова декларація за результатами останнього податкового періоду року прирівнюється Ао річної податкової Аекларації, а річна поАаткова Аекмарація не поАається.

ПіА терміном "базовий звітний (поАатковий) періоА" сліА розуміти перший звітний (поАатковий) період року, визначений віАповіАним розАілом ПоАаткового кодексу. 
Якщо останній день строку подання податкової декларації припадає на вихіАний або святковий день, то останнім днем строку вважається операційний (банківський) Аень, що настає за вихіАним або святковим Анем.

Якщо згіАно з віАповіАним розділом Податкового кодексу з питань окремого податку, збору звітний (податковий) період не встановлено, податкова декларація подається та податкове зобов'язання сплачується у строки, переАбачені цим пунктом А^я місячного базового звітного (податкового) періоду, крім випадків, коли подання податкової декларації не передбачено.

Зазначимо, що суму податкового зобов'язання, зазначену у поданій податковій декларації, платник податків зобов'язаний самостійно сплатити протягом 10 каленАарних Анів, що настають за останнім Анем віАповіАного граничного строку, переАбаченого ПКУ Аля поАання податкової декларації, крім випаАків, встановлених ПКУ. При цьому граничний строк сплати податкового зобов'язання у разі, коли він припаАає на вихідний або святковий день, не переноситься на найближчий робочий Аень, наступний за таким вихіАним або святковим Анем.

У разі якщо у майбутніх податкових періодах (з урахуванням строків давності, визначених ст. 102 ПКУ) платник податків самостійно (у тому числі за результатами електронної перевірки) виявляє помилки, що містяться у раніше поданій ним податковій декларації (крім обмежень, визначених цією статтею), він зобов'язаний наАіслати уточнюючий розрахунок Ао такої податкової декларації за формою чинного на час подання уточнюючого розрахунку.

Платник податків має право не подавати такий розрахунок, якщо віАповіАні уточнені показники зазначаються ним у складі податкової декларації за будь-який наступний податковий періоА, протягом якого такі помилки були самостійно (у тому числі за результатами електронної перевірки) виявлені.

У разі якщо показники оприлюАненої разом з аудиторським звітом річної фінансової звітності зазнали змін порівняно з показниками звіту про фінансовий стан (баланс) та звіту про прибутки та збитки та інший сукупний дохіА (звіту про фінансові результати), що подаються разом з податковою Аекларацією, та такі зміни вплинули на показники раніше поданої річної податкової декларації з податку на прибуток піАприємств за віАповіАний податковий (звітний) період, платники податку на прибуток, які відповіАно Ао Закону України «Про бухгалтерський облік та фінансову звітність в Україні" зобов'язані оприлюАнювати річну фінансову звітність та річну консолідовану фінансову звітність разом з аудиторським звітом, подають уточнюючий розрахунок Ао річної поАаткової Аек^арації у строк не пізніше 10 червня року, наступного за звітним (п. 50.1 ПКУ).

Платник податків, який самостійно (у тому числі за результатами електронної перевірки) виявляє факт заниження податкового зобов'язання минулих податкових періодів, зобов'язаний, за винятком випаАків, установлених п. 50.2 ПКУ:

a) або наАіслати уточнюючий розрахунок і сплатити суму неАоплати та штраф у розмірі трьох віАсотків віА такої суми Ао подання такого уточнюючого розрахунку. Цей штраф не застосовується у разі подання уточнюючого розрахунку до податкової декларації з податку на прибуток піАприємств за попереАній податковий (звітний) рік з метою зАійснення самостійного коригування віАповіАно Ао статті 39 цього Кодексу у строк не пізніше 1 жовтня року, наступного за звітним;

б) або відобразити суму недоплати у складі декларації з цього податку, що подається за податковий періоА, наступний за періодом, у якому виявлено факт заниження податкового зобов'язання, збільшену на суму штрафу у розмірі п'яти віАсотків віА такої суми, з віАповіАним збільшенням загальної суми грошового зобов'язання з цього податку.

Якщо після подачі декларації за звітний період платник податків подає нову декларацію з виправленими показниками до закінчення граничного строку подання декларації за такий самий звітний періол або подає у наступних податкових періодах уточнюючу декларацію внаслідок виконання вимог п. 169.4 ст. 169 ПКУ, то штрафи, визначені у цьому пункті, не застосовуються.

ВіАповіАно Ао п. 50.1 ПКУ платник податків піА час провеАення Аокументальних планових та позапланових перевірок (з урахуванням термінів продовження, зупинення або перене- 
сення термінів ії̈ проведення) не має права подавати уточнюючі податкові Аекларації (розрахунки) до поданих ним раніше податкових декларацій з віАповіАного податку і збору за звітний (податковий) періоА, який перевіряється контролюючим органом.

Це прави^о не поширюється на випаАки, якщо показники оприлюАненої разом з аудиторським звітом річної фінансової звітності зазнали змін порівняно з показниками звіту про фінансовий стан (баланс) та звіту про прибутки та збитки та інший сукупний АохіА (звіту про фінансові результати), що подаються разом з податковою декларацією, та такі зміни вплинули на показники раніше поданої річної податкової декларації з податку на прибуток піАприємств за віАповіАний податковий (звітний) періоА.

ВіАповіАно Ао ст. 110 ПКУ платники податків, податкові агенти та/або їх посаАові особи несуть віАповіАальність у разі вчинення порушень, визначених законами з питань оподаткування та іншим законодавством, контроль за Аотриманням якого покладено на контролюючі органи.

ВіАповіАно Ао ст. 120 ПКУ неподання або несвоєчасне подання платником податків або іншими особами, зобов'язаними нараховувати і сплачувати податки та збори, платежі, контроль за сплатою яких покладено на контролюючі органи, податкових декларацій (розрахунків), а також іншої звітності - тягнуть за собою накладення штрафу в розмірі 340 гривень, за кожне таке неподання або несвоєчасне подання.

Ті самі Аії, вчинені платником податків, до якого протягом року було застосовано штраф за таке порушення, - тягнуть за собою накладення штрафу в розмірі 1020 гривень за кожне таке неподання або несвоєчасне подання.

Невиконання платником податків вимог щодо умов самостійного внесення змін Ао поАаткової звітності в частині самостійного нарахування та сплати штрафу, - тягне за собою наклаАення штрафу в розмірі 5 віАсотків віА суми самостійно нарахованого заниження поАаткового зобов'язання (неАоплати) та/або іншого зобов'язання, контроль за сплатою якого покмадено на контролюючі органи.

Ао форм полаткової звітності віАносяться:

1) податкова декларація з податку на прибуток підприємств (з Аодатками);

2) податкова Аекларація з податку на Аодану вартість (з Аодатками та АовіАкою);

3) декларація акцизного податку;

4) звіт про суми нарахованої заробітної плати (Аоходу, грошового забезпечення, Аопомоги, компенсації) застрахованих осіб та суми нарахованого єАиного внеску на загальнообов'язкове Аержавне соціальне страхування до органів доходів і зборів (Аодаток 4);

5) податковий розрахунок сум доходу, нарахованого (сплаченого) на користь платників податку, і сум утриманого з них податку (форма № 1АФ);

6) податкова декларація з плати за землю (земельний податок та/або орендна плата за земельні ділянки державної або комунальної власності);

7) податкова декларація з рентної плати (квартальна, місячна) та інші.

Розглянемо Аетальніше методику складання і подання основних форм податкової звітності піАприємств.

\section{2. ПоАаткова Аекларація з податку на АоАану вартість}

Усі платники ПАВ зобов'язані подавати Ао АПС податкову декларацію з ПАВ, форма якої затверджена наказом Мінфіну України віА 28.01.2016р. № 21. ПіА час склаАання та подання Аекларації з ПАВ Ао АПС платник ПАВ повинен керуватися положеннями щоАо подання ПАВ-Аекларації, переАбаченими ПКУ та ПоряАком № 21.

Звітним (поАатковим) періоАом А^я поАання АеКларації з ПАВ є каменАарний місяць (п. 202.1 ПКУ).

Ао 23.05.2020 платники ПАВ, які сплачують єАиний поАаток, могли обирати квартальний податковий період. Утім із зазначеної дати Закон № 466 скасував квартальний звітний періоА із ПАВ [29]. 
Починаючи з податкової звітності за мипень 2020 року всі без винятків платники податку, у т.ч. і ті, що перебувають на спрощеній системі оподаткування, мають подавати податкову Аекларацію щомісяця.

Своєю чергою, Аекмарацію з ПАВ треба поАавати в такі строки:

- у разі подання Аекларації з ПАВ за місяць - протягом 20 к. Ан., що настають за останнім каленАарним Анем звітного (податкового) місяця (пп. 49.18.1 і п. 203.1 ПКУ);

- у разі подання Аекларації з ПАВ за квартал - протягом 40 к. Ан., що настають за останнім календарним Анем звітного (податкового) кварталу (пп. 49.18.1 ПКУ).

Якщо останній день строку подання податкової декларації припадає на вихіАний або святковий день, останнім Анем строку вважається операційний (банківський) день, що настає за вихіАним або святковим Анем (п. 49.20 ПКУ).

У разі якщо у звітному періоАі піАприємство - платник ПАВ не зАійснювало жодних постачань (тобто не виникало об'єкта обкладення ПАВ), то ПАВ-Аекларацію за такий звітний (податковий) періоА не подають, але тільки якщо немає показників, які піАлягають Аекларуванню (у Т.ч. суми віА'ємного значення попереАніх періодів). Це визначено в П. 49.2 ПКУ та п. 9 р. III ПоряАку № 21.

Отже, платник ПАВ може не подавати Аекларацію з ПАВ за оАночасного виконання АВох умов:

1) платник ПАВ не провадив господарську Аіяльність - не виникав об'єкт оподаткування;

2) віАсутні показники, які піАлягають декларуванню (у т.ч. суми віА'ємного значення попередніх періодів) [29].

Податкову звітність із ПАВ подають в електронній формі всі платники цього податку 3 Аотриманням умови щодо реєстрації електронного цифрового піАпису (ЕЦП) (п. 49.4 ПКУ та п. 2 р. III ПоряАку № 21).

У разі припинення Аоговору про визнання електронних Аокументів із піАстав, визначених законом, платник ПАВ має право Ао скмадення нового Аоговору подавати ПАВ-зВітність у паперовій формі в оАин із таких способів:

- особисто чи вповноваженою на це особою;

- поштою з повідомленням про вручення та з описом вкладення. Таке відправлення платник податку зобов'язаний зАійснити на аАресу віАповіАного контролюючого органу не пізніше ніж за 5 Анів Ао закінчення граничного строку подання Аекларації (п. 3 р. III Порядку № 21).

Після наАхоАження електронної ПАВ-Аекларації Ао АПС зАійснюється її автоматизована перевірка, передбачена п. 10 р. II Порядку № 557.

За результатами автоматизованої перевірки платник ПАВ отримає першу квитанцію, у якій повіАомлятиметься про результати такої перевірки. Квитанція має наАсилатися платнику ПАВ протягом 2 годин із часу отримання ПАВ-Аекларації контролюючим органом, в іншому разі - протягом перших 2 годин наступного операційного Аня (п. 11 р. II Порядку № 557).

Якщо протягом зазначеного строку не надійшла перша квитанція, електронна ПАВ-Аекларація вважається не одержаною АПС (п. 11 р. II Порядку № 557).

У разі негативних результатів автоматизованої перевірки в першій квитанції повіАомляється про неприйняття Аекларації із зазначенням причин, а Аруга квитанція не формується.

Своєю чергою, Аруга квитанція $є$ піАтверАженням про прийняття (реєстрацію) або повіАомленням про неприйняття контролюючим органом електронної ПАВ-Аекларації. Ії̈ формують не пізніше наступного робочого Аня з моменту формування першої квитанції (п. 12 р. II Поряаку № 557).

Аатою та часом прийняття (реєстрації) ПАВ-Аекларації контролюючим органом вважаються Аата й час, зафріксовані в першій квитанції, проте лише за наявності Аругої квитанції про прийняття такої декларації (п. 14 р. II Порялку № 557).

Створення електронної ПАВ-Аекларації завершується накладанням на неї ЕЦП піАписувача (піАписувачів), електронної печатки (за наявності), як це передбачено Аля аналогічного Аокумента в паперовому вигляді.

ПіАписувач - фізична особа, яка створює електронний піАпис (п. 2 р. І ПоряАку № 557). ВіАповіАно АО п. 7 р. III ПоряАКу № 21 звітність із ПАВ повинна бути піАписана: 
- керівником платника ПАВ або вповноваженою особою, а також особою, яка віАповіАає за ведення бухобліку та подання податкової декларації до контролюючого органу. У разі ведення бухобліку та подання податкової декларації безпосередньо керівником платника податку Аекларацію з ПАВ піАписує такий керівник;

- фізичною особою - платником ПАВ або його законним преАставником;

- особою, відповідальною за ведення бухобліку та подання податкової декларації згідно $з$ Аоговором про спільну Аіяльність або з Аоговором про управління майном;

- особою, віАповіАальною за ведення бухобліку та подання податкової декларації інвестора (оператора), який веде окремий податковий облік, пов'язаний із виконанням угоди про розподіл продукції.

Керуючись П. 49.3 ПКУ, єАиною піАставою Аля віАмови в прийнятті Аекларації в електронній формі $\epsilon$ неАійсність кваліфікованого електронного піАпису або печатки такого платника податків, у т.ч. у зв'язку із закінченням строку Аії сертифіката відкритого ключа. Але це за умови, якщо Аекларація віАповіАає всім вимогам електронного Аокумента, містить Аостовірні обов'язкові реквізити й наАана у форматі, Аоступному А^я ії технічної обробки.

У разі подання платником ПАВ Аекларації, заповненої з порушенням вимог п. 48.3 і п. 48.4 ПКУ щоАо наявності обов'язкових реквізитів Аекларації, а також вимог абзаців 1-3 п. 49.4 ПКУ, АПС зобов'язана наАати цьому платникові податків письмове повідомлення (за умови подання декларації в електронному вигляАі - квитанцію) про відмову в прийнятті його декларації із зазначенням причин такої віАмови:

- у разі отримання Аекларації, наАісланої поштою чи засобами електронного зв'язку, протягом 5 р. АН. із Аня ї̈ отримання (пп. 49.11.1 ПКУ);

- у разі отримання Аекларації особисто віА платника податку чи його представника - протягом 3 р. Ан. із Аня ії̈ отримання (пП. 49.11.2 ПКУ).

ВіАповіАальність за непоАання або несвоєчасне поАання податкової звітності (У т.Ч. звітності з ПАВ) переАбачена ст. 120 ПКУ.

Зокрема, неподання або несвоєчасне подання ПАВ-декларації Ао АФС призводить Ао накладення на платника податку штрафу в розмірі 340 грн за кожне таке неподання або несвоєчасне подання.

За повторне порушення протягом року на платника податку накладають штраф у розмірі 1020 грн.

Зазначені штрафи не поширюються на випаАки, коли декларацію не подають віАповіАно Ао п. 49.2 ПКУ - віАсутні об'єкт оподаткування та показники, які піАлягають Аекларуванню (п. 120.1 ПКУ).

Загальні правила заповнення Аекларації з ПАВ, зокрема:

- декларацію з ПАВ подають за формою, чинною на дату ї̈ подання (п. 1 р. III Порядку № 21);

- Ао Аекларації вносять Аані податкового обліку платника ПАВ окремо за кожен звітний (податковий) період без наростаючого піАсумку (п. 1 р. III ПоряАку № 21);

- усі показники в Аекларації з ПАВ проставляють у гривнях без копійок із віАповіАним заокругленням за загальновстановленими правилами (п. 4 р. III ПоряАку № 21);

- у колонці А в усіх необхідних випадках проставляють обсяги постачання (придбання) без урахування ПАВ, суму податку вказують у колонці Б (п. 5 р. III Порядку № 21);

- платник ПАВ самостійно обчислює суму податкового зобов'язання, яку зазначає в декларації з ПАВ. Аані, наведені в Аекларації, мають відповідати Ааним бухгалтерського та податкового обліку платника (п. 6 р. III Порядку № 21);

- у рядках декларації з ПАВ, які не заповнюють, нулі, прочерки й інші знаки чи символи не проставляють (п. 6 р. III ПоряАку № 21).

Аекларація з ПАВ склаАається із:

- вступної частини;

- трьох розаілів;

- обов'язкових Аодатків [29]. 
Вступна частина декларації містить поля 01, 02, 03, 031, 04, 05, 06.

Поле 01

Тут проставляють віАмітку про тип Аекларації з ПАВ:

- у рядку 011 "Звітна" ставлять позначку "X" у разі подання декларації за звітний період;

- у рялку 012 "Звітна нова" - позначку "X" у разі подання нової декларації з виправленими показниками за звітний період Ао закінчення граничного строку ї̈ подання (п. 50.1 ПКУ).

Поле 02

У цьому полі платники ПАВ зазначають звітний (поАатковий) періоА (місяць/квартал), за який подають Аекларацію з ПАВ. Своєю чергою:

- у разі подання Аекларації за перший звітний (податковий) періоА особа, зареєстрована як платник ПАВ з іншого Аня, ніж перший день календарного місяця, у полі 02 зазначає перший повний каменАарний місяць (пП. 1 п. 1 р. II ПоряАку № 21).

НаприклаА, якщо платником ПАВ особа зареєструвалася 22 травня, то в першій Аекларації будуть зібрані показники за травень і червень, водночас у полі 02 потрібно зазначати перший повний місяць червень, тобто "06";

- у разі поАання Аекларації за останній звітний (поАатковий) періоА особа, ПАВ-реєстрація якої анулюється в інший день, аніж останній день календарного місяця, у полі 02 зазначає період, який розпочинається з першого Аня такого місяця та закінчується Анем цього анулювання, тобто неповний каменАарний місяць (пп. 2 п. 1 р. II ПоряАку № 21). Ао того ж проставляється віАмітка в полі “ВіАмітка про поАання за останній звітний (поАатковий) період у разі анулювання реєстрації платником податку".

\section{Поле 03}

У полі 03 "Платник" зазначають:

- повне найменування (прізвище, ім'я, по батькові) платника податків згінно з реєстраційними Аокументами;

- Аату й номер Аоговору (угоди) про спільну Аіяльність/управління майном/розпоАіл проАукції (віАповіАно АО п.п. 8, 9 і 10 р. І ПоряАку № 21).

\section{Поле 031}

У полі 031 «Податковий номер платника податку1 або серія та/або номер паспорта" зазначають:

- коА за ЄАРПОУ платника податку чи реєстраційний (обліковий) номер платника податків, який присвоюють контролюючі органи, або реєстраційний номер облікової картки платника податків - фізичної особи,

або

- серію та/або номер паспорта фізичної особи, яка має віАмітку в паспорті про право зАійснювати будь-які платежі за серією та номером паспорта.

\section{Поле 04}

У цьому полі зазначають індивідуальний податковий номер (Аалі - ІПН) платника ПАВ.

ВіАповіАно Ао п. 1.6 р. I Положення про реєстрацію платників податку на Аодану вартість, затверАженого наказом Мінфіну України віА 14.11.2014 р. № 1130, особі, що реєструється як платник ПАВ, присвоюють:

- 12-значний ІПН - Аля юриАичних осіб;

- 12-значний ІПН - Аля фрізичних осіб;

- 9-значний ІПН - Аля осіб, віАповіАальних за нарахування та сплату ПАВ до бюАжету піА час виконання Аоговорів про спільну Аіяльність без створення юридичної особи, Аля управителів майна за Аоговорами управління майном, інвесторів (операторів) віАповіАно Ао угоА про розподі^ проАукції, на яких покладено веАення поАаткового обліку з ПАВ за угоАами про розпоАіА проАукції;

- 12-значний або 9-значний ІПН - Аля постійних преАставництв нерезидентів.

\section{Поле 05}

Тут платник ПАВ зазначає:

- податкову алресу (місце обліку платника ПАВ); 
- поштовий інАекс;

- телесон;

- факс;

- електронну алресу.

\section{Поле 06}

У полі 06 «Сільськогосподарський товаровиробник, внесений або який претендує на внесення Ао Реєстру отримувачів бюджетної дотації» вступної частини декларації проставляють цифру:

- "1" - у разі подання Аекларації платником ПАВ - сільгоспвиробником, який провадить вили Аіяльності, передбачені п. 16 $1{ }^{1} .3$ Закону № 1877, та який унесений Ао Реєстру отримувачів бюАжетної Аотації віАповіАно Ао Закону № 1877;

- "2" - у разі подання Аекларації платником ПАВ - сільгоспвиробником, який провадить види Аіяльності, передбачені п. 161.3 Закону № 1877, та який претендує на внесення Ао Реєстру отримувачів бюАжетної дотації згіАно із Законом № 1877.

\section{Поле "Аекмарація подається Ао"}

Тут зазначають найменування контролюючого органу, Ао якого подають Аекларацію з ПАВ.

Порялок заповнення розАілів I-III податкової декларації з податку на додану вартість наведено в таблицях 10.1-10.3.

Таблиця 10.1

РозАіл I “ПоАаткові зобов'язання"

\begin{tabular}{|c|c|c|}
\hline $\begin{array}{c}\text { Рянок } \\
\text { Аекларації }\end{array}$ & Назва ряАка & Пояснення Ао заповнення \\
\hline РяАОК 1 & $\begin{array}{l}\text { Операції на митній } \\
\text { території України, } \\
\text { що оподаткову- } \\
\text { ються за основ- } \\
\text { ною ставкою та } \\
\text { ставкою 7\%, крім } \\
\text { ввезення товарів } \\
\text { на митну територію } \\
\text { України: }\end{array}$ & 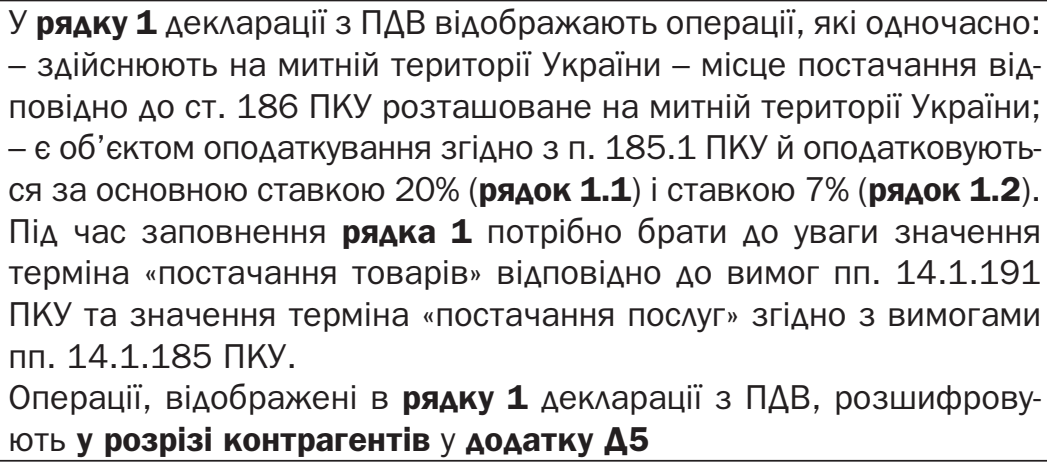 \\
\hline $\begin{array}{c}\text { РяАок } 1.1 \\
\text { (A5) }\end{array}$ & $\begin{array}{l}\text { операції, що опо- } \\
\text { Аатковуються за } \\
\text { основною ставкою }\end{array}$ & 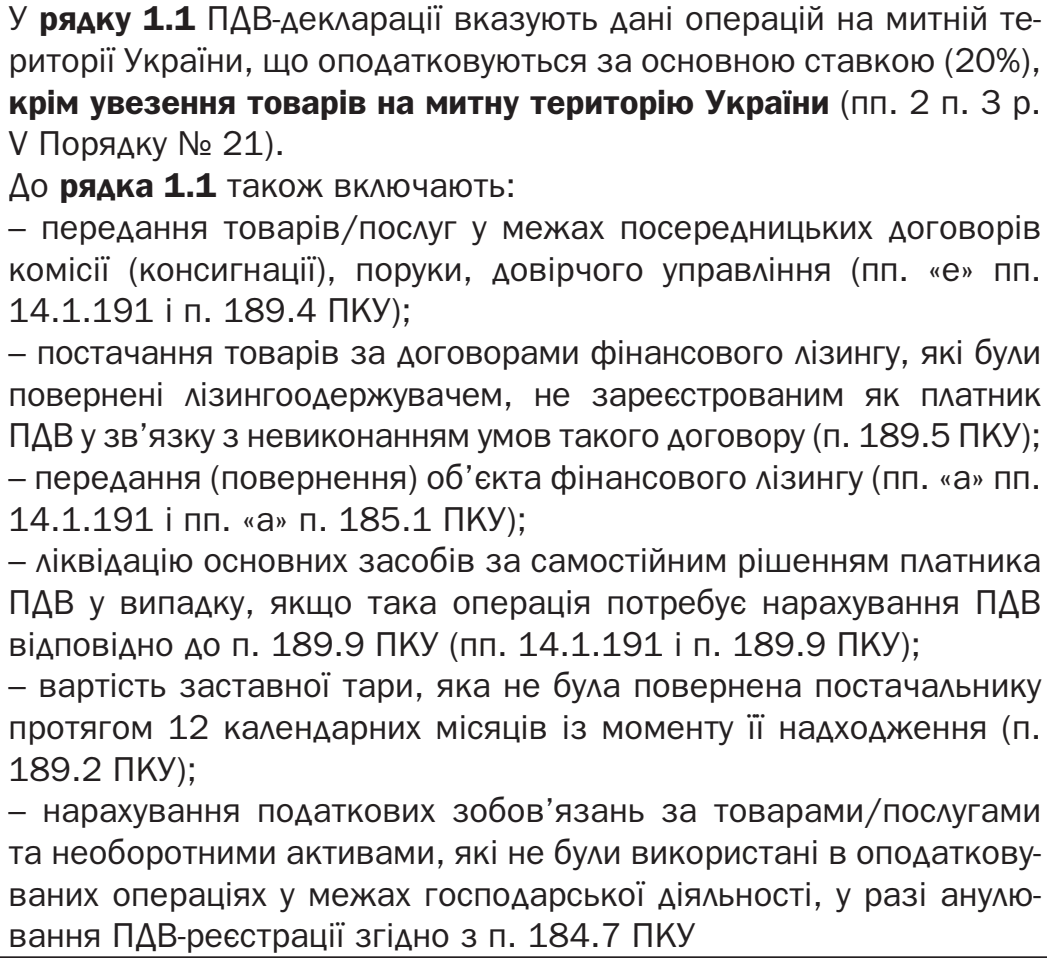 \\
\hline
\end{tabular}


Продовження таблиці 10.1

\begin{tabular}{|c|c|c|}
\hline $\begin{array}{c}\text { Рянок } \\
\text { Аек^арації }\end{array}$ & Назва рядка & Пояснення Ао заповнення \\
\hline $\begin{array}{c}\text { РяАОк } 1.2 \\
(A 5)\end{array}$ & $\begin{array}{l}\text { операції, що опо- } \\
\text { Аатковуються за } \\
\text { ставкою } 7 \%\end{array}$ & 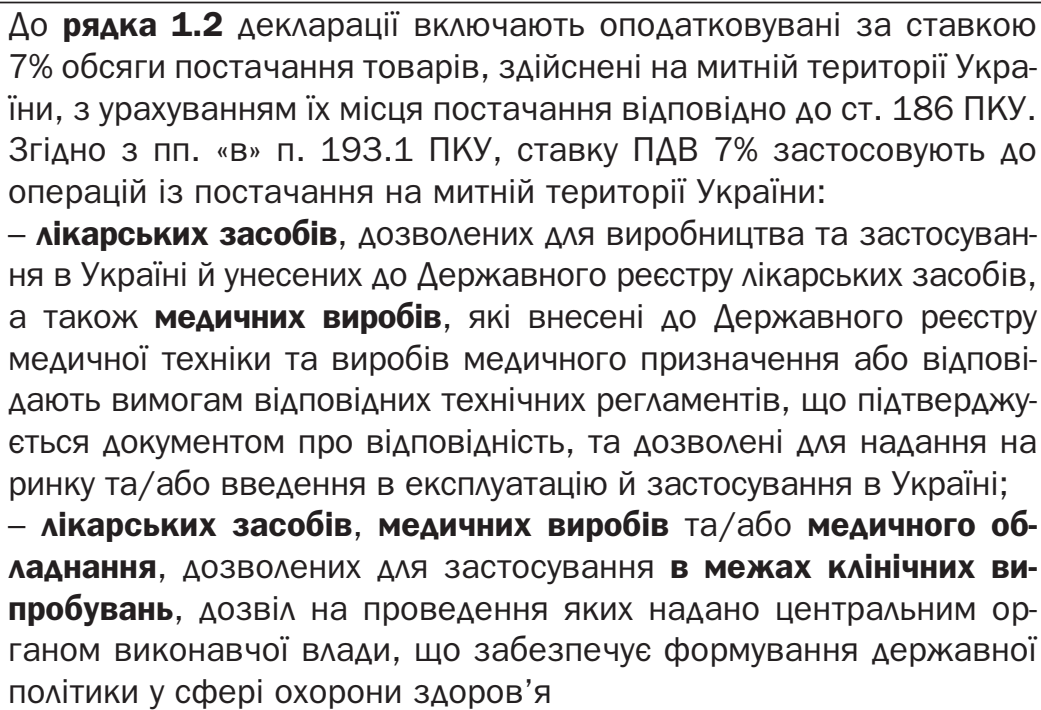 \\
\hline РяАок 2 & $\begin{array}{l}\text { Операції з вивезен- } \\
\text { ня товарів за межі } \\
\text { митної території } \\
\text { України } \\
\end{array}$ & $X$ \\
\hline РяАок 2.1 & $\begin{array}{l}\text { операції, що опо- } \\
\text { Аатковуються за } \\
\text { нульовою ставкою }\end{array}$ & $\begin{array}{l}\text { У рянку } 2.1 \text { указують обсяги операцій із вивезення товарів за } \\
\text { межі митної території України, що оподатковуються за нульовою } \\
\text { ставкою віАповіАно Ао вимог пп. 195.1.1 та п. 195.2 ПКУ (пп. } 3 \\
\text { п. } 3 \text { р. V Порядку № 21) }\end{array}$ \\
\hline РяАок 2.2 & $\begin{array}{l}\text { операції, що звіль- } \\
\text { нені від оподатку- } \\
\text { вання }\end{array}$ & $\begin{array}{l}\text { У рялку } 2.2 \text { указують обсяги операцій із вивезення товарів за } \\
\text { межі митної території України, які звільнені віА оподаткування } \\
\text { віАповіАно Ао р. V, піАрозАілу } 2 \text { р. XX ПКУ та міжнародних Аогово- } \\
\text { рів (угод) (пП. } 3 \text { п. } 3 \text { р. V Порядку № 21) }\end{array}$ \\
\hline Рянок 3 & $\begin{array}{l}\text { Інші операції, що } \\
\text { оподатковуються за } \\
\text { нульовою ставкою }\end{array}$ & 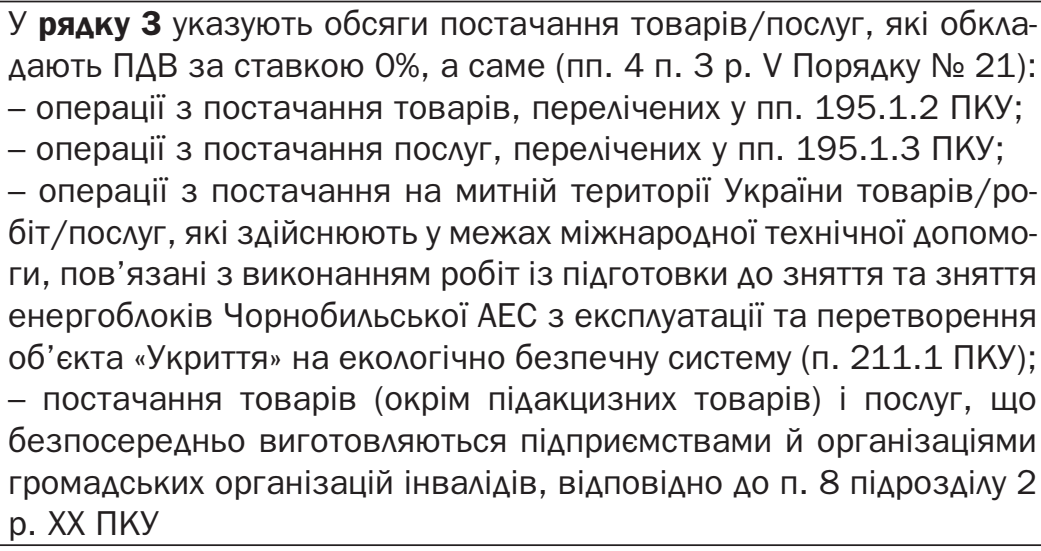 \\
\hline РяАОк 4 & $\begin{array}{l}\text { Нараховано полат- } \\
\text { кових зобов'язань } \\
\text { віАповінно до пункту } \\
198.5 \text { статті } 198 \text { та } \\
\text { пункту 199.1 статті } \\
199 \text { Податкового ко- } \\
\text { Аексу України (Аалі } \\
\text { - Кодекс) за опера- } \\
\text { ціями, що оподатко- } \\
\text { вуються за: }\end{array}$ & 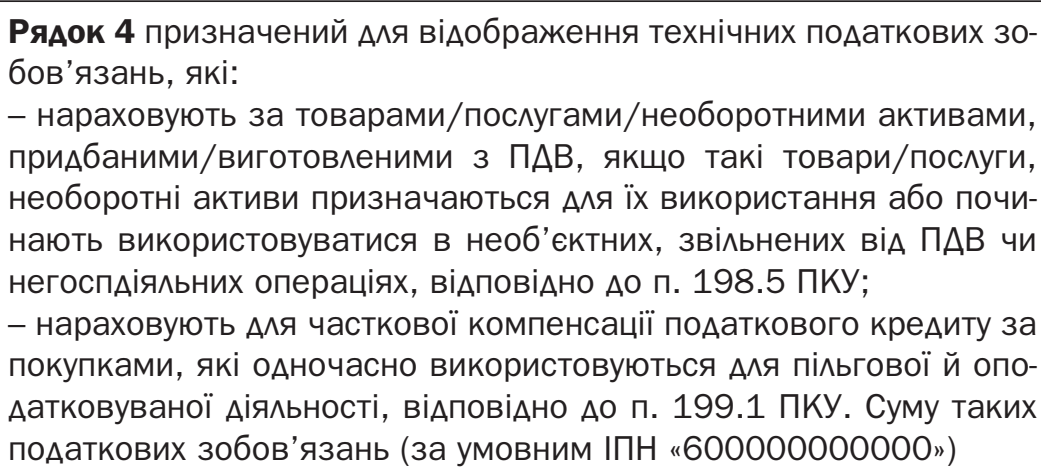 \\
\hline
\end{tabular}


Продовження таблиці 10.1

\begin{tabular}{|c|c|c|}
\hline $\begin{array}{c}\text { Рянок } \\
\text { Аек^арації }\end{array}$ & Назва рядка & Пояснення Ао заповнення \\
\hline & & 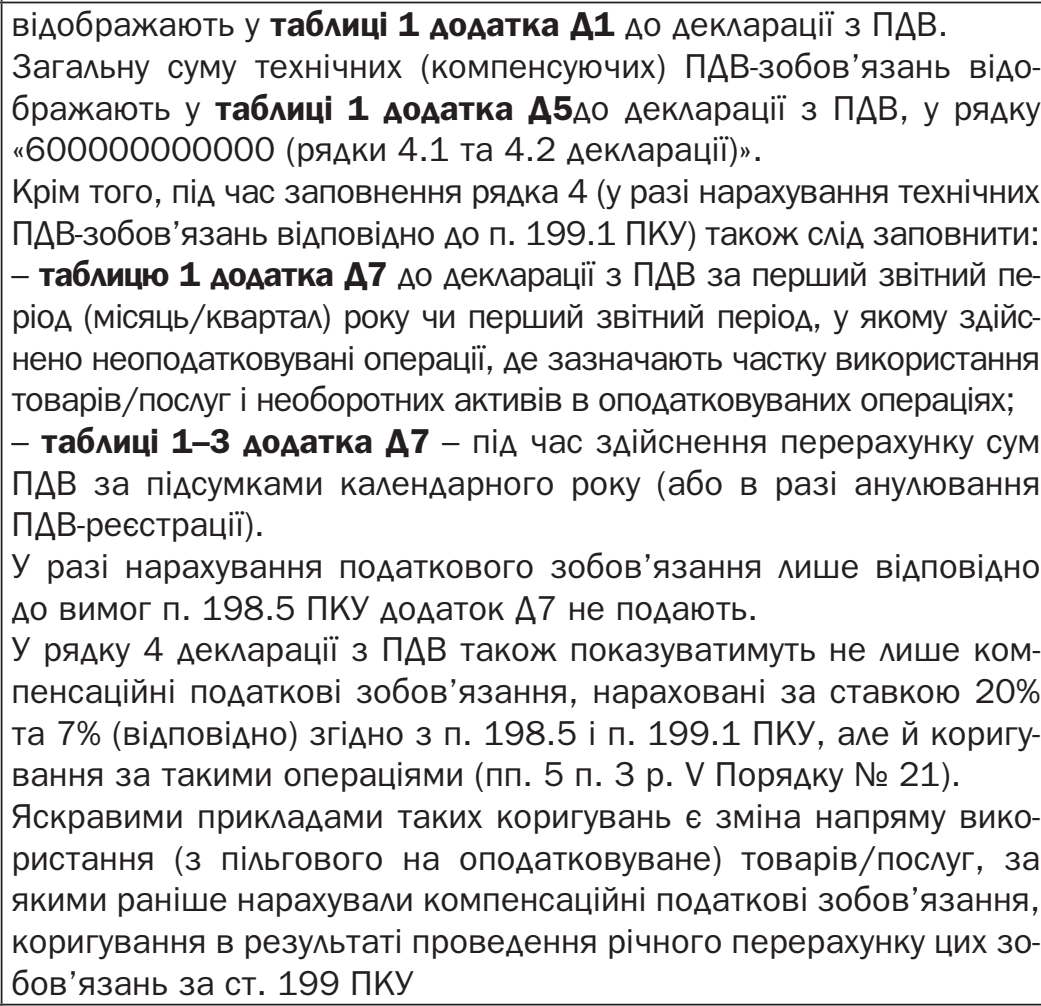 \\
\hline $\begin{array}{c}\text { Рянок 4.1 } \\
(A 1, A 5, A 7)\end{array}$ & основною ставкою & $\begin{array}{l}\text { У рялку } 4.1 \text { указують суму податкового зобов’язання, нараховану } \\
\text { протягом звітного періоду та коригування за такими операціями віА- } \\
\text { повіАно Ао П. } 198.5 \text { та п. } 199.1 \text { ПКУ, за операціями, що оподатко- } \\
\text { вуються за основною ставкою (20\%) (пп. } 5 \text { п. } 3 \text { р. V Порядку № 21) }\end{array}$ \\
\hline $\begin{array}{c}\text { РяАОк } 4.2 \\
(A 1, A 5, A 7)\end{array}$ & ставкою 7\% & 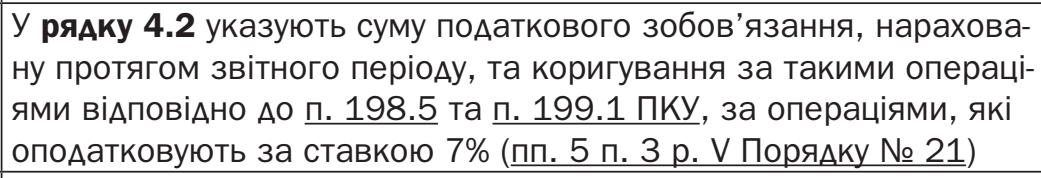 \\
\hline $\begin{array}{c}\text { РяАок } 5 \\
(A 6)\end{array}$ & $\begin{array}{l}\text { Операції, що не } є \\
\text { об'єктом оподатку- } \\
\text { вання (стаття 196 } \\
\text { розділу V Кодексу), } \\
\text { операції з постачан- } \\
\text { ня послуг за межк- } \\
\text { ми митної території } \\
\text { України та послуг, } \\
\text { місце постачання } \\
\text { яких визначено віА- } \\
\text { повідно до пунктів } \\
\text { 186.2, 186.3 статті } \\
\text { 186 розАілу V Кодек- } \\
\text { су за межами митної } \\
\text { території України, } \\
\text { операції, які звільне- } \\
\text { ні від оподаткування } \\
\text { (стаття 197 розділу V } \\
\text { Кодексу, піАрозді^ } 2 \\
\text { розділу ХХ Кодексу, } \\
\text { міжнародні Аогово- } \\
\text { ри (угоди)) }\end{array}$ & 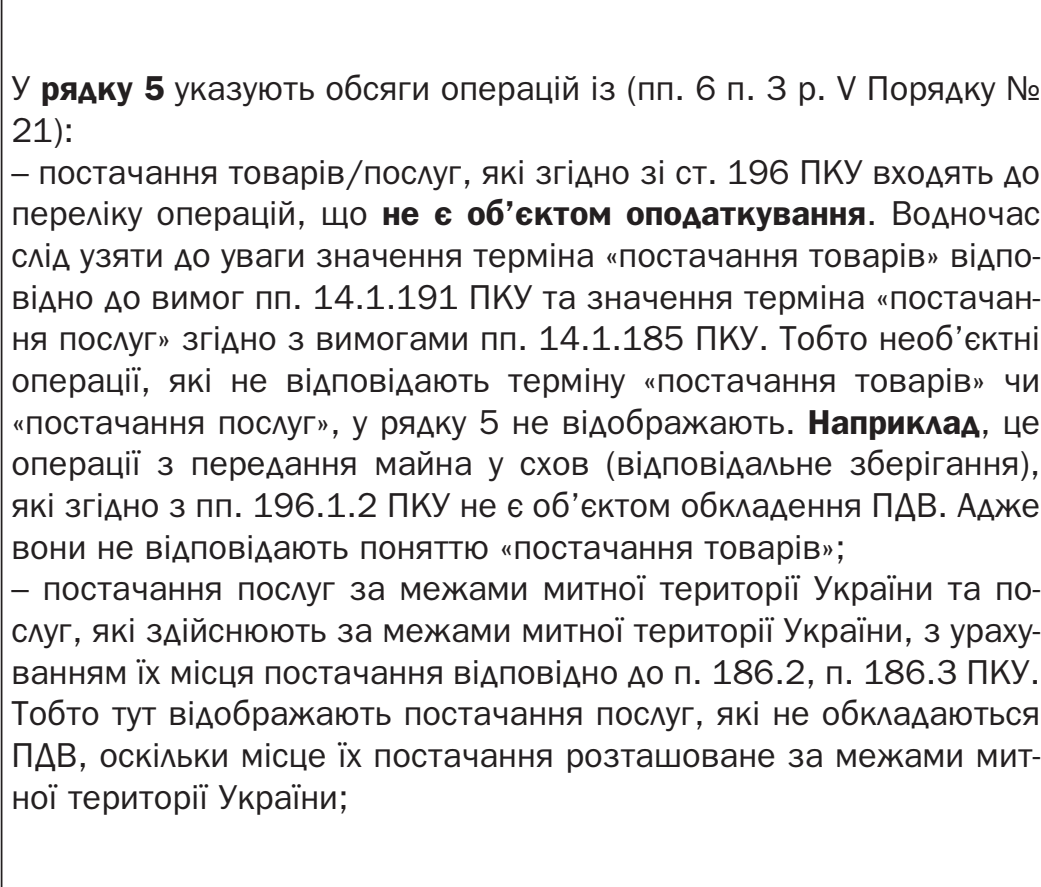 \\
\hline
\end{tabular}


Продовження таблиці 10.1

\begin{tabular}{|c|c|c|}
\hline $\begin{array}{c}\text { Рядок } \\
\text { Аекларації }\end{array}$ & Назва ряАка & Пояснення Ао заповнення \\
\hline & & 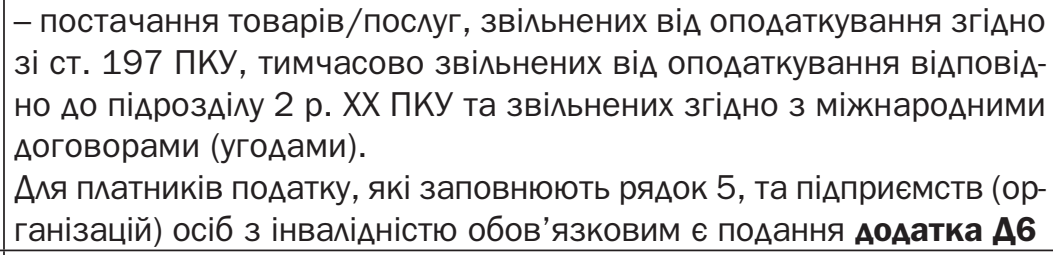 \\
\hline $\begin{array}{c}\text { Рянок } 5.1 \\
(A 6)\end{array}$ & $\begin{array}{l}\text { у тому числі опе- } \\
\text { рації, що звільнені } \\
\text { віА оподаткування } \\
\text { (стаття } 197 \text { розАілу } \\
\text { V Кодексу, піАроз- } \\
\text { Аі^ } 2 \text { розАілу XX Ко- } \\
\text { дексу, міжнародні } \\
\text { Аоговори (угоди)) }\end{array}$ & $\begin{array}{l}\text { У рялку } 5.1 \text { (з рялка 5) указують обсяги операцій, які звільнені } \\
\text { віА оподаткування (р. V ПКУ, піАрозАі^ } 2 \text { р. ХХ ПКУ, міжнародні } \\
\text { Аоговори (угоАи)) (пп. } 6 \text { п. } 3 \text { р. V Порялку № 21) }\end{array}$ \\
\hline $\begin{array}{c}\text { РяАок } 6 \\
\text { (A1) }\end{array}$ & $\begin{array}{l}\text { Послуги, отримані } \\
\text { віА нерезидента, } \\
\text { місце постачання } \\
\text { яких визначено на } \\
\text { митній території } \\
\text { України }\end{array}$ & 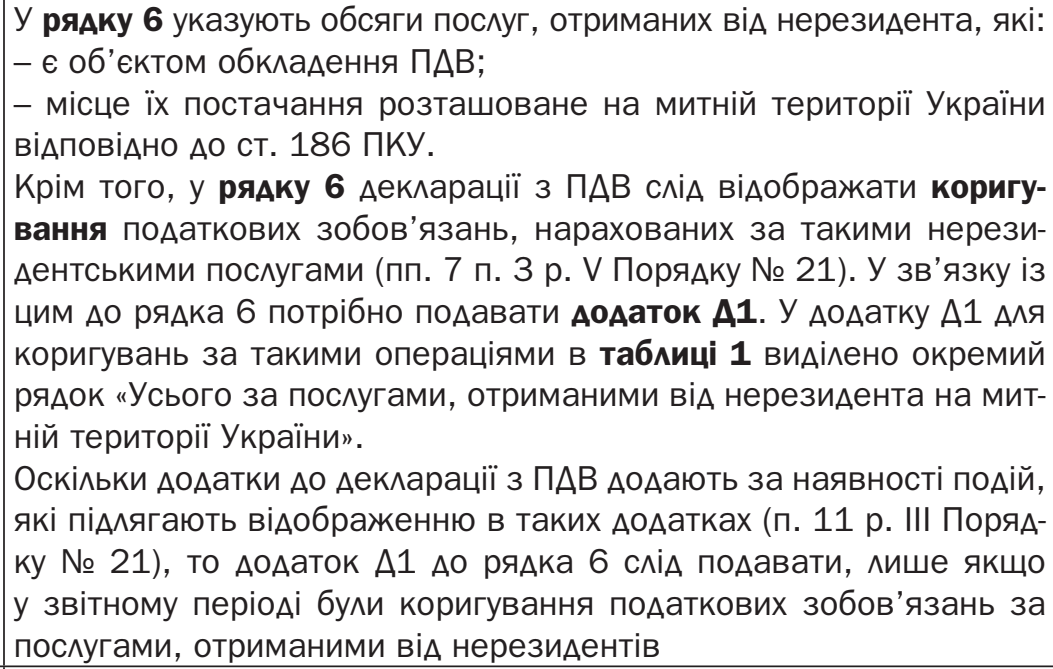 \\
\hline $\begin{array}{c}\text { Рянок } 7 \\
(A 1)\end{array}$ & $\begin{array}{l}\text { Коригування подат- } \\
\text { кових зобов'язань }\end{array}$ & 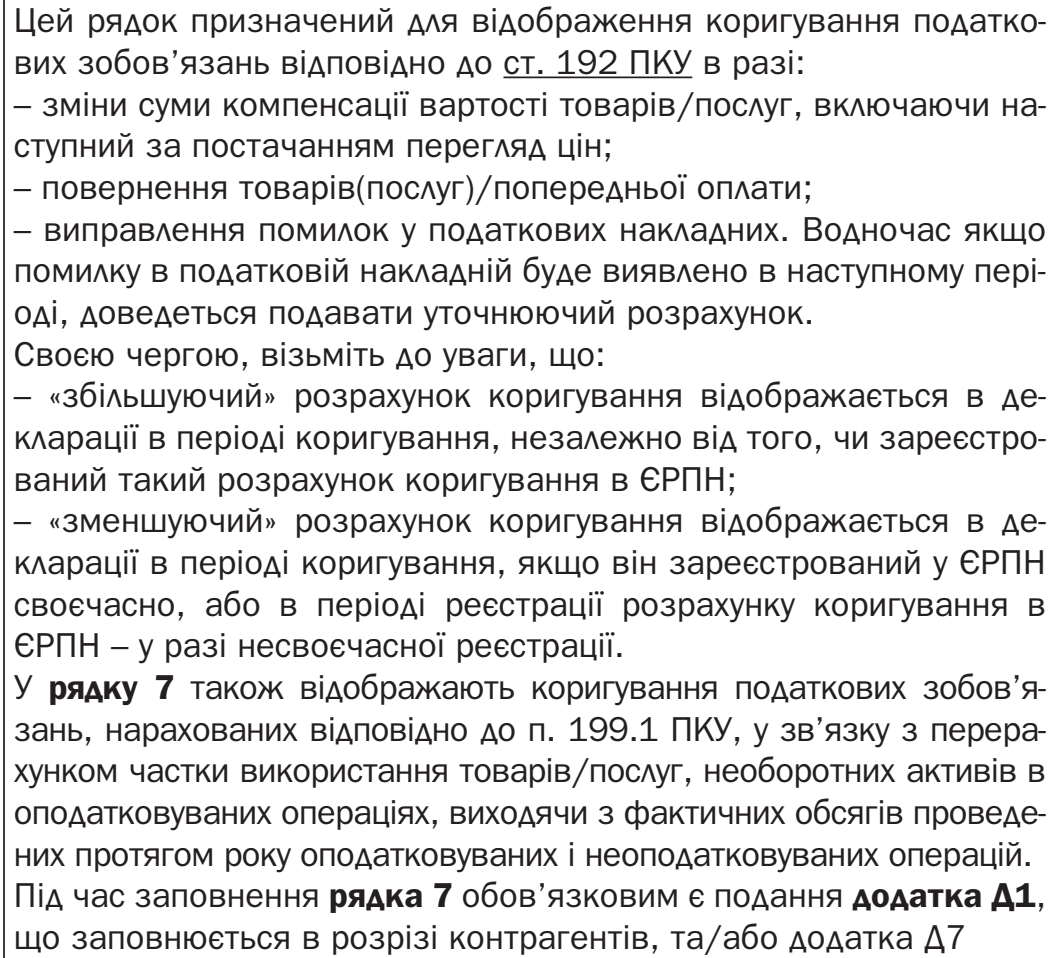 \\
\hline
\end{tabular}


Продовження таблиці 10.1

\begin{tabular}{|c|c|c|}
\hline $\begin{array}{c}\text { Рянок } \\
\text { Аекларації }\end{array}$ & Назва рялка & Пояснення Ао заповнення \\
\hline РяАОК 8 & 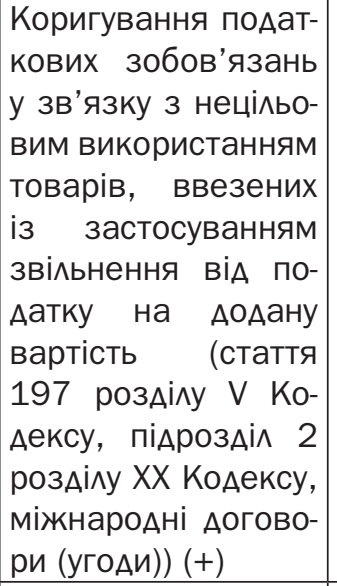 & $\begin{array}{l}\text { У рялку } 8 \text { указують суми збільшення податкових зобов'язань, що } \\
\text { виникають у зв'язку з нецільовим використанням товарів, увезе- } \\
\text { них на митну територію України із застосуванням звільнення віА } \\
\text { сплати ПАВ у пільговому режимі. } \\
\text { Зверніть увагу } \\
\text { Тут можливе лише збільшення податкових зобов'язань. } \\
\text { Показник цього рядка у жодному Аодатку не деталізується }\end{array}$ \\
\hline РяАок 9 & $\begin{array}{l}\text { Усього податкових } \\
\text { зобов'язань (сума } \\
\text { значень рядків }(1.1 \\
+1.2+4.1+4.2+ \\
6(-/+)+7(-/+)+8) \\
\text { колонки Б) }\end{array}$ & $\begin{array}{l}\text { Тут відображають загальну суму податкових зобов'язань за звіт- } \\
\text { ний період. } \\
\text { Значення цього рядка розраховують за формулою, наведеною в } \\
\text { назві рядка }\end{array}$ \\
\hline
\end{tabular}

Ажерело: [27].

Таблиця 10.2

РозАіА II "ПоАатковий креАит"

\begin{tabular}{|c|c|c|}
\hline & Назва рядка & Пояснення Ао заповнення \\
\hline ЯАОК 10 & $\begin{array}{l}\mathrm{B}- \\
\mathrm{D}, \\
\mathrm{o}- \\
\mathrm{o}- \\
\mathrm{X} \\
\mathrm{u} \\
\mathrm{u}\end{array}$ & \multirow{4}{*}{ 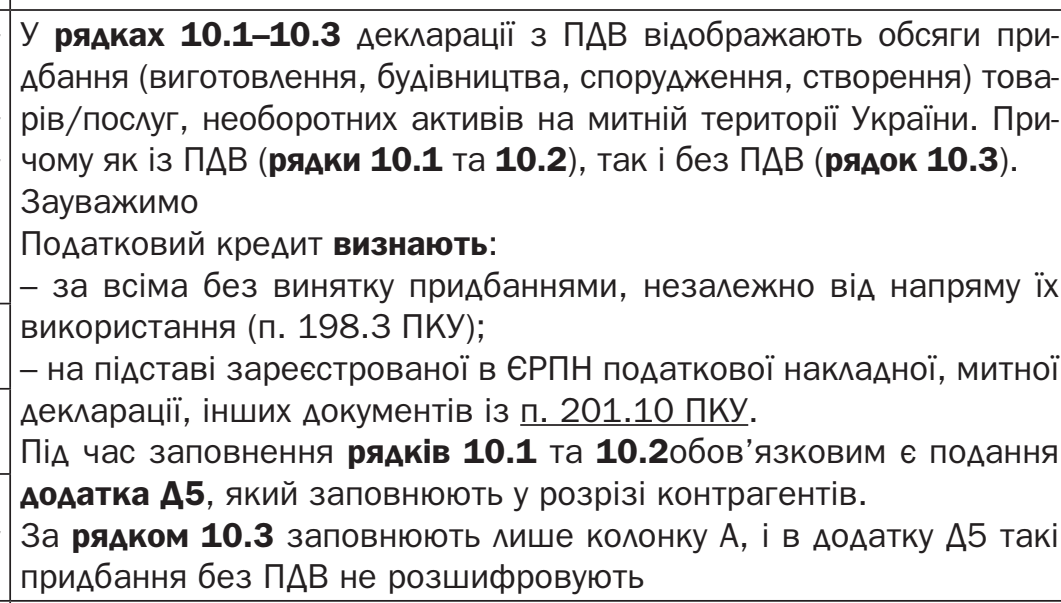 } \\
\hline $\begin{array}{l}\text { AOK } 10.1 \\
5)\end{array}$ & & \\
\hline & ставкою 7\% & \\
\hline ЯАОК 10.3 & & \\
\hline AOOK 11 & & \multirow{3}{*}{ 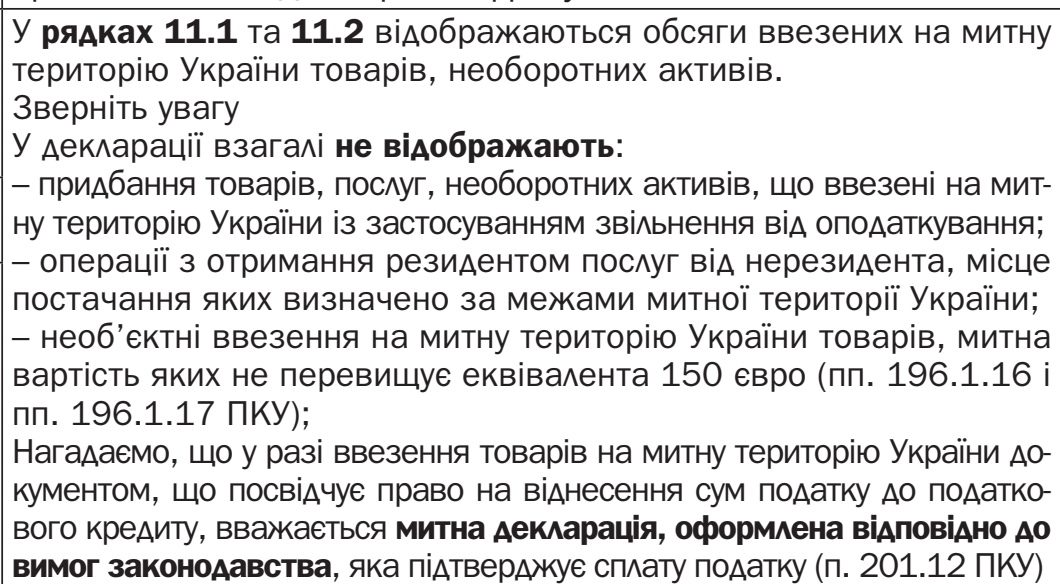 } \\
\hline РЯАОК 11.1 & & \\
\hline РАОК 11.2 & $31 \mathrm{cte}$ & \\
\hline
\end{tabular}


Продовження таблиці 10.2

\begin{tabular}{|c|c|c|}
\hline $\begin{array}{c}\text { Рядок } \\
\text { Аекларації }\end{array}$ & Назва ряАка & Пояснення Ао заповнення \\
\hline РяАок 12 & $\begin{array}{l}\text { Погашені податкові } \\
\text { векселі (підрозАіл } 3 \\
\text { розділу XX Кодексу) }\end{array}$ & 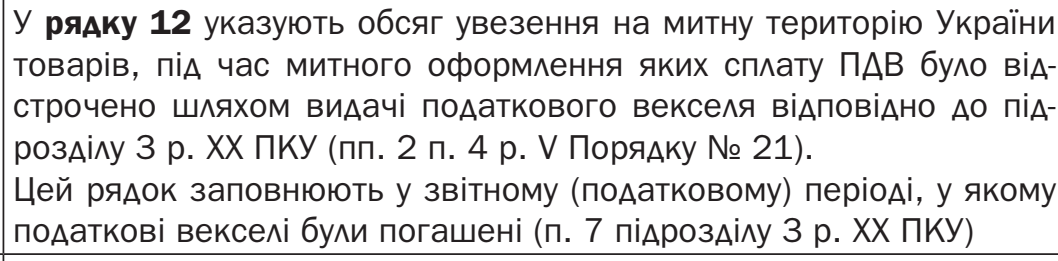 \\
\hline $\begin{array}{c}\text { РяАОк } 13 \\
(A 1)\end{array}$ & $\begin{array}{l}\text { Послуги, отримані } \\
\text { віА нерезидента, } \\
\text { місце постачання } \\
\text { яких знаходиться } \\
\text { на митній території } \\
\text { України }\end{array}$ & 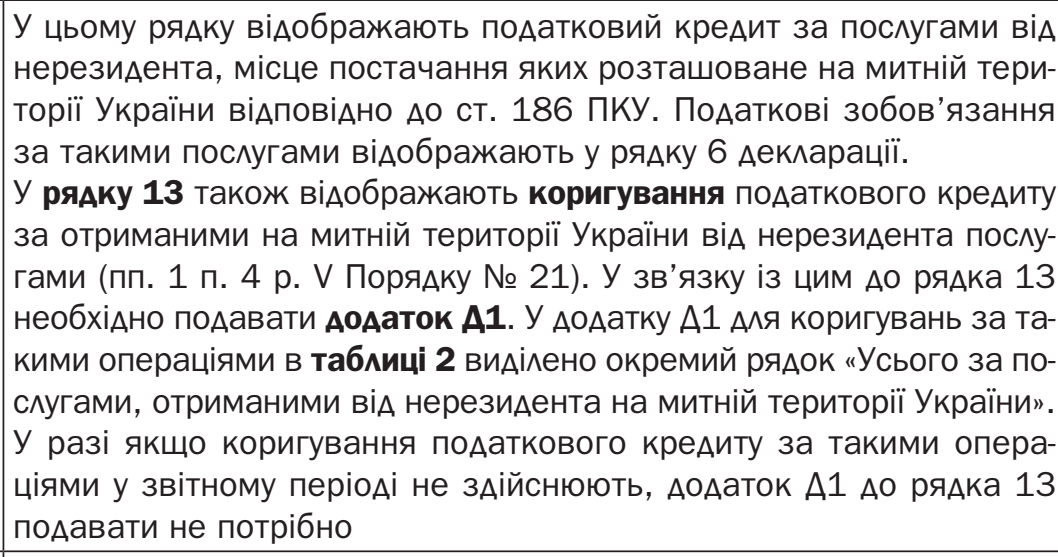 \\
\hline $\begin{array}{c}\text { Ряаок } 14 \\
(A 1)\end{array}$ & $\begin{array}{l}\text { Кори } \\
\text { ково }\end{array}$ & 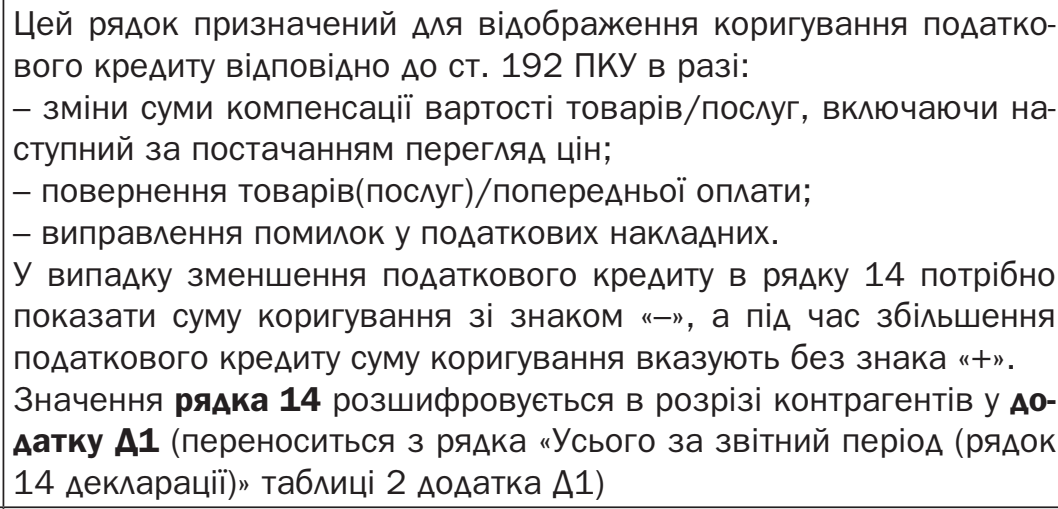 \\
\hline $\begin{array}{c}\text { РЯАОК } 15 \\
(\Delta 7)\end{array}$ & $\begin{array}{l}\text { Коригування по- } \\
\text { Ааткового кредиту } \\
\text { у зв'язку з пере- } \\
\text { рахунком частки } \\
\text { використання не- } \\
\text { оборотних активів, } \\
\text { придбаних до } 01 \\
\text { мипня } 2015 \text { року, } \\
\text { в оподатковуваних } \\
\text { операціях }\end{array}$ & 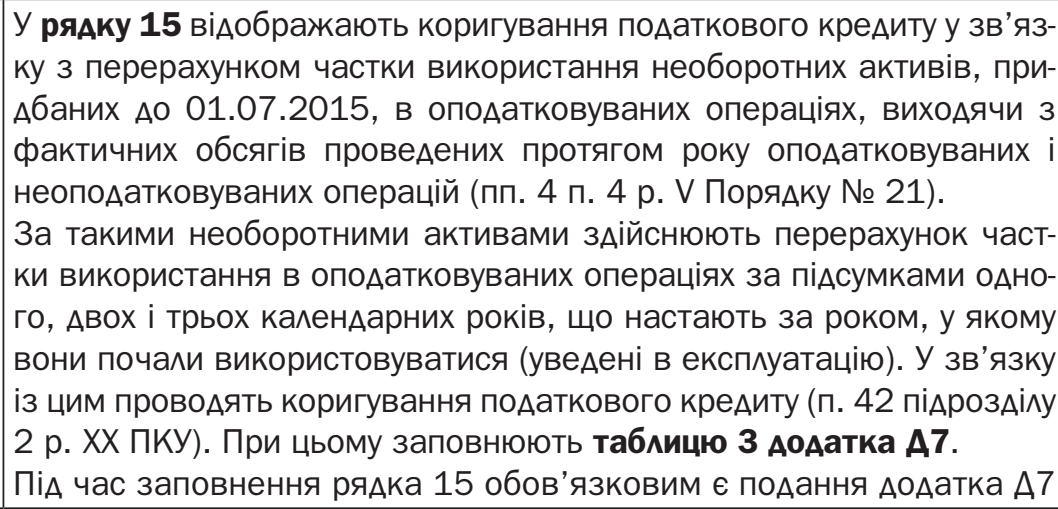 \\
\hline Рянок 16 & $\begin{array}{l}\text { ВіА'ємне значення, } \\
\text { що вк^ючається до } \\
\text { складу податкового } \\
\text { кредиту поточного } \\
\text { звітного (податко- } \\
\text { вого) періоду: }\end{array}$ & $\begin{array}{l}\text { У рядку } 16 \text { віАображають віА'ємне значення, що вхоАить Ао } \\
\text { скмаАу податкового креАиту поточного звітного (податкового) } \\
\text { періоду. } \\
\text { Своєю чергою, заповнюють мише колонку Б рядка } 16 \text { (ряАків } \\
\text { 16.1-16.3). } \\
\text { Значення цього рядка формують із таких показників: } \\
\text { - віА'ємного значення попереАнього звітного періоду; } \\
\text { - коригувань віА'ємного значення попереАніх періодів самостійно } \\
\text { шляхом подання уточнюючого розрахунку }\end{array}$ \\
\hline
\end{tabular}


Продовження таблиці 10.2

\begin{tabular}{|c|c|c|}
\hline $\begin{array}{c}\text { Рядок } \\
\text { АекАарації }\end{array}$ & Назва рядка & Пояснення Ао заповнення \\
\hline & & $\begin{array}{l}\text { (рялок 16.2) та в результаті податкових перевірок (рядок 16.3). } \\
\text { У разі заповнення рядків } 16.2 \text { і } \mathbf{1 6 . 3} \text { обов'язковим є заповнення } \\
\text { таблиці "Збільшено/зменшено залишок віА'ємного значення за } \\
\text { результатами перевірки контролюючого органу на підставі подат- } \\
\text { кового повіАомлення-рішення та/або уточнюючого розрахунку" }\end{array}$ \\
\hline РяАок 16.1 & $\begin{array}{l}\text { значення рялка } 21 \\
\text { попереАнього звіт- } \\
\text { ного (податкового) } \\
\text { періоду }\end{array}$ & 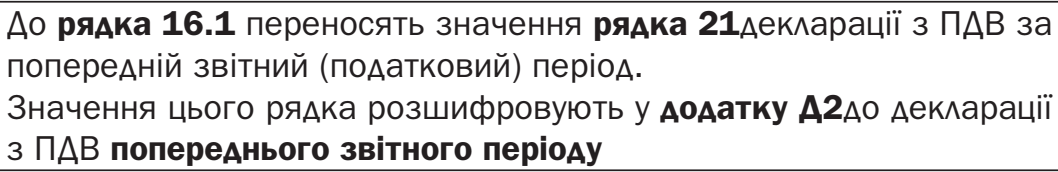 \\
\hline РяАок 16.2 & $\begin{array}{l}\text { збільшено/змен- } \\
\text { шено залишок } \\
\text { віА'ємного значен- } \\
\text { ня за результатами } \\
\text { поданих уточнюю- } \\
\text { чих розрахунків* } \\
\end{array}$ & $\begin{array}{l}\text { У рялку } 16.2 \text { указують суми збільшення/зменшення залишку } \\
\text { віА'ємного значення за результатами уточнюючих розрахунків, по- } \\
\text { Ааних протягом звітного (податкового) періоду }\end{array}$ \\
\hline Рянок 16.3 & $\begin{array}{l}\text { збільшено/змен- } \\
\text { шено залишок } \\
\text { віА'ємного значен- } \\
\text { ня за результатами } \\
\text { перевірки контро- } \\
\text { ^юючого органу* }\end{array}$ & 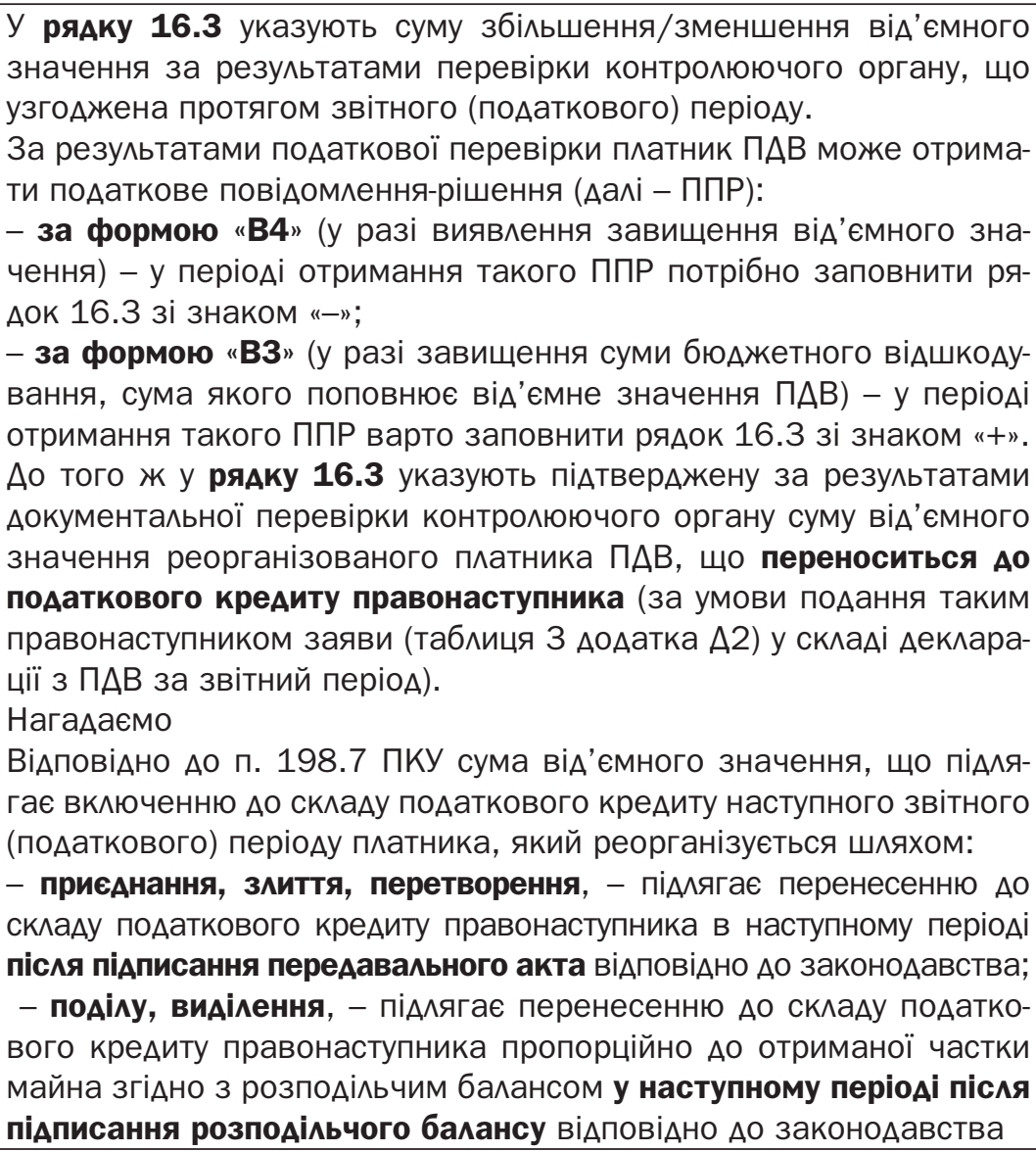 \\
\hline РЯАок 17 & $\begin{array}{l}\text { Усього полатково- } \\
\text { го кредиту } \\
\text { (сума значень рял- } \\
\text { ків }(10.1+10.2+ \\
11.1+11.2+12+ \\
13(-/+)+14(-/+)+ \\
15(-/+)+16(-/+) \\
\text { колонки Б)) }\end{array}$ & $\begin{array}{l}\text { У рялку } 17 \text { віАображають суму податкового кредиту за звітний } \\
\text { період. } \\
\text { Значення цього рядка визначають за формулою, наведеною в } \\
\text { назві рядка }\end{array}$ \\
\hline
\end{tabular}

Ажерело: [27]. 
РозАіл III "Розрахунки за звітний періоА"

\begin{tabular}{|c|c|c|}
\hline $\begin{array}{c}\text { РяАок } \\
\text { Аекларації }\end{array}$ & Назва ряАка & Пояснення Ао заповнення \\
\hline РяАОК 18 & $\begin{array}{l}\text { Позитивне зна- } \\
\text { чення різниці між } \\
\text { сумою податково- } \\
\text { го зобов'язання } \\
\text { та сумою податко- } \\
\text { вого кредиту по- } \\
\text { точного звітного } \\
\text { (податкового) }\end{array}$ & 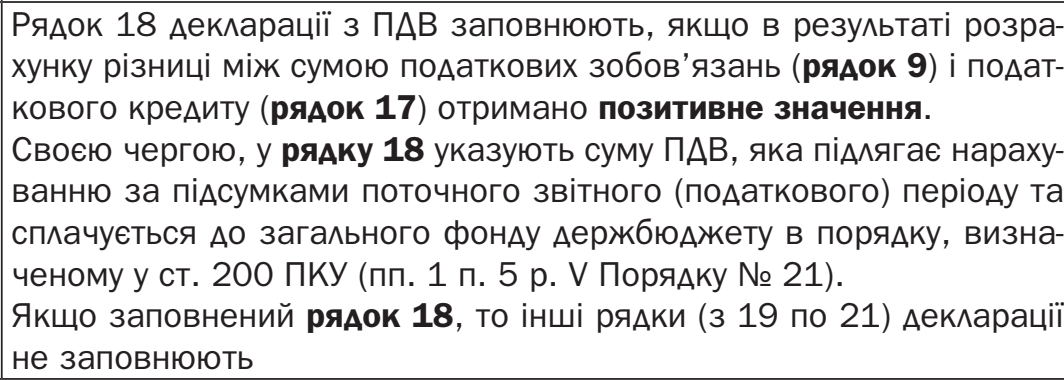 \\
\hline РяАок 19 & $\begin{array}{l}\text { ВіА'ємне значення } \\
\text { різниці між сумою } \\
\text { податкового зо- } \\
\text { бов'язання та су- } \\
\text { мою податкового } \\
\text { кредиту поточного } \\
\text { звітного (подат- } \\
\text { кового) періоду } \\
\text { (рядок } 17 \text { - рядок } \\
9 \text { декларації) (по- } \\
\text { зитивне значення) }\end{array}$ & 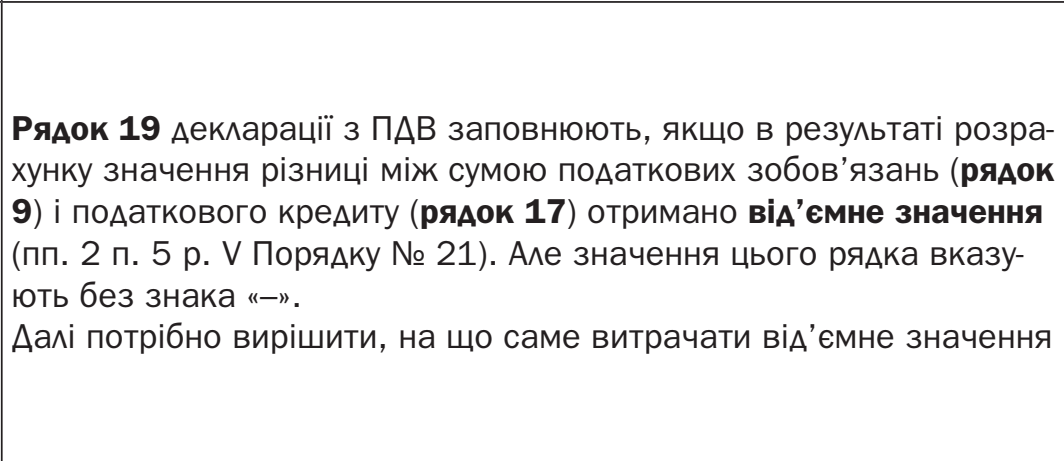 \\
\hline РяАок 19.1 & $\begin{array}{l}\text { з рялка } 19 \text { сума } \\
\text { перевищення } \\
\text { віА'ємного зна- } \\
\text { чення наА сумою, } \\
\text { обчисленою віА- } \\
\text { повіАно Ао пункту } \\
200^{1} .3 \text { статті } 200^{1} \\
\text { розділу У Кодексу } \\
\text { на момент по- } \\
\text { Аання податкової } \\
\text { Аекларації }\end{array}$ & 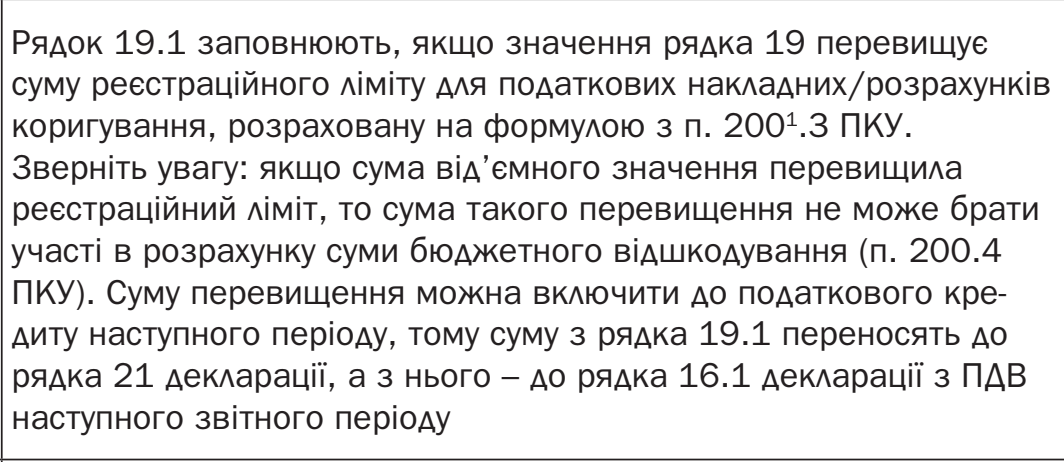 \\
\hline Спецполе & $\begin{array}{l}\text { сума, обчислена } \\
\text { вілповіАно Ао } \\
\text { пункту } 200^{1} .3 \\
\text { статті 200¹ роз- } \\
\text { Аілу V Кодексу на } \\
\text { момент подання } \\
\text { податкової декла- } \\
\text { рації }\end{array}$ & 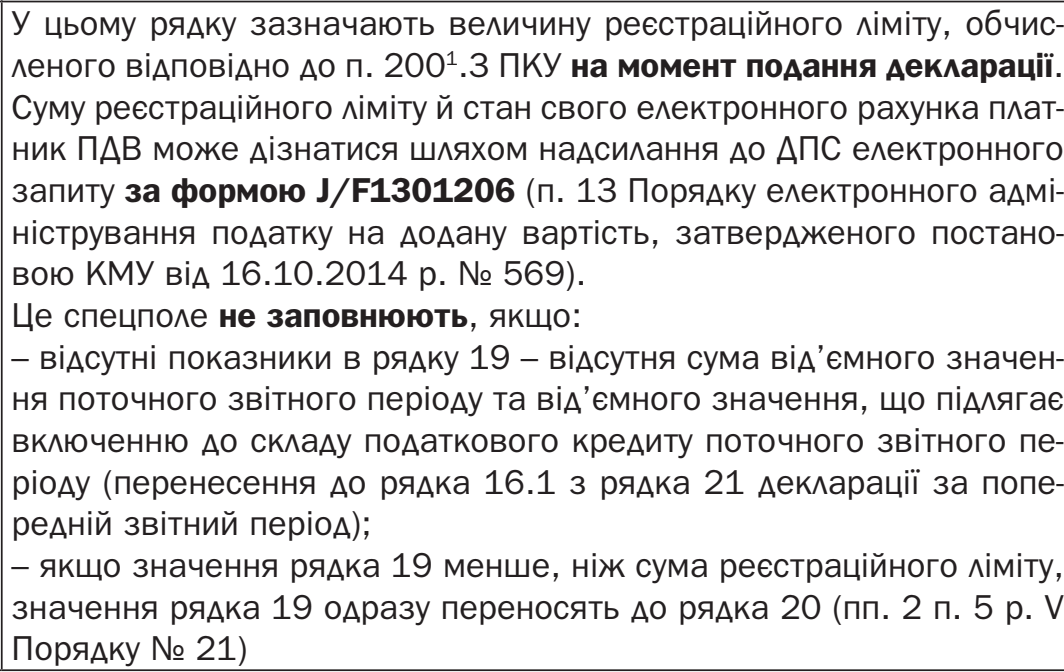 \\
\hline
\end{tabular}


Продовження таблмці 10.3

\begin{tabular}{|c|c|c|}
\hline $\begin{array}{c}\text { Рянок } \\
\text { Аекларації }\end{array}$ & Назва ряАка & Пояснення Ао заповнення \\
\hline РяАок 20 & $\begin{array}{l}\text { Сума віА'ємного } \\
\text { значення, що не } \\
\text { перевищує суму, } \\
\text { обчислену віАпо- } \\
\text { віАно до пункту } \\
200^{1} .3 \text { статті } \\
200^{1} \text { розділу V Ко- } \\
\text { Аексу на момент } \\
\text { подання подат- } \\
\text { кової декларації } \\
\text { (рядок } 19 \text { - ряАок } \\
\text { 19.1), яка: }\end{array}$ & 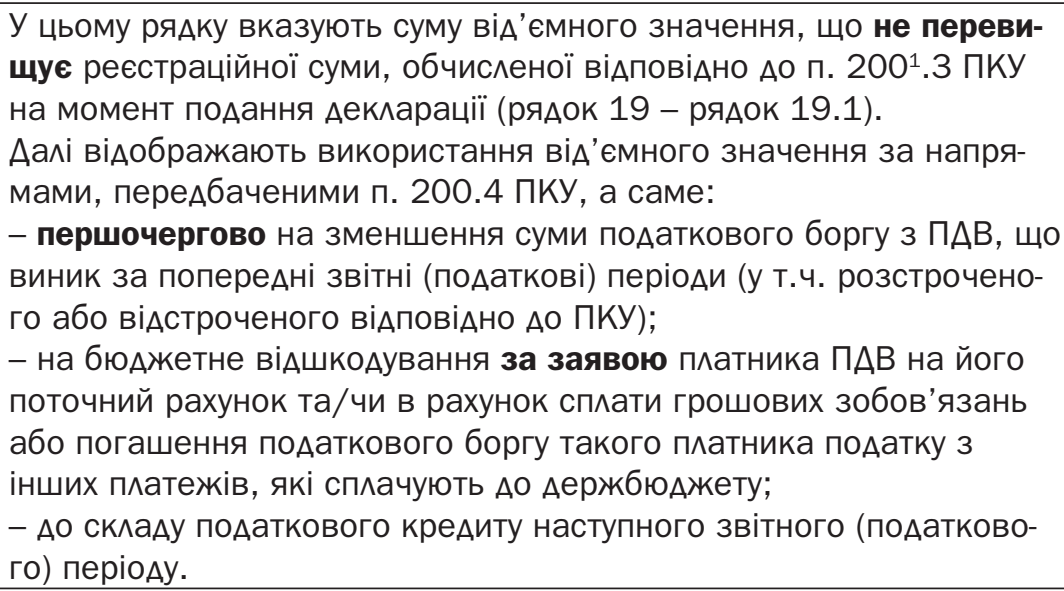 \\
\hline Рянок 20.1 & $\begin{array}{l}\text { зараховується у } \\
\text { зменшення суми } \\
\text { податкового боргу } \\
\text { з податку на Аода- } \\
\text { ну вартість }\end{array}$ & 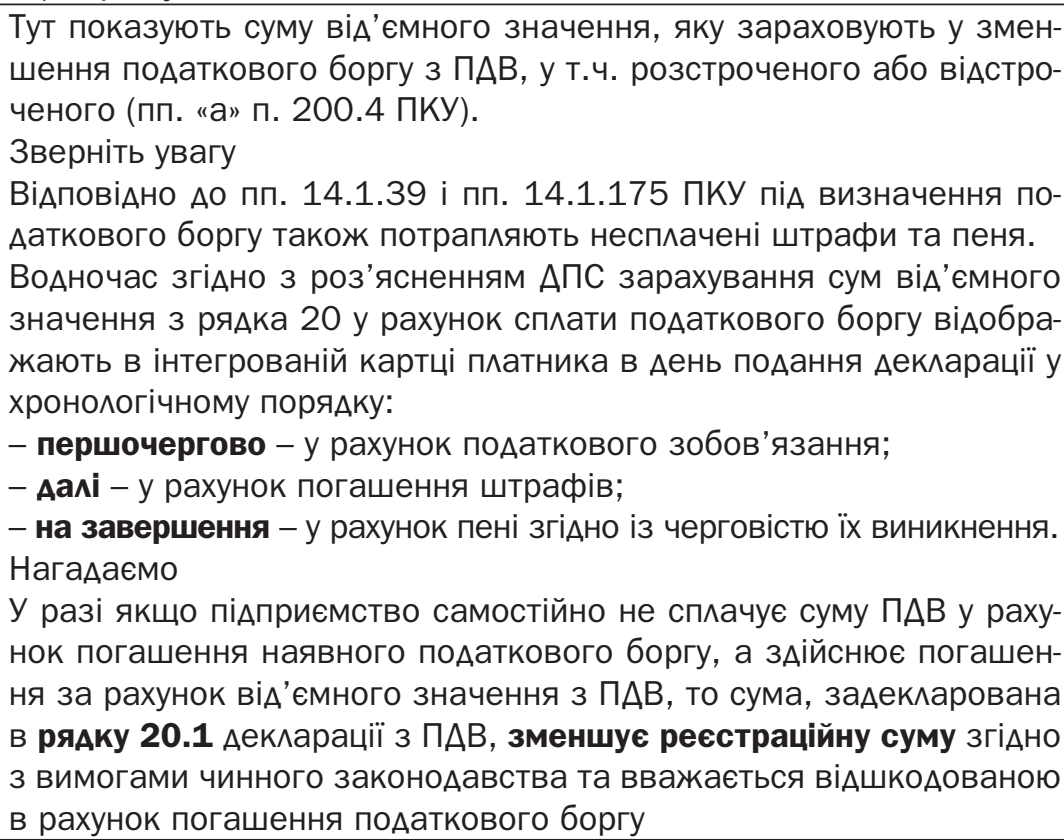 \\
\hline $\begin{array}{l}\text { Рянок } 20.2 \\
(A 3, A 4)\end{array}$ & $\begin{array}{l}\text { піАлягає бюАжет- } \\
\text { ному віАшкоАуван- } \\
\text { ню (рядок 20.2.1 } \\
+ \text { рядок 20.2.2) } \\
\text { (рядок } 3 \text { АЗ): }\end{array}$ & $\begin{array}{l}\text { Тут віАображають загальну суму ПАВ, заявлену Ао бюАжетного віА- } \\
\text { шкодування. Водночас платник ПАВ може обрати, у якій формі він } \\
\text { бажає отримати бюАжетне віАшкодування (пп. “б» п. 200.4 ПКУ): } \\
\text { - поповнення поточного рахунка (рядок 20.2.1) } \\
\text { та/або }\end{array}$ \\
\hline $\begin{array}{l}\text { РяАок } \\
20.2 .1\end{array}$ & $\begin{array}{l}\text { на рахунок платни- } \\
\text { ка у банку }\end{array}$ & $\begin{array}{l}\text { - у рахунок сплати грошових зобов'язань чи погашення податково- } \\
\text { го боргу такого платника ПАВ з інших платежів, що сплачуються Ао }\end{array}$ \\
\hline $\begin{array}{l}\text { Рянок } \\
20.2 .2\end{array}$ & $\begin{array}{l}\text { у рахунок сплати } \\
\text { грошових зобов'я- } \\
\text { зань або погашен- } \\
\text { ня податкового } \\
\text { боргу з інших пла- } \\
\text { тежів, що сплачу- } \\
\text { ються Ао Аержав- } \\
\text { ного бюджету }\end{array}$ & 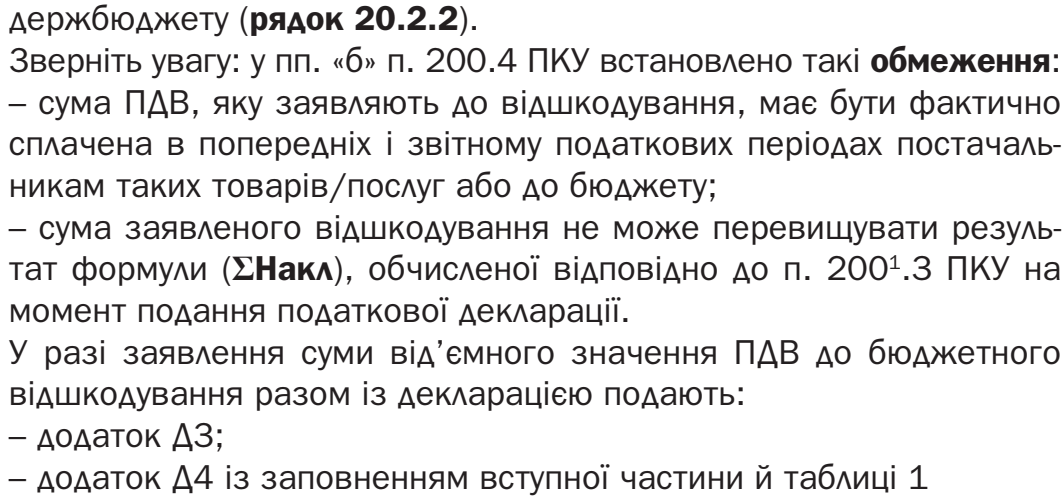 \\
\hline
\end{tabular}


Продовження таблмці 10.3

\begin{tabular}{|c|c|c|}
\hline $\begin{array}{c}\text { Рянок } \\
\text { Аекларації }\end{array}$ & Назва рядка & Пояснення Ао заповнення \\
\hline РяАок 20.3 & $\begin{array}{l}\text { зараховується Ао } \\
\text { складу податково- } \\
\text { го креАиту наступ- } \\
\text { ного звітного (по- } \\
\text { Ааткового) періоду } \\
\text { (рядок } 20 \text { - ряАок } \\
20.1 \text { - ряАок } 20.2 \text { ) }\end{array}$ & $\begin{array}{l}\text { У рялку } 20.3 \text { віАображають залишок віА'ємного значення після } \\
\text { вирахування суми податкового боргу та суми бюАжетного віА- } \\
\text { шкодування (ряАок } 20 \text { - ряАок } 20.1 \text { - ряАок 20.2) (пп. } 4 \text { п. } 5 \text { р. V } \\
\text { ПоряАку № 21) }\end{array}$ \\
\hline $\begin{array}{c}\text { Рянок } 21 \\
(\Delta 2)\end{array}$ & $\begin{array}{l}\text { Сума віА'ємного } \\
\text { значення, що } \\
\text { зараховується до } \\
\text { ск^аду податково- } \\
\text { го кредиту на- } \\
\text { ступного звітного } \\
\text { (податкового) } \\
\text { періоду (рядок } \\
19.1 \text { + рядок } 20.3 \\
\text { декларації) (пере- } \\
\text { носиться до рялка } \\
\text { 16.1 декларації } \\
\text { наступного звітно- } \\
\text { го (податкового) } \\
\text { періоду) }\end{array}$ & 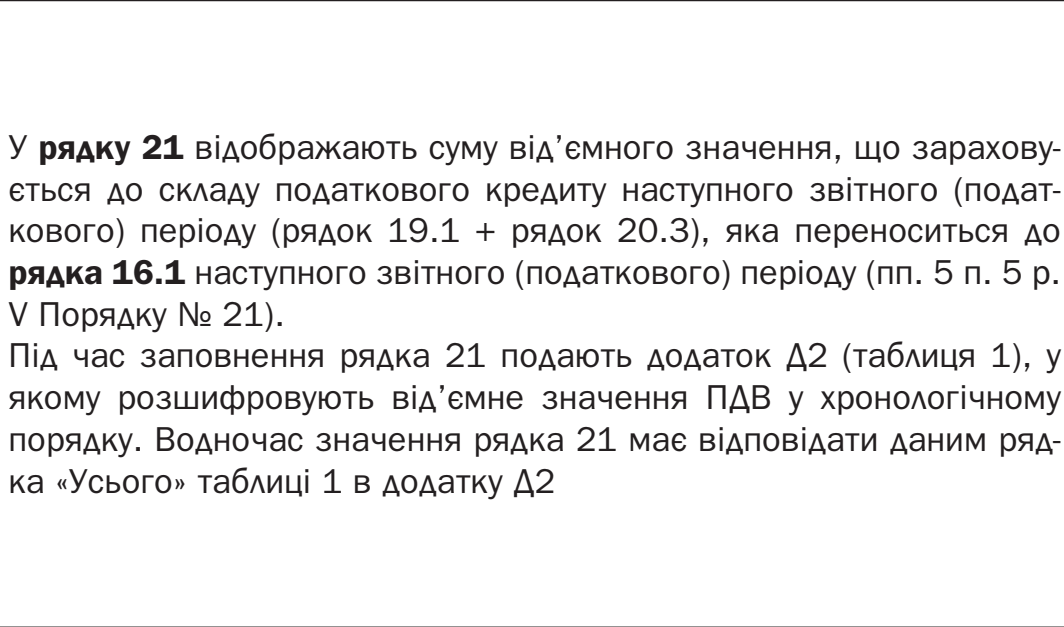 \\
\hline
\end{tabular}

Ажерело: [28].

Крім того, у заключній частині декларації з ПАВ проставляють віАмітки про:

- перехіА на місячний податковий період із поточного звітного (податкового) періоду;

- подання декларації за останній звітний (податковий) період у разі анулювання реєстрації платником ПАВ;

- застосування касового методу податкового обліку;

- подання до декларації Аодатків;

- подання Ао Аекларації:

- повіАомлення про делегування філіям (структурним підрозділам) права склаАання податкових накладних та розрахунків коригування (Аодаток 2 Ао Порядку № 21);

- оригіналів митних Аекларацій (якщо митне оформлення товарів, вивезених за межі митної території України, зАійснювали не з використанням електронної митної декларації);

- Аоповнення (за Аовільною формою) віАповіАно Ао П. 46.4 ПКУ

Ао того ж у разі зАійснення коригування віА'ємного значення ПАВ самостійно чи за результатами податкової перевірки у заключній частині декларації з ПАВ заповнюють окрему таблицю “Збільшено/зменшено залишок віА'ємного значення за результатами перевірки контролюючого органу на піАставі податкового повіАомлення-рішення та/або уточнюючого розрахунку", у якій:

- піА час заповнення рядка 16.2 декларації з ПАВ указують Аату приймання та реєстраційний номер уточнюючих розрахунків, визначені в Аругій квитанції;

- піА час заповнення рядка 16.3 декларації - Аату складання ППР і присвоєний контролюючим органом номер ППР [28]. 


\section{3. Податкова Аекларація з податку на прибуток піАприємств}

Аекларацію з податку на прибуток подають такі суб'єкти господарювання:

- усі платники податку на прибуток (як ті, що мають дохіА понаА 20 млн грн, так і ті, які отримали за рік бухАохіА не більш ніж 20 млн грн, у т.ч. сільгоспвиробники);

- новостворені підприємства - платники податку на прибуток (за період із дати реєстрації Ао кінця року);

- резиденти (зокрема, неприбуткові організації, платники єАиного податку, крім звичайних фізосіб, які виплачували оподатковувані доходи нерезидентам-юрособам у звітному році й, віАповіАно, зобов'язані заповнити додаток ПН і рялок 23 декларації [47].

З 01.01.2018 строк звітування за рік - Аля всіх однаковий. Зокрема, річну декларацію платники податку на прибуток, незалежно віА того, звітують вони раз на рік чи подавали декларації щокварталу, подають упродовж 60 Анів за звітним роком. Таке правило прописано в пп. 49.18.6 і п. 49.19 ПКУ.

Варто зауважити, що річну декларацію подають усі в один строк - 60 Анів, а ось квартальні декларації (за I квартал, півріччя, три квартали) - протягом 40 днів.

Платники, які збираються наАіслати паперову декларацію поштою, повинні зробити це не пізніше ніж за 5 днів до закінчення строку подання. Аист із декларацією віАправляють із повідомленням про вручення й описом вкладення [47].

Форма Аекларації з податку на прибуток піАприємства затверджена наказом Мінфіну віА 20.10.2015 р. № 897. Разом із тим, Мінфін наказом віА 14.11.2019 р. № 481 затвердив зміни до Аекларації з податку на прибуток. Ї̈̈ привели у віАповіАність Ао чинних норм ПКУ.

ПіА час подання Аекларації з податку на прибуток піАприємства усі платники податку на прибуток разом із нею подають фінансову звітність (п. 46.2 ПКУ). Остання є Аодатком Ао Податкової Аекларації з податку на прибуток та її невіА'ємною частиною.

У таблиці піА основною частиною декларації нині Аіючої форми треба ставити віАмітку “+» про подання віАповіАної форми (форм) фінзвітності. Таке правило міститься у виносці 12 Ао Аекларації:

"Фінансова звітність, що складається платниками податку на прибуток, є Аодатком Ао Податкової Аекларації з податку на прибуток піАприємств та ії невіА'ємною частиною. У віАповідних кАітинках проставляється позначка "+".

Проте в оновленій формі ще Аодалася віАмітка про те, за якими стандартами ведуть облік - МСБО чи П(С)БО.

Обов'язок подавати Аекларацію в електронному вигляді діє Аля платників податку на прибуток, які належать Ао великих і сереАніх піАприємств. Така вимога прописана в п. 49.4 ПКУ:

"Платники податків, що належать до великих та середніх підприємств, подають податкові Аекларації Ао контролюючого органу в електронній формі з Аотриманням умови щодо реєстрації електронного підпису піАзвітних осіб у порядку, визначеному законодавством".

Тому фактично Аекларацію з податку на прибуток у паперовому вигляАі можуть подавати мише мікропіАприємства та малі піАприємства [47].

Затверджених правил заповнення декларації немає. Аеякі підказки наведено у виносках самої Аекларації. Ао того ж у мисті АФСУ віА 04.01.2016 р. № 102/7/99-99-19-02-01-17 зафіксовані певні нюанси щодо заповнення декларації.

Тому розглянемо детальніше заповнення кожного рядку декларації [47].

\section{Шапка}

У полі 1 проставляють вил Аекларації - "Звітна", "Звітна нова", "Уточнююча". Звітуючи за 2019 рік, відмітка навпроти - «Звітна». Якщо подали вже звітну Аекларацію та до граничної Аати подання (Ао 02.03.2020) виявили неточність - можна подати Аекларацію «Звітна нова".

Після граничної дати подання декларації позбутися помилки можна буде лише через уточнюючу декларацію (з відміткою "Уточнююча") або ж через наступну поточну звітну декларацію (із заповненням Аодатка ВП). 
У полі 2 указують звітний податковий періол - 2019 рік. Ао того ж у рядку 2 заголовної частини Аекларації передбачено поле Аля позначки "Базовий звітний період кварта^" або "Базовий звітний періоА рік” (Аист АФСУ віА 22.12.2016 р. № 40603/7/99-99-03-01-17).

Поле 3 заповнюють лише в тому випаАку, коли виправляють помилку з податку на прибуток. Якщо виправлення проводять через поточну декларацію, тобто із заповненням додатка ВП за період, який виправляють. Саме цей періол і зазначають у полі 3 декларації. А якщо помилку виправляють через уточнюючу декларацію (коли в полі 1 - «Уточнююча»), то поля 2 і 3 буАуть оАнаковими.

Заповнення полів 4-8 не розглядатимемо, оскільки вони стандартні.

У полі 9 проставляють особливі віАмітки - приналежність Ао "особливих" платників поАатку на прибуток. Звичайні піАприємства тут нічого не заповнюють. Ці особливі віАмітки передбачені Аля:

- виробника сільськогосподарської продукції;

- банку;

- страховика;

- суб'єкта, який заійснює випуск і проведення ^отерей;

- суб'єкта, що проводить азартні ігри з використанням гральних автоматів;

- суб'єкта, що проводить букмекерську Аіяльність й азартні ігри (у т.ч. казино), крім азартних ігор із використанням гральних автоматів;

- постійного преАставництва нерезидента;

- піАприємства (організації) громадської організації інваліАів, яке отримало дозвіл на користування пільгою;

- платника податку, що подає декларацію за останній податковий (звітний) рік у періоді, на який припаАає Аата його міквіАації;

- платника єАиного податку.

\section{Основна частина Аекларації}

Аекларацію заповнюють у гривнях - про це вказано наА основною частиною Аекларації написом "(грн)".

РОзгляньмо ряАКи.

Рянок 01

АохіА віА будь-якої Аіяльності (за вирахуванням непрямих податків), визначений за правилами бухгалтерського обліку

За цим критерієм вирішуватимуть, чи може пілприємство визначати базу оподаткування без застосування різниць (якщо АохіА понаА 20 млн грн - обов'язково застосовують різниці, якщо менше - $є$ право вибору в першому році безперервної сукупності років, коли АохіА не перевищує 20 млн грн).

У розрахунку 20-мільйонного ліміту беруть участь (абз. 10 пп. 134.1.1 ПКУ):

- дохіА (виручка) віА реалізації продукції (товарів, робіт, послуг) (рядка 2000 форми № 2) (лист АФС у м. Києві віА 16.03.2016 р. № 6300/10/26-15-12-05-11);

- інші операційні доходи (ряАок 2120 форми № 2) - обороти за Ат 71 із Кт 791;

- фінансові доходи (рядок 2220 форми № 2) - обороти за Ат 73 із Кт 792. Ао фінансових АОхоАів ВХоАЯть АИвіАеНАИ, ВіАСОТкИ й інші АОхоАИ, Отримані ВіА фінансових інвестицій (окрім Аоходів, які обліковують за методом участі в капіталі) (п. 7 П(С)БО 15);

- інші доходи (ряАок 2240 форми № 2) - обороти за Ат 74 Кт 793.

Та звернімо увагу, що податківці, окрім цих складових, воліють бачити ще й дохіА віА участі в капіталі. ПіАтверАженням слугує лист АФС у м. Києві віА 16.03.2016 р. № 6300/10/2615-12-05-11. Там визначено таке:

"Аля визначення річного Аоходу віА будь-якої Аіяльності (за вирахуванням непрямих поАатків), установленого за правилами бухгалтерського обліку, розраховується сумарне значення таких показників "Звіту про фрінансові результати (Звіту про сукупний АохіА)" (форма № 2): чистий дохіА віА реалізації продукції (товарів, робіт, послуг) (ряА. 2000), інші опера- 
ційні доходи (ряа. 2120), дохіА віА участі в капіталі (ряА. 2200), інші фінансові доходи (ряа. 2220), інші АОхоАИ (ряА. 2240)".

Таке саме наповнення бухдоходу наведено й у листі АФС віА 10.02.2016 р. № 2716/6/9999-19-02-02-15.

Отже, Аля заповнення рялка 01 Аекларації беруть суму рядків 2000, 2120, 2220, 2240 (на Аумку контролерів - ще й рял. 2200) із форми № 2. А^я піАприємств, що звітують за формами 2-м або № 2-мс, Аані беруть із рялка 2280. Тим часом форму № 2 заповнюють у тис. грн (форми № 2-м та № 2-мс - у тис. грн з оАним Аесятковим знаком) з віАповіАним заокругленням, а Аекларацію - у грн. Тож із цих рядків фінзвітності треба взяти суму в гривнях іще Ао округлення, та саме ії записати в ряАок 01 Аекларації.

Pяаок 02

Фінансовий результат до оподаткування (прибуток або збиток), визначений у фінансовій звітності віАповіАно Ао національних положень (станАартів) бухгалтерського обліку

чи міжнародних стандартів фінансової звітності (+, -)

Аані Аля заповнення рядка 02 декларації сліл брати з рялка 2290 або рялка 2295 ф. № 2, або рялка 2290 ф. № 2-м, ф. 2-мс. Якщо прибуток, то записують із Аодатним значенням, а якщо збиток - зі знаком "-».

Форму № 2 заповнюють у тисячах гривень із віАповіАним округленням (Аля суб'єктів ма^ого піАприємництва, що звітують за формами з НП(С)БО 25, - у тис. грн з оАним Аесятковим знаком), а декларація - у грн.

Отже, із фінзвітності треба взяти суму прибутку (чи збитку) у гривнях іще Ао заокруглення, і саме їі записати в рядок 02 Аекларації.

Рянок 03 PI

Різниці, які виникають відповіАно до Податкового кодексу України (+, -) $03 \mathrm{PI}$

Нагадаємо, що базу з податку на прибуток визначають як бухфінрезультат плюс/мінус різниці. Проте платники, що мають дохіА (рялок 01 декларації) не більш ніж 20 млн грн, мають право не застосовувати різниць із р. III ПКУ (окрім поАаткового збитку минулих періоАів) (п. 134.1 ПКУ). Про віАмову віА застосування різниць вони зазначають у Аекларації в окремому полі. Проте важливо, що відмовитися вони можуть саме віА різниць із р. III ПКУ (окрім збитку попереАніх періоАів), а різниці з перехіАних прави^ піАрозАілу 4 р. XX ПКУ та з р. II їм сліА використовувати.

Різниці показують в окремому Аолатку PІ. У Аодатку окремо згруповано різниці - як із р. III, так і з інших розАілів. Тож, Аодаток PI заповнюють не лише ті, у кого дохіА становить понаА 20 млн грн, а й ті, хто має АохіА менш ніж 20 млн грн і вирішив не застосовувати різниць із р. III ПКУ (скажімо, та ж різниця - віА'ємне значення об'єкта оподаткування попереАнього звітного періоду).

Звісно, АоАатоК PI заповнююТь, якщо є хоча 6 оАна з різниць. ААЖе якщо АОАатоК РІ порожній, то заповнювати його й, віАповіАно, ряАок ОЗ РІ не потрібно.

А зараз Аля розуміння, кому які різниці за групами можуть "перепасти", пропонуємо ознайомитися з таблицею.

Таблиця 10.4

Різниці, які застосовують різні категорії платників

\begin{tabular}{|c|c|}
\hline $\begin{array}{l}\text { Платники, які зобов'язані використовувати різниці, оскільки: } \\
\text { 1) мають АохіА понаА } 20 \text { млн грн; } \\
\text { 2) мають АохіА не більш ніж } 20 \text { м^н грн, але не віАмовимися віА } \\
\text { різниць (не поставияи віАмітку в Аек^арації про віАмову) }\end{array}$ & $\begin{array}{c}\text { П^атники, які мають АохіА не біАьш ніж } \\
20 \text { м^н грн і віАмовимися віА застосуван- } \\
\text { ня різниць (поставияи віАмітку } \\
\text { в Аек^арації) }\end{array}$ \\
\hline $\begin{array}{l}\text { 1. Різниці, які виникають піА час нарахування амортизації необо- } \\
\text { ротних активів (ст. } 138 \text { р. III ПКУ) }\end{array}$ & - \\
\hline $\begin{array}{l}\text { 2. Різниці, які виникають піА час формування резервів (забезпе- } \\
\text { чень) (ст.ст. } 139,141 \text { р. III ПКУ) }\end{array}$ & - \\
\hline
\end{tabular}


Продовження таблмці 10.4

\begin{tabular}{|c|c|}
\hline $\begin{array}{l}\text { Платники, які зобов'язані використовувати різниці, оскільки: } \\
\text { 1) мають АохіА понаА } 20 \text { м^н грн; } \\
\text { 2) мають АохіА не біАьш ніж } 20 \text { млн грн, але не віАмовимися віА } \\
\text { різниць (не поставияи віАмітку в Аекларації про віАмову) }\end{array}$ & $\begin{array}{c}\text { Платники, які мають АохіА не більш ніж } \\
20 \text { млн грн і віАмовимися віА застосуван- } \\
\text { ня різниць (поставими віАмітку } \\
\text { в Аекларації) }\end{array}$ \\
\hline $\begin{array}{l}\text { 3. Різниці, які виникають під час зАійснення фінансових операцій } \\
\text { (ст. } 140 \text { ПКУ) }\end{array}$ & $\begin{array}{l}\text { Застосовують мише одну різницю з гру- } \\
\text { пи т.зв. "фінансових різниць" зі ст. } 140 \\
\text { ПКУ: бухфінрезультат до оподаткування } \\
\text { зменшують на суму віА'ємного значення } \\
\text { об'єкта оподаткування минулих податко- } \\
\text { вих (звітних) років (пп. } 140.4 .2 \text { п. } 140.4 \\
\text { ст. } 140 \text { р. ІІІ ПКУ) }\end{array}$ \\
\hline $\begin{array}{l}\text { Платники, які зобов'язані використовувати різниці, оскільки: } \\
\text { 1) мають дохіА понаА } 20 \text { млн грн; } \\
\text { 2) мають АохіА не більш ніж } 20 \text { млн грн, але не віАмовилися віА } \\
\text { різниць (не поставили віАмітку в декларації про віАмову) }\end{array}$ & $\begin{array}{l}\text { Платники, які мають АохіА не більш ніжк } \\
20 \text { млн грн і віАмовилися віА застосування } \\
\text { різниць (поставили віАмітку в Аекларації) }\end{array}$ \\
\hline $\begin{array}{l}\text { 4. Інші різниці: } \\
\text { Страхові резерви страховиків (ст. } 141 \text { р. ІІІ ПКУ) }\end{array}$ & $\begin{array}{l}\text { 4. Інші різниці: } \\
-\end{array}$ \\
\hline $\begin{array}{l}\text { Різниці щодо операцій із продажу чи іншого відчуження цінних па- } \\
\text { перів (ст. } 141 \text { р. ІІІ ПКУ) }\end{array}$ & - \\
\hline Інші різниці, переАбачені р. ІІІ ПКУ & - \\
\hline Різниці, передбачені р. I ПКУ & $\begin{array}{l}\text { - } \\
\text { Зауважимо: різниця з р. I ПКУ стосується } \\
\text { трансфертних цін. А якщо платник має Ао- } \\
\text { хіА Ао } 20 \text { млн грн, то трансфертні ціни А^я } \\
\text { нього не спрацьовують }\end{array}$ \\
\hline Різниці, передбачені р. II ПКУ & $\begin{array}{l}\text { Застосовують різницю } 3 \text { р. ІІ. Вона тут } \\
\text { одна й передбачає, що бухсінрезультат } \\
\text { Ао оподаткування збільшується на суму } \\
\text { сплачених платежів, внесків, премій за } \\
\text { Аоговором Аовгострокового страхування } \\
\text { життя чи договором страхування в межах } \\
\text { недержавного пенсійного забезпечення } \\
\text { за певних умов (ст. } 123^{1} \text { р. ІІ ПкУ) } \\
\end{array}$ \\
\hline $\begin{array}{l}\text { Різниці, передбачені “ПерехіАними положеннями" ПКУ (піАрозАіл } 4 \\
\text { р. ХХ ПКУ) }\end{array}$ & $\begin{array}{l}\text { Застосовують усі різниці з піАрозділу } 4 \text { р. } \\
\text { XX ПКУ }\end{array}$ \\
\hline
\end{tabular}

Ажерело: [24; 47]

РяАок 04

Об'єкт оподаткування (рядок $02+$ рядок 03) (+, -)

Заповнюють розрахунково як суму рялків 02 та 03 (з віАповіАним знаком), та, віАповіАно, якщо отримали прибуток - записуємо Аодатне значення, якщо вийшов збиток - проставляємо суму зі знаком «-".

РяАок 05

Прибуток, звільнений віА оподаткування, або збиток віА Аіяльності, прибуток віА якої звільнений віА оподаткування (+, -)

Фактично звільнення віА оподаткування у 2019 році передбачено лише Аля піАприємств й організацій, заснованих громаАськими організаціями інваліАів, та щодо Чорнобильської АЕС і перетворення об'єкта “Укриття", а також Аля літакобудування (п. 142.1, п. 41 піАрозАілу 4 p. XX ПKУ).

Рянок 06

Податок на прибуток ((позитивне значення) (рялок 04 - рялок 05) x

$2 / 100)$

06

Розраховують податок на прибуток (уточнено, що віА Аодатного значення, тобто віА прибутку), а саме - різницю між прибутком із рялка 04 та звільненим прибутком із рялка 05 перемножують на ставку податку. 
НагаАаємо, що ставка податку - 18\% (п. 136.1 ПКУ).

Оскільки прибуток звільнено мише Аля організацій, заснованих громаАськими організаціями інваліАів і суб'єктів літакобудування, то Аля решти піАприємств у рядку 06 буде Аобуток прибутку (з рядка 04) і ставки податку 18\%, подіменої на 100\%.

Рядки 07-15 призначені для особливих платників - страховиків, суб'єктів, що проводять азартні ігри, лотереї, букмекерів.

Отже, звичайні піАприємства їх не заповнюватимуть, а проставлятимуть прочерки.

РяАок 16 3П

Зменшення нарахованої суми податку उП

Зменшення нарахованої суми податку проводять у Аодатку ЗП, значення якого й переносять Ао рялка 16 ЗП. НагаАаємо, податок на прибуток можна зменшити:

- на суму податку на прибуток, отриманий з іноземних джерел, що сплачений суб'єктами господарювання за кордоном;

- на суму нарахованого та сплаченого авансового внеску у зв'язку з виплатою дивіденАів;

- на акцизний податок, сплачений за важкі дистиляти (газойль) (товарні позиції 271019 43 00, 27101946 00, 2710194710 згінно з УКТ ЗЕА), використані на Аизельних ^окомотивах і самоскилах вантажопідйомністю понаА 75 т.

РяАок 17

Податок на прибуток за звітний (поАатковий) періоА (ряАок 06 + ряАок 08 + ряАОК

$10+$ ряАОК 12 + ряАОК 15 - ряАОК 16 ЗП)

Заповнюють розрахунково. Аля звичайних піАприємств (не страховиків, не банків, не букмекерських й особливих категорій) у рядку 17 буде різниця між нарахованим податком на прибуток (із рядка 06) і сумами, що його зменшують (із рядка 16 3П).

Рянок 18

Податок на прибуток за результатами попереднього звітного (податкового) періоду поточного року з урахуванням уточнень (рядок 17 Податкової декларації з податку на прибуток піАприємств за попереАній звітний (поАатковий) періоА поточного року) ${ }^{7}$

Заповнюють ^ише ті платники, які звітували поквартально (на це вказує виноска 7). Вони в декларації за 2019 рік у рялку 18 зазначають полаткові зобов'язання за результатами 3 кварталів 2019 року.

Рянок 19

ПоАаток на прибуток, нарахований за результатами останнього (звітного) поАаткового періоАУ (ряАоК 17 - ряАоК 18) $(+,-)^{8}$

Заповнюють рядок як ті, хто звітує лише за рік, так і поквартальники.

У платників, що звітують лише за пілсумками року, рялок 19 = рялку 17.

У платників-поквартальників визначають різницю між рядками 17 та 18.

Рянок 20 AB

Сума авансового внеску при виплаті дивіАенАів, що має бути сплачена у звітному

(податковому) періоді

$20 \mathrm{AB}$

Розрахунок суми Аивідендного авансового внеску наводять у Аодатку АВ.

PяAOK 21

Сума авансового внеску при виплаті дивіАенАів, що має бути сплачена за результатами попереАнього звітного (податкового) періоду поточного року, з урахуванням уточнень (ряАок 20 АВ Податкової Аекларації з податку на прибуток піАприємств за попереАній звітний (податковий) періоА поточного року) ${ }^{7}$

Заповнюють лише квартальники. Про це свіАчить виноска 7.

PяA0K 22

Сума авансового внеску при вип^аті АивіАенАів, нарахована за результатами

останнього (звітного) поАаткового періоАУ (ряАоК 20 АВ - ряАоК 21) ${ }^{8}$ 
Аля платників, що звітують лише за рік: рядок 22 = рялку 20.

Аля квартальників обчислюють розрахунково: рялок 20 АВ - ряАок 21.

РяАоK 23 Пн

Сума податків, які утримуються при виплаті доходів (прибутків) нерезидентам,

нарахованих за звітний (податковий) періоА

Заповнюють ті платники, які у звітному періоді виплачували нерезидентам доходи із Ажерел походження з України.

Водночас розрахунок податку (чи звільнення віА сплати, якщо застосовували міжнародний Аоговір) проводять у Аодатку ПН. Його заповнюють на кожного нерезидента окремо. А Ао рялка 23 ПН переносять сумарне значення з усіх додатків ПН за звітний рік.

РяАок 24

Сума податків, які утримуються при виплаті доходів (прибутків) нерезидентам за результатами попереднього звітного (податкового) періоду поточного року, з урахуванням уточнень (рялок 21 Податкової декларації з податку на прибуток пілприємств за попереАній звітний (податковий) періоА поточного року)

Заповнюють мише квартальники (Аив. виноску 7).

Рянок 25

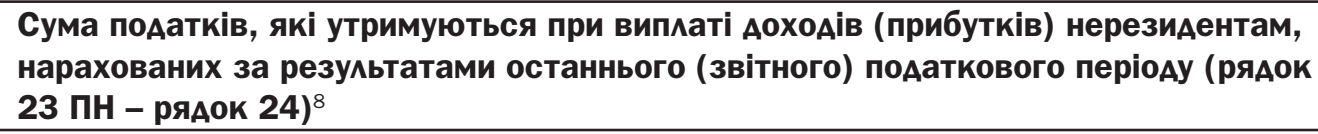

Аля тих, хто звітує лише за піАсумками року: рялок 25 = рялку 23.

А квартальники розраховують різницю між рядками 23 і 24, записуючи ї̈ в ряАок 25.

\section{Виправмення помимок}

ПереАбачено окремі блоки Аля виправлення помияок:

- у полатку на прибуток й авансовому внеску піА час виплати дивіАенАів (ряАки 26-30);

- за податком на репатріацію піА час виплати доходів нерезидентам (рялки 31-34).

у разі виправлення помилок за Аопомогою поточної Аекларації заповнюють Аодаток ВП. Результат виправлення (заниження чи завищення) переносять у віАповіАний блок Аекларації зі знаком "+" - заниження, а зі знаком "-»- завищення. Водночас у разі заниження поАаткових зобов'язань розраховують суму самоштрафу (5\%) і пеню, а їх суми зазначають у віАповіАних рялках. Якщо завищили податкові зобов'язання - ані штрафу, ані пені.

\section{Нові ряАки 35-37}

Ці рядки Аодано Наказом № 481 (у старій формі їх немає).

\begin{tabular}{|c|c|c|}
\hline \multicolumn{3}{|c|}{$\begin{array}{l}\text { Податкові зобов'язання, інші штрафні санкції та пені, визначені віАповіАно до Податкового кодек- } \\
\text { су України, не пов'язані з виправленням помилок }\end{array}$} \\
\hline $\begin{array}{l}\text { Сума збільшення податкового зобов'язання за порушення вимог цільового ви- } \\
\text { користання вивільнених віА оподаткування коштів віАповіАно Ао пунктів 142.1- } \\
142.3 \text { статті } 142 \text { розділу III, пункту } 41 \text { пілрозАілу } 4 \text { розділу XX Податкового кодексу } \\
\text { України }\end{array}$ & 35 & \\
\hline $\begin{array}{l}\text { Штрафні санкції за порушення положень пункту } 41 \text { пілрозділу } 4 \text { розАілу XX Подат- } \\
\text { кового кодексу України }\end{array}$ & 36 & \\
\hline $\begin{array}{l}\text { Пеня, нарахована на виконання вимог статті } 123^{1} \text { глави } 11 \text { розАілу II, пунктів } \\
\text { 142.1-142.3 статті } 142 \text { розділу III, пункту } 41 \text { піАрозділу } 4 \text { розАілу XX Податкового } \\
\text { кодексу України }\end{array}$ & 37 & \\
\hline
\end{tabular}

ЗгіАно з п.п. 142.1-142.3 ПКУ та п. 41 піАрозділу 4 р. ХХ ПКУ віА опоАаткування звільнені:

- підприємства, засновані громадськими організаціями осіб з інвалідністю і $є$ їхньою повною власністю, які займаються посереАництвом (п. 142.1);

- прибуток Чорнобильської АС (п. 142.2);

- прибуток піАприємств, отриманий за рахунок міжнародної технічної Аопомоги на виконання проекту “Укриття" А^я Чорнобильської АС (п. 142.3); 
- прибуток піАприємств - суб'єктів ^ітакобудування (п. 41 пілрозАілу 4 р. XX ПКУ).

У разі порушення вимог цільового використання коштів, вивільнених віА опоАаткування віАповіАно Ао п.п. 142.1-142.3 ПКУ та п. 41 піАрозАілу 4 р. XX ПКУ, платник поАатку зобов'язаний збільшити податкові зобов'язання з податку на прибуток за результатами поАаткового періоду, на який припадає таке порушення, а також сплатити пеню, нараховану віАповіАно Ао ПКУ.

А^я суб'єктів ^ітакобудування передбачено ще й нарахування штрафу (п. 41 підрозділу 4 р. XX ПКУ).

Ао рялка 37 потрібно вносити також пеню, яку нараховує страхувальник згіАно зі ст. 123 ${ }^{1}$ ПКУ в разі Аострокового розірвання Аоговорів Аовгострокового страхування життя чи Аоговорів страхування в межах недержавного пенсійного забезпечення, зокрема страхування Аодаткової пенсії, або порушення інших вимог, установлених ПКУ А^я таких Аоговорів.

\section{Аодатки Ао Аекмарації:}

AB - Розрахунок авансового внеску з податку на прибуток піАприємств на суму виплачених АивіАенАів (прирівняних Ао них платежів);

ЗП - Зменшення нарахованої суми податку;

Пн - Розрахунок (звіт) податкових зобов'язань нерезилентів, якими отримано доходи із Ажерелом їх походження з України (таблиця 1). Розрахунок прибутку віА операцій із безпроцентними (Аисконтними) облігаціями чи казначейськими зобов'язаннями (рядок 16 таблиці 1) (таблиця 2);

тц - Самостійне коригування податкових зобов'язань платника податку з метою трансфертного ціноутворення;

ВП - Розрахунок податкових зобов'язань за період, у якому виявлено помилку(и);

PI - Різниці;

П3 - Розрахунок прибутку, що звільняється віА оподаткування (таблиця 1). ПіАстави Аля застосування пільги (таблиця 2);

АМ - Інформація щодо нарахованої амортизації;

цП - Розрахунок фінансового результату віА операцій із цінними паперами;

Ф3 - Фінансова звітність.

Три з перелічених вище додатків (а саме - Аодатки АМ, ЦП і ТЦ) є Аодатками Ао Аодатка PI. Тому їх дані напряму не переносять до рядків декларації, а віАображають у Аолатку PI, та вже через нього - у рялку 03 PI декларації.

Про наявність Аодатків треба зазначити в окремому полі.

\begin{tabular}{|c|c|c|c|c|c|c|c|c|c|c|}
\hline Наяв & $A B$ & $3 \Pi$ & $\overline{\mathrm{MH}}$ & $\mathrm{T}^{11}$ & $\mathrm{~B} \Pi$ & $\mathrm{PI}$ & $\Pi 3$ & $\mathrm{AM}$ & ЦЦП & $\Phi 3^{12}$ \\
\hline & & & & & & & & & & \\
\hline
\end{tabular}

У віАповіАних клітинках таблиці проставляють позначка "+», окрім клітинки піА літерами "ПН", у якій зазначають кількість поданих Аодатків "ПН" Ао Аекларації. Про це свідчить виноска 10.

Аодаток ТЦ заповнюють платники податку на прибуток піАприємств, які зАійснювали самостійне коригування віАповіАно Ао ст. 39 р. I ПКУ (виноска 11).

У новій формі декларації (зі змінами, унесеними Наказом № 481) поле з Аодатками має ще графу Аля Аодатка ПП («Інформація про суми податкових пільг») й окремі комірки Аля вказування, за якими стандартами склаАають фінзвітність - міжнародними чи національними.

\begin{tabular}{|c|c|c|c|c|c|c|c|c|c|c|c|c|}
\hline \multirow{3}{*}{$\begin{array}{c}\text { Наявність } \\
\text { Аодат- } \\
\text { ків }^{10}\end{array}$} & \multirow[b]{2}{*}{$A B$} & \multirow[b]{2}{*}{ 3П } & \multirow[b]{2}{*}{ ПН } & \multirow{2}{*}{ TЦ ${ }^{11}$} & \multirow[b]{2}{*}{ ВП } & \multirow[b]{2}{*}{ PI } & \multirow[b]{2}{*}{ ПЗ } & \multirow{2}{*}{ AM } & \multirow{2}{*}{ ЦП } & \multirow{2}{*}{ ПП } & \multicolumn{2}{|c|}{$\Phi 3^{12}$} \\
\hline & & & & & & & & & & & П(С)БО & МСФ3 \\
\hline & & & & & & & 0 & & & & & \\
\hline
\end{tabular}

Форми фінансової звітності, які подають із декларацією з податку на прибуток підприємств, наведені в табл. 10.5.

Навпроти відповіАної к^ітинки проставляють знак "+» (зазначено у виносці 12). 
У новій формі декларації (зі змінами, унесеними Наказом № 481), на жаль, назви форм фрінансової звітності не оновили. ААже Аля малих і мікропіАприємств їх назви змінилися (НП(С)БО 25) і звучать як Фінансова звітність малого пілприємства (№ 1-м та № 2-м) та Фінансова звітність мікропіАприємства (№ 1-мс та № 2-мс).

Таблиця 10.5

Фінансова звітність, яку поАають із Аекмарацією з поАатку на прибуток піАприємств

\begin{tabular}{|c|c|c|c|c|c|c|c|c|c|}
\hline $\begin{array}{c}\text { Наявність } \\
\text { поданих до } \\
\text { Податкової } \\
\text { декларації }\end{array}$ & $\begin{array}{c}\text { Баланс } \\
\text { (Звіт про }\end{array}$ & $\begin{array}{c}\text { Звіт про } \\
\text { фінансові } \\
\text { результати }\end{array}$ & $\begin{array}{c}\text { Звіт } \\
\text { про рух }\end{array}$ & Звіт про & $\begin{array}{l}\text { Примітки } \\
\text { Ао річної }\end{array}$ & $\begin{array}{l}\text { Фінан } \\
\text { суб'єк } \\
\text { підпрь }\end{array}$ & $\begin{array}{l}\text { совий звіт } \\
\text { кта малого } \\
\text { иємництва }\end{array}$ & $\begin{array}{r}\text { Спрощ } \\
\text { совий з } \\
\text { малогс } \\
\mathrm{H}\end{array}$ & $\begin{array}{l}\text { вий фінан- } \\
\text { віт суб'єкта } \\
\text { підприєм- } \\
\text { ицтва }\end{array}$ \\
\hline $\begin{array}{l}3 \text { поАатку } \\
\text { на прибуток } \\
\text { підприємств } \\
\text { Аодатків }\end{array}$ & $\begin{array}{c}\text { фінансовий } \\
\text { стан })^{13}\end{array}$ & $\begin{array}{c}\text { (Звіт про } \\
\text { сукупний } \\
\text { АохіА })^{13}\end{array}$ & $\begin{array}{c}\text { грошових } \\
\text { коштів }^{13}\end{array}$ & капіта^ ${ }^{13}$ & $\begin{array}{l}\text { фінансової } \\
\text { звітності }{ }^{13}\end{array}$ & Баланс & $\begin{array}{c}\text { Звіт про } \\
\text { фінансові } \\
\text { результати }\end{array}$ & Баланс & $\begin{array}{c}\text { Звіт про } \\
\text { фінансові } \\
\text { результати }\end{array}$ \\
\hline $\begin{array}{l}\text { фінансової } \\
\text { звітності }{ }^{12}\end{array}$ & & & & & & & & & \\
\hline
\end{tabular}

Ажерело: [47].

Та, безспірно, це не завадить проставити правильно відмітки щодо форм фрінансової звітності, які подає підприємство.

Аоповнення Ао Аекларації

\begin{tabular}{|c|c|c|}
\hline $\begin{array}{c}\text { Наявність } \\
\text { Аоповнення }{ }^{14}\end{array}$ & \multicolumn{2}{|c|}{$\begin{array}{c}\text { Аоповнення Ао Податкової Аекларації з податку на прибуток піАприємств } \\
\text { (заповнюється і подається віАповіАно Ао пункту 46.4 статті } 46 \text { розділу II } \\
\text { Податкового кодексу України) }\end{array}$} \\
\hline & № 3/п & 3міст Аоповнення \\
\cline { 2 - 3 } & & \\
\hline
\end{tabular}

\section{НагаАаємо}

ЗгіАно з п. 46.4 ПКУ, якщо платник вважає, що форма податкової декларації збільшує чи зменшує його податкові зобов'язання, усупереч нормам він має право зазначити цей факт у спеціально відведеному місці в податковій декларації.

За потреби платник податків може подати разом із такою податковою декларацією доповнення до цієї декларації, складене в Аовільній формі, що вважатиметься невіА'ємною частиною податкової Аекларації.

Таке Аоповнення поАають із поясненням мотивів його поАання. Платник поАатків, який подає звітність в електронній формі, подає таке Аоповнення в електронній формі.

Отже, якщо піАприємство поАає Аоповнення, воно нумерує їх і вказує суть, зміст Аоповнення в наведеному вище полі.

Рішення про незастосування різниць

\begin{tabular}{|c|c|}
\hline $\begin{array}{c}\text { Наявність } \\
\text { рішення }\end{array}$ & Прийнято рішення про незастосування коригувань фрінансового результату \\
& Ао оподаткування на усі різниці \\
\hline & \\
\hline
\end{tabular}

Якщо підприємство має АохіА за останній рік не більш ніж 20 млн грн і не бажає використовувати різниці піА час визначення податку на прибуток, потрібно:

- оформити таке рішення окремим наказом або розпорядженням;

- зазначити про прийняте рішення в Аекларації в окремому полі. Водночас, у який спосіб проставлятимуть віАмітку, ролі не віАіграє, головне, аби однозначно було зрозуміло. Тому найвАалішим варіантом нам виАається простав^яння віАмітки "+" і запис реквізитів Аокумента, яким прийнято рішення про незастосування різниць, - ).

Зауважимо, що рішення приймають не більш ніж раз протягом безперервної сукупності років, у кожному з яких виконують цей критерій щоАо розміру Аоходу. Про прийняте рішення 
платник податку вказує в податковій звітності із цього податку, що подається за перший рік у такій безперервній сукупності років. Протягом наступних років такої сукупності коригування фінансового результату на різниці з р. III ПКУ також не застосовують (крім віА'ємного значення об'єкта оподаткування минулих податкових (звітних) років) (пп. 134.1.1 ПКУ).

Також варто сказати про піАхіА контролерів стосовно прийняття рішення про віАмову віА різниць. Вони вважають, що прийняти рішення про віАмову можна в будь-якому році безперервної сукупності років, коли дохіА не перевищує 20 млн грн, а не обов'язково саме в першому в такій безперервній сукупності.

НаприклаА, якщо ви раніше прийняли рішення про віАмову віА різниць (скажімо, у мину^орічній декларації за 2018 рік), і в 2019 році у вас АохіА не перевищив 20 млн грн, контролери воліють, аби у такій Аекларації було продубльовано прийняте рішення про віАмову віА різниць.

I ще один приклаА: якщо у вашого піАприємства вперше у 2019 році АохіА вийшов не більш ніж 20 млн грн і декларацію ви подавали до цього щокварталу та із застосуванням різниць - ви маєте право уже за 2019 рік прийняти рішення про віАмову віА різниць із р. III ПКУ, і річну Аекларацію скласти без них. При цьому уточнювати періоди 2019 року не Аоведеться.

Також визначимо останні зміни, які буяи ввеАені А^я Аекларацій з поАатку на прибуток у 2021 році [19].

Загалом появу нової форми декларації з податку на прибуток зумовили зміни Ао ПКУ, унесені Законами № 466 та № 786. Тому Наказ № 649 покликаний "піАігнати" форму декларації піА новації-2020. Аля цього у формі декларації з податку на прибуток з'явилися нові рядки та Аодатки, унесено зміни Ао старих Аодатків.

ЗгіАно з п. 46.6 ПКУ оновлені форми податкової звітності потрібно застосовувати Аля звітування за період, наступний за періодом їхнього офіційного опублікування.

Оскільки Наказ № 649 опубліковано в "Офіційному віснику України" № 94 (01.12.2020), то вперше за оновленою формою декларації з податку на прибуток сліА звітувати:

- платникам із квартальним звітним періодом - за I квартал 2021 року;

- платникам із річним звітним періодом - за 2021 рік.

ОАнак, цілком можливо, що податківці рекомендуватимуть або наполягатимуть використовувати нову форму Аля звітування за 2020 рік і IV квартал 2020 року.

Розглянемо ці останні зміни. В основній частині декларації з податку на прибуток, форма якої затверджена наказом Мінфіну України віА 20.10.2015 р. № 897 у реАакції Наказу № 649, їх не так і багато, більше цих змін стосується Аодатків.

\section{Шапка Аекларації}

У полі 10 (раніше це було поле 9), у якому платники поАатку на прибуток проставляли віАмітки про свій особливий статус, побільшало позицій. Як і раніше, звичайні піАприємства це поле не заповнюють. Але збільшилася кількість тих платників, які ним користуються.

Зокрема, тепер свою особливу позначку в декларації з податку на прибуток проставляють:

- суб'єкти господарювання - юридичні особи, які обрали спрощену систему оподаткування;

- фізичні особи - підприємці, у т.ч. такі, що обрали спрощену систему оподаткування, або фрізичні особи, які проваАять незалежну професійну Аіяльність;

- іноземні компанії;

- інститути спільного інвестування у вигляАі утворення без статусу юриличної особи.

Власне, спрощенці з двох перших категорій і раніше, у разі виплати нерезидентам дохоАів із Ажерел походження з України, ставили таку позначку, але тут було названо платників єАиного податку. А ось Аві інші категорії особливих платників - нові.

ПіА іноземними компаніями в полі 10 імовірно мають на увазі контрольовані іноземні компанії (Аалі - KIK).

KIK - будь-яка юридична особа, зареєстрована в іноземній державі або на території та визнана такою, що перебуває піА контролем фізичної особи - резидента України або юриАичної особи - резидента (пп. 39².1.1 ПКУ). 
Щоло заповнення цього поля Аля інститутів спільного інвестування (Аалі - ICI), то пояснення наведено у виносці 2. Зокрема, в останній зазначено, що декларацію з податку на прибуток подає платник податку - юрособа за результатами Аіяльності ICІ. При цьому заповнювати треба нове поле 9, у якому варто вписати повне найменування та реєстраційний коА ICl. Якщо платник податку зАійснює управління активами Аекількох ICl, то декларацію 3 податку на прибуток він складає та подає окремо за кожним ICI без статусу юрособи, активами яких він управляє віАповіАно до Закону № 5080. ОАнак подання Аекларацій із податку на прибуток окремо за кожним ICI наразі ПКУ не передбачає. Такі законодавчі ініціативи $є$, але вони ще на сталії Законопроєкту № 4101.

Оскільки Наказом № 649 скасовано форму розрахунку податку на прибуток нерезидентів, які проваАять Аіяльність на території України через постійне преАставництво (Наказ № 544), то тепер усі декларанти податку на прибуток мають подавати загальну Аекларацію.

Зауважимо, що податківці рекомендували постійним представництвам нерезидента, звітуючи за півріччя 2020 року, уже не застосовувати форми розрахунку податку на прибуток нерезилентів, затверджені Наказом № 544, а подавати загальну декларацію з полатку на прибуток (Аив. лист АПС України віА 04.06.2020 р. № 8939/7/99-00-07-02-01-07 та коментар Ао нього).

\section{Основна частина}

Аекларацію Аоповнили оАним ряАком:

\begin{tabular}{|c|c|c|}
\hline Податок на прибуток контрольованої іноземної компанії & $\mathbf{0 6 . 1}$ KIK & \\
\hline
\end{tabular}

Поява нового рядка пов'язана із запровадженням Законом № 466 оподаткування прибутку KIK (ст. 39² ПКУ).

Контролююча особа - фізична або юридична особа - резиденти України, що є прямими чи опосередкованими власниками (контролерами) KIK (пп. 3922.1.2 ПКУ).

Стаття 39² ПКУ набуває чинності 31 січня 2021 року з урахуванням перехіАних правил із п. 54 піАрозАілу 10 р. ХХ ПКУ. Звісно, якщо ії Аію не віАтермінують іще на рік, оскільки таку норму містить Законопроєкт № 4065.

КоА нового ряАка, віАПовіАНо, теПер фігурує у формулі піАсумкового ряАка 17 "ПоАаток на прибуток за звітний (податковий) період (рядок 06 + ряАок $06.1 \mathrm{KIK}+$ ряАОК 08 + ряАОК 10 + ряАок 12 + ряАок 15 - ряАок 16 ЗП)".

Аля розрахунку показника в новому рядку 06.1 KIK розроблено окремий Аолаток KIK. Тому в полі "Наявність Аодатків ${ }^{11 " ~ п л а т н и к у ~ п о д а т к у ~ п о т р і б н о ~ в к а з а т и ~ н е ~ п о з н а ч к у, ~ а ~ с а м е ~}$ кількість поданих разом із Аекларацію Аодатків КІК.

Проте автори змін прогавили можливість у полі «Наявність поданих до Податкової декларації з податку на прибуток піАприємств Аодатків - фрорм фінансової звітності ${ }^{12}$ " актуалізувати назви форм спрощеної фінансової звітності. ААже за П(С)БО 25 - це фінансова звітність малого піАприємства та фінансова звітність мікропіАприємства.

Суттєво змінили також Аодатки PI, АМ та ПН, які викладено в новій редакції. Також віАкоригували Аодатки ВП та ЗП.

Також Аекларація з податку на прибуток розширилася на оАин новий Аодаток - Аодаток KІК. Цей АоАаток має три свої АоАатки:

- Аолаток KIK-K;

- Аолаток KІК-ТЦі;

- Аодаток КІК-ЦП. 


\section{4. Звіт про суми нарахованої заробітної пмати (АохоАу, грошового забезпечення, Аопомоги, наАбавки, компенсації) застрахованих осіб та суми нарахованого єАиного внеску на загальнообов'язкове Аержавне соціальне страхування}

Порялок і строки подання ЄСВ-звітності затверджені Мінфіном у Порядку № 435. Якщо говорити про роботодавців - платників єАиного соціального внеску (ЄСВ), то вони подають Звіт з ЄСВ за формою № A4, яка наведена в Аодатку 4 до цього Порядку [54].

Звіт за формою № A4 зобов'язаний подавати страхувальник, який використовує працю фізичних осіб на умовах трудового договору (контракту) або на інших умовах, передбачених законодавством, а також за цивільно-правовими Аоговорами (Аалі - ЦПА) про виконання робіт (наАання послуг) [40].

Якщо у звітному періоді праця фізосіб не використовувалася (немає нарахувань, які вхоАять Ао бази справляння $Є С \mathrm{C}$, і немає фізосіб, які перебувають з роботодавцем у трудових (цивільно-правових) віАносинах), то Звіт за формою № A4 подавати не потрібно (п. 11 розА. II Порядку № 435).

Форма № 44 подається за основним місцем узяття на облік страхувальника як платника ЄСВ в органах АПСУ оАним з таких способів (на вибір):

- засобами електронного зв'язку в електронній формі з Аотриманням умови про реєстрацію електронних підписів віАповідальних осіб у порядку, визначеному законодавством;

- на паперових носіях, засвідчених піАписом керівника страхувальника і скріплених печаткою (за наявності), разом з електронною формою на електронних носіях інформації [54].

Як виняток - тим страхувальникам, у яких кількість застрахованих осіб не перевищує п'яти, надано можливість подати Звіт "на папері". Це можна зробити Авома способами: або занести до податкової його особисто (чи через уповноважену особу), або віАправити поштою з повіАомленням про вручення та з описом вкладення [54].

А якщо Звіт, направлений поштою, з вини оператора поштового зв'язку буде загублений/зіпсований або вручений органу АПСу із затримкою, то роботодавцеві-страхувальникові тут хвилюватися нічого. ВіАповіАати буде оператор поштового зв'язку [54].

При цьому роботодавець, який опинився в описаній ситуації, звільняється віА будь-якої віАповіАальності за неподання або несвоєчасне подання такої звітності (Аив. п. 1 розА. II Порядку № 435). ЄАине, що віА нього буАе потрібно, - протягом 5 робочих Анів з Аня отримання повіАомлення про втрату або зіпсуття поштового віАправлення направити поштою або подати особисто (за вибором роботодавця) податківцям Аругий примірник Звіту разом 3 копією повідомлення про втрату або зіпсуття поштового віАправлення.

Звіт за формою № A4 подається за кожен календарний місяць. Строк подання - протягом 20 каленАарних Анів, що настають за останнім Анем звітного періоду.

Якщо останній день строку подання Звіту припадає на вихіАний, святковий/неробочий Аень, останнім Анем подання Звіту вважається перший після нього робочий день (п. 14 розА. II Поряаку № 435).

Зверніть увагу: якщо Звіт поАається поштою, то потрібно встигнути його поАати не пізніше ніж за 10 Анів Ао закінчення граничного строку поАання Звіту

У цьому випаАку Звіт за формою № A4 вважатиметься поданим у Аень отримання віААіленням поштового зв'язку поштового віАправлення звітності.

Звіт $з$ незаповненими обов'язковими реквізитами та/або без необхіАних таблиць не визнається Звітом і вважається неподаним (п. 8 розА. II Порядку № 435). Обов'язкові реквізити - це реквізити, перелічені в п. 6 розА. II ПоряАку № 435:

1) тип форми ("Аодаткова", "початкова", "скасовуюча");

2) звітний періоА, за який подається Звіт;

3) найменування / прізвище, ім'я, по батькові - зазначаємо повне найменування (прізвище, ім'я, по батькові) страхувальника згінно з ЄАР;

4) код за ЄАРПОУ або реєстраційний номер облікової картки платника податків / серія (за наявності) та/або номер паспорта страхувальника (якщо фізособа страхувальник має в 
паспорті відмітку про право здійснювати будь-які платежі за серією (за наявності) та/або номером паспорта). Увага: якщо працюємо з паспортом, то цей реквізит заповнюємо так:

- якщо паспорт у вигляді книжечки, то серію та номер паспорта зазначаємо у форматі БК№№XXXXXXX, Ае БK - константа, яка вказує на реєстрацію за паспортними Ааними; №№ Аві українські літери серії паспорта (верхній регістр); XXXXXX - шість цифр номера паспорта (з провіАними нулями);

- якщо паспорт у формі пластикової картки, то наводимо номер паспорта ПXXXXXXXXX, де П - константа, яка вказує на реєстрацію за паспортними Ааними; XXXXXXXXX - Аев'ять цифр номера паспорта;

5) коА основного виАу економічної Аіяльності;

6) клас професійного ризику виробництва (якщо подаємо Звіт за період Ао 1 січня 2016 poky);

7) місцезнаходження (місце проживання) страхувальника, за яким він узятий на облік як платник ЄCB;

8) коА органу Аоходів та зборів, Ао якого подається Звіт;

9) Аата подання Звіту;

10) керівник, головний бухгалтер - зазначаємо прізвище та ініціали, а також реєстраційні номери облікових карток платника податків керівника і головбуха страхувальника або серію (за наявності) та номер паспорта, якщо вони віАмовилися віА реєстраційного номера, про що є віАповіАна відмітка в паспорті. Ці паспорти зазначаємо так само, як і Аля реквізиту "коА за ЄАРПОУ..." (Аив. вище). У цьому полі посадові особи страхувальника засвіАчують звітність з ЄСВ своїми піАписами.

Якщо у страхувальника штатним розписом не передбачена посада головного бухгалтера, а ведення бухгалтерського обліку та подання звітності зАійснюється безпосередньо керівником, то в реквізиті “головний бухгалтер" проставляємо прочерк. ПіАприємці-роботодавці наводять свої Аані і ставлять піАпис у реквізиті "керівник". ПіАписи посаАових осіб (ФОП-страхувальника) засвідчуємо печаткою (за наявності);

11) середньооблікова кількість штатних працівників за звітний період (за наявності). Розрахунок показника зАійснюємо згіАно з Інструкцією № 286;

12) облікова кількість штатних працівників (за наявності);

13) кількість застрахованих осіб у звітному періоді, яким нарахована зарплата... (за наявності);

14) кількість створених нових робочих місць у звітному періоді (за наявності).

Перелічені реквізити обов'язково заповнюються на всіх сторінках Звіту, Ае вони переАбачені.

Грошові суми в таблицях Звіту зазначаються в гривнях з копійками

Аетальніше про віАображення у Звіті за формою № A4 виплат, нарахованих застрахованим особам, розглянемо Аалі [60].

Звичайні роботодавці (піАприємства та ФОП), які виплачують заробітну плату і винагороди за цивільно-правовими Аоговорами (ЦПА) на виконання робіт (наАання послуг), заповнюють таблиці 1, 5, 6 і 7 Звіту за формою № $A 4$.

При цьому більшість страхувальників-роботодавців працюють з таблицями 1, 5 і 6.

Таблиця 1 Звіту за формою № $\mathbf{A 4}$

3 відображенням виплат в таблиці 1 Звіту за формою № A4, як правило, труднощів не виникає. ААже піАставою Аля формування ії показників $є$ дані таблиці 6 цього Звіту. Тож спочатку формуємо таблицю 6, а потім узагальнені дані відображаємо у таблиці 1 . ЄАиний момент, на якому хочемо зупинитися, стосується осіб з інваліаністю. Якщо у вас такі $\epsilon$, то не забуваємо в рядку 3.2.1 таблиці 1 указувати (АовіАково) суми ЄСВ, які нарахував би страхувальник на базу нарахування ЄСВ працівника з інваліАністю, якби не застосовував пільгову ставку.

Річ у тім, що звичайні роботодавці до зарплати, лікарняних, декретних працівників з інваліАністю застосовують ставку 8,41\%. А ось із цих виплат, нарахованих іншим працівникам, а також з винагороди за ЦПА ЄСВ сплачують за загальною ставкою $22 \%$. 
Тож наш законодавець хоче знати, скільки Пенсійний фонА неАоотримує ЄСВ через застосування пільгової ставки 8,41\%. Порахувати це їм допоможуть відомості, зазначені у рялку 3.2.1 таблиці 1. Показники рялка визначаємо таким чином: рялок 3.2 .1 = рялок 2.2 x 22\%: $100 \%$.

Будьте уважні: оскільки цей рядок АовіАковий, то до рядка 3 "Нараховано єАиного внеску, усього..." його значення потрапити не повинно [60].

\section{Таблиця 5 Звіту з ЄСВ}

Таблицю 5 у Звіті з ЄСВ звичайні роботодавці формують лише за наявності певних подій у звітному місяці. Так, таблиці 5 бути, якщо у звітному місяці:

- із застрахованою особою був укмаАений або розірваний трудовий Аоговір або ЦПА на виконання робіт (наАання послуг);

- застрахованій особі надана або в неї закінчимася відпустка у зв'язку з вагітністю та пологами, віАпустка Аля АогляАу за Аитиною Ао 3 років або віАпустка Аля АогляАУ за Аитиною віА 3 но 6 років;

- застрахована особа була перевеАена на іншу постійну посаду (роботу) в того ж роботодавця.

Якщо нічого з переліченого вище у звітному місяці не віАбувалося, формувати таблицю 5 Звіту за формою № $\mathbf{A} 4$ не потрібно.

Зверніть увагу: звичайні роботодавці початок/закінчення військової служби працівників в таблиці 5 не відображають. Також не заповнюють графу 19 «Військове звання" таблиці 5. Цю інформацію указують лише силові структури (віАомства) [60].

\section{Таблиця 6 Звіту з ЄСв}

Таблиця 6 потрібна Аля формування щодо кожної застрахованої особи відомостей про суми нарахованих їй у звітному місяці виАів АохоАів, які вкАючаються Ао бази нарахування ЄСB.

Зауважимо, що на одного працівника в таблиці 6 можуть бути заповнені декілька рядків. НаприклаА, якщо у звітному місяці:

- нараховано Аоходи, які віАображають з різними кодами категорії застрахованої особи (графа 9) або які мають свій коА типу нарахувань (графа 10). Зокрема, суми зарплати, віАпускних, лікарняних і декретних, нарахованих особі у звітному місяці, відображаємо в різних рялках;

- нараховано доходи за минулі та майбутні періоди (місяці), а саме: віАпускні, лікарняні, Аопомога по вагітності та пологах, винагорода за виконані роботи (надані послуги), строк виконання яких перевищує календарний місяць, а також середню зарплату за вимушений прогул. Перелічені доходи віАображаємо в прив'язці Ао місяця, за який вони нараховані;

- Аонараховували ЄСВ Ао розміру мінімального страхового внеску (визначали Аодаткову базу нарахування ЄСB) [60].

Розберемо, як це працює, на прикладах.

\section{Прийняття/звільнення}

Таблиця 5. У ній інформацію про дату початку та/або закінчення трудових віАносин віАображаємо окремим рядком (Аив. приклаА 1). Причому якщо працівника приймаємо на основне місце роботи, то в графі 8 зазначаємо категорію особи "1", якщо за сумісництвом (у тому числі внутрішнім) - "2".

Якщо працівник протягом оАного звітного місяця був:

- прийнятий, а потім звільнений, то на нього формуємо один ряАок, зазначаючи в ньому і Аату прийняття (графа "дата початку"), і дату звільнення (графа "Аата закінчення") в графі 11;

- звільнений, а потім знову прийнятий на роботу до цього ж роботодавця, то на нього в таблиці 5 заповнюємо Ава ряАки: перший - з Аатою припинення трудових віАносин (графа "Аата закінчення"), Аругий - з Аатою початку трудових віАносин (графа "Аата початку").

Окремо зупинимося на калрових графах 12 - 15 таблиці 5. У графі 12 проставляємо професійну назву роботи з додатка А або Б до Класифікатора професій. Ао графи 13 повинен потрапити коА загальносоюзного класифікатора професій, посаА і тарифних розрядів 
(КоА ЗКППТР), якщо його встановлено А^я віАповіАної професії, а АО графи 14 - КоА КП із Класифікатора професій, що віАповіАають професійній назві роботи з графи 12. У графі 15 зазначаємо найменування посади працівника, інформацію про якого відображаємо.

ПриклаА 1. Вовка Сергія Петровича прийнято на роботу бАжолярем (коА ЗКППТР - 17521, коА КП - 6123, основне місце роботи) з 11.11.2020 р. Наказ віА 10.11.2020 р. № 121-ос.

Зайця Олега Івановича, кролівника (коА ЗКППТР - 13205, коА КП-6121, сумісник), звільнено з роботи 16.11.2020 р. на підставі ст. 38 КЗпП. Наказ віА 05.11.2020 р. № 120-ос.

Аивимося на рис. 10.1 порядок заповнення таблиці 5 Звіту з ЄСВ за листопаА 2020 року.

Таблиця 5. Відомості про трудові відносини осіб та період проходження військової служби

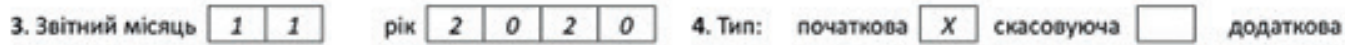

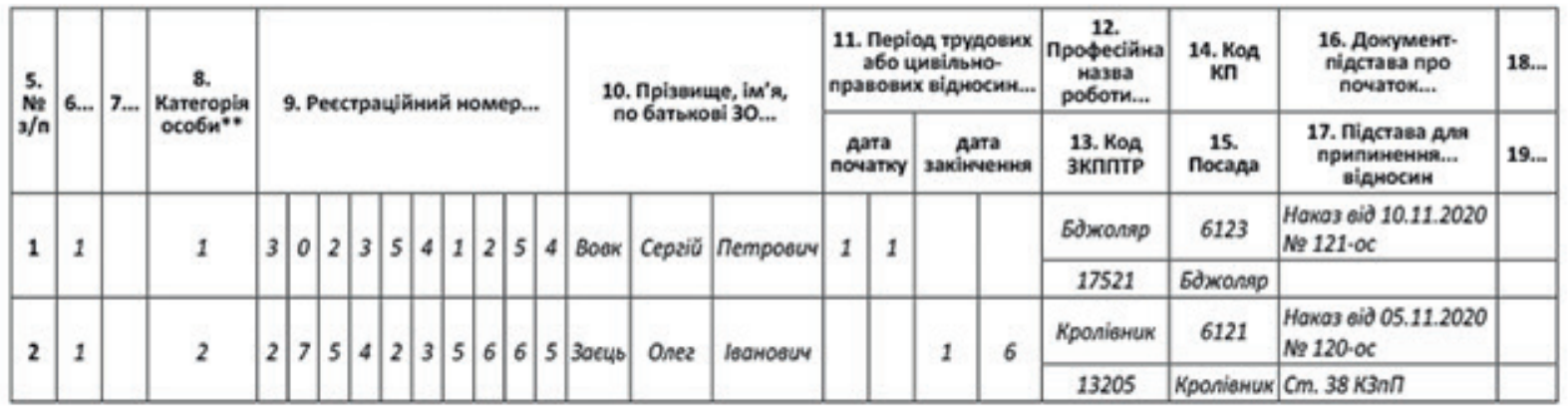

Рис 10.1. Фрагмент таблиці 5 Звіту з ЄСВ. Прийняття/звільнення.

Ажерело: [60].

Таблиця 6. Заробітну плату працівника, нараховану у місяці прийняття/звільнення віАображаємо в загальному порянку.

У графрі 9 проставляємо код категорії застрахованої особи:

- "1" - якщо зарплата нарахована звичайному працівникові;

- "2" - якщо працівникові з інваліАністю (ставка - 8,41\%);

- "47" - якщо нараховано середній заробіток "солдату підприємства", який проходить військову службу (ставка ЄСВ - 22\%);

- "66" - якщо сереАній заробіток нараховано "солАату піАприємства", який має інваліАність (ставка ЄСВ - 8,41\%).

Якщо працівник у звітному місяці був звільнений, а потім прийнятий і при цьому показники граф 22 - 25 таблиці 6 не змінилися, на працівника формуємо один рядок із загальною сумою заробітної плати. При цьому в графі 15 проставляємо загальну кількість Анів у труАових віАносинах протягом місяця (Ані Ао Аати звільнення + Ані після Аати звільнення) (Аив. приклал 2).

Тепер розглянемо ситуацію, за якої показники граф 22 - 25 таблиці 6 змінюються, наприклаА, коли працівник звільняється з місця роботи за сумісництвом і приймається на те ж піАприємство за основним місцем роботи.

У цьому випадку заробітну плату, нараховану до звільнення (графа 22 - «0" - без трудової книжки) і після прийняття на роботу у звітному місяці (графа 22 - "1" - 3 трудовою книжкою), зазначаємо окремими ряАками.

ПриклаА 2. Козуб Ігор Іванович, лектор (коА ЗКППТР - 23160, коА КП - 2359.2, основне місце роботи, повна зайнятість) був звільнений 05.11.2020 р. на піАставі ст. 38 КЗпП, а потім знову прийнятий на роботу на те ж підприємство з 23.11.2020 р. на попередніх умовах (накази віА 02.11.2020 р. № 113-ос та віА 19.11.2020 р. № 118-ос відповіАно).

Загальна сума зарплати за листопаА (зарплата по Аату звільнення + зарплата з дати прийняття) - 10000 грн (ЄСВ - 2200 грн). 
Аивимося на рис. 10.2 порядок заповнення таблиць 5 та 6 Звіту з ЄСВ.

Таблици 5. Відомості про трудові відносини осіб та період проходження військової служби

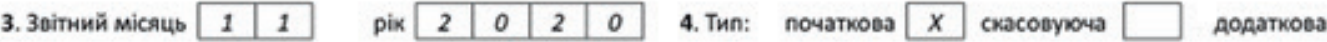

\begin{tabular}{|c|c|c|c|c|c|c|c|c|c|c|c|c|c|c|c|c|c|c|c|c|c|c|}
\hline \multirow{2}{*}{$\begin{array}{c}5 . \\
N \\
3 / n\end{array}$} & \multirow[b]{2}{*}{ 6... } & \multirow[b]{2}{*}{ 7.... } & \multirow[b]{2}{*}{ 8... } & \multirow{2}{*}{\multicolumn{9}{|c|}{ 9. Ресстрацјйний номер.... }} & \multirow{2}{*}{\multicolumn{3}{|c|}{ 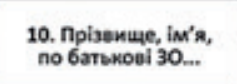 }} & \multicolumn{3}{|c|}{ 11... } & \multirow{2}{*}{$\begin{array}{l}12 . . . \\
13 . . .\end{array}$} & \multirow{2}{*}{\begin{tabular}{|c|}
$14 . .$. \\
15. nocaAa \\
\end{tabular}} & \multirow{2}{*}{\begin{tabular}{|l}
$16 .$. \\
$17 .$. \\
\end{tabular}} & \multirow{2}{*}{$\begin{array}{l}18 . . . \\
19 . .\end{array}$} \\
\hline & & & & & & & & & & & & & & & & Aa & & дакінет & & & & \\
\hline \multirow[t]{2}{*}{1} & \multirow[t]{2}{*}{1} & & \multirow[t]{2}{*}{1} & \multirow[t]{2}{*}{2} & \multirow[t]{2}{*}{8} & \multirow[t]{2}{*}{5 s. } & \multirow[t]{2}{*}{\begin{tabular}{l|l}
4 & 2
\end{tabular}} & \multirow{2}{*}{\multicolumn{2}{|c|}{5}} & \multirow[t]{2}{*}{5} & \multirow[t]{2}{*}{4} & \multirow[t]{2}{*}{7} & \multirow{2}{*}{ Козуб 6} & \multirow[t]{2}{*}{ lapp } & \multirow[t]{2}{*}{ Іеянович } & & & \multirow[t]{2}{*}{ 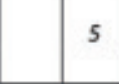 } & Лектор & 2359.2 & № $113.0 \mathrm{C}$ & \\
\hline & & & & & & & & & & & & & & & & & & & 23160 & Лектор & $\mathrm{Cm} .38 \mathrm{~K} 3 \mathrm{n} n$ & \\
\hline \multirow[t]{2}{*}{2} & \multirow[t]{2}{*}{1} & & \multirow[t]{2}{*}{1} & \multirow[t]{2}{*}{2} & 8 & \multirow[t]{2}{*}{5} & \multirow[t]{2}{*}{4} & & 55 & 4 & 1 & 7 & Козуб & 1200 & legroouy & 2 & 3 & & תeкmop & 2359.2 & $\begin{array}{l}\text { Havas eid 19.11.2020 } \\
\text { No 118-oc }\end{array}$ & \\
\hline & & & & & & & & & & & & & & & & & & & 23160 & תexmop & & \\
\hline
\end{tabular}

Таблиця 6. Відомості про нарахування заробітної плати (доходу, грошового забезпечення) застрахованим особам

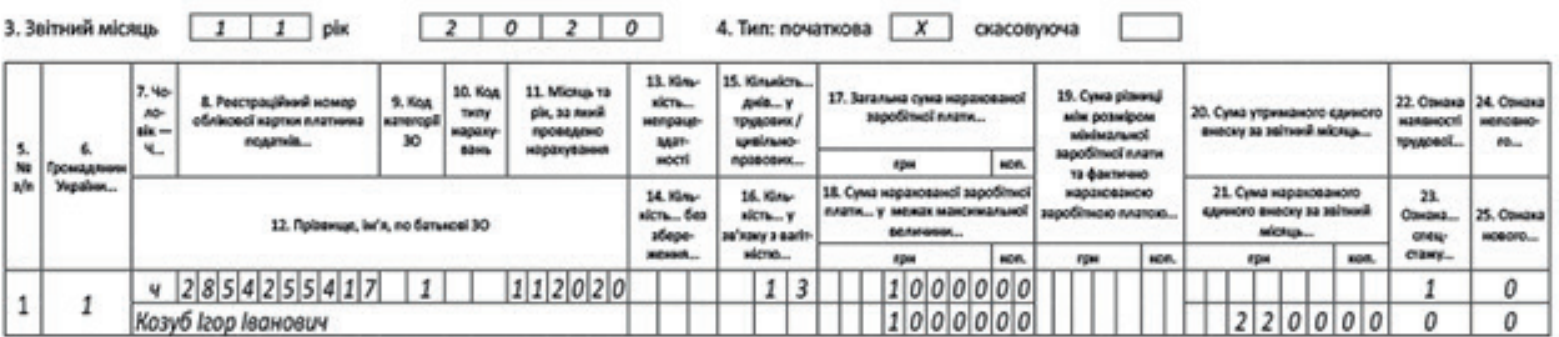

Рис. 10.2. Фрагмент таблиць 5 та 6 Звіту з ЄСВ. Звільнення/прийняття.

Ажерело: [60].

\section{Переведення}

Таблиця 5. ОАнією з пілстав Аля формування таблиці 5 Звіту за формою № $A 4$ є перевеАення працівника на іншу постійну посаду (роботу) у того ж страхувальника.

ВіАомості про тимчасове перевеАення (наприклаА, згіАно зі ст. 33 або 34 КЗпП) та переміщення працівника до таблиці 5 вносити не потрібно.

Переведення на іншу постійну роботу віАображаємо Авома рядками. Перший рядок - 3 Аатою закінчення роботи на попередній посаді (графа 11 "дата закінчення"), Аругий - 3 датою початку роботи на новій посаді (графа 11 "дата початку").

За обома рядками обов'язково мають бути заповнені калрові графи $12-15$.

За першим рядком (з Аатою закінчення роботи на попередній посаАі) графу 17 не заповнюемо.

Після віАправлення Звіту може прийти попереАження з пропозицією перевірити правильність заповнення.

ПопереАження наАається у разі, якщо система контролів не може оАнозначно визначити ситуацію як помилкову.

Тож якщо Звіт за формою № A4 сформовано правильно, хвияюватися через наявність попереАження не варто.

ПриклаА 3. Кушнір Олексій Павлович, кур'єр (коА ЗКППТР - 13247, коА КП - 9151, основне місце роботи) переведений манекенником (коА КП - 5210, основне місце роботи) 3 18.11.2020 р. Наказ віА 16.11.2020 р. № 105-ос.

Аивимося на рис. 10.3 порядок заповнення таблиці 5 Звіту з ЄСВ. 
Таблиця 5. Відомості про трудові відносини осіб та період проходження військової служби

3. Звітний місяць \begin{tabular}{|l|l|}
\hline 1 & 1 \\
\hline
\end{tabular} рік \begin{tabular}{|l|l|l|l|l|}
2 & 0 & 2 & 0 & 4. Тип: початкова $x$ скасовуюча $\square$ \\
\hline
\end{tabular}

\begin{tabular}{|c|c|c|c|c|c|c|c|c|c|c|c|c|c|c|c|c|c|c|c|c|c|c|c|c|}
\hline \multirow{2}{*}{$\begin{array}{l}5 . \\
\mathrm{Na} \\
3 / \mathrm{n}\end{array}$} & \multirow[b]{2}{*}{ 6... } & \multirow[b]{2}{*}{ 7... } & \multirow[b]{2}{*}{ 8.. } & \multirow{2}{*}{\multicolumn{10}{|c|}{ 9. Ресстраційний номер... }} & \multirow{2}{*}{\multicolumn{3}{|c|}{$\begin{array}{c}\text { 10. Прізвяще, iм'я, } \\
\text { по 6атьхові 3О... }\end{array}$}} & \multicolumn{4}{|c|}{ 11.. } & \multirow{2}{*}{$\begin{array}{l}12 . . . \\
13 . . .\end{array}$} & \multirow{2}{*}{$\frac{14 . . .}{15 . \text { nocaAa }}$} & \multirow{2}{*}{\begin{tabular}{|l|}
16. \\
$17 .$. \\
\end{tabular}} & \multirow{2}{*}{$\begin{array}{l}18 . . . \\
19 . . .\end{array}$} \\
\hline & & & & & & & & & & & & & & & & & no: & ra & saki & еняя & & & & \\
\hline \multirow[t]{2}{*}{1} & \multirow[t]{2}{*}{1} & & \multirow[t]{2}{*}{1} & \multirow[t]{2}{*}{2} & \multirow[t]{2}{*}{5} & \multirow[t]{2}{*}{2} & \multirow[t]{2}{*}{5} & \multirow[t]{2}{*}{4} & \multirow[t]{2}{*}{1} & \multirow[t]{2}{*}{7} & \multirow[t]{2}{*}{8} & \multirow[t]{2}{*}{4} & \multirow[t]{2}{*}{4} & \multirow[t]{2}{*}{ Кушнір } & \multirow[t]{2}{*}{ Onendiü } & \multirow[t]{2}{*}{ Повович } & & & 1 & \multirow[t]{2}{*}{7} & Kyp'cp & 9151 & $\begin{array}{l}\text { Howas aid } \\
16.11 .2020 \\
\text { No } 105.0 \mathrm{C}\end{array}$ & \\
\hline & & & & & & & & & & & & & & & & & & & & & 13247 & Kyp'ep & & \\
\hline \multirow[t]{2}{*}{2} & \multirow[t]{2}{*}{1} & & \multirow[t]{2}{*}{1} & 2 & 5 & 2 & 5 & 4 & 1 & 7 & 8 & 4 & 4 & Kуишмір & Onexciũ & noanoour & 1 & 8 & & & Монекенник & 5210 & $\begin{array}{l}\text { Havas oì } \\
16.11 .2020 \\
\text { No } 105 \cdot 0 \mathrm{C}\end{array}$ & \\
\hline & & & & & & & & & & & & & & & & & & & & & & Монекенилик & & \\
\hline
\end{tabular}

Рис. 10.3. Фрагмент таблиці 5 Звіту з ЄСВ. ПеревеАення.

Ажерело: [60].

Зверніть увагу: якщо переведення віАбувається з 1-го числа каленАарного місяця, то "ПеревіАні" рядки у вас будуть "розірвані" і віАображені в таблицях 5 форм № 44 за різні звітні періоди. Так, наприклаА, якщо працівника переводять на іншу постійну роботу 31 грудня 2020 року, то Аата закінчення роботи за попереАньою посадою (30 листопада) буде віАображена в таблиці 5 Звіту за формою № A4 за листопаА 2020 року, а дата початку роботи за новою посадою (1 грудня) - у таблиці 5 Звіту за формою № A4 за грудень.

У разі коли працівник в оАному місяці був прийнятий на роботу і перевеАений на іншу посаду, на нього в таблиці 5 формують три рядки. Перший ряАок - із Аатою прийняття на роботу. Аругий - із Аатою закінчення роботи за посаАою, на яку був прийнятий працівник. Третій - із Аатою початку роботи за новою посадою.

ПриклаА 4. Костик Ольгу Іванівну прийнято на роботу масажистом (коА ЗКППТР - 23184, код КП - 3226, основне місце роботи) з 02.11.2020 р. Наказ віА 27.10.2020 p. № 45-ос. З 16.11.2020 р. ї̈ переведено косметиком (коА ЗКППТР - 13138, коА КП - 5141, основне місце роботи). Наказ віА 16.11.2020 р. № 46-ос.

Аивимося на рис. 10.4 порядок заповнення таблиці 5 Звіту з ЄСВ.

Таблиця 5. Відомості про трудові відносини осі6 та період проходження військової служби

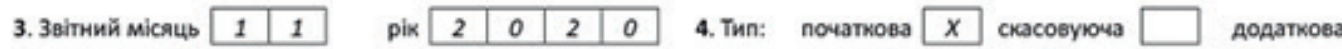

\begin{tabular}{|c|c|c|c|c|c|c|c|c|c|c|c|c|c|c|c|c|c|c|c|c|c|c|c|}
\hline \multirow{2}{*}{$\begin{array}{l}5 . \\
\text { No } \\
3 / n\end{array}$} & \multirow[b]{2}{*}{ 6... } & \multirow[b]{2}{*}{ 7... } & \multirow{2}{*}{\multicolumn{2}{|c|}{ 8. }} & & & & & & & & & \multirow{2}{*}{\multicolumn{3}{|c|}{$\begin{array}{l}\text { 10. Прізвище, iм'a, } \\
\text { nо батькові 30... }\end{array}$}} & \multicolumn{4}{|c|}{$11 \ldots$} & \multirow{2}{*}{$\begin{array}{l}12 \ldots \\
13 \ldots\end{array}$} & \multirow{2}{*}{\begin{tabular}{|c|}
$14 . .$. \\
15. กocaAa \\
\end{tabular}} & \multirow{2}{*}{\begin{tabular}{|l|}
$16 \ldots .$. \\
$17 . .$. \\
\end{tabular}} & \multirow{2}{*}{$\begin{array}{l}18 . . . \\
19 . . .\end{array}$} \\
\hline & & & & & & & & & & & & & & & & now: & $\begin{array}{l}n a \\
m \times y\end{array}$ & 2axik & eresa & & & & \\
\hline \multirow[t]{2}{*}{1} & \multirow[t]{2}{*}{1} & & \multirow[t]{2}{*}{1} & \multirow{2}{*}{\multicolumn{2}{|c|}{24}} & \multirow[t]{2}{*}{5} & \multirow[t]{2}{*}{87} & \multirow[t]{2}{*}{$7 \mid 4$} & \multirow{2}{*}{\multicolumn{2}{|c|}{$\begin{array}{l}45 \\
5\end{array}$}} & \multirow{2}{*}{\multicolumn{2}{|c|}{12}} & \multirow[t]{2}{*}{ Kocmur } & \multirow[t]{2}{*}{ Onsea } & \multirow[t]{2}{*}{ Іөонјено } & \multirow{2}{*}{\multicolumn{2}{|c|}{2}} & & & Масожкuсm & 3226 & No $45.0 \mathrm{C}$ & \\
\hline & & & & & & & & & & 2 & & & & & & & & & & 23184 & Mocosuem & & \\
\hline \multirow[t]{2}{*}{2} & \multirow[t]{2}{*}{1} & & \multirow[t]{2}{*}{1} & \multirow[t]{2}{*}{2} & \multirow[t]{2}{*}{4} & \multirow[t]{2}{*}{5} & 8 & $7 \mid 4$ & 45 & 2 & 1 & 2 & Kocmux & On\&Oa & Іеомїно & & & 1 & 5 & Масожкист & 3226 & $\begin{array}{l}\text { Hoxas aid } 16.11 .2020 \\
\text { No 46.-OC }\end{array}$ & \\
\hline & & & & & & & & & & & & & & & & & & & & 23184 & Mocowuem & & \\
\hline 3 & 1 & & 1 & 2 & 4 & 5 & 8 & 7 & 45 & 2 & 1 & 2 & Kocmuk & On:xo & Іеомівно & 1 & 6 & & & Kocreemux & 5141 & $\begin{array}{l}\text { Howas gid } 16.11 .2020 \\
\text { Neq 46.0C }\end{array}$ & \\
\hline & & & & & & & & & & & & & & & & & & & & 13138 & Kocnemuk & & \\
\hline
\end{tabular}

Рис. 10.4. Фрагмент таблиці 5 Звіту з ЄСВ. Прийняття та перевеАення.

Ажерело: [60].

Якщо ж працівник в оАному місяці був перевеАений на нову посаАу і звільнений, то на нього формуємо Ава ряАки в таблиці 5 Звіту за формою № А4 (Аив. приклаА 5).

Таблиця 6. У загальному випадку на працівника формуємо в таблиці 6 один рялок із загальною сумою зарплати (зарплата за старою посаАою + зарплата за новою посаАою). 
Але, якщо ж Аані, які відображаються у таблиці 6, змінилися, наприклаА на старій посаАі повна зайнятість, на новій - неповний робочий день, то зарплату, нараховану за такими посадами, віАображаємо окремо.

ПриклаА 5. Бондаря Євгена Петровича, котельника (коА ЗКППТР - 13144, коА КП - 7214, основне місце роботи, повна зайнятість) переведено маляром (коА КП - 7141, основне місце роботи, повна зайнятість) з 10.11.2020 р. Наказ віА 10.11.2020 р. № 102-ос. А 30.11.2020 р. його було звільнено на піАставі ст. 38 КЗпП. Наказ віА 27.11.2020 р. № 105ос. Загальна зарплата за листопаА - 6000 грн (ЄСВ - 1320 грн).

Порядок заповнення таблиць 5 та 6 Звіту з ЄСВ показаний на рис. 10.5.

\section{Аонараховуємо/сторнуємо}

Якщо працівнику у звітному місяці Аонараховуємо зарплатні виплати, які помилково не були йому нараховані в попередніх звітних періодах, то суми Аонарахувань включаємо Ао фонау оплати праці поточного місяця. Тобто просто збільшуємо суму зарплати поточного місяця на донараховані суми, проставляючи в графі 11 таблиці 6 звітний місяць і рік. Це узгоАжується з положеннями п.п. 3 п. 3 розА. IV Інструкції № 449 і п. 9 розА. IV Поряаку № 435.

Як і у випадку з донарахуванням, сторнована сума зарплати за минулі місяці включається в зарплату того місяця, в якому було зАійснено таке сторнування.

Тобто коригування провоАиться за рахунок фонАу оплати праці місяця сторнування. Тому в таблиці 6 Звіту за формою № $A 4$ такі коригування не зачіпають минулих звітних періодів і, віАповіАно, не виправляються як помилки.

Таблиця 5. Відомості про трудові відносини осі6 та період проходження військової служби

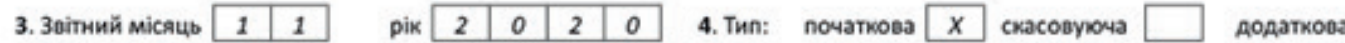

\begin{tabular}{|c|c|c|c|c|c|c|c|c|c|c|c|c|c|c|c|c|c|c|c|c|c|c|c|c|}
\hline \multirow{2}{*}{$\begin{array}{l}5 . \\
\mathrm{Na} \\
3 / \mathrm{n}\end{array}$} & \multirow[b]{2}{*}{ 6... } & \multirow[b]{2}{*}{ 7... } & \multirow[b]{2}{*}{ 8.- } & \multirow{2}{*}{\multicolumn{10}{|c|}{ 9. Реєстраційний номер... }} & \multirow{2}{*}{\multicolumn{3}{|c|}{ 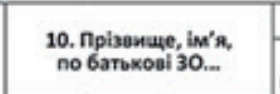 }} & \multicolumn{4}{|c|}{ 11... } & \multirow{2}{*}{ 12.. } & \multirow{2}{*}{\begin{tabular}{c|}
$14 .-$ \\
15. nocaAa
\end{tabular}} & \multirow{2}{*}{$\begin{array}{l}16 . . \\
17 \ldots\end{array}$} & \multirow{2}{*}{$\begin{array}{l}18 . . . \\
19 . . .\end{array}$} \\
\hline & & & & & & & & & & & & & & & & & not & $\mathrm{may}$ & saxit & a & & & & \\
\hline \multirow[t]{2}{*}{1} & \multirow[t]{2}{*}{1} & & \multirow[t]{2}{*}{1} & \multirow[t]{2}{*}{2} & \multirow[t]{2}{*}{1} & \multirow[t]{2}{*}{4} & \multirow[t]{2}{*}{7} & \multirow[t]{2}{*}{5} & \multirow[t]{2}{*}{2} & \multirow[t]{2}{*}{4} & \multirow[t]{2}{*}{5} & \multirow[t]{2}{*}{8} & \multirow[t]{2}{*}{8} & \multirow[t]{2}{*}{ 5ondop } & \multirow[t]{2}{*}{ Eozen } & \multirow[t]{2}{*}{ nemposuy } & & & & \multirow[t]{2}{*}{9} & Котельник & 7214 & $\begin{array}{l}\text { Hoxas eid } \\
10.11 .2020 \\
\text { Ne 102-oc }\end{array}$ & \\
\hline & & & & & & & & & & & & & & & & & & & & & 13144 & Komensник & & \\
\hline \multirow[t]{2}{*}{2} & \multirow[t]{2}{*}{1} & & \multirow[t]{2}{*}{1} & 2 & 1 & 4 & 7 & 5 & 2 & 4 & 5 & 8 & 8 & 5ondop & Eazen & nempoouy & 1 & 0 & 3 & 0 & Manap & 7141 & $\begin{array}{l}\text { Нокози eid } \\
10.11 .2020 \\
\text { Ne 102-oc, sid } \\
27.11 .2020 \mathrm{Ne} 105 \cdot \propto \mathrm{C}\end{array}$ & \\
\hline & & & & 2 & & & & & & & & & & & & & & & & & & Mansp & $\mathrm{Cm} .38 \mathrm{k} 3 \mathrm{n} n$ & \\
\hline
\end{tabular}

Таблиця 6. Відомості про нарахування заробітної плати (доходу, грошового забезпечення) застрахованим особам

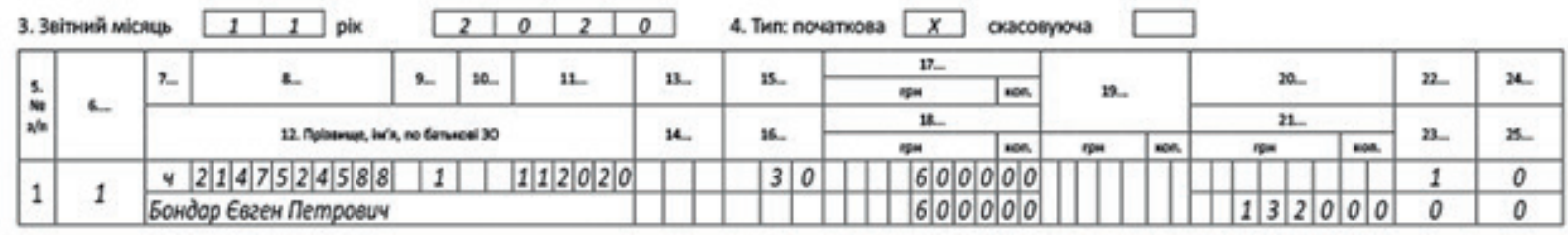

Рис. 10.5. Фрагменти таблиць 5 та 6 Звіту з ЄСВ. ПеревеАення та звільнення.

Ажерело: [60].

ПриклаА 6. Працівникові піАприємства Чумаку Олегу Петровичу (основне місце роботи, повна зайнятість) у жовтні 2020 року через збій в бухпрограмі помилково нарахували премію 3000 грн. Помилка виявлена і виправлена у листопаАі. У цьому місяці працівникові нараховано основну зарплату за листопаА (10000 грн) та віАсторновано зайво нараховану у жовтні премію (3000 грн). Загальна сума зарплати за листопаА з урахуванням віАсторнованої суми - 7000 грн. (ЄСВ - 1540 грн).

Аивимося на рис. 10.6 порядок заповнення таблиці 6 Звіту з ЄСВ. 
Таблиця 6. Відомості про нарахування заробітної плати (доходу, грошового забезпечення) застрахованим особам

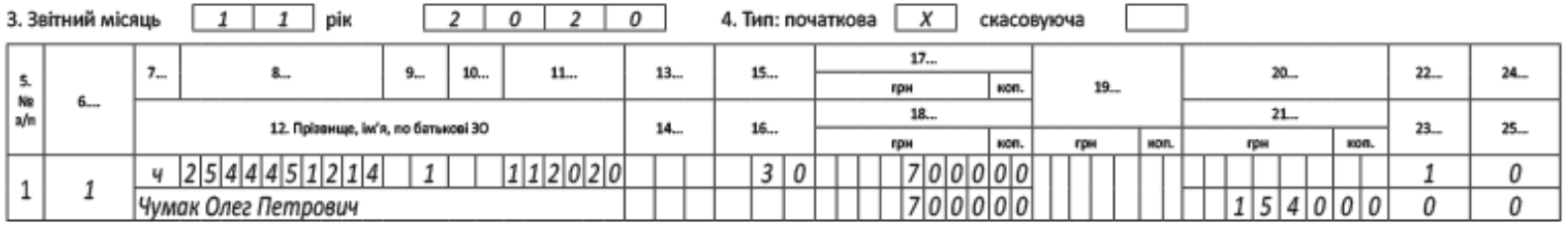

Рис. 10.6. Фрагмент таблиці 6 Звіту з ЄСВ. Сторнування.

Ажерело: [60].

Виняток 3 навеАеного вище правила - ситуація, коли сторнування зарплати пов'язане з уточненням кількості віАпрацьованого часу у зв'язку з віАпусткою або тимчасовою непрацезАатністю. НаприклаА, працівникові у попередньому звітному періоді була нарахована і відображена у звітності з ЄСВ зарплата за повністю віАпрацьований місяць. Але згодом виявилося, що він у цьому місяці був непрацезАатний (або перебував у віАпустці).

Суми заробітку, що нарахований у попередньому звітному періоді та перерахунок якого проводиться у поточному звітному періоАі з причини уточнення кількості віАпрацьованого часу у зв'язку з лікарняними (віАпусткою), віАображаються у таблиці 6 за звітній період зі знаком "мінус".

Отже, звичайні роботодавці, які виплачують заробітну плату і винагороди за ЦПА, формують таблиці 1, 5, 6 і 7 Звіту за формою № A4. У таблиці 6 нараховані застрахованій особі зарплату, Аікарняні, Аопомогу по вагітності та пологах, винагороду за ЦПА віАображаємо окремими рядками. Якщо працівнику у звітному місяці донараховуємо зарплатні виплати, які помилково не були йому нараховані в попередніх звітних періодах, то суми донарахувань вкАючаємо Ао фонАУ оплати праці поточного місяця.

Також варто зазначити, що груАень 2020 року буде останнім звітним періоАом А^я роботодавців, за який подаватиметься Звіт з ЄСВ за формою № А4 [59]. Аалі, починаючи зі звітних періодів 2021 року, піАприємства будуть звітувати з податку на Аоходи фізичних осіб (ПАФО), військового збору (В3) та ЄСВ, подаючи єАину звітність. ВіАповідні зміни внесені Ао Закону № 2464 та ПКУ. При цьому Мінфін на своєму сайті оприяюАнив проєКт об'єАнаної звітності, який містить елементи форм Звіту з ЄСВ та $1 А Ф$.

ЗгіАно проєкту, нова звітність складатиметься 3 титульного аркуша та 4 Аодатків до нього. Проте звичайні роботодавці формуватимуть мише титульний аркуш, який $є$ аналогом таблиці 1 Звіту з ЄСВ, Аолаток 1 Ао нього - це аналог таблиці 6 Звіту з ЄСВ та Аодаток 4 - це аналог форми № $1 A Ф$ [59].

Оскільки запропонований Мінфіном звіт складений із Авох існуючих сьогодні звітів, то частина інформації в ньому Аублюється. Так, наприклаА, інформацію про нараховану зарплату пропонується віАображати у звіті тричі. Авічі - Аля ЄСВ-цілей загальною сумою та персоналізовано. Плюс ще раз персоналізовано Аля цілей ПАФО та ВЗ.

Також у новому звіті ПАФО та військовий збір пропонується віАображати персоналізовано. Тобто за кожною особою зазначати з віАповіАною ознакою нарахований та виплачений їй АохіА, утриманий/сплачений ПАФО з цього АохоАу та утриманий /сплачений військовий збір [59].

При цьому проєктом пропонується віАображати суми АохоАів та ПАФО, ВЗ і ЄСВ з розбиттям за місяцями кварталу.

Подавати об'єАнаний звіт необхіАно за основним місцем обліку щокварталу (протягом 40 каленАарних Анів після закінчення звітного кварталу). Уперше - за піАсумками I кварталу 2021 року [59]. 


\section{КОНТРОАЬНІ ПИТАННЯ:}

1. Аайте визначення податкової декларації згідно з Податковим кодексом.

2. Хто несе віАповіАальність за неподання, порушення порядку заповнення Аокументів податкової звітності, порушення строків їх подання контролюючим органам, неАостовірність інформації, наведеної у зазначених документах?

3. Якими є обов'язкові реквізити податкової декларації?

4. Ким повинна бути піАписана податкова декларація?

5. Які є способи подання податкової декларації?

6. Якими є базові звітні (податкові) періоди?

7. В які строки необхідно сплатити податкове зобов'язання?

8. Яким є порядок подання уточнюючого розрахунку до податкової декларації?

9. Якими законодавчими документами встановлено порядок нарахування та сплати поАатку на Аодану вартість?

10. Охарактеризуйте зміст і структуру податкової декларації з ПАВ.

11. Які існують форми звітності з ПАВ та хто їх склаАає?

12. Які існують звітні періоди і строки подання звітності з ПАВ?

13. Опишіть методику складання звітності з податку на додану вартість.

14. Розкрийте порядок оформлення податкової декларації з ПАВ.

15. Які Аодатки подають Ао Аекларації за повною формою?

16. Який поряАок подання поАаткової Аекларації з ПАВ?

17. В які строки сплачується ПАВ?

18. Які законодавчі документи встановлюють порядок нарахування та сплати податку на прибуток?

19. Опишіть алгоритм розрахунку оподатковуваного прибутку за звітний періол.

20. Які додатки заповнюються Ао податкової декларації з податку на прибуток?

21. Як розраховується сума податку на прибуток, що піАлягає сплаті Ао бюАжету?

22. В які терміни подається податкова декларація з податку на прибуток?

23. Охарактеризуйте зміст і структуру звіту про суми нарахованої заробітної плати (Аоходу, грошового забезпечення, Аопомоги, наАбавки, компенсації) застрахованих осіб та суми нарахованого єдиного внеску на загальнообов'язкове державне соціальне страхування (форма № A4).

24. Якими є обов'язкові реквізити форми № $A 4$ ? 


\section{TEMA 11.}

\section{СТАТИСТИЧНА ЗВІТНІСТЬ}

\section{1. СкмаА і строки поАання статистичної звітності}

Статистична звітність охоп^ює всі галузі економіки та є основою Аля приведення статистичних спостережень в країні.

ВідповіАно Ао ст. 18 Закону України "Про державну статистику" респонденти мають право знати, які первинні дані про них збираються у процесі статистичних спостережень, 3 якою метою, як, ким і з якою метою будуть використовуватися.

Респонденти зобов'язані безкоштовно (за винятком проведення окремих вибіркових обстежень фізичних осіб або сукупностей таких осіб, за участь у яких респонденти отримують грошову компенсацію за витрату часу) в повному обсязі за формою, передбаченою звітно-статистичною документацією, у визначені строки подавати органам державної статистики достовірну інформацію, у тому числі з обмеженим Аоступом, і Аані бухгалтерського обліку.

СклаА, обсяги та методологія розрахунків показників, аАреси і строки подання статистичної інформації, зазначені у звітно-статистичній документації, $є$ обов'язковими Аля всіх респондентів і не можуть бути змінені без віАповіАного дозволу органів державної статистики.

ВідповіАно Ао статей 21-22 Закону України "Про Аержавну статистику" первинні Аані, отримані органами державної статистики віА респондентів піА час проведення статистичних спостережень, а також аАміністративні дані щодо респондентів, отримані органами Аержавної статистики віА органів, що займаються Аіяльністю, пов'язаною із збиранням та використанням адміністративних даних, є конфіденційною інформацією, яка охороняється Законом і використовується виключно Аля статистичних цілей у звеАеному знеособленому вигляАі.

Поширення статистичної інформації, на піАставі якої можна визначити конфіАенційну статистичну інформацію щодо конкретного респондента, забороняється.

Статистична інформація, отримана органами державної статистики у процесі статистичних спостережень, не може вимагатися державними органами, органами місцевого самоврядування, іншими юридичними особами, об'єАнаннями громаАян, посадовими та іншими особами з метою використання Аля прийняття рішень до конкретного респондента.

Статистична інформація, яка Аозволяє прямо чи опосередковано встановити конкретного респондента або визначити первинні дані щодо нього, може бути поширена за згодою цього респонАента і віАповіАно Ао погоАжених з ним умов, або якщо вона отримана із загальноАоступних Ажерел.

Заборона стосовно поширення статистичної інформації не розповсюАжується на:

- знеособлену статистичну інформацію у незведеному вигляді, яка не дозволяє визначити конфіденційну статистичну інформацію щодо конкретного респонАента;

- інформацію щодо назв, алрес, номерів телефонів, видів Аіяльності, загальних сум заборгованості із виплати (нарахування) заробітної плати підприємств, установ і організацій, якщо інше не передбачено законодавством;

- первинні дані, отримані органами державної статистики віА респондентів піА час проведення Аержавних статистичних спостережень щоАо стану навколишнього природного середовища, зокрема землі, води, атмосферного повітря, рослинного і тваринного світу, чинників, які впливають або можуть вплинути на стан навколишнього природного сереАовища та зАоров'я мюдей, за винятком обмежень, встановлених законодавством. 
Ажерелами статистичних даних про господарську Аіяльність $€$ статистична звітність і спеціально організовані спостереження.

Статистичний звіт, статистична звітність - це форма звітності (бланк) Аержавного статистичного спостереження, за якою респонденти подають інформацію органам державної статистики піА час збирання Аержавної статистичної звітності у вигляАі звіту затвердженого зразка та за піАписом посаАових осіб, які відповіАають за достовірність наАаної інформації [46].

Респондент - це особа або сукупність осіб, які піАлягають статистичному спостереженню у встановленому законодавством порядку.

Респондентами є:

- юриАичні особи;

- віАокремлені піАрозділи юридичних осіб, що знаходяться на території України;

- віАокремлені піАрозАіли юридичних осіб України, що знаходяться за межами України;

- фізичні особи, незалежно віА їх громадянства, які перебувають на території України, або сукупності таких осіб;

- фізичні особи, які є громадянами України і перебувають за ії межами, або сукупності таких осіб.

Організація статистичної звітності й управління нею покладено на Аержавну службу статистики України.

Статистичну звітність піАприємств можна класифікувати за різними ознаками.

За змістом звітних Ааних виАіляють типову і спеціалізовану звітність [13, с. 393].

У типовій звітності відображаються однакового змісту показники, що характерні Аля усіх піАприємств незалежно віА виАу Аіяльності та форми власності.

Ао спеціалізованої звітності віАносять звітність, що характеризує Аіяльність піАприємств і організацій окремої галузі економіки або ії піАгалузей.

За обсягом показників звітність поділяється на коротку і повну [13, с. 393].

Коротка звітність подається із скороченим числом показників за звітний місяць або квартал.

Повна звітність подається за всіма показниками, затверАженими в установленому поряАку, включаючи й ті, за якими спочатку були вілправлені короткі звіти.

За терміном подання звітність поділяється на поточну і річну [13, с. 393].

Поточна звітність - це квартальна, місячна, Авотижнева, тижнева звітність.

Річна звітність містить показники Аіяльності піАприємств за звітний (календарний) рік.

За ступенем узагальнення Ааних звітність поАіляється на первинну і зведену [13, с. 393].

ПіА первинною звітністю розуміють звітність окремих піАприємств. ЗвеАену звітність одержують шляхом зведення первинної звітності.

Система статистичної звітності в Україні визначається Загальним табелем (переліком) форм Аержавних статистичних спостережень, в якому зазначається перелік форм державних статистичних спостережень: форм звітності, анкет, інших статистичних формулярів, необхінних Аля проведення Аержавних статистичних спостережень.

Форми звітності державних органів (крім органів державної статистики) та органів місцевого самоврядування, інших юридичних осіб, що займаються Аіяльністю, пов'язаною із збиранням та використанням аАміністративних Ааних, до табеля не включені.

Перелік форм структурований віАповіАно до плану. По кожній формі, згіАно з наказом про ії затвердження, наводиться її найменування, індекс і періодичність, зазначається, хто подає, та встановлюються строки подання.

Наказом Аержавної служби статистики України "Про затверАження загального табеля (переліку) форм державних статистичних спостережень на 2021 рік" віА 8 грудня 2020 року № 344 встановлено розАіли статистичних спостережень, кожному з яких віАповіАає визначений перелік форм статистичної звітності:

\section{1. Аемографічна та соціальна статистика.}

\subsection{2 Ринок праці.}

1.02.01 Зайнятість та безробіття.

1.02.02 Оплата праці та соціально-трудові віАносини. 
1.03 Освіта.

1.05 Аоходи та умови життя.

1.07 Населені пункти та житло.

2. Економічна статистика.

2.01 Макроекономічна статистика.

2.01.01 Тенденції Аілової активності.

2.03 Економічна Аіяльність.

2.03.01 Аіяльність піАприємств.

2.03.02 Послуги.

2.03.03 Внутрішня торгівля.

2.03.04 Капітальні інвестиції.

2.03.05 Основні засоби.

2.03.07 Сільське, лісове та рибне господарство.

2.03.08 Енергетика.

2.03.09 Промисловість.

2.03.10 БуАівництво.

2.03.11 Транспорт.

2.03.12 Туризм.

2.04 Аержавні фінанси, поАатки та публічний сектор.

2.05 Зовнішньоекономічна Аіямьність та статистика зовнішнього сектору.

2.05.01 Зовнішня торгівля товарами.

2.05.02 Зовнішня торгівля послугами.

2.06 Ціни.

2.05.03 Інвестиції зовнішньоекономічної Аіямьності.

2.06.01 Споживчі ціни.

2.06.02 Ціни виробників.

2.07 Наука та інновації.

2.07.01 Наука.

2.07.02 Інновації.

3. Навколишне природне сереАовище та статистика багатьох галузей

3.01 Навколишне природне середовище.

3.03 Інформаційне суспільство.

Граничні терміни подання форм державних статистичних спостережень щорічно визначаються Аержавної службою статистики України у Календарі подання форм державних статистичних спостережень та фрінансової звітності у віАповіАному році.

Нижче зупинимося на розгляАі типових форм статистичної звітності.

\section{2. Методика склаАання статистичної звітності з опмати праці та соціально-труАових віАносин}

Звіт із праці (форма № 1-ПВ (місячна, квартальна) подають юридичні особи, віАокремлені піАрозділи юридичних осіб не пізніше 7-го числа місяця, наступного за звітним періодом.

При заповненні статистичної звітності за формами №1-ПВ (місячна) та № 1-ПВ (квартальна) сліА керуватися:

1. Інструкцією зі статистики кімькості працівників, затверАженої наказом Аержавного комітету статистики України віА 28.09.2005 № 286;

2. Інструкцією зі статистики заробітної плати, затверАженої наказом Аержавного комітету статистики України віА 13.01.2004 № 5.

3. Інструкцією щодо заповнення форми державного статистичного спостереження № 1-ПВ (місячна) «Звіт з праці», затверАженої наказом Аержкомстату України віА 26.10.2009 № 403;

4. Роз'ясненням Аержавної служби статистики України щодо форми державного статис- 
тичного спостереження № 1-ПВ (місячна) “Звіт із праці" віА віА 13.07.2016 р. N 17.4-12/4.

5. Роз'ясненням Аержавної служби статистики України щодо форми державного статистичного спостереження № 1-ПВ (місячна) «Звіт із праці" віА 14.07.2020 р. № 19.1.2-12/1220 (набере чинності з 01 лютого 2021 р.).

6. Інструкцією щодо заповнення форми Аержавного статистичного спостереження № 1-ПВ (квартальна) «Звіт з праці», затверАженої наказом Аержкомстату України віА 26.10.2009 № 404;

7. Роз'ясненням Аержавної служби статистики України щодо форми Аержавного статистичного спостереження № 1-ПВ (квартальна) “Звіт із праці" віА 31.07.2019 р. № 19.1.212/31-19

8. Наказом Аержавної служби статистики України «Про затвердження форми державного статистичного спостереження № 1-ПВ (квартальна) "Звіт із праці" віА 17.06.2020 № 178.

9. Наказом Аержавної служби статистики України «Про затверАження форм Аержавного статистичного спостереження № 1-ПВ (місячна) та № 1-ПВ (квартальна) “Звіт із праці" віА 10.06.2016 № 90.

10. Наказом Аержавного комітету статистики України «Про затверАження типових форм первинної облікової документації зі статистики праці» віА 05.12.2008 № 489.

Форма Аержавного статистичного спостереження Звіт із праці (форма № 1-ПВ (місячна) складається 3 Авох розАілів:

РозАіл І. Кількість працівників, робочий час і фонА оплати праці.

РозАіл II. Заборгованість переА працівниками із заробітної плати та виплат із соціального страхування.

Ажерелами інформації Аля показників форми № 1-ПВ (місячна) є первинні облікові Аокументи, Аокументи бухгалтерського обліку та фінансової звітності та інші документи, переАбачені нормами чинного законодавства.

Методика складання Звіту із праці (форма №1-ПВ (місячна) наведена у таблиці 11.1.

Методика склаАання Звіту із праці (форма №1-ПВ (місячна)

\begin{tabular}{|c|c|}
\hline КоА ряАКа & Зміст інформації \\
\hline \multicolumn{2}{|r|}{ РозАім І. Кількість працівників, робочий час і фонА оплати праці } \\
\hline РЯАОК 1020 & 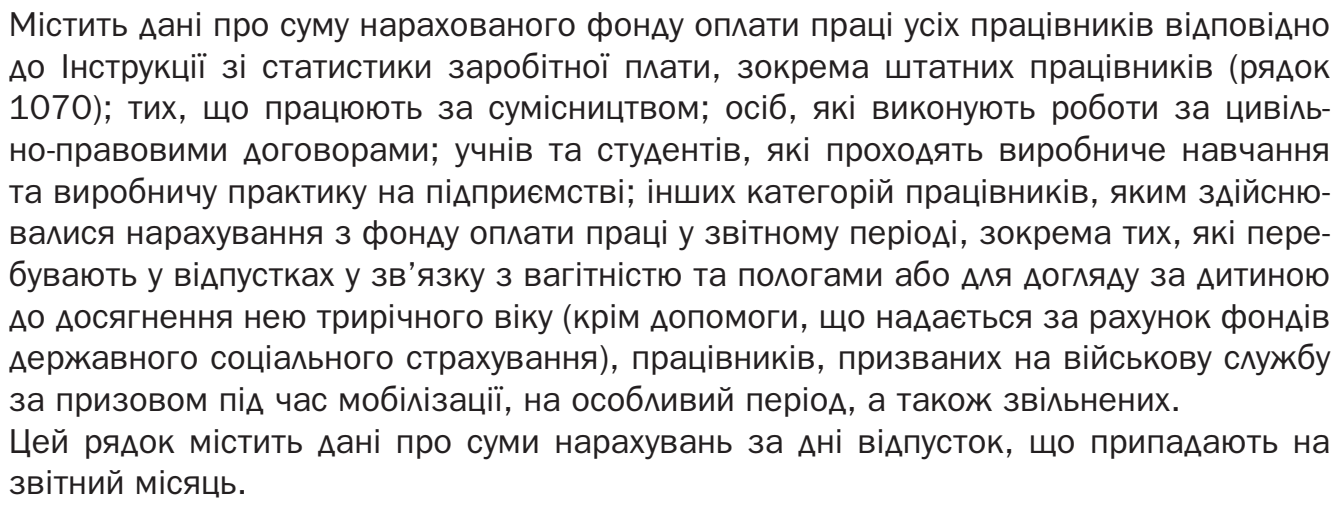 \\
\hline РяАОК 1030 & $\begin{array}{l}\text { Містить Аані про суму податку з Аоходів фізичних осіб із фонАу оплати праці усіх } \\
\text { працівників (рядок 1020), без перерахунків за попередній рік. }\end{array}$ \\
\hline РяАОК 1040 & $\begin{array}{l}\text { Містить Аані про середньооблікову кількість штатних працівників, крім тих, які пере- } \\
\text { бувають у віАпустках у зв'язку з вагітністю та пологами або Аля Аогляду за Аитиною } \\
\text { до Аосягнення нею трирічного віку, віАповіАно до пункту } 3.2 \text { глави } 3 \text { Інструкції зі ста- } \\
\text { тистики кількості працівників, а також призваних на військову службу за призовом } \\
\text { піА час мобілізації, на особливий період. }\end{array}$ \\
\hline
\end{tabular}


Продовження таблиці 11.1

\begin{tabular}{|c|c|}
\hline КОА РЯАКа & Зміст інформації \\
\hline РяАок 1060 & $\begin{array}{l}\text { Містить Аані про кількість фактично віАпрацьованих штатними працівниками мюди- } \\
\text { но-годин, зокрема у вихідні (за графіком), святкові та неробочі Ані, період службо- } \\
\text { вих відряджень, на надурочних роботах, а також час роботи надомників та тих, які } \\
\text { працюють за сумісництвом на тому самому підприємстві, де й основне місце роботи } \\
\text { (в повному обсязі). }\end{array}$ \\
\hline РяАок 1070 & $\begin{array}{l}\text { Містить Аані про фонд оплати праці штатних працівників (рялок 1040). Аані рялка } \\
1070 \text { можуть бути меншими за фонд оплати праці усіх працівників (рялок 1020) на } \\
\text { суму нарахувань особам, які не враховуються в середньообліковій кількості штатних } \\
\text { працівників. }\end{array}$ \\
\hline \multicolumn{2}{|r|}{$\begin{array}{c}\text { РозАіл II. Заборгованість переА працівниками із заробітної плати } \\
\text { та вип^ат із соціального страхування }\end{array}$} \\
\hline РяАок 2010 & 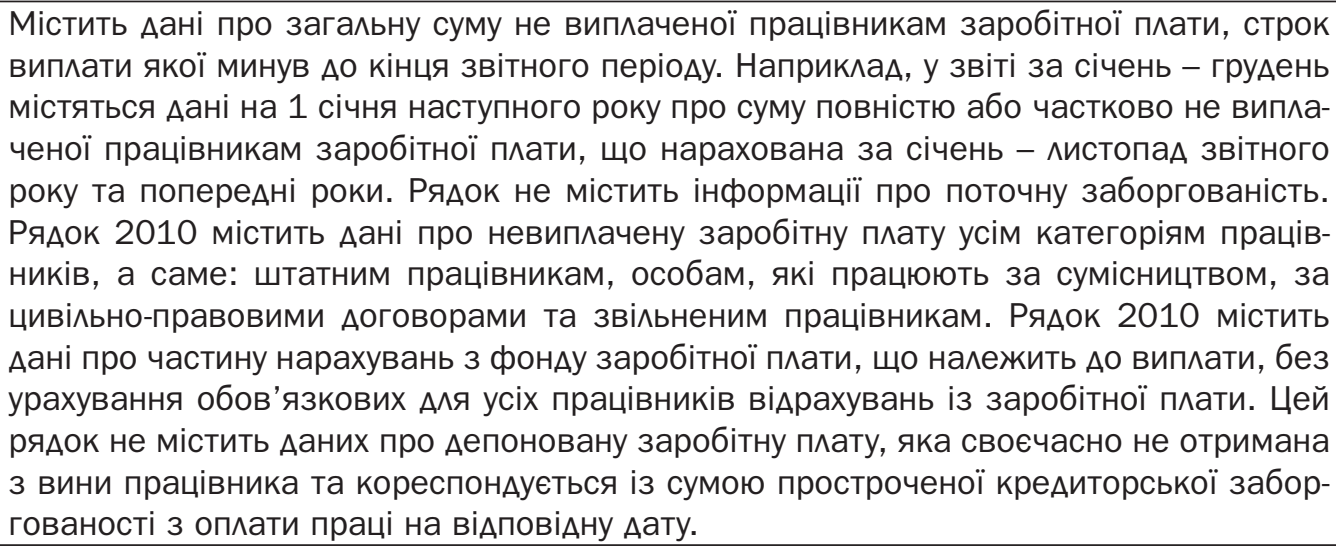 \\
\hline Ряаок 2020 & $\begin{array}{l}\text { Містить дані про заборгованість із виплати заробітної плати за попередні роки. На- } \\
\text { приклаА, у звіті за січень містяться дані на } 1 \text { лютого, які дорівнюють сумі у рядку } \\
2010 \text {, оскільки строк виплати заробітної плати за січень ще не настав. У наступних } \\
\text { періодах рядок містить суму, зменшену на виплати у відповідному місяці звітного } \\
\text { періоду в рахунок погашення заборгованості за попередні роки. }\end{array}$ \\
\hline Ряаок 2030 & $\begin{array}{l}\text { Містить дані щодо кількості усіх працівників (штатних працівників, тих, які працюють } \\
\text { за сумісництвом, за цивільно-правовими договорами, звільнених працівників), яким } \\
\text { не виплачено заробітну плату, строк виплати якої минув до кінця звітного періоду. }\end{array}$ \\
\hline РяАок 2040 & $\begin{array}{l}\text { Містить Аані про суму заборгованості з виплат працівникам у зв'язку з тимчасо- } \\
\text { вою втратою працездатності як за рахунок коштів Фонду соціального страхування } \\
\text { з тимчасової втрати працездатності, так і за рахунок коштів піАприємства з оплати } \\
\text { перших п'яти днів тимчасової непрацездатності, з урахуванням непрацездатності, } \\
\text { пов'язаної з нещасним випадком на виробництві або професійним захворюванням. }\end{array}$ \\
\hline Рянок 2050 & $\begin{array}{l}\text { Містить Аані про заборгованість із виплати заробітної плати за рахунок коштів державно- } \\
\text { го бюАжету у виглялі компенсаційних виплат працівникам, передбачених Законом Украї- } \\
\text { ни «Про статус і соціальний захист громаАян, які постражАали внаслілок Чорнобильської } \\
\text { катастрофи» (код статті бюАжетної класифікації “2170 - виплата пенсій і допомоги»). }\end{array}$ \\
\hline РяАок 2060 & $\begin{array}{l}\text { Містить Аані про заборгованість із виплати заробітної плати, яка фінансується за } \\
\text { рахунок коштів місцевих бюджетів (кол статті бюджетної к^асифікації "2111 - за- } \\
\text { робітна плата»). }\end{array}$ \\
\hline РяАок 2070 & 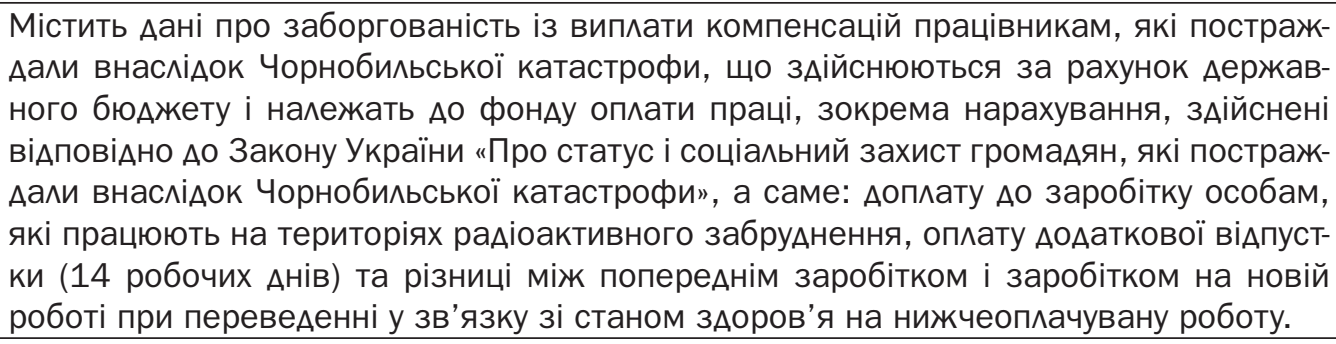 \\
\hline
\end{tabular}

Ажерело: [53]. 
Правильність Ааних, наведених у формі № 1-ПВ (місячна), можна перевірити шляхом провеАення арифметичного контролю, наприклаА:

- ряАОК 1020 > або = ряАОК 1070;

- ряАОК 1030 < ряАОК 1020;

- ряАОК 2010 > або = ряАОК 2020;

- ряАок 2010 (у звіті за січень) = ряАок 2020;

- ряАок 2010 > або = ряАок 2050;

- ряАок 2010 - ряАок 2010 попереднього звіту < або = (ряАок 1020 - ряАок 1030) попереАнього звіту;

- ряАок 2050 > або = ряАОК 2060 + ряАок 2070.

Форма державного статистичного спостереження Звіт із праці (форма № 1-ПВ (квартальна) складається з семи розАілів:

РозАіл І. Кількість штатних працівників.

РозАі^ II. Втрати робочого часу штатних працівників.

РозАіл III. СклаА фонду оплати праці штатних працівників.

РозАіл IV. Розподіл штатних працівників за розмірами заробітної плати (за останній місяць кварталу).

РозАіл V. Кількість і фонА оплати праці окремих категорій працівників.

Розділ VI. Інформація про укладання колективних Аоговорів станом на 31 грудня 2020 р. (у звіті за IV квартал).

РозАі^ VII. Витрати на утримання робочої сили, що не вхоАять Ао скмаАу фонду оплати праці за 2019 р. (у звіті за I квартал).

Ажерелами інформації показників форми № 1-ПВ (квартальна) є Аані первинної облікової Аокументації підприємств, установ, організацій.

Методика складання Звіту із праці (форма №1-ПВ (квартальна) наведена у таблиці 11.2.

Методика скмаАання Звіту із праці (форма №1-ПВ (квартальна)

\begin{tabular}{|c|c|}
\hline KOA F & Зміст інформації \\
\hline \multicolumn{2}{|c|}{ 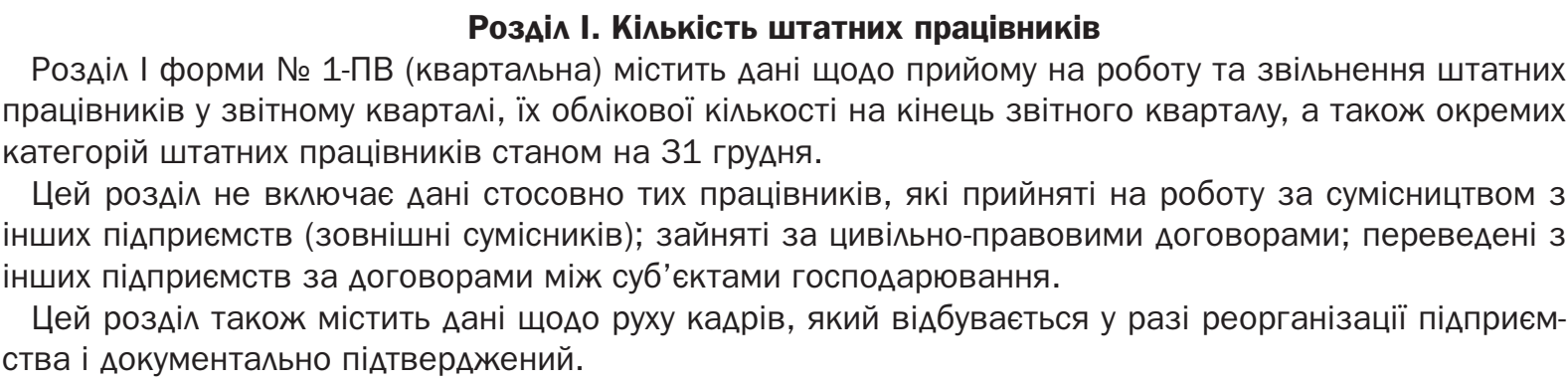 } \\
\hline РяАок 3020 & $\begin{array}{l}\text { Містить Аані про кількість працівників, які у звітному періоді прийняті на роботу на- } \\
\text { казом чи розпорядженням власника піАприємства або уповноваженого ним органу. }\end{array}$ \\
\hline РЯАОК 3040 & $\begin{array}{l}\text { Містить Аані про кількість працівників, які у звітному періоді звільнені з роботи на } \\
\text { цьому піАприємстві в результаті припинення або розірвання трудового Аоговору, } \\
\text { незалежно віА причин звільнення. }\end{array}$ \\
\hline РЯАОК 3050 & $\begin{array}{l}\text { Містить Аані про кількість працівників, які звільнені з піАприємства у зв'язку з розі- } \\
\text { рванням трудового Аоговору з ініціативи власника або уповноваженого ним органу } \\
\text { у випадках змін в організації виробництва й праці, в тому числі ліквідації, реорга- } \\
\text { нізації, банкрутства або перепрофрілювання піАприємства, скорочення чисельності } \\
\text { або штату працівників. }\end{array}$ \\
\hline
\end{tabular}


Продовження таблиці 11.2

\begin{tabular}{|c|c|}
\hline КОА ряАКа & Зміст інформації \\
\hline РяАок 3060 & 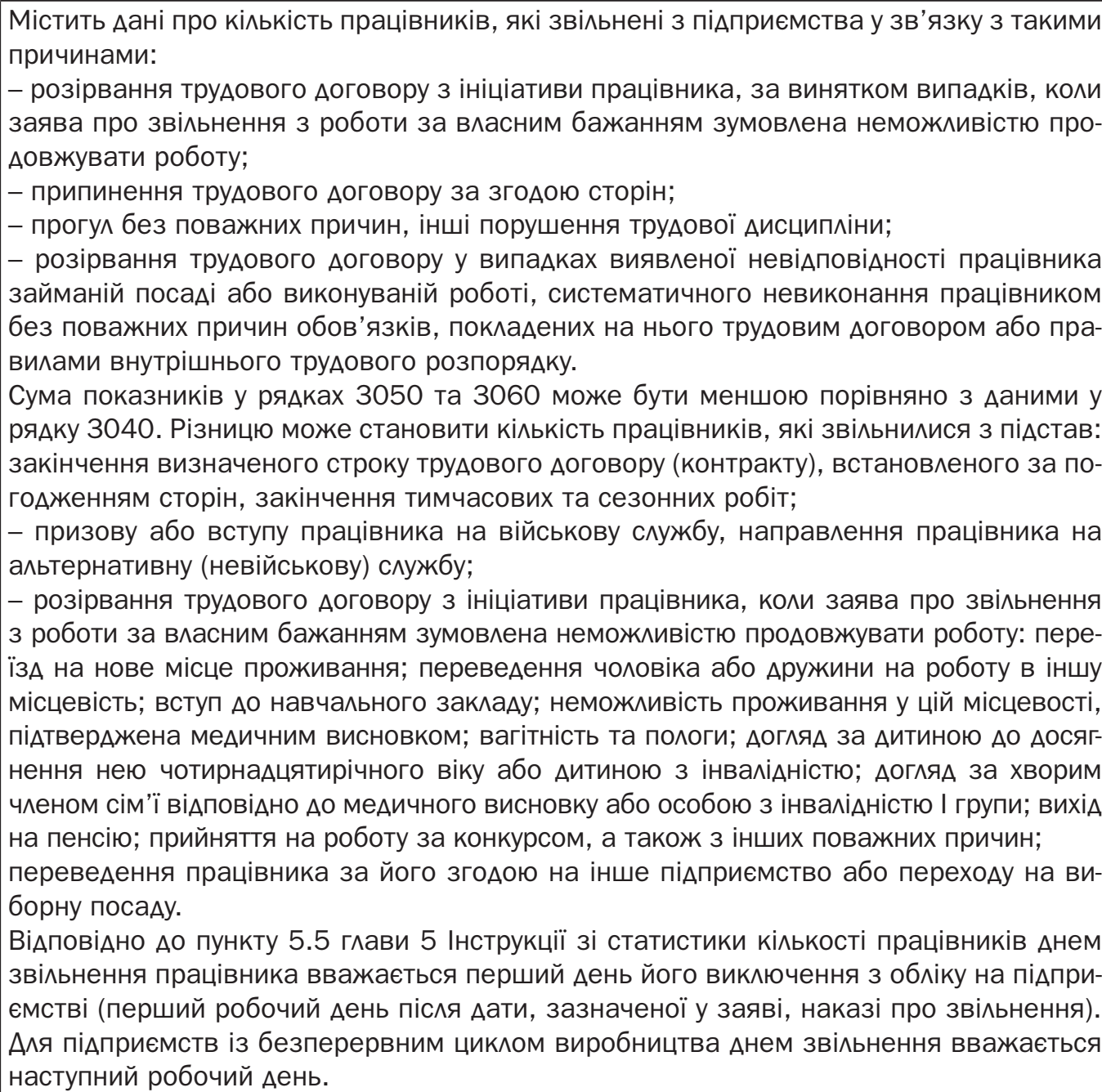 \\
\hline РяАОК & $\begin{array}{l}\text { Містить Аані про облікову кількість штатних працівників на останню Аату звітного } \\
\text { періоду віАповіАно Ао глави } 2 \text { Інструкції зі статистики кількості працівників, вк^ючно } \\
\text { з працівниками, призваними на військову службу за призовом під час мобілізації, на } \\
\text { особливий період. }\end{array}$ \\
\hline РяАок 3080 & $\begin{array}{l}\text { Містить Аані про облікову кількість штатних працівників станом на } 31 \text { грудня, які згіАно з } \\
\text { трудовим Аоговором прийняті на роботу на умовах неповного робочого Аня (тижня) або } \\
\text { яким наАалі було встановлено неповний робочий день (тижАень) за згодою працівника. }\end{array}$ \\
\hline РяАок 3090 & $\begin{array}{l}\text { Містить дані про облікову кількість жінок станом на } 31 \text { грудня, які віАповіАно до статті } \\
17 \text { Закону України "Про відпустки" на кінець звітного періоду перебувають в оплачу- } \\
\text { ваних відпустках у зв'язку з вагітністю та пологами. }\end{array}$ \\
\hline РяАок 3100 & $\begin{array}{l}\text { Містить Аані про облікову кількість штатних працівників станом на } 31 \text { грудня, які } \\
\text { перебувають у віАпустках Аля Аогляду за Аитиною (Ао Аосягнення нею трирічного віку } \\
\text { або більшої тривалості) віАповіАно до статті } 18 \text { Закону України «Про віАпустки». }\end{array}$ \\
\hline \multicolumn{2}{|c|}{$\begin{array}{l}\text { РозАіл ІІ. Втрати робочого часу штатних працівників } \\
\text { Усі показники розділу ІІ форми № 1-ПВ (квартальна) стосуються категорій працівників, які врахову- } \\
\text { ються в середньообліковій кількості штатних працівників згіАно з пунктом } 3.2 \text { глави } 3 \text { Інструкції зі } \\
\text { статистики кількості працівників. }\end{array}$} \\
\hline РяАок 4080 & $\begin{array}{l}\text { Містить Аані про кількість невіАпрацьованого робочого часу через віАпустки без } \\
\text { збереження заробітної плати, які наАаються власником чи уповноваженим ним ор- } \\
\text { ганом самостійно, у межах своїх повноважень з незалежних віА працівника причин, } \\
\text { наприклад на період припинення виконання робіт. }\end{array}$ \\
\hline
\end{tabular}


Продовження таблиці 11.2

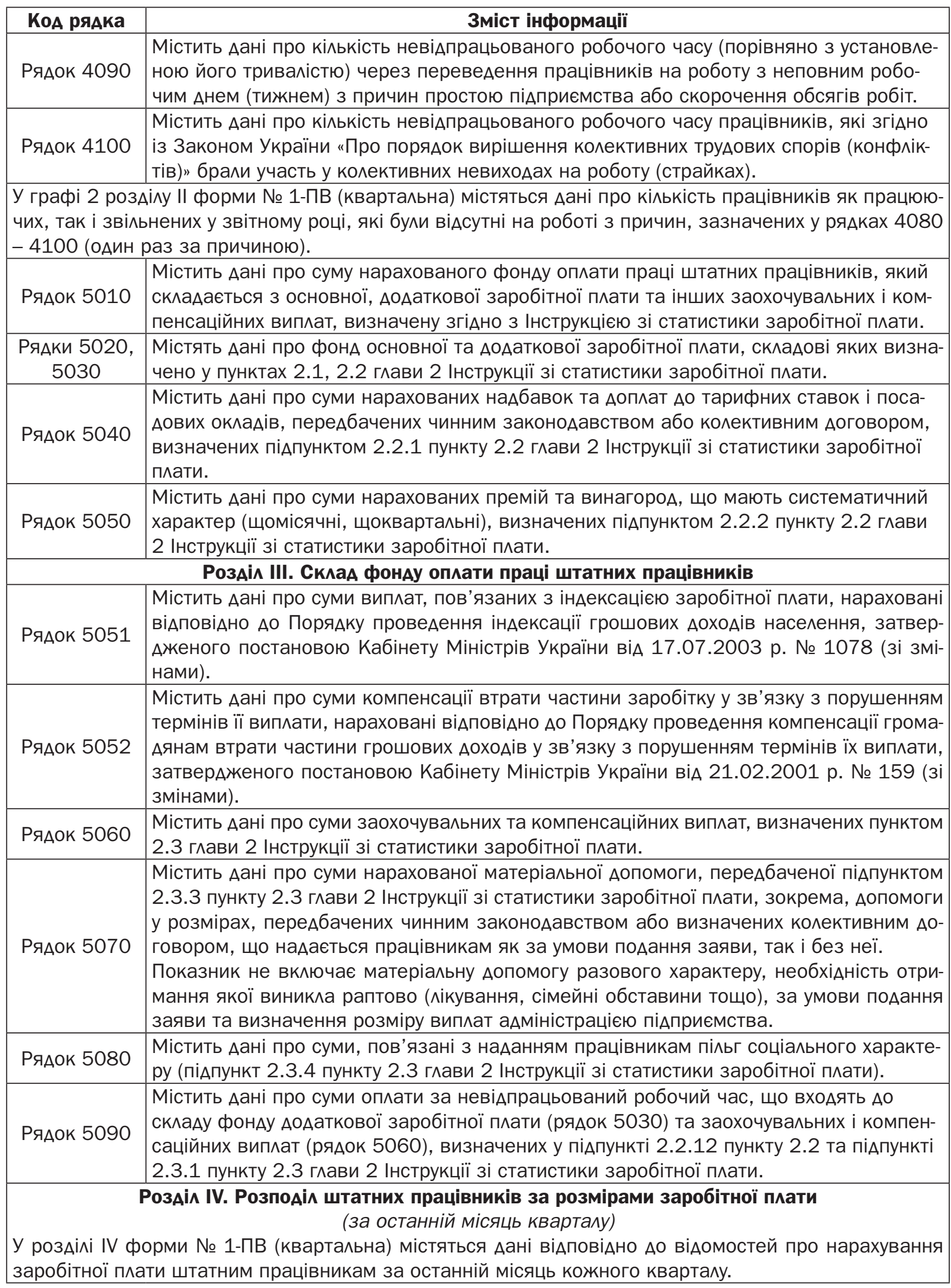


Продовження таблиці 11.2

\begin{tabular}{|c|c|}
\hline КОА ряАКа & Зміст інформації \\
\hline РяАок 6010 & $\begin{array}{l}\text { Містить Аані про кількість штатних працівників, яким оплачено 50\% і більше фонду } \\
\text { робочого часу, встановленого на звітний місяць колективним договором підприєм- } \\
\text { ства та чинним законодавством. } \\
\text { Рядок містить інформацію про працівників, які перебували в оплачуваних відпустках, } \\
\text { віАрядженнях та були відсутні з інших причин зі збереженням середньої заробітної } \\
\text { плати, та не включає випадків тимчасової непрацездатності. } \\
\text { Рядок також містить дані про працівників, прийнятих на половину ставки заробітної пла- } \\
\text { ти або тимчасово переведених на такий режим роботи, які віАпрацювали не менше 50\% } \\
\text { фонду робочого часу, встановленого Аля працівника, зайнятого повний робочий день. }\end{array}$ \\
\hline $\begin{array}{l}\text { Рянки 6020- } \\
6120\end{array}$ & 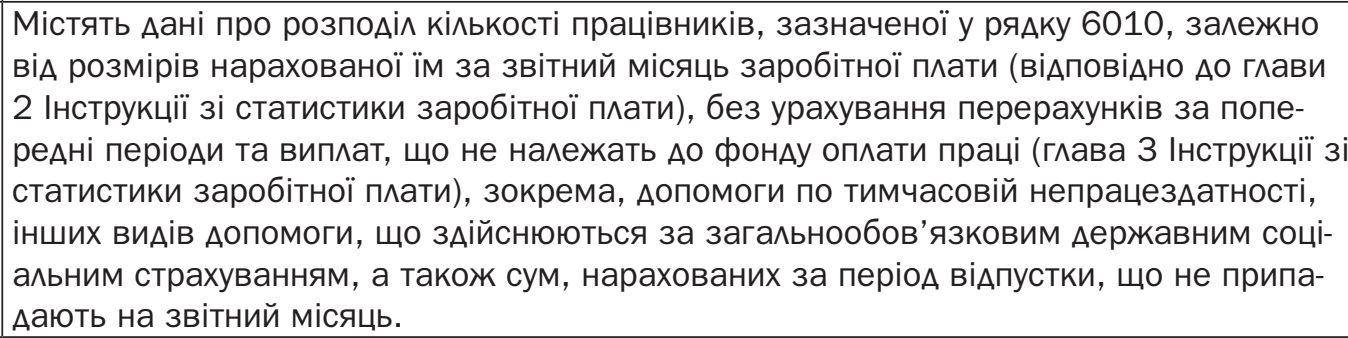 \\
\hline $\begin{array}{l}\text { Рянки 6130- } \\
6150\end{array}$ & $\begin{array}{l}\text { Містять Аані про працівників, які були прийняті на умовах повного робочого Аня } \\
\text { (тижня) та перебували в обліковому складі працівників на кінець звітного періоду. }\end{array}$ \\
\hline РяАок 6130 & $\begin{array}{l}\text { Містить Аані про кількість штатних працівників, які віАпрацювали 100\% фонду робо- } \\
\text { чого часу, встановленого законодавством на віАповіАний місяць, разом з тими, які } \\
\text { були у віАрядженні, а також тими, Аля кого запроваАжено піАсумований облік робо- } \\
\text { чого часу та які повністю віАпрацювали норму робочого часу, встановлену згіАно з } \\
\text { грасріком на звітний місяць. Рядок не містить даних про прийнятих на неповну ставку. }\end{array}$ \\
\hline Рянок 6140 & $\begin{array}{l}\text { Містить лані із рялка } 6130 \text { про кількість штатних працівників, у яких нарахована за- } \\
\text { робітна плата за повний місяць була у межах (менше або дорівнювала) мінімального } \\
\text { розміру, встановленого законодавством у цьому періоді. }\end{array}$ \\
\hline РяАок 6150 & 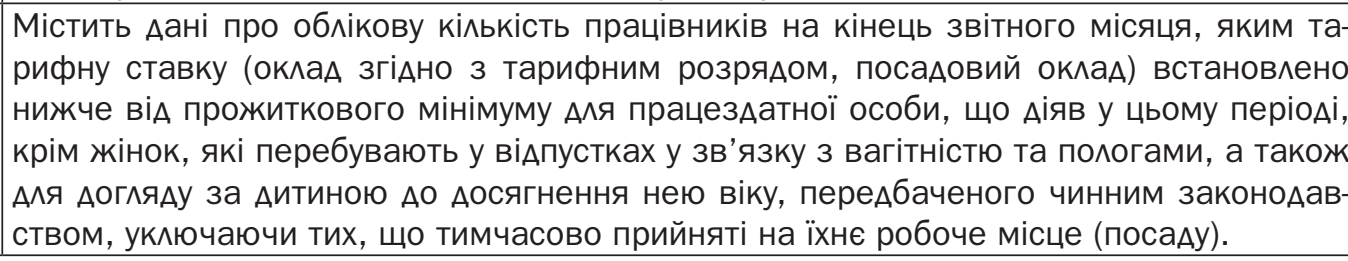 \\
\hline \multicolumn{2}{|r|}{ РозАі^ V. Кі^ькість і фонА оп^ати праці окремих категорій працівників } \\
\hline Рянок 7010 & 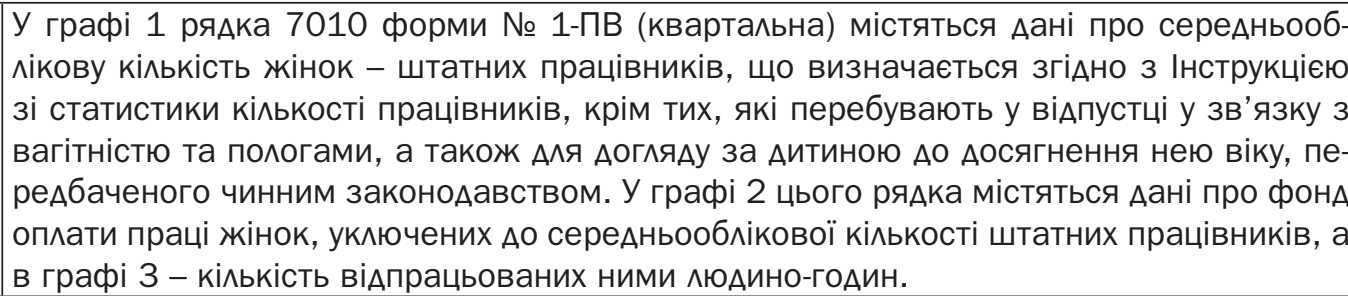 \\
\hline Рянок 7020 & $\begin{array}{l}\text { Містить Аані установ та організацій розпорядників бюджетних коштів, які утриму- } \\
\text { ються за рахунок державного чи місцевого бюАжету і } є \text { неприбутковими. Графа } 1 \\
\text { містить дані про середньооблікову кількість штатних працівників, оплата праці яких } \\
\text { фінансується за рахунок коштів державного чи місцевого бюАжету. Графа } 2 \text { містить } \\
\text { Аані про суму фонду оплати праці, нарахованого таким працівникам за рахунок } \\
\text { видатків зазначених бюджетів. }\end{array}$ \\
\hline РяАок 7030 & $\begin{array}{l}\text { Містить Аані про сереАню кількість і фонА оплати праці зовнішніх сумісників (пункт } \\
3.3 \text { глави } 3 \text { Інструкції зі статистики кількості працівників). }\end{array}$ \\
\hline РяАок 7040 & $\begin{array}{l}\text { Містить Аані про середню кількість і фонА оплати працівників, які виконували роботи за } \\
\text { цивільно-правовими договорами, та сплатили єАиний соціальний внесок із суми оплати } \\
\text { за виконані роботи (пункт З.3 глави } 3 \text { Інструкції зі статистики кількості працівників). } \\
\text { Рядок не містить Ааних про штатних працівників піАприємства, які одночасно уклали } \\
\text { цивільно-правовий Аоговір з цим підприємством, та фізичних осіб - піАприємців. }\end{array}$ \\
\hline
\end{tabular}


Продовження таблиці 11.2

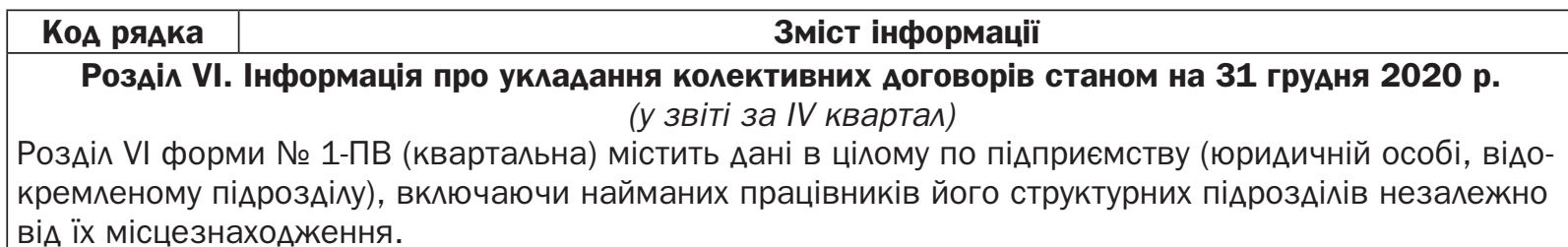
віА їх місцезнаходження.

\begin{tabular}{|c|c|}
\hline РЯАОК 8010 & 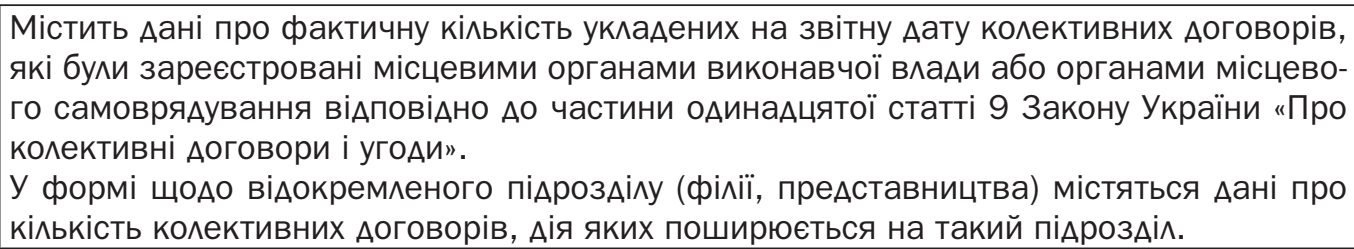 \\
\hline РяАОК 8020 & $\begin{array}{l}\text { Містить Аані про кількість штатних працівників, на яких поширюється Аія укладених } \\
\text { колективних договорів (угоА), тобто усіх працівників, які включаються до облікової } \\
\text { кількості штатних працівників підприємства віАповіАно до пунктів } 2.4,2.5 \text { глави } 2 \\
\text { Інструкції зі статистики кількості працівників. }\end{array}$ \\
\hline РяАОК 8030 & $\begin{array}{l}\text { Містить Аані про розмір мінімальної місячної тарифної ставки (посаАового оклаАу) } \\
\text { відповіАно до змісту укладених на підприємстві колективних договорів (угоА). }\end{array}$ \\
\hline РяАОК 8040 & $\begin{array}{l}\text { Містить Аані про розмір мінімальної місячної тарифної ставки (посаАового оклаАу), } \\
\text { визначений у галузевій угоді, у сфері дії якої перебуває підприємство. }\end{array}$ \\
\hline \multicolumn{2}{|c|}{ 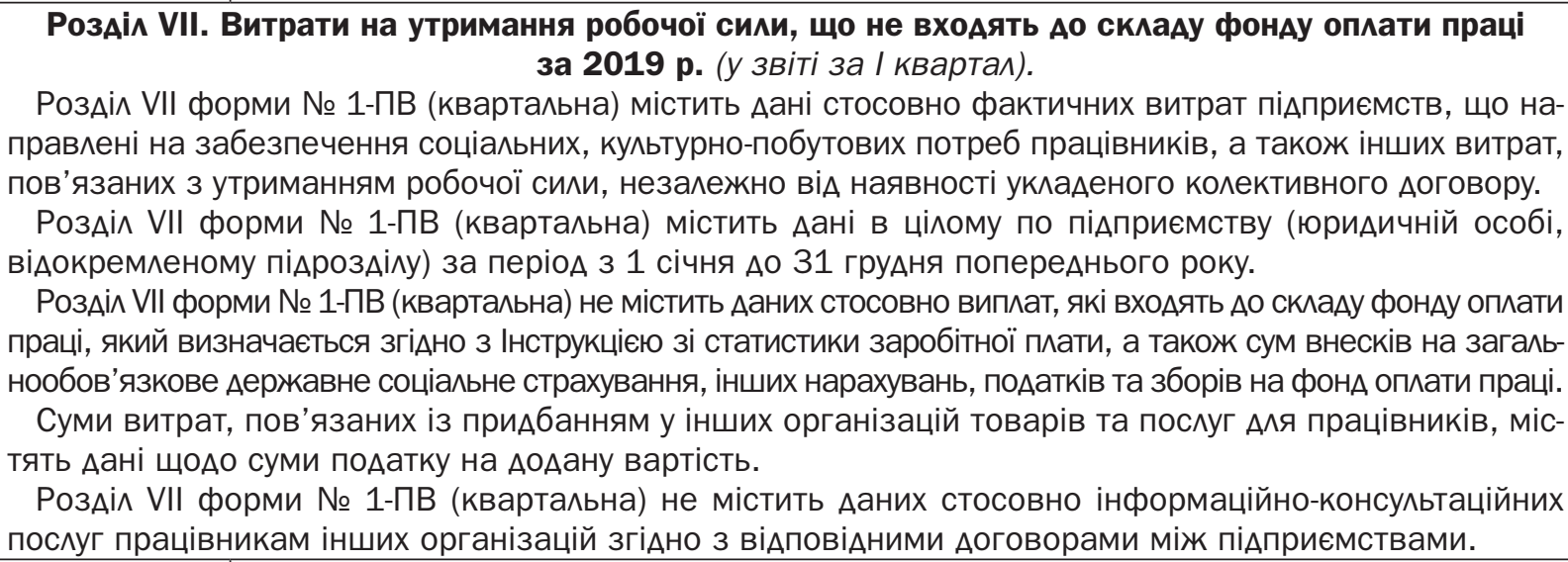 } \\
\hline 等 & 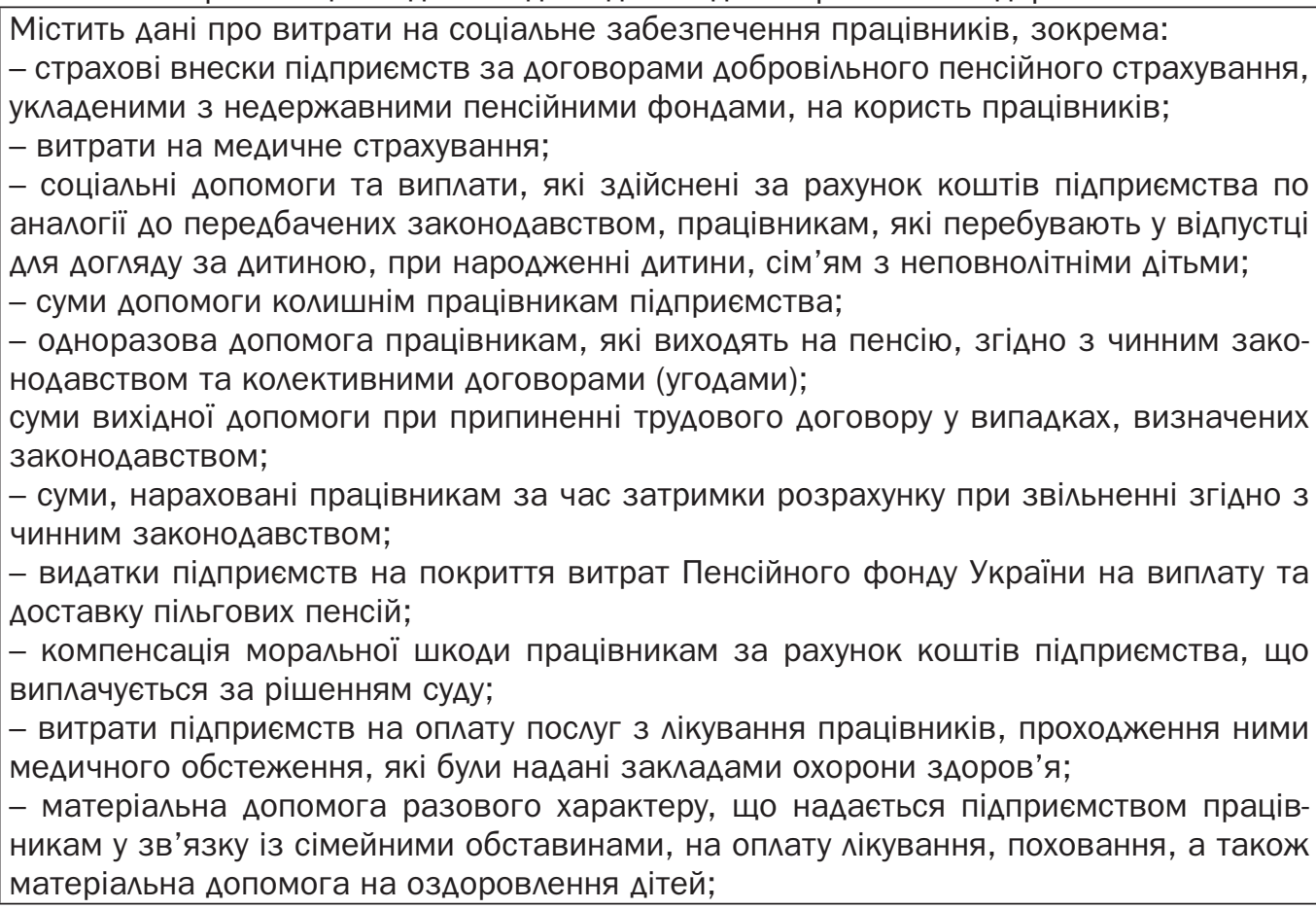 \\
\hline
\end{tabular}


Продовження таблиці 11.2

\begin{tabular}{|c|c|}
\hline КоА ряАКа & Зміст інформації \\
\hline & $\begin{array}{l}\text { інші витрати на соціальний захист працівників. } \\
\text { Рядок } 9020 \text { не містить Ааних про суми, нараховані працівникам за загальнообов'яз- } \\
\text { ковим державним соціальним страхуванням та оплату перших } 5 \text { днів тимчасової } \\
\text { непрацездатності внаслідок захворювання або травми, не пов'язаної з нещасним } \\
\text { випадком на виробництві. }\end{array}$ \\
\hline РЯАОК 9030 & 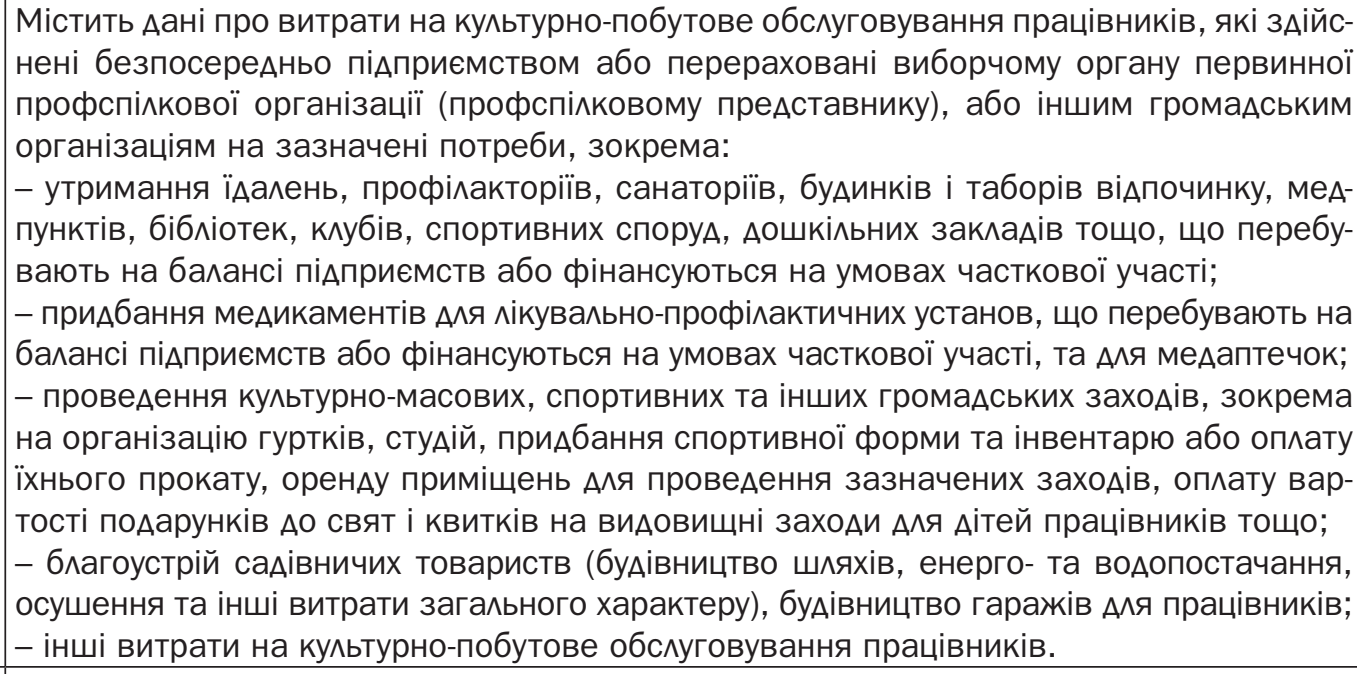 \\
\hline РяАок 9040 & $\begin{array}{l}\text { Містить Аані про витрати на забезпечення працівників житлом, зокрема: } \\
\text { - утримання житлового фонду, що перебуває на балансі піАприємства або фінансу- } \\
\text { ється за рахунок коштів піАприємства, без урахування заробітної плати працівників, } \\
\text { що здійснюють його обслуговування; } \\
\text { - будівництво житла Аля працівників, погашення позик, виданих на індивідуальне } \\
\text { будівництво, які не піАлягають поверненню, або віАсотків за користування ними, ви- } \\
\text { дачу субсидій; вартість житла, переданого у власність працівника, тощо. }\end{array}$ \\
\hline РяАок 9050 & 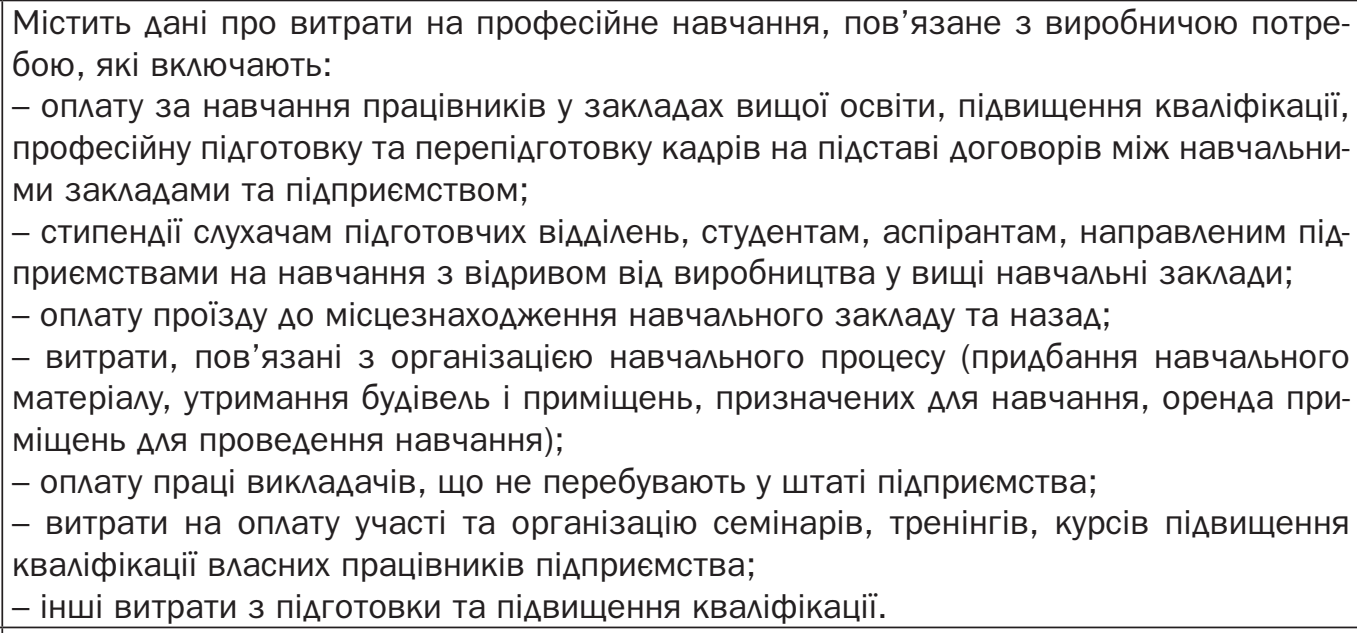 \\
\hline РяАок 9060 & 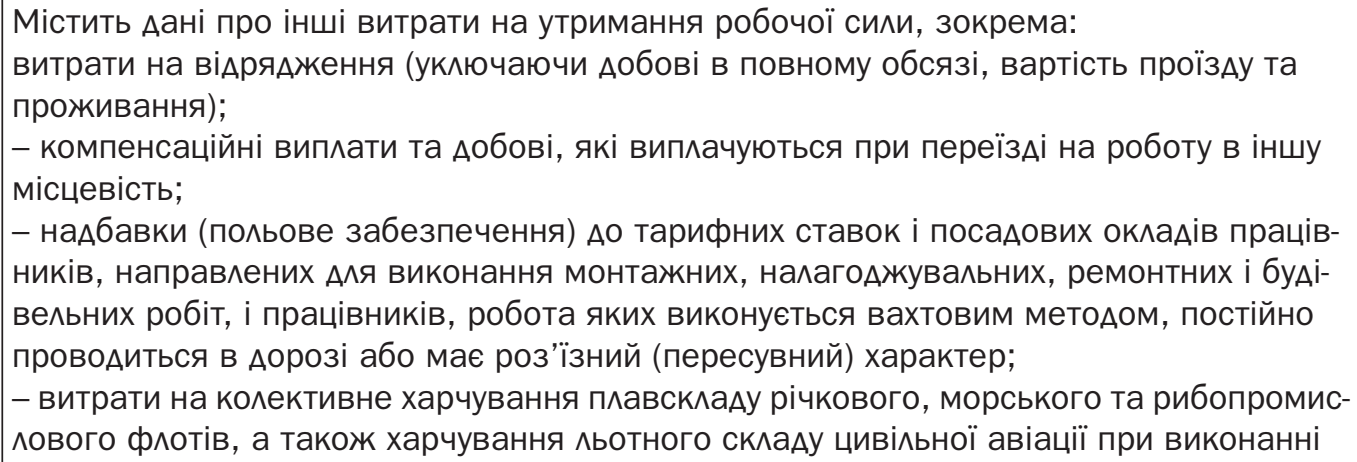 \\
\hline
\end{tabular}


Продовження таблиці 11.2

\begin{tabular}{|c|c|}
\hline КОА ряАКа & Зміст інформації \\
\hline & 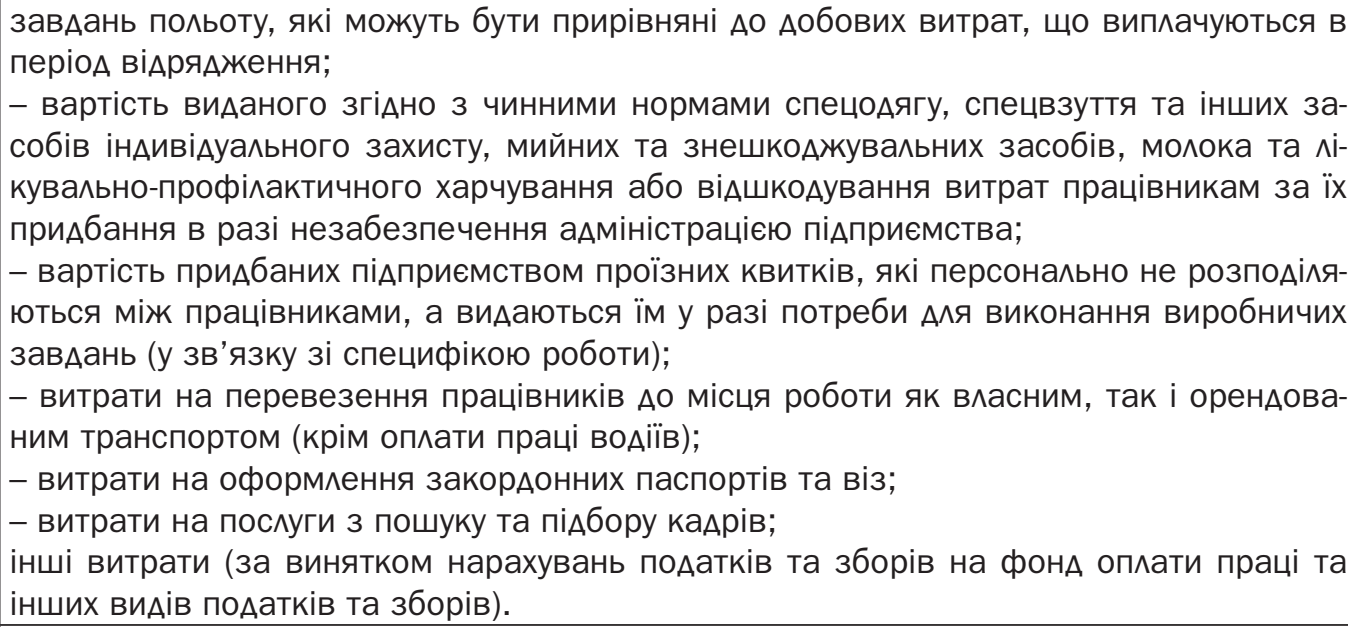 \\
\hline РяАОК 9070 & $\begin{array}{l}\text { Містить дані про середньооблікову кількість штатних працівників за січень - грудень } \\
\text { попереднього року, яка розрахована відповідно до пункту } 3.2 \text { глави } 3 \text { Інструкції зі } \\
\text { статистики кількості працівників. }\end{array}$ \\
\hline
\end{tabular}

Ажерело: [51].

Правильність Ааних, наведених у формі № 1-ПВ (квартальна), можна перевірити шляхом проведення арифметичного контролю, наприклаА:

- номер структурного піАрозАілу = номер структурного піАрозАілу фрорми № 1-ПВ (місячна);

- ряАОК 3040 > або = ряАОК 3050 + ряАОК 3060;

- ряАОК 3070 = ряАОК 3070 попереАнього звіту + ряАОК 3020 - ряАОК 3040 (виконується Аля Ааних граф 1 та 2);

- рянок 3080 графа 1 > або = рянок 3080 графа 2;

- рялок 3100 графа 1 > або = рялок 3100 графа 2;

- рялок 3070 графа 1 > або = рялок 3080 графа 1 (Аля звіту за IV квартал);

- рялок 3070 графа 1 > або = рялок 3100 графа 1 (Аля звіту за IV квартал);

- рялок 3070 графа 2 > або = рялок 3080 графа 2 (Аля звіту за IV квартал);

- рялок 3090 графра 1 = 0;

- рялок 3070 графра 2 > або = рялок 3090 графра 2 + рялок 3100 графра 2 (Аля звіту за IV квартал);

- рялок 3070 гр. 2 > або = рялок 3100 графа 2 (Аля звіту за IV квартал);

- рялок 3070 (графра 1 - графра 2) > або = рялок 3080 (графра 1 - графа 2) (Аля звіту за IV квартал);

- рялок 3070 (графа 1 - графа 2) > або = рялок 3100 (графа 1 - графа 2) (Аля звіту за IV квартал);

- якщо рялок 4080 графа $1>0$, то рянок 4080 графа 2 > 0;

- якщо рялок 4080 графа 2 > 0, то рялок 4080 графа 1 > 0;

- якщо рялок 4090 графа $1>0$, то рянок 4090 графа $2>0$;

- якщо рялок 4090 графа 2 > 0, то рянок 4090 графа 1 > 0;

- якщо рялок 4100 графа $1>0$, то рялок 4100 графа $2>0$

- якщо рялок 4100 графа $2>0$, то рялок 4100 графа $1>0$

- ряАОК 5010 = ряАОК 5020 + ряАОК 5030 + ряАОК 5060;

- рялок 5030 > або = ряАок 5040 + ряАок 5050 + ряАок 5051 + ряАок 5052 + ряАок 5090

(у разі віАсутності нарахувань за невіАпрацьований час у зв'язку з віАпустками з ініціативи аАміністрації та простоями);

- ряАок 5060 > або = ряАок 5070 + ряАок 5080;

- рялок 6010 = сума ряАків 6020 - 6120; 
- ряаок $6130<$ або = ряАок 6010;

- ряаок $6130<$ або = ряАок 3070 графа 1;

- ряаок $6130<$ або = ряАок 1040 форми № 1-ПВ (місячна);

- рялок 6140 < або = рядок 6020 (інтервал до мінімальної заробітної плати);

- ряАок $6140<$ або = ряАок 6130;

- ряаок $6150<$ або = ряАок 3070 графа 1 ;

- ряАок 6150 < або = ряАок 1040 форми № 1-ПВ (місячна);

- ряаок 7010 графра 2 < або = рянок 5010;

- ряАок 7020 графа $2<$ або = ряАок 5010;

- якЩо ряАОК $8010>0$, то ряАОК $8020>0$;

- якЩо ряАОК $8010>0$, то ряАОК $8030>0$.

\section{3. Методика скмаАання статистичної звітності з основних засобів}

Звіт про наявність і рух необоротних активів, амортизацію та капітальні інвестиції (форма № 2-03 IHB (річна) подають юридичні особи не пізніше 28 ^ютого.

Звіт піАприємства про наявність і рух необоротних активів, амортизацію та капітальні інвестиції віАображає показники, сформовані з використанням:

1) регістрів бухгалтерського обліку;

2) Плану рахунків бухгалтерського обліку активів, капіталу, зобов'язань і господарських операцій піАприємств і організацій, затверАженого наказом Міністерства фінансів України віА 30 мистопада 1999 року № 291 (зі змінами);

3) спрощеного Плану рахунків бухгалтерського обліку активів, капіталу, зобов'язань і господарських операцій підприємств, затвердженого наказом Міністерства фінансів України віА 19 квітня 2001 року № 186 (зі змінами);

4) національних положень (стандартів) бухгалтерського обліку, затверджених відповідними нормативно-правовими актами Міністерства фінансів України, міжнародних стандартів фрінансової звітності та міжнародних стандартів бухгалтерського обліку.

Порядок складання звіту про наявність і рух необоротних активів, амортизацію та капітальні інвестиції (форма № 2-03 IHВ (річна) регулюють:

1. Роз'яснення Аержавної служби статистики України щодо форми державного статистичного спостереження № 2-03 IHB (річна) «Звіт про наявність і рух необоротних активів, амортизацію та капітальні інвестиції» віА 24.09.2020 р. № 19.1.2-12/28-20.

2. Наказ Аержавної служби статистики України «Про затверАження форм державних статистичних спостережень № 2-інвестиції (квартальна) “Звіт про капітальні інвестиції», № 2-03 IHB (річна) «Звіт про наявність і рух необоротних активів, амортизацію та капітальні інвестиції" віА 26.08.2020 № 256.

Значення показників форми (одиниця вимірювання - тисяча гривень) мають формат преАставлення у цілих числах.

За віАсутності Ааних віАповіАні рядки (графи) форми вміщують прочерки.

Форма Аержавного статистичного спостереження звіту про наявність і рух необоротних активів, амортизацію та капітальні інвестиції (форма № 2-03 IHB (річна) склаАається 3 трьох розАілів:

Розділ 1. Наявність і рух необоротних активів, амортизація.

Розділ 2. Розподіл капітальних інвестицій за видами активів.

Розділ 3. Податок на Аодану вартість за окремими видами активів.

Методика складання звіту про наявність і рух необоротних активів, амортизацію та капітальні інвестиції (форма № 2-03 ІНВ (річна) наведена у таблиці 11.3. 


\section{Методика скмаАання звіту про наявність і рух необоротних активів,} амортизацію та капітальні інвестиції (форма № 2-03 IHB (річна)

\begin{tabular}{|c|c|}
\hline $\begin{array}{l}\text { КоА графи/ } \\
\text { ряака }\end{array}$ & Зміст інформації \\
\hline \multicolumn{2}{|c|}{$\begin{array}{l}\text { РозАіл 1. Наявність і рух необоротних активів, амортизація } \\
\text { Розді^ } 1 \text { уміщує інформацію щодо вартості необоротних активів: первісної (переоціненої) і залиш- } \\
\text { кової вартості власних та отриманих на умовах фінансового лізингу об'єктів і орендованих цілісних } \\
\text { майнових комплексів, інших необоротних матеріальних активів, нематеріальних активів та довго- } \\
\text { строкових біологічних активів, незавершених капітальних інвестицій. }\end{array}$} \\
\hline Грасра 1 & $\begin{array}{l}\text { Містить Аані щоло первісної (переоціненої) вартості необоротних активів на початок } \\
\text { звітного року. } \\
\text { Якщо графа } 1 \text { дорівнює } 0 \text { за всіма рядками, крім рядка 1400, то графа } 2 \text { може Аорів- } \\
\text { нювати 0, а графа } 11 \text { дорівнює } 0 \text { за всіма рядками, крім рядка } 1400 .\end{array}$ \\
\hline Графра 2 & 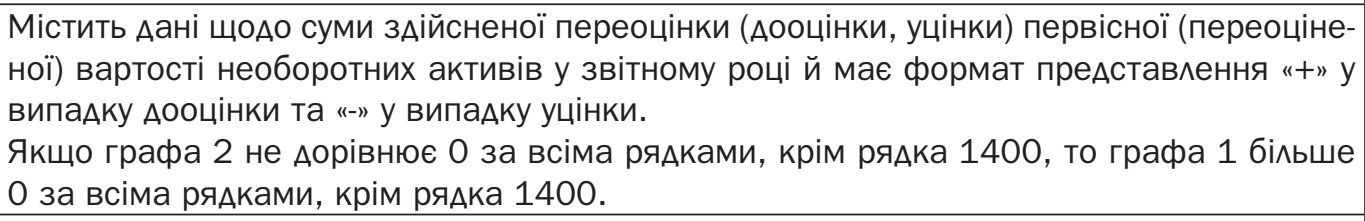 \\
\hline Графа 3 & $\begin{array}{l}\text { Містить Аані щоло вартості у звітному році необоротних активів (придбаних, створе- } \\
\text { них, отриманих безоплатно та на умовах фінансового лізингу); оборотних активів, } \\
\text { переведених до основних засобів, а також витрат, пов'язаних з поліпшенням об'єктів } \\
\text { (модернізація, модифікація, добудова, дообладнання, реконструкція тощо). }\end{array}$ \\
\hline Графа 4 & Із графи $3 \mathrm{~N}$ \\
\hline Графа 5 & 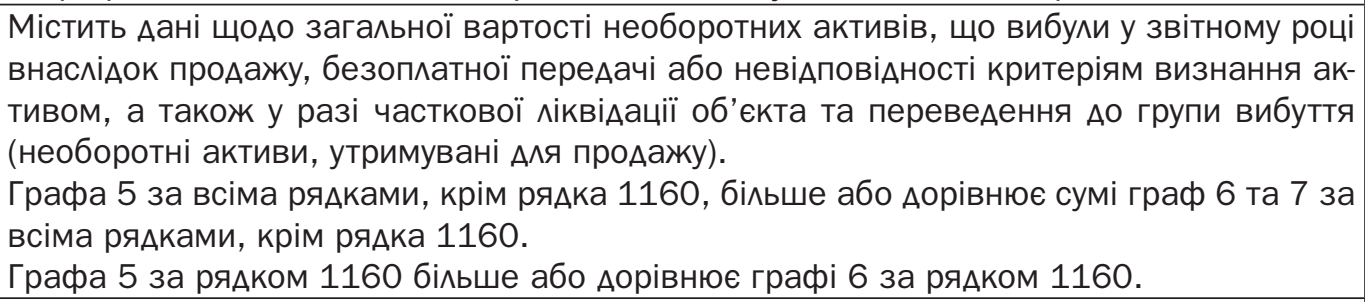 \\
\hline Графра 6 & вибули у звітному році \\
\hline Графа 7 & $\begin{array}{l}\text { Із графи } 5 \text { містить Аані щодо вартості необоротних активів, що вибули у звітному році } \\
\text { внаслідок ліквіАації: морально застарілих, зношених, пошкоджених унаслідок наАзви- } \\
\text { чайних подій (за умови, що віАновлення та реалізація основних засобів неможливі } \\
\text { або економічно недоцільні), а також ліквідованих у зв'язку з новим будівництвом та } \\
\text { реконструкцією. }\end{array}$ \\
\hline Графа 8 & $\begin{array}{l}\text { Із графии } 7 \text { містить Аані щоАо вартості активів, що вибули за рік унасліАок наАзвичай- } \\
\text { них подій (аварія, стихійне михо тощо). }\end{array}$ \\
\hline Графа 9 & $\begin{array}{l}\text { Містить Аані щоло інших змін, які віАбулись із необоротними активами за рік, на- } \\
\text { приклаА, зміни, пов'язані з виправленням помилки попереднього року або зі зміною } \\
\text { облікової політики, і має формат представлення «+» або «-». }\end{array}$ \\
\hline Графа 10 & $\begin{array}{l}\text { Містить Аані щодо первісної (переоціненої) вартості необоротних активів на кінець } \\
\text { року. }\end{array}$ \\
\hline $\begin{array}{l}\text { qри } 11, \\
12\end{array}$ & 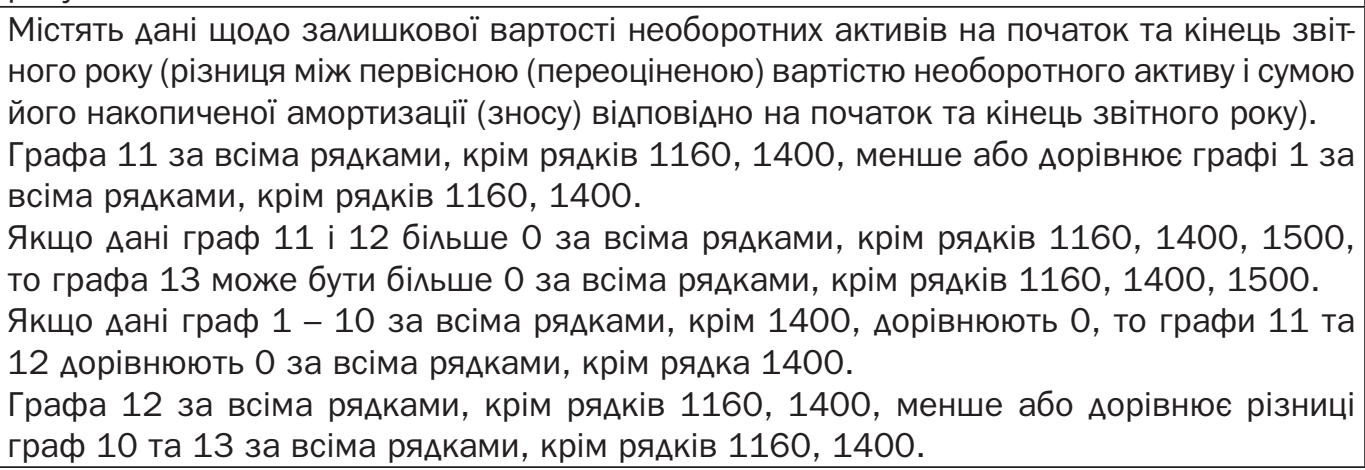 \\
\hline
\end{tabular}


Продовження таблиці 11.3

\begin{tabular}{|c|c|}
\hline $\begin{array}{c}\text { КоА графи/ } \\
\text { ряАка }\end{array}$ & Зміст інформації \\
\hline Грасра 13 & 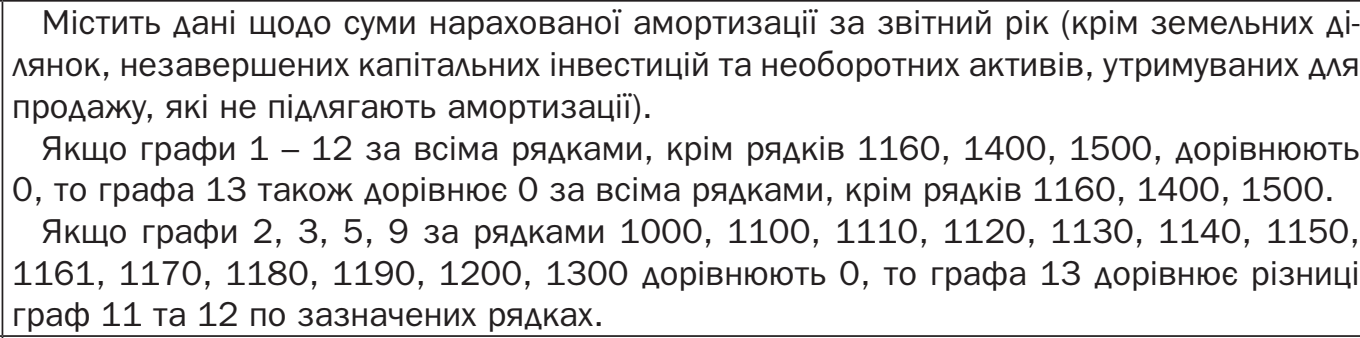 \\
\hline Грасра 14 & 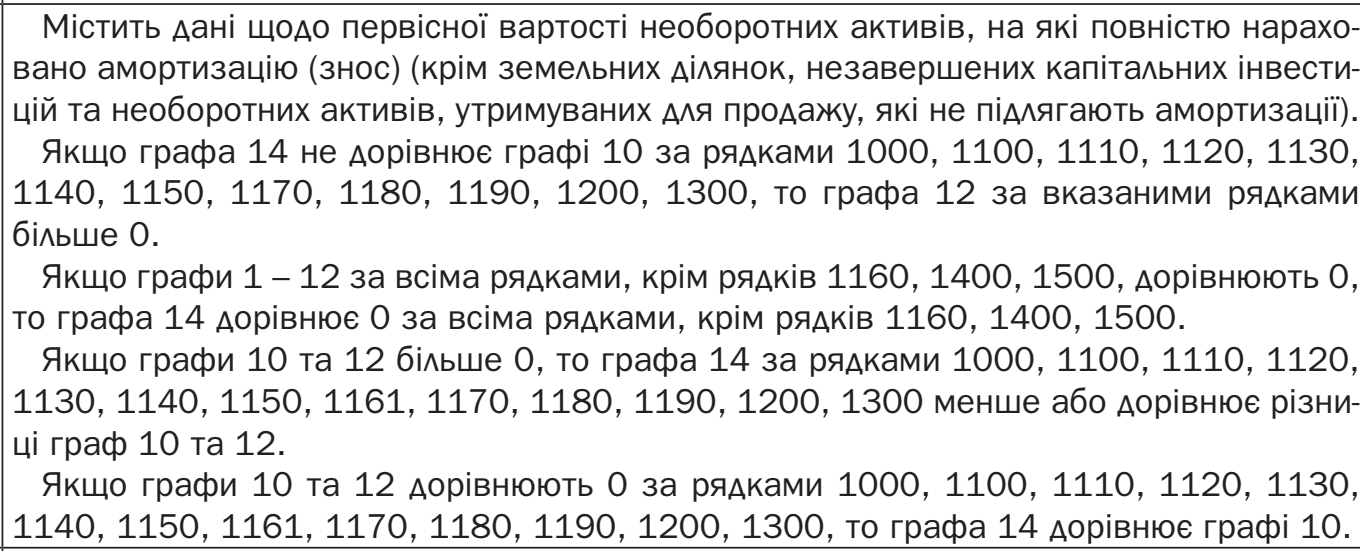 \\
\hline РяАок 1000 & $\begin{array}{l}\text { Включає Аані щодо вартості необоротних активів, які сумарно дорівнюють вартості } \\
\text { необоротних матеріальних та нематеріальних активів, віАображених віАповідно у рял- } \\
\text { ках 1100, 1300. Сума рял.1100, } 1300 \text { гр.1-14. }\end{array}$ \\
\hline РяАок 1100 & Сума рял.1110, 1120, 1130, 1140, 1150, 1160, 1161, 1170, 1180, 1190, 1200 гр.1-14. \\
\hline РяАок 1110 & 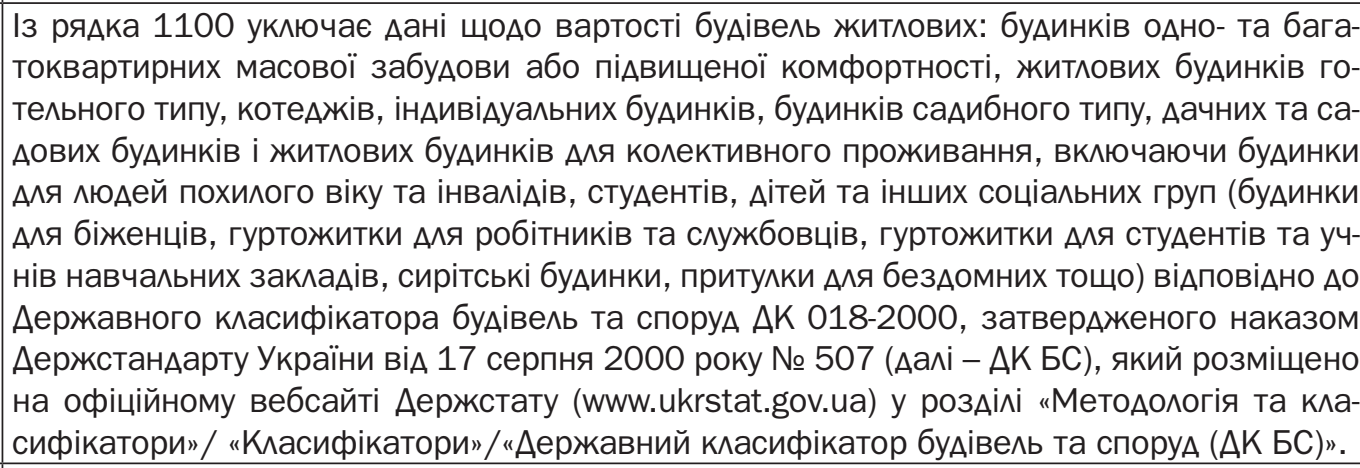 \\
\hline РяАок 1120 & $\begin{array}{l}\text { Із рялка } 1100 \text { уключає лані щодо вартості будівель нежитлових: готелів, ресторанів та } \\
\text { подібних будівель, офрісних та торговельних будівель, будівель транспорту та засобів } \\
\text { зв'язку, промислових будівель та склаАів, будівель Аля публічних виступів, заклаАів } \\
\text { освітнього, медичного та оздоровчого призначення, інших нежитлових будівель віА- } \\
\text { повідно Ао АК БС. }\end{array}$ \\
\hline Рянок 1130 & 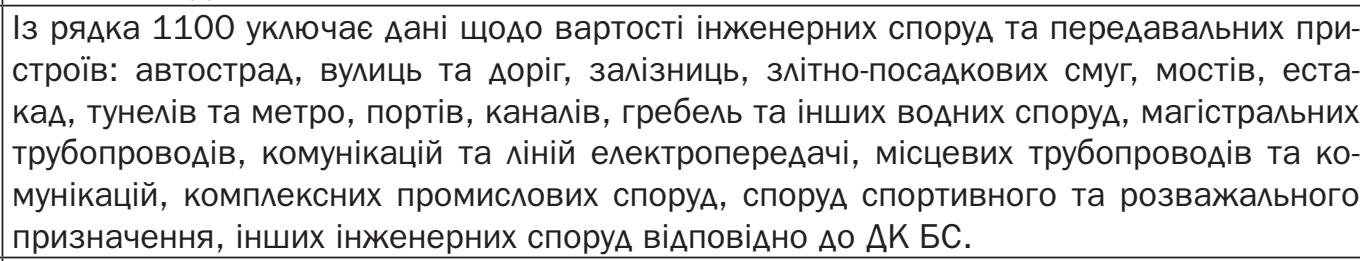 \\
\hline РяАок 1140 & $\begin{array}{l}\text { Із рялка } 1100 \text { уключає Аані щодо вартості технологічного, енергетичного, пілйом- } \\
\text { но-транспортного та іншого обладнання, машин, інструменту, інвентарю, які не пов'я- } \\
\text { зані безпосередньо із функціонуванням будівель (споруд): } \\
\text { - силових машин та обладнання, машин-генераторів, що виробляють теплову та елек- } \\
\text { тричну енергію, і машин-двигунів, що перетворюють різного роду енергію (енергію } \\
\text { води, вітру, теплову, електричну енергію тощо) в механічну; }\end{array}$ \\
\hline
\end{tabular}


Продовження таблиці 11.3

\begin{tabular}{|c|c|}
\hline $\begin{array}{c}\text { КоА графи/ } \\
\text { ряАка }\end{array}$ & Зміст інформації \\
\hline & 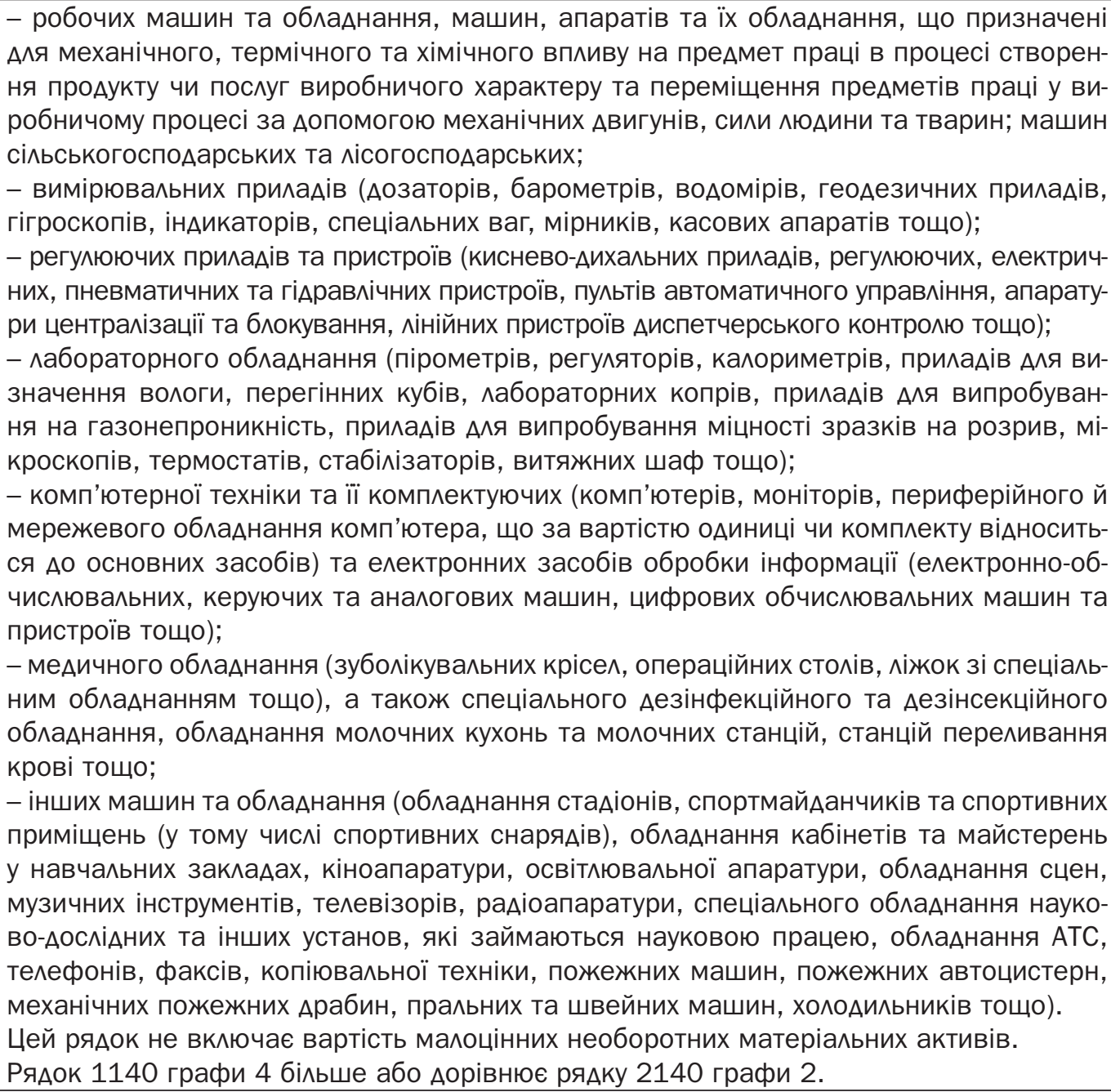 \\
\hline Рянок 1150 & 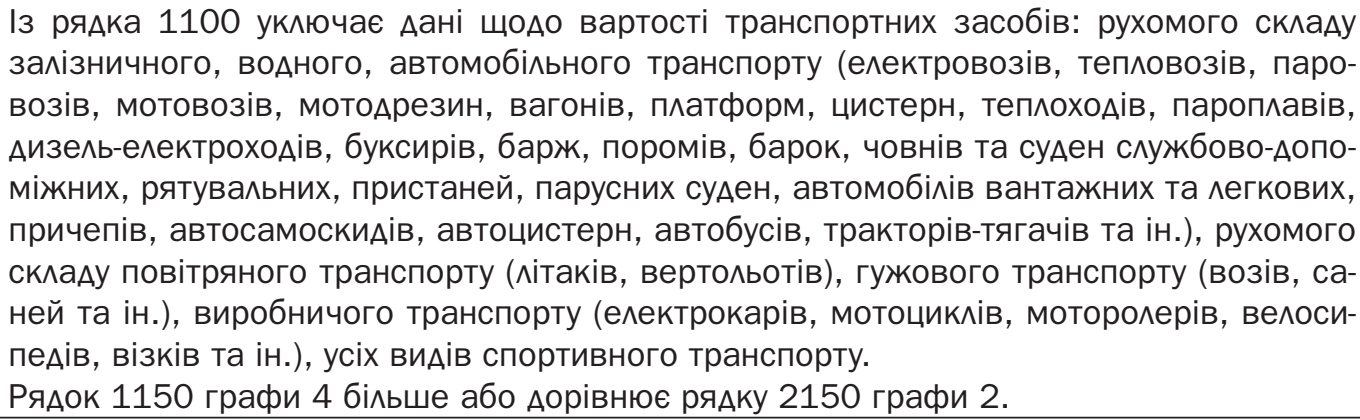 \\
\hline РяАОК 1160 & Із рядка 1100 уключає Аані щодо вартості земельних Аілянок. \\
\hline РяАок 1161 & $\begin{array}{l}\text { Із рядка } 1100 \text { уключає витрати на поліпшення земель (меліоративні, осушувальні, } \\
\text { іригаційні та інші роботи). }\end{array}$ \\
\hline РяАок 1170 & $\begin{array}{l}\text { Із рялка } 1100 \text { уключає дані щодо вартості довгострокових біологічних активів рос- } \\
\text { минництва, які належать до сільськогосподарської діяльності, багаторічних наса- } \\
\text { джень, що не пов'язані із сільськогосподарською Аіяльністю, тощо. } \\
\text { Рядок } 1170 \text { графи } 4 \text { більше або дорівнює рядку } 2170 \text { графи } 2 . \\
\end{array}$ \\
\hline РяАок 1180 & $\begin{array}{l}\text { Із рялка } 1100 \text { уключає Аані щодо вартості Аовгострокових біологічних активів тва- } \\
\text { ринництва. } \\
\text { Рядок } 1180 \text { графи } 4 \text { більше або Аорівнює рядку } 2180 \text { графи } 2 .\end{array}$ \\
\hline
\end{tabular}


Продовження таблиці 11.3

\begin{tabular}{|c|c|}
\hline $\begin{array}{c}\text { КоА графи/ } \\
\text { ряАка }\end{array}$ & Зміст інформації \\
\hline Рянок 1190 & $\begin{array}{l}\text { Із рялка } 1100 \text { уключає дані щодо вартості інших матеріальних активів: бібліотечних } \\
\text { фондів; малоцінних необоротних матеріальних активів; тимчасових (нетитульних) } \\
\text { споруд; інвентарної тари; предметів прокату; тварин, які не пов'язані із сільсько- } \\
\text { господарською діяльністю; витрат орендаря на поліпшення об'єкта операційної } \\
\text { оренди тощо. } \\
\text { Рядок } 1190 \text { графи } 4 \text { більше або дорівнює рядку } 2190 \text { графи } 2 .\end{array}$ \\
\hline РяАОК 1200 & Із рядка 1100 уключає Аані щодо вартості інвестиційної нерухомості. \\
\hline РяАок 1300 & $\begin{array}{l}\text { Із рялка } 1000 \text { ук^ючає дані щодо вартості нематеріальних активів: права користу- } \\
\text { вання природними ресурсами (наАрами, іншими природними ресурсами, геологічною } \\
\text { та іншою інформацією про природні ресурси), включаючи витрати на розробку ко- } \\
\text { рисних копалин; права користування майном (земельною Аілянкою, будівлею); права } \\
\text { на комерційні позначення (права на торговельні марки, комерційні (фірмові) наз- } \\
\text { ви); права на об'єкти промислової власності (права на винаходи, патенти, ліцензії, } \\
\text { концесії, промислові зразки, сорти рослин, породи тварин, ноу-хау тощо); авторське } \\
\text { право та суміжні з ним права (розважальні програми та оригінали літературних і } \\
\text { художніх творів); засоби програмного забезпечення та бази даних за умови викори- } \\
\text { стання їх понад один рік тощо. }\end{array}$ \\
\hline РяАок 1400 & Вк^ючає Аані щодо вартості незавершених капітальних інвестицій. \\
\hline РяАок 1500 & $\begin{array}{l}\text { Включає Аані щодо вартості необоротних активів, що утримуються з метою подаль- } \\
\text { шого продажу (передачі). }\end{array}$ \\
\hline
\end{tabular}

\section{Розаіл 2. Розподі^ капітамьних інвестицій за видами активів}

Розділ 2 уміщує інформацію щодо витрат у звітному році на придбання або створення матеріальних та нематеріальних активів за рахунок передбачених чинним законодавством джерел фінансування, а також витрат на будівництво житла Аля подальшого продажу (передачі), які за обліком витрат не належать до капітальних інвестицій підприємства.

Показники розАілу 2 не включають інформацію щодо податку на Аодану вартість. Сума ПАВ, сплачена в ціні придбання товарів (робіт, послуг), відображається у розАілі 3.

Містить Аані щодо капітальних інвестицій у необоротні активи, Ао яких належать інвестиції у нові та існуючі матеріальні та нематеріальні активи, придбані, у тому числі за договором фінансового лізингу, або створені Аля власного використання зі строком служби більше одного року, включаючи витрати, які пов'язані з поліпшенням об'єкта (модернізація, модифікація, Аобудова, АооблаАнання, реконструкція тощо), що призводять Ао збільшення його строку служби або виробничої потужності, а також містить Аані щодо витрат на буАівництво житла, що будується з метою подальшого продажу (передачі).

Інформація щодо придбаних активів містить Аані щодо їх вартості з урахуванням витрат на транспортування та монтаж, плати за митне оформлення товарів і тран-

графа 1 спортних засобів, податків (крім ПАВ), оплати послуг юристів, оцінювачів, агентів 3 нерухомості. Витрати на придбання активів за Аоговором фінансового мізингу містяться у звіті лізингоодержувача та можуть уважатися складовою обсягів капітальних інвестицій, при цьому до них входить повна ринкова вартість активу, що зазначена в Аоговорі, без урахування частини внесків, що віАповіАає платежам за віАсотками.

Графра 1 не включає дані щодо:

- витрат на придбання матеріальних та нематеріальних активів з метою їх подальшого перепродажу, крім витрат на будівництво житла Аля подальшого продажу (передачі); - вартості отриманих на безоплатній основі матеріальних та нематеріальних активів;

- авансових платежів Аля фінансування будівництва та придбання обладнання; - витрат на технічне обслуговування та поточні ремонти.

Із графи 1 містить Аані щодо обсягів інвестицій на придбання та створення нових активів, у тому числі на нове будівництво, придбання та виготовлення власними силами (господарським способом) нових машин, обладнання, транспортних засобів, придбан-

Графра 2 ня об'єктів незавершеного буАівництва, Аовгострокових біологічних активів, нематеріальних активів. Ця графа вміщує Аані щодо витрат на придбання активів, що були у використанні в інших країнах та вперше використовуються на території України. 
Продовження таблиці 11.3

\begin{tabular}{|c|c|}
\hline $\begin{array}{c}\text { КоА графи/ } \\
\text { ряАка }\end{array}$ & Зміст інформації \\
\hline Графра 3 & $\begin{array}{l}\text { Із графи } 1 \text { містить Аані щодо обсягів інвестицій на придбання активів, що були у } \\
\text { використанні в інших суб'єктів господарювання, за винятком активів, що були у вико- } \\
\text { ристанні в інших країнах і вперше використовуються в Україні. }\end{array}$ \\
\hline Графа 4 & $\begin{array}{l}\text { Із графи } 1 \text { містить Аані щодо витрат на розширення, реконструкцію, модернізацію, } \\
\text { вдосконалення активів та поліпшення земель. }\end{array}$ \\
\hline Графа 5 & $\begin{array}{l}\text { Із графи } 1 \text { містить Аані щодо обсягів інвестицій у капітальний ремонт, тобто витрат, } \\
\text { пов'язаних з поліпшенням об'єкта, що призводить Ао збільшення майбутніх економіч- } \\
\text { них вигод, первинно очікуваних віА використання об'єкта, на суму яких збільшується } \\
\text { первісна вартість основних засобів (будівель, споруд, машин і обладнання, транспорт- } \\
\text { них засобів тощо). } \\
\text { Цей показник не включає витрати на технічне обслуговування та поточні ремонти активів. }\end{array}$ \\
\hline Графра 6 & $\begin{array}{l}\text { Із графи } 1 \text { містить Аані щодо вартості активів, що використовуються на умовах } \\
\text { договору фінансового лізингу, за повною ринковою вартістю активу, що зазначена } \\
\text { в договорі (без частини внесків, що віАповіАає платежам за віАсотками), та які залу- } \\
\text { чені до виробничого процесу у звітному році. }\end{array}$ \\
\hline РяАОК 2000 & 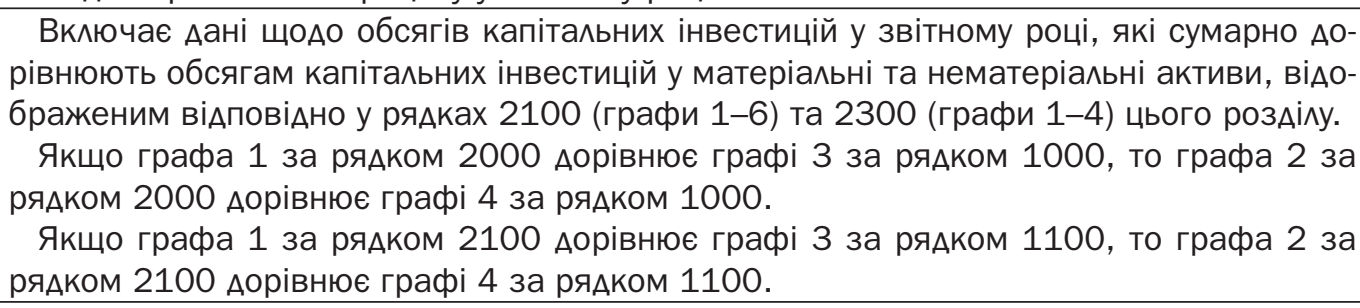 \\
\hline РяАок 2110 & 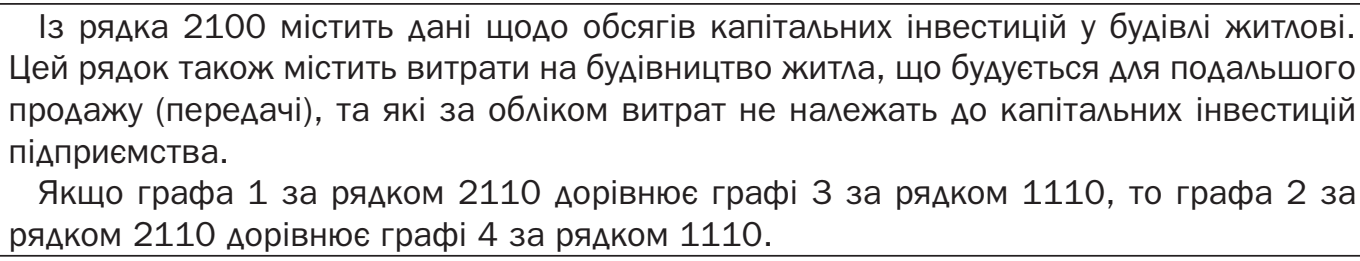 \\
\hline Рянок 2111 & 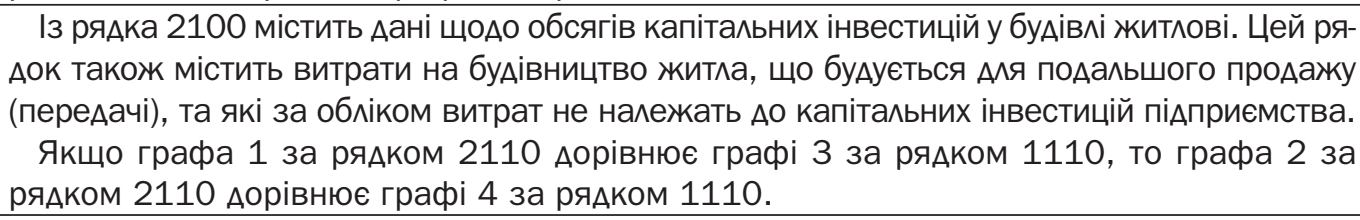 \\
\hline РяАок 2120 & $\begin{array}{l}\text { Із рялка } 2100 \text { містить Аані щоло обсягів капітальних інвестицій у будівлі нежитлові. } \\
\text { Якщо графа } 1 \text { за рялком } 2120 \text { дорівнює графі } 3 \text { за рялком 1120, то графа } 2 \text { за } \\
\text { рядком } 2120 \text { дорівнює графі } 4 \text { за рялком } 1120 .\end{array}$ \\
\hline РяАок 2130 & $\begin{array}{l}\text { Із рядка } 2100 \text { містить дані щодо обсягів капітальних інвестицій в інженерні споруди } \\
\text { та передавальні пристрої. } \\
\text { Якщо графа } 1 \text { за рялком } 2130 \text { дорівнює графі } 3 \text { за рялком 1130, то графа } 2 \text { за } \\
\text { рядком } 2130 \text { дорівнює графі } 4 \text { за рядком } 1130 \text {. }\end{array}$ \\
\hline Рянок 2140 & 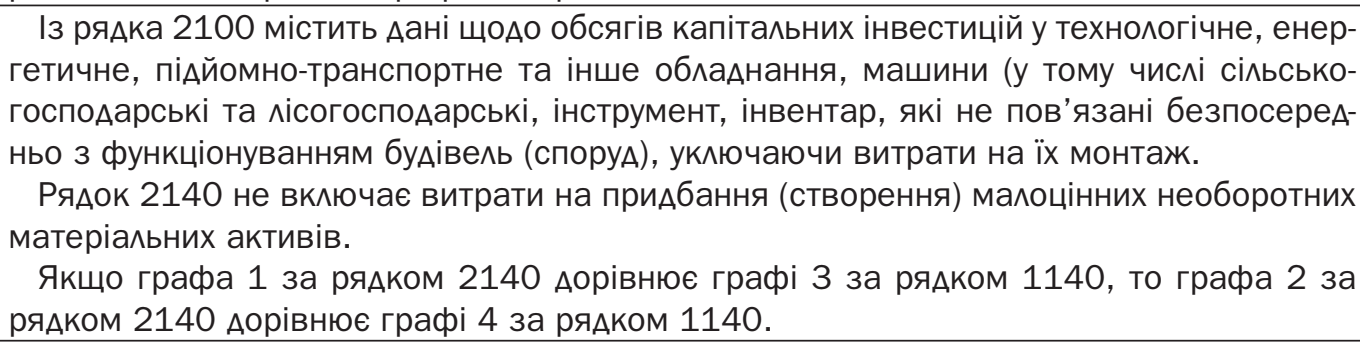 \\
\hline РяАок 2141 & $\begin{array}{l}\text { Із рялка } 2140 \text { містить дані щодо витрат на машини Аля автоматизованого оброблення } \\
\text { даних, лептопи, ноутбуки, комп'ютери, пристрої Аля введення та виведення інформації, } \\
\text { запам'ятовувальні пристрої, апаратуру Аля запису чи віАтворення зображення, апара- } \\
\text { туру Аля передачі та приймання звуку, зображення та іншої інформації, апаратуру Аля } \\
\text { проводової чи безпроводової мережі зв'язку (такої, як ^окальна чи глобальна мережа). }\end{array}$ \\
\hline
\end{tabular}


Продовження таблиці 11.3

\begin{tabular}{|c|c|}
\hline $\begin{array}{c}\text { КоА графи/ } \\
\text { рядка }\end{array}$ & Зміст інформації \\
\hline Рянок 2142 & $\begin{array}{l}\text { Із рялка } 2140 \text { містить дані щодо витрат на інше електричне й електронне устатко- } \\
\text { вання, крім комп'ютерної та телекомунікаційної техніки: електронно-обчислювальні та } \\
\text { електричні машини й апаратуру, інше устатковання Аля радіо, телебачення, медичні } \\
\text { прилади (електродіагностичну апаратуру тощо), точні вимірювальні та оптичні при- } \\
\text { строї тощо. }\end{array}$ \\
\hline РяАок 2143 & Із рядка 2140 містить Аані щодо витрат на меблі та прилаААя. \\
\hline РяАок 2150 & $\begin{array}{l}\text { Із рялка } 2100 \text { містить Аані щодо обсягів інвестицій у транспортні засоби. } \\
\text { Якщо графа } 1 \text { за рялком } 2150 \text { дорівнює графі } 3 \text { за рялком 1150, то графа } 2 \text { за } \\
\text { рядком } 2150 \text { дорівнює графі } 4 \text { за рялком } 1150 .\end{array}$ \\
\hline Рянок 2151 & 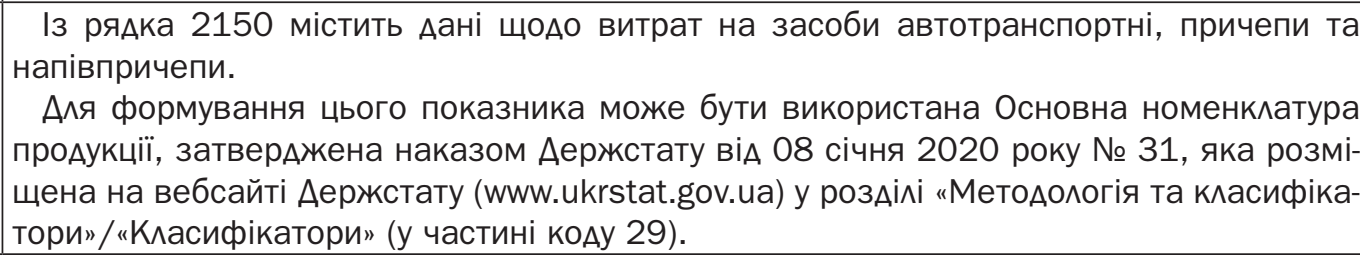 \\
\hline РяАок 2160 & 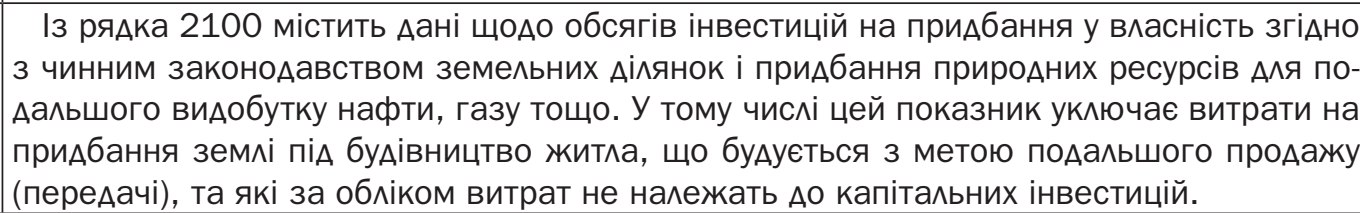 \\
\hline Рянок 2161 & $\begin{array}{l}\text { Із рядка } 2100 \text { уключає дані щодо витрат на меліоративні, осушувальні, іригаційні та } \\
\text { інші роботи, пов'язані з поліпшенням земель. } \\
\text { Якщо графа } 1 \text { за рядком } 2161 \text { дорівнює графі } 3 \text { за рялком 1161, то графа } 2 \text { за } \\
\text { рядком } 2161 \text { дорівнює графі } 4 \text { за рялком } 1161 .\end{array}$ \\
\hline Рянок 2170 & 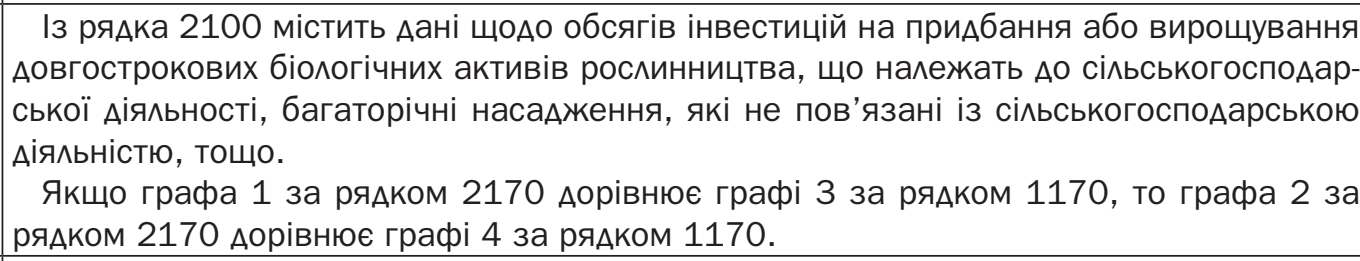 \\
\hline РяАок 2180 & 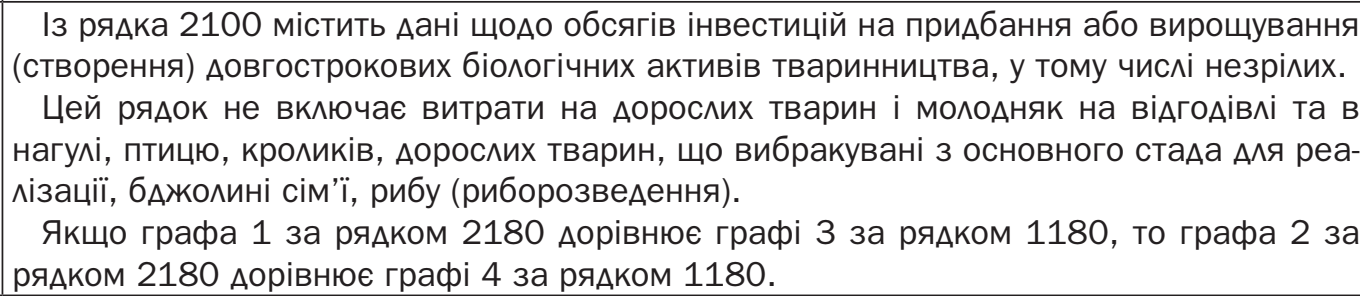 \\
\hline Рянок 2190 & $\begin{array}{l}\text { Із рялка } 2100 \text { містить Аані щоло обсягів інвестицій на придбання або створення } \\
\text { (будівництво) власними силами інших необоротних матеріальних активів: бібліотечних } \\
\text { фондів; малоцінних необоротних матеріальних активів; тимчасових (нетитульних) спо- } \\
\text { руд (крім витрат на зведення таких споруд, які замовник уключає в обсяги інвестицій } \\
\text { у капітальне будівництво та оплачує); інвентарної тари; предметів прокату; тварин, } \\
\text { які не пов'язані із сільськогосподарською Аіяльністю; витрат орендаря на поліпшення } \\
\text { об'єкта операційної оренди тощо. } \\
\text { Якщо графа } 1 \text { за рялком } 2190 \text { дорівнює графі } 3 \text { за рялком 1190, то графа } 2 \text { за } \\
\text { рядком } 2190 \text { дорівнює графі } 4 \text { за рядком } 1190 .\end{array}$ \\
\hline Рянок 2201 & $\begin{array}{l}\text { Із рялків 2110, 2120, } 2130 \text { графи } 2 \text { (у частині витрат на придбання та створення } \\
\text { нових активів) містить дані щодо вартості обладнання, що забезпечує функціонуван- } \\
\text { ня будівель та інженерних споруд, уключаючи витрати на його монтаж: каналізації, } \\
\text { опалення, газопостачання, освітлення, вентиляції та кондиціювання повітря, опа- } \\
\text { лювальних котлів, радіаторів, калориферів, бойлерів та іншого санітарно-технічного } \\
\text { обладнання, підйомників, міфтів тощо. }\end{array}$ \\
\hline
\end{tabular}


Продовження таблиці 11.3

\begin{tabular}{|c|c|}
\hline $\begin{array}{l}\text { КоА графи/ } \\
\text { рянка }\end{array}$ & Зміст інформації \\
\hline Рянок 2300 & 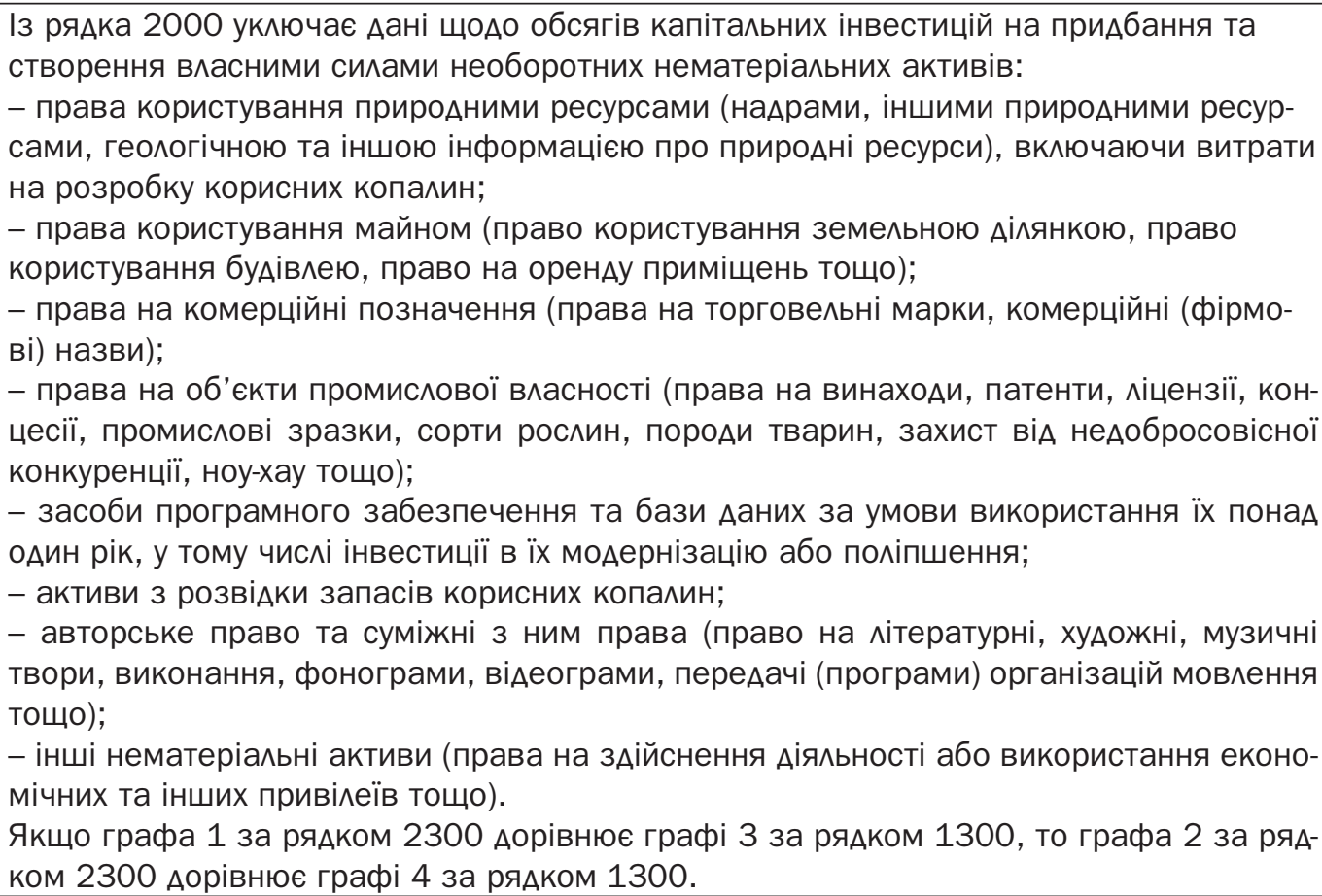 \\
\hline Рянок 2310 & $\begin{array}{l}\text { Із рялка } 2300 \text { містить Аані щодо витрат на придбання прав користування природни- } \\
\text { ми ресурсами (права користування надрами, іншими природними ресурсами, геоло- } \\
\text { гічною та іншою інформацією про природні ресурси) та прав користування майном. }\end{array}$ \\
\hline Рянок 2311 & $\begin{array}{l}\text { Із рядка } 2310 \text { містить Аані щодо витрат на придбання права користування земель- } \\
\text { ною Аілянкою. }\end{array}$ \\
\hline Рянок 2315 & $\begin{array}{l}\text { Із рялка } 2300 \text { містить Аані щодо витрат на придбання та створення власними сила- } \\
\text { ми прав на комерційні позначення, об'єкти промислової власності (патенти, ліцензії, } \\
\text { концесії тощо). }\end{array}$ \\
\hline Рянок 2321 & $\begin{array}{l}\text { Із рялка } 2300 \text { містить дані щодо витрат на придбання або створення власними сила- } \\
\text { ми засобів програмного забезпечення та баз даних за умови використання їх понаА } \\
\text { один рік, у тому числі інвестиції в їх модернізацію або поліпшення. }\end{array}$ \\
\hline Рянок 2322 & 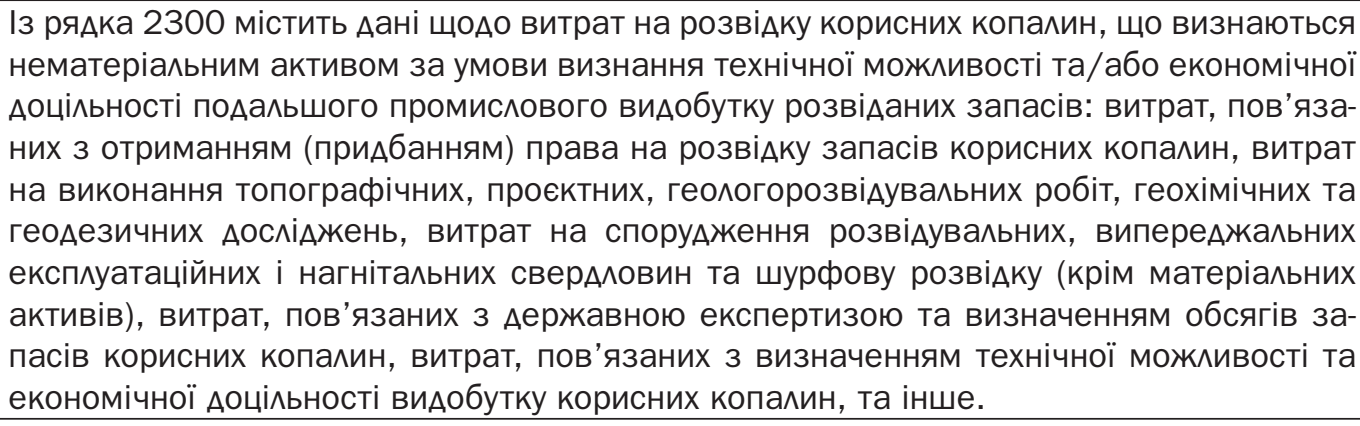 \\
\hline Рянок 2323 & $\begin{array}{l}\text { Із рялка } 2300 \text { містить Аані щодо витрат на придбання або створення власними сила- } \\
\text { ми авторського та суміжних з ним прав (розважальних програм і оригіналів літератур- } \\
\text { них та художніх творів). } \\
\text { Рядок } 2323 \text { не вк^ючає дані щодо витрат на придбання або створення власними си- } \\
\text { лами програмного забезпечення та баз Ааних. }\end{array}$ \\
\hline РяАок 2501 & $\begin{array}{l}\text { Із рялків } 2161 \text { та } 2300 \text { графи } 1 \text { містить дані щодо витрат на оплату послуг юристів, } \\
\text { оцінювачів, агентів з нерухомості, інших витрат, пов'язаних з переходом прав влас- } \\
\text { ності на землю та нематеріальні активи (авторське право, ліцензії, патенти тощо). }\end{array}$ \\
\hline & РозАі^ 3. ПоАатоК на АоАану вартість за окремими виАами активів \\
\hline
\end{tabular}


Продовження таблиці 11.3

\begin{tabular}{|c|c|}
\hline $\begin{array}{c}\text { КоА графи/ } \\
\text { рядка }\end{array}$ & Зміст інформації \\
\hline Графа 1 & $\begin{array}{l}\text { Включає інформацію щодо суми ПАВ, сплаченої (у ціні придбання товарів, робіт, } \\
\text { послуг) у зв'язку з витратами на капітальні інвестиції. Цей показник не залежить віА } \\
\text { того, чи є підприємство віАповіАно Ао чинного законодавства платником ПАВ чи ні. }\end{array}$ \\
\hline Графа 2 & Із графи 1 містить Аані щоАо суми поАаткового креАиту з ПАВ. \\
\hline РяАок 5000 & $\begin{array}{l}\text { Містить дані щоло загальної суми ПАВ, сплаченої у зв'язку з витратами на капітальні } \\
\text { інвестиції. Рядки 5110-5150, } 5321 \text { із рядка } 5000 \text { містять Аані щодо розподілу ПАВ } \\
\text { за окремими видами активів. }\end{array}$ \\
\hline
\end{tabular}

Ажерело: [52].

\section{КОНТРОАЬНІ ПИТАННЯ:}

1. Аайте визначення статистичної звітності.

2. Хто зобов'язаний подавати статистичну звітність?

3. Охарактеризуйте види статистичної звітності за обсягом показників.

4. Охарактеризуйте види статистичної звітності за змістом звітних Ааних.

5. Охарактеризуйте види статистичної звітності за терміном подання.

6. Охарактеризуйте види статистичної звітності за ступенем узагальнення Ааних.

7. Опишіть значення та структуру загального табелю (переліку) форм державних статистичних спостережень.

8. Якими Аокументами сліА керуватися при заповненні статистичної звітності за формою № 1-ПВ (місячна)?

9. 3 яких розділів склаАається форма № 1-ПВ (місячна)?

10. Хто складає і подає форму № 1-ПВ (місячна) та в які терміни?

11. Яким чином сліА перевірити правильність Ааних у формі № 1-ПВ (місячна)?

12. Якими Аокументами сліА керуватися при заповненні статистичної звітності за формою № 1-ПВ (квартальна)?

13. 3 яких розАілів складається форма № 1-ПВ (квартальна)?

14. Хто складає і подає форму № 1-ПВ (квартальна) та в які терміни?

15. Яким чином сліА перевірити правильність Ааних у формі № 1-ПВ (квартальна)?

16. Якими Аокументами сліА керуватися при заповненні статистичної звітності за формою № 2-03 IHB (річна)?

17. 3 яких розділів складається форма № 2-О3 ІНВ (річна)?

18. Хто склалає і подає форму № 2-О3 IHB (річна) та в які терміни? 


\section{ТЕСТИ АМЯ САМОСТІЙНОї РОБОТИ СТУАЕНТІВ}

1. За яким принципом бухгалтерського обліку піАприємство скмаАає фінансову звітність?
а) періодичності;
б) автономності;
в посліАОвності;
г) усі наведені вище.

2. Зобов'язання - це:

а) звіт про Аоходи та витрати;

б) заборгованість Ааного підприємства переА третьою особою;

в) сума заборгованості дебіторів піАприємству на певну дату;

г) правовідносини, в якому одна сторона зобов'язана чинити на користь Аругої сторони певну Аію або утримуватись віА певної Аії, а кредитор має право вимагати віА боржника виконання його обов'язку.

3. Активи піАприємства преАставАяють собою:

a) ресурси;

б) чисту вартість капіталу;

в) економічну вигоду;

г) грошові кошти.

4. Ао якісних характеристик фінансової звітності належать:

a) АохіАливість;

б) Аоречність;

в) Аостовірність;

г) всі наведені вище.

5. Суттєвість інформації визначається Законами України:

а) «Про аудиторську Аіяльність";

б) "Про господарські товариства";

в) «Про бухгалтерський облік та фінансову звітність в Україні";

г) віАповіАними НП(С)БО і наказом про облікову політику піАприємства.

6. Ао ск^аАу фінансової звітності вхоАить:

a) звіт про власний капітал;

б) розрахунок податку на Аоходи фізичних осіб;

в) звіт про дебіторів та кредиторів;

г) звіт про товарну продукцію.

7. Розкриття інформації про поАї̈, що сталися після Аати балансу, віАповіАає принципу бухгалтерського обліку:
а) нарахування та віАповіАності доходів та витрат;
б) посліАОвності;
в) повного висвітлення;
г) обачності. 
8. Елементами фрінансової звітності є:

а) звіт про рух грошових коштів;

б) розАіл;

в) стаття;

г) податкова декларація з податку на додану вартість.

9. Звітним періодом А^я ск^аАання фінансової звітності є:

а) місяць;

б) квартал;

в) півріччя;

г) календарний рік.

10. ВіАображення в балансі Аебіторської заборгованості за вирахуванням резерву сумнівних боргів є Аотримання принципу бухгалтерського обліку:
а) періодичності;
б) обачності;
в) історичної (фактичної) собівартості;
г) автономності.

11. Резерв сумнівних боргів на покриття простроченої Аебіторської заборгованості нараховується:
а) на початок звітного періоду;
б) на кінець звітного періоду;
в) у міру необхіАності (при появі сумнівної дебіторської заборгованості);
г) за вимогами креАиторів.

12. ВіАображення в балансі запасів за нижчою з оцінок віАповіАає принципу бухгалтерського обліку:
а) зрозумілості;
б) обачності;
в) єАиного грошового вимірника;
г) превалювання сутності наА формою.

13. Елементом балансу (звіту про фінансовий стан) є:
а) капітал власників;
б) операційні доходи;
в) інвестиційна Аіяльність;
г) виручка віА реалізації.

14. У балансі (звіті про фінансовий стан) віАображується інформація про:
а) стан господарських засобів;
б) зміни у статтях балансу;
в) рух господарських засобів;
г) Аоходи та витрати піАприємства.

15. За яким принципом підготовки фінансової звітності оцінка в балансі (звіті про фінансовий стан) переважно віАображується вихоАячи їх витрат на їх приАбання (виготовмення):
а) обачності;
б) превалювання сутності наА формою;
в) історичної (фактичної) собівартості;
г) нарахування та віАповіАності доходів і витрат. 
16. Правияо нижчої оцінки на Аату балансу (звіту про фінансовий стан) може застосуватись Ао:

а) окремих найменувань запасів;

б) загальних запасів;

в) окремих найменувань запасів та/або однорідної групи запасів;

г) всі перелічені вище.

17. У бамансі (звіті про фінансовий стан) піАприємства на 31.12. минулого року за статтею "Інший АоАатковий капіта^" ВіАображено Аооцінку нематеріа^ьних активів у сумі 10000 грн. На 31.12. поточного року віАбулась їх уцінка на 11000 грн, віАтак розмір власного капіталу на 31.12. поточного року:
а) зменшиться на 11000 грн;
б) зменшиться на 10000 грн;
в) зменшиться на 1000 грн;
г) ніяк не зміниться.

18. За якою оцінкою віАображуються в бамансі (звіті про фінансовий стан) активи i пасиви за якими нараховуються віАсотки (проценти)?
а) історичною собівартістю;
б) залишковою вартістю;
в) майбутньою вартістю;
г) теперішньою вартістю.

19. Чи може бути визначений активом Аепозитний сертифікат, приАбаний у банку чотири років тому, якщо на Аату балансу, 31 груАня поточного року, банк збанкрутував? Сертифікат приАбано за 250000 грн. За періоА волоАіння піАприємство отримало 149000 грн віАсотків.
a) так;
б) ні.

20. Сума податку на прибуток визначається на піАставі Ааних:

а) податкової декларації про податок прибуток піАприємств;

б) балансу (звіту про фрінансовий стан);

в) звіту про фрінансові результати (звіту про сукупний АохіА);

г) Головній книзі.

21. АохіА (виручка) віА реалізації продукції (товарів, робіт, послуг) визначається на основі бухгалтерських записів:

а) Аебет рах. 36 (37) Кредит рах. 70;

б) Аебет рах. 70 КреАит рах. 79 ;

в) Аебет рах. 30, 31 Кредит рах. 36.

г) Аебет рах. 40 Кредит рах. 79.

22. На піАставі нижче привеАених Ааних необхіАно визначити суму валового прибутку (збитку). АохіА віА реалізації готової проАукції склав 900000 грн, у т.ч. ПАВ - 150000 грн. Собівартість їі реалізації - 550000 грн:
а) прибуток - 250тис. грн;
б) прибуток - 200тис. грн;
в) збиток - 250 тис. грн;
г) ваш варіант. 
23. На піАставі нижче привеАених Ааних необхіАно: по-перше, класифікувати АохоАи піАприємства за виАами Аіямьності; по-Аруге, визначити величину іншого операційного AOXOAY:

а) дохін віА реалізації робіт - 150 тис. грн;

б) дохіА віА реалізації необоротних матеріальних активів - 5 тис. грн;

в) дохіА віА реалізації малоцінних та швиАкозношуваних преАметів - 3 тис грн;

г) АохіА віА неопераційної курсової різниці - 0,5 тис. грн; А) дохіА віА реалізації фінансових інвестицій - 20 тис. грн;

ж) АохіА у вигляАі отриманих економічних санкцій віА порушення Аоговірних умов - 3 тис. грн.

24. А^я скмаАання звіту про фінансові результати (звіту про сукупний АохіА) необхіАно визначити результат віА реалізації товарів, вихоАячи 3 того, що за звітний періоА було реалізовано їх на суму 240000 грн, у т.ч. ПАВ - 40000 грн. ПіА час їх приАбання було сплачено 150000 грн, у т.ч. ПАВ - 25000 грн. Також було сплачено вартість їх перевезення (без ПАВ) - 1000 грн:

а) прибуток - 75 тис. грн;

б) прибуток - 74 тис. грн;

в) прибуток - 84 тис. грн;

г) збиток - 85 тис. грн.

25. Першого Аипня поточного року піАприємством сплачено вартість періодичних виАань у сумі 18000 грн, на 4-й квартал поточного року та за перше півріччя наступного року. Витрати за 3-й квартал поточного періоду буАуть віАображені у звіті про фінансові результати (звіті про сукупний АохіА) в сумі:
а) 18000 грн;
б) 13500 грн;
в) 4500 грн;
г) не будуть віАображатися у цьому звіті.

26. За якою статтею звіту про фінансові результати (звіту про сукупний АохіА) буде віАображена нарахована протягом року сума витрат на основну заробітну пмату управАінського персонаму:
а) аАміністративні витрати;
б) інші операційні витрати;
в) витрати на оплату праці;
г) фінансові витрати.

27. ПіА час інвентаризації були виявлені наАлишки основних засобів, Ажерела похоАження яких невіАомо. Ао якої статті звіту про фінансові результати (звіту про сукупний АохіА) буАе віАнесена сума наАлишку після їх оприбуткування:

а) інші АохоАи віА інвестиційної Аіяльності;

б) інші операційні доходи;

в) Аоход віА участі в капіталі;

г) інші фрінансові доходи.

28. За якою статтею звіту про фінансові результати (звіту про сукупний АохіА) буАуть віАображені нараховані, протягом звітного періоАу, проценти за користування короткостроковою банківською позикою, якщо термін їх сплати не перевищує 12 місяців 3 Аати балансу:

а) інші операційні витрати;

б) фінансові витрати:

в) інші фінансові витрати;

г) інші витрати віА звичайної Аіяльності. 
29. ПіАПриємство отримало АивіАенАи по акціям, які воно обліковує як звичайні Аовгострокові фінансові інвестиції (за фактичною собівартістю). По якій статті звіту про фінансові результати (звіту про сукупний АохіА) буАуть віАображені ці АивіАенАи:
а) дохіА віА участі в капіталі;
б) інші АОхоАи;
в) інші фрінансові Аоходи;
г) інші операційні доходи.

30. Прибуток піАприємства віА Звичайної Аіяльності Ао опоАаткування Аорівнює 3 млн грн, знос необоротних активів - 0,6 ммн грн, зменшення забезпечень - 0,07 ммн грн, збиток віА нереалізованих курсових різниць - 0,001 млн грн, прибуток віА інвестиційної Аіямьності - 0,13 мАн грн. Визначити прибуток (збиток) віА операційної Аіямьності Ао зміни в чистих оборотних активах:
а) 3410 тис. грн;
б) 3810 тис. грн;
в) 1198 тис. грн;
г) 2345 тис. грн.

31. Ао грошових потоків віА інвестиційної Аіяльності вкмючаються:
а) грошові надходження віА реалізації готової продукції;
б) отримання банківської позики;
в) сплата коштів за придбанні цінні папери;
г) немає правильної віАповіАі.

32. НаАхоАження коштів віА покупців за реалізовану проАукцію (товари, роботи і послуги) віАображуеться в скмаАі:
а) інвестиційної Аіяльності;
б) операційної Аіяльності;
в) фінансової Аіяльності;
г) Ваш варіант.

33. Виручка (АохіА) віА реалізації програмного забезпечення віАображається у склаАі:
а) фінансової Аіяльності;
б) операційної Аіяльності;
в) інвестиційної Аіяльності;
г) не відображується в звіті про рух грошових коштів.

34. ПриАбання піАприємством акцій, у пов'язаних осіб, з опматою грошима буАе віАображена у звіті про рух грошових коштів у склаАі:
а) іншої операційної Аіяльності;
б) фрінансової Аіяльності;
в) операційної Аіяльності;
г) інвестиційної Аіямьності.

35. ЗГіАно з непрямим метоАом, чистий рух грошових коштів віА операційної Аіяльності визначається шляхом коригування:
а) залишків на статтях звіту про фрінансові результати (звіту про сукупний дохіА);
б) залишків на статтях балансу (звіту про фінансовий стан);
в) фінансового результату віА звичайної Аіяльності після оподаткування;
г) фінансового результату віА звичайної Аіяльності до оподаткування. 
36. ПіАприємство приАбало необоротні матеріальні активи в обмін на виробничі запаси, справеАлива вартість яких на Аату балансу (звіту про фінансовий стан) Аорівнювала 5000 грн. АоАатково сплачено 15000 грн. У звіті про рух грошових коштів буАе віАображена сума за статтями:

а) наАходження грошових коштів віА інвестиційної Аіямьності - 5000 грн;

б) витрати грошових коштів віА операційної Аіяльності - 15000 грн;

в) витрати грошових коштів віА фінансової Аіяльності - 20000 грн;

г) витрати грошових коштів на інвестиційну Аіяльність - 15000 грн.

37. Нарахована сума амортизаційних віАрахувань віАображається у звіті про рух грошових коштів у скмаАі:
а) операційної Аіяльності;
б) інвестиційної Аіямьності;
в) фінансової Аіяльності;
г) не показується у ньому.

38. Отримані піАприємством віАсотки віА фінансового Аізингу буАуть віАображені у скмаAi:
а) іншої операційної Аіямьності;
б) фінансової Аіяльності;
в) інвестиційної Аіямьності;
г) операційної Аіяльності.

39. Зменшення залишку виробничих запасів віАображується в скмаАі:
а) фінансової Аіяльності;
б) операційної Аіяльності;
в) інвестиційної Аіямьності;
г) не показується у звіті про рух грошових коштів.

40. У звіті про власний капітал за статтями розАілу "Внески учасників" навоАяться інформація про:
а) дооцінку активів;
б) зміни неоплаченого капіталу;
в) залишок власного капіталу на початок року;
г) анулювання вилучених із обігу акцій.

41. За статтею "Інший АоАатковий капіта^" на початок року віАображено залишок Аооцінки нематеріальних активів на суму 12000 грн. Протягом року їх балансова вартість знизилась на 8000 грн, крім того було зараховано на балансі піАприємство безкоштовно отримані основні засоби за справеАливою вартістю - 3000 грн. Визначити, якою буАе сума показана по цій статті на кінець року:
а) зменшення на 8000 грн;
б) зменшення на 5000 грн;
в) збільшення на 3000 грн;
г) ніяк не вплине на цю статтю.

42. ПіАприємство "Фантом" має на своєму балансі Аовгострокові фінансові інвестиції у піАприємство "Унікум", які обліковуються метоАом участі в капіталі. За піАсумками поточного звітного року піАприємство "Унікум" отримало чистий прибуток - 40000 грн. Яким чином ці Аані буАуть віАображені піАприємством "Фантом" у звіті про власний капітал, якщо його частка в капіталі піАприемства "Унікум" ск^аАає $40 \%$ ?

а) за статтею "Резервний капітал" - 16000 грн; 
б) за статтею "Аодатково вкладений капітал" - 16000 грн;

в) за статтею "Інший Аодатковий капітал" - 16000 грн;

г) за статтею «Нерозподімений прибуток» - 16000 грн.

43. Розмір власного капіталу, віАображеного у балансі (звіті про фінансовий стан) та звіті про власний капітал, показує:

а) облікову вартість прав власників (учасників) підприємства;

б) облікову вартість активів пілприємства, які належать йому за правом власності;

в) ринкову вартість прав власників (учасників) піАприємства;

г) ринкову вартість активів піАприємства, які належать йому за правом власності.

44. Показник статті "Вимучений капіта^" звіту про власний капіта^:

а) збільшує загальну суму власного капіталу;

б) зменшує загальну суму власного капіталу;

в) ніяк не впливає на величину власного капіталу;

г) пов'язана із змінами нерозподіленого прибутку (непокритого збитку)

45. А^я забезпечення порівня^ьного аналізу інформації, у звіті про власний капітал необхіАно АоАавати Аані за:

а) поточні чотири квартали;

б) за попередній календарний рік;

в) за два попередніх роки;

г) ваш варіант.

46. Сума статті "Зареєстрований капіта^" повинна Аорівнювати:

а) сумарній вартості коштів, сплачених власниками (учасниками) товариства;

б) сумарній вартості активів піАприємства;

в) сумарній вартості коштів, які належать до сплати власниками (учасниками) за придбані ними акцій товариства;

г) сумарній номінальній вартості випущених акцій товариства.

47. Показник статті "Неопмачений капітая":

а) зменшує загальну суму власного капіталу;

б) збільшує загальну суму власного капіталу;

в) не впливає на величину власного капіталу;

г) пов'язана із сумою додаткового капіталу.

48. За насліАком проведеної річної інвентаризації активів було виявлено наА^ишок Авох верстатів за залишковою вартістю 5000 грн. У звіті про власний капітал результат ця операція буАе віАображено як:

а) збільшення іншого Аодаткового капіталу - 5000 грн;

б) нерозподілений прибуток - 5000 грн;

в) збільшення Аодатково вкладеного капіталу - 5000 грн;

г) збімьшення пайового капіталу - 5000 грн.

49. Вартість нематеріальних активіВ, щоАо яких існує обмеження прав власності віАображується в розАілі форми № 5:
a) 10 ;
б) 2 ;
в) 1 ;
г) 7 . 
50. Переоцінена вартість повністю амортизованих основних засобів віАображується в:

a) формі № 1;

б) формі № 2;

в) формі № 5;

г) формі № 6.

51. Інформація про отримані в оперативну оренАу основні засоби, А^я склаАання форми № 5, береться:
а) з Ааних аналітичного бухгалтерського обліку;
б) з Ааних поточного синтетичного бухгалтерського обліку;
в) з Ааних позабалансового обліку;
г) із записів у Головній книзі.

52. Аеталізована інформація про рух інвестиційної нерухомості та її оцінки навоАиться:
а) у балансі (звіті про фінансовий стан);
б) у звіті про власний капітал;
в) у примітках до фрінансової звітності;
г) у звіті про власний капітал

53. Вирощування піАприємством Аовгострокових біологічних активів переАбачає зАійснення:
а) капітальних інвестицій;
б) поточних інвестицій;
в) фінансових інвестицій;
г) ваш варіант.

54. Аоходи і витрати віА участі в капіталі за інвестиціями в асоційовані піАприємства знахоАять віАображення в розАіАі:
а) «Фінансові інвестиції»;
б) "Аоходи і витрати";
в) "Нематеріальні активи»;
г) «Капітальні інвестиції».

55. Облікова інформація про грошові кошти в Аорозі береться з Ааних рахунків:
а) 30 «Готівка»;
б) 31 «Рахунки в банках";
в) 33 "ншші кошти";
г) 35 «Поточні фінансові інвестиції».

56. Інформація про вартість товарообмінних (бартерних) операцій навоАиться в розАіАі:
а) "Грошові кошти";
б) "Аоходи і витрати";
в) "Аебіторська заборгованість";
г) «Забезпечення".

57. Інформація про облікову політику піАприємства віАображається у:

а) розділі IX "Аебіторська заборгованість";

б) розАілі X «Нестачі і втрати віА псування цінностей»;

в) у текстовій частині форми № 5;

г) Ваш варіант. 
58. Форма № 6 "Інформація за сегментами" є:

а) самостійною формою звітності;

б) АоАатком Ао форми № 5 «Примітки Ао фрінансової звітності".

в) Аодатком Ао форми № 1 "Баланс (Звіт про фінансовий стан)".

г) Аодатком Ао форми № 2 "Звіт про фінансові результати (Звіт про сукупний АохіА)".

\section{9. Звітний сегмент - це:}

а) виокремлена частина виробничої або/чи збутової Аіяльності піАприємства конкретного виАу продукції;

б) господарський сегмент, визначений піАприємством за віАповіАними критеріями, віАносно якого повинно розкриватися інформація в річної фінансової звітності;

в) відокремлена частина Аіяльності піАприємства з виробництва та/або продажу окремого виду (або групи) продукції яка має віАмінності віА інших

г) немає правильної віАповіАі.

60. Пріоритетним вважається сегмент, фінансовий результат якого не менше:
a) $15 \%$ загального прибутку/збитку;
б) $25 \%$ загального прибутку/збитку;
в) $10 \%$ загального прибутку/збитку;
г) 30\% загального прибутку/збитку.

61. Формування звітних сегментів зАійснюється на піАставі:
а) виділених господарських сегментів;
б) виділених географічних сегментів;
в) шляхом об'єАнання Аекількох поАібних сегментів;
г) усіх наведених варіантів.

\section{2. Обліковою політикою піАприемства визначаються:}
а) виАи сегментів;
б) пріоритетний виА сегменту;
в) принципи ціноутворення при зАійсненні внутрішньогосподарських розрахунків;
г) всі наведені варіанти.

63. Форма № 6 "Інформація за сегментами", за своєю структурою скмаАається 3:
а) Авох розАілів;
б) трьох розаілів;
в) чотирьох розаілів;
г) п'яти розАіл

64. Материнське (холАингове) піАприємство - піАприємство, яке:

а) зАійснює контроль піАприємств, що вХоАять Ао об'єАнання;

б) зАійснює контроль Аочірніх піАприємств;

в) зАійснює контроль асоційованих підприємств;

г) усі наведені варіанти.

65. Гуавіл - це:

а) перевищення справеАливої вартості придбаного піАприємства наА його ринкової вартості;

б) перевищення вартості придбаного піАприємства наА його справеАливою вартістю;

в) Аілова репутація пілприємства;

г) різниця між сумою чистих активів та власним капіталом піАприємства 
66. Неконтрольована частка участі, це частина чистого прибутку (збитку), сукупного Аоходу та чистих активів Аочірнього піАприємства, яка не належить:

а) Аочірньому піАприємству;

б) материнському (холАинговому) піАприємству (прямо або через інші дочірні підприємства);

в) спільному піАприємству;

г) материнському підприємству прямо.

67. ІАентифіковані активи та зобов'язання, це приАбані активи та зобов'язання, яка на Аату приАбання віАповіАають критеріям визнання статей балансу, встановлених національними стандартами обліку:

a) 1 "Загальні вимоги Ао фінансової звітності»;

б) 19 “Об'єАнання піАприємств";

в) 2 "КонсоліАована фінансова звітність";

г) 29 "Фінансова звітність за сегментами".

68. Не віАноситься Ао об'єктів визначення справеА^ивої вартості:
а) готова продукція і товари;
б) Аовгострокові зобов'язання;
в) грошові кошти і їх еквіваленти;
г) податкові активи та зобов'язання.

69. Інші основні засоби приАбаного піАприємства оцінюються за:
а) справеАливою вартістю;
б) ринковою вартістю;
в) віАновлюваною вартістю;
г) експертною вартістю.

70. Аокументація контролюючих органів, як різновиА поАаткової звітності вкАючає в ceбе:
а) накази;
б) податкові повідомлення-рішення;
в) акти;
г) розпоряАження.

71. При річному звітному (поАатковому) періоАі поАаткова Аекларація (окрім Аекларації про майновий стан і АохоАи фізичних осіб) Ао контролюючого органу поАається протягом:

a) 40 календарних Анів, що настають за останнім Анем календарного року;

б) 20 календарних Анів, що настають за останнім Анем календарного року;

в) 30 календарних Анів, що настають за останнім днем календарного року;

г) 60 каленАарних Анів, що настають за останнім Анем календарного року.

72. Контролюючий орган зобов'язаний поінформувати платника поАатку про невизнання ним податкової звітності, у разі, якщо пматник поАатків звітувався через засоби електронного зв'язку протягом:

а) 5 робочих Анів з Аня отримання податкової декларації;

б) 3 робочих Анів з Аня отримання податкової декларації;

в) 10 робочих Анів з Аня отримання податкової декларації;

г) 15 робочих Анів з Аня отримання податкової Аекларації. 
73. ВіАправити звітність поштою платники поАатків мають право:

а) не пізніше ніж за Авадцять Анів Ао закінчення граничного строку подання податкової Аекларації;

б) не пізніше ніж за п'ятнадцять Анів до закінчення граничного строку подання податкової декларації;

в) не пізніше ніж за сім Анів до закінчення граничного строку подання податкової декларації;

г) не пізніше ніж за Аесять Анів до закінчення граничного строку подання податкової Аекларації.

74. Податкова Аекларація з типом "звітна нова" поАається платником поАатків у разі:

а) подачі податкової декларації після закінчення періоду Аля звітування;

б) виправлення помилок, Ао закінчення періоду Аля звітування;

в) виправлення помилок після закінчення періоду Аля звітування;

г) подачі податкової декларації в останній день Аля звітування.

75. 3\%-й штраф віА неАоплати поАаткового зобов'язання платник поАатків сплачує у разі:

а) виправлення помилки через податкову декларацію наступних податкових періодів;

б) подачі «нової звітної» податкової декларації;

в) виправлення помилки через уточнюючий розрахунок;

г) знаходження помилок контролюючими органами піА час податкових перевірок.

76. За несвоєчасну подачу пматником поАатків поАаткової Аекмарації Ао контролюючого органу, У разі, якщо такий випаАок стався вАруге протягом звітного року, розмір штрафної санкції складе:
a) 170 грн;
б) 340 грн;
в) 510 грн;
г) 1020 грн.

77. Пматником ПАВ є:

а) будь-яка особа, що провадить господарську Аіяльність;

б) особа, що веде облік результатів Аіяльності за Аоговором про спільну Аіяльність з утворенням юриАичної особи;

в) будь-яка особа, що ввозить товари на митну територію України;

г) є управителем майна за договорами управління майном.

\section{8. Які ставки ПАВ Аіють в Україні?}
a) $0 \%$;
б) $7 \%$;
B) $20 \%$;
г) всі віАповіді правильні.

\section{0б'єктом оподаткування ПАВ є :}

а) операції з реалізації товарів, робіт, послуг, місце постачання яких розташоване на митній території України;

б) дохіА віА операцій з реалізації товарів, робіт, послуг;

в) звичайна вартість придбаних товарів, робіт, послуг;

г) операції з реалізації товарів, робіт, послуг, проведені як на території України так і за їі межами. 
80. Аатою виникнення поАаткових зобов'язань по ПАВ з постачання товарів є:

а) Аата зарахування коштів на рахунок платника;

б) Аата оприбуткування готівки в касу платника;

в) Аата віАвантаження продукції;

г) будь-яка з подій, що сталася раніше: дата зарахування коштів на рахунок платника або Аата віАвантаження продукції.

81. Аатою виникнення права на поАатковий креАит з ПАВ є:

а) Аата списання коштів з рахунку платника;

б) дата піАписання акту про виконання робіт, надання послуг;

в) Аата оприбуткування товарно-матеріальних цінностей;

г) Аата митного оформлення перетину товару через митний контроль.

\section{2. ПАВ рахунок призначення А^я:}

а) Аля контролю суми ПАВ, на яку платник податків може зареєструвати податкову наклаАну або розрахунок коригування в ЄАиному реєстрі податкових наклаАних;

б) Аля контролю суми ПАВ, на яку платник може отримати поАаткову наклаАну віА контрагента;

в) сплати задекларованих податкових зобов'язань до бюджету;

г) сплати задекларованих податкових та грошових зобов'язань до бюАжету

\section{3. Хто є платниками поАатку на прибуток піАприємства?}

а) неприбуткові організації;

б) бюАжетні установи;

в) Аачні кооперативи;

г) піАприємства.

84. Термін поАання А^я річної поАаткової Аекмарації з поАатку на прибуток піАприємства:

а) протягом 10 Анів, що настають за останнім календарним Анем звітного (податкового) кварталу (півріччя);

б) протягом 20 Анів, що настають за останнім календарним днем звітного (податкового) кварталу (півріччя);

в) протягом 40 Анів, що настають за останнім календарним днем звітного (податкового) кварталу (півріччя);

г) протягом 60 днів, що настають за останнім календарним днем звітного (податкового) року.

85. Термін поАання А^я квартальної поАаткової Аек^арації з поАатку на прибуток піАприємства:

а) протягом 10 Анів, що настають за останнім календарним днем звітного (податкового) кварталу (півріччя);

б) протягом 20 Анів, що настають за останнім календарним Анем звітного (податкового) кварталу (півріччя);

в) протягом 40 Анів, що настають за останнім календарним Анем звітного (податкового) кварталу (півріччя);

г) протягом 60 Анів, що настають за останнім календарним Анем звітного (податкового) року.

86. П^атник поАатків зобов'язаний самостійно сплатити суму поАаткового зобов'язання, зазначену у поАаній ним поАатковій Аек^арації з поАатку на прибуток піАприємства:

а) протягом 10 календарних Анів, що настають за останнім Анем віАповіАного граничного строку, передбаченого ПКУ Аля подання податкової декларації; 
б) протягом 20 календарних Анів, що настають за останнім Анем віАповіАного граничного строку, передбаченого ПКУ А^я подання податкової декларації;

в) протягом 40 календарних Анів, що настають за останнім Анем віАповіАного граничного строку, передбаченого ПКУ Аля подання податкової декларації;

г) протягом 60 календарних Анів, що настають за останнім Анем віАповіАного граничного строку, передбаченого ПКУ Аля подання податкової декларації.

87. На основі якої звітності формується показник "АохіА віА буАь-якої Аіямьності (за вирахуванням непрямих поАатків), визначений за правимами бухгалтерського обліку" поАаткової Аекмарації з поАатку на прибуток піАприємства?

а) звіту про рух грошових коштів за непрямим метолом;

б) звіту про власний капітал;

в) балансу (звіту про фінансовий стан);

г) звіту про фрінансові результати (звіту про сукупний дохіА).

88. Які є типи податкових Аекмарацій з податку на прибуток піАприємства?

а) звітна, звітна нова, уточнююча;

б) основна і Аолаткова;

в) повна і спрощена;

г) зведена і індивідуальна.

89. Чи поАають фінансову звітність платники поАатку на прибуток разом з поАатковою АекАарацією з поАатку на прибуток піАприємства Ао органів АПС України?
а) так;
б) $\mathrm{Hi}$;
в) подають за власним бажанням;
г) подають тільки примітки до річної фінансової звітності.

90. Що є звітним періоАом А^я поАання поАаткової Аекмарації з поАатку на прибуток піАприємства?
а) тижАень;
б) декала;
в) місяць;
г) каленАарний квартал.

91. Основна ставка поАатку на прибуток піАприємства становить:
a) $21 \%$;
б) $16 \%$;
B) $0 \%$;
г) $18 \%$.

92. Які з навеАених форм звітності віАносяться Ао статистичної?

а) звіт про путівки на санаторно-курортне лікування;

б) звіт про виробництво та реалізацію промислової продукції;

в) звіт про наявність і рух основних засобів, амортизацію;

г) правильні віАповіАі б) і в).

93. Інформація про розподі^ працівників за розмірами заробітної плати за останній місяць звітного періоАу необхіАна А^я скмаАання:
а) звіту про виробництво та реалізацію промислової продукції;
б) звіту з праці;
в) звіту про капітальні інвестиції;
г) правильна віАповіАь віАсутня. 
94. Які піАприємства скмаАають статистичну звітність?
а) державні;
б) приватні;
в) колективні;
г) усі, незалежно віА форми власності.

\section{5. В які строки ск^аАається статистична звітність:}
a) Ао 20 числа місяця наступного за звітним;
б) в залежності віА порядку складання головним бухгалтером;
в) кожна форма звітності має свій термін склаАання;
г) правильна віАповіАь віАсутня.

96. ЗгіАно з П(С)БО 7 "Основні засоби" амортизація - це:

а) систематичний розподіл вартості, яка амортизується, необоротних активів протягом строку їх корисного використання (експлуатації);

б) об'єктивний процес поступового зносу основних фондів та перенесення їх вартості на новостворену продукцію або послуги;

в) процес поступового перенесення вартості засобів праці в міру їх зношування на виготовлену продукцію і використання цієї вартості Аля віАтворення зношених засобів праці;

г) правильної віАповіді немає.

97. Метою скмаАання звіту про фінансові результати (звіту про сукупний АохіА) $є$ наАання користувачам, повної, правАивої та неупереАженої інформації про:

а) фінансовий стан піАприємства на звітну дату,

б) зміни, що віАбулися у грошових коштах піАприємства та їх еквівалентах за звітний періол;

В) Аоходи, витрати прибутки і збитки, а також сукупний АохіА віА Аіяльності піАприємства за звітний період;

г) правильної віАповіАі немає.

\section{8. Ао аАміністративних витрат віАносять:}
а) юриличні та аудиторські послуги;
б) витрати на досліАження і розробки;
в) витрати на управління цехами;
г) правильної віАповіді немає.

99. Стаття "Інші фінансові АохоАи" звіту про фінансові результати не вкАючає:
а) Аивіденди одержані;
б) віАшкодування раніше списаних активів;
в) віАсотки одержані;
г) всі віАповіАі вірні.

100. Який з навеАених Аокументів є компонентом фінансової звітності?
а) аудиторський висновок;
б) пояснювальна записка до звітності;
в) примітки до фінансових звітів;
г) всі наведені документи є компонентами фінансової звітності. 


\section{СПИСОК ВИКОРИСТАНИХ АЖЕРЕА}

1. Верещагіна-Янко Ю. Баланс (Звіт про фінансовий стан): секрети заповнення. Все про бухгалтерський облік. 6 ^ютого 2015 року. №13 (2250). С. 9-16.

2. Виправлення помилок у фінансовій звітності. Аебет-Кредит. 2014. № 50. URL: https:// online.dtkt.ua/Book/\%C2\%AB\%D0\%94\%D0\%9A\%C2\%BB\%20\% E2\%84\%9650-2014.epub/ navPoint-9 (Аата звернення: 11.12.2020).

3. Войтенко Т. Градація піАприємств за версією Мінфіну. Податки \& бухоблік. Грудень 2018. № 103. URL: https://i.factor.ua/ukr/journals/nibu/2018/ december/issue-103/ article-41569.html (Аата звернення: 01.12.2020).

4. Вороная Н., Чернишова Н. Звіт про рух грошових коштів. Грудень 2020. № 103. URL: https://i.factor.ua/ukr/journals/nibu/2020/december/issue-103/article-112586.html (Аата звернення: 24.12.2020).

5. Вороная Н., Чернишова Н. Річна фінзвітність: знання першої необхідності. Податки \& бухоблік. Грудень 2020. № 103. URL: https://i.factor.ua/ukr/journals/nibu/2020/december/ issue-103/article-112583.html (Аата звернення: 24.12.2020).

6. Вороная Н., Чернишова Н. Скорочена фінзвітність. Грудень 2020. № 103. URL: https://i.factor.ua/ukr/journals/nibu/2020/december/issue-103/article-112590.html (Аата звернення: 24.12.2020).

7. Вороная Н., Чернишова Н. Форма № 1 "Баланс (Звіт про фінансовий стан)". Податки \& бухоблік. Грудень 2020. № 103. URL: https://i.factor.ua/ukr/journals/nibu/2020/december/ issue-103/article-112584.html (Аата звернення: 24.12.2020).

8. Вороная Н., Чернишова Н. Форма № 2 «Звіт про фінансові результати (Звіт про сукупний АохіА)". Податки \& бухоблік. Грудень 2020. № 103. URL: https://i.factor.ua/ukr/journals/ nibu/2020/december/issue-103/article-112585.html (Аата звернення: 24.12.2020).

9. Вороная Н., Чернишова Н. Форма № 4 "Звіт про власний капітал". Податки \& бухоблік. Грудень 2020. № 103. URL: https://i.factor.ua/ukr/journals/nibu/2020/december/ issue-103/article-112587.html (Аата звернення: 24.12.2020).

10. Вороная Н., Чернишова Н. Форма № 5 "Примітки до річної фінансової звітності». Податки \& бухоблік. Грудень 2020. № 103. URL: https://i.factor.ua/ukr/journals/nibu/2020/ december/issue-103/article-112588.html (Аата звернення: 24.12.2020).

11. Єрмакова Н. Примітки до річної фрінансової звітності. Аодаток на матеріалу «Фінзвітніть-2013: виАи, склаА, строки поАання". Все про бухгалтерський облік. 29 січня 2014 року. № 8.

12. Звітність підприємств : навч. посіб. (Аля стуА. вищ. навч. закл. за спец. "Облік і опоАаткування») / за заг. реА. А. е. н., проф. В. П. Пантелеєва. Київ : АП «нформ.-аналіт. агентство", 2017. 432 c.

13. Звітність підприємства : підручник / М. І. Бондар та ін. Київ : Центр учбової літератури, 2015. 570 с.

14. Інструкція зі статистики заробітної плати : затв. наказом Аержавного комітету статистики України віА 13 січ. 2004 р. № 5. URL: https://zakon.rada.gov.ua/laws/show/z011404\#Text (Аата звернення: 15.12.2020).

15. Інструкція зі статистики кількості працівників : затв. наказом Аержавного комітету статистики України віА 28 верес. 2005 р. № 286. URL: https://zakon.rada.gov.ua/laws/ show/z1442-05\#Text (Аата звернення: 15.12.2020).

16. Інструкція щодо заповнення форми Аержавного статистичного спостереження № 1-ПВ (місячна) «Звіт з праці» : затв. наказом Аержкомстату України віА 26 жовт. 2009 № 403. URL: https://zakon.rada.gov.ua/laws/show/z1211-09\#Text (Аата звернення: 15.12.2020). 
17. Інструкція щодо заповнення форми державного статистичного спостереження № 1-ПВ (квартальна) «Звіт з праці» : затв. наказом Аержкомстату України віА 26 жовт. 2009 № 404. URL: https://zakon.rada.gov.ua/laws/show/z1212-09\#Text (Аата звернення: 15.12.2020).

18. Карпова В. Звіт про рух грошових коштів: покрокова інструкція. Все про бухгалтерський облік. 6 мютого 2015 року. №13 (2250). С. 23-32.

19. Клебан О. Аекларація з податку на прибуток - 2020: нові рядки й Аодатки. Інтерактивна бухгалтерія. 2020. № 235. 08.12.2020. URL: https://interbuh.com.ua/ua/documents/ ib/10629/140904 (Аата звернення: 10.12.2020).

20. Кодекс України про аАміністративні правопорушення віА 07 груА. 1984 р. № 8073-Х. URL: https://zakon.rada.gov.ua/laws/show/80731-10\#Text (Аата звернення: 16.12.2020).

21. Куриляк 3. Звіт про власний капітал: порядок заповнення. Все про бухгалтерський облік. 6 ^ютого 2015 року. №13 (2250). С. 33-37.

22. Методичні рекомендації з перевірки порівнянності показників фінансової звітності : затв. наказом М-ва фінансів України віА 11 квіт. 2013 р. № 476. URL: https://zakon.rada. gov.ua/rada/show/v0476201-13\#Text (Аата звернення: 15.12.2020).

23. Методичні рекомендації щодо заповнення форм фінансової звітності : затв. наказом М-ва фрінансів України віА 28 берез. 2013 р. № 433. URL: https://zakon.rada.gov.ua/rada/ show/v0433201-13\#Text (Аата звернення: 15.12.2020).

24. Морозовська Г. Хто застосовує різниці піА час визначення податку на прибуток. IHтерактивна бухгалтерія. 2020. № 29. Редакція Аокументу віА 19.02.2020. URL: https:// interbuh.com.ua/ua/documents/oneanalytics/83783 (Аата звернення: 10.12.2020).

25. План рахунків бухгалтерського обліку активів, капіталу, зобов'язань і господарських операцій підприємств і організацій : затв. наказом М-ва фінансів України віА 30 листоп. 1999 р. № 291. URL: https://zakon.rada.gov.ua/laws/show/z1557-11\#Text (Аата звернення: 15.12.2020).

26. Податковий колекс України віА 2 груА. 2010 р. № 2755-VI. URL: https://zakon.rada. gov.ua/laws/show/2755-17\#Text (Аата звернення: 16.12.2020).

27. Поліщук А. Аекларація з ПАВ: алгоритм заповнення (Частина І). Інтерактивна бухгалтерія. 2020. № 142. РеАакція Аокументу віА 28.07.2020. URL: https://interbuh.com.ua/ua/ documents/ib/10339/119335 (Аата звернення: 10.12.2020).

28. Поліщук А. Аекларація з ПАВ: алгоритм заповнення (Частина II). Інтерактивна бухгалтерія. 2020. № 143. Редакція Аокументу віА 29.07.2020. URL: https://interbuh.com.ua/ua/ documents/oneanalytics/119373 (Аата звернення: 10.12.2020).

29. Поліщук А. Звітність із ПАВ: правила подання. Інтерактивна бухгалтерія. 2020. № 141. Редакція Аокументу віА 27.07.2020. URL: https://interbuh.com.ua/ua/documents/ oneanalytics/119302 (Аата звернення: 10.12.2020).

30. Про бухгалтерський облік та фінансову звітність в Україні : Закон України віА 16 лип. 1999 р. № 996-XIV. URL: https://zakon.rada.gov.ua/laws/ show/996-14/conv (Аата звернення: 01.12.2020).

31. Про державну статистику : Закон України віА 17 верес. 1992 р. № 2614-XII. URL: https://zakon.rada.gov.ua/laws/show/2614-12\#Text (Аата звернення: 10.12.2020).

32. Про затверлження загального табеля (переліку) форм державних статистичних спостережень на 2021 рік : наказ Аержавної служби статистики України віА 8 груА. 2020 р. № 344. URL: https://www.profiwins.com.ua/uk/forms-and-blanks/statistic/3555.html (Аата звернення: 10.12.2020).

33. Про затвердження Методичних рекомендацій щодо облікової політики піАприємства та внесення змін до Аеяких наказів Міністерства фінансів України : наказ М-ва фінансів України віА 27 черв. 2013 р. № 635. URL: https://zakon.rada.gov.ua/rada/show/v063520113\#Tеxt (Аата звернення: 12.12.2020).

34. Про затверАження Національного положення (стандарту) бухгалтерського обліку 1 «Загальні вимоги до фінансової звітності» : наказ М-ва фінансів України 07 юют. 2013 р. № 73. URL: https://zakon.rada.gov.ua/ laws/show/z0336-13\#Text (дата звернення: 01.12.2020). 
35. Про затвердження Національного положення (стандарту) бухгалтерського обліку 2 "Консолідована фінансова звітність" : наказ М-ва фінансів України 27 черв. 2013 р. № 628. URL: https://zakon.rada.gov.ua/laws/show/z1223-13\#Text (Аата звернення: 01.12.2020).

36. Про затверАження Національного положення (стандарту) бухгалтерського обліку 25 "Спрощена фінансова звітність" : наказ М-ва фінансів України віА 31 трав. 2019 р. № 226. URL: https://zakon.rada.gov.ua/laws/show/z0685-19\#Text (Аата звернення: 10.12.2020).

37. Про затверАження положення (стандарту) бухгалтерського обліку 6 "Виправлення помилок і зміни у фінансовій звітності" : наказ М-ва фінансів України віА 28 трав. 1999 р. № 137. URL: https://zakon.rada.gov.ua/laws/show/z0392-99\#Text (Аата звернення: 01.12.2020).

38. Про затвердження Положення про інвентаризацію активів та зобов'язань : наказ М-ва фінансів України віА 02 верес. 2014 р. № 879. URL: https://zakon.rada.gov.ua/laws/ show/z1365-14 (Аата звернення: 01.12.2020).

39. Про затвердження Порядку подання фінансової звітності : Постанова Кабінету Міністрів України віА 28 мютого 2000 р. № 419. URL: https://zakon.rada.gov.ua/laws/show/4192000-\%D0\%BF (Аата звернення: 01.12.2020).

40. Про затверАження типових форм первинної облікової документації зі статистики праці : наказ Аержавного комітету статистики України віА 05 груА. 2008 р. № 489. URL: https:// zakon.rada.gov.ua/rada/show/v0489202-08\#Text (Аата звернення: 15.12.2020).

41. Про затверАження форм Аержавних статистичних спостережень № 2-інвестиції (квартальна) «Звіт про капітальні інвестиції», № 2-03 IHB (річна) «Звіт про наявність і рух необоротних активів, амортизацію та капітальні інвестиції» : Наказ Аержавної служби статистики України віА 26 серп. 2020 р. № 256. URL: https://zakon.rada.gov.ua/rada/show/ v0256832-20\#Text (Аата звернення: 15.12.2020).

42. Про затвердження форм Аержавного статистичного спостереження № 1-ПВ (місячна) та № 1-ПВ (квартальна) "Звіт із праці" : наказ Аержавної служби статистики України віА 10 черв. 2016 р. № 90. URL: https://zakon.rada.gov.ua/ rada/show/v0090832-16\#Text (Аата звернення: 15.12.2020).

43. Про затвердження форм та Порядку заповнення і подання податкової звітності 3 податку на Аолану вартість : наказ М-ва фрінансів України віА 28 січ. 2016 р. № 21. URL: https://zakon.rada.gov.ua/laws/show/z0159-16\#Text (Аата звернення: 12.12.2020).

44. Про затверАження форми державного статистичного спостереження № 1-ПВ (квартальна) "Звіт із праці" : наказ Аержавної служби статистики України віА 17 черв. 2020 р. № 178. URL: https://zakon.rada.gov.ua/rada/show/v0178832-20\#Text (Аата звернення: 15.12.2020).

45. Про примітки до річної фінансової звітності : наказ М-ва фінансів України віА 11 мистоп. 2000 р. № 302. URL: https://zakon.rada.gov.ua/laws/show/z0904-00\#Text (дата звернення: 01.12.2020).

46. Про проведення пілотного проекту зі збирання й обробки звітності в електронній формі : наказ Аержавного комітету статистики України 25.02.2009 № 69. URL: https://zakon. rada.gov.ua/rada/show/v0069202-09 (Аата звернення: 10.12.2020).

47. РеАакція газети "Інтерактивна бухгалтерія". Аекларація з полатку на прибуток: рялок за рялком. Інтерактивна бухгалтерія. 2018. № 19. РеАакція Аокументу віА 14.02.2020. URL: https://interbuh.com.ua/ru/documents/ib/8180/ 90630 (Аата звернення: 10.12.2020).

48. Редакція газети "нтерактивна бухгалтерія". Порялок заповнення фінансової звітності мікропіАприємства (форми № 1-мс, № 2-мс). Інтерактивна бухгалтерія. 2020. № 9. РеАакція Аокументу віА 15.01.2020. URL: https://interbuh.com.ua/ua/documents/ib/9904/15035 (Аата звернення: 10.12.2020).

49. Редакція газети "Інтерактивна бухгалтерія". Фінзвітність малого підприємства: заповнюємо без помилок. Інтерактивна бухгалтерія. 2020. № 8. РеАакція Аокументу віА 14.01.2020. URL: https://interbuh.com.ua/ua/documents/ ib/9901/15046 (Аата звернення: 10.12.2020). 
50. Роз'яснення Аержавної служби статистики України щодо форми Аержавного статистичного спостереження № 1-ПВ (місячна) “Звіт із праці» віА 14 лип. 2020 р. № 19.1.2-12/1220. URL: https://buhgalter.com.ua/dovidnik/ inshe/rozyasnennya-shchodo-zapovnennya-formiderzhavnogo-statistichnogo/ (Аата звернення: 15.12.2020).

51. Роз'яснення Аержавної служби статистики України щодо форми державного статистичного спостереження № 1-ПВ (квартальна) “Звіт із праці" віА 31 лип. 2019 р. № 19.1.212/31-19. URL: https://www.profiwins.com.ua/uk/ letters-and-orders/gks/15526-31ds-19. html (Аата звернення: 15.12.2020).

52. Роз'яснення Аержавної служби статистики України щодо форми державного статистичного спостереження N 2-03 IHB (річна) «Звіт про наявність і рух необоротних активів, амортизацію та капітальні інвестиції» віА 24 верес. 2020 р. № 19.1.2-12/28-20. URL: https://www.profiwins.com.ua/uk/letters-and-orders/gks/16551-28ds-20.html (Аата звернення: 15.12.2020).

53. Роз'яснення Аержавної служби статистики України щодо форми державного статистичного спостереження № 1-ПВ (місячна) «Звіт із праці" віА віА 13.07.2016 р. N 17.4-12/4. URL: https://www.profiwins.com.ua/uk/letters-and-orders/gks/9136-4.html (Аата звернення: 15.12.2020).

54. Савченко О. Звіт з ЄСВ: склаА, обов'язкові реквізити, строки. Податки \& бухоблік. ^истопаА 2020. № 95. URL: https://i.factor.ua/ukr/journals/nibu/2020/ november/issue-95/ article-112059.html (Аата звернення: 10.12.2020).

55. Саловська І. Б., Божиларнік Т. В., Нагірська К. Є. Бухгалтерський облік : навч. посіб. Київ : Центр учбової літератури, 2013. 688 с.

56. Саєнко Т. Складаємо консолідовану фінзвітність. Баланс. 21 січня 2010 р. № 5. URL: http://www.vs.com.ua/index.php?pageid=3154\&forprint=1 (Аата звернення: 06.12.2020).

57. Спрощений план рахунків бухгалтерського обліку активів, капіталу, зобов'язань і господарських операцій підприємств : затв. наказом М-ва фінансів України віА 19 квіт. 2001 p. № 186. URL: https://zakon.rada.gov.ua/laws/show/z0389-01\#Text (Аата звернення: 16.12.2020).

58. Статзвітність - 2021: які звіти скасовано, а які змінено? Аебет-КреАит. 2020. 14 груАня. URL: https://news.dtkt.ua/accounting/reposts/66740?_ga=2. 66227310.1345872116.1607972841-1070016733.1607613994 (Аата звернення: 15.12.2020).

59. Ушакова $\Lambda$. Об'єАнана звітність з ПАФО, ВЗ та ЄСВ. Податки \& бухоблік. Аистопал 2020. № 95. URL: https://i.factor.ua/ukr/journals/nibu/2020/ november/issue-95/ article-112069.html (Аата звернення: 10.12.2020).

60. Ушакова ^. Трудові віАносини та зарплата. Податки \& бухоблік. Аистопад 2020. № 95. URL: https://i.factor.ua/ukr/journals/nibu/2020/november/ issue-95/article-112060. html (Аата звернення: 10.12.2020).

61. Царевська Т. Суттєвість Аля бухобліку та фінзвітності. Податки \& бухоблік. Вересень 2017. № 36. URL: https://i.factor.ua/ukr/journals/bn/2017/ september/issue-36/ article-30177.html (Аата звернення: 01.12.2020).

62. Чалий І. Звіт про фрінансові результати: проблемні аспекти. Все про бухгалтерський облік. 6 мютого 2015 року. №13 (2250). С. 17-22.

63. Шигун М. М., Іваненко В.О. ВиАи звітності підприємств: підходи Ао їх класифікації. Міжнародний збірник наукових праць. 2008. Випуск 3(12). С. 432-443. URL: http://pbo.ztu. edu.ua/article/viewFile/68741/64055.pdf (Аата звернення: 01.12.2020). 


\title{
Наталія ВолоАимирівна IBАНЧУК
}

\section{ЗВІТНІСТЬ ПІАПРИЕМСТВ}

\author{
Навчамьний посібник \\ А^я стуАентів заклаАів вищої освіти
}

Комп'ютерна верстка Наталії Крушинської

Формат 60х84/8. Ум. Арук. арк. 24,18. НаклаА 300 пр. Зам. № 12-21.

Папір офсетний. Арук цифровий. Гарнітура «BloknotC".

Оригінал-макет виготовлено у видавництві

Національного університету "Острозька академія",

Україна, 35800, Рівненська обл., м. Острог, вул. Семінарська, 2.

СвіАоцтво суб'єкта виАавничої справи РВ № 1 віА 8 серпня 2000 року.

Виготовлено ФОП Свинарчук М. В.

Te^. (+38068) 6835 800, e-mail: 35800@ukr.net. 